FAGULTAD DE FILOSOFÍA Y LETRAS DE LA UNIVERSIDAD DE BUENOS AIRES

\title{
ALFONSO EL SABIO
}

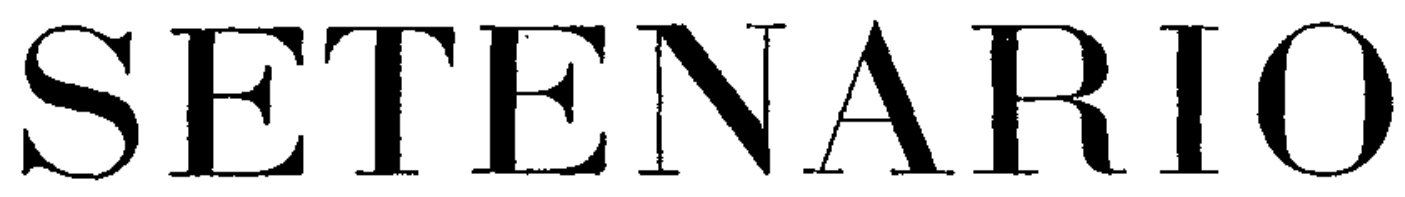

EDICIÓN E INTRODUGGIÓN

$\mathrm{DE}$

KENNETH H. VANDERFORD

INSTITUTO DE FILOLOGÍA 


\section{ÍNDICE GENERAL}

Página

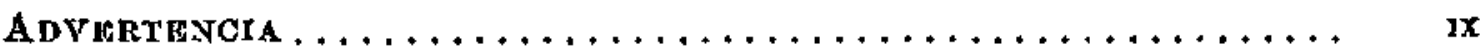

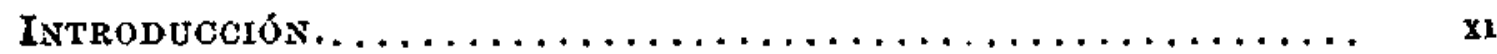

I. Antecedentes del Setenario ..................

II. Bibliografía del Setenario ................... xvm

III. El Setenario y las Siele partidas...............

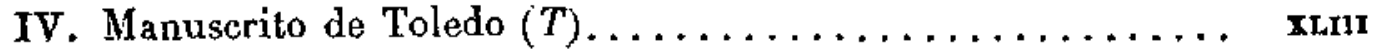

V. Manuscrito del Escorial $(E) \ldots \ldots \ldots \ldots \ldots \ldots \ldots \ldots \ldots \ldots \ldots$

VI. Manuscrito de Madrid $(\boldsymbol{M}) \ldots \ldots \ldots \ldots \ldots \ldots \ldots \ldots \ldots \ldots \ldots \ldots \ldots \ldots$

VIf. Parentesco de los manuscritos ................. L L

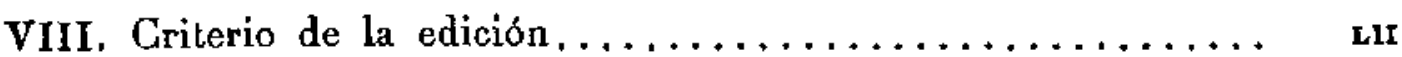

IX. Transcripción de $T \ldots \ldots \ldots \ldots \ldots \ldots \ldots \ldots \ldots \ldots \ldots \ldots$ Lri

X. Variantes de $T \ldots \ldots \ldots \ldots \ldots \ldots \ldots \ldots \ldots \ldots \ldots \ldots$ nxin

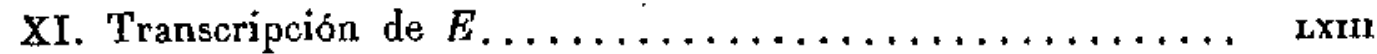

XII. Variantes de $E \ldots \ldots \ldots \ldots \ldots \ldots \ldots \ldots \ldots \ldots \ldots \ldots \ldots \ldots$

XIII. Particularidades del uso ortográfico de $T$ y $E \ldots \ldots \ldots \ldots \ldots \mathbf{L x \times 1}$

XIV. Nota sobre las láminas . . . . . . . . . . . . . Lxxvi

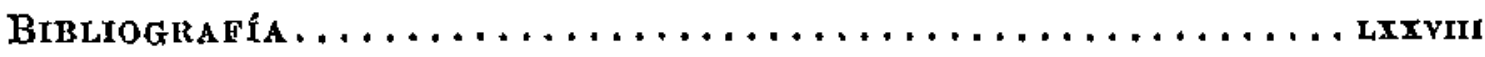

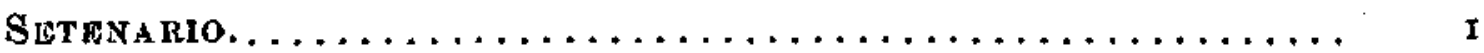

LFX I. - [De las ssiete letras de Alpha et $\mathrm{O}$ que muestran cada vna ssiete

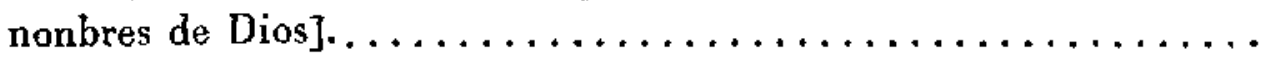

LEY IX. - De lo que muestran las ssiete letras del nonbre del rrey don Ffernando ..............................

Lwy III. - De los bienes que entendíe el rrey don Ffernando en esta

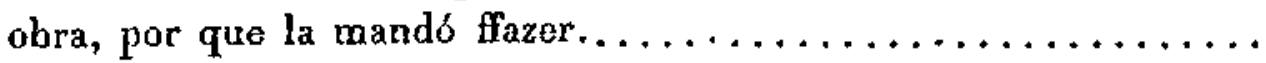

LEY IV. - De los bienes que ffzo el rrey don Fernando al rrey don Alffonso su ffijo .......................... to

Ley V. - De las vertudes ssiete que puso Dios en el rrey don Ffer-

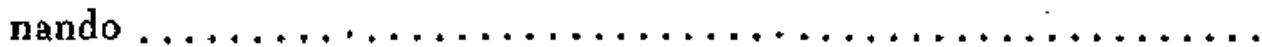

LEY VI: - De cómmo el rrey don Ferrnando era bien costunbrado en

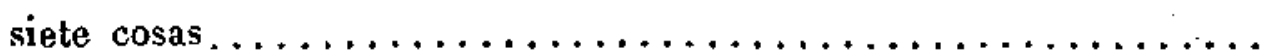

LeY VII. - De cómmo el rrey don Ffernando era bien acostunbrado

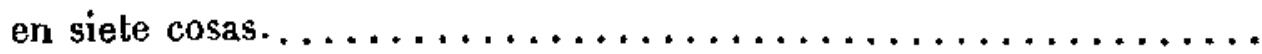

LIFY VIII. - En qué cosas se mostró el rrey don. Ffernando por ssier-

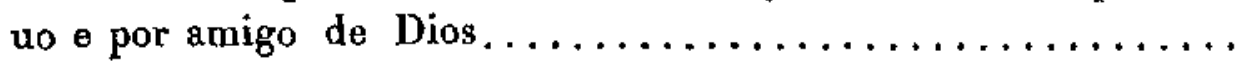


LwY IX. - De las merçedes que ffizo Dios al rrey don Ffernando en

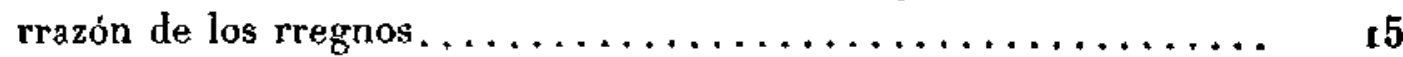

LEY X. - De las bondades del rregno de Seuilla ............. 19

LEX XI. - Por quáles rrazones pusiemos nonbre a este libro Sselenario. $\quad 25$

LWY XII. - Qué quier dezir ssecta................ 47

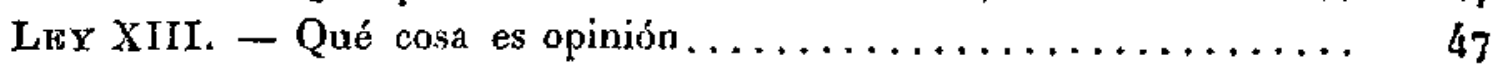

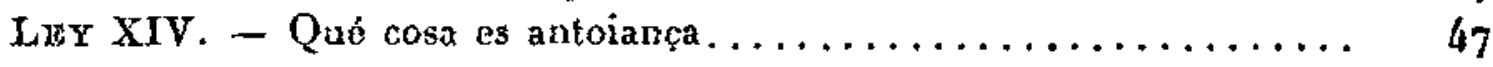

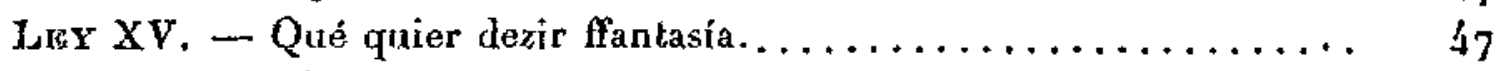

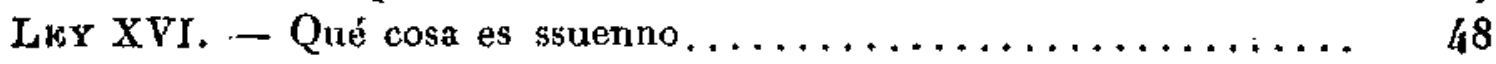

LEY XVII. - Qué cosa es visión .................... 48

LEY XVIII. - De cómmo non deue omne aorar sinon a Dios solo... 49

LaY XIX. - De los que adorauan la tierra.............. 5o

LwY XX. - De los que aorauan el elemento del agua .......... 5r

LEY XXI. - De los que aorauan el elemento del ayre.......... 53

LwY XXII. - De los que zorauan el ffuego................ 53

LkY XXIII. - De Ios que sse aorauan vnos a olros............ 55

LEX XXIV. - De cómmo el ssonnar ffazía a los omnes caer en gran-

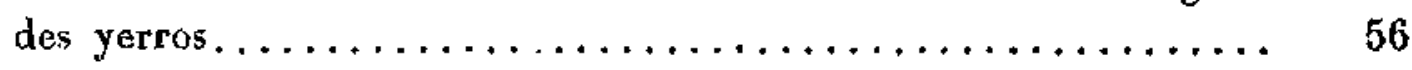

Lex XXV. - Do las planetas.................... 57

LEY XXVI. - De cómmo a la luna llamauan los antigos mugier del ssol, e por qué rrazón es así llamada .................. 58

Lex XXVII. - De la propriedat que dauan a Mercurio.......... 58

LeY XXVIII. - Qué quier dezir Venus, e qué propriedades le dauan. $\quad 59$

LeY XXIX. - De las virtudes que dauan al sol .............. 6o

LEY XXX. - De la planeta Mars e de las propriedades quel dauan... 60

LxY XXXI. - De la honestat que dauan a Jupiter e de ssus propriedades. $\quad 62$

LkY XXXII. - De la ffortaleza que dauan a Ssaturno........... 63

LeY XXXIIr, - Por qué rrazón aorauan los antigos al octauo çielo. . 63

LiY XXXIV. - Del departimiento de Ios ssignos.............. 64

LuY XXXV. - De cómmo Nuestro Sennor Dios non puede ser conosçido por estas setas que son dichas, mas por la ley biua c verdadera

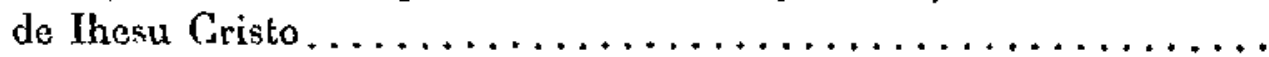

LaY XXXVI. - De cómmo Dios Padre fizo por amor de Jhesu Cristo su fijo los pielos e la tierra.................. $6_{7}$

LRY XXXVII. - Qué cosa es Spíritu Santo................ 67

Ley XXXVIII. - Qué cosa es Santa Eglesia e por qué la llaman asy. $\quad 69$

LEY XXXIX. - De la segunda manera a que llaman Eglesia...... 69

LwY XL. - De los artícolos de la Fe................ $7^{\circ}$

LEx XLI. - Quáles son Ilamados apóstoles.............. $7 \mathbf{I}$

LrY XLII. - De las palabras que dixieron los apóstolos en cómmo

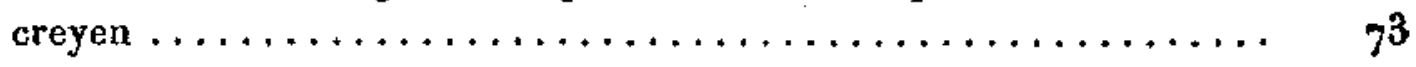

LeY XLIII. - De cómmo los que aorauan la tierra, a Santa María

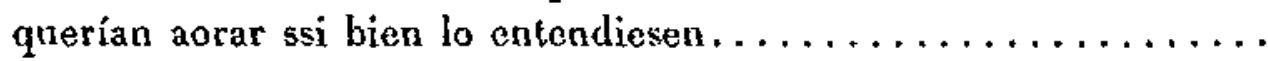

LEX XLIV. - De cómmo los que aorauan el helemento del agua, erâ

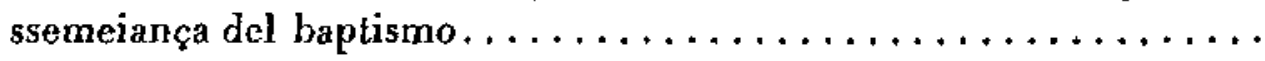

LnY XLV. - De los que aorauan el elemento del ayre, ssinifficaua a la linpia vida que fizo Nuestro Ssennor lhesu Gristo en este mundo. 
LeY XLVI. - De las conparaçiones que ha el ffuego al Spíritu Santo. LEY XLVIX. - De cómmo los que aorauan los vii çielos, fiué a ssemeiança de los vii mouimientos que fizo Nuestro Ssennor thesu Cristo e de los vii dones que dió Dios a ssus amigos............

LiY XLVIII, - De cómmo los que aorauan a la luna, a Ssanta María

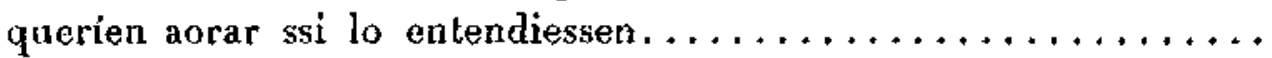

LeY XLIX. - De cómmo sse muestra que los que aorauan a Mercurio, que a Ihesu Cristo lo deuyeran ffazer..................

LaY L. - De cómmo se muestra que las uertudes e las amiztades que dauan a la planeta Venus ssus aoradores, a la piadat de Dios la

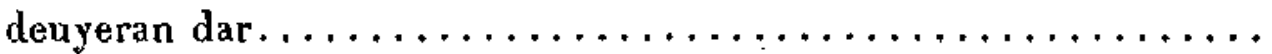

LwY LI. - De cómmo errauan los que orauan el ssol, cuydando que la nobleza que él auye en ssí era de ssuyo, e non entendíen cómmo

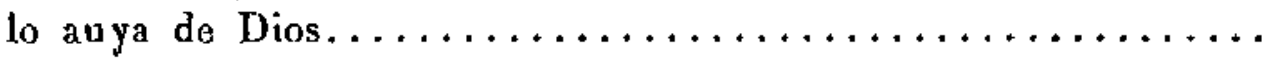

LeY LII. - De cómmo sse muestra que el poder que auya Mars para destruyr ssu ffechura e en ffazer mal, ouo Ihesu Cristo en ffazer

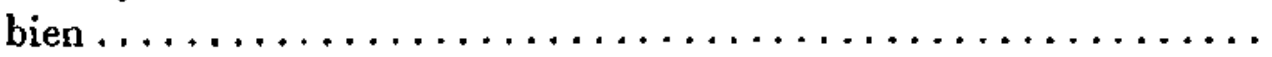

LkY LIII. - Do cómmo la onestad que dauan los antigos a Jupiter, a Ihesu Cristo la deuyeran dar ssi bien lo entendiesen...........

LEY LIV. - De cómmo la antigüedat que dauan a Ssaturno e el mouimiento tardinero, a Dios Padre lo deuyeran dar, que nunca sse

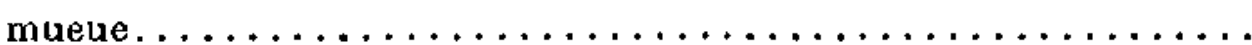

LEY LV. - De cómmo la ffigura de carnero que daun al ssigno de Aries, a Ihesu Gristo la deuyeran dar, que es cordero uerdadero de

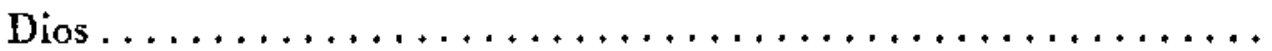

Lry LVI. - De cómmo errauan los que orauan el ssigno de Tauro, queriendo aorar a thesu Cristo, por non lo entender..........

Luy LVIT. - Del ssigno de Gémini e de lo que ssignifficaua la ssu ffigura, que es dos cuerpos ayuntados en vno, que a Ihesu Cristo le deuieran dar $\ldots \ldots \ldots \ldots \ldots \ldots \ldots \ldots \ldots \ldots \ldots \ldots \ldots$

Lry LVIII. - De cómmo los que aorauan al Cangreio, a Ihesu Cristo deuyeran aorar si bien lo entendiesen................

Lxy LIX. - Del ssigno del León e de cómmo los quel aorauan quisieran aorar a Ihesu Cristo si lo entendieran ..............

Lex LX. - De las ssemeianças que ouo Santa María con [el ssigno de]

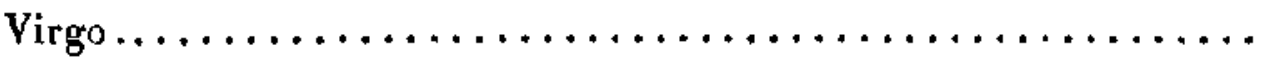

Lex LX: - De cómmo los que orauan a Libra, a Ihesu Cristo querían aorar ssi lo entendieran .....................

LEY LXII. - De las ssiete propriedades que dauan al Escurpión, a Nuestro Ssennor lhesu Cristo las deuyeran dar, ssegunt sse aquí

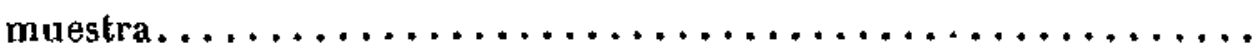

LEY LXIII. - Qué quier dezir Ssagitario e de la semeiança que dieron a Nuestro Senuor Ihesu Cristo dél.................

LEY LXIV. - De cómmo las propriedades que dauan a la ffigura del Capricornio, a Jhesu Cristo las douyeran dar.............

Lex LXV. - - De cómmo las propriedades que dauan a Aquario, a Ihesu Cristo las douyeran dar, que las ouo en ssí conplidamientre. 
LeY LXVI. - De çómmo se muestra que los que aorauan el ssigno de Pisçis, a Thesu Cristo lo douyeran ffazer.................

LEY LXVII. - Commo Tolomeo fabla altamiente en ffecho de astrología, así flizo Sant Iohán en las propriedades de Dios..........

LEX LXVIIr. - De cómmo los xii ssignos son ffechos e conparados a

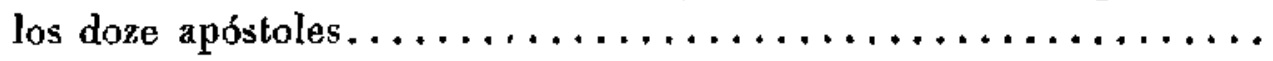

LwY LXIX. - De cómmo los prophetas mostraron que quatro euangelistas deuen sser e non más.......................

LEY LXX. - Quántos sson los ssacramentos e en quántas maneras son guardados e sagrados e qué pro viene dellos a los que los rreçiben.

Lxy luXX1. - Por qué rrazón sson los sacramentos ssiete e non pue-

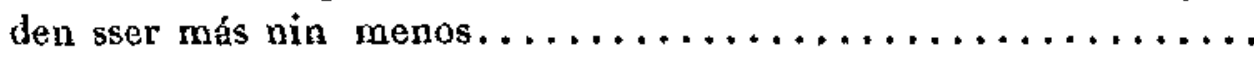

LIEY LXXII. - Quántas maneras de clérigos pueden dar los ssacramentos conplidamente.........................

LẹY LXXIII. - Quántas maneras de prelados rreligiosos pueden dar

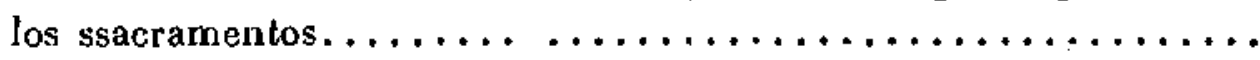

LEX LXXIV. - Por quáles rrazones pueden dar los legos los tres sacramentos que son baptismo e penitençia e casamiento.........

LEY LXXV. - Por qué rrazón es llamada la Eglesia cathólica......

Ley LXXVJ. - Quáles ssazones deuen sser catadas para dar los sacra-

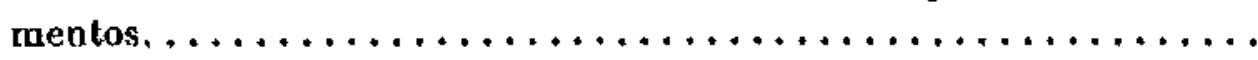

LEY LXXVII. - Qué cosa es en sí el baptisno e qué sacramento es.

LIt Y LXXVII, - Quién estableçió el baplismo e quándo, e cómmo Sant Iohán ouo nonbre Babtista por rrazón del baptismo........

LeY LXXIX. - De las palabras çiertas por que sse ffaze el baptismo. .

LEY LXXX. - Quántas e quáles son las maneras en que se non puede fazer el bautismo..........................

LEY LXXXI. - Cómmo son tres maneras del bautismo, pero la virtut toda es vna.............................

Lry LXXXII. - A qué cosas tiene pro el bautismo quando es fecho

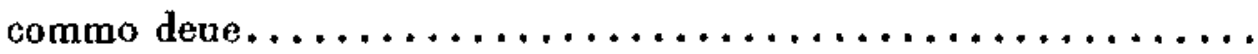

LeY LXXXIII. - Qué quiere dezir saçerdote.............

LwX LXXXIV. - De cómmo se muestrá la Trenidat conplidamente en las cosas que se fazen ante del bautismo e en las cosas que son fe-

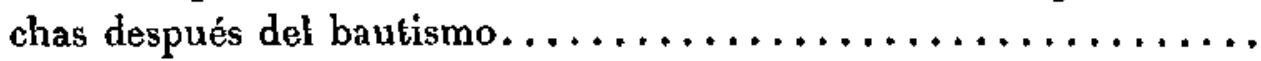

LEX LXXXV. - Quántas e quáles sson aquellas cosas que frazen en vno con el baptismo........................

LEY LXXXVI. - De las cosas que deuen ffazer después del baptisrao, cómmo son ffechas en ssiete maneras. .................

LEY LXXXVII. - De cómmo deue sser onrrado el baptismo por ssiete rrazones e guardado por otras tantas.................

LuY LXXXVIII. - Qué cosa es en sí la crisma e quién la puede ffazer

LwY LXXXIX. -- De cómmo estableçieron los santos padres la crisma.

LEY XC. - De las maneras de los olios de que sse faz la crisma....

LEY XCI. - Del tienpo' que fué estableçido para ffazer la crisma...

LWY XCII. - De cómmo deuen tener apareiadas todas las cosas que sson mester para ffazer la crisma.................. 
LRY XCIII. - En qué manera sse deue ffazer la crisma.......... 167

LEY XCIV. - De cómmo deuen boluer el olio de la crisma con del olio del bálsamo...........................

LEY XCV. - Por quáles cosas deue sser conssagrado el olio para los cathecúminos e neóffitos . ......................

LEX XCVI. - Del ssegundo ssacramento, que es la conffirmaçión, e de las cosas que sse deuen ffazer en él. ..................

LEX XCVII. - Del terçero ssacramento, que es la penitençia, e dónde

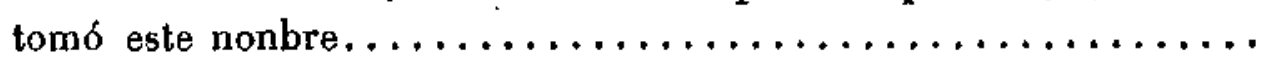

LEx XCVIII. - De los peccados que ffazen los omnes de que han mester de tomar penitençia, e quántas maneras sson dellos.......

LEY XCIX. - Qué quier dezir çitar e dónde fué tomada esta palabra

Lex C. - Quién puede dar la penitençia e de las preguntas que deuen

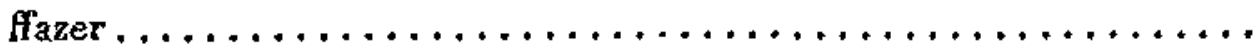

LkY CI. - Quáles deuen sser llamados conffesadores e cómmo deuen

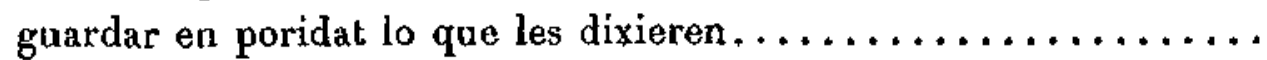

LEY CII. - De cómmo sse muestra quál penitençia es ssolenpne e

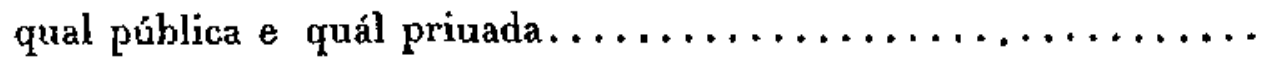

LWY CIII. - De cómmo se amortiguan los bienes que omne faz por el pecado mortal e cómmo se abiuan por la penitençia.........

LwX CIV. - Del quarto sacramento, que es la comunión.........

LIE Y CV. - [De las cosas que sson estableçidas en Ssanta Eglesia para frazer el cuerpo de Nuestro Ssennor Ihesu Cristo $]. . . \ldots \ldots \ldots$.

LFY CVI. - [De las vestiduras que sson estableçidas en Ssanta Egle sia para los prelados menores $]. \ldots \ldots \ldots \ldots \ldots \ldots \ldots \ldots \ldots$

LEY CVII. - De las vestimientas que sson establecidas en Ssanta

Eglesia para los mayores ssaçerdotes...................

Lxy CVIII. - Que assí commo las armaduras tenporales fiueron estableçidas para deffendimiento de la carne, otrossí las spirituales para se deffender del diablo..........................

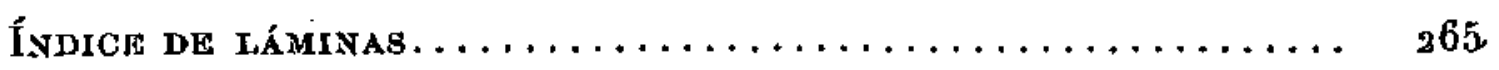





\section{$A$ \\ $M I S \quad P A D R E S$}

\section{CORRIGENDA}

So han encontrado en esta edición las siguientes erratas, que, como son simples referencias a páginas en las variantes, no afectan directamente la integridad de la transcripción :

\begin{tabular}{|c|c|c|}
\hline Pág. 28 , lín. 29. & $\begin{array}{l}\text { Donde dico } \\
\text { pág. } 2 \%\end{array}$ & $\begin{array}{l}\text { Léase } \\
\text { púg. } 29\end{array}$ \\
\hline Pág. 28, lín. $33 \ldots \ldots \ldots$ & pág. $2 \&$ & pág. 30 \\
\hline Pág. 29 , lín. $34 \ldots \ldots \ldots$ & $p a ́ g .26$ & puig. 28 \\
\hline Pág. 29, lín. 34.. & pág. 28 & pág. 30 \\
\hline Pág. 3o, lín. 3ı... & pág. 26 & pág. 28 \\
\hline
\end{tabular}

Además, durante la impresión se han producido algunas leves imperfecciones de caráctor mecánico - tipos rolos, aplastados total o parcialmente, división lalsa en palabras quedando por lo tanto algunos ejemplares defectuosos. Va a continuación la lista completa de los casos notados para que el lector los salve, si existen, on su gjemplar:

\begin{tabular}{|c|c|c|}
\hline & Donde dice & Léase \\
\hline Páğ. 7r, lín. 3̋o. & niere & quiere \\
\hline Pág. $\quad 7 \mathbf{1}$, lin. $33_{1}, \ldots \ldots$ & en ados & enbiados \\
\hline Pág. I I $8, \operatorname{lín.} 32 \ldots \ldots \ldots$ & poridad es & poridades \\
\hline Pág. rgr, lín. $3-\ldots \ldots \ldots$ & supiero azer & supicron fazer \\
\hline Pág. 306 , lín. $34 \ldots \ldots \ldots$ & Iom anifestare & 10 manifestare \\
\hline
\end{tabular}





\section{ADVERTENGIA}

La edición del Setenario me la sugirió el profesor Hayward Keniston, entonces de la Universidad de Chicago, el Día de Acción de Gracias de 1933. Acepté inmediatamente, y en agosto de 1940 tuve el honor de presentar los originales de mi trabajo a la Facultad de Humanidades de aquella universidad, para optar al título de Doctor en Filosofía en el Departamento de Lenguas y Literaturas Románicas. Es para mi un deber y un placer declarar aquí mi deuda de gratitud con el profesor Keniston por su dirección sabia y paciente y el entusiasmo que ha sabido infundirme en todos los momentos de la realización de ese trabajo.

He contraido también una deuda de gratitud con el Seminario de Estudios Medievales Españoles de la Universidad de Wisconsin, y especialmente con los profesores Lloyd A. Kasten y J. Homer Herriott, por su valiosa ayuda en la preparación de los materiales para la papeletización del léxico del Setenario. Con esos materiales pude preparar un fichero de unas 35.000 papeletas que abarcan todas las voces del texto (con excepción de las formas del artículo, de unos pocos pronombres y adjetivos, y de las partículas más repetidas), lo que ha hecho posibles los recuentos estadísticos de las últimas partes de la Introducción, asi como un tratamiento más completo y sistemático del texto que lo que hubiera sido factible de otro modo.

Las primeras tres divisiones de la Introducción se han publicado ya en la Revista de Filología Hispánica, III, I941, págs. 233-262, con el título de $E l$ "Setenario " y su relación con las "Siete partidas ". Me ha parecido, sin embargo, imprescindible incluir aquí de nuevo ese material en vista de la importancia de la tesis demostrada y la naturaleza necesariamente complicada y tenue de la demostración, que de otro modo no se prestaria a un resumen convincente. La Revisia de Filología Hispánica me ha autorizado 
generosamente para publicar el contenido de ese artículo - en forma reelaborada - en el presente volumen.

Es para mí un placer mencionar funalmente la agradable vinculación que he tenido con el ambiente de trabajo y de colaboración del Instituto de Filología de la Universidad de Buenos Aires durante los varios meses en que estaba en curso la presente edición. Debo gratitud especial al profesor doctor Amado Alonso, director del Institulo, que ha hecho posible mi edición y la ha dirigido hasta su término. Quiero expresar también mi agradecimiento a los doctores Pedro Henriquez Ureña y Ángel Rosenblat por su valiosa ayuda en la traducción de la Introducción. A ellos, y al doctor Raimundo Lida, al señor Andrés Ramón Vázquez; al profesor Raúl Moglia y a los demás miembros del Instituto les debo todo mi reconocimiento por sus consejos y ayuda en la solución de los muchos problemas que ofrecía la publicación de esta edición del Setenario.

Buenos Aires, Día de Acción de Gracias, 1945. 
INTRODUGGIÓN 



\section{ANTECEDENTES DEL SETENARIO}

Irtereses jurídicos de Fernando III. - La unificación del código legal ha sido ideal grato a todo buen gobernante. Fernando III ( $1217-1252)$, "que ganó a Sevilla ", no fué una excepción. Las antiguas crónicas, dedicadas a la guerra y a la biografía de los reyes y príncipes, raras veces mencionan cosas tan prosaicas como la administración de justicia, pero se cuenta de Fernando que, después de convalecer de una enfermedad que padeció en Burgos, salió de la ciudad "et començó a andar por la tierra, faziendo muy grant justiçia et castigando su tierra et parándola bien, ca era muy mester " ${ }^{1}$. Hasta en momentos en que un monarca menos concienzudo habría podido permitirse algún descanso de sus deberes oficiales, Fernando, según recuerda Mariana, estaba en actividad. En la ocasión de su casamiento con Juana de Ponthieu, su segunda esposa, en 1237 , " concluídas las fiestas, y con deseo de visitar el reino, trujo a la nueva casada por las principales ciudades de León y de Gastilla ; visitaba con esto sus estados " ${ }^{2}$ - visita que, como se puede ver por lo que dice Mariana a continuación, estaba dictada principalmente por la preocupación de que hubiera justicia en sus dominios. El que la justicia, según criterios posteriores, fuese extremadamente rara en modo alguno niega el interés que en ella ponia Fernando. La afirmación del Obispo de Túy, "En tanta paz rigió el reyno a sí subjecto que mayores ni menores no se osauan mouer para tomar las cosas de los otros " ${ }^{3}$, es una exageración idilica que discrepa mucho del testimonio del Setenario.

1 Primera crónica general, edición de Ramón Menéndez Pidal, tomo $\mathrm{V}$ de la Nueva Biblioteca de Autores Españoles, Madrid, rgo6, pág. 742. En esta cita, y en las demás que siguen, la puntuación y la acentuación van de acuerdo con el uso actual.

- Padre Juan de Mariana, Historia general de España, tomo XXX de la Biblioteca de Autores Españoles, Madrid, 1864 , pág. $37 \mathbf{I}$.

- Lucas, Obispo de Túx, Crónica de España, edición de la Roal Academia de la Historia, Madrid, 1926 , pág. 418. 
El hecho es que, si bien el reinado de Fernando fué de los más afortunados, la situación general de su reino, en el orden legislativo, dejaba mucho que desear. La explicación, según la concebía su hijo y sucesor, Alfonso X ( $1252-1284)$, era clara :

Fuero dEspana antiguamiente en tienpo de los godos fué todo uno. Mas quando moros ganaron la tierra, perdiéronse aquellos libros en que eran escriptos los fucros. E después que los christianos la fueron cobrando, así como la yvan conquiriendo, tomavan de aquellos fueros algunas cosas segunt se acordavan, los unos de una guisa e los otros de otra. E por esta razón vino el departimiento de los fueros en las tierras ${ }^{1}$.

La reconquista de territorios ocupados por los moros tuvo como consecuencia el establecimiento de ciudades libres, generalmente situadas en regiones fronterizas. El privilegio era la norma de la época, y los fueros concedidos a esos municipios contenían a menudo disposiciones y exenciones especiales, destinadas a inducir a las gentes a establecerse allí. Pocos de los fueros son de fecha anterior al siglo xr, en que la Reconquista alcanzó por fin a Castilla; su periodo de esplendor fué precisamente el siglo xır. El código visigodo del Forım judicum, que habia dado unidad legislativa a la España premusulmana, se mantuvo generalmente como ley común del país, pero pocos fueros hubo que no lo derogaran en pormenores. Un intento de unificar la multiplicidad de la legislación foral se manifiesta ya en la tendencia a modelar los fueros nuevos sobre determinados fueros antiguos tomados como tipos. Paso más significativo fué que Fernando adoptara el Fuero juzgo, ahora por primera vez traducido en lengua vulgar, como carta fundamental para Córdoba y otras ciudades después de 1241 . Pero se estaba preparando el terreno para una iniciativa de mayor alcance. La unidad jurídica debía ir precedida de la unidad política, y Fernando hizo más en este sentido que ninguno de sus predecesores inmediatos. No sólo reunió los reinos de Castilla y León a la muerte de su padre, Alfonso IX de León, en × 230 , sino que también reconquistó buena parte de la tierra ocupada por los moros. Mientras dos siglos y medio antes los moros estaban en posesión de tres cuartas partes de la Peninsula, el reinado de Fernando, que cul-

- El espéculo, tomo I de Opúsculos legales del rey don Alfonso el Sabio, edición de la Real Academia de la Historia, Madrid, 1836, pág. 3ı5. 
minó con la conquista de Sevilla en 1248 , cerró la era de las cruzadas españolas y dejó a la España musulmana reducida a la estrecha faja de territorio que era el reino de Granada.

Era concepto de la Edad Media que el progreso consistía ante todo en el retorno al glorioso pasado, desgraciadamente perdido a causa de la perversidad siempre creciente del hombre. Así Fernando podia anhelar, según las palabras de Alfonso, el retorno a los buenos tiempos de algunos de sus antepasados, que no se identifican claramente - quizá a los reinados de Fernando I y de Alfonso VII, que habían adoptado, uno y otro, el título de Emperador - :

Et aun ssin todo esto quisiera ennobleçer e onrrar más ssus ffechos, tornando su ssennorío a aquel estado en que ssolía sser e mantouyeran antiguamiente los enperadores e los rreyes onde él viníe; e esto ffuera sennaladamiente en ssiete cosas : EN RRAZÓN DE ENPERIO; EN SU CORTE; EN SU CONSEIO; EN SUS OFFIÇIALES; EN TOLLER los malos fuenos; be dar de las SSOLladas; en Justiçia. En rtazón del enperio, quisiera que ffuesse así llamado ssu ssennorío e non rregno, e que ffuese él coronado por enperador segunt lo ffueron otros de su linage... Otrosí que los fueros e las costunbres e los vsos que eran contra derecho e contra rrazón ffuesen tollidos e les diese e les otorgase los buenos... Et otrosí la justiçia que ffuese ordenada ssegunt que lo era en aquel tienpo ${ }^{1}$.

La pronta implantación de estas reformas se la reclamaban a Fernando sus vasallos y sus consejeros de más confianza. "Mas él, commo era de buen seso e de buen entendimiento e estaua sienpre aperçebido en los grandes ffechos, metió mientes e entendió que commo quier que ffuese bien e onrra dél e de los suyos en ffazer aquello quel conseiauan, que non era en tienpo de lo ffazer, mostrando muchas razones buenas que non se podía fazer en aquella sazón " : No sólo no se habían recuperado aún todas las tierras que ocupaban los moros, sino que, lo que era todavía más importante, "los omnes non eran adereçados en ssus ffechos así commo deuian, ante desuiauan e dexauan mucho de ffazer lo que les conuinía que fliziesen segunt ffizieron los otros donde ellos venían " 3 . En palabras que sugieren, y no poco, la eterna queja de la vieja generación. contra la nueva, leemos cómo los vasallos de Fernando erraban

1 Texto, pág. 22, lín. 3 y sigs.

-Texlo, pág. 22, lín. 26 y sigs.

3 Texto, pág. 23 , lín. 3 y sigs. 
contra Dios, contra sus principes y señores, y unos contra otros. Por todas estas razones Fernando :

... cató que lo meior más apuesto que puede sser era de fazer escriptura en que les demostrase aquellas cosas que auyan de fazer para sser buenos e auer bien, e guardarse de aquellos que los ffiziesen malos por que ouyesen a ffazer mal... Et esto que ffuese puesto en libro que oyesen a menudo... Et que lo ouyesen por fluero e por ley conplida e çierta ${ }^{1}$.

InigtaGión del Setenario bajo la diRegción de Alfonso el Sabio. - Este gran proyecto, que debía introducil un poco de orden en la caótica legislación de Castilla y León, se puso en marcha durante el reinado de Fernando, encargándose de él, en buena parte, Alfonso. Pero como al llegar Fernando al fin de su vida la tarea estaba todavía sin terminar, el rey apremió a su hijo para que la completase. Alfonso cumplió este mandato de su padre, no sólo como hijo obediente, sino también porque comprendía los altos propósitos que guiaron a Fernando en la empresa y las grandes ventajas que de ella obtendria su propio reino. Todo esto está claramente indicado en afirmaciones que hace Alfonso en el Setenario:

Onde, por toller estos males e otros muchos que viníen por esta rrazón, et desuiar los otros que podrían uenir, mandó el rrey don Fferrando ffazer este libro que touyese él e los otros rreyes que después dél viniesen por tesoro e por mayor e meior conseio que otro que pudiessen tomar, e por mayor seso, en que sse viessen ssienpre commo en espeio para ssaber emendar los ssus yerros e los de los otros e endereçar ssus ffechos e ssaberlos ffazer bien e conplidamiente. Et por toller estos ssiete males partió este libro en siete partes. Et mostró en cada vna dellas rrazones con que entendiesen los omnes lo que les conuinía que ffiziesen e de lo que sse deuyan guardar... Onde nos, queriendo conplir el ssu mandamiento commo de padre e obedeçerle en todas las cosas, metiémosnos a ffazer esta obra mayormiente por dos rrazones: la vna, porque entendiemos que auya ende grant ssabor; la otra, porque nos lo mandó a ssu ffinamiento quando estaua de carrera para yr a paraíso, o creemos que él ffué ssegunt las obras que él ffizo. Et porque entendimos conplidamienle quál era ssu uoluntad quel mouye a ffazerlo e ssobre qué rrazones teníe que lo deuye ffazer, e

- Texto, pág, 23, lín. r5 y sigs. 
metiemos nos otrossí nuestra uoluntad e ayudámosle a començar en ssu uida e conplirlo después de ssu ffin... Onde, por todas estas e por otras muchas bondades que en él auya e por todos estos bienes que nos ffizo, quisiemos conplir después de ssu fin esta obra que él auya començado en su vida e mandó a nos que la cunpliésemos. Et por ende punnamos de leuarla cabadelante quanto pudiemos e sseguir - aquella carrera. Et ssiguiemos aquel ordenamiento que entendiemos que era más segunt su uoluntad... Et nos don Alffonso, desque ouymos este libro conpuesto e ordenado, pusiémosle nonbre Septenario segunt que entendiemos que conuiníe a la natura de las rrazones e a la manera de fabla ${ }^{4}$.

\section{BIBLIOGRAFIA DEL SETENARIO}

Conviene ahora analizar brevemente la bibliografía del Setenario, porque, de todas las obras atribuídas a Alfonso el Sabio, ha sido una de las menos conocidas y la que con más insistencia ha sido mal interpretada. Factores diversos, sin duda, han contribuído a esta situación : 1) la simple circunstancia de que el manuscrito de Toledo, el primero que conocieron los eruditos, estaba casualmente encuadernado $\mathrm{y}$ foliado con otras obras de varia especie; 2) el hecho de que la escritura del fragmento de la Primera partida que sigue - y que forma con el Setenario la parte principal de aquel volumen - es al parecer la misma que la del Setenario"; 3) una cláusula discutida en uno de los testamentos de Alfonso ${ }^{3}$. Solamente ocho escritores, anónimo uno de ellos, han aportado contribuciones más o menos sustanciales y originales al buen entendimiento de la obra. La mayor parte de ellos la conocieron seguramente de primera mano en uno u otro de los tres manuscritos que se conservan. Aunque, naturalmente, están de acuerdo en general cuando tratan de los materiales que contiene, sus conclusiones sobre el verdadero carácter y significación de la obra resultan - caso sorprendente - muy variadas. Unos pocos han

Texto, pág. 25, lín. 7 y sigs. ; pág. 9, lín. 3 y sigs. ; pág. 1o, lín. 25 y sigs. ; pág. 25 , lín. 18 y sigs.

- Gfr. A. G. Solabinde, Un códice misceláneo con obras de Alfonso $X$ y otros escritos, en Revisla de Filología Española, XI, I934, pág. I8o, donde se describe este fragmento como "de letra igual a los folios anteriores".

- Véase más abajo, págs. xLI-xLır. 
descubierto alguna relación entre el Setenario y las Siete partidas; los demás no han visto esa relación o la han negado.

La descripción más antigua del Setenario puede atribuirse al Padre Andrés Marcos Burriel, el gran anticuario jesuita. La portada del manuscrito de Madrid, fechado en $\mathbf{1}_{7} 5_{2}$, que es copia del manuscrito de Toledo hecha por el Padre Burriel, lleva la calegórica afirmación de que el Setenario "es vna Introducción a la Obra de las Siete Partidas " '.

La primera mención impresa del Setenario es la de Terreros y Pando, que publicó, y no íntegramente, tres de las breves leyes referentes a San Fernando y presentó una reproducción, copiada a mano, de unas pocas líneas del manuscrito de Toledo?. Hablando de esta reproducción, describe así el Setenario :

La lámina $9^{\text {a }}$ se ha tomado de otro tomo en papel, que contiene la primera de las Siete Partidas, y antes de ella un libro que acaso las servía de Prólogo, o introducción, que trata principalmente de las cosas de la Religión Christiana, aunque se tocan en él casi todas las Ciencias, dirigido a los Reyes con título de Septenario. Su autor, el citado Rey Don Alonso $\mathrm{X}$, o Sabio, en cuyo tiempo está escrito, después de varios elogios de Dios, puso un largo $\mathrm{Pa}$ negyrico de su Padre San Fernando III, distribuído, según el méthodo de toda la Obra, por el número Septenario. ${ }^{3}$.

1 Véase más abajo, pág. L. El manuscrito de Madrid fué uno de los cmanuscritos pertenecientes a S. M., que se hallaban en el aposento del R. Padre Andrés Burriel " después de su muerte; corresponde al núm. 47 del Inventario de estos manuscritos hecho por Juan de Santander y publicado en la Colección de documentos inédilos para la historia de España, tomo XIll, Madrid, 1848 , págs. 33y-365. Una descripción similar del Setenario se halla en una carta escrita por el Padre Burriel al Padre Francisco de Rábago, confesor de Fernando VI : “... [he] copiado y corregido el Septenario, obra de este Rey, que servía de prólogo a sus Partidas ". Cfr. Antomio Valcadares de Sotomayor, Semanario erudito, tomo II, Madrid, 1787, pág. 14 .

- Padre Estevan de Tegkeros $x$ Pando, Paleografía española, Madrid, 1758 , págs. $7^{6-84}$.

${ }^{3}$ Ibid., pág. 76. La paternidad de Ia Paleografía española, publicada por primera vez en 1755 como tomo XIII do la traducción del francés que Terreros y Pando hizo del Espectáculo de la naluraleza ( 16 tomos, $17^{53-1} 7_{75}$ ) de Pluche, está en discusión ; algunos la han atribuído al Padre Burriel. Cfr. Emizio CoTARELo Y Mori, Diccionario biográfico y bibliográfico de calígrafos españoles, tomo II, Madrid, IgI6, págs. $269-270$. Sin tratar de resolver el problema de la paternidad de la Paleografia, es casi seguro que la descripción citada del Setenario se remonta por lo menos en espíritu al Padre Burriel, pues el mismo 
Las Memorias para la historia de la poesía y poetas españoles de Sarmiento, publicadas póstumamente, estaban escritas ya, en parte al menos, en $174^{\prime}$. De todos modos, sus observaciones nada deben a las obras antes mencionadas. Sarmiento no sólo supone que todas las obras encuadernadas junto con el manuscrito toledano del Setenario son " propia producción ... de nuestro Rey D. Alonso el Sabio ", sino que concibe el Setenario mismo como tres obras distintas y separadas :

Es un Códice en folio, en papel, y en letra antigua, el qual se conserva asimismo en la dicha Bibliotheca Toledana; y contiene las piezas siguientes. Primeramente una Vida del Santo Rey D. Fernando, que escribió su mismo hijo el Rey D. Alonso, y está con este artificio. Lo que hoy decimos Fernando, antiguamente se decia Ferrand, Ferrando, Ec. El Rey D. Alonso, como apasionado del número siete, y como se ve en el Prólogo de las Siete Partidas, le supone escrito así, Ferando, compuesto de solas siete letras. Después ideó siete capítulos; y en cada uno, según una letra de las siete de Ferando, va refiriendo varias virtudes del Santo Rey D. Ferando, o Fernando, su padre; hablando siempre de él como que era su propio hijo.

Después se sigue en el mismo Códice otro libro llamado Septenario ; y es una como Miscelánea de Philosophía, Astrología, y de cosas de nuestra Fe Cathólica. Item: se sigue la Misa, y sus Rúbricas, todo en antiguo Castellano. Item : la Primera Partida sola, de las siete de las Leyes. Item : una Visión de S. Patricio. Sospecho si acaso es la de aquel famoso Odoeno, de quien se dice entró en la cueba. Y finalmente, a lo último están diferentes retazos de historia. Por no tener ahora presente el dicho Códice, no puedo hablar con la extensión que quisiera ".

Correspondió a Rodríguez de Castro presentar un análisis más completo del Setenario ${ }^{3}$. Después de mencionar el manuscrito de Toledo y las observaciones de Terreros sobre la obra, procede a

Terreros reconoce la deuda que con él contrajo porque fué quien escogió Ias dieciocho ilustraciones que habían de incluirse en el volumen y quien las cotejó cuidadosamente con los originales (cfr. págs. 159-16o).

- Fr. Martím Sarmento, Memorias para la historia de la poesia y poetas españoles, Madrid, 1775 . Cfr. pág. I17 : "(este presente año 174r)".

"Ibid., págs. 288-289.

3 Josepri Rodrtguez de Castro, Biblioteca española, tomo II, Madrid, 1786 , págs. 680-686. 
transcribir los títulos de las leyes según el manuscrito del Escorial. Gita además el comienzo y el final del manuscrito - dice que ambos son deficientes - asi como la parte última de la ley I, la primera parte de la ley XI, e íntegras las leyes XLV y LXXVII. Su descripción del Setenario no incluye referencia alguna a las Siete partidas :

Esta Obra es una exposición y declaración de la Dotrina Christiana, con que el Rey D. Alonso quiso instruir así a los doctos como a los ignorantes en todos los misterios de la $\mathrm{Fe}$ Católica, demostrando el error de los Gentiles en haber adorado sus falsos Dioses, por no haber llegado a entender que las virtudes que les aplicaban, y las adoraciones que les prestaban, eran propiamente todas del verdadero Dios, de María Ssma., de los Santos Apóstoles y de los quatro Evangelistas; probando esto y demostrando la verdad de la Religión Católica en cada uno de los capítulos de este Libro por siete razones, traídas adequadamente a la materia de aquel capítulo: lo que se verá más claro en estos dos que se copian aquí, pertenecientes a los dos obgetos de este Soberano en su Libro, que intituló Setenario, porque cada cosa de las que trata en él están confirmadas por siete razones, o explicadas de siete modos ${ }^{2}$.

En un Informe sobre las obras del Rey Sabio, elevado al Gobierno en 1798 por la Academia de la Historia, cuyo autor probablemente había examinado una de las fuentes originales, se describe así el Setenario:

Es una obra enciclopédica, donde a la explicación de la variedad de materias que comprende, se procede constantemente explicándolas por siete medios o artículos, cuya división pareció al autor ser la más ajustada a la naturaleza de las razones y al método de hablar; y por esto le llamó Septenario ".

En las Memorias para la vida del santo rey don Fernando III, de Manuel Rodríguez, el propósito principal del autor era ofrecer materiales para glorificar la memoria del santificado monarca de España ". El "elogio " que hizo Alfonso de su padre (desde la par-

Ibid., pág. 684.

- Cita de José Amador de los Ríos, Historia crílica de la literalura española, tomo III, Madrid, 1863, pág. 557.

- Memorias para la vida del santo rey don Fernando $I I$, dadas a Iuz con apéndices y otras ilustraciones por don Miguel de Manuel Rodríguez, Madrid, 1800. Esta extensa obra fuć íntegramente atribuida por Manuel Rodríguez al Padre 
te final de la ley I hasta la ley XI, o sea desde la pág. 7, lin. s 8 hasta la pág. 25 , lín. 20 de nuestro texto), que servía por excelencia a ese propósito, quedó incluído y es así la única porción extensa que llegó a imprimirse hasta hoy del Setenario. Parte del pasaje que sirve de introducción a la transcripción del "elogio" dice así :

Hállase al principio de un tratado, que intituló don Alonso Septenario, sin duda porque, preciándose su autor de filósofo, abrazó la idea de dividir en siete miembros o partes todo quanto iba tratando en períodos separados; lo que demuestra que el método pitagórico era algo del genio y gusto poco fino de este Rey. Todo el tratado se reduce a explicar ciertas partes filosóficas en general, otras en particular, y por último concluir con la exposición de las que pueden pertenecer a un catecismo bastante curioso, y ajustado a lo que conviene que supiesen los christianos en aquella edad '.

Más de medio siglo después, Amador de los Ríos, teniendo presente gran parte de los trabajos mencionados, analizó el Setenario

Burriel, atribución casi universalmente aceptada. La idea de las Memorias, según su propia Introducción (págs. v-vur), aparece bosquejada en una petición que el Padre Burriel dirigió, en los primeros meses de $\mathbf{1}_{7} \mathbf{5 2}$, a Fernando VI en procura de apoyo real para la inmediala preparación de una obra de esa índole que se publicaría en el quinto centenario de la muerte de San Fernando. La transcripción del "elogio " del manuscrito de Toledo, acompañada de una muestra paleográfica, fué la primera ilustración documental anexa a la petición. Por uno u otro motivo, la ayuda solicitada no llegó nunca. Hay sin embargo prucba abundante de que la atribución de las Memorias al Padre Burriel és falsa. La paternidad exacta de distintas partes de esta obra es uno de los más enredados problemas menores de la bibliografía española, y problema demasiado complejo para que lo tratemos adecuadamente en este estudio. Baste decir que, si bien Manuel Rodriguez pudo quizá haber utilizado ciertos documentos del $\mathrm{Pa}$ dre Burriel, el primer tercio del volumen, poco más o menos, es sin duda adaptación de un manuserito copiado por el Padre Burriel, obra acaso de otro jesuíta, el Padre José Gassani. Todo el resto, seguramente, es en gran medida obra del propio Manuel Rodríguez, aunque no hay modo de determinar qué parte se debe a su anónimo continuador, pues una nota al final de la Introducción (pág. xir) explica que Manuel Rodríguez murió mientras esas pocas páginas estaban en prensa, $y$ da una clara impresión de que la mayor parte del texto del volumen no existía aún en la forma prometida por la Introducción y proyectada por Manuel Rodríguez. Gfr. José Kegrnio de Uriarte, Ciafálogo razonado de obras anónimas y seudónimas de autores de la Compañia de Jesús, tomo III, Madrid, Igo6, págs. 338-343.

\footnotetext{
Ibid., pág. 217.
} 
mucho más en detalle que ninguno de los anteriores ${ }^{1}$. Pinta un cuadro general de Jos comienzos del siglo xiII y se da cuenta del proyecto de Fernando de unificar la legislación del reino, según lo demuestran tanto la parte inicial del Setenario como el Prólogo de las Siete partidas; en tal virtud, trata de delimitar cuidadosamente la relación del Setenario con este proyecto y con otras obras legales de la época :

Iniciado de esta manera el pensamiento de reformar la múltiple y contradictoria legislación de León y Castilla, y obligado el rey don Alfonso por mandato expreso de su padre a poner mano en tan difícil empresa, acometía la de escribir aquella suerte de catecismo político, moral y religioso que debía en su entender facilitarla, y que siendo verdadero resumen de todos sus conocimientos en ciencias y letras, recibía el enigmático nombre de Septenario... Se ve pues claramente que el libro intitulado Septenario fué ideado por San Fernando, y aun comenzado a escribir, como una preparación moral para el Libro de las leyes que meditaba, y con objeto puramente didáctico. Así lo convencen plenamente su forma y las materias que contiene ".

Aunque Amador de los Ríos enumera las más de las principales secciones del Setenario, da importancia desproporcionada a un rasgo secundario, si bien interesante, del conjunto: las siete artes liberales. Tres de los cuatro breves pasajes que transcribe del manuscrito del Escorial se refieren a ellas. En conclusión, hace explícitamente el siguiente resumen sobre el carácter de la obra :

Tal es en suma el Septenario, o más bien diciendo la parte que de tan peregrino monumento ha llegado a los tiempos modernos. Conocidas ya las materias de que trata, ¿ será posible seguir confundiéndolo con las Partidas 3... Pudo servir, y quisieron don Fernando III y su hijo que sirviera, de introducción, no a este código precisamente, sino a un cuerpo legal que uniformase todos los fueros".

Otros escritores hablan del Setenario con mayor brevedad, dedicando no más de una o dos frases, por lo general, a descripciones que se basan, al parecer, en fuentes secundarias. Vargas y Ponce

1 Amador de los Ríos, obra citada, págs. 442 sigs.

- Ibid., pág. 483.

I Ibíd, pág. 560 . 
incluye entre las obras de Alfonso "Como Historiador", "El libro que llamó Septenario, y antecedía a las Partidas, en que puso un magnífico elogio de su padre " '. Pérez Bayer, en una nota a la noticia que da Nicolás Antonio sobre las Siete partidas, menciona los tres manuscritos del Setenario de Alfonso, "quod

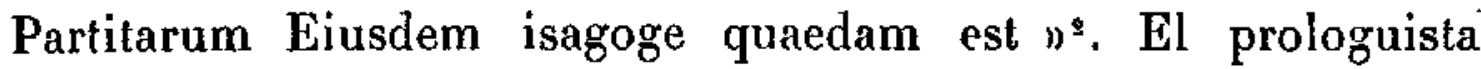
de la edición académica de las Siete partidas, aunque menciona los manuscritos de Toledo y de Madrid y describe el Setenario y los demás fragmentos encuadernados con el manuscrito de Toledo, se contenta con citar el juicio contenido en la $\mathrm{Pa}$ leografía española, atribuyendo esta obra al Padre Burriel '. Los traductores castellanos de la Historia de la literatura española de Bouterwek también mencionan el Setenario como "introducción" o "prólogo " a las Partidas *. Clarus, que se apoya en Sarmiento, lo describe como " ein Mischmasch aus Philosophie, Astrologie und Theologie " ". Marichalar y Manrique, en su Historia de la legislación, concluyen, después de apresurado examen de las $M e$ morias de Mantuel Rodríguez, que "el Setenario no es otra cosa que un panegírico del rey San Fernando, escrito, según la opinión más fundada, por el mismo Don Alonso ", y hablan de las "trece secciones" que comprende el Setenario, errónea noción derivada de los trece grupos de cuadrados, correspondientes a los " óvalos " de los manuscritos, que en esas Memorias aparecen a lo ancho de las páginas de la transcripción del « elogio » ${ }^{6}$ : Baist, para

1 Joserh de V VRgas y Ponce, Elogio del Rey Don Alonso el Sabio, premiado por la Real Academia Española, en junta que celebró el día 15 de octubre de 1782, en Obras de eloqüencia y de poesia premiadas por la Real Academia Española, tomo I, Madrid, s. a., págs. 69 y 73 (cada una de las once obras encuadernadas en este volumen tiene su paginación propia).

- Nicoldo Antonio Hispalensi, Bibliolheca hispana vetus, edición de Francisco Pérez Bayer, tomo II, Madrid, I788, pág. 87.

${ }^{3}$ Las siete partidas del rey don Alfonso el Sabio, edición de la Real Academiá de la Historia, tomo I, Madrid, 1807 , págs. xxxix-xus.

- Frederick Boutarwek, Historia de la literatura española, escrita en alemán, traducida al castellano y adicionada por D. José Gómez de la Cortina y D. Nicolás Hugalde y Mollinedo, Madrid, 1829, págs. ı22-1 23.

- Ludwig Clanus, Darslellung der spanischen Literatur im Miltelalter; tomo I, Maguncia, 1846, pág. 340.

- Amalio Marichalar, Marqués de Montesa, y Capetano Manrigue, Historia de la legislación y recitaciones del derecho civil de España, tomo III, Madrid, I 862, págs. $9^{t-9}$. 
subrayar su descripción del Setenario como obra enciclopédica, cita del Libro de la caza de Juan Manuel una referencia a Alfonso, "que fizo tralladar en este lenguaje de Castiella todas las sçiençias, tan bien de thelogía commo la lógica, e todas las siete artes libertales commo toda la arte que dizen mecánica ", y parece haber creído que la "mecánica " haya figurado en una parte perdida del texto ".

Dos de los catálogos de la Biblioteca del Escorial mencionan el manuscrito escurialense del Setenario. Llacayo y Santa Maria lo incluye en un capítulo intitulado "Códices literarios y curiosos " y lo describe como "Tratado de moral, filosofía e historia, en que se habla de Dios, de la fe y del Rey D. Fernando, padre de D. Alfonso el Sabio " : En la obra de Zarco Cuevas se le incluye, en el índice, entre las obras de "Teología dogmática, moral y pastoral " 3 .

La más sorprendente de todas las descripciones del Setenario - la que aceptan, sin excepciones apenas, los recientes manuales de historia de la literatura española - es la que lo convierte en tratado de las siete artes liberales. Esta definición parece remontarse a Amador de los Ríos, el cual no sólo, como hemos visto, da gran importancia al tema de las artes liberales mientras dedica sólo unas pocas frases a resumir la parte principal del contenido, sino que además habla específicamente del Setenario como " el primer modelo de este linaje de obras, que, encerrando toda la cien cia de la edad media, llegaron a formularse en casi todas las literaturas ". Además, combate la posible suposición de que los Livres dou trésor de Bruncto Latini se hayan escrito antes que el Setenario y se les pueda atribuir así la distinción de haber servido de modelo. Henry Butler Clarke fué, según parece, el primero en adoptar esta descripción, cuando afirma que entre las obras más importantes de la especie de los tratados didácticos o morales hay

- Gottrkied Barst, Die spanische Lileralar, en Grundriss der romanischen Philologie, tomo II, parte II, Estrasburgo, 1897, pág. 41 I. La cita está tomada directamente de la obra de Juan Manuel, edición de Baist, Halle, I88o, pág. I.

- Augusto Leacayo y Santra María, Anliguos manuscritos de historia, ciencia y arte militar, medicina y literarios existentes en la Biblioteca del montasterio de San Lorenzo del Escorial, Sevilla, 1878, pág. 330.

${ }^{3}$ P. Fr. Julán Zarco Cuevas, Calálogo de los manuserilos castellanos de la Real Biblioteca de El Escorial, tomo III, San Lorenzo de El Escorial, 1929, pág. 388. Solalinde, que también ha examinado y descrito el manuscrito de Toledo (abra cilada, págs, 178-183), no da definición ninguna del Selenario.

+ A mador de los Ríos, obra cilada, pág. $56 \mathbf{r}$. 
que contar "the Setenario of Alfonso the Wise, a treatise on the seven branches of learning, comprising the trivio, Grammar, Rhetoric, and Logic, and the cuatrivio, Music, Astronomy, Physics, and Metaphysics " $"$.

Resulta evidente que el Setenario ha significado cosas distintas a distintas personas. Todos los autores mencionados vislumbraron parte de la verdad, pero bien puede decirse que ninguno la vió toda. La descripción primera de todas, repetida después varias veces, es ciertamente la más acertada de ellas, porque atiende, aunque no con mucho rigor, a una relación entre el Setenario y las Siete partidas. El clasificarlo como exposición y declaración de doctrina cristiana o como una especie de catecismo moral y religioso llama la atención sobre el hecho de que casi todo su contenido puede describirse como de carácter religioso o doctrinal, pero no advierte las implicaciones mayores de este contenido * Decir que es obra de tipo " filosófico " significa poco más que decir que es de propósito dicláctico, como es obvio. Llamarlo obra enciclopédica no"es tampoco adelantar mucho, porque igual cosa cabe decir de tantas otras obras de la época sin por eso definirlas en particular. El Setenario no es, ciertamente, obra histórica ni mero panegírico de San Fernando, puesto que el " elogio " abarca menos de diez de sus ciento ocho leyes. Ni es tampoco un tratado sobre las artes liberales, porque sólo trata de ellas en la ley XI, aunque sea ésta la más larga de todas. En cierto sentido el Setenario es todas estas cosas, pero también es algo más.

${ }^{1}$ Hemrx Butrer Graree, Spanish Lileralure: an Elementary Handbook, Londres, 1893 , pág. 23 . Los manuales siguientes, casi sin variación, repiten esta clasificación : Ánger. Sataedo y Ruiz, La lileratara española, tomo I, Madrid, 1915, págs. 260-261; Jucio Cejsbor y Fravas, Historia de la lengua y lileralura castellana, tomo I, Madrid, I915, págs. J99-200; Javes Fitzmaurice-Kelly, History of Spanish Literature, Nueva York, 1931 , pág. 64 ; ERnest Mérmée, Précis d'histoire de la litlérature espagnole, París, rg22, pág. 74 ; Juan J. ReMos y Rurro, Cur'so de historia de la literatura castellana, La Habana, 1922, pág. 64 ; Luowig Praxdu, Spanische Literalurgeschichte, tomo I, Berlín, 1923, pág. 24; Agustín Basave, Breve historia de la literatura castellana, Guadalajara de México, 1925, pág. 28 ; Manuel de Montolíu, Literatura castellana, Barcelona, 1930 , pág. 7 r.

- Ha sido opinión, por lo menos de un historiador, que aun las Siete partidas fueron concebidas simplemente como obra doctrinal destinada a preparar al país para reformas legales posteriores. Cfr. Juair Sampene y Guarinus, Biblioteca española económico-política, tomo II, Madrid, I804, págs. 48-53. 


\section{EL SETENARIO Y LAS SIETE PARTIDAS}

La descripgión de Martivez Marina. - He omitido deliberadamente, en la anterior exposición, el nombre de un autor que estudió el Setenario en fuente original. Éste es el único que percibió todo el significado de la obra. Me refiero a Francisco Martínez Marina, cuyo inestimable Ensayo histórico-crilico sobre la antigua legislación estuvo destinado, en su origen, a servir de prólogo a la edición académica de las Siete partidas '. Su análisis del Setenario se reduce a unos párrafos, pocos pero bien concebidos. No indica su fuente, que debió de ser el manuscrito de Toledo o el de Madrid, y los pocos pasajes que cita están ligeramente modernizados en ortografía y acertadamente corregidos. Parece muy posible que Martínez Marina llegara a sus conclusiones ante todo por intuición, porque Ia falta de pormenores en su descripción no hace pensar que haya examinado la obra tan detenidamente como algunos de los otros autores ya citados, si bien con esto no quiero quitarle los méritos que le corresponden. Su descripción del Setenario es como sigue :

El libro Setenario, según le disfrutamos hoy, se puede dividir en dos partes: en la primera, que viene a ser una especie de introducción añadida por don Alonso el Sabio, se trata difusamente de varias cosas notables, comprehendidas en el número siete, como de siete nombres de Dios; de los siete dones del Espíritu Santo; de siete virtudes del rey don Fernando; de siete perfecciones de la ciudad de Sevilla ; de las siete artes liberales; de lns siete planetas; y otras de esta naturaleza. La segunda abraza las mismas materias de la primera Partida; pero no llega más que hasta el sacrificio de la misa. Comienza por un tratado sobre la Santa Trinidad y fe católica, con cuyo motivo se trata de la idolatría y errores de los gentiles, de la naturaleza de los astros que ellos adoraban, y de los signos del zodíaco : van a continuación las leyes relativas a los sacramentos, muy pesadas y difusas".

- Frangisco Martfezz Marima, Ensayo histórico-erilico sobre la antigua legislación y principales cuerpos legales de los reynos de León y Castilla, especialmente sobre el códiga de D. Alonso el Sabio, conocido con el nombre de las Siete Partidas, Madrid, 1808.

I Ibid., pág. 243. 


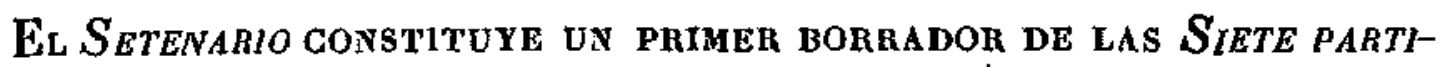
DAS. - La hipótesis principal de Martínez Marina puede resumirse asi : El Setenario representa una primera versión incompleta del proyecto, concebido por Fernando, de unificar los procedimientos jurídicos de España, el cual dió su fruto pleno en las Siete partidas de Alfonso el Sabio \&. Las páginas siguientes se dedicarán a presentar las pruebas en apoyo de esta tesis y a explicar cómo y por qué el material del Setenario llegó a adaptarse a las finalidades de la Primera partida. Puede decirse que las pruebas no son abundantes; las más de ellas son indirectas, otra parte es mera conjetura, pero de cuando en cuando aparece alguna prueba incontrovertible.

Plan del Setenario. - Conviene, para los fines de este análisis, considerar dividido el Setenario en diez secciones, de acuerdo con las materias tratadas. En el cuadro siguiente se indica el porcentaje aproximado que ocupa cada una de estas secciones dentro de la obra total, y también las páginas de las porciones que les corresponden en general en la Primera partida ${ }^{*}$ :

I. Introducción (incluso el « elogio $»)$, I-XI $(16 \%) \ldots \ldots$ I-9

2. Sectas idólatras de la antigüedad, XII-XXXIX $(9 \%) \ldots$ (10-36)

3. Artículos de fe, XL-XLII $(2 \%) \ldots \ldots \ldots \ldots \ldots \ldots, 36-45$

4. Justificación de sectas idólatras, XLIII-LXIX $(18 \%) \ldots$

5. Sacramentos en general, LXX-LXXVI $(3 \%) \ldots \ldots \ldots$ 45-52

6. Primer sacramento (bautismo), LXXVII-LXXXVII (10\%) $52-77$

7. Crisma, LXXXVIII-XGV $(8 \%) \ldots \ldots \ldots \ldots \ldots \ldots 7^{-110}$

8. Segundo sacramento (confirmación), XCVI $(2 \%) \ldots \ldots$ r $10-115$

9. Tercer sacramento (penitencia), XCVII-CIII $(18 \%) \ldots$ r 8 5- 170

1o. Cuarto sacramento (comunión), GIV-CVIII (14\%) .... 170-1 87

- Debe decirse que los siguientes autores, que probablemente se inspiran en Martinez Marina, dan noticias correctas en lo esencial sobre el Setenario : Rosseeuw Samr-Hichine, Histoire d'Espagne depuis les premiers temps historiques jusqu’à la mort de Ferdinand VII, tomo IV, París, I 844, págs. 226 y 228-23o ; Gronge Ticrmor, History of Spanish Lilerature, tomo I, Boston, I864, págs. 35 y 46 ; Manuet Colmeno, Reyes cristianos desde Alonso VI hasta Alfonso XI en Castilla, Aragón, Navarra y Portugal, tomo $\mathrm{V}$ de Hisloria general de España, Madrid, 1891 , pág. 3a7; Rafael Artamira y Crevea, Hisloria de España y de la civilización española, Barcelona, I 909 , tomo I, pág. 434, y tomo II, págs. $78-$ 79 ; Remé Bastranini, Curso de historia de la literatura castellana: texlo y antología, tomo I, Buenos Aires, 1922, págs. 185-186.

* Las indicaciones de página de la Primera partida se refieren a la edición académica de las Siete partidas, ya citada. 
Se observará que el orden general de los materiales en el Setenario y en la Primera partida es uno mismo. El Setenario corresponde al Prólogo de las Partidas y a los primeros cuatro "títulos" de los veinticuatro que comprende la Primera partida. Las secciones 2 y 4 , propiamente hablando, no tienen correspondencia, aunque los títulos I y II ("Que fabla de las leyes" y "Que fabla del uso et de la costumbre en qué manera debe ser ") vienen en cierto modo a sustituir las seis primeras y breves leyes de la sección $2{ }^{*}$. La sección 3 corresponde al título III ( " De la Santa Trinidat "), mientras que las secciones 5- io corresponden al título IV ("Que fabla de los sacramentos de Santa Eglesia ").

Detalle de las correspondencias entre el SETENario y la PrIMERa PARTIDA. - La correspondencia entre los comienzos de las dos obras sólo puede establecerse por deducción, puesto que el Setenario está incompleto al comienzo, faltándole probablemente un solo folio en el manuscrito de Toledo ${ }^{2}$. En la ley I, que trata de los siete nombres de Dios derivados de cada una de las siete letras del nombre "Alpha et $\mathrm{O}$ ", faltan todos los correspondientes a las dos primeras letras, excepto las últimas líneas relativas a los nombres que comienzan con $L$. Hacia el final de esta ley, como resumen de estos nombres de Dios, inmediatamente antes del " elogio", aparecen las frases siguientes :

Onde la A con rrazón demuestra, ssegunt de ssuso dixiemos, que Dios es comienço, et la $0 \mathrm{Jfin}$; non porque Dios ouo comienço en ssí nin puede sser acabado, mas porque él da comienço $\mathrm{e}$ acabamiento a todas las cosas que él ffizo. Et las otras çinco letras que sson en medio muestran las otras cosas que en él sson, ssegunt el ssaber e el poder e la uertud que ha ${ }^{3}$.

Compárese este pasaje con la primera frase del Prólogo de las Siete partidas : "Dios es comienzo et medianía et fin el acabamiento de todas las cosas, et sin él cosa alguna non puede ser ; ca por el su saber son fechas, et por el su poder guardadas, et por la su bondat mantenidas " *. La semejanza de las palabras que van en cursiva

- Véase más abajo, pág. xxxil.

2 Véase más abajo, pág. xlrv.

3 'Texto, pág. 7 , lín. 5 y sigs. La cursiva en las citas del Setenario y de la Primera parlida, aquí y de aquí en adelante, es mía.

- Primera parlida, pág. I. 
en estos dos pasajes, y además el hecho de que alguna variación sobre el tema de "Alfa y Omega" era la nota adecuada para comenzar obras de esta índole, sugiere la probabilidad de que los comienzos de ambas fueran sustancialmente iguales. A menos que se suponga que el folio perdido del Setenario contuviera alguna afirmación semejante a la que inicia las Partidas, no hay nada a que pudiera referirse la expresión "ssegunt de ssuso dixiemos".

La sección a del Setenario corresponde en general al Prólogo de las Partidas (págs. I-9). Más específicamente, la ley XI corresponde a la segunda mitad del Prólogo, que lleva un encabezamiento algo semejante: "Por quáles razones este libro es departido en siete partes ». El principio de esta parte del Prólogo dice como sigue :

Setenario es un cuento muy noble que loaron mucho los sabios antiguos, porque se fallan en él muy muchas cosas et muy señaladas que se departen por cuento de siete, así como todas las criaturas, que son departidas en siete maneras. Ca segunt dixo Aristótilis et los otros sabios, o es criatura que non ha cuerpo ninguno, mas es espiritual, como ángel et alma; o es cuerpo simple que non se engendra nin se corrompe por natura, et es celestial, así como los cielos et las estrellas; o ha cuerpo simple que se corrompe et se engendra por natura, como los elementos; o ha cuerpo compuesto et alma de crecer et de sentir et de razonar, como home; o ha cuerpo compuesto et alma de crecer et de sentir et non de razonar, así como las otras animalias que no son homes; o ha cuerpo compuesto de crecer, mas non de sentimiento nin de razón, así como los árboles et todas las otras plantas; o ha cuerpo compuesto et non alma nin sentimiento, así como los metales et las piedras et las cosas minerales que se crían en la tierra [cfr. págs. 27, 20-28,10]. Otrosí todas las cosas naturales han movimiento, que se departe en siete maneras; ca o es asuso o ayuso, o adelante $o$ atrás, o a diestro o a siniestro, o en derredor [cfr. pág. 28,11-19]. Et en este mesmo cuento fallaron los sabios antiguos las siete estrellas más nombradas, a que llaman planetas, et de que tomaron cuento por los siete cielos en que están por los sus nombres [c $f r$. pág. 39,30-32]; et ordenaron por ellos los siete días de la semana [cfr. págs. 39,32-40,2]. Et los sabios departieron por este cuento de siete las partes de toda la tierra, a que llaman climas [cfr. pág. 40,7-11]. Et por este mesmo cuento departieron los metales [cfr. págs. 40,12-42,19]. Et otrosí algunos hi hobo que por este cuento de siete partieron los saberes, a que llaman artes [cfr. págs. 
$29,19-39,27]$ : eso mesmo fecieron de la edad del home [cfr. págs. $28,20-29,18]^{3}$.

Una comparación entre los ejemplos del leit-motiv septenario aducidos en el pasaje anterior y los pasajes del texto del Setenario indicados entre corchetes revelará cómo esta parte del Prólogo de las Partidas representa una simple enumeración, aunque no siempre en el mismo orden, de casi todo el material contenido en la ley XI, donde por lo general esos ejemplos ilustrativos están presentados con bastante detenimiento.

A pesar de que la ley XI es casi dos veces más larga que la más larga de las leyes restantes, es todavía incompleta. A causa de una ruptura existente - la única importante - en la continuidad interna del Setenario, ruptura que ocurre tanto en el manuscrito de Toledo como en el del Escorial, esta ley sólo abarca cuatro de las siete divisiones originalmente proyectadas. Parecería probable, pues, que el resto del Prólogo, desde el pasaje citado hasta el comienzo de la Primera partida propiamente dicha, pueda igualmente representar en el Setenario una condensación de la materia que falta al final de la ley XI. La continuación del pasaje anterior, que comprende diez ejemplos más para ilustrar el leit-motiv septenario, todos de fuente bíblica, y además una indicación del contenido de cada una de las siete partidas de la obra, dice así en parte :

Et aun por ese mesmo cuento demostró Dios a los que eran sus amigos muchas de sus poridades por fecho et por semejanza, así como a Noé, a quien mandó facer el arca, en que se salvase del deluvio, et que le mandó que de todas las cosas que fuesen buenas et limpias metiese en ella siete. Otrosí Jacob, que fué patriarca, servió a su suegro siete años por Rachel, et porque le dió a Lía servió otros siete por ella mesma, et esto fué por muy grant significanza... Et en este cuento mesmo nos dió Nuestro Señor lesu Cristo siete sacramentos, por que nos podiésemos salvar. Et otrosí en este mesmo cuento nos mostró él mesmo la oración del Pater noster, en que ha siete cosas en que le debemos pedir me[r]ced... Onde por todas estas razones, que muestran muchos bienes que en este cuento son, partimos este nuestro libro en siete partes, et mostramos en la primera dellas de todas las cosas que pertenescen a la santa fe católica, que facen al home conoscer a Dios por creencia...

Primera partila, págs. 6-7. 
Et en la setena partida, de todas las acusaciones et los males et las enemigas que los homes facen de muchas maneras, et de las penas et de los escarmientos que merescen por razón dellos ${ }^{1}$.

¿Qué pruebas hay de que alguna parte de este material de las Partidas estuvo originalmente incorporado al Setenario? Hay una sola, pero de las más convincentes. Ya muy avanzado el Setenario, en la ley $\mathrm{C}$, aparece la siguiente frase : " Et en la ssegunda oración del Pater noster sson ssiete petiçiones que Nuestro Ssennor Ihesu Cristo nos amostró, con que ssopiéssemos pedir merçet a Dios ssu padre, ssegunt es dicho en el comienço deste libro, offabla del cuento del ssetenario " ". Estas palabras finales deben considerarse como alusión segura a alguna afirmación perdida de la ley $\mathrm{XI}$, semejante a las primeras líneas que van en cursiva en la cita inmediatamente anterior de la Primera partida. La primera mención del Pater noster en el Setenario, tal como lo conocemos, no ocurre en lo que podría llamarse el comienzo de la obra, sino en la ley LXXXIV, o sea en la segunda mitad del texto ${ }^{3}$. Puede agregarse que el empleo de setenario como sustantivo común sólo se da, fuera del ejemplo citado, en la ley XI.

Lo omitido en la Prisera partida. - No hay huella en Ia Primera partida del "elogio" de Alfonso a su padre, que incluye también un panegírico del reino de Sevilla ". Así mismo, las secciones 2 y 4, cuyo interés primordial sólo podía ser erudito, se omitieron totalmente. De este modo, las secciones 1,2 y 4 , que abarcan como el $43 \%$ del Setenario en la forma en que ha llegado hasta nosotros (si los materiales perdidos al comienzo de la obra y al final de la ley XI se tomaran en cuenta, la proporción se aproximaría a un $50 \%$ del total), o se omitieron totalmente o

1 Primera partida, págs. 7-9.

Texto, pág. 204 , lín. 23 y sigs.

'Texlo, pág. 145, lín. 8 .

- La única referencia a Fernando en las Partidas es la siguiente, que le concede todo su mérito en la iniciativa del proyecto legislativo que estamos estudiando: " Et posimos cada una destas [razones] onde conviene, et a esto nos movió señaladamiente tres cosas : la primera, que el muy noble et bienaventurado rey don Fernando, nuestro padre, que era muy complido de justicia et de verdat, lo quisiera facer si más visquiera, et mandó a nos que lo feciésemos... "; cfr. Primera partida, pág. 5. 
se condensaron en el espacio de unas dos páginas de la Primera partida. Todo este material, pensándolo bien, no era particularmente apropiado para un libro de leyes, aun desde el punto de vista del siglo xir. La indole esencialmente extraña de las muchas leyes relativas a las sectas idólatras se nos manifiesta además en el hecho de que las leyes que se encuentran al final de cada una de esas dos secciones - las leyes XXXV-XXXIX y LXVII-LXIX no se ajustan exactamente a las secciones en que se han clasificado, sino que más bien sirven de transición hacia el material que sigue en cada caso. Es cierto que materiales más en consonancia con los propósitos de la Primera partida han venido a sustituir a la primera parte de la sección 2 del Setenario, que corresponde al comienzo propiamente dicho de esta Partida (págs. 10-36). Donde el Setenario trae leyes que definen y explican las palabras secta, opinión, antojança, fantasía, suenno y visión, la porción correspondiente de la Primera partida trata de modo similar las palabras ley, uso, costumbre y fuero.

Correspondevcias máximas. - La correspondencia entre la Primera partida y las secciones 3 y 5-9 del Setenario es, por lo general, estrecha. No tanto en el material que sirve de introducción a cada una de las dichas secciones, donde apenas hay una leve semejanza, o sólo una semejanza de tono, pero sí, sobre todo, en los pasajes ritualísticos de ambas obras, así como en muchos otros, que son casi idénticos. La siguiente yuxtaposición de textos ilustrará hasta qué punto esto puede ser cierto:

\section{Setenario}

Poder de ffazer la crisma, esto non es dado a otre ssinon a los prelados mayores, assí commo apostóligos o patriarchas o primados o arçobispo o obispo, porque ellos tienen logar de los apóstoles, que flueron conpaneros de Nuestro Ssennor Ihesu Cristo et vieron todo ssu ffecho et entendieron spiritualmiente las sus obras, a que ouyeron a rrecudir; et conosçieron por el ssu ssuor e ssu trabaio e

\section{Primera partida}

Poder de facer la crisma non es dado a otro sinon a los perlados mayores, así como al apostóligo o patriarca o primado o arzobispo o obispo. Et esto es porque ellos tienen el lugar de los apóstoles, que fueron compañeros de Nuestro Señor Iesu Gristo et vieron todo su fecho et entendieron espiritualmente todas las sus obras, a que habían de recodir ; et conoscieron que el suor et el trabajo et la su 
la ssangre que esparzió, ssuffriendo penas e en cabo muerte en la cruz por uos, que ffué vngüento por que fluésemos ssanos e rredemidos de nuestros peccados. Et que a ssemeiante de aquello que ffué estableçido ffiziessen este otro, que es llamado crisma, por que los cristianos sson ssagrados e an nonbre de Cristo; ca crissma tanto quiere dezir en griego commo vngüento sagrado en ssí que sagra las otras cosas. Et por ende ordenó Santa Eglesia que otro non ouyese poder de ffazer crisma, que es el ssu vngüento, ssinon los prelados mayores, porque ellos tienen las ssus veres en tierra a ssemeiante dél.

Que a los rreyes e a los ssaçerdotes ssolian vntar antiguamiente con olio e con otros vngüentos preçiados, et esto non tan ssolamiente ge lo ffazían en la ffruente e en las espallas, commo vntan los de agora, mas de ssomo de la cabeça fasta ffondón de las piernas. Et Moysés mismo lo ffizo Âarón quando lo vngió por ssaçerdote en la eglesia de Dios que era entonçe por que ffiziese el ssu ssacriffiçio. Et Ssamuel el propheta vntó a Ssaúl, que ffué el primero rrey de los judíos, por mandado de Dios, et otrossí lo ffizo al rrey Dauid. Et Natán el propheta vntó a Ssalamón.

Que ffué más noble e más conplida la vnçión de Ihesu Cristo que todas las otras, et esto ffué porque todos los otros lo rreçibieron por mano de omnes, et él rreçibiólo por Dios ssu padre. Et ssi ellos lo ouyeron rreçebido por ayunta- sangre que él esparció, sofriendo penas et en cabo muerte en la cruz por nos, que fué engüento por que fuésemos sanos et redimidos de nuestros pecados. Et que a semejante de aquello feciesen este otro, que es llamado crisma; ca tanto quiere decir crisma en griego como engüento sagrado en sí et con que sagràn otras cosas.

Et esto solíen facer antiguamiente a los reyes et a los sacerdotes; ca les untaban las cabezas con olio et con otros engüentos preciados. Et Moysén mesmo lo fizo a Arón su hermano quando lo ungió por sacerdote en la eglesia de Dios que era estonce por que feciese el su sacrificio. Et Samuel el profeta untó a Saúl, que fué primeramente rey del pueblo de Israel, por mandado de Dios. Et eso mesmo fizo el rey David, et Natán profeta untó a Salomón.

Mas la unción de Nuestro Señor Iesu Cristo fué más noble et más complida que todas; ca si los otros la recebieron por homes, él recjbióla por Dios su padre. Et si la recibieron por ayuntamiento de confeciones, él recibióla por ayun- 
miento de conffecçiones, él rreçibiólo por ayuntamiento de la Ssanta Trinidat, que sse ayuntó en él. Et por ende a Sant Iohán Babtista, por quien dixo Nuestro Ssennor Ihesu Cristo que era propheta e más de profecta, vinieron preguntar los judíos a qui dizían phariseos ssi era él Cristo. Et él dixo non, mas después dél uerníe aquel que ffuera ffecho ante que él, del qual él non era digno de descalçar la correa del ssu çapato. [Et en esto mostró la Trinidat, do dixo que después dél uerníe aquel que ffuera ffecho ante que él, del qual non era digno tan ssolamiente de descalçar la correa del ssu çapato.] Et otrossí dió este testimonio de la Trinidat, allí do mostró que ssopiera por Dios que ssobre aquel que viesse desçender el Spíritu Santo en ffigura de paloma, que aquél era el que baptizaua en Spíritu Santo.

Que tenporalmiente ffué ssagrado Nuestro Ssennor Ihesu Cristo ssegunt rrey muestra que ffué rreçibiendo muerte e passión por nos; ca allí do lo alçaron en la cruz e le pusieron corona de espinas por desonrra, [allí ffué él alçado de Dios ssu padre por onrra] quandol dió poder ssobre todas las cosas e le coronó en los çielos e le dió el rregno por ssienpre. Et la vntura sagrada desto ffué la ssangre que ssalió del ssu cuerpo, de que ffué cubierto e vntado de ssomo de la cabeça fasta ffondón de tanza de la Santa Trinidat, que se ayuntó en él. Et por ende a Sant Johán Baptista, por quien dixo Nuestro Señor Iesu Gristo que era profeta et más de profeta, venieron a preguntar los judíos a quien decían fariseos si era él Cristo. Et él dixo que non, mas que después dél vernía aquel que era fecho ante que él, del qual él non era digno solamente de tañer ni de desatar las correas de los sus zapatos. Et en esto mostró la Trenidat, do dixo que después dél vernía aquel que fuera fecho anle que él, et al qual non era digno tan solamiente de taĩer los sus pies. Et otrosí dió este testimonio de la Trenidat, allí do mostró que sopiera por Dios que sobre aquel que viese decender el Espíritu Santo en figura de pàloma, que aquél era el que bautizaba en Espíritu Santo. Et sin esto dió testimonio dél quando bautizaba a Iesu Cristo, que oyó la voz del Padre quel dixo que aquél era el su fijo que él mucho amaba.

Et desta guisa fué Nuestro Señor Iesu Cristo sagrado espiritualmente por mayor sacerdote, mas temporalmente segunt rey fué sagrado recibiendo muerte et pasión por nos ; ca allí do lo alzaron en la cruz et le posieron corona de espinas por deshonra, allí fué él alzado de Dios su padre por honra quandol dió poder sobre todas las cosas et lo coronó en los cielos et le dió regno para siempre. Et la untura sagrada desto fué la sangre que salló del su cuerpo, donde fué él untado et cobierto desde en somo. 
los pies. Onde por todas estas rrazones que auemos dicho ffué Nuestro Ssennor ssagrado ssegunt obispo en ssantidat e en ssaber, ssegunt rrey en poder e en justiçia : de la cabeza fasta en fondón de los pies. Onde por todas estas razones que habemos dichas fué Nuestro Señor Iesu Cristo sagrado segunt obispo en santidat et en saber, et segunt rey en poder et en justicia. Et por ende ordenó Santa Eglesia que non hobiese otri poder de facer la crisma, que es el su ungüento, sinon los perlados mayores, segunt deximos en el comienzo desta ley, porque ellos tienen las sus veces en tierra a semejante dél ".

El pasaje del Setenario es la parte de la ley LXXXIX ("De cómmo estableçieron los santos padres la crisma ") que se ocupa de las últimas cuatro de las siete subdivisiones siguientes : "por el nonbre que ganó de Thesu Cristo; porque él fué vntado con ella spiritualmiente por ssaçerdote; porque tenporalmiente fué vntado por rrey; de los que la pueden ffazer; cómmo lo ssolian ffazer antigaamiente a los rrejes e a los ssaçerdotes; por rrazón que ffaé más noble la vnçión de Ihesa Cristo que la de los otros; de cómmo Ihesu Cristo ffué ssagrado tenporalmiente ssegunt rrey". El pasaje de la Primera partida es una ley completa ("Quién puede facer la crisma "). Algunas de las leves diferencias que hay entre los dos pasajes se deben, como puede verse, a que el último rompe la división septenaria. Además, las líneas en cursiva del primero aparecen más apropiadamente al final del segundo pasaje, siendo - como son - el resumen de toda la ley.

Que esta cita de la Primera partida se remonta al Setenario (no a un manuscrito existente del Setenario, sino a uno perdido) se confirma por el hecho de que suple líneas realmente esenciales para el presente texto. La primera parte en cursiva del pasaje de la Primera partida o bien alguna variación de la misma pertenece muy probablemente al Setenario, pues de otra manera el "otrossí dió este testimonio de la Trinidat " que va inmediatamente después parece enteramente inexplicable. La última parte en cursiva del mismo pasaje representa un caso indudable de omisión de tipo

1 'Texto, págs. I55-i 57 .

- Primera partida, págs. 79-80. 
homeográfico en la familia de manuscritos existentes del Setenario. Uń examen detenido de los dos pasajes revelará otros casos aunque no puedan demostrarse con tanta certeza como los señalados - en los cuales la Primera partida podría suplir otras lecciones del Setenario y por su parte el Setenario lecciones de la Primera partida ${ }^{1}$.

Correspondencias mínimas. - Hay muy escasa correspondencia entre la sección 10 del Setenario y la Primera partida, aunque, desde luego, la materia es en general la misma. Mientras que en el Setenario se expone el ritual completo de la misa, en la Primera partida sólo hay referencias dispersas al rito mismo. La omisión no tiene nada de sorprendente. Ya hemos visto que el "elogio" de San Fernando y las secciones 2 y 4 fueron omitidos en la compilación de la Primera partida, sin duda por no considerárselos oportunos. El compilador ya había expuesto el ritual del bautismo excusándose del modo siguiente: "Et como quier que se face grant alongamiento en las palabras et en el fecho dél, tovimos por grant derecho de lo poner en este libro por que los que lo leyesen et lo oyesen leer entendiesen la pro et la virtud que ha en el bau-

- El objeto de este estudio ha sido establecer únicamente un parentesco general entre el Setenario y las Siete partidas. Baste decir que una mitad aprorimada de las leyes de las secciones 3 y 5-9 muestran, con la Primera partida, una correspondencia poco más o menos tan clara como la del ejemplo señalado, y muchas otras una correspondencia más leve, aunque es verdad que el orden de los materiales es a menudo diferente. Para un examen más detallado de correspondencias habrá que esperar la edición de la Primera partida prometida por J. Howen Henaiotr (A Thirteenth-Century Manuscript of the "Primera partida ", en Speculum, XIII, I938, págs. 278-294) y una clasificación completa de los manuscritos de esa obra. Herriott ha señalado que el manuscrito A, copiado en el scriptorium de Alfonso, tiene en general sumo parecido con el B. R. 3, impreso íntegramente en cursiva al pie de página, como variante de la primera parte de la Primera partida, en la edición de la Academia. El Setenario se atiene en general más estrictamente al grupo básico de manuscritos de esta edición. Sin embargo, muchos pasajes del Selenario se reflejan sólo en el texto en cursiva. Y una referencia a Judas Macabeo que Herroot (ibid., págs. 29a293) encuentra en el manuscrito $A, y$ que no aparoce en la edición mencionada, se encuentra, con parecido contexto y en forma ampliada, en el Selenario (pàg. 227, lín. 8 y sigs.). En conclusión, bien puede ser significativo el hecho de que todos los manuscritos de la Primera parlida empiezan a concordar sustancialmente a partir de un punto (Título IV, ley 10 ' de la edición acádémica) que coincide casi exactamente con el final del Selenario. 
tismo ${ }^{1}{ }^{1}$. Al parecer, ya no se consideraban allí necesarias mayores explicaciones del ritual.

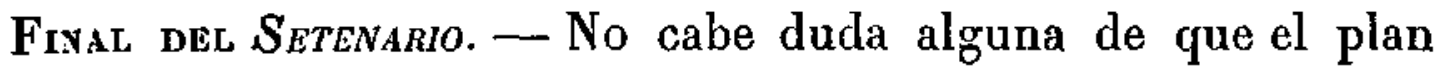
general del Setenario era precisamente septenario, pues ya hemos visto en ese sentido la afirmación de Alfonso *. Ciertas referencias aisladas (por ejemplo, "ssegunt sse muestra en otras leyes que vienen adelante, o ffablan desta rrazón ") a cosas que se promete tratar más adelante y que no se encuentran en la obra tal como ha llegado hasta nosotros son una prueba más de que está incompleta ${ }^{3}$. Tenemos también en nuestro texto pruebas de la identidad entre el proyectado final del Setenario y el de las Siete partidas. Por ejemplo: "... esto sse muestra adelante conplidamiente en este libro do ffabla de las penas tenporales $n$ y " ... ssegunt sse muestra conplidamiente en el libro o ffabla de las penas tenporales " 4 Estos dos pasajes parecerian aludir a la proyectada parte séptima del Setenario, de plan idéntico al de las Partidas, puesto que hablan precisamente de la parte esencial de la materia tratada en la Setena partida, según ya la hemos visto anunciada por el $P$ rólogo ${ }^{5}$. En todo caso, si existe alguna duda, la desvanece una última cita: "Pero ssi cayese en mano de juez sseglar ante que de los clérigos, que aya tal pena commo muestra en la ssetena partida dește libro, o ffabla de los escarmientos " ".

No hay prueba alguna de si se llegó o no a ese proyectado final del Setenario. No hay, en efecto, más que conjeturas. Es verdad que Alfonso mismo es bastante explícito al respecto : "Et nos don

${ }^{1}$ Primera partida, pág. 69. Más abajo (pág. 87), hablando de la crisma, da una explicación más completa todavía de las razones por las cuales se ha incluído ese material ilustrativo : " Et como quier que estas palabras que ponemos aquí aluenguen mucho el libro, non deben por eso ser escusadas que se hi non pongan, por que aquellos que las leyeren, et otrosí los legos que non saben leer nin entender latín, oyendo palabras por el nuestro lenguaje, que entiendan que en toda nuestra ley no hay cosa dicha nin fecha que non sea llena de santidat et de significanza de los maravillosos bienes que Dios fizo et mostró a sus amigos".

- Véase el pasaje citado más arriba, pág. XrI.

${ }^{3}$ Véanse entre otros los siguientes pasajes del texto: págs. ı35,;22-23; 184,10-1 $2 ; 187,21-22 ; 188,7-8 ; 219,6-7 ; 231,5-6 ; 332,23 ; 243,33-34$.

- Texto, págs. r91,26-27 y 309,20-21.

- Véase el pasaje citado más arriba, pág. xxxı.

- Texto, pág. 243, r 1-14. 
Alffonso, desque ouymos este libro conpuesto e ordenado, pusiémosle nonbre Septenarion". Acaso la conclusión más obvia sea que en efecto así se hizo y que se ha perdido todo el material que seguía al texto existente. Pero dudo que sea así. El manuscrito de Toledo, el más extenso, termina antes de llenar la primera columna de su último folio, lo cual parece excluir la posibilidad de una simple pérdida de material en la parte final de este manuscrito 2 Supongo por mi parte que ése era también el final del arquetipo de los manuscritos de Toledo y del Escorial. Gierto que, aun admitiendo estas conjeturas, nada podría concluirse en definitiva sobre la extensión del manuscrito original mismo. Pero no veo razón alguna para suponer que el arquetipo se apartara de su predecesor o predecesores como no fuera en detalles secundarios, ni veo tampoco ventaja alguna que pueda derivarse de semejante suposición. No puedo menos de pensar que la muerte sorprendió al rey Fernando cuando el Setenario había llegado al final actual, y que el rey Alfonso, con agregar el "elogio " y otros trozos de introducción, pudo considerar enteramente cumplida la orden de su padre de completar la obra después de su muerte. El cálido afecto con que Alfonso habla de su padre en el "elogio " autoriza a inferir que esa "terminación" del Setenario se realizó muy poco tiempo después de la muerte del rey Fernando. Que Alfonso no debió de sentirse culpable contra la voluntad paterna al dar así por concluído el Setenario resulta más probable aún si consideramos que ya debía de estar madurando sus planes para la compilación de las Siete partidas; en efecto, las Parlidas se comenzaron sólo cuatro años después de la ascensión de Alfonso al trono, y se tardó unos nueve años en completarlas ${ }^{3}$.

- Texto, pág. 25,18-19.

- Tiene cierta apariencia de terminación la forma en que está escrita la última palabra, que debía ser ssobrellas. El copista escribió las cuatro primeras letras, con lo que llegó exactamente a la línea del margen; entonces, al parecer, tuvo un momento de indecisión ante la perspectiva de empezar un nuevo renglón para el resto de la palabra, y se decidió a terminar la palabra sobrepasando el margen, sólo que al hacerlo repilió innecesariamente, la letra $b$ y escribió ssobbrellas. Acaso sea también significativo el que la ley última de la obra parece estar completa.

- No se han mencionado hasta aquí otras dos compilaciones jurídicas atribuídas a Alfonso el Sabio : el Espéculo, o Esspejo de lodos los derechos, y la conocida con el nombre - entre otros - de Fuero real. Ninguna de ellas es tan 
Las Partidas y eq material del $S_{\text {etenario. - Aunque en las }}$ Partidas se iba a conservar la división septenaria general del Setenario, debían al mismo tiempo introducirse ciertas modificaciones al plan de esta obra e imponerse ciertas restricciones a su exuberancia septenaria. Hay muchas pruebas dispersas de que el Setenario fué un esbozo no del todo madurado del amplio libro de leyes proyectado por el rey Fernando, con la particularidad de que el programa sugerido en el título indujo a digresiones y mezcolanzas que luego se salvaron en las Partidas, mucho más homogéneas. El lector casual de nuestro texto se dará cuenta de que la idea legalista original por poco se pierde entre puerilidades septenarias. Este leit-motiv, que es el rasgo de estilo más característico de la obra, aparece utilizado con tanta insistencia que a menudo se acumulan materias bastante dispares para mantener la división simétrica en 7. Por otra parte, sucede frecuentemente que una ley contenga más materiales que os necesarios para un ajuste adecuado a esa división. Muchos de los epígrafes, sobre todo en la última parte de la obra, resultan totalmente inadecuados; son poco más que una variante de la primera frase o frases que siguen en el texto. Esto puede deberse quizá al copista del arquetipo, pero lo cierto es que en más de un caso el contenido de una ley no constituye una unidad lógica. La ley XCI ( "Del tienpo que fué estableçido para ffazer la crisma ") puede servir de ejemplo, Tiene las siete subdi-

ambiciosa como las Siete partidas, y es probable que Alfonso las considerara como compilaciones meramente provisionales mientras esperaba que se llevara a término el proyecto mayor. Ambas datan probablemente del año $1954 \delta$ × 355 . Gfr. Martíxez Marina, obra citada, págs. 244-254. La afirnación de E. D. LaBorde (A History of Spanish Lilerature, Londres, r931, pág. 38) de que "Three rough sketches, El septenario, El espejo, and El fuero real (1 355 ), seem to have been made in the order given, and between 1256 and 1265 Alfonso at length drew up the famous code of Las siete partidas " es bastante exacta, aunque pudiera hacer pensar en una relación entre el Espéculo y el Fuero real por una parte y el Setenario y las Siete partidas por otra, cuando esa relación probablemente no existe. Se ha sugerido que el Espéculo puede haber constituído un borrador preliminar, o aun la versión original, de las Siele parlidas (crr. la edición citada del Espéculo, pág. v, y Herrotr, obra cilada, pág. 381). En la forma fragmentaria en que ha llegado a nosotros, no es particularmente notable su semejanza con las Partidas, aunque refleja, como ellas, la ley romana $y$ canónica. Es imposible la comparación entre el Setenario y el Espéculo, pues los pasajes de introducción y de materia religiosa, que constituyen todo el contenido del Sctenario, han quedado tan reducidos en el Espéculo que casi han desaparecido. 
visiones siguientes : " en qué día ; et en qué tienpo; et por qué rrazón ffué ffecho en tienpo de la pasqua; que sse deue ffazer en logar linpio; et en logar onrrado; et que los obispos lo pueden ffazer en los arçobispados, non seyendo y ssus mayorales; et que la pueden ffazer por rruego de otros ${ }^{\prime}{ }^{1}$. En la Primera partida, los tres primeros de estos puntos están englobados en una ley con el título de "En qué tiempo se debe facer la crisma " y los tres subsiguientes más lógicamente en otra ley intitulada "En qué logar debe ser fecha la crisma " ", mientras que el séptimo está simplemente omitido. Las Siete partidas no son un modelo perfecto de orden y de lógica según las normas modernas, pero es difícil negar que en ellas se cumple la empresa legalista original del rey Fernando infinitamente mejor que en cualquier continuación con que hubiera podido prolongarse el Selenario.

Intervención personal de Alfonso en el Setenano. - Como en otras obras alfonsinas, hay completa evidencia de que en el Setenario el rey Alfonso tenía a su servicio a personas conocedoras no solamente de la ley canónica y del ritual de la Iglesia, sino también del latín, del hebreo, del griego y de otras lenguas. No sabemos nada en absoluto acerca de estos colaboradores, $y$ sería infructuoso especular sobre su identidad. Con todo, el Setenario es sin duda la más personal de todas las obras atribuídas a Alfonso el Sabio. Sin embargo, no hay prueba concluyente del grado exacto en que él intervino. Sarmiento, con su concepción singular del Setenario, créa - al parecer - que todos los fragmentos encuadernados con el manuscrito de Toledo pudieron ser escritos directamente por Alfonso ', mientras que Manuel Rodríguez, o más probablemente su continuador anónimo, suponía que " todo lo correspondiente a catecismo es original del santo Rey, y lo meramente filosófico de su hijo don Alonso, que en esta parte tuvo como una especie de mania de quererlo lucir" ". Prescindiendo del hecho de que no puede probarse participación alguna de Fernando en la obra, fuera de la concepción original dol proyecto, sin duda la opinión de Manuel Rodríguez acierta sustancial-

- Texto, pág, 159 , lín, so y sigs.

- Primera partida, págs. 83-84.

- Véase más arriba, pág. xix.

- Manuel Redríquez, obra citada, pág. 217. 
mente cn cuanto a la intervención personal de Alfonso. Pero no sugiere una delimitación suficiente. Parece muy probable que Alfonso haya tenido una participación personal en la composición del " elogio " de San Fernando - y hasta que haya compuesto el borrador original de su propia mano - y posiblemente también de las partes que preceden y siguen inmediatamente al "elogio", es decir, las leyes I-XI inclusive. El último pasaje en que el rey Alfonso se nos aparece hablando en primera persona es el final de la ley XXXVII ${ }^{~}$, pero es ése el único ejemplo después del comienzo de la ley XI. Como las Jeyes I-XI corresponden, según se ha indicado ya, al Prólogo de las Partidas, me parece que Alfonso no intervino personalmente en la redacción de lo que está después de la ley XI y que esos renglones de la ley XXXVII los intercaló probablemente un copista cuando se agregó el material de introducción ". Se advertirá también que el uso de los "óvalos " para dar relieve al leit-motiv septenario, to cual proporciona cierta unidad estilistica a las leyes I-XI, no se encuentra en el resto de la obra.

Interpretación de una clí́dula en un testamento de Alfonso. En elisegundo testamento del rey Alfonso hay una cláusula dudosa - Sarmiento fué el primero que llamó la atención sobre ella - que ha contribuído con mucho al fracaso general en la filiación correcta del Setenario. Esta cláusula, que aparece en el ejemplar del testamento agregado a la Chrónica del muy esclarecido príncipe y rex don Alonso el qual fué par de emperador e hizo el libro de las siete partidas (Valladolid, г554), dice así, según la cita de Sarmiento: "Item : Mandamos al que lo nuestro heredare, el Libro que Nos hezimos, Serenaro, este Libro es las Siete Partidas " ${ }^{3}$. Sarmiento fué el primero en sugerir que el final de la cláusula (" este Libro es las Siete Partidas ") era probablemente un añadido del copista,

1 Texto, pág. 68, Ín. 36 y sigs. Hay, adomás, muchos casos de primera persona de plural en que no se ha tenido necesariamente el propósito de representar a Alfonso hablando, o que al menos no aparecen directamente asociados con su nombre.

- Es bastante curioso observar que en ese pasaje, después de varios verbos en prinera persona de plural, aparece un verbo ("sé») en la primera del singular; cfr. texto, pág. 69,6. El simple hecho de que es el único caso en el Setenario en que el rey Alfonso aparece hablando en primera persona de singular contribuye a reforzar la impresión de que todo el pasaje es una intercalación del copista.

${ }^{3}$ Shmierto, obra cilada, pág. 292. 
Io cual se ha aceptado generalmente; Martínez Marina no pudo descubrir rastro alguno de ese final en distintos manuscritos de la Crónica que examinó '. Esta yuxtaposición de títulos - aunque a la palabra " setenario " pudo originariamente habérsele dado significación adjetiva - , en una época en que el nombre de la más grande de las compilaciones jurídicas de Alfonso había cristalizado ya en las "Siete partidas", puso indebidamente en guardia a los. investigadores contra la hipótesis de una relación demasiado estrecha entre ambas obras. Así, por ejemplo, Sarmiento opinaba que la expresión " el Libro que Nos hezimos " no era tan apropiada para " las Leyes de las Siete Partidas, las quales no las hizo, sino que las autorizó y publicó, quanto para los siete capítulos de la Vida de S. Fernando, o para el libro Septenario, que uno y otro hizo el propio Rey D. Alonso " ${ }^{2}$. Es dudoso que sea necesariamente exacta esta interpretación del verbo " hezimos ". La versión latina del testamento, que, según Daumet, se hizo sobre el original poco antes de la muerte de Alfonso para transmitirla al rey de Francia, dice así : a ... illum librum quem nos fieri fecimus, Septenarius apellatus" ". De todos modos, no hay que insistir en la denominación exacta de las Siete partidas, pues no sólo no parece que se citaran generalmente con ese título hasta más de un siglo después de su compilación, sino que Martínez Marina menciona muchas referencias indudables a ellas bajo los nombres de « el libro Setenario" y "el Setenario" ". Parece poderse concluir en justicia, con Martínez Marina, que las Siete partidas serían objeto más digno de la atención del monarca que el inconcluso Setenario, en momento tan solemne como el de la meditación sobre la muerte cercana ${ }^{5}$.

- Martínez Marina, obra citada, pág. 260.

- Sarmiento, obra citada, púgs. 292-293.

3 Grorges Daumet, Les testaments d'Alphonse $\mathrm{X}$ le Savant, Roi de Castille, en Bibliothèque de 'École des Chartes, LXVII, 19o6, pág. 91.

4 Matínez Marina, obra cilada, págs. 260-261. Según Henriotr (obra cilada, págs. 293-294), el manuscrito A de la Primera partida establece que la obra llevaba originariamente el título de Libro del fuero de las leyes.

3 Los dos testamentos de Alfonso - sin el añadido del copista arriba mencionado - están incluídos en las Antologias de Alfonso $X$ el Sabio, prólogo, selección y glosarios de Antonio G. Solalinde, tomo II, Madrid, s. a., págs. 155-193. El primero lleva la fecha del 8 de noviembre de 1283 , mientras que el segundo es del 2 i de enero de I 284 , escasamente dos meses antes de la muerte de Alfonso ( 4 de abril). 
Si el Setenario y las Siete partidas se consideran como dos manifestaciones de una misma idea - como borrador preliminar y redacción final, respectivamente, de un proyecto jurídico que enlazaba el reinado de Fernando III con el de Alfonso X -, entonces este agregado del copista al testamento de Alfonso aparece como bien intencionado y, en lo esencial, exacto. A la luz de esto, y sólo así, resulta inteligible la afirmación del cronista de Alfonso : "... e [porque] el rey don Ferrando su padre avía comenzado a facer los libros de las Partidas, este rey don Alfonso su fijo fízolas acabar " ${ }^{ \pm}$. A la misma luz puede explicarse la aparente contradicción entre la referencia categórica de Alfonso a la terminación del Setenario y la conclusión extraída más arriba de que el Setenario, hablando propiamente, no se continuó, con toda probabilidad, más allá del texto que poseemos hasta ahora.

\section{MANUSGRITO DE TOLEDO $(T)$}

La versión más antigua que existe del Setenario se encuentra en un códice misceláneo de la biblioteca capitular de la catedral de Toledo. Mencionado primeramente por Terreros y Pando y por Sarmiento, este códice sólo ha sido adecuadamente descrito por Solalinde :

Es un códice misceláneo, en papel, de varias letras del siglo xiv; mide $312 \times 230 \mathrm{~mm}$.; tiene 199 folios numerados modernamente, con lápiz. La mayoría de sus páginas están escritas a dos columnas; esporádicamente contiene rúbricas e iniciales sencillas, pero, en general, se han dejado huecos para su adición posterior. La encuadernación, acaso del siglo xvir, cuando ya se habían perdido varios folios, es en pergamino, $y$ en el lomo se ha puesto el siguiente letrero: "Partidas del rey don Alonso", añadiendo la signatura moderna : " 43-20" ".

- Crónica del rey don Alfonso Décimo, en Crónicas de los reyes de Castilla, tomo I, Madrid, 1875, pág. 8. Juan de Maruasia (obra cilada, pág. 382) expresa la misma idea al hablar de la muerte del rey Fernando : “Demás desto, encargó a personas principales y doctas el cuidado de hacer nuevas leyes y recoger las antiguas en un volumen, que hoy se Ilama vulgarmente las Partidas, obra de inmenso trabajo, y que se comenzó por este tiempo, y últimamente se puso en perfección y se publicó en tiempo del rey don Alonso, hijo deste don Fernando".

"Soldlinde, obra citada, pág. $17^{8}$. 
Solalinde enumera a continuación las siete obras distintas que reúne el códice. Hay que señalar que el Setenario y la segunda, un fragmento considerable de la Primera partida, abarcan 158 de los I 99 folios del conjunto.

Sobre los 77 folios del Setenario (a los cuales se refiere la designación de $T$ ) se pueden agregar los siguientes detalles adicionales. El fol. Ir está encabezado por las siguientes palabras, en letra cursiva moderna : "Obra de el Rey D. Alonso el Sabio "; e inmediatamente después, la signatura antigua de la obra : "Cax. 26. $14^{\circ}$ ". Antes de la foliación y de la encuadernación se habian perdido algunos folios, al comienzo del manuscrito y entre los folios $23 \mathrm{y}$ 24, 41 y 42, y 65 y 66 . Todo este material, excepto el comienzo, está suplido por el manuscrito $E$, y como $T$ carece de reclamos que puedan denunciar la división en cuadernillos, sólo una medida comparativa del contenido de folios en $T$ y $E$ nos da la clave para calcular el número de folios perdidos. Esta comparación indica que probablemente se han perdido, en esos sitios, $x, 3,3$ y 5 folios, respectivamente. Si estos cálculos son correctos - y el resultado mismo parecería indicar que sí lo son -, las pérdidas ocurren bien al principio o bien al fin de grupos de 12 folios ${ }^{1}$. Parece que no se han perdido folios al final de $T$, ya que el manuscrito termina dejando en blanco un espacio como para tres renglones en la primera columna y toda la segunda columna del fol. $77 \mathrm{r}$.

$T$ está escrito a dos columnas y, con excepción de algunas correcciones y palabras añadidas entre líneas o en los márgenes, es de mano de un solo copista. La letra es pequeña y estrecha, del tipo descrito por Terreros y Pando como "letra de albalaes " y que Millares Carlo prefiere Ilamar "cursiva gótica ". El manuscrito data probablemente de alrededor del año $1300^{3}$. El número de

- Es decir, se puede suponer que el manuscrito consistía originariamente en siete cuadernillos completos de ia folios cada uno y un cuadernillo incompleto, como sigue : un folio perdido más folios I-II; folios 12-33; tres folios perdidos más folios 24-3 a folios 33-4 I más tres folios perdidos; folios 42-53; folios 54-65 ; cinco folios perdidos más folios 66-72; folios $73-77 \mathrm{r}$ (incompleto).

- Agustín Millares Ciarlo, Paleografia española, tomo I, Rarcelona, 1929, pág. 323.

* Mientras que Solalinde coloca el manuscrito $T$, como todos los trabajos encuadernados con él en el códice toledano, en el siglo xıv; el copista del manuscrito de Madrid lo describe como de "letra coetánea al Rey su Autor"; véase más abajo, pág. c. Tennenos y Paxdo (obra citada, en el epígrafe de la 
líneas por columna en los folios i 4-23 varía notablemente del número en el resto del manuscrito. En los folios I-13 y 24 hasta el fin, el número de líneas oscila entre un caso de 27 y dos de 37 , con una media de 32 ; en los folios 14-23, Ja oscilación es de 21 a 28 con una media de 24 , y la última columna incompleta, que precede inmediatamente a la primera laguna, sólo tiene 13 líneas.

Fuera del uso infrecuente del punto, el manuscrito carece en absoluto de signos de puntuación. El copista aisla por lo común entre puntos una letra del allabeto cuando el texto discurre sobre su significación, y los números romanos van generalmente del mismo modo colocados entre puntos. El manuscrito tiene relativa abundancia de mayúsculas, sin que sigan, en muchos casos, un criterio coherente. De los 66 espacios reservados para mayúsculas grandes en los folios $\mathbf{I} \sim 23$, sólo se han llenado los nueve que hay en los folios 1 y 2 , uno en el fol. 7 va y otro en el fol. 1/4 va; los 68 espacios reservados desde el fol. 24 hasta el fin se han llenado todos menos uno, aunque por lo común con un simple trazado lineal. Todos esos espacios abarcan verticalmente dos líneas, excepto cinco casos - cuatro de ellos a pie de columna - en que abarcan una sola línea; en uno de estos casos una $S$ está acostada ${ }^{1}$. Las capitales no sobrepasan ordinariamente el espacio que les está reservado, pero hay un caso de $P$ en que el trazado vertical abarca cuatro líneas en el margen ${ }^{2}$. Como última irregularidad, uno de los espacios ha sido llenado con una $C$ acostada, abierta hacia abajo, de manera que con los dibujos parece una $M$, y que al margen aparece aclarada con una $C$ corriente, al parecer de la misma mano. Todas estas capitales son por lo menos de dos manos distintas, y ninguna de ellas parece la del copista de $T$. En algunos casos hay al margen o en el mismo espacio reservado una letra minúscula que indica la mayúscula que había que dibujar.

El uso de calderones es muy común en $T$, aunque muchas veces su colocación es completamente arbitraria. Además del tipo dominante, hay una cantidad que responden a un tipo secundario ".

lámina que está frente a la pág. 78 ) y Ma vure Ronnígtez (obra cilada, pág. 317) taubién lo hacen remontar al siglo xur.

- Véase la lámina $\mathrm{X}$, pág. 238 .

- Véase la lúmina $1 X$, pág. $23 \%$.

- Para el tipo dominante véase cualquiera de las láminas de $T$; para el tipo secundario véase la lámina IX, pág. 237 (col. $a$, líneas I-4). 
Este último parece estar relacionado de alguna manera con la división del manuscrito en cuadernillos, ya que ocurren exclusivamente en los folios I y 2 y $42-45 r$, así como también en el fol. 66 , junto con cuatro del tipo dominante, $y$ en las primeras pocas líneas del fol. 67ra. Posiblemente el tipo secundario no representa nada más que la adición, por una mano diferente, de un trazo vertical que parte hacia abajo desde el punto donde termina la curva inferior del tipo dominante. Hay además, esparcidos en $T$, unos quince casos de calderón en ángulo recto, por lo común con líneas finas trazadas simétricamente entre los dos lados del ángulo ${ }^{t}$.

En los trece primeros folios el copista ha llamado especialmente la atención, en 37 casos, sobre los grupos de siete subdivisiones que se tratan en el texto, rodeando cada una de éstas con un trazo que forma un "óvalo " ?. En los folios 66-75r una mano diferente ha señalado en el margen o en el intercolumnio, con numeración romana, el número de orden correspondiente a las subdivisiones mayores. En los folios 67 y 68 aparecen varias partes del texto encerradas con rayas finas : el texto encerrado en esos casos tiene el valor de acotación teatral, que explica la acción que acompaña al rito de la misa, y las rayas tienen el efecto de separar la acción de la oráción ${ }^{3}$.

\section{MANUSCRITO DEL ESCORIAL $(E)$}

El segundo manuscrito existente del Setenario es el II. P. 20 de la Biblioteca del Escorial. Nuestra primera noticia de él data de ${ }_{7} 786$, en que Rodríguez de Gastro lo describió brevemente del modo siguiente:

Se conserva MS. en la Real Biblioteca del Escorial, en ij. P. so. en un Códice en folio escrito en papel, sin foliación, con los títulos de los capítulos de encarnado, y las iniciales en blanco, y está incompleto ${ }^{4}$.

Otros detalles ha dado Zarco Cuevas, el cual agrega que está compuesto de 105 folios y que miden $286 \times 205 \mathrm{~mm}$. ; que está

- Véanse dos ejemplos en la lámina X, pág. 238 (col. a, lín. 7 y col. $b$, lín. 23 ).

* Véanse las láminas I y Il, págs. 77 y 18.

s Véanse las láminas IX y X, págs. 237 y 238.

- Rodníguez de Gastro, obra citada, päg. 680. 
escrito a dos columnas, con una letra que califica de "letra gótica deformada "; que la foliación está hecha con lápiz y en números arábigos; y que la encuadernación es la de la Real Biblioteca en el siglo xviII. Dice además que el papel tiene una marca de agua que consiste en "cetro (?), dos círculos ", y el signo de interrogación es de él 1 .

Hay que señalar varios detalles adicionales sobre $E$. El fol. $\boldsymbol{I}^{*}$ está encabezado por las palabras "Libro Llamado Setenario », escritas con letra moderna, y la signatura del manuscrito. Data probablemente de alrededor del año I $400^{3}$. Es obra de un solo copista, sólo que los epígrafes y las palabras encerradas en " óvalos "fueron suplidos más tarde por una mano diferente, o bien por dos manos diferentes ${ }^{3}$. Hay también numerosas palabras retocadas y muchas añadidas entre líneas o en los márgenes, así como también de vez en cuando en el intercolumnio, todas - excepción hecha de los casos de retoque e interlineado del copista original - de una tercera mano diferente. Trece inserciones en el margen, al parecer de esa misma mano, no tienen valor alguno para el texto, pues son simples glosas de palabras o de ideas ${ }^{4}$. $E$ está todo él escrito con bastante

' Zarco Guevas obra citada, tomo II, Madrid, 1926, pág. 336 .

Z Zarco Cuevas ("híd.) lo hace remontar al siglo xiv, mientras que Abrador oe los Ríos (obra cizada, pág. 560) y Leacaro y Saxta Marí (obra cilada, pág. 330) lo colocan en el siglo xy.

3 Ia mayoría de los epígrafes y todos los grupos de palabras que van en "óvalos" - con excepción de un grupo - parecen ser de una sola mano. Pero los veintitrés epígrafes de los folios $23 v-35 r$ (leyes XXXI-LIII) y el caso único de los "óvalos " del fol. $7 r$ (correspondiente a la pág. 22,7) son seguramente de una segunda mano diferente. Son también de esta última mano los nombres de los santos (excepto el primero) en el Credo in Deum, del fol. $39 \mathrm{ra}$, así como la palabra dixo que sigue por lo común a cada uno de esos nombres.

- Algunas de estas glosas marginales no pueden leerse íntegramente, tan descuidada es la escritura. En la medida en que he podido descifrarlas, y sin pretender en ello el mismo grado de exactitud que en la transcripción del texto y de las variantes, las reúno a continuación : fol. 4 rb (corresponde a la pág. i3, 22 del texto): "contar nueuas dizen por las que en (palabra indescifrable) que son (palabra indescifrable) rrimadas "; fol. 14rb (corresponde a la pág. 38,23): "cabo prender es rocablo antiguo que dizen agora (palabra tachada) tomar (palabra totalmente ilegible)"; fol. 2ova (corresponde a la pág. 54,14-15): " commo lo fazen plateros e ferreros"; fol. alrb (corresponde a la pág. 56, 4): " non llamauan al beuedor dios del vino mas al inuentor de las plantas deus "; fol. Irva (corresponde a la pág. 56,12): " por que ya non se podían dannar "; fol. 5ora (corresponde a la pág. 121,21-25): "non la culpa de 
uniformidad ; cada columna tiene, como promedio, unas $3 \mathbf{I}$ líneas. La mayoría de los espacios reservados para las mayúsculas grandes abarcan tres líneas de altura, pero muchos abarcan solamente dos y unos pocos cuatro. En muchos casos la mayúscula que había que suplir está indicada en el margen por una letra pequeña, probablemente de la misma mano que los epígrafes. Muchas veces los rasgos - por lo común verticales - de letras en la primera y última línea de las columnas han sido prolongados hacia arriba o hacia abajo, respectivamente, con intención decorativa ". Se han empleado en $E$ grupos de "óvalos", en total 33 veces en los primeros 16 folios, de la misma manera que en $T$.

El manuscrito usa de manera relativamente consecuente las mayúsculas y la puntuación. El copista original emplea como signos de puntuación: una raya inclinada, un punto, o bien esa misma raya senuida de punto o un punto seguido de la raya. Todos estos signos son intercambiables, y el más usado es, con mucho, la raya seguida de punto. El signo tironiano está normalmente acompañado por una especie de rasgo curvo como el que abre paréntesis. De la misma manera aparecen las palabras $a$ y $o$, o bien cualquier vocal inicial de palabra cuando cae al final de línea y la palabra continúa en la línea siguiente, y aun sílabas como co en estas mismas circunstancias. La vocal $i$, que nunca tiene punto, lleva en cambio, generalmente, encima de ella un rasgo curvo que se proIonga hacia arriba y a la derecha, sin duda con el fin de facilitar la identificación. Los números romanos y las letras del alfabeto (cuando el texto llama la atención especialmente sobre ellas) aparecen habitualmente colocados entre puntos. La primera de las manos diferentes que he señalado coloca generalmente después del

adam"; fol. $77^{r b}$ (corresponde a la pág. 177,23-24): "confirmar es aprouar e rratificar lo que ya fuc fecho o dicho "; fol. 8ova (corresponde a la pág. 184 , 15-16): "veniales son dichos de venia que quiere dezir perdon por que son ligeros de perdonar - criminales por que an pena tan bien en los cuerpos por justiçia commo en las almas - mortales por que matan el anima para sienpre»; fol. 85va (corresponde a la pág. $194,19-23$ ): "non en que (palabra indescifrable) o danna el vagar n; fol. 86va (corresponde a la pág. 196,26-3o): "conuiene saber maria orando e maria obrando "; fol, g5ra (corresponde a la pág. 214,13) : «licençia es otorgamiento (palabra borrada y otra indescifrable) e con (palabra indescifrable)"; fol. $105 v a$ (corresponde a la pág. 236,3o-31): "qui pridie quam paderetur»; fol. 105va (corresponde a la pág. 239,7): "post quam cenatus est".

1 Véaso especialmente la lámina V, pág. 137 . 
epígrafe, y a veces también después de un grupo de "óvalos", dos rayas inclinadas seguidas de tres puntos en disposición triangular. Usa también frecuentemente el mismo signo al final de la linea del copista original que precede a un epígrafe, y completa esa línea o la línea final de su epígrafe con una raya horizontal terminada con esos tres puntos, o bien con varias rayas horizontales seguidas cada una de esos tres puntos '. Al parecer la misma mano ha agregado en el margen, en trece casos, una raya vertical rematada en su parte alta por esos tres puntos '; comúnmente esa raya se arquea en la parte inferior hacia los dos lados, como dos raíces divergentes de un tronco. Estos signos no parece que tuvieran significación alguna. La segunda de las manos diferentes suele principiar y acabar sus epigrafes simplemente con tres puntos, también en dispositivo triangular. Faltan enteramente en el manuscrito los calderones, excepción hecha de unos pocos en ángulo recto, con una sola línea fina trazada simétricamente entre los dos lados del ángulo ${ }^{3}$; han sido añadidos seguramente por una de las manos diferentes.

Los reclamos se hallan en los folios $10,22,34,46,58,7$, 82 y 94 , indicando así que $E$ se compone de nueve cuadernillos de doce folios cada uno, aunque faltan dos folios al comienzo del primer cuadernillo y uno al final del último. Estas pérdidas son anteriores a nuestra primera noticia del manuscrito y a su foliación. Si suponemos que hủbo una pérdida adicional de aproximadamente un cuadernillo completo al final, resultaría que la extensión original de $E$ era igual a la de $T$.

\section{MANUSCRITO DE MADRID (M)}

El tercero y último manuscrito existente del Setenario es el r 299 I de la Biblioteca Nacional de Madrid. No hay descripción publicada de este manuscrito, aunque ya lo mencionó Pérez Bayer en ${ }_{17} 88^{\circ}$.

- Vóanse las láminas V y VII, págs. 137 y 223 .

- Véase un ejemplo en la lámina $V$, pág. 137 .

3 Véase un ejemplo en la lámina $V$, pág. 137 .

- Antosio, obra cilada, pág. 87. Bartolomé José Galeardo (Ensayo de una biblioteca española de libros raros y curiosos, tomo 1, Madrid, 1863, col. xr33) anota un manuscrito acéfalo del siglo $x v$, al que titula «El Setenario, o tratado de las Siete Partidas Morales", obra que no tiene relación con las obras de Alfonso el Sabio. 
El primer folio de guarda lleva el nombre de "Po. Burriel", a cuya inicialiva se ha atribuído generalmente el haberse hecho la copia, y debajo la signatura antigua del manuscrito : "Dd. Io". El fol. I $r$ dice lo siguiente :

FRAGMENTO / DEL LIBRO / INTITULADO / SEPTENARIO / escrito / por Don ALONSO X. / Rey de Castilla, y de Leon / llamado por excelencia el/SABIO/El qual es vna Introduccion à la / Obra de las Siete Partidas. / Sacose de un Tomo manuscrito en papel / antiguo, y Letra coetanea al Rey su / Autor, què se guarda en la Libreria/de la Santa Iglesia de Toledo Primada/de las Españas, Caxòn 26. numo. / I4. y se cotejò esta Copia con/su Original / ANO DE M.DCG.LII.

Los I 99 folios de $M$ están escritos a una sola columna y son obra de un solo copista, el cual, si hemos de entender literalmente sus palabras, debe de haber sido el mismo Padre Burriel ' ${ }^{\text {. Tiene }}$ numerosas correcciones, notas marginales y casos de "NB" en los márgenes, de dos o más manos, una de las cuales es probablemente la de Pérez Bayer, el cual afirma haber cotejado $M$ con $T$ ^. Los originales latinos, griegos y hebreos correspondientes a las últimas tres series de nombres de Dios que van en "óvalos" en la ley I han sido añadidos en el margen por algún erudito, quizá Pérez Bayer, quizá el mismo Padre Burriel. Al encontrarse con la primera laguna en $T$, el copista dejó un poco más de un folio en blanco y retomó el texto en las palabras "en el Credo in Deum", que escribió en grandes mayúsculas en lo alto del fol. $55 \mathrm{r}$. Ek copista indicó también, mediante anotaciones marginales, la existencia de las otras lagunas y de varias inconexiones y rupturas en la continuidad de su original.

Cada página de $M$ termina con un reclamo. Numerales arábigos en el ángulo superior izquierdo de algunos folios, en el lado recto, parecerian indicar que los cuadernillos I y 2 y 4-I 2 tienen diez folios cada uno, que el cuadernillo 3 es de ocho folios, pero que todos los cuadernillos restantes, numerados del 13 al 52 , tienen sólo dos folios cada uno. El manuscrito termina en la mitad del fol. I $99 r$.

1 Véase más arriba, pág. x riIr, nota I,

- Axtonio, obra citada, pág. 87. 


\section{PARENTESCO DE LOS MANUSCRITOS}

No hay más que un recurso para averiguar la procedencia de $T$ y $E$, y es la coincidencia en el error. Sin embargo, como la línea genealógica parece ser sencilla, este recurso proporciona resultados convincentes. Cierto número de omisiones sustanciales de $T$, ya que están suplidas en $E$, demuestran que $E$ no es una copia de $T$. Por otra parte, el acuerdo de ambos manuscritos en muchas omisiones importantes (representadas en nuestro texto con lecciones que van entre corchetes) ${ }^{1}$, en rupturas de continuidad (que están representadas con puntos suspensivos) ${ }^{2}$, en la inversisón en el orden de los elementos ${ }^{3}$, y en una cantidad de lecciones erróneas " - todo esto prueba un origen común de $T$ y $E$.

El número algo mayor de omisiones largas de $T$ quizá parecería contradecir esa afirmación, pero casi todas ellas son de tipo homeográfico. Igualmente, los casos de confusión de epígrafes y las diferencias relativamente pequeñas de las palabras que usan, así como la lirecuencia con que palabras o grupos de palabras de los " óvalos " están mal colocadas, pueden explicarse por el hecho de que fueron dejados en blanco por los respectivos copistas - con toda seguridad en $E$, donde son de mano diferente, y probablemente también en $T$ - para ser llenados posteriormente. Fuera de una cantidad muy considerable de omisiones menores y lecciones erróneas de poca cuantía, la mayoría de las cuales pueden explicarse por motivos psicológicos, tales como anticipación o repetición, no hay ninguna diferencia de verdadera importancia entre el texto de $T$ y $E$.

Todo lo dicho hasta ahora induce también a pensar que el arquetipo de $T$ y $E$ no era indudablemente el manuscrito original. Obsérvese particularmente la ruptura de la continuidad en la pág. 47 , lín. Io, la cual, como ya hemos visto, representa una

1 Por ejemplo, texto, págs. Io5,27；111,10-II； I17,20；126,27-28; $156,17-20 ; 156,37$. Con referencia a los dos últimos de estos casos, véase más arriba, págs. xxxı v-xxxvi.

Texto, págs. 47,10; 107,17; 118,$31 ; 129,5$.

3 Texto y variantes, págs. 14,$3 ; 128,11-12 ; 138,21-25 ; 182,3-4$.

4 Por ejemplo, texto y variantes, págs. 15,$6 ; 29,28 ; 34,24 ; 64,14 ; 186,21$; 189,$28 ; 235,7$. 
importante pérdida del texto ${ }^{`}$. Pero sería realmente pura conjetura afirmar que esa pérdida — probablemente de varios folios - se ha producido en el arquetipo, en el original, o en un manuscrito intermedio.

\section{CRITERJO DE LA EDICIÓN}

La presente edición ${ }^{2}$ se basa en el manuscrito $T$ porque es más antiguo que $E$ y podría presumirse que está lingüísticamente más cerca del original. No es, sin embargo, enteramente seguro que sea así. La verdad es que ambos manuscritos representan una mezcolanza curiosa de voces y formas populares y cultas, antiguas y nuevas. La preferencia casi absoluta de $E$ por los imperfectos y condicionales en -íe, por ejemplo, refleja probablemente mejor la lengua del original que la ligera preferencia de $T$ por la terminación -ia, lo mismo que las formas del tema y de las desinencias que usa $E$ en la conjugación de los verbos dezir, fazer, recebir, venir y muchos otros. Por otra parte, $T$ presenta invariablemente las terminaciones adverbjales -miente $\mathrm{y}$-mientre $\mathrm{y}$ voces como antigo, eglesia y logar, mientras que $E$ emplea invariablemente la terminación más moderna -mente y muestra preferencia decidida por las formas antiguo, iglesia y lugar. El uso de secta en $T$ frente a seta en $E$ ofrece un curioso contraste con el uso de propheta en $T$ frente al ultracorrecto profecta que prefiere $E^{2}$.

El manuscrito $E$ suple las tres lagunas de $T$, así como numerosas omisiones menores, y permite rectificar numerosas lecciones

1 Véase más arriba, págs. $\mathbf{x} \times \mathbf{x}-\mathbf{x x \times 1}$.

- En distintas ocasiones se prometió editar el Selenario o se exhortó a hacerlo. Martím Sarmiento (obra cilada, págs. 29o-293) aboga elocuentemente por la protección real para que se publiquen en forma adecuada todas las obras de Alfonso el Sabio, con especial referencia al Selenario. No mucho después la Real Academia de la Historia publicó su edición de las Siete partidas y declaró su propósito de sacar a luz, "a su tiempo ", una edición del Setenario; cfr. el prólogo de la edición ya citada de las Siete partidas, pág. xxv. En nuestros tiempos, Solalinde (obra citada, pág. 179, nota 2) prometió también editarlo, aunque más tarde desistió de ello y cedió el proyecto a Hayward Keniston, entonces profesor en la Universidad de Chicago. La presente edición, en efecto, se basa por entero en las copias fotostáticas de los manuscritos que me ha proporcionado generosamente el profesor Keniston.

- Para más ejemplos véase más abajo, págs. exxir sigs. 
insatisfactorias de $T$. De este modo, las tres cuartas partes del texto aproximadamente muestran correspondencia entre los dos manuscritos, mientras que las tres lagunas se basan únicamente en $E$ y una porción equivalente a ellas en extensión - la parte que va antes del comienzo de $E$ y después de su fin - se basa únicamente en $T$. El manuscrito $M$, ya que es una copia de $T$ y carece por consiguiente de autoridad textual, no se ha empleado en la preparación del presente texto.

La numeración de las divisiones mayores del texto no se basa en los manuscritos, y su designación como "leyes " se basa en la autoridad de muchas referencias del texto del tipo de la siguiente: " cosas que sson dichas en la ssetena ley ante désta ". Mayúsculas y minúsculas, puntuación y división en párrafos son enteramente. mías, y la unión y separación de palabras se han conformado por lo general al uso del español moderno '. Se ha empleado la acentuación moderna para facilitar la lectura del texto, pero no se ha extendido a las variantes ${ }^{2}$. Los cambios de folio, recto y verso, de $T$ están indicados entre corchetes intercalados en el mismo texto ; del mismo modo los de $E$ cuando suple las lagunas de $T$, pero en los otros casos van entre corchetes en las variantes, inmediatamente después de la palabra que termina cada página del manuscrito. En las variantes se indica también dónde empieza y termina cada una de las tres lagunas. Cada grupo de palabras que aparecen en ambos manuscritos rodeadas por "óvalos " figuran en la presente edición, por razones de orden tipográfico, en cuadrados ; cada línea de cuadrados cuenta en la numeración como una sola línea de texto. La numeración romana de los manuscritos se ha mantenido, tal como aparece, en minúscula, y las abreviaturas

- Los pronombres referentes a Dios y a Jesucristo se han dejado con minúscula, como en los manuscritos, porque, en vista de su gran frecuencia, el uso de mayúsculas, especialmente en formas como "dÉl ", " quẾl ", etc., hubiera contribuido a complicar innecesariamente el aspecto del texto. Las palabras tan bien y toda vía se han dejado siempre separadas, porque nunca equivalen exactamente a las modernas tambien y todavia. En cambio, he tratado de que la separación o la unión de si non y por que responda a las diferencias de sentido. La puntuación tiende siempre, en lo posible, a respetar y destacar el leit-motiv septenario de la obra.

- $\mathrm{El}$ acento ortográfico que va puesto a los imperfectos y condicionales en -ie no implica, dada la vacilación existente en aquella época, que el acento recayera necesariamente en la $i$. 
para indicar las formas masculina y femenina de los ordinales están representadas con una ${ }^{\circ}$ o una ${ }^{a}$, colocadas al final de los números y no sobre ellos, como en los manuscritos. Análogamente se ha mantenido el símbolo $N^{\circ}$, que se emplea únicamente tres veces en $T^{1}$ (y una sola vez en $E$ ) para indicar el nombre, que había que suplir en cierta oración, del papa, del obispo y del rey, como hoy se díría "el papa N., el obispo N., el rey N. ". No se han conservado en la impresión los puntos que preceden y siguen habitualmente a los números romanos y letras del alfabeto. Las vocales embebidas están indicadas con un acento circunflejo $(\wedge)$, colocado sobre la vocal "embebedora ", y se ha preferido mantenerlo así, en la porción del texto correspondiente a $T$, aun en los casos en que $E$ daba las dos vocales. La especie de acotación teatral que usa el manuscrito $T$ al describir el ritual de la misa, en la ley GIV, se ha puesto entre paréntesis en el texto, a fin de producir análogo efecto de separación entre las acotaciones del ritual y la propia oración.

He querido reducir al mínimo posible el número de enmiendas al texto. Dado que casi cada caso difiere de algún modo de todos los demás, haciendo imposible la aplicación de un criterio único y enteramente objetivo, no parece fuera de lugar hacer aquí una breve exposición de los principios generales que me he esforzado en seguir. Puesto que he tomado a $T$ como manuscrito básico, le he asignado naturalmente alguna mayor autoridad textual que a $E$. No he considerado ni necesario ni conveniente elegir en cada caso, entre $T$ y $E$, lo que podía parecerme de alguna manera vaga la " mejor" lección. Aun en los casos en que $E$ parece ofrecer una lección mejor o más clara, he preferido no rechazar la lección del manuscrito básico, si parecía tener algún'sentido concebible, o una grafía determinada de una palabra, siempre que pareciera justificable, en última instancia, por algún fundamento fonético. Para mencionar sólo unos pocos casos concretos, no he alterado por lo común el uso del manuscrito básico en cuanto a los modos y tiempos de verbos, ni he insistido tampoco en una concordancia estricta entre los pronombres relativos o complementarios y su antecedente, entre el adjetivo y el nombre o entre el verbo y su sujeto, siempre que haya podido imaginar la posibilidad de que la discordancia se deba a razones psicológicas. En suma, he preferido equivocarme

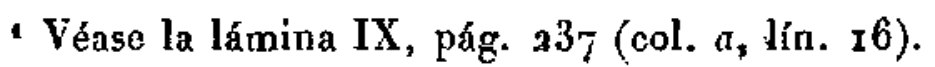


manteniendo un caso raro que puede haberse debido a simple descuido del copista más bien que rechazando o enmendando una lección que puede haber sido intencional en el copista. Por otra parte, y puesto que ni el uno ni el otro de los manuscritos puede pretender una autoridad textual de orden biblico, no he vacilado en introducir enmiendas para corregir errores obvios, para armonizar discordancias demasiado inmediatas y evidentes, o simplemente para hacer más inteligibles algunos pasajes que son defectuosos hasta el punto de ser incomprensibles. El número total de enmiendas, en todo caso, es mayor de 8oo. La legitimidad de la gran mayoría de ellas, desde la omisión de simples palabras esenciales o la simple confusión ortográfica hasta las largas omisiones de tipo homeográfico, es indiscutible. Pero algunas de las enmiendas hechas, así como algunas de las que habrían podido hacerse y no se han hecho, pueden hacer pensar al lector cuidadoso - una cosa que admito con toda franqueza - que no he sido capaz de aplicar estos principios generales con perfecta consecuencia. Sea lo que fuere, esta edición aspira a presentar todos los materiales existentes entre el texto, las variantes y las noticias de esta Introducción para la discusión y reconstrucción de cualquier parte del texto.

Aunque no he querido recargar el texto con signos eruditos, me ha parecido un deber el empleo de corchetes para indicar unas $7^{5}$ lecciones, incluyendo tres epígrafes, que he suplido sin autoridad directa de los manuscritos. He empleado también corchetes en unas 60 enmiendas en que la lección de ambos manuscritos - o del único - era insatisfactoria ; la mayoría de éstas ocurren en la cuarta parte del texto basada en un solo manuscrito. En todas estas lecciones que van entre corchetes, suplidas por mí, he tratado de imitar la ortografía del copista de $T$ o de $E$, según el caso, para no intercalar en el texto la ortografía moderna. No he usado corchetes, sin embargo, para indicar simples enmiendas de forma (es decir, tiempo, modo, número, género, etc.) y de lecciones tan evidentemente erróneas como " la boco " y "vestmientas ". Tampoco se han empleado corchetes en el caso de las iniciales grandes que no han sido suplidas por los copistas de ambos manuscritos. Seis casos de ruptura en la continuidad del texto que no han podido salvarse por el contexto se han indicado con puntos suspensivos ${ }^{1}$.

- Texto, págs. 249,7 y 252,21, además de los casos mencionados más arriba, pág. ur, nota 3. Estos seis no son de ninguna manera los únicos pasajes 
He tratado de simplificar en todo lo posible la manera de indicar las variantes. Las variantes simples y fáciles de reconocer están referidas sencillamente a la línea del texto. En general, en todos los casos de omisión, adición, sustitución y orden de palabras, las variantes de lección comienzan y terminan, para su delimitación, con palabras comunes a ambos manuscritos o con variaciones fácilmente reconocibles de esas palabras. Pero en algunos casos de omisiones extensas o de omisiones al fin de párrafo se ha recurrido a la indicación más directa de omite (los puntos suspensivos que generalmente se usan en estas variantes tienen el sentido de "hasta la palabra que les sigue, inclusive "). Se ha empleado libremente, en el interior de una variante de lección, la abreviatura mediante la letra inicial para indicar palabras que son comunes al texto y a la variante, aunque en ningún caso se ha abreviado así un monosílabo; se utiliza con el mismo fin una abreviatura un poco más extensa, que siempre termina en una o más consonantes, para abreviar palabras de tres o más sílabas que están al final de la variante de lección o en el interior de ella cuando la inicial sola podría inducir a confusión ". La puntuación del texto no se ha tenido en cuenta para las variantes, pero en general se ha conservado el mismo uso de las mayúsculas. Una sencilla omisión, adición, sustitución o diferencia en el orden de palabras que suceda a principio de frase se ha indicado comúnmente poniendo con

del texto que han quedado deficientes de uno u otro modo. Aunque la significación es generalmente bastante clara, he dejado'gramaticalmente incompletos algunos otros pasajes por la simple razón de que para convertirlos en frases correctas hubiera tenido que tomarme con el texto mayores libertades que las que quería tomar. En algunos casos la deficiencia puede deberse sin duda a la manera de pensar del autor original. Por ejemplo, la idea de la frase que empieza en la pág. 7,18 parece continuarse vagamente en varios otros pasajes (los que empiezan en las págs. 8,$13 ; 9,3 ; 10,1 ; 10,25$ ) para concluirse finalmente en la pág. 25, 18-20. En otros casos se ha perdido probablemente algún elemento de la frase, que no he podido suplir adecuadamente; véanso entre otros casos las págs. 1 $45,1-6$ y $349,4-6$.

- Aunque las abreviaturas revelarán frecuentemente pequeñas diferencias ortográficas entre los dos manuscritos, ello es puranente incidental. Para una comprensión apropiada de las variantes es necesario tener en cuenta que en esta edición la abreviatura se emplea exclusivamente para indicar palabras que son idénticas a palabras del texto o difieren tan ligeramente que, de acuerdo con los principios expresados más abajo (págs. Lxx sigs.), no figurarían como variantes por sí mismas. 
mayúscula la primera palabra de la variante y continuándola hasta la palabra en que coinciden los dos manuscritos. Sólo se ha prescindido en las variantes de la mayúscula que comienza una frase del texto en la circunstancia de una variante que comienza dentro de una frase y continúa en la primera parte de la frase siguiente. Se ha empleado una raya oblicua (/) para separar dos o más variantes correspondientes a una misma línea del texto. A menos que una variante aparezca expresamente atribuída a $T$, hay que entender que procede del manuscrito $E$. Y cuando una variante aparece indicada como procedente de $T$ y $E$, la ortografía de la variante es la de $T$.

\section{TRANSCRIPCIÓN DE T}

He intentado una transcripción del tex to de $T$ todo lo fielmente que permiten las limitaciones de los signos convencionales del alfabeto moderno. Es bastante frecuente que aparezcan abreviaturas en el manuscrito: en realidad, aproximadamente un tercio de las palabras están abreviadas de uno u otro modo. Sin embargo, el uso de signos y símbolos paleográficos es, en general, bastante consecuente y ofrece relativamente pocas dificultades. No es propósito de esta Introducción dar un cuadro completo de los usos paleográficos de $T$, sino simplemente indicar la solución dada a aquellos casos cuya transcripción presentaba algún problema.

Los casos de ff y ss iniciales e interiores se han conservado tal como aparecen, para dar una imagen fiel del manuscrito y por la significación que se les pueda atribuir. En dos casos, sin embargo, $f f$ se ha transcrito necesariamente con $F$ (págs. 3,7 y 8,2 I).

Las formas largas y cortas de la vocal $i$, incluyendo la $i$ de rasgo alargado que va al final de los numerales romanos, se han transcrito con $i$. Las formas largas y corlas de la consonante correspondiente se han transcrito, quizá inconsecuentemente con lo anterior, $c o n j$ e $i$ respectivamente.

La $R$ y $r$ iniciales y mediales se han transcrito con $r$, excepto un caso de $R$ que se ha mantenido necesariamente como $R$ (pág. 8,24 ). Hay en $T$ un caso de razón, con $r$ inicial simple (pág. 82,18 ).

Una $L$ mayúscula de doble rasgo vertical es el tipo dominante en todo el manuscrito (a partir del fol. 37 ocurre también, muy de vez en cuando, una $L$ mayúscula de un solo rasgo). Este signo 
se ha transcrito con $l$ o $l l$ según los usos establecidos del manuscrito en otros casos de las mismas palabras en que ocurre ${ }^{~}$.

El tilde encima de una vocal que precede a consonante oclusiva bilabial se ha transcrito con $n$, sobre la base de algunos pocos casos auténticos de $n$, y ninguno de $m$, en voces como nonbre $\mathrm{y}$ sienpre.

Análogamente, cuando la vocal con tilde precede a pn, se ha resuelto la combinación con $n p n$. Ello ocurre únicamente en cinco casos de solepne o solepnidat y uno de condepnado. Es significativa a este respecto la división de esta última, condep/nado, al cambiar de línea en el manuscrito.

La abreviatura $\bar{n}$ se ha transcrito regularmente con $n n$. Sin embargo, no he transcrito el tilde en un caso de terrenales (pág. 29, 24) y otro de peñas (pág. 102, I1). Todos los casos de $n$ donde podría haberse esperado $n$ se han conservado como $n$.

El tilde en abreviaturas como castllo se ha resuelto con ie, ya que todas las voces procedentes del lat. -êllım que están desarrolladas en el manuscrito se escriben con ie.

Confusión entre $u$ y $n$ mediales es sumamente rara en $T$. En un caso de tornadas, torna y toruanan se ha leído toruadas, torua y tornauan (págs. 178,$5 ; 207,6 ; 233,23-24) ; y$ en dos casos de deūe se ha Icído denne (págs. I63, 14 y 175,15 ).

El signo tironiano correspondiente a " $y$ " (corrientemente dibujado como un tilde ondulado, pero a veces también como una coma alargada) "se ha transcrito $e$. La forma de la conjunción cuando está escrita con mayúscula - excepto en siete casos, la mayoría de ellos al parecer de otra mano - tiene el valor de $E t$, como puede verse comparándola con los casos de $E$ mayúscula '. Se confirma esto, además, con varios casos en que hay una $t$ inmediatamente después del espacio reservado para una $E$ mayúscula grande, espacio que unas veces se ha llenado y otras no. Podría argüirse que el signo quizá represente también $e t$, y se puede decir

- Para la $L$ de doble rasgo véase la lámina IX, pág. 237 (passim). En la práctica, este signo ocurre generalmente en formas del arlículo definido, y liene plenamente el valor de $l$ simple en todos los casos monos dos de formas del verbo llamar.

- Para los dos tipos del signo véase cualquiera de las láminas de $T$.

s Compárense las palabras En y Et en la lámina X, pág. a3o (col. a, líneas I y 2). 
que hay pruebas independientes para establecer uno u otro valor. En dos casos se encuentra el signo dentro de espacios dejados en blanco para mayúsculas grandes, para indicar que esa inicial era $E$; otra vez se ha colocado sobre el signo una tilde, representando así la palabra "en" (pág. 254,27). Por otra parte, ha sido necesario asignar al mismo signo el valor de et en dos casos en que constituye el primer miembro del doble signo que he transcrito con etçétera (pág. 242,3 y 28). El signo se ha transcrito también de este mismo modo en el único caso en que aparece en el manuscrito la expresión completa "Alpha et $O$ " (pág. 49,20 ), ya que la intención de la ley I presupone claramente et en este caso.

Las formas de la palabra " hombre" que ocurren en $T$ son ome,

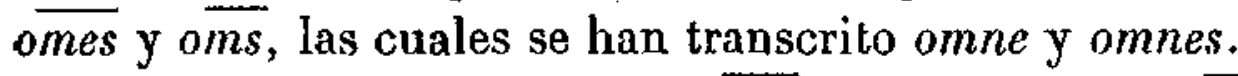

Los 28 casos del singular mugr, dos casos de magr's y uno de mugres se han transcrito mugier y mugieres, sobre la base de cuatro casos en que el diptongo aparece escrito en la forma del plural.

Las abreviaturas $\overline{x p o}$ y $x^{\circ}$ se han transcrito Cristo, y un caso único de $\overline{x p s}$, Cristus; $\overline{x p i a n o}$ y dos casos de $\overline{x p i a}$ dat se han transcrito igualmente cristiano y cristiandat. Ninguna de estas formas aparece desarrollada en el manuscrito. También, el único caso de la palabra cristal aparece abreviada en $\overline{x p a l}$.

La grafía io $\overline{h n}$, que es la forma predominante con que aparece el nombre, un caso de $\overline{i h n}$ y otro de $i o \overline{h a}$ y seis de $i^{\circ}$ se han transcrito Iohán. Un caso único de grafía errónea ihoan, con la $h$ luego tachada, se ha conservado como Ioán (pág. 1 I 2,6 ).

La abreviatura de Dauid ', que no está nunca desarrollada en el manuscrito, se ha transcrito de ese modo sobre la base de la decidida preferencia de $T$ por la $u$ consonántica más bien que por $v$.

La abreviatura $j \overline{h r l m}$, que sólo ocurre dos veces y nunca está desarrollada, se ha transcrito Jherasalem.

La abreviatura $a b r \overline{a a}$, que no está nunca desarrollada, se ha transcrito Abraam por analogía con Adam y Jherusalem, que tienen invariablemente $m$ final escrita en el manuscrito.

Dos casos de $\overline{q l}$ y otros dos de $\overline{q l e s}$, con una abreviatura que regularmente corresponde a ue después de $q$, se han transcrito qual (págs. 169,1 y 182,3) y quales (págs. 54,18 y $174, \mathbf{1}$ ). Hay que suponer que el copista simplemente omitió agregar el elemento secundario de la abreviatura, un pequeño rasgo curvo trazado

1 Para esta abreviatura véase la lámina VI, pág. I65 (col. a, lín. 8). 
desde el extremo izquierdo del tilde hacia abajo y a la derecha ". Un caso único de tié, que va al final de línea del manuscrito, se ha transcrito tiene (pág. I9; I6). Es enteramente posible, sin embargo, que la intención del copista fuera escribir tien, que es la lección que trae el manuscrito $E$, en este caso particular.

Dos casos de cruz griega sencilla ", en la expresión " ssigno(s) de - ", se han representado con $\dagger$ (págs. 236,27 y 28).

Una sola palabra, $A$ mochr $\overline{r c h}$ (pág. ar 8,24 ), se ha dejado en su forma abreviada por no haberla podido resolver.

Cuatro casos de tentaçons y uno de saludaçon, conparaçons, significaçoes y tribulaçoes se han transcrito tentaçiones, saludaçión, conparaçiones, significaçiones y tribulaçiones, sobre la base de otros casos desarrollados de las dos primeras palabras y de todas las palabras análogas, que siempre presentan -çion en el manuscrito. Hay además cuatro casos de offiço, que se han transcrito offiçio.

Numerosos casos de oron, pnia (y voces derivadas) y $\overline{\text { gra }}$, y los dos únicos de snia se han transcrito oraçión, penitençia, graçia y sentençia, sobre la base de unos pocos casos desarrollados de las. dos primeras palabras, todos los cuales presentan $\xi$.

He leído qui en 29 casos de $\bar{q}$ de persona (con el valor del moderno quien) $)^{3}$. Aunque qui, bajo la forma de $q^{i}$, se encuentra 17 veces en el manuscrito ", el uso de la abreviatura $\bar{q}$ con el valor de qui sólo puede explicarse suponiendo una confusión paleográfica entre $\bar{q}$ y $q^{i}$ en el arquetipo de los manuscritos $T$ y $E$. En realidad,

- Para esta abreviatura véanse las palabras quales y qual en la lámina IX, pág. 237 (col. $a$, lín. 12 y col. $b$, lín. 17 ).

- Véase la lámina IX, pág. 237 (col. b, líneas 22 y 24).

3 Texto, págs. 22,12; 22,$16 ; 24,30 ; 27,2 ; 35,2 ; 39,27 ; 73,27 ; 80,5$; 82,$24 ; 107,21 ; 112,7 ; 122,20 ; 124,28 ; 130,9 ; 130,13 ; 130,15 ; 141,23 ;$ 143,$15 ; 153,19 ; 156,14 ; 159,4 ; 183,7 ; 192,7 ; 206,4 ; 207,18 ; 214,16 ;$ 233,$2 ; 344,35 ; 250,29$. Uno de estos casos de $\bar{q}$ ha presentado un problema: especial. Tal como aparece en el manuscrito, en un pasaje confuso, el copista lo escribió sin duda por la conjunción que; por otra parte, tal como aparece en el texto, corregido con la ayuda de $E$, representa un pronombre y debiera transcribirse qui de acuerdo con los principios arriba mencjonados. En vista del hecho de que cualquiera de las dos soluciones sería acertada desde un punto de vista y falsa desde el otro, se ha transcrito qui para mantener el sistema del texto. Cfr. texto y variantes, pág. 233,2 .

- Texto, págs. 37,$25 ; 44,26 ; 129,5 ; 141,21 ; 153,17 ; 160,23 ; 175,17 ;$ 176,$28 ; 180,6 ; 181,1 ; 181,7 ; 182,28 ; 199,19 ; 200,24 ; 203,27 ; 215,4 ;$ 232,14 . 
no hay pruebas de esa confusión en $T$ fuera de los casos mencionados del pronombre : cuando $T$ no escribe íntegramente la sílaba $q u i$, recurre invariablemente, excepto en esos casos, a la $i$ sobreescrita. He admitido la existencia de esa confusión sobre todo por las pruebas abundantes que hay de ello en $E^{1}$. La decisión de cuáles casos de $\bar{q}$ debieron transcribirse con qui se ha tomado después de un estudio de los casos auténticos de qui en el manuscrito y la extensión de los principios así obtenidos a todos los casos de $\bar{q}$ relativo, bien sujeto de verbo con antecedente tácito, bien complemento de preposición con antecedente expreso, siendo el" antecedente con toda seguridad una persona o personas".

Los casos de omisión de signos de abreviación (por lo común de tilde) y de la cedilla de la $c$ ante $a$ u $o$ se han salvado generalmente sin más en la transcripción. Dada la profusión de abreviaturas del manuscrito, no es sorprendente encontrar I5 r casos que se han considerado auténticos de esa omisión. En la mayoría de ellos no puede caber ninguna duda de Ia omisión. Si bien es verdad que un tercio o más de los casos son formas fonéticamente plausibles, tal como aparecen en el manuscrito, el hecho de que esas mismas palabras ocurran escritas con tilde en la inmensa mayoría de los casos es prueba clara de que el copista tenía la intención de escribirlas de ese modo ${ }^{3}$. Va a continuación la lista completa de formas existentes en el manuscrito (cuando no se indica el número entre paréntesis, se entiende que el caso aparece una sola vez) :

accidetes, adelant (2), alcar, alubrar, ant (2), apsonado, aql, ayutamiento (4), ayutar (4), braco, cabeca, codenpnado, coffessa-

- Véase más abajo, pág, Lxviri-txix.

- Los casos auténticos de qui usado como complemento de preposición se dan sólo en el caso de que la preposición sea $a$. No he logrado ver diferencia alguna a este respecto entre a y las otras preposiciones, y por consiguiente todo $\bar{q}$ de persona lo he transcrito qui cualquiera que sea la preposición que lo acompañe.

3 Por otra parte, las siguientes palabras, que podía esperarse que estuvieran escritas con tilde, se han mantenido tal cual están porque, a falta de más casos de las mismas palabras, es imposible saber con seguridad cuál era la intención del copista : yuyerno (pág. 16o,20), costrinimiento (pág. 166,12), costrennir (pág. 166, 13), castrenir (pág. 25 1,5), enpoçonadas y poçonia (pág. a I1,7), y enpoçonnado (pág. 211, ro). Huelga decir que muchos de los casos de fluctuación entre $n n$ y $n$ on el texto - por ejemplo, los citados costrennir y costrenir - pueden también deberse simplemente a omisión del tilde por descuido, aunque no Jos he considerado así, como se dice más arriba (pág. Lvar). 
dor (3), coffessar (12), coffession (9), coffirmaçion (5), coffirmamiento, colfirmar (6), como (3), coplido, copuesto, coracon, cosseiar, cosentir, cotenente, cotra, coueniente, couenir (9), couertir (3), crianca, deptido, dla, dlos (2), do [ ( don »], enderecar, enssachar, enteder (2), entedido, entedimiento $(\bar{l})$, entendimieto (2), espança [" esperança "], estableçiero, etender, fech, ffirmedubre, grdar, ihu ["Ihesu "] (2), mengsemos ["menguásemos "], mereçimieto, -miete, mietre, much, mudo [" mundo "], nigun, no, nobrar, nobre (5), oms, pccado (4), pccador (2), pccar, pder, pdonar, pdurable, propha (2), q (2), qrençia, rrazo, rrepetimiento, ssacrameto (2), ssagrentar, sat, spu ["spíritu »], ta ["tan»], tçera (2), tien, uolutad (3) '.

También se han salvado en la transcripción, sin más, unos 30 casos de signos de abreviación superfluos y cedillas puestas a otras. letras que la $c$.

\section{VARIANTES DE $T$}

En la edición de textos del antiguo español ha sido norma dema-siado frecuente recoger únicamente "las variantes de alguna importancia ", elegidas con criterio enteramente subjetivo. Sin embargo, siendo las variantes una de las convenciones eruditas que hay que. observar, aun cuando inevitablemente contengan mucho material que no interese particularmente a nadie, no me he sentido capaz: de afrontarlas más que con un criterio definido y objetivo. Por consiguiente, se han registrado entre las variantes de esta edición todas las lecciones de $T$ que han sido rechazadas del texto, por. poca importancia que tengan.

Me ha parecido conveniente resumir a continuación una serie de. indicaciones de cierto tipo que a veces se hacen entre las variantes, pero que interesan sólo en el sentido de revelar algo de los. hábitos del copista de $T$. No se han recogido, pues, unos 20 casos en que una o más palabras fueron escritas erróneamente y luego

- Los casos señalados de formas como adelant, ant, como, much, nigun, no y tien son, desde luego, un escasísimo porcentaje del total de casos en que apa-. recen esas palabras. Pero la posibilidad de que coffessar etc., coffirmar etc., couenir etc. y couertir hubieran podido transcribirse exactamente como aparecen en el manuscrito está indicada por el hecho de que los casos scñalados representan porcentajes relativamente elevados de la frecuencia total de esas palabras : $16 \%, 22 \%$, I $\%$ y $25 \%$, respectivamente. 
tachadas. En unos 50 casos en que una o más palabras están añadidas sobre la línea o en el margen, eso no se ha indicado, aunque se ha recogido, desde luego, el texto añadido. En unos i5 casos en que hay una palabra retocada sobre otra palabra o escrita sobre un raspado, esto no se ha indicado, pero sí se ha recogido la corrección. No se ha indicado que en unos 60 casos hay alteración de una parte de la palabra o inserción de una o dos letras en el interior de palabra o sobre la línea. Tampoco se han recogido unos 45 casos de simple repetición de una o varias palabras, ni unos 3o casos variados, entre casos de una o más letras escritas erróneamente y dejadas sin tachar, de una o más letras borroneadas cuando se han vuelto a escribir, y de una o más letras que empiezan una palabra al final de línea cuando luego empieza de nuevo la palabra en la línea siguiente.

La mayoria de esos casos son de mano del copista original, aunque en muchos ha intervenido una mano diferente. De cualquier modo, no se ha dejado de recoger entre las variantes esa clase de casos o de hacer esa clase de indicaciones siempre que la lección afectada difiere de la del manuscrito $E$ o pudiera parecer de algún interés especial. Cuando ha habido seguridad de que ha intervenido una mano diferente, ello se ha indicado.

No se han recogido entre las variantes los siguientes casos, ya tratados más arriba: confusión entre $u$ y $n$; omisión de signos de abreviación y cedillas y uso superfluo de los mismos ${ }^{1}$.

\section{TRANSCRIPGIÓN DE $E$}

He intentado también una transcripción de $E$ - donde suple las lagunas de $T$ y en todos los casos de variantes de lección — con entera fidelidad al manuscrito, pero, como en el caso de $T$, sin apartarme de los signos del alfabeto convencional. $E$ usa sólo la mitad de abreviaturas, aproximadamente, que $T$. Con todo, el manuscrito presenta quizá más problemas que $T$, en parte por la no muy consecuente aplicación de signos y símbolos paleográficos.

1 Aunque la mayoría de los numerosos errores de número en los verbos, tanto en $T$ como en $E$, probablemente no represente nada más que un descuido en la colocación del tilde sobre la tercera persona del singular o en la onisión misma. del tilde, todos esos casos, desde luego, se han recogido. 
No hay en $E$ casos de $\mathscr{f}$, y tampoco de $s s$ de mano del copista original. Se han conservado cuatro casos de $s s$ de mano diferente ${ }^{1}$.

Las formas largas y cortas de $i$ y $j$, vocales o consonantes, se han transcrito como en el caso de $T$.

La $R$ y $r r$ iniciales e interiores se han transcrito regularmente con $r$. En un caso, sin embargo, en que una mano diferente ha añadido el nombre de "Ferrando " de tal modo que sus " siete" letras encabecen los siete puntos tratados abajo, la $r r$ se ha transcrito necesariamente como $R$ (pág. 8, 19), y en las líneas siguientes la $R$ del manuscrito se ha mantenido como $R$ (variantes, pág. ${ }^{*} 8,24$ ). Hay un caso único de $r$ inicial simple en $E$, y ocurre en la palabra raís (pág. $3 \mathrm{I}, 3 \mathrm{i}$ ).

El tilde colocado sobre una vocal que precede a consonante oclusiva bilabial se ha transcrito con $n$, sobre la base de muchos casos auténticos de $n, \mathrm{y}$ ninguno de $m$, en voces como nonbre y sienpre.

Análogamente, cuando la vocal con tilde precede a $p n$, se ha resuelto la combinación con npn. Los únicos casos son condepñado (variantes, pág. 143, I I-I2), dapnōo (variantes, pág. 147, I4-16) y acalopnädor (pág. 225,22). El lugar que ocupa el tilde en estas palabras no tiene importancia por sí mismo, porque es bastante frecuente en $E$ que el tilde caiga dos o tres letras fuera del lugar que le corresponde propiamente. El hecho de que la segunda de esas palabras aparezca dividida, $d a / p n \bar{o}$, al cambiar de línea en el manuscrito, podría indicar la intención del copista de escribir dapnno. En todo caso, no es cuestión de gran importancia, y la transcripción adoptada sólo quiere mantener la coherencia con la solución ya mencionada en la misma situación del manuscrito $T$. Todos los casos de solepne y solepnidad y uno de depnaron, todos los cuales aparecen sin tilde, se han transcrito tal cual aparecen.

La abreviatura $\bar{n}$ se ha transcrito regularmente con $n n$. No he transcrito, sin embargo, el tilde en un único caso de terrenales (variantes, pág. $\left.{ }^{*} 29,24\right)$. Todos los casos de $n$ en que podría haberse esperado $\bar{n}$ se han conservado como $n$.

1 Ssaber (variantes, pág. *7,29), ssetas (variantes, pág. 4 $7,1 \mathrm{I}$ ), enssaneldar (variantes, pág. 169,11) y fiziesse (texto, pág. I 89,28). Se emplea un asterisco desde aquí on adelante para indicar el lugar de una lección de $E$ que en realidad no aparece en las variantes, o por ser idéntica a la lección de $T$ que aparece en el texto o por diferir de ella tan ligeramente que no figura como variante de acuerdo con los principios seralados más abajo (págs. Lxx sigs.). 
Todas las voces procedentes del lat. -êllum aparecen en el manuscrito con la grafía -illo desarrollada. El tilde en un caso único de $\overline{c a b l l o}$ (variantes, pág. $\left.{ }^{*} 16 \mathrm{r}, 25\right)$ se ha resuelto con $i$.

La confusión entre $u$ y $n$ mediales es bastante frecuente en $E$. Las dos formas del verbo toruar antes mencionadas al tratar de $T$ aparecen del mismo modo en $E$ : tornadas y torna. Formas como despnes, pnso y bolniendo no son de ninguna manera raras. De 2 I casos indudables de formas del verbo dennar en $E$, sólo una se sabe con toda seguridad que fué reconocida como tal por el copista, con la gralía depnaron (variantes, pág. 14r, I). Dos de las tres formas de pretérito de singular deno aparecen escritas con uria separación que parece indicar que se las interpretaba como "de non ". De mano del copista original, hay nueve casos de denne que aparecen como dea $\bar{e}$, otros tres como deuen enteramente desarrollado ${ }^{3}, \mathrm{y}$ dos como deue ${ }^{4}$; dos casos en que el sentido del texto exige "dennó n también aparecen como deuen desarrollado ${ }^{5}$; y un caso único de dennes aparece como deues (variantes, pág. 235,28 ). Una mano diferente ha añadido tres correcciones en el margen o sobre la línea y ha retocado dos de los casos de deuen y el caso de deues en la misma línea.

En los casos más diferenciados, $b$ y $v$ se distinguen claramente en $E: b$ tiene el rasgo inicial vertical y la base redondeada ; $v$ tiene el rasgo inicial fuertemente inclinado hacia la izquierda y la base puntiaguda. En la gran majoría de los casos, sin embargo, ambos caracteres son prácticamente idénticos. Eu la transcripción de estos casos ambiguos me he guiado, hasta cierto punto, por la grafía predominante en el manuscrito en las palabras en cuestión. Sin embargo, he conservado la $b$ inicial en unas pocas ocasiones en que el uso regular es $v$ (por ejemplo, bisión, ber, biniera).

El manuscrito $E$ muestra la confusión entre las formas de $s$ y $z$ común a los manuscritos de este período. La $s$ larga y la $s$ redondeada del tipo moderno no han presentado dificultades de trans-

1 Variantes, págs. 140,$10 ; 152,14 ; 1033,17$.

2 Variantes, págs. 139,$31 ; 141,14 ; 142,30 ; 148,16 ; 163,14 ; 169,10 ;$ $169,30 \cdot 3 \mathrm{x} ; 180,20 ; 235,23$.

${ }^{3}$ Variantes, págs. $172,13-14 ; 175,15 ; 191,2$.

- Variantes, págs. 1411,23-24 y $143,15$.

5 Variantes, pág. 179,23; texto y variantes, pág. $231,22$. 
cripción. He llegado a la convicción de que cualquiera de las otras varias formas, cuando le sigue una vocal unida a ella, puede representar la $z$, y por lo tanto esos casos se han transcrito con $z$ en todas las ocasiones en que corresponden a una $z$ o $c$ (ante $e, i$ ) modernas. En posición final de palabra o de silaba, en casos en que el español moderno usa $z$, se ha hecho una distinción sobre la base del rasgo superior de la letra: la que tiene el rasgo superior bien redondeado, la cual en general es algo más pequeña que la otra, se ha transcrito con $s$; la que tiene el rasgo superior más o menos alargado horizontalmente se ha transcrito $\operatorname{con} z^{1}$. Un recuento hecho al azar de 75 casos en que aparece ese signo (en las palabras $b o z, v e z, p a z$, pez y Badajoz) indica que un $40 \%$ aproximadamente de voces como ésas en $E$ terminan con $s$. La tendencia del copista a escribir $s$ en posición final, y con ello la justeza de la distinción arriba indicada, se prueba por el hecho de que en muchos de los casos conservados como $z$ el rasgo superior alargado aparece, con bastante claridad, como un alargamiento en sentido horizontal de un rasgo originalmente redondeado.

El símbolo de la conjunción " $\mathrm{y}$ " se ha transcrito con $e$. Aunque la forma escrita con mayúscula parecería a primera vista correspon-. der a $E t$ con tanta seguridad como en el caso de $T$, tiene también el valor de $E$, como prueba su comparación con otros casos de $E$ mayúscula 9 . En un caso aparece escrita la letra $e$ minúscula en lugar del signo en la expresión "Alpha e $O$ " (variantes, pág. $* 49,20)$, donde la intención de la ley I presupone la forma et. He encontrado también dos casos de $e l$, al parecer por "e le " (pág. $7 \mathrm{r}, 36$ y variantes, pág. $205,3-4)$.

La abreviatura omé se ha transcrito omne; y omes, om $\bar{m}$ y tres casos de $\overline{o e s}$ se han transcrito omnes. Se han conservado los casos de ome y omes, ya que el total de 63 veces en que

1 En la gran mayoría de los casos la $z$ que se encuentra unida con la rocal siguiente no se diferencia mayormente de la z en posición final, de modo que no hay por lo común peligro de confusión con $s$. Pero de vez en cuando los mismos caracteres que se encuentran comúnmente en voces como segunl y asi, en las que van también unidos con la rocal siguiente, se encuentran en voces como fazer y dezir. Por otra parte, el signo con el rasgo superior alargado se encuentra ocasionalmente en palabras, como las y todos, en que no cabe ninguna posibilidad de una interpretación como $z$.

- Compárense las palabras $E$ y Esto en la lámina V, pág. 137 (col. b, líneas 3 ; 5 ). 
aparecen descarta la idea de una omisión accidental del tilde ${ }^{1 .}$ Las abreviaturas $x p \bar{o}$ y $x^{\circ}$ se han transcrito Cristo, y un caso único de $x p^{i}$, Cristus; $x^{i}$ ano, tres casos de $\overline{x a n o}$ y otros tres de xpiano se han transcrito igualmente cristiano, y tres casos de $x^{i}$ andad, cristiandad. Ninguna de estas formas aparece desarrollada en el manuscrito.

Quince casos de vlud (con un trazo diagonal ondulado que cruza el lado izquierdo de la $v)^{2}$ se han transcrito vertud sobre la base de dos casos desarrollados. El manuscrito tiene también 99 casos de virtud desarrollados, lo que podría hacer creer que el copista tenía presente esta forma cuando abreviaba. Creo, sin embargo, que el copista, en su tendencia general a modernizar esta palabra entre otras en el material que estaba copiando, caía a veces inadvertidamente en vertud - representada por la abreviatura - , la cual supongo que era la forma usada exclusiva o predominantemente por el arquetipo de los manuscritos $T$ y $E$. Es significativo que los dos casos desarrollados de vertud son los primeros de la palabra en $E$ y que más de la mitad de las formas abreviadas ocurren en el primer tercio del manuscrito.

Veintitrés casos de plado (con un trazo horizontal que cruza la parte inferior de la $p$ ) " se han transcrito perlado sobre la base de dos casos así desarrollados.

Un caso de $b a^{o}$ y otro de $b^{o}$ se han transcrito bateo, sobre la base de un desarrollo de esta palabra (como también uno de pateo) con el valor de bautismo.

Un caso de applos y dos de appllos se han transcrito apóstolos, sobre la base de 37 casos en que la palabra aparece escrita con $p$ y $l$ simples. Del mismo modo se ha transcrito un caso único de applls, debido además a la decidida preferencia de $E$ por esa grafía en lugar de apóstoles. Un caso único de appl se ha transcrito análogamente apóstol.

La abreviatura $\overline{\text { hr } l m}$, que ocurre tres veces y no tiene nunca desarrollo, se ha transcrito Jherasalem.

${ }_{1}$ Es curioso señalar que en los pasajes de $E$ que suplen las lagunas de $T$. sólo hay lres casos de ome y omes en un total de 69 casos de la palabra $(4 \%)$, mientras que en cl resto del manuscrito hay 60 casos escritos sin tilde sobre un total de 344 , es decir, un $17 \%$.

- Para esta abreviatura véase la lámina III, pág. 4r (col. a, lín. 6).

- Para esta abreviatura véasc la lámina VII, pág. 223 (col. a, lín. a y passim). 
Un caso de la abreviatura isrly otro de isrl' - las cuales nunca están desarrolladas - se han transcrito Isrrael.

Un caso único de $\overline{\text { alld }}$ se ha transcrito alcalde; y uno de $\overline{\text { alldes, }}$ aunque la significación del tex to requeriría "alcaldias ", se ha transcrito alcaldes (variantes, pág. 88, I 2 ).

Un caso de āqrio se ha transcrito Aquirio sobre la base de un desarrollo de esta palabra con el valor de Acario o Aquario, formas que también se encuentran en el manuscrito.

Se ha pasado por alto el tilde una ve\% en el caso de cauallo. Como ésta es la abreviatura regular de "cauallero ", lección que no tendría sentido en el caso en cuestión (variantes, pág. ${ }^{*}$ 105,6), hay que suponer que el tilde se ha puesto por error.

Dos casos únicos de tie, ambos al final de línea del manuscrito, se han transcrito tiene (págs. 227,36 y 228,6 ).

Un caso único de cruz paté levantada sobre una peana doble ${ }^{\text {, }}$ que aparece en la expresión "signo de $-n$, se ha representado con una simple † (pág. ı38,3).

Numerosos casos de pnia y penia ${ }^{2}$, unos pocos de grāa y un único de $s b a ̈$ se han transcrito respectivamente penitençia, graçia y substançia, sobre la base de varios casos desarrollados de penitençia (así como todas las voces derivadas) y de graçia, la mayoría de los cuales presentan $c$.

Aplicando los mismos principios que en el caso de $T$, he leído qui en 17 casos de $\bar{q}$ de persona en $E^{3}$. Si bien qui sólo aparece desarrollado una vez en el manuscrito - en la combinación quiquier (variantes, pág. 125,29 ) -, se explica bastante satisfactoriamente la lección qui por $\vec{q}$ si se tiene en cuenta la confusión paleográfica existente. El tilde tiene en $E$ una gran variedad de formas, todas las cuales pueden ser completamente intercambiables. Como indicación de uso, $E$ tiene 30 casos de quien desarrollado enteramente, $\mathbf{I} 7$ de $\overline{q e n}$ con tilde recto y nueve de $\bar{q} e n$ con tilde

1 Véase la lámina $V$, pág. I 37 .

- En realidad el signo que se emplea en estas dos abreviaturas no es un simple tilde. liste signo tiene dos formas más o menos distiutas - las mismas que alternan generalmente en muchas otras situaciones en el manuscrito - y se pueden ver en la lámina VIII, pág. 22$\}$, eur las palabras penitençia (col. a, lín. 14 y passim) y mostrur (col. a, lin. 32 ).

${ }^{3}$ Variantes, págs. ${ }^{*} 24,30 ; * 35,3 ; 45,3 ; * 80,5 ; * 82,34 ;{ }^{*} 12,7 ;{ }^{*} 24,38$; *เ30,13; $4\{3,15 ; 158,23 ; 159,30-30 ; 210,3 ; 212,2 ; 214,5 ;$ texto, págs. 67,$91 ; 135,30 ; 230,13$. 
redondeado, abierto hacia abajo; también, i 5 casos de aqui enteramente desarrollado, uno de $\overline{a q}$ con tilde recto, dos de $a \bar{q}$ con tilde redondeado y uno de $a q^{i}$ con tilde redondeado (con su típica forma de media luna, abierta hacia abajo), pero cuyo extremo izquierdo está levantado hacia arriba, llegando casi a la posición vertical, de tal modo que parece servir como una especie extravagante de $i$ sobreescrita '. Diecisiete casos de que de persona enteramente desarrollado ", en situaciones exactamente iguales que los casos que se han leído qui, constituyen una prueba más de la confusión paleográfica que ha de haber existido en el arquetipo.

De manera análoga, la abreviatura $\vec{q}$ con tilde redondeado se ha transcrito con qui en i 9 casos de $\bar{q}$ sieron y formas emparentadas, sobre la base de 47 casos de quisieron etc., desarrollados enteramente.

Casos genuinos de omisión de signos de abreviación y cedillas, así como casos de empleo superfluo de esos mismos signos, no se indican en la transcripción de $E$, aunque no se ha intentado aquí una exposición tan detallada del uso como en el caso de $T$. El copista de $E$ tenia gran afición al uso de un tilde no funcional sobre palabras como mucho, dicha y grant. Puede decirse, de manera general, que, puesto que la abreviación es mucho menor en $E$, hay consiguientemente menos casos de omisión indudable. Los signos más comúnmente omitidos son los que representan a $e r$ y a $u a$, como en perdón y guardar, y también la cedilla en voces como coraçón. La omisión del tilde mismo es excepcionalmente rara,y la preferencia, en la proporción de cuatro contra uno, por conocer frente a connocer no puede explicarse por simple omisión ${ }^{3}$.

- Este último tipo de abreviatura no es por cierto una $i$ sobreescrita, propiamente dicha, aunque es lo que más se le parece en el manuscrito. Aparece de vez en cuando para representar, por ejemplo, ui y rien palabras como quinia y trinidad. Pero exactamente la misma abreviatura puede representar, en alguna ocasión, ue en una palabra como rriqueza. Y ambos tildes, el relondeado $\mathrm{y}$ el recto, se emplean aun más frecuentemente con los tres valores.

2 Variantes, págs. 22,$16 ; 27,3 ; 34,33 ; 73,27-28 ; 107,21$, I 10,2-3 (dos casos); 130,$15 ; 156,14 ; 159,4 ; 182,27-38 ; 200,24 ; 214,16 ; 214,20-2 x ;$ texto, págs. 70,$11 ; 136,8 ; 231,16$.

- Como en el caso de $T$, las palabras como (14), ni, y no (4) se han transcrito commo, nin y non, como si hubieran tenido tilde, porque ésa era indiscutiblemente la intención del copista. Dos casos de no de mano diferente, en que no puede demostrarse si ha habido intención de usar tilde, se han conservado tal cual aparecen (variantes, pág. 206,26 ; texto, pág. 222,4). 
Se han registrado todas las variantes de lección de $E$ que implican omisión, adición, sustitución u orden de palabras. $Y$ se ha tomado nota, bien en los párrafos siguientes o en las variantes, de todas las diferencias ortográficas que representan diferencias de pronunciación. Se ha considerado, en cambio, que las diferencias siguientes no representan diferencias de pronunciación :

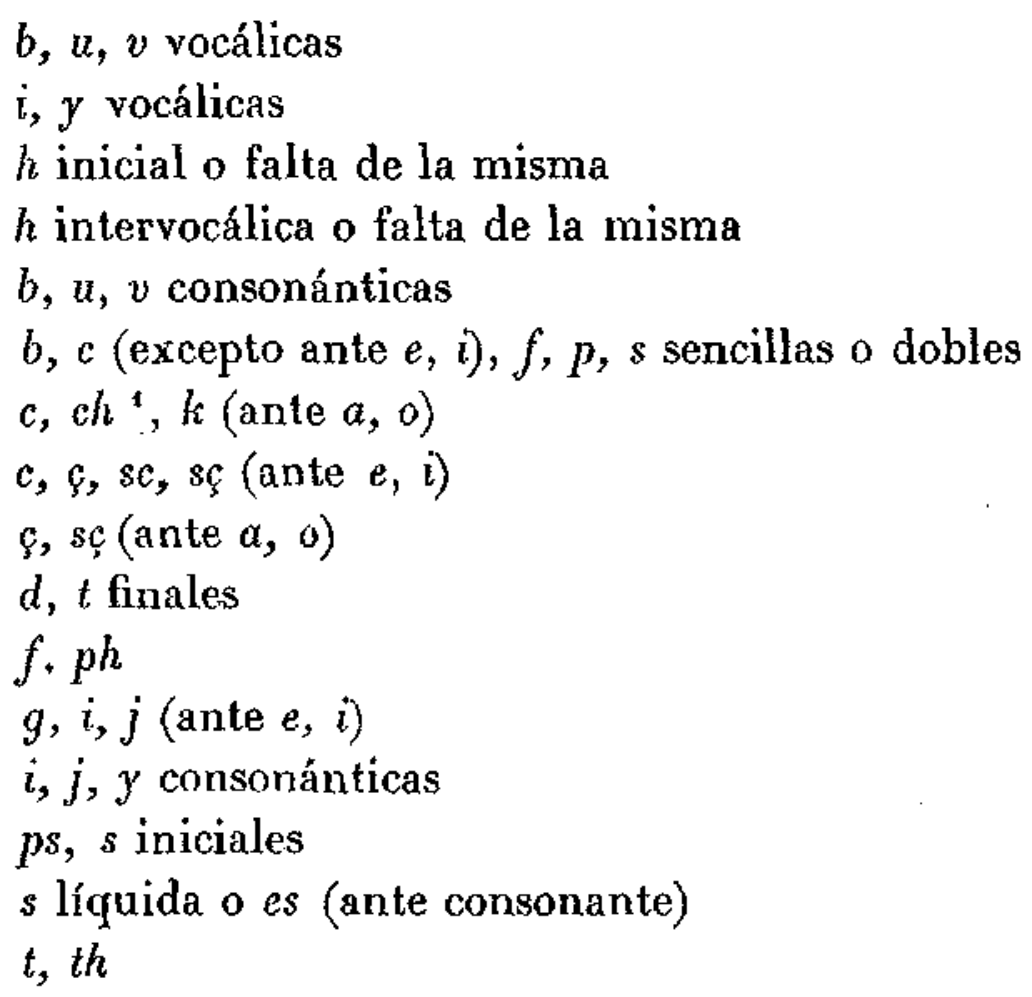

elisión en preposiciones y conjunciones o falta de la misma"

No se han registrado las variantes ortográficas, aun cuando representen diferencias de pronunciación, en los tres casos siguientes : r) una serie considerable de voces y terminaciones en que la variación es bastante sistemática; 2) imperfectos y condicionales en $-i a,-i c$, etc. ; 3 ) numerales. He creído que la presentación de estos materiales aquí en la Introducción tendría más utilidad que registrar cada caso en el lugar donde ocurre, con lo cual, además, quedan descargadas las variantes del texto del peso de unos 3.0oo casos. Estos materiales, tratados en forma estadística, los he reunido en la parte siguiente de la Introducción.

- Se eutiende en las grafías helenizantés.

- Las voces en que ocurre esta elisión son las siguientes; de, sobre, qque, ante, entre y desde. 
Por lo demás, en el caso de $E$ no se ha intentado presentar un cuadro completo de minucias de copia tales como tachado, interlineado, retoque, repetición de palabras, etc. Puede decirse que hay escasa diferencia a este respecto entre los dos manuscritos. $E$ presenta varias repeticiones de una o más líneas enteras, mientras que $T$ llega cuando más a repetir cuatro palabras. Esas minucias de copia no se han indicado entre las variantes más que, análogamente con el caso de $T$, cuando la lección afectada difiere de la del manuscrito básico o puede parecer de algún interés es pecial.

No se han recogido generalmente entre las variantes los siguientes casos, antes tratados: confusión entre $u$ y $n$; omisión de signos de abreviación y cedillas y uso superfluo de los mismos; variaciones entre et de $T$ y $e$ del manuscrito $E$. Unas poquísimas palabras añadidas en el margen o sobre la línea por una mano diferente no se han incluído entre las variantes por la sencilla razón de no haberlas podido descifrar en la fotocopia del manuscrito. Se han omitido igualmente las trece glosas marginales arriba mencionadas y transcritas ${ }^{1}$.

\section{PARTIGULARIDADES DEL USO ORTOGRÁFICO DE T Y E}

Esta parte de la Introducción no aspira de ninguna manera a ser una exposición completa de las modalidades ortográficas de nuestros manuscritos. Su propósito es, ante todo, reunir sistemáticamente ciertos materiales - los mencionados en la página anterior - que una vez expuestos aquí justifiquen el ser omitidos como variantes al pie de página. Sin embargo, los párrafos siguientes servirán para ilustrar en cierta medida los hábitos ortográficos de ambas manuscritos. A este respecto hay que observar que "ortográfico" se usa en sentido amplio, ya que algunas de las variaciones anotadas y tratadas pueden ser más bien morfológicas.

I) Voges y terminaciones de varragión sistemática. - El cuadro que va a continuación contiene la mayoría de aquellas voces o terminaciones que, entre $T$ y $E$, presentan una variación más o

\footnotetext{
- Véase más arriba, págs. xlyu-xlytu.
} 
menos sistemática, repetila cinco o más veces. Hay que señalar que el cuadro se refiere únicamente a las tres cuartas partes del texto que abarcan ambos manuscritos. En ese cuadro no se han indicado los números totales de casos, pero los números de casos en que hay diferencia entre los dos manuscritos, en las diez formas más comunes, son los siguientes:-miente, -mientre (339 variantes), baptismo y voces derivadas ( 150$), \log a r$ ( I $\mathrm{x}$ ), fizieron etc. ${ }^{\prime}$ (103), connocer y voces derivadas (100), eglesia $(89)$, vertud $(80)$, diziendo, dizia $(78)$, mismo (74) y omne (6o). Los números que van en paréntesis en el cuadro siguiente indican el porcentaje del total de casos que responden a la ortografía indicada, y cuando no se indica porcentaje, se entiende que se da en un $100 \%$ :

Ms. $T$

absolver $(86 \%)$

algún

antigo

aorar $(63 \%)$, orar $(33 \%)$, adorar

$(4 \%)$

apóstoles $(78 \%)$

asesegar $y$ voces derivadas

baptismo $y$ voces derivadas $(96 \%)$,

babtismo $(4 \%)^{3}$

bendito $(39 \%)$, bendicho $(39 \%)$,

benedito $(17 \%)$, benedicto $(5 \%)$ cálice $(86 \%)$

Capricornio *

conjurio $(9 \circ \%)$

connocer $y$ voces derivadas $(92 \%)$

contenente

crencia $(86 \%)$
Ms. $E$

asolver

algunt

antiguo $(93 \%)$

aorar $(89 \%)$, orar $(8 \%)$, adorar $(3 \%)$

apóstolos $(80 \%)$

asosegar ${ }^{2}$

bautismo $(98 \%)$, baptismo,

babtismo $(2 \%)$

bendicto $(71 \%)$, bendicho $(18 \%)$,

bendito ( $11 \%$ )

cáliz

Capicornio

conjuro

conocer $(80 \%)$

continente $(45 \%)$

creencia

- Cuando sigue etc. a una forma de pretérito, ello quiere decir que se sobreentienden también las formas del imperfecto y futuro de subjuntivo, incluyendo las formas en -ra en su uso como pluscuamperfecto de indicativo.

- No se han tomado en cuenta aquí un caso de sosegamiento (variantes, pág. 29,12 ) y otro de sosegasen (variantes, pág. 215,5).

3 No se ha tomado en cuenta aquí un caso de batizan (pág. 152,6 ).

- No se ha tomado en cuenta aquí un caso de la grafía errónea Capriconrnio (variantes, pág. 106,23).

- No se ha tomado en cuenta aquí un caso de la grafía Capiconio (variantes, pág. $63,24-2 \tau)$. 


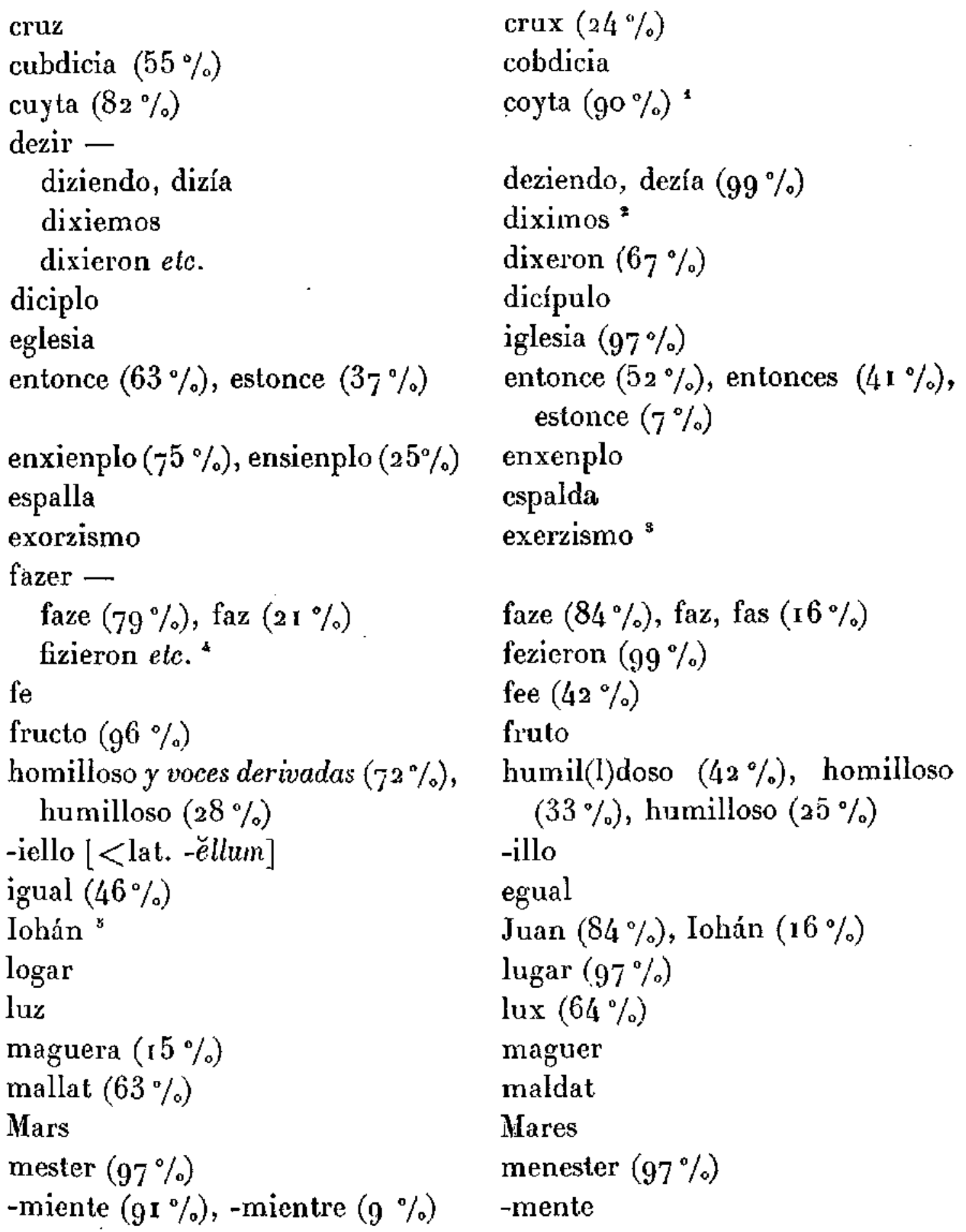

1 No se ha tomado en cuenta aquí un caso de la grafía cueytas (variantes, pág. 158,29 ).

2 No se han tomado en cuenta aquí un caso de la grafía dixemos (variantes, pág. 7,5 ) y otro de deximos (variantes, pág. $9^{8,16}$ ). En las partes de $E$ que corresponden a las lagunas de $T$ hay también dos casos de dixiemos (págs. 7o, I I y 134,1 ).

${ }^{3}$ No se ha tomado en cuenta aquí un caso de la grafía exerçismo (variantes; pág. $\left.15 \dot{3}, 9^{-10}\right)$.

- No se ha tomado en cuenta aquí un caso de ffaziera (pág. 20,24).

Jo se ha tomado en cuenta aquí un caso de la grafía errónea lhoan, con la $h$ luego tachada, que se ha transcrito en el lexto Ioán (pág. I 12,6). 
mismo

morir -

muriendo, muría, muriexon etc. mugier

ningún

omne

parrochia $y$ voces derivadas

pasqua $(78 \%)$

piadat $(80 \%)$

poder -

pudieron etc.

poner -

pusieron etc.

predicar $y$ voces derivadas $(89 \%)$, predigar ( $11 \%$ )

prelado

propheta

propriedat $(93 \%)$

querer --

quier [en el tipo "(quier dezir"] $(55 \%)$

recebir -

recibiendo, recibía, recibió, recibieron elc.

reyes

sabiduría

salir, sale

secta

seello $y$ voces derivadas

$\operatorname{ser}(99 \%)$

seyendo

solenpne $y$ voces derivadas

tener -

tenido

venir -

viniendo, vinía, vinieron etc. veniendo, venía, venieron $(95 \%)$ $\left(9^{3} \%\right)$

- No se ha tomado en cuenta aquí un caso de bnbre, añadido en el margen por una mano diferente de la del copista original (variantes, pág. 196,15).

- No se ha tomado en cuenta aquí un caso de perrochano (variantes, pág. 200,19 ).

${ }^{3}$ Inn las partes de $E$ que suplen las lagunas de $T$ hay también un caso de la grafía prefetas (pág. 68,17). mesmo $(73 \%)$

moriendo, moría, morieron $(76 \%)$

muger

ningunt

ome $(16 \%)^{1}$

perrochia $^{2}$

pascua

piedat

podieron

posieron

pedricar $(89 \%)$, predicar $(11 \%)$

perlado

profecta $(95 \%)^{3}$

propiedat

quiere

recebiendo, recebía, recebió, recebieron $(95 \%)$

reys

sabidoría $(92 \%)$

sallir, salle $(36 \%)$

seta

sello

seer $(15 \%)$

siendo $(3, \%)$

solepne

tenudo $(57 \%)$ 
$\operatorname{ver}(71 \%)$

vertud $(97 \%)$

$-\mathrm{z}^{\mathrm{1}}$ veer $(36 \%)$

virtud $(85 \%)$

$-\mathrm{s}(40 \%)$

2) Imperfectos y condicionales ex -ía, -ie etc. - Un examen de todas las formas de tercera persona del imperfecto y condicional de los diez verbos más comunes de la segunda y tercera conjugación, en los dos manuscritos en su totalidad, muestra que sobre $58 \mathrm{I}$ casos de $T$ hay preferencia por - $i a$ en un $63 \%$, mientras que sobre 57 I casos de $E$ hay preferencia por - $i e$ en un $93 \%$. El cuadro siguiente presenta el detalle de la cifra mencionada de $T$ :

\begin{tabular}{|c|c|c|c|}
\hline & Total de casos & $-i \alpha$ & $-i e$ \\
\hline auer $\ldots \ldots \ldots$ & 170 & $78 \%$ & \\
\hline fazer........ & 128 & $54 》$ & \\
\hline poder......... & 74 & $77 n$ & \\
\hline tener........ & 44 & & $6, \%$ \\
\hline sor $\ldots \ldots \ldots$. & $4 \mathrm{I}$ & $68 n$ & \\
\hline $\operatorname{dezir} \ldots . . .$. & 35 & $51 "$ & \\
\hline querer........ & .37 & $56 "$ & \\
\hline deuer ......... & 24 & & $58 "$ \\
\hline venir........ & 20 & & $85 "$ \\
\hline saber ......... & 18 & $89 n$ & \\
\hline
\end{tabular}

El uso de $E$ es mucho más constante, variando de un $90 \%$ para auer y fazer hasta un roo $\%$ para ser y saber, y el $93 \%$ mencionado vale en general para todos los otros verbos de esas conjugaciones que ocurren en el manuscrito. Un examen de todos los otros casos de esta terminación en $T$ - en 72 verbos adicionales - revela el hecho curioso de que en estos verbos menos comunes hay una preferencia por -ie en un $68 \%$. Si se toma en cuenta el conjunto de casos de $T$, hay sólo un $55 \%$ a favor de -ia. Estas cifras indican indudablemente una tendencia del copista de $T$ a modernizar las terminaciones en los verbos más comunes, mientras mantenía en general, en los verbos menos frecuentes, to que era sin duda el uso del arquetipo exclusiva o predominante mente.

3) Numerales. - El manuscrito $T$ tiene I.074 casos de numerales, cardinales y ordinales, desde "uno" hasta "docen. Apro-

1 No se han tomado en cuenta aquí un caso de Beatrís (pág. 7,20 ) y otro de pes (́pág. 1 11,21), que son las únicas palabras de $T$ que llevan $-s$ en lugar de $-z$. 
ximadamente el $8 \%$ de ellos son números romanos, porcentaje que es algo menor en $E$. Sólo los ordinales desde "sexto " a "décimo " inclusive muestran más de una forma desarrollada al lado de la forma romana. Las formas de estos ordinales encontradas en los dos manuscritos en su totalidad, con la indicación del número de veces que aparece cada una, son las siguientes :

\begin{tabular}{|c|c|c|}
\hline & $M_{8 .} T$ & Ms. $E$ \\
\hline sesto $\ldots \ldots \ldots$ & $5 \mathrm{I}$ & 58 \\
\hline $\operatorname{sesen} 0 . \ldots \ldots \ldots$ & 4 & I \\
\hline$v{ }^{\circ} \ldots \ldots \ldots \ldots$ & II & 8 \\
\hline seteno......... & $5 \mathrm{r}$ & 14 \\
\hline septimo $\ldots \ldots$ & 3 & \\
\hline sétimo ....... & & 48 \\
\hline$v$ vii $^{\circ} \ldots \ldots \ldots$ & 16 & 7 \\
\hline octauo........ & 6 & \\
\hline otano......... & & 9 \\
\hline ochauo ....... & I & \\
\hline $\operatorname{viii}^{\circ} \ldots \ldots \ldots$ & t & \\
\hline noveno ....... & 4 & 6 \\
\hline nono $\ldots . . . \ldots$ & & 2 \\
\hline $\mathrm{ix}^{\mathrm{o}} \ldots \ldots \ldots \ldots$ & $\mathbf{r}$ & \\
\hline dezeno ....... & $\mathbf{r}$ & $\mathbf{r}$ \\
\hline dézimo ....... & & 1 \\
\hline$x^{a} \ldots \ldots \ldots \ldots$ & $x$ & \\
\hline
\end{tabular}

XIV. NOTA SOBRE LAS LÁMINAS

Las láminas del presente volumen intentan dar una idea del aspecto de los manuscritos $T$ y $E$ e ilustrar algunos puntos tratados en esta Introducción. Están reproducidas por el procedimiento llamado "grabado a pluma", procedimiento de reproducción fotográfica tan exacto como los más comúnmente usados.

Si no se mencionaran las limitaciones de ese procedimiento y algunas deficiencias evidentes en las láminas reproducidas, el lector podria formarse una impresión falsa de los manuscritos mismos. Hay que tener en cuenta, antes de nada, que las láminas han sido hechas sobre negativos sacados de las fotocopias que yo be utilizado para hacer esta edición. Se verá que las reproducciones de $E$ son mucho más claras que las de $T$, sencillamente porque la letra del primero es relativamente más grande y más clara. La 
reproducción a pluma no registra el color gris o rasgos demasiado tenues, lo cual da a la escritura un aspecto algún tanto carcomido ". Cedillas, tildes y diversas prolongaciones de las letras aparecen en general recortadas, perdiéndose los exlremos más finos. En unos pocos casos las cedillas, tildes y otros rasgos se han perdido enteramente en las láminas ". Pequeños borrones a través de los cuales se pueden leer las letras en las fotocopias resultan enteramente negros en las láminas ${ }^{3}$. Esas deficiencias de las láminas están determinadas por las condiciones de los manuscritos o de las fotocopias. Pero hay, en cambio, algunos casos de letras o rasgos que son perfectamente claros en las fotocopias y aparecen inexplicablemente omitidos en las láminas '. Las rayitas, puntitos y pequeñas manchas que aparecen ocasionalmente en las láminas y nada tienen que ver con la lectura del texto se encuentran también, en su mayor parle, en las fotocopias mismas".

Después de estas breves observaciones, tengo la esperanza de que las láminas servirán adecuadamente para los fines expuestos.

- Las líneas que delimitan las columnas en $T, y$ que por lo regular aparecen completas en las fotocopias, están borradas total o parcialmente en las láminas. Esas líneas son tan débiles en las fotocopias de $E$ que no se podría esperar que fueran reproducidas.

${ }^{2}$ El lector que quiera tomarse la molestia de comparar detenidamente las láminas con el texto correspondiente descubrirá una docena de casos (en las láminas de $T$ ) en que no aparecen en las láminas, a aparecen casi imperceptiblemente, cedillas o tildes que figuran en la transcripción. La débil raya transversal con que una mano diferente tachó la $r$ final de cerrar (VII, 6,13 ) con la intención evidente de que la palabra se leyese çerca - así la he transcrito, sin indicación ninguna en las variantes - no aparece en la lámina correspondiente. Tampoco aparece la raya que tacha la $a$ de adixeron (VIII, $a, 6$ ) - circunstancia no jndicada en las variantes - ni la que tacha el nos en la línea signiente - circunstancia st indicada en las variantes por su posible conexión con la forma del confesan que le sigue. No se notaría, sin duda, ninguna huella de la raya que tacha a faze (VIII, b, 22) si esta circunstancia no estuviera indicada en las variantes.

${ }^{3}$ Véanse las láminas $\mathrm{V}(b, 30) .1 \mathrm{X}(a, 10)$ y X $(b, \mathrm{I} 1)$.

- Los principales casos se encuentran en las láminas V $(a, 29)$. VI $(a$, r 3 ; $a, 23 ; b, 2-3)$, VII $(a, 20)$ y IX $(b, 17-21)$. Con referencia al último de estos casos, los dos trazos verticales escritos después de $\bar{q}(b, 18)$ son el comienzo de una palabra crónea empezada en ss largas off.

- En cambio, no son de las fotocopias los pequeños redondeamientos de rasgos que aparecen en las láminas I $(b, \mathbf{I}\}$, en la palabra algo), V ( $a, \mathbf{I}$, encima de la $g$ de ninguno), VI $(b, \mathbf{1 5}$, después de $E t)$ y IX $(a, 30$, en la $S$ maýscula). 


\section{BIBLIOGRAFÍA ${ }^{3}$}

[Arfonso el Sabro]. - Antologías de Alfonso $X$ el Sabio. Prólogo, selección y glosarios de Antonio G. Solalinde. - Tomo II, Madrid, s. a.

[Alronso el Sabro]. - El espéculo. Tomo I de Opúsculos legales del rey don Alfonso el Sabio. Edición de la Real Academia de la Historia: - Madrid, 1836.

[Alfonso el Sablo]. - Las siete partidas del rey don Alfonso el Sabio. Edición de la Real Academia de la Historia. - Madrid, 1807 , 3 tomos.

Altamtia y CRevea, Rafael. - Historia de España y de la civilización española. $2^{\mathrm{a}}$ edición, corregida y aumentada. - Barcelona, $19 \circ 9,2$ tomos.

Amabor de los Ríos, José. - Historia crítica de la literatara española. Tomo III, Madrid, 1863.

Antomo Hispalensi, Nicolao. - Bibliotheca hispana vetus. Edición de Francisco Pérez Bayer. - Tomo II, Madrid, 1788.

Baist, Gotrfried. - Die spanische Literatur. En Grundriss der romanischen Philologie. - Tomo II, parte II, Estrasburgo, $\mathbf{1} 897$.

Basave, Agustin. - Breve historia de la literatura castellana. - Gua-

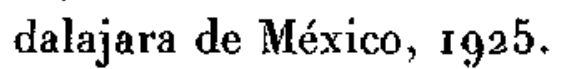

Bastianini, Reń́. - Curso de historia de la literatura castellana : texto y antología. Tomo I, desde los orígenes hasta el siglo xvi - Buenos Aires, 1922.

Bovterwer, Fredericr. - Historia de la literalura española. Escrita en alemán [1804], traducida al castellano y adicionada por D. José Gómez de la Cortina y D. Nicolás Hugalde y Mollinedo. - Madrid, 1829 .

Gejador y Frauca, Julio. - Historia de la lengua y literatara castellana. - Tomo I, Madrid, igi5.

Glarke, Henry Butber. - Spanish Lilerature: an Elementary Handbook. -- Londres, 1893 .

- En esta bibliografía dispongo en orden alfabético todas las obras que he utilizado en la preparación de la presente edición y que están ya citadas a lo largo de la Introducción. Como se verá, no todas las obras citadas son del más alto valor, y además, falta la mayoría de los títulos conocidos de la bibliografia alfonsina. He citado las primeras por tener algunas noticias sobre el Setencuio, y omitido las segundas porque no aportan nada - dado lo poco que ha sido estudiado el Setenario - a este estudio particular. 
Chanos, Ludwig. - Darstellung der spanischen Literatur im Miltelalter. - Tomo I, Maguncia, 1846.

Colección de documentos inéditos para la historia de España. - Tomo XIII, Madrid, 1848.

Colmeino, Manuel. - Reyes cristianos desde Alonso VI hasta Alfonso XI en Castilla, Aragón, Navarra y Portugal. Tomo $\mathrm{V}$ de Historia general de España. -- Madrid, I $89 \mathbf{1}$.

Cotaremo y Moni, Emino. - Diccionario biográfico y bibliográfico de caligrafos españoles. - Tomo II, Madrid, $\mathbf{g}^{\mathbf{I}} 6$.

Crónica del rey don Alfonso Décimo. En tomo I de Crónicas de los reyes de Castilla. - Madrid, ${ }_{1} \$_{7} \tilde{5}$. Biblioteca de Autores Españoles, tomo LXVI.

Daumet, Gronges. - Les testaments d'Alphonse $X$ le Savant, Roi de Castille." En Bibliothèque de l'Ecole des Chartes, LXVII, ıgo6, págs. 7o-99.

Fitzmaurige-Kelly, James. - History of Spanish Literalure. - Nueva York, $192 \mathrm{I}$.

Gallakdo, Bartoloné José. - Ensayo de una biblioteca española de libros raros y curiosos. - Tomo 1, Madrid, 1863.

Henriots, J. Homer. - A Thirteenth-Century Manuscript of the "Primera partida ). En Speculam, XIII, I938, págs. 278-294.

Juan Manuel. -- El libro de la caza. Edición de G. Baist. - Halle, $188 \mathrm{o}$.

Laborde, E. D. - A History of Spanish Lilerature. - Londres, I93r.

Lucas, Obispo de Túy. - Crónica de España. Edición de la Real Academia de la Historia. - Madrid, $19^{26}$.

Llacayo y Santa María, Augusro. - Antiguos manuscritos de historia, ciencia $y$ arte militar, medicina y literarios existentes en la Biblioteca del monasterio de San Lorenzo del Escorial. - Sevilla, ${ }_{1} 8_{7} 8$.

[Manufl Ronríguez, Miguel de] - Memorias para la vida del santo rey don Fernando III. Dadas a Juz con apéndices y otras ilustraciones por don Miguel de Manuel Rodríguez. - Madrid, 1800.

Mariana, Padre Juan de. - Historia general de España. - Madrid, I 864. Biblioteca de Autores Españoles, tomo XXX.

Marichalar, Amalio, Marquess de Montesa, y Maneigue, Cayetano. Historia de la legislación y recitaciones del derecho civil de España.Tomo III, Madrid, I862.

Martinez Marina, Francisco. - Ensayo histórico-crítico sobre la antigua legislación y principales cuerpos legales de los reynos de León y Castilla, especialmente sobre el código de D. Alonso el Sabio, conocido con el nombre de las Siete Partidas. - Madrid, 1808.

Mérmée, Ernest. - Précis d'histoire de la littérature espagnole. Édition cutièrement refondue. - París, I922. 
Murdares Careo, Agustix. - Paleografía española. -- Tomo I, Barcelona, I929.

Montolíu, Manuel De. - Literalura castellana. $2^{2}$ edición. - Barcelona, Ig3o.

Prande, Ludwig. - Spanische Literaturgeschichte. Erster Band, Mittelalter und Renaissance. - Berlin, 1923.

Primera crónica general. Edición de Ramón Menéndez Pidal. - Madrid, Igo6. Nueva Biblioleca de Aulores Españoles, tomo V.

Reros y Rubio, Juan J. -- Curso de historia de la titeratura castellana. Tercera edición, corregida y aumentada. - La Habana, 1922.

Rodríguez de Cistro, Josepa. - Biblioteca española. Tomo segundo, que contiene la noticia de los escritores gentiles españoles, y la de los christianos hasta fines del siglo xu de la Iglesia. - Madrid, 1786 .

Saint-Hilaire, Rosseeuw. - Histoire d'Espagne depuis les premiers temps historiques jusqu'à la mort de Ferdinand VII. Nouvelle édition, revue et corrigée. - Tomo IV, París, 1844.

Salcedo y Rulz, Áxger. - La literatura española. - Tomo 1, Madrid, 1915 .

Sampere y Guarinos, Juan. - Biblioteca española económico-política. Tomo II, Madrid, I804.

Sarmiento, Fr. Mantín. - Memorias para la historia de la poesia y poetas españoles. - Madrid, 17,5 .

Solatinde, A. G. - Un códice misceláneo con obras de Alfonso $X$ y otros escritos. En Revista de Filología Española, XI, 1924, págs. 178-183.

Tenneros y Pando, Padre Estevan de. - Paleografía española. - Madrid, 1758 .

Ticknon, Geonge. - History of Spanish Lilerature. Third American edition, corrected and enlarged. - Tomo I, Boston, 1864.

Uriatite, José Eugento de. - Calólogo razonado de obras anónimas y seudónimas de autores de la Compañia de Jesús. - Tomo III. Madrid, 1906 .

Valladares de Sotomayor, Antomo. - Semanario erudito. - Tomo 1I, Madrid, 1787 .

Vandermohd, Kenneth H. - El "Setenario" y sa relación con las "Siete partidas \#. En Revista de Filología Hispánica, III, 194 r, págs. 233-26a.

Vargas y Ponce, Joseph dx. - Elogio del Rey Don Alonso el Sabio, premiado por la Real Academia Española, en junta que celebró el día 15 de octubre de 1782. En tomo l de Obras de eloqüencia y de poesía premiadas por la Real Academia Española. - Madrid, s. a.

Zarco Cuevas, P. Fr. Julíx. - Catálogo de los manuseritos castellanos de la Real Biblioleca de El Escorial. - Tomos II y III, Madrid, $19^{26}$ y San Lorenzo de El Escorial, $19^{29}$. 
SETENARIO 

[LEY I. - De las ssiele letras de Alpha el O que muestran cada vna ssiete nonbres de Dios.]

[II] ... conplidamiente en ssí; ca non es ssometido a ninguna cosa e todas lo sson a él. Et él ha poder de librar los ssieruos del mundo e del diablo e de los tornar de sseruidunbre a libertad 5 conplida, lo que otro non puede ffazer.

F es la terçera letra que muestra otrossí ssiete nonbres de Dios en latín, que sson éstos :

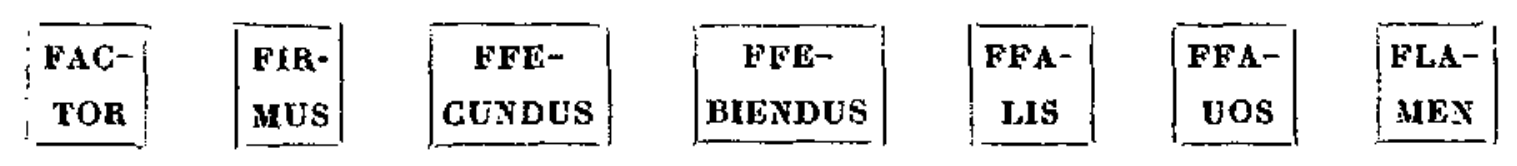

Et cada vno destos nonbres muestra muy derechamiente las so obras buenas de las bondades de Dios. Ca él es ffazedor de todas las cosas e las ffizo tan marauillosamiente que non metió y ssinon la palabra ssola. Et tan luego que dixo que ffuesen, fueron fechas. Ffirmedunbre èstabledat ha en ssí enteramiente; ca maguer ffaze todas las cosas, él en ssí nunca sse mueue. Abastado es; que nirl- 15 gunas cosas non le falleçen nin ha dellas mengua, ante abonda a todo conplidamiente. Marauillosamiente es bien rrazonado; ca él por rrazón derecha e çierta ffaz entender todas las cosas, quáles sson en ssí e qué deuen frazer dellas. Bienauenturado es conplidamiente; ca él non ha en ssí natura por que pueda rreçebir mengua 20 nin desauentura. Otorgador es llamado con derecho; ca él otorga los bienes a aquellos que los ffazen e los mereçen auer. Flamen sse entiende por llama de Spíritu Ssanto con que ençienden e alunbran los coraçones de aquellos que él ama.

A es la quarta letra de Alpha e muestra otros ssiete nonbres de 25 Dios en latin, que sson éstos:

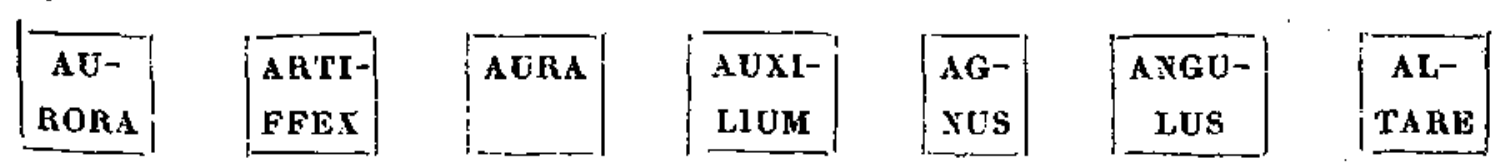

Onde el nonbre de Aurora, que quiere dezir por la lunbre que viene quando aluoreçe ante que ssalga el ssol, esto sse entiende 
que él alunbra el mundo, assí commo' el ssol ffaz el alua, con la ssu merçet et escalienta ol ssol con la ssu piedat. Artiffex quiere dezir maestro conplido, e esto con grant rrazón ; ca él ffizo las cosas e las ssopo ffazer de tal manera que por otro maestro non pueden

5 sser asmadas nin ffechas. Aura quiere otrossí dezir oriella. Esto sse entiende por Dios; ca él es oriella buena e tenprada e ssana con que guaresçen las enffermedades e rressuçitan los muertos e sse perdonan los peccados. Auxilium es tanto commo ayuda e defendedor de todas las cosas que con él sse tienen. Agnus sse muestra

ro por cordero mansso; que assí commo él es más manssa bestia que otra, assí la manssedunbre dél es tan grande que non podría sser asmada commo que él uençe e quebranta los coraçones duros e malos e los trae a ssu uoluntad. Et a los quel desaman, ffaze quel amen quando él quiere. Angulus quiere tanto dezir commo rren-

íj cón. Este nonbre conuyene mucho a Dios ; que assí commo en el rrencón sse ayuntan todas las lauores e sse ffirman, assí en Dios sson ayuntados todos los bienes e dél rreçiben creçimiento e ffirmedunbre. Altar es nonbrado con grant rrazón ; que todos los ssacriffiçios ffazen a él e por él sson ffechos. [1v]

20 E es letra uocal que muestra otros ssiete nonbres de Dios en ebraico :

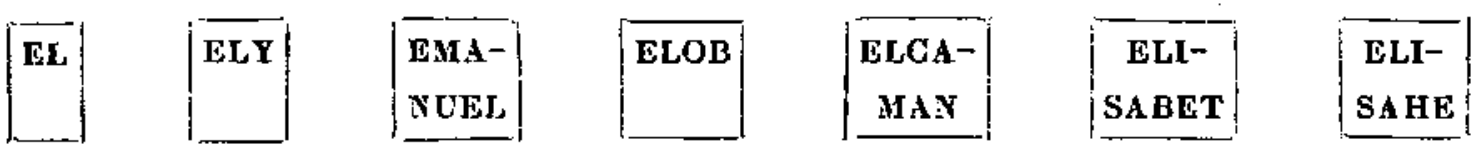

Onde el primer [nonbre], que es llamado El, le cae muy derechamiente a Dios; ca atanto quiere dezir que él es en ssí mismo 25 Dios en deidat. Ely quiere dezir vn Dios. Et esta palabra sse entiende que la puede dezir toda criatura que aya entendimiento e lengua para ffablar; ca él es Dios de todos e de cada vno por ssí que les da uida e los mantiene. Emanuel quiere dezir Dios connusco, e muestra que ssienpre ssomos e sseremos con él ssi por nos non

$3 o$ flincare. Eleb quiere dezir Dios de nuestros padres, e este nonbre cae con rrazón ; ca él ffué padre de los primeros que ffizo llegar el linaie a estos de agora, e assí lo sserá ffasta la ffin. Et Elcaman sse entiende por Dios dador de ssennorios. Et esto puede él ffazer más conplidamiente que otro ; ca todas las cosas son en ssu sse35 nnorío, e él las da e él las tuelle al que quiere. Elisabet sse entiende por guardar. Et este nonbre es ssennaladamiente de Dios por la 
grant merçet que nos ffaze; ca ssi non fuese por la ssu guarda, todos sseríamos perdidos en cuerpos e en almas por las obras que ffazemos. Elisahe es nonbre que quiere dezir que Dios es ssalut. Et esto es con grant uerdat; ca segunt él es en ssí ssalut conplida, assí la da a todas las cosas que la quieren rreçebir commo 5 deuen.

T es la ssesta letra que muestra otrossí ssyete nonbres de Dios, que sson éstos :

\begin{tabular}{|c|c|c|c|c|c|c|}
\hline $\begin{array}{c}\text { THE- } \\
\text { OS }\end{array}$ & $\begin{array}{l}\text { ATHI- } \\
\text { YUO }\end{array}$ & $\begin{array}{l}\text { THE- } \\
\text { TIGA }\end{array}$ & $\begin{array}{l}\text { THETRA- } \\
\text { GAMATON }\end{array}$ & $\begin{array}{l}\text { THL- } \\
\text { TAM }\end{array}$ & $\begin{array}{l}\text { THI- } \\
\text { PUS }\end{array}$ & $\begin{array}{l}\text { THE- } \\
\text { JON }\end{array}$ \\
\hline
\end{tabular}

El primer nonbre es Theos, que sse muestra por Dios temeroso, io e esto es con muy grant rrazón; ca a él temen todas las criaturas biuas que sson en cl çielo e en la tierra. Et esto porque él es ssobre todo lo que es ffecho e sse ha de ffazer; que ninguna cosa non sse le asconde. Thimian es commo olor que ffazen e conponen de muchas buenas espeçias; ca assí commo la cosa que huele bien 15 conorta el coraçón, do está el alma, e la cabeça, do están los ssentidos, assí la olor mansa de piadat de Nuestro Ssennor conorta los ssentidos del alma e del cuerpo. Thetica quiere dezir deidat ssobre todas las deidades, e por esso la llaman en latín Deus Deorum, que es tanto commo Dios de los dioses; non porque ssea otro 20 Dios ssinon él, mas porque los antigos llamauan a los ángeles e a los omnes ssantos e buenos dioses et sse mostrauan que las uertudes que ellos auyen, que les vinie de Dios el mayor, sso cuyo poder eran. Thetagramaton en griego quiere dezir nonbre de Dios ascondido, e por esto, porque algunas gentes lo nonbrauan por ssennal 25 de letras, e non por uoz; porque tenien que lengua de omne mortal non era digna de nonbrar a él nin ponerle nonbre ssennalado. Titan es nonbre del ssol, e por esso le llamaron a Dios porque él ffaze nasçer e creçer todas las [2r] cosas, assí commo el ssol ffaze por el poder e por la vertud que él le dió. Et por esso le llamaron a Dios 30 Ssol de Justiçia porque alunbra e escalienta toda cosa ssegunt con-

2 obras $[E I F] .-3$ noble (relocado sobre nobro). - 4 ansi. -9 Theos, Timan, Theotica, Thetragramaton, Thitan, Tipus, Thelon, -- so primero / se demuestra. - 12 en ç. e en tierra. - 12-13 porque sabe todo. - í4 Thiman. 18 Theotica. - Ig las otras d. e por esol llaman. - 20 que quiere t. dezir commo. - 21-22 llamauan a los omnes. - 23-23 muestra que la vertut que en e. auie. -24 Thetragramaton. -25 esto era que a. g. le, $-26 \mathrm{~T}$ temien. $-28 \mathrm{lo}$. - 3o eso llam. - 3 I escalienta a toda. 
uyene. Tipus es otrossi nonbre que quier tanto dezir commo ffigura. Et esto cae mucho en Dios, non porque él mismo ssea ffigurado, mas porque él da ffigura a todas las cosas. Telon muestra otrossí que Dios es Iuengo. Esta rrazón es uerdadera en dos maneras : la 5 vna, en morança; la otra, en tienpo. Ca él mora en todo e por todo quanto ffizo, que es muy luengo de contar. Et otrossí ssu tienpo es tan luengo que non ouo comienço nin aurá ffin, nin pude sser contado commo de las otras cosas que él fizo, que ffueron començadas en él e sse acabarán quando él quisiere.

ro La $O$ es la ssetena letra de que ssalen otros ssiete nonbres con que llaman los omnes a Dios. Et estos ssiete sson de bueltas de letras de todos lenguaies destos sobredichos, que son griego e ebraico e latin :

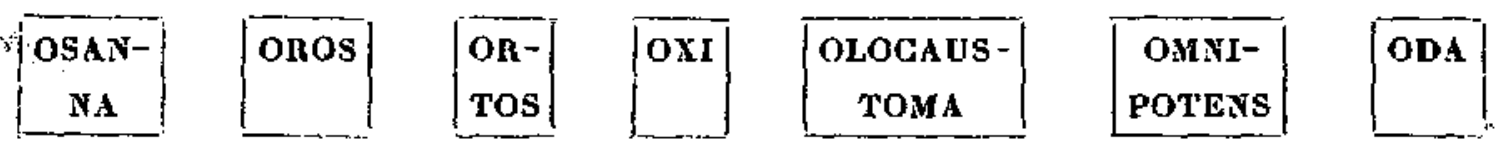

15 Onde Osanna, que es el primero, quiere dezir ssaluador. Et esto es conplidamiente en Nuestro Ssennor; ca él ssalua todas las cosas, mostrándoles carrera por do uengan a ssaluaçión. Oros otrossi quiere tanto dezir commo visión de paz; ca ninguno non puede uer a Dios en visión ssi paz e assesegamiento non ouyere 20 en la uoluntad. Ortos quiere dezir derecho. Otrossí esto cae muy bien a Dios; ca él es muy derechurero en ssí e ffaz que lo ssean aquellos que ssiguen la ssu carrera, connosçiendo las cosas derechamicnte e obrando por ellas con derecho. Oxi muestra tanto commo acuçia, e este nonbre es derechamiente de Dios, que es tan 25 acuçioso en ssí que ssienpre faze las cosas e las desata quando entiende que conuyene que ssean desffechas. Olocaustoma quiere tanto dezir commo que Dios es rreçebidor del ssacriffiçio que ffazen por las almas de los muertos, queriéndoles auer merçet e perdonándoles los yerros que ffizieron. Omnipotens en latin es 30 tanto commo poderoso en todas las cosas, e es Dios conplidamiente; ca el ssu poder es tan grande que non podría sser contado nin mesurado. Ca él puede dar pena a las cosas spirituales e ten-

3 porque da. -7 puode. -8 otras quel. - Io es [E 1 1 ] / otrosy. - I Estos bueltos de letras. - ia $T$ lenguaies que / griego ebr. - $1 / 4$ Osana, Oros, Ortus, Exi, Olacaustoma, Omnipotens, Oda. - 15 Osana, - i6 $T$ ssaluo. - 20 en su vol. -23 que segunt la. -23 Exi. -24 acuzia. $-20-27$ Olocaustoma que q. d. t. commo. -28 por almas. -29 perdonando los yerros. - 3o todas c. es. 
porales, et a las que non han cuerpo para ssoffrir pena commo a las que lo han. Oda quiere dezir ffin e acabamiento de las cosas. Et esto es en Dios conplidamiente; ca bien assí commo en él se comiençan, por ffuerça conuyene que en él sse acaben.

Onde la A con rrazón demuestra, ssegunt de ssuso dixiemos, $\overline{5}$ que Dios es comienço, et la $\mathrm{O}$ ffin ; non porque Dios ouo comienco en ssí nin puede sser acabado, mas porque él da comienço e acabamiento a todas las cosas que él ffizo. Et las otras çinco letras que sson en medio muestran las otras cosas que en él sson, ssegunt el ssaber e el poder e la uertud que ha. Et esto sse entien- 10 de que es la Trinidat conplida; ca por el $[2 v]$ poder sse entiende el Padre, e el ssaber el Ffijo, e el querer e la uertud con que huebran, el Spíritu Ssanto. Porque conuyene que todo omne que quisiere alguna buena obra començar e sseguir e acabar bien, que la comiençe en el nonbre de Dios e uaya por ella en la 15 ffiuza del ssu grant poder e acábela con la ssu merçet del ssu amor, que es querer acabado.

Et por ende nos don Alffonso, ffijo del muy noble e bienauenturado rrey don Ffernando e de la muy noble rreyna donna Beatrís ; e ssennor heredero, primeramiente por la merçet de Dios, 20 e después por derecho linaie, de que heredamos los rregnos de Castiella, de Toledo, de León, de Gallizia, de Seuilla, de Córdoua, de Murçia, de Jahén, e de Badaioz, e del Algarbe; cuyo nonbre quiso Dios por la ssu merçet quiso que sse començasse en $A$ e sse ffeneçiesse en $O$, en que ouyesse ssiete letras, ssegunt 25 el lenguaie de Espanna, a ssemeiança del ssu nonbre. Por estas ssiete letras enbió ssobre nos los ssiete dones del Spíritu Ssanto, que sson éstos :

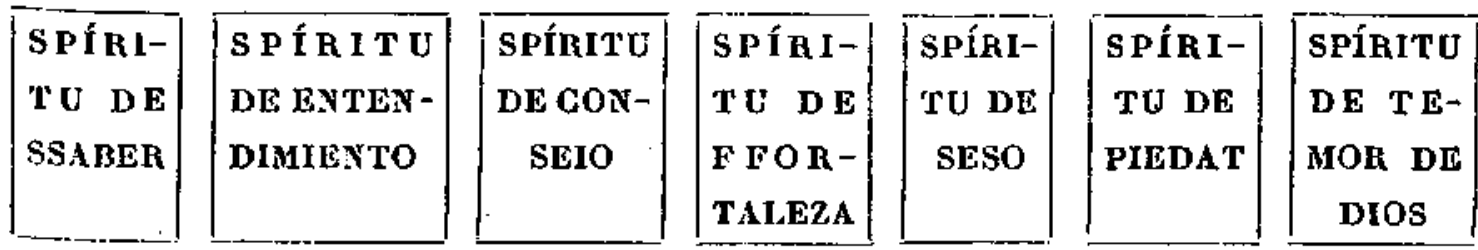

Con que nos alunbre nuestro entendimiento e nuestra uoluntad 30 por que nos podamos saber aquellas cosas que ffueren a ssu

5 dixemos, - 6-7 porque Dios en sy fue començado nin, -- ro Esto. - 13 Padre e por el s. el F. e por el q. la. - I3 obra. - I4 conençar [E 2r]/ acabar conviene. - 16 fiuzia. - - 18-19 $T$ noble auenturado. - 23 Badajoz del. - 24 merçet que. - 36 lynaje (lengua añadido en el margen, olra mano) i semejante / Por que estas. -27 enbien. - $30 T$ alunbro. 
sseruiçio et entender lo que a él más ploguiere. Et ayamos ssienpre buen conseio para ffazerlo. Et nos dé ffortaleza contra ssus enemigos por que los podamos quebrantar e acreçentar el ssu nonbre, et sseso por que ssepamos ffazer nuestros ffechos ssesuda-

5 miente en manera que non erremos en ello. Et que aya piadat de nos, non catando a los pesares e a los yerros que ffiziemos para darnos pena por ello, mas catando a la ssu grant misericordia de cómmo él quiso sser omne e rreçebir muerte e passión en la cruz por nos saluar. Et por ende que quiera tornar la ssu uoluntad más a

ro ffazernos merçet para perdonar que a justiçia para dar pena. E que ssienpre ayamos connosçimiento de temerle e guardarnos de ffazerle pesar.

Et que por la uertud destos spíritus quiera él que este libro que nos començamos por mandado del rrey don Ffernando, que ffué I5 nuestro padre naturalmiente e nuestro sennor, en cuyo nonbre, ssegunt el lenguaie de Espanna, ha ssiete letras.

LEY II]. - De lo que muestran las ssiete letras del nonbre del rrey don Ffernando.

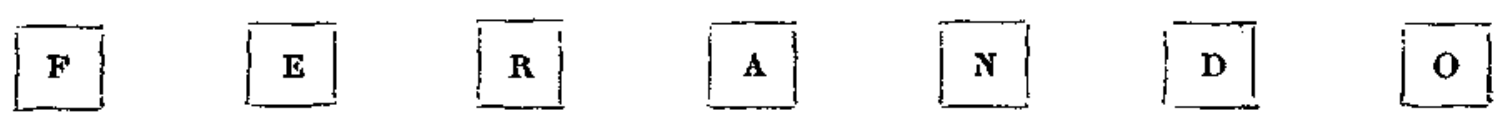

20 Et todas éstas muestran la bondat que Dios en él puso. Ca la F quier dezir tanto commo ffe, de que ffué él más conplido que otro rrey que nunca ffuese de ssu linage. Et la $E$ muestra que él ffué mucho encerrado en ssus ffechos e ouo muy grant entendimiento para connosçer Dios et todas las cosas buenas. La $\mathbf{R}$ 25 muestra que ffué muy rrezio en la uoluntad e en ffecho para quebrantar los enemigos de la Ffe e otrossí los malffechores. La A muestra otrossí que ffué amigo de Dios e amador [3r] de derecho. La N, que ouo nobleza de coraçón en todos ssus ffechos, por que ganó nonbradía e buena ffama ssobre todos los otros rreyes que 3 o ouo en Espanna. La D muestra otrossí que ffué derechurero e leal, tan bien en dichos commo en ffechos. Por la $\mathrm{O}$ sse entiende que

6 quel fezieremos. -8 rresçebir p.e m. en. - r ro $T$ omilc para perdonar... pena. - I I tenerle. - I3-r 4 libro que com. - I 7 muestran de las. - I 9 añade

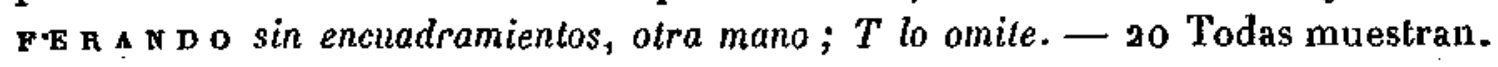
-23 ençerrado [E 2v]. -24 conosçer a Dios. -25 mucho. -28 todos fechos. -29 -3o $E$ omite que ... ffue. 
ffué omne conplido de buenas maneras e de buenas costunbres, por que ffué onrrado de Dios e de los omnes.

Onde nos, queriendo conplir el ssu mandamiento commo de padre e obedeçerle en todas las cosas, inetiémosnos a ffazer esta obra mayormiente por dos rrazones: la vna, porque entendiemos 5 que auya ende grant ssabor ; la otra, porque nos lo mandó a ssu flinamiento quando estaua de carrera para yr a paraíso, o creemos que él ffué ssegunt las obras que él ffizo. Et porque entendimos conplidamiente quál era ssu uoluntad quel mouye a ffazerlo e ssobre qué rrazones teníe que lo deuye ffazer, e metiemos nos otro- ro ssí nuestra uoluntad e ayudámosle a començar en ssu uida e conplirlo después de ssu ffin, connosçiendo que en este ffecho auye ssiete bienes por quél se mouyera a fazerlo.

[LEy III]. - De los bienes que entendie el rrey don Ffernando en esia obra, por que la mandó ffazer.
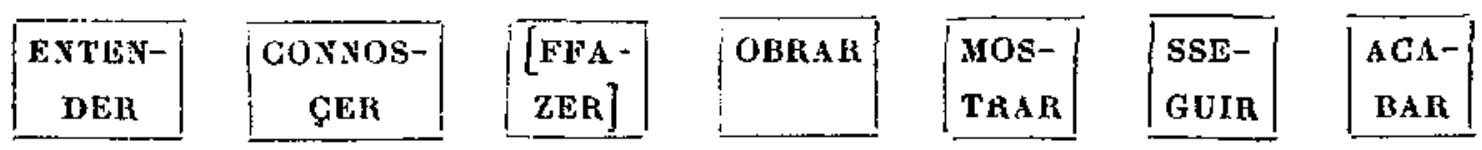

Ca ssin ffalla estas siele cosas le mouyeron a ffazerlo más que al : la primera, por que él e los otros rreyes que después dél viniessen entendiesen derecho e rrazón, para ssaber mantener por ello a los pueblos que auyan a mandar; por que el entendimiento los 20 aduxiesse a connosçer las cosas ssegunt que eran, primeramiente a Dios, dessí a ssí mismos, desí a todo lo al que ouyessen a dezir o a fiazer; de guisa que la connosçençia les endereçase a ffazer ssus cosas bien e derechamiente; e obrar en las cosas ssegunt conuyniese a ellos e a aquellas en que obrassen; et que pudiesen 25 mostrar a los de ssus ssennoríos aquello que auyan a dezir o a ffazer, e otrosí de lo que sse deuían partir e dexar; et los bienes que començasen, que los ssopiesen sseguir en manera que non prisiessen dellos enfadamiento nin enoio; assí que los pudiesen bien acabar a onrra e a pro de sí e de los ssuyos.

3 mandado. -4 metimosnos. - 5 cntendemos. -8 que fue / entendemos. - ro fazer metimos nos y otr. - I 2 que este. - I4-15 Ferrnando por que lo. - 16 entender, conosşer, saber (también $T$ ), mostrar, seguir, acabar, obrar. - i7 lo. - r9-2o saber por ello m. los pucblos (a escrito y tachado después de ello). - 3 I segunt eran. - 22 mesmros e desy. -23 los. - 24 sus obras lsien. - 24-25 conveniese. - $25 T$ ellas / e aquello. -26 que deuien d. o fazer. - $28-29$ presiesen. - 3o acabar [ $\left.E \begin{array}{ll}E & 3 r\end{array}\right]$. 
El viniéndonos emiente otrosí de las muchas e grandes mercedes que nos él fizo, e sennaladamiente en siete maneras.

[LEy IV]. - De los bienes que ffizo el rrey don Fernando al rrey don Alffonso sn ffijo.

- La primera, que nos fizo omne; ca quiso Dios que él fuese nuestro padre e por él viniésemos al mundo. La ssegunda, que nos fizo en noble logar e en mugier de grant linaie, a quien fizo Dios muchas merçedes en que quiso que ffuese buena en todas ro bondades que duenna lo deuya sser. La terçera, amándonos mucho e ffiándosse mucho en nos e metiéndonos mucho en sus consseios e en ssus fablas, maguer [3v] que la nuestra hedat non era tamanna por quel sopićsemos conseiar segunt convinie a la su nobleza e a los sus ffechos. La quarta, onrrándonos en tantas

I5 maneras quantas nunca onrró rrey en Espanna a ffijo que ouyese. La quinta, ffaziéndonos mucho bien con quel sseruyésemos; que es merçet sennalada que faze sennor a uasallo en fazerle bien con quel pueda seruir, e darle carrera por que lo faga más. La sesta, castigándonos muy conplidamiente e mostrándonos aquellas so cosas por que ffuésemos bueno e mereçiésemos aner bien. Otrossí ffaziéndonos entender las cosas por que non ffiziésemos yerro, de guisa que non menguásemos en bondat nin rreçibiésemos danno. La setena, perdonándonos quando algunos yerros ffazíemos contra él o contra otre.

25 Onde, por todas estas e por otras muchas bondades que en él auya e por todos estos bienes que nos ffizo, quisiemos conplir después de ssu fin esta obra que él auya començado en su vida e mandó a nos que la cunpliésemos. Et por ende punnamos de leuarla cabadelante quanto pudiemos e sseguir aquella carrera. Et

1 veniendonos o. e. de. - 3-5 $T$ invierle el orden de rúbrica y encuadramientos. - $5 T$ omnes / E omite bicn. - 8 linaje e a. - 9 quier. - ro deue. - I f fandose en nos e met. en. -13 tanmanna por que podiesemos c. s. conviene. -14 a sus. - I 7 semulada en que. - I $2 T$ seruir darle / quel faga. - Ig conplidamente mostr. -33 faziamos, -25 cstas cosas e. -26 quisimos. $-37-28$ e que mando. -28 conpliesemos. $-28-29$ de la leuar adelante q. mas podimos. 
ssiguiemos aquel ordenamiento que entendiemos que era más segunt su uolunlad, catando las bondades conplidas que Dios en él pusiera, e ssennaladamiente ssiete a que llaman en latín vertudes.

[LEY V]. - De las vertudes ssiete que puso Dios en el rrey don Ffernando.

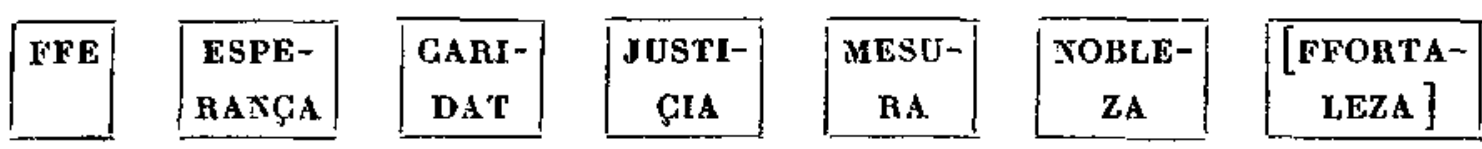

Fe ouo el rrey don Ffernando muy conplidamiente en Nuestro Sennor, segunt de suso es dicho, para creer en él en todas las maneras que Santa Eglesia manda. Esperança ouo ssienpre de ro auer el ssu bien en este mundo, commo lo ovo demientra que en él visco, e después en el otro; porque oy en día muestra Dios que la su merçet que atendíe auer dél, que la ouo muy conplidamiente. Amor de caridat ouo dél otrosí ; ca non tan solamiente lo amó Dios, mas a todas las otras cosas que lo amauan o que eran i5 dél amadas. Justiçia amó mucho e la ouo conplidamiente, galardonando los bienes e escarmentando los males. Mesura puso tanta en él que ningún omne non podríe más aner en sí que en él auye. Nobleza de coraçón auye en él muy grande para desdennar e despreçiar las cosas malas e viles e de pagarse de onrrar las 20 nobles. De ffortaleza era muy conplido; ca desque entendiese que la cosa que auya de ffazer era derecha, non se camiaría della por omne del mundo nin por amor nin por desamor, nin por cosa quel diesen nin le prometiesen a dar.

Esto ouo en ssí naturalmiente ssin otras buenas costunbres e 25 maneras quel dió Dios tantas e tales que todo omne ssería acabado para auerlas.

I seguimos/ entendimos. - I-2 mas meior segunt. - 3 siete que. -5 De la graçia quc. - 7 fermosura, apostura, buen contenente, buen donayre, buen enteudimiento, buena palabra, buena manera $[E 3 v] / T$ flirmedumbre. 8 Fernando conpl. - 9- 10 todas man. - - I 3 merçet at. / $T$ atiende. -15 quel amaua. - $16 \mathrm{~T}$ amados. - 18 podrie a. mas en sy que el anie. - I9 oto miry. - 2 c ca de que ent. - 22 T auyan. 
[Ley VI]. - De cómmo el rrey don Ferrnando era bien costinbrado en siete cosas.

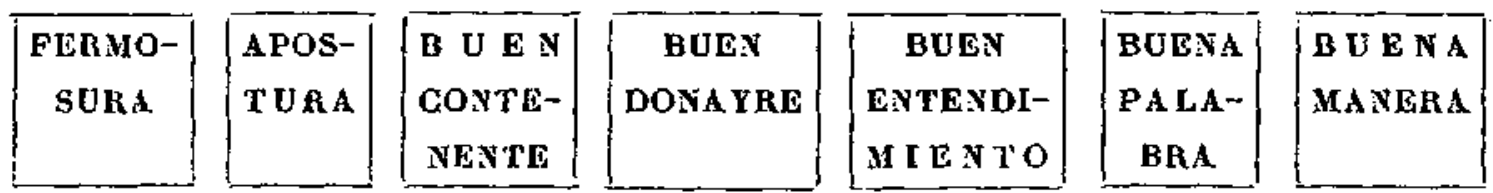

Fué muy fermoso omne de color en todo el cuerpo ; e apuesto 5 en sser bien ffaçionado e en todos sus mienbros e en sabersse ayudar de cada vno dellos muy apuesta[4\%]miente. E buen contenente conplido auya otrossí en todas las cosas que vsaua de ffazer. Buen donayre auya otrossí; ca todos los quel oyen ffablar, o le veyen, o mostrar alguna cosa de las que él ssabía ffazer se paga-

Io uan dellas. Buen entendimiento auya en las cosas; ca sienpre las entendíe sanamiente e a la meior parte. Muy buena palabra auya otrosí en todos sus dichos, non tan solamiente en mostrar ssu rrazón muy buena e muy conplida a aquellos que la mostraua, mas rretraer aun e departir e jugar e rreyr; e en todas las otras. I5 cosas que ssabían bien ffazer e vsar los omnes corteses e palaçianos. Buena manera auya tomada para ffazer ssus cosas ; ca ffazíelas ssienpre en la sazón que deuyen sser fechas e segunt conueníe, non mucho arrebatado nin muy de uagar.

[LEY VII]. - De cómmo el rey don Ffernando era bien acostunbrado en siete cosas.

\begin{tabular}{|c|c|c|c|c|c|c|}
\hline $\begin{array}{c}\text { COMIEN- } \\
\text { DO }\end{array}$ & $\begin{array}{c}\text { BEUIEN- } \\
\text { DO }\end{array}$ & $\begin{array}{c}\text { SEYEN- } \\
\text { DO }\end{array}$ & $\begin{array}{c}\text { YAZIEN- } \\
\text { DO }\end{array}$ & $\begin{array}{c}\text { ESTAN- } \\
\text { DO }\end{array}$ & $\begin{array}{c}\text { A NDAN- } \\
\text { DO }\end{array}$ & $\begin{array}{l}\text { CAUAL- } \\
\text { GANDO }\end{array}$ \\
\hline
\end{tabular}

Ca él comíe mesuradamiente, nin mucho nin poco. Esto mismo ffazía en el beuer; ca beuye quanto conueníe e non en otra guisa, e aun esto non mucho nin a menudo. Ser sabíe en tan buen con25 tenente que todo omne quel veye connosçíe que él era el ssennor de los otros que y estauan. Jazer e echarsse sabía muy apuestamiente e en buen contenente, e dormir ; et olrosi non era dormidor. Estando en pie sse mostraua otrosí por noble omne; ca non

I-3 $T$ umile rúbrica. -5 facionado en todos. $-8-9$ quel v. e lo o. f. o mostrar. - Io della. - 13 rrazon muy c. e muy b. a aq. - 14 mas avn saber $r$. e dep. - 15 sabie. -- 15 - 16 palancianos. - 16 tomado para saber $f$. todas sus. - 17 sazon $\left[\begin{array}{ll}E & 4 r\end{array}\right]$. -18 nin $\mathrm{m}$. arr. nin mucho. - 20 costunbrado. -23 quando. $-24 T$ saljio. -25 era sennor. -27 dormir o. pero non. 
estaua sinon a las sazones que connenie, assí commo quando oye las misas o las otras horas que dizen en Santa Eglesia, o quando era en poridat en ssn casa o estando a pie algunas uezes con algunos buenos omnes que estauan con él. Et andar de pie otrosi muy bien; ca nin lo ffazíe mucho a menudo nin mucho de uagar, nin 5 lo husaua de ffazer ssinon quando non lo podía escusar, assi commo quando yua de vna casa a otra, o ssi ffallaua huerto o prado o logar ffermoso por o ouyese sabor de andar por rreçebir gasaiado o ssolaz contra los enxecos e trabaios que rrecibíe en cuydar e en ffablar en los grandes ffechos que auya de flazer. Caual- io gando se conponie otrosí muy bien en ftazerlo otrosí muy apuestamiente e en buenas bestias e ffermosas e bien apuestas de ffrenos e de ssiellas; ca sabía yr muy apuesto en la ssiella e leuar los pies en las estriberas e saber andar por la carrera nin muy de uagar nin muy apriesa, desviándose sienpre del camino por non fazer 15 enoio en el rrastro a los omnes de pie nin a las bestias cargadas.

Et ssin todo esto era mannoso de todas buenas maneras que buen cauallero deuyese vsar ; que él ssabíe bien boffordar e alançar e tomar armas e armarse muy bien e mucho apuestamiente. Era muy sabidor de caçar toda caça ; otrosí de jugar tablas e ascaques 20 e otros juegos buenos de muchas maneras; e pagándose de omnes cantadores e sabiéndolo él ffazer; et otrosí pagándose de omnes de corte que ssabian bien de trobar e cantar, e de joglares que ssopiesen bien [4v] tocar estrumentos; ca desto sse pagaua él mucho e entendía quién lo ffazían bien o quién non.

Onde todas estas uertudes e graçias e bondades puso Dios en el rey don Ffernando porquel falló leal su amigo.

\section{[LEY VIII]. - En qué cosas se mostró el rrey don Ffernando} por ssierluo e por amigo de Dios.

Amor uerdadero, ssegunt dixieron los sabios, es muy noble 30 cosa; ca él uençe todas las otras que pueden sser. Et esto ouo el

1-2 quando veye las m. e las. - 3 eslaua en por. - 4 Andar. -5 menudo nin muy. -6 quando lo. $-7 T$. ffallaua ver (final de palabra ilegible) -8 por do. - I I fazerlo nucho ap. - 13 syllas e sabie / Ileuar. - 15 mucho. I6 $T$ rrostro. - I 7 buenas mannas. - I 8 lançar. -20 escaques. $-21 T$ de buenas man. - 22 cantadores s. el f. muy bien otr. $-23-24$ trobar a de contar nueuas o de juglares que supiesen bien tanner estr. o desto. -25 entendie quando lo $f$. bien o non. -26 todas $[E$ 4 6 ] virt. -37 porque lo. -28 cosa. - 29 e amigo. 
rrey don Ffernando conplidamiente a Lodo aquel que ono de amar, e primeramiente a Dios.

\begin{tabular}{|c|c|c|c|c|c|c|}
\hline $\begin{array}{l}\text { CONNOS- } \\
\text { CEERLE }\end{array}$ & $\begin{array}{c}\text { EN } \\
\text { AMARLE }\end{array}$ & $\begin{array}{l}\text { EN ORE- } \\
\text { DEGERLE }\end{array}$ & $\begin{array}{l}\text { EN TE- } \\
\text { MERLE }\end{array}$ & $\begin{array}{c}\text { EN LO- } \\
\text { ARLE }\end{array}$ & $\begin{array}{c}\text { EN SER- } \\
\text { UIRLE }\end{array}$ & $\begin{array}{l}\text { EN ON- } \\
\text { RRARLE }\end{array}$ \\
\hline
\end{tabular}

Sin ffalla en connosçer a Dios, nunca rey meior le connosçió 5 que él, e en demostrar a los omnes por ssu palabra muy bien la crençia de Jhesu Giristo, lo que él non sopiera por ninguna manera fazer ssi a Dios non connoçiese. Et connosçiéndol, ssópol amar conplidamiente más que otra cosa, punnando sienpre en ffazerle plazer en todas las cosas que entendíe que más le plazíen. ObedeIo çerle ssopo muy bien; ca nunca ffizo cosa que contra la ffe de Ssanta Figlesia de Rroma fruese, mas sienpre andido a ssu mandado e le ffué obediente. Temiól otrosí muy uerdaderamiente; ca sienpre punnó de guardarse del non ffazer pesar por non auer a ganar ssu desamor e caer en ssu ssanna. Loarle sopo en todas Jas 15 maneras que él pudo: lo vno, en acreçentar el ssu nonbre e leuarle adelante; lo al, en destroyr a aquellos quel non querian creer. Siruiól otrosí muy lealmiente de guisa que en ssu seruiçio despendió toda su vida. E estando en él, priso la su muerle, e murió ante que non muriera por el affán grande que tomó ssiruiéndol.

20 En onrrar a Dios otrosí punnó mucho, e esto en dos maneras : lo vno, por palabra; lo otro, por obra. Ca mostrando su palabra, frazie entender a los omnes quánto onrrada cosa es en sí, et cómmo le denyen todos onrrar en dicho e en fecho para sser ellos onrrados en este mundo e en el otro. Et por ende le onrrana en

25 dos maneras: la vna, en onrrar los quel onrrauan; la otra, en onrrar las eglesias en todas las maneras que él ssabíe e podíe onrrar. Et más, tollíelas a los enemigos de Dios que las teníen florçadas e tornáualas a la ffe de Jhesu Cristo.

Onde, porque en todas estas cosas sopo tan bien abenir, ffizol

$3 T$ y $E$ invierten el orden de en obedeçerle $y$ en temerle / en serurle. 4-5 lo amo que. - 6 supiera. - 6-7 $T$ manera ssi. - $7^{\circ}$ Dios bien non c. $e$ conosciendolo sopolo. - 8 pugnando. - I0-i i de la Igl. - i 2 les. - r3-13 Temie el o. muy r. a Dios ca s. puno do g. de non fazerle (a Dios añadido en el margen, otra mano). - 14 de ganar. - 15-16 acrescentar su n. e leuar a. e lo al en d. aq. que non q. creer en el (en el añadido en el margen, otra mano). - 17-18 espuso (espendio añadido en el margen, otra mano). - i 8 la muerte. - 9 seruiendolo. - 20 pugno. -23 lo. -24 lo. $-25-26$ honrrar los que tenie quel ho. la o. honrrando. -26 el p. nin sabic. $-28 \mathrm{la} \mathrm{ley.}-29$-lc. 
Dios por ello ssiete merçedes sennaladas quales non ffizo a otro rrey de ssu linage de grandes tienpos acá.

[LEY IX]. - De las merçedes que ffizo Dios al rrey don Ffernando en rrazón de los rregnos.

\begin{tabular}{|c|c|c|c|c|c|c|}
\hline $\begin{array}{c}\text { POR } \\
\text { AYUNTA- } \\
\text { MIENTO }\end{array}$ & $\begin{array}{l}\text { POR HE- } \\
\text { R E D A- } \\
\text { MLENTO }\end{array}$ & $\mid \begin{array}{c}\text { POA COY } \\
\text { QUISTA }\end{array}$ & $\begin{array}{c}\text { POR LE- } \\
\text { MAGE }\end{array}$ & $\begin{array}{c}\text { POR } \\
\text { UASA- } \\
\text { LLOS }\end{array}$ & $\begin{array}{c}\text { POR PLE- } \\
\text { TESIAS }\end{array}$ & $\begin{array}{l}\text { POR } \\
\text { PAZ }\end{array}$ \\
\hline
\end{tabular}

En [ayuntamiento] de los rregnos de Espanna le ffizo tan grant merçet que aquello que perdieron los otros rreyes por mal sseso e por mal conseio, onde nasçieron muchas guerras e muchos destruymientos de las tierras e muertes de omnes, ayuntólos Dios en vno por que los heredase él en paz. Ca de parte del padre heredó ro a León, e Gallizia, e Asturias, [5r] et aun el rregno de Badaioz, que ffué antiguamiente muy onrrada cosa; et de parte de la madre heredó Castiella, e Toledo, e Estremadura, e Alua, e Guipuzca, que tollieron los rreyes de Castiella a los de Nauarra porque les negaron sennoríos. Por conquista ganó el rregno de Córdoua, e i. de Jahén, e de Sseuilla, con muchas huestes e buenas que ffizo en ganarlo; ca ffué él y con ssu cuerpo, en que suffrió trabaio e affán e lazeria por Dios. Por ssu linaie ganó el rregno de Murçia, e sennaladamiente por ssu fijo el mayor don Alffonso; e ffízol auer el de Jahén e otrossí el del Algarbe, et ayudól a ganar la cibdal 20. de Sseuilla e lo más de todo el rregno. Et por sus uasallos ganó vna partida del rregno de Nauara, et en los rregnos de Córdoua, e de Murçia, de Jahén, e de Sseuilla. E ayudaron y las órdenes, e ssennaladamiente los de Huclés e de Calatraua. Por pletesía ganó todo aquello que ffincó de ganar destos rregnos que non auya 25 ganados. Por paz que puso con los moros de Espanna e con partida de los de Áffrica ganó grant auer dellos, con que assesegó en siete maneras lo que anye ganado:

4 rregnos $\left[\begin{array}{ll}E & 5 \\ r\end{array}\right]$. -5 por pleytesia. $-6 T$ y $E$ heredamiento / rreys. $-7-8$ por mal c. e por mal s. onde. $-8-9$ e destruymiento. - IO-II heredo Leon. - 13 Alaua. - I 7 fue y por el su c. con que s. mucho trab. (por añadido sobre la línea, otra mano). - ig ca fizol. - 20 e el / $T$ ajudal, $E$ ayudole. - 21 los mas. - 22-23 Cordoua de Murçia. - 23 Ayudaron. - 24 Voles / pleytesia. - 26-27 e con la p. de los de Allica grant a. g. dellos. 


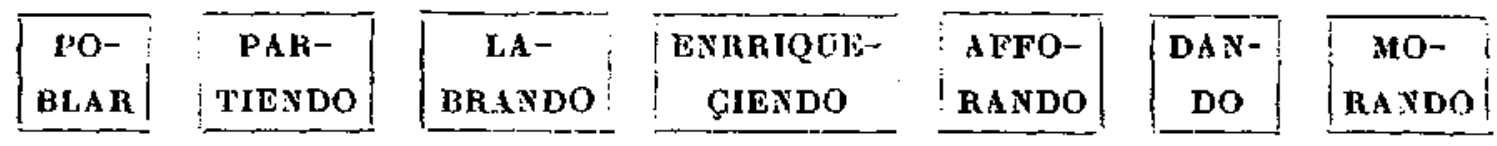

Poblando la tierra, esto frazía él muy bien ; ca non poblaua tan ssolamiente lo que ganaua de los moros, que fuera ante poblado, mas lo al que nunca ouyera poblança, entendiendo que era logar 5 para ello. Et partiéndolo otrossí muy bien desque lo auya ganado, dándoles buenos quinnones a los que ge lo ayudauan a ganar, $\mathrm{e}$ desí a los otros que entendíe que eran buenos pobladores. Et sin todo esto labraua muy bien los castiellos e las fortalezas que entendíe que sserian buenas para guardar las tierras. Otrossí enrrito queçí los omnes: lo vno, dándoles aueres e las otras cosas por que entendíe que serían rricos; lo otro, faziéndoles auer guerra con los moros de guisa que sienpre eran uençedores e ganauan muy grant algo. Afforáualos otrosí muy bien en darles quales ffueros e franquezas querien por que ouyesen sabor de poblar la tierra

I5 e guardarla. Et dáuales otrosí muy grandes términos por que ouyesen los omnes de que seruir a Dios e ganar adelante ssienpre de los moros. El aun por assesegarlo más moraua mucho en los logares do entendie que auye mester de poblarse, por que los omnes de las tierras viniesen e traxiesen lo que ouyesen mester, de guisa 20 que los moradores de aquel logar pudiesen bien ucnder lo suyo e conprar lo ageno.

Onde, ffaziendo el rrey don Fferrando estas cosas todas para sseruir a Dios, que es galardonador de todos los bienes, quísol dar buen galardón e buena çima a su ffecho. Por ende contra [5v] cabo 25 de sus días diól a ganar la çiudat de Sseuilla, en quél ençimó todos bienes quel fizo en darle preçio e ffama grande de bondat sobre todos los otros rreyes porque él acreçentaua la ssu fie e ensalçaua el su santo nonbre. Et por ende quiso él que así commo el su cuerpo ffué onrrado en la vida, que assí lo ffuese en la muerte 3 o quando le flizo auer a Sseuilla, en que ençimó ssus días; ca esta çibdat es la más noble de Espanna de siete cosas.

I $T$ poblar, partiendo, cn nasciendo, labrando, aflorando, dando, morando / poblando. -4 era buen logar. -6 que lo ayud. - ro cosas [E 5v]. I g guerras. - 13 -les. - I 1 pidien. - 16 de seruir / $T$ añade que y a sobre la línea, olra muno. - 18 menester que se poblase. - ig veniesen y e troxiesen. 22 Ferrando t. e. c. para. - 23 -le. - 24 E contra (cerca el añadido en el margen, otra mano). - 25 -le. - 36 todos los b. que fizo / c grant f. de. 3o quandol fizo; que el enc. 


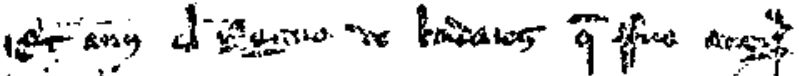

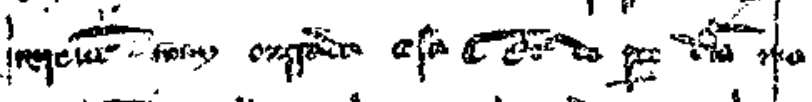

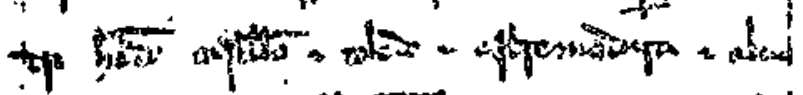

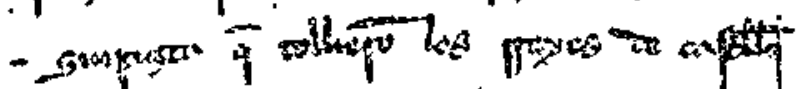

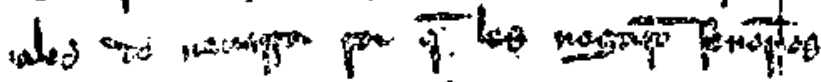

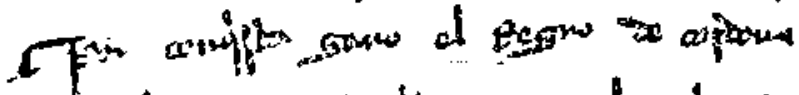

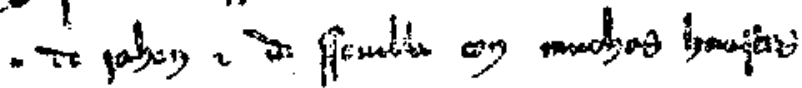
- Lurya

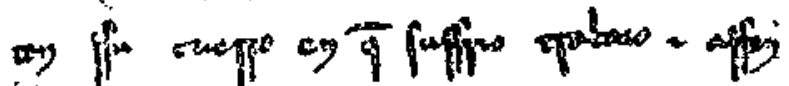

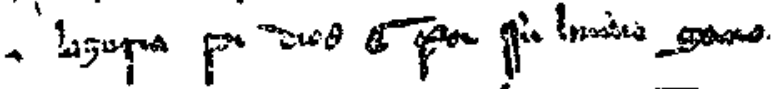

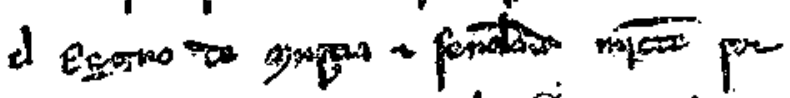

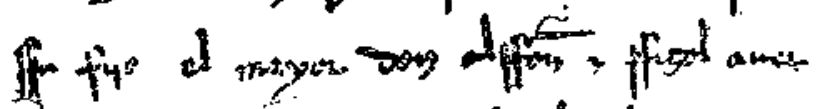

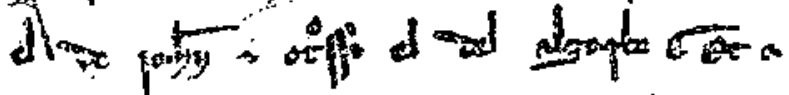

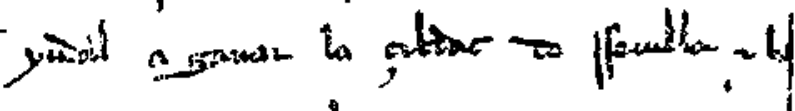

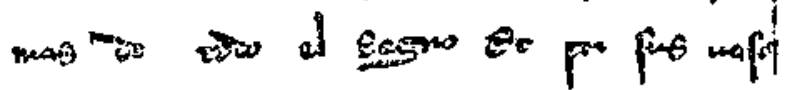
Li:

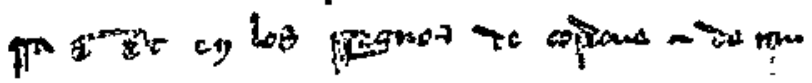

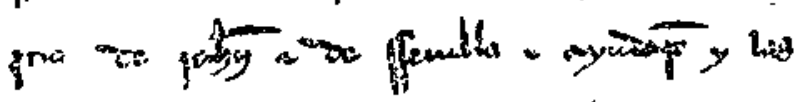

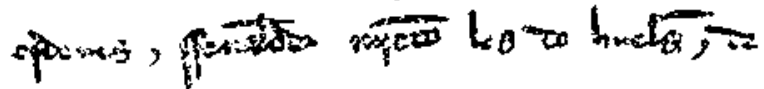

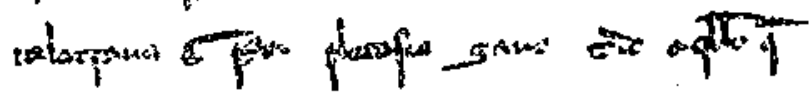

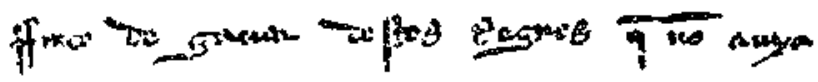
-

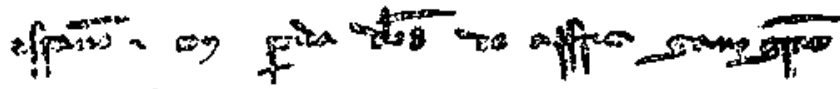

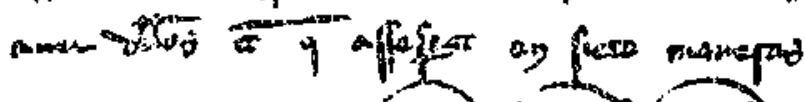

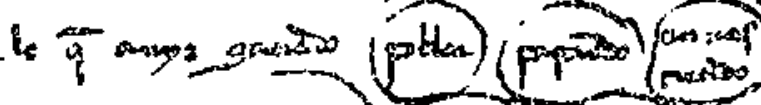

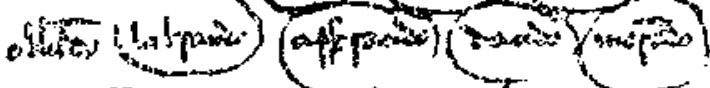

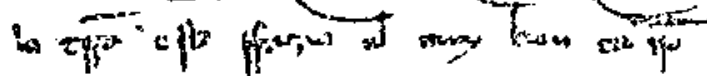

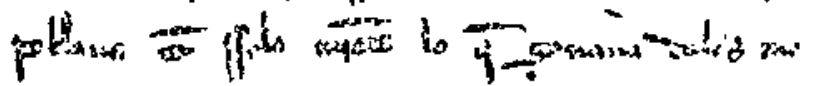

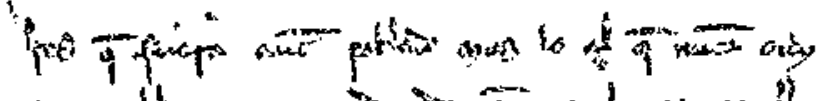

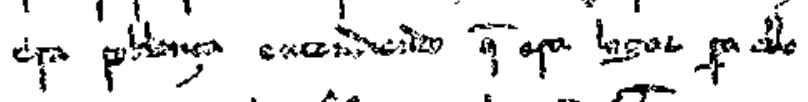

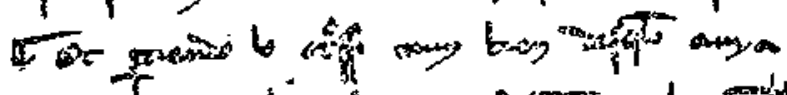

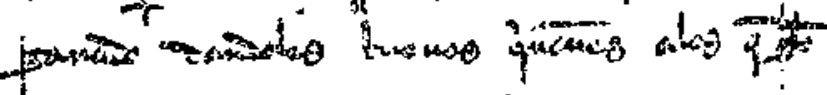

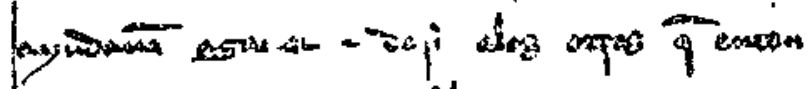

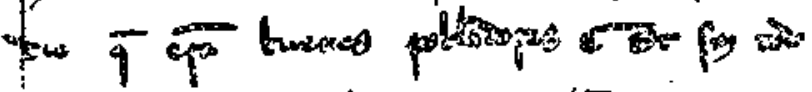

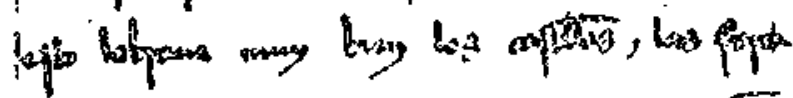

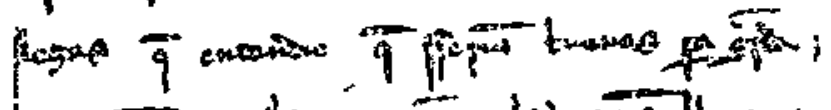

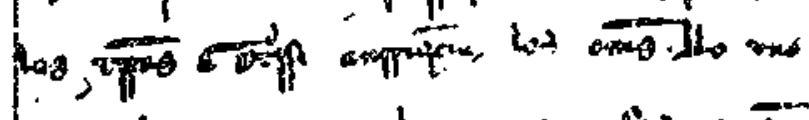

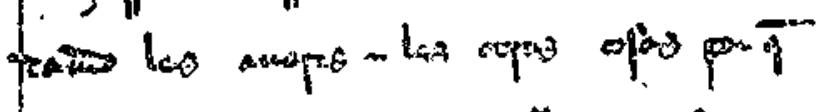

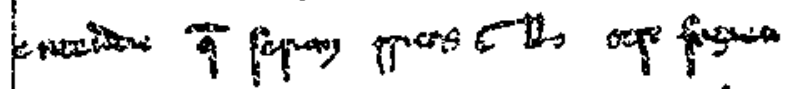

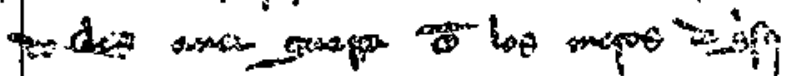
If propt T

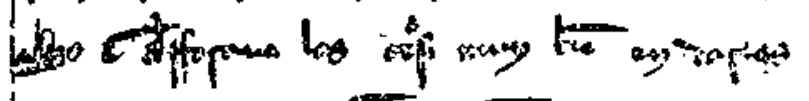

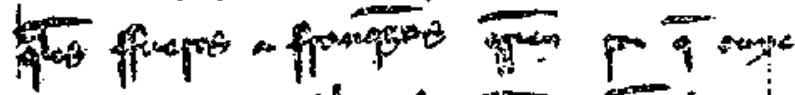

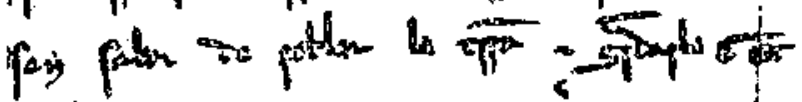

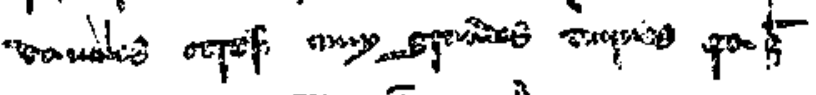

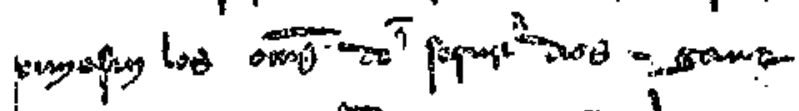

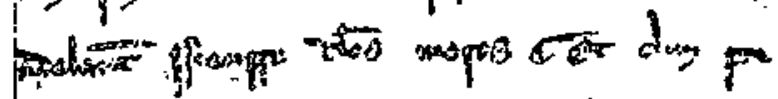

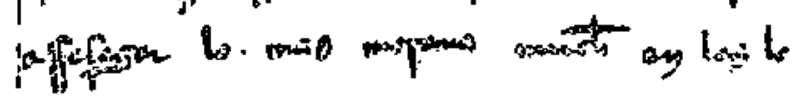

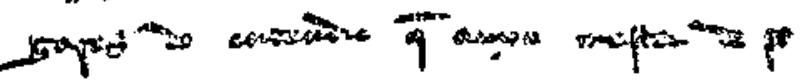

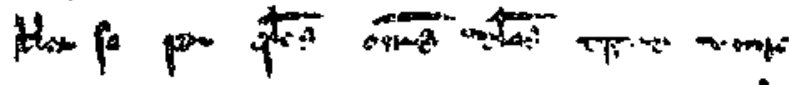

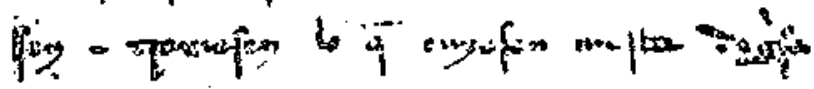

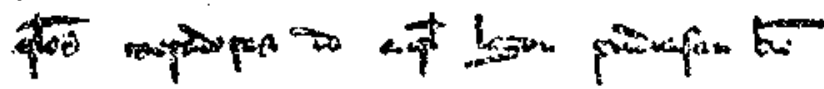

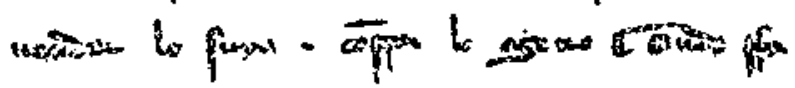

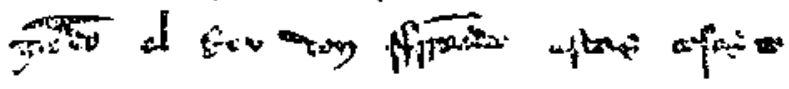

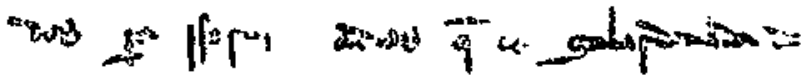

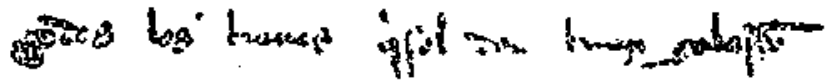

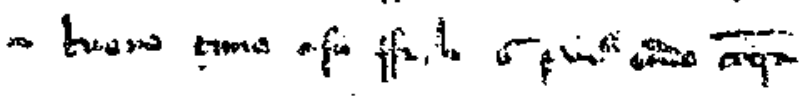




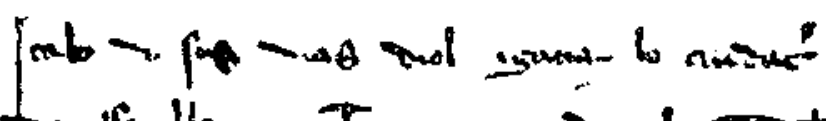

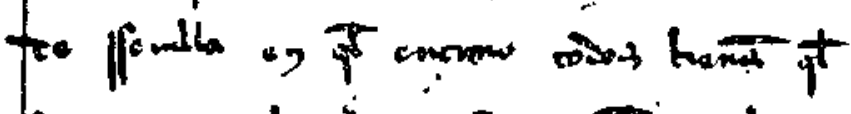

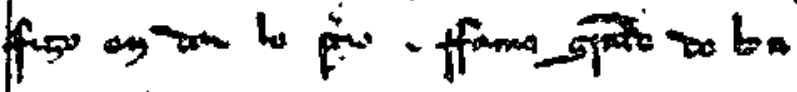

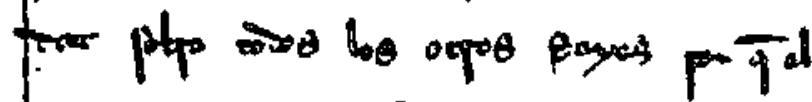

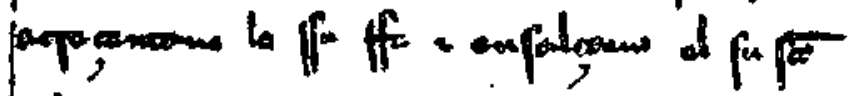

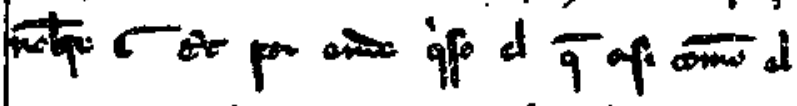

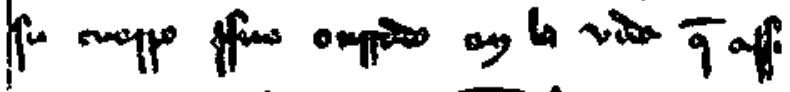

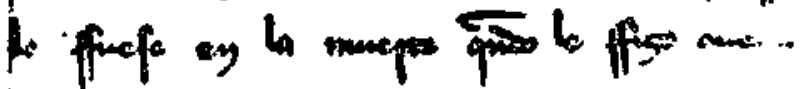

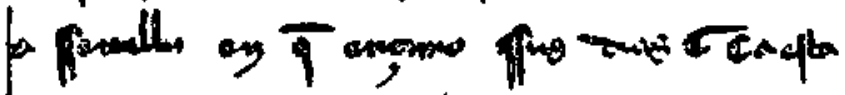

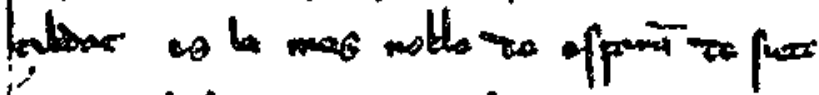

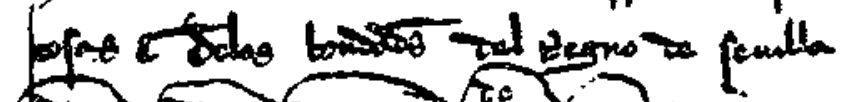

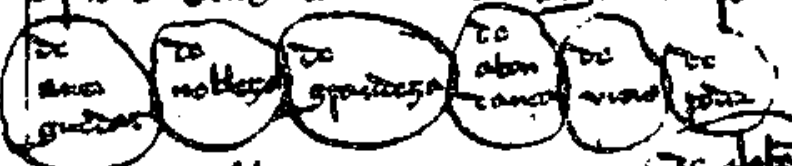

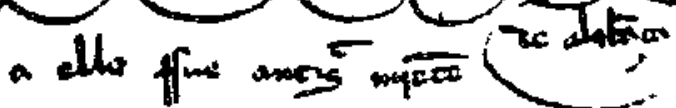

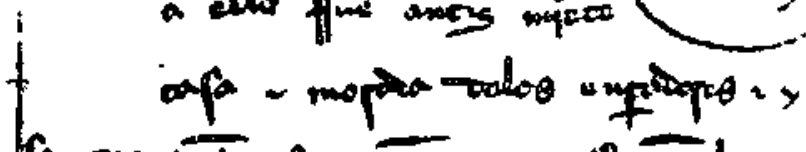

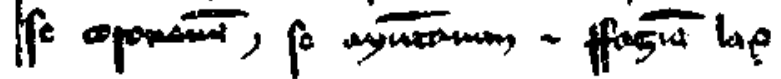

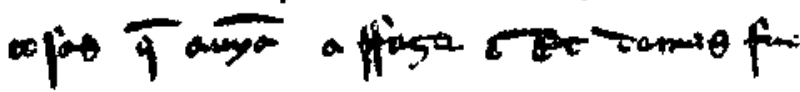

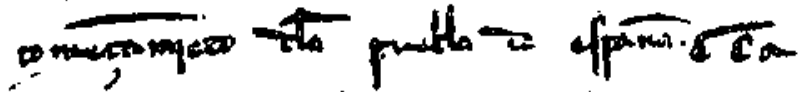

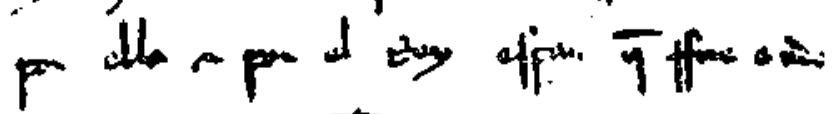

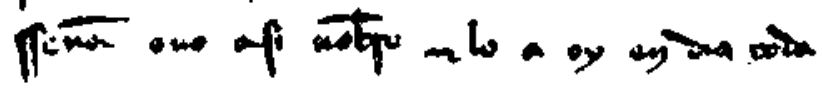

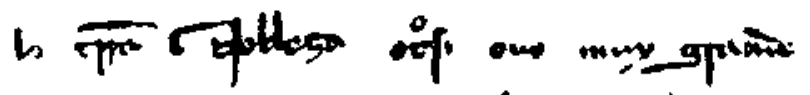

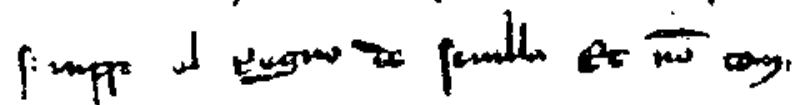

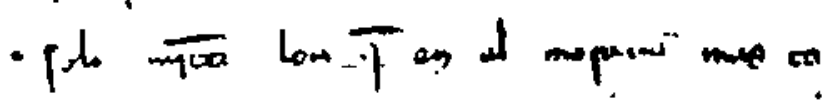

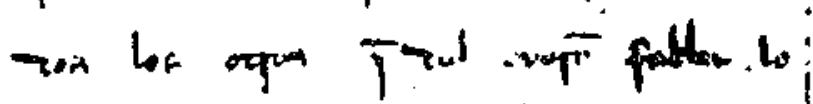

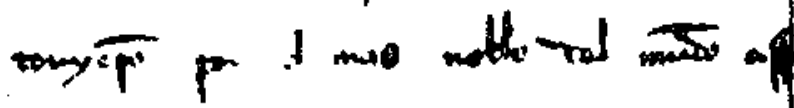

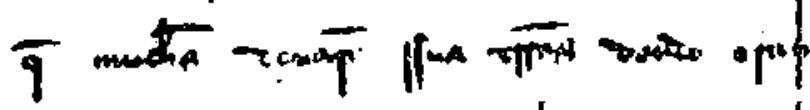

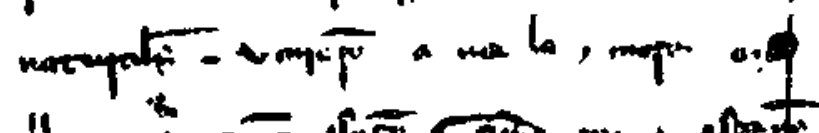

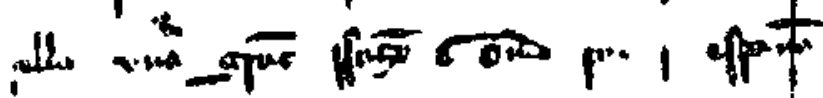

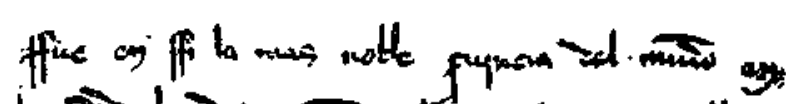

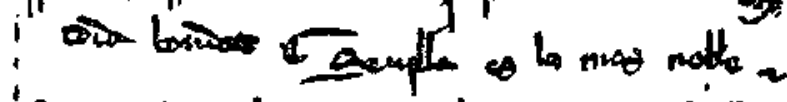

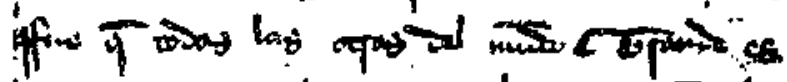

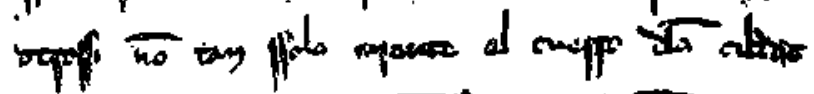

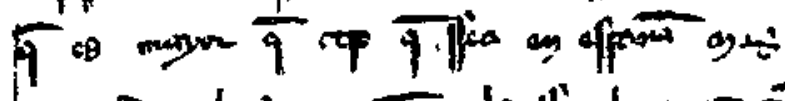

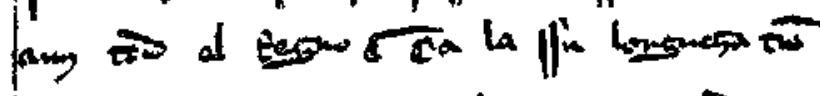

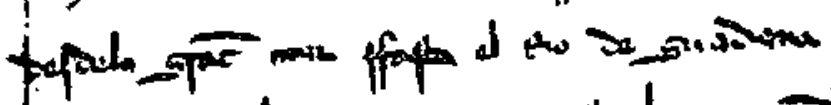

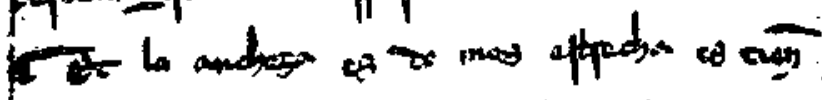

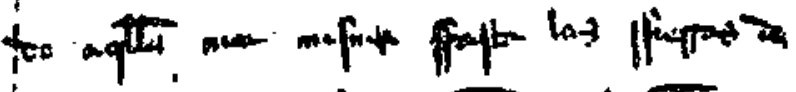

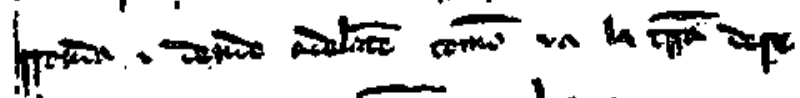

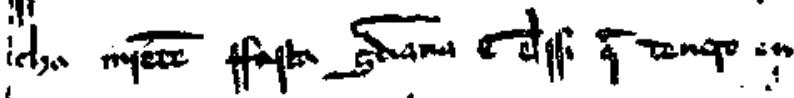

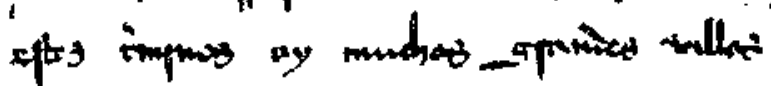

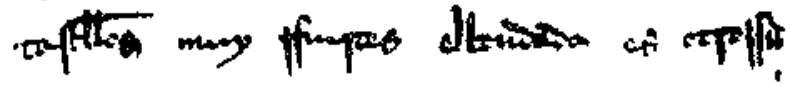

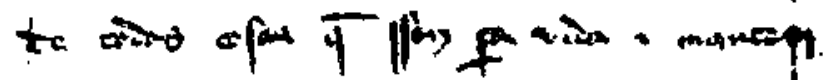

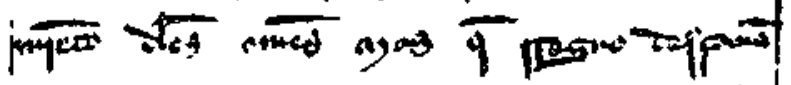

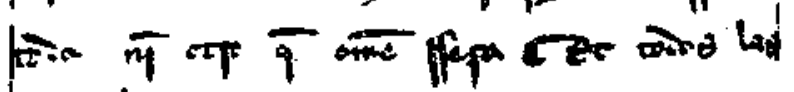

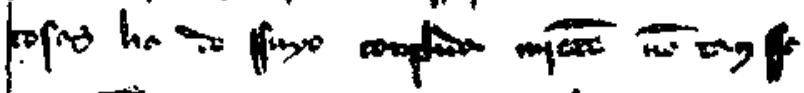

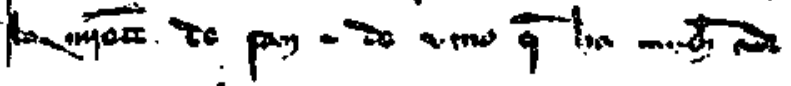

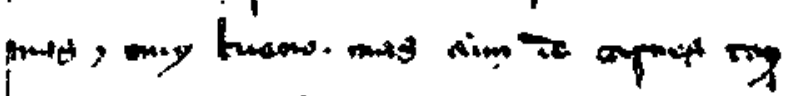

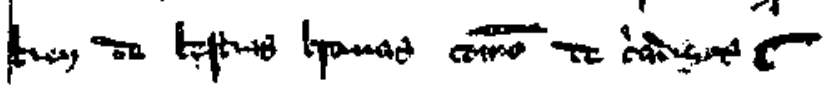

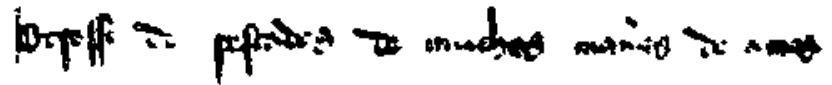

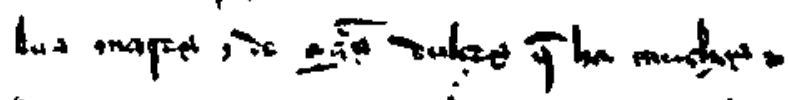

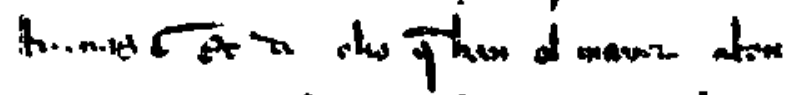

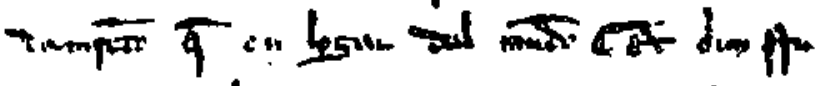

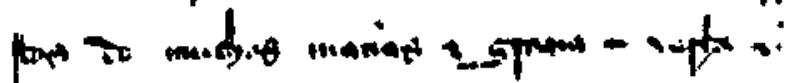

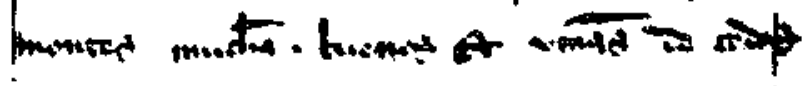

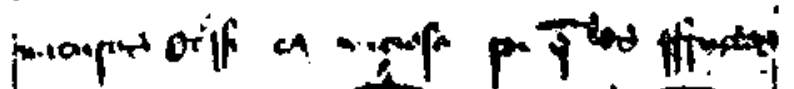

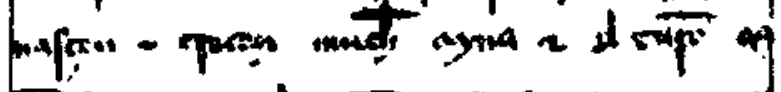

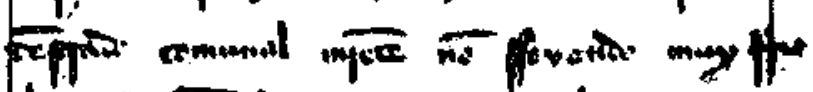

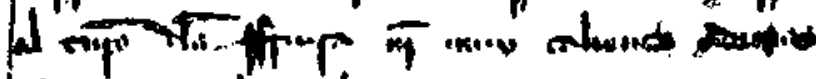

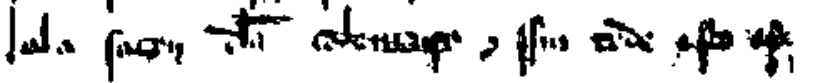


[Ler X]. - De las bondades del rregno de Senilla.

\begin{tabular}{|c|c|c|c|c|c|c|}
\hline DE & DE & DS & DE & DE & DE & DE \\
\hline $\begin{array}{c}\text { AXTI- } \\
\text { GÜEDAT }\end{array}$ & $\begin{array}{c}\text { NO- } \\
\text { BLEZA }\end{array}$ & $\begin{array}{c}\text { GRAN- } \\
\text { DEZA }\end{array}$ & $\begin{array}{l}\text { ABON- } \\
\text { DANGA }\end{array}$ & $\begin{array}{l}\text { VI- } \\
\text { GIO }\end{array}$ & $\begin{array}{l}\text { PO- } \\
\text { DER }\end{array}$ & $\begin{array}{c}\text { ALA- } \\
\text { BANGAA }\end{array}$ \\
\hline
\end{tabular}

Ca ella fué antiguamiente casa e morada de los enperadores, e y se coronauan e se ayuntauan e flazían las cosas que auyan a ffazer. Et demás, fué començamiento de la puebla de Espanna ; ca 5 por clla e por el rrey Espán, que ffué ende ssennor, ouo así nonbre, e lo a oy en día toda la tierra. Nobleza otrosí ouo muy grande sienpre el rregno de Seuilla. Et non tan solamientc los que en él morauan, mas todos los otros que dél oyeron fablar, lo touyeron por el más noble del mundo, assí que muchos dexaron ssus tierras io donde eran naturales e vinieron a uerla e morar en ella vna grant ssazón. Onde, porque Espanna ffué en ssí la más noble prouincia del mundo en toda bondat, Seuilla es la más noble e ffué que todas las otras del mundo. Grande es otrossí, non tan ssolamiente el cuerpo de la çibdat, que es mayor que otro que ssea en Espanna, 15 mas aun todo el rregno. Ca la ssu longueza tiene desde la grant mar frasta el rrío de Guadiana. Et la ancheza es, do más estrecha es, tiene de aquella mar misma ffasta las ssierras de Rronda e dende adelante, commo va la tierra, derechamiente ffasta Guadiana; assí que dentro en estos términos ay muchas grandes villas e castiellos 20 muy ffuerles. Abondada es otrossi de todas cosas que sson para vida e mantenimiento de los omnes más que rregno dEspanna toda nin otro que omne ssepa. Et todas las cosas ha de ssuyo conplidamiente, non tan ssolamiente de pan e de vino, que ha mucho además e muy bueno, mas aun de carnes, tan bien de bestias 25 brauas commo de criadizas; otrossí de pescados de muchas maneras de amas las mares e de aguas dulçes, que ha muchas e buenas; et de olio, que han el mayor abondamiento que en logar del mundo; et aun frutas de muchas maneras e grana e yerba; e montes muchos e buenos et vinnas de todas naturas. Otrossí es viçiosa; 30 porque los ffructos nasçen e crecen mucho ayna e el tienpo es

I rreyno. -2 de grantdeza. -5 de toda la. -6 Yspan. -7 Nobleza ouo o. muy. - I I onde / verle o a m. vna. - 13 Seuilla fue e es la mas n. que. - I4 otrosy mucho $[E 6 \mathrm{r}]$ non. - 16 tien. - 18 Rronda onde. - $20 T$ villas cast. - 22 rregno de t. Esp. - $23 \mathrm{E}$ por todas; de eso conpl. - 24 an ay mucho. -26 otrosy p. muchas. -27 han. -28 meior. -30 buenos e mineras de. $-30-3 \mathrm{I}$ viciosa ademas porque. 
tenprado comunalmiente, non ssejendo muy frío al tienpo de la ffriura nin muy caliente además a la sazón de la calentura, e ssin todo esto es $[6 r]$ cosa que ayuda mucho âcreçentar el viçio. Poderoso rregno es otrosí para quebrantar ssus enemigos, non tan sso-

5 lamiente los que están çerca dél en Espanna, mas aun los otros de allén mar. Ca él ha en poder amas las mares: la mayor, que çerca todo el mundo; e la menor, a que llaman Medioterránea, que ua por medio de la tierra. Et ha muchas ffortalezas e buenas para guerrear los omnes en tienpo de la guerra e otrossí deffendersse quando

ro es mester. Et por todas estas cosas que es alabado ssobre todas las otras tierras e gentes del mundo, assí que todos que han ssabor del uer e de fablar de los ssus bienes comunalmiente más que de otra tierta; ca maguer cada vno se pague de ssu tierra onde es uatural e la alaba por rrazón de la naturaleza, ésta por ssu bondat es

15 tan ssolamicnte alabada de todos. Ca en ella han lo que an mester para los que y moran e para abondar las otras tierras, leuándolo por tierra e por mar.

Onde por todas estas rrazones le dió Dios al rrey don Ffernando e porque quiso que cunpliese y ssus días muy onrradamiente 20 e que ffuesse y ssu ssepultura después que y muriese, por que después que los que del ssu linage viniesen e los de ssu ssennorío ffuesen tenidos de onrrar este rregno sobredicho, guardándolo e acresçentándolo. Et por ende el rrey don Ffernando entendió todas estas merçedes e onrras que Dios le ffaziera, e creçiéndol el cora25 çón en todo bien, ouo sabor de onrrar a sí e a su tierra e al ssu sennorío, el noble estado que los antigos rreyes donde él viníe mantouyeran; et porque así Dios le adelantaua la onrra, así adelantase e ourrase él ssus ffechos. Et esto queríe ffazer en ssiete cosas :

I a la sazon de. -2 ademas al de la c. syn. - 3 esto que es. -7 menor que ll. Medioterraneo. - $8 \mathrm{E}$ muchas. $-9 T$ omile los ... guerra. 10-1 I cosas es loado s. todas las gentes. - I1-12 todos han s. de veerle e ojr fablar. - 13 maguer que c. vso (vno añadido en el margen, otra mano) / $T$ maguer se. -15 todas / ha lo. $-16 T$ - la. - I9 conpliese ay. - 20 su $[E 6 v]$ s. d. que mor. -2 r e los del su. $-32-23$ guardandolo acr. -23 eutendiendo (tilde $y$-do añadidos sobre el final de entendie, olra mano). - 24 -le. 25-26 lierra e tornar cl su s. en noble. -26 viene. -27 adelantaua e lo honrraua asy. -38 el e sus f. esto. 


\begin{tabular}{|c|c|c|c|c|c|c|}
\hline $\begin{array}{c}\text { ON- } \\
\text { RRAXDO } \\
\text { A DIOS }\end{array}$ & $\begin{array}{c}\text { A SSÍ } \\
\text { MISMO }\end{array}$ & $\begin{array}{l}\text { A LOS } \\
\text { QUE PA- } \\
\text { SAUAN } \\
\text { DE SU } \\
\text { LIYAJE }\end{array}$ & $\mid \begin{array}{c}A \text { LOS } \\
\text { QUE } \\
\text { ERAN } \\
\text { ESTONCTE }\end{array}$ & $\begin{array}{l}\text { A LOS } \\
\text { QUE } \\
\text { AUYAX } \\
\text { A SSER }\end{array}$ & $\begin{array}{c}\text { A LOS } \\
\text { QUE ERAN } \\
\text { NOBLES } \\
\text { E ONRRA- } \\
\text { DOS }\end{array}$ & $\begin{array}{c}\text { A LOS } \\
\text { DE SSU } \\
\text { SSEvXo- } \\
\text { Río }\end{array}$ \\
\hline
\end{tabular}

Ca en onrrar a Dios, fiazílo con grant derecho porque la onrra que auya, él ge la diera e daua e ge la podría dar e non otro. Et por ende ffizo en Sseuilla de la mezquita mayor que era vna eglesia de las nobles del mundo e a onrra e a loor de la virgen $\bar{\sigma}$ Santa María, madre de Nuestro Ssennor Thesu Crisio, en que flizo arçobispado muy rrico e muy noble; e otras muchas eglesias en la çiudat et aun por toda la tierra que entonçe ganara, do que echó el nonbre de Mafímat que era y apoderado e metyó y el de Ihesu Cristo e de ssus ssantos. Rt ffizo y otrosí monesterios de io muchas maneras de rreligiones que loasen a Dios e lo sseruyesen. A ssí mismo ssopo ourrar e ganar la tierra muy bien, ssuffriendo mucho affán con su cuerpo e espendiendo y su auer muy granadamieate. Et por esta rrazón, onrrando a sí mismo, acreçentó en la onrra que auyan los otros de cuyo linage viníe. Otrosí a los que i5 eran entonçe con él ; ca sopo guisar cómmo ouyesen parte en todo el bien e el preçio e la onrra que él ganara. Ei a los $[6 u]$ que auyan a sser adelante de su linage, melió en carrera por do fuesen loados e onrrados, e mostrándoles cómmo sseruyesen bien a Dios e sser ellos buenos. Et a los omnes buenos e onrrados de su tierra 20 acreçentó en su onrra, heredándoles de lo que ganaua, fraziéndoles mucho bien, por que los que ouyeron buen sseso ffueron después onrrados e rricos e bienandantes. E a los de su rrez̧rino e de su ssennorio ganó buen preçio e flama de bondat sobre las otras gen-

I $T$ onrrando a Dios, a los que auyan a sser, a los de ssu ssennorio, a ssi mismo, a los que pasauan de su linaje, a los que eran estonçc, a los que eran nobles e conrrados / a lo que pasaua de su lin. - 2 honrrando a Dios fazia muy grant. -4 otre / mesquita. $\rightarrow 5$ vna de las $n$. iglesias del mundo / $T$ eglesia (con -s cscrila y tachada). - 8 ganaran. - 9 Mahomat. - ro de los sus. - 12-13 ganar muy bien la t. s. y mucho. - I5 linage el venie. - it $T$ sopo commo. - I ganaua. - I7-18 $T$ los anyan. - IS-I9 fucsen ho. e 1. m. cornmo s. a Dios. - 20 omnes nobles e. - $2 x$ heredandolos / ganauan. - 23 por que aquellos que buen s. o. fueron. - $23 \mathrm{~T}$ añade $\mathrm{E}$ sobre la línea; $E$ lo omile. $-23-24$ los de su scunorio. -24 fama $\left[\begin{array}{ll}E & \pi\end{array}\right]$. 
tes, non tan solamiente de Espanna, mas aun en todas las otras ticrras.

Et aun ssin todo esto quisiera ennobleçer e onrrar más ssus ffechos, tornando su ssennorío a aquel estado en que ssolía sser c 5 mantouyeran antiguamiente los enperadores e los rreyes onde él vinie; e esto ffuera sennaladamiente en ssiete cosas:

\begin{tabular}{|c|c|c|c|c|c|c|}
\hline $\begin{array}{l}\text { EY RRA- } \\
\text { ZÓY DE } \\
\text { ENPERIO }\end{array}$ & $\begin{array}{l}\text { Fi SU } \\
\text { conte }\end{array}$ & $\begin{array}{c}\text { EN SU } \\
\text { CONSE- } \\
\text { Io }\end{array}$ & $\begin{array}{l}\text { EN SUS } \\
\text { OFFI- } \\
\text { GIALES }\end{array}$ & $\begin{array}{c}\text { EY TO- } \\
\text { LLER } \\
\text { LOS } \\
\text { MAEOS } \\
\text { FUEROS }\end{array}$ & $\begin{array}{c}\text { EN DAR } \\
\text { DE LAS } \\
\text { SSOLLA- } \\
\text { DAS }\end{array}$ & $\begin{array}{c}\text { EN JUS- } \\
\text { TIÇLA }\end{array}$ \\
\hline
\end{tabular}

En rrazón del enperio, quisiera que ffuesse así llamado ssu ssennorio e non rregno, e que ffuese él coronado por enperador ro segunt lo ffueron otros de su linage. Et otrossí que estableçiese su corte, commo entonces era establescida, de omnes nobles e onrrados quel ssopiesen bien onrrar e sseruir e de qui ffuese la tierra ontrada e preçiada. Et que ouyese otrosí tales en ssu conseio quel amasen lealmiente e lo sopiessen bien conseiar, e que ffuesen

I5 onrrados e entendidos e de buen sseso. Et otrosí los que touyesen los ssus offiçios, ffuesen tan nobles e tan buenos de qui él ffuesse sseruido e aconpannado bien e onrradamiente. Otrosí que los ffueros e las costunbres e los vsos que eran contra derecho e contra rrazón ffuesen tollidos e les diese e les otorgase los buenos. Et

20 las tierras que ffuesen partidas ssegunt eran entonçe. Et Jas ssoldadas que las diesen ssegunt las dauan a los caualleros ffijos dalgo en aquella sazón. Et otrosí la justiçia que ffuese ordenada ssegunt que lo era en aquel tienpo.

Et todas estas cosas conseiauan al rtey don Fferrando ssus uasa25 llos e los que eran más de su conseio affincadamiente que las fiziese. Mas él, commo era de buen seso e de buen entendimiento c estaua sienpre aperçcbido en los grandes ffechos, metió mientes e entendió que commo quier que fuese bien e onrra dél e de los suyos en ffazer aquello quel conseiauan, que non era en tienpo de 3o lo ffazer, mostrando muchas rrazones buenas que non se podía

3 enoblesçer. - $; E$ omite en rrazon / de inperio / en dar las soldadas. - 8 inperio. - 10 otros muchos de su l. otr. - Ir $T$ omile su ... establesçida. - I 2 seruír a que. -14 que lo an. - $15 T$ entendidos de. $-16 \mathrm{de}$ que. -17 bien honr. - 19 rrazon que fuesen. -23 segunt lo. $-24 \cos a s$ le cons. / Fernando. 
fazer en aquella sazón: primeramiente, porque la tierra daquent mar non era conquerida toda e los moros fincauan en ella; et la otra, porque los omnes non eran adereçados en ssus ffechos así commo devían, ante desuiauan e dexauan mucho de ffazer lo que les conuinía que ffiziesen segunt flizieron los otros donde ellos 5 venían. Et por ende teníe que deuíe fazer ssegunt ellos ffizieron por que conplidamiente mereçiesen sser onrrados commo ellos fueron, e que este adereçamiento non se podía fazer sinon por castigo e por conseio que ffiziesen él e los otros rreyes que después dél viniesen, e esto que ffuese cutianamiente. Mas porque 10 los rreyes esto non podían ffazer por los grandes ffechos e buenos en que eran e auían $[7 r]$ toda vía a sser, conueníe que este casligo que ffuese ffecho por escripto para ssienpre, non tan solamiente para los de agora, mas para los que auyan de venir. Et por ende cató que lo meior e más apuesto que puede sser era i 5 de fazer escriptura en que les demostrase aquellas cosas que auyan de fazer para sser buenos e auer bien, e guardarse de aquellos que los ffiziesen malos por que ouyesen a frazer mal. Et esta escriptura que la ffiziesen e la touyesen así commo heredamiento de padre e bienffecho de ssennor e commo conseio de buen amigo. 20 Et esto que ffuese puesto en libro que oyesen a menudo, con que se costunbrasen para sser bien acostunbrados, e que sse affiziesen e vsasen, rraigando en sí el bien e tolliendo el mal. Et que lo ouyesen por ffuero e por ley conplida e çierta e por que ouyese a toller de los coraçones siete cosas en que errauan los que eran 25 entonçe por desentendimiento. Et teníe que erraríen más ssi ante non ssopiesen cómmo sse auyan a guardar.

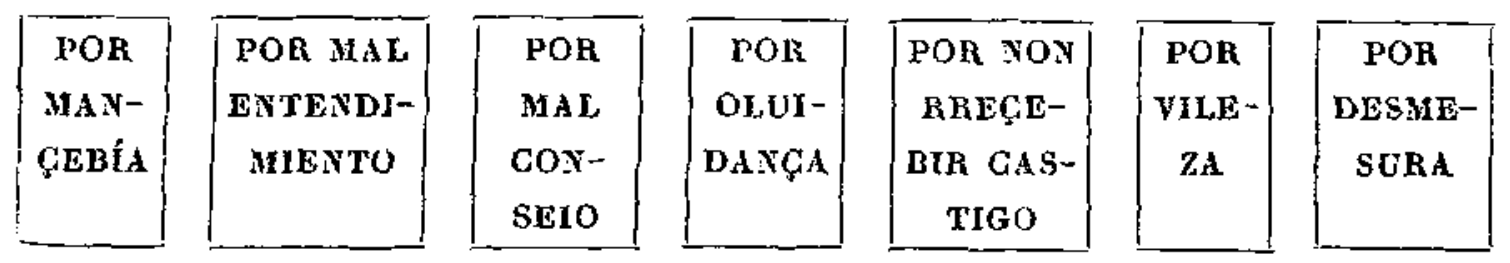

Por mançebía errauan; ca los omnes buenos ançianos, que vsauan buenas costunbres e maneras e las aprisieran e las oyeran 30

I-3 de aquen mar avn non, $-4-5$ fazer los que c. que feziese. -6 sleuie $\left[\begin{array}{ll}E & 7 \mathrm{v}\end{array}\right]$. - 9 o por. - I 1 podiesen. - $13-14$ solamente los de ag. I5 podie. - 16 los. - ${ }_{17}-18$ aquellas que los $\mathrm{m}$. f. por. - i9 que la tou. 21 ouiesen. - 32 acostunbrasen / e con que se afeziesen. - 24 çierta por. $35 T$ las que. -26 defendimiento. -27 auien de guardar. $-28 T$ por ent. $/ T$ por $r$. cast. $-29 T$ errauan los. -30 apresicran. 
de los otros que ffueran ante dellos, e eran ya muertos, e fincaua todo el ffecho en mançebos de poco seso. E del mal entendimiento; ca entendíen el mal por bien e el tuerto por derecho, auyendo creyente que valien más que los que frueran ante delios e que

5 ffazien meior todos sus ffechos. Et a esto ayudaua mucho el mal conseio que auían; que sienpre se aconseiauan con omnes de mal seso, de quien rresçebien mal conseio. E avn auíe y al peor, que toda cosa que les conseiauan de bien, oluidáuanlo ayna, e viníeseles el mal emienle e queríenlo e ffazíenlo. Demás, cas-

so tigo bueno que les diesen, non lo querían rreçebir, ante lo desdennauan e lo despreçiauan muy fieramiente. Otrosí todos sus fechos ffazían vilmiente con conseio de omnes viles e rreffeçes. Et ssin esto eran mucho atreuidos e desmesurados en palabra e en ffecho.

I5 Et estas desconnosçencias los flazían desconnosçer a Dios e non creer en él commo deuíen e al ssemor natural, et non lo ssaber onrrar nin sseruir nin temer uin gradeçer el bien que les ffazíe a sí mismos. Otrossí non connosçícn nin les venia emiente el bien que les ffizieron aquellos oude ellos vinien, nin lo que 20 ellos eran tenidos de frazer. Contra rrazón pasauan mucho otrossí; ca non eran entendidos nin lo querian entender, ante les pesaua con el derecho quando ge lo mostrauan, tan bien en vso commo en costunbre, commo en ffuero commo en rrazón. Contra naturaleza de ssennorio viníen, en ffurtando, en ascondiendo, e tolliendo 25 a los ssennores ssu derecho e la tierra donde eran naturales e menguándoles ssus onrras quanto podian, e punnar en desatar los bienes que ffazían e otrosí los que eran en la tierra. E todo esto era con malquerençia que auían voos de otros. Contra natura viníen, non se amando a sí mismos commo deuyen nin a los $3 o$ de ssu linage, nin a aquellos con qui auyan de[ $7 v]$ recha amiztad

I $T$ ffincauan. - a $\mathbf{E}$ de mal. -4 valen. -5 meior sus f. t. e. -6 ca s. se conseiauan. - 6-8 $T$ aconseiauan mal et el bien oluidauanlo. - 9-ro veniales e. al mal e queriendolo e faziendolo d. ningunt c. que. - 12 rrahezes. - $13 T$ atreuidos en pal. - 14 fecho $[E 8 \%$. - I5 lo. - $15+16$ Dios de non. - I6-r 7 nol saber. - I7 temer nin lo grad. - 18-19 veniendo mientes el bicn que fez. - 20-2 I pasatan o. m. ca non la entendien nin la quer. -24 biuien. -25 maturales los sus anteçesores e. -26 punar endo sacar. - 28 makquercnçia e con enbidia que a. v. con otros. - 99 biuien. - 30 nin aq. / amistat. 
e buena o que les ffazían algo, e non ge lo ssabian gradeçer nin amar por ello. Otrosí metiéndose por ffijos dalgo los que lo non eran nin podrían sser, e los malos metiéndose por buenos, e los ssin entendimiento por entendidos. Et ssin todo eslo flazían otras cosas malas e desaguisadas e contra natura, en que errauan a 5 Dios e a toda bordat.

Onde, por toller estos males e otros muchos que viníen por esta rrazón, et desuiar los otros que podrían uenir, mandó el rrey don Fferrando ffazer este libro que touyese él e los otros rreyes que después dél viniesen por tesoro e por mayor e meior conseio que ro otro que pudiessen tomar, e por mayor seso, en que sse viessen ssienpre commo en espeio para ssaber emendar los ssus yerros e los de los otros e endereçar ssus ffechos e ssaberlos ffazer bien e conplidamiente. Et por toller estos ssiete males partió este libro en sicte partes. Et mostró en cada vna dellas rrazones con que enten- 15 diesen los omnes lo que les conuinia que ffiziesen e de lo que sse deuyan guardar.

Et nos don Alffonso, desque ouymos este libro conpuesto e ordenado, pusiémosie nonbre Septenario segunt que entendiemos que conuinie a la natura de las rrazones e a la manera de ffabla. 2o

\section{[LEY XI]. - POr quáles rrazones pusiemos nonbre a este libro Ssetenario.}

Setenario pusiemos nonbre a este libro porque todas las cosas que en él sson van ordenadas por cuento de siete. Et esto ffué porque es más noble que todos los otros, ssegunt que adelante sse 25 mostrará por las rrazones que sse dizen en él desdel comienço ffasta la finn, e sennaladamiente en esta ley, o a muchos más setenarios que en qualquier de las otras por demostrar por ellos más conplidamiente el nonbre del libro, que ssale de ssiete rrazones.

1 saber grad. - 2 amor / $T$ dalgo lo que. - 2-3 que non c. min lo podion. - 4 sesudos. -7 anien. - 9 Fernando. - io $T$ de vin. - 1 I quel pod. / veyesen. - 12 en $m$ esp. - $12-13$ e de. - 18 nos rrey don. - 19 ponimoslo / $T$ añado Septenario en el margen, otra mano; $E$ lo omile / entendimos. ao convenio / manera de que fabla. $-2 x-22$ Por q. r. a este t. n. Set. [E 8v]. - 23 posimos. - 25 otros cuentos s. ad. (cuentos añadido en el margen, alra mano). -27 do muchos. -29 al libre del libro. 
Las vii rrazones prinçipales de que ssale el nonbre deste libro, a que llaman Ssetenario:

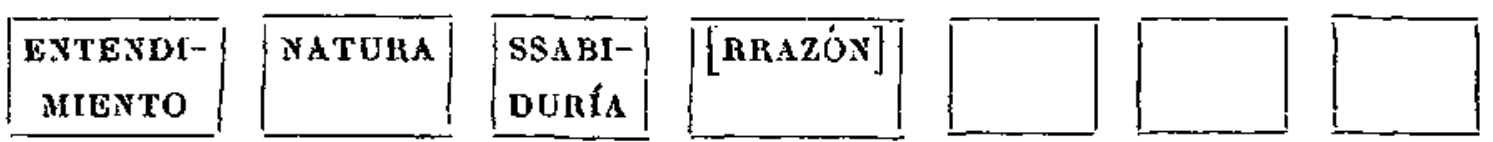

El entendimiento es noble cosa ; ca él ffaze connosçer todas las 5 otras, cada vna quál es en ssí. Et commo quier que esto non pueda ffazer ssinon sobre las cosas que es naturalmiente en alguna manera, e segunt esta rrazón la natura deuya ante sser puesta que él, pero la su nobleza pasa todas las cosas e muestra quál es en ssí e cómmo obra cada vna. Et por eso lo adelantaron los philósophos e lo puro sieron primeramiente que la natura. Et partiéronlo en ssiete partes. Onde el primero es Dios, que es él en ssí e nunca ffué ffecho e ffaz sser todas las cosas. Et por el ssegundo es la vertud del mouimiento que mueue el çielo noueno et ffaz mouer todos los otros. El terçero es de los mouimientos de los cuerpos çelestiales assí Io commo los çielos e las estrellas. El quarto es que da las fformas a las cosas criadas, por que sson vistas e connosçidas cada vna quál es. El quinto es que gana omne por ssabiduria, ssacando el saber de la natura. El ssesto es el que aprende omne de los ssaberes ante que salgan de la materia. Et el sseteno es entendimiento material, 20 que nasçe con el omne en el comienço e le $[8 r]$ ffaze entender por natura qué es aquello ssegunt quel conuyene por natura.

Natura es la ssegunda parte deste setenario, que muestra las cosas ónde nasçen e cómmo e en qué guisa obran por ssipse o vnas con otras, e otrosí en qué manera sse desffazen. Et esto partieron los 25 sabios en siete partes:

\begin{tabular}{|c|c|c|c|c|c|c|}
\hline $\begin{array}{c}\text { NATURA } \\
\text { NATU- } \\
\text { RADOR }\end{array}$ & $\begin{array}{c}\text { NATURA } \\
\text { NATU- } \\
\text { RADA }\end{array}$ & $\begin{array}{c}\text { NATURA } \\
\text { SSIY- } \\
\text { PLE }\end{array}$ & $\begin{array}{l}\text { NATURA } \\
\text { GON- } \\
\text { pUESTA }\end{array}$ & $\begin{array}{l}\text { NATURA } \\
\text { ORDE- } \\
\text { NADOR }\end{array}$ & $\begin{array}{l}\text { NATURA } \\
\text { OBRA- } \\
\text { DOR }\end{array}$ & $\begin{array}{l}\text { NATURA } \\
\text { ASCOY- } \\
\text { DIDA }\end{array}$ \\
\hline
\end{tabular}

r-3 T invierte el orden de Las ... Ssetenario y encuadramientos. - I-2 libro que. $-3 E$ omile entendimiento ... rrazon $/ T$ deja en blanco los cualro úllimos encuadramientos. - 4 Entendimiento. - 7 apuesta. -9 obra en c. vna e por esol ad. - 12 las otras c. e el seg. - $14 \mathrm{E}$ el t. es del mouimiento. 16-17 qual es en sy el q. el que. - I7 sabor. - 18 la materia / sabores. - 19 El set. / $T$ material (retocado sobre natural). - 2 I aquello quel c. s. su nat. - 23 sise vnas. -3 ! se fazen, $-26 T$ natura naturador, $n$. conpuesta, n. ordenador, n. naturada, n. ssinple, n. obrador, n, ascondida/natura escondida $[E, 9 r]$. 
Et la primera es natura naturador ; ésta es Dios, que ffué sienpre e sserá e de qui salen todas las otras e en él sson ençerradas. Et ésta auían por el su ssaber e por el su poder e por el ssu querer. La ssegunda es llamada natura naturada, que quier dezir que flué ffecha del naturador. Et éstas son las criaturas a que llaman 5 ángeles, que han en ssí poder e ucrtud de obrar ssobre las cosas que quiere Dios que ffaga cada vno ssegunt el offiçio que ha. Isa terçera es natura ssinple, que es por ssipse ssegunt la materia ssola de que sse ffaze la cosa. La quarta es natura conpuesta, que conpone las vnas cosas con las otras ssin ffazer forma. La quinta es ro natura ordenador, que ordena a cada cosa dó deue sser e córnmo e quándo. La sesta es natura obrador, que obra con la fforma en la natura apareiada. La ssetena es natura marauillosa, que está ascondida de los entendimientos de los omnes; que non pueden alcançar a ella nin otra natura ffazer lo que ella ffaz. Éstos son los miraglos í que vienen de la natura que ha Dios en sí mismo e de la uertud que ssale della; ca maguer sea vista por oio, non puede llegar a sser entendida por entendimiento de omne segunt quál es en sí misma.

Et por ende Aristótiles e los otros philósoplios ffablaron en esta 20 rrazón muy conplidamiente e mostraron por ella todas las cosas, cómmo eran conpuestas e ordenadas segunt natura spiritual e tènporal. Et esto es en siete maneras naturales que ssalen destas otras e sson commo desponimiento dellas:
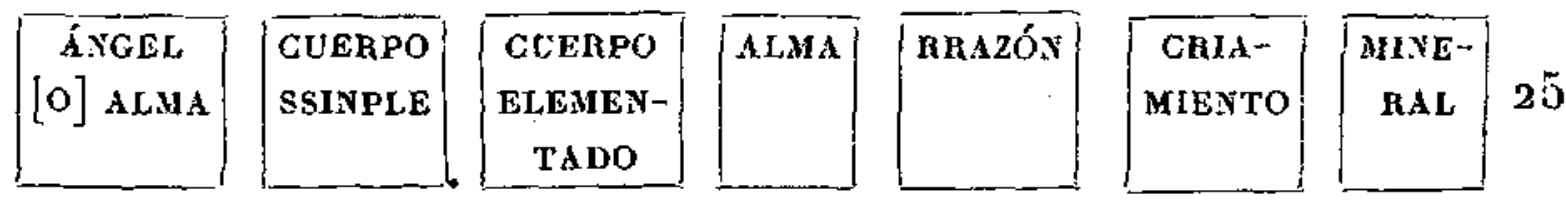

Onde la primera cosa es spiritual e entiéndese por ángel o alma, que es criatura que non ha cuerpo nin alma. La ssegunda es cuerpo ssinple ssin otra cosa que sea ajuntada en él e non sse engendra nin se corronpe por natma, así commo los çielos e las estrellas, que son cuerpos çelestiales llamados. La terçera es cuerpo en ssí 30 mismo que se engendra e sse corronpe, assí commo los helementos.

I $L_{\alpha}$ prim. - 2 sera de que / en ella. -- 3 viene. $-3-4 T$ quereer (retocado sobre creer). - 4 segunda ham. -5 las naturas. - 7 fagan / su of. 8 syse s. la natura. - $10 T$ vnas con. - 11 cosa o. - I $3-13$ en la materia (retom cado sobre natura). - I5 E estos. - i6 e la. - I7 e maguer. - $18 \mathrm{~T}$ entendmiento. $-20 \mathrm{~T}$ phiosophos. $-23 \mathrm{E}$ desto en. -26 spiritual se entiende. - 97 cuerpo ningtuno la. - 28 ayunlada a el que non. 
La quarta es de cuerpo conpuesto que a alma de creçer e de sentir, commo todas las animalias del omne en affuera. La quinta, que ha cuerpo conpuesto de los helementos e alma de creçer e de ssentir e de rrazonar, assi commo omne o mugier. La ssesta, que ha

5 cuerpo conpuesto e alma para creçer, mas non con_sintimiento nin con $[8 v]$ rrazón, assí commo los árboles e todas las otras plantas que nasçen de la tierra. La ssetena, que ha cuerpo conpuesto, mas non alma de ninguna manera que ssintimiento aya nin rrazón, así commo los melales e las piedras e las cosas minerales que en la Io tierra se crían.

Otrosy fallaron que todas las cosas naturales han ssiete maneras, que sson éstas :

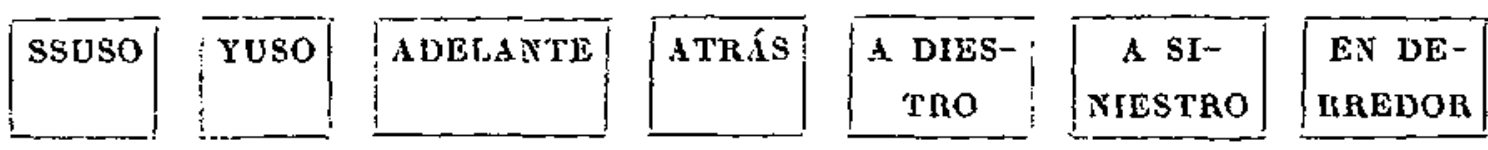

Suso, ssubiendo contra arriba toda vía a lo más alto; e yuso, $\mathbf{5}$ baxándosse, desçendiendo a lo más baxo ; adelante, ffaziendo ssu mouimiento derecho, yendo toda vía por él ; atrás, mouiéndosse contra çaga; e tornando a diestro e a ssiniestro, enssanchando cada vno destos mouimientos en la ladeza cada parte; a deredor, ffaziendo çerco yzual.

20 Et por este cuento mismo partieron las ssiete hedades del omne, en esta guisa :

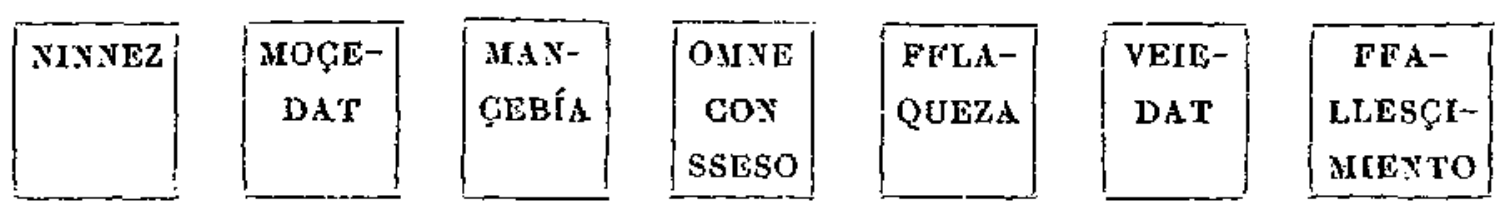

Ende ninnez, que es la primera, dura mientre el ninno non ssabe nin puede comer e mama. Moçedat es quando ssale de ninno e 25 comiença a sser moço e aprende las cosas, quáles sson en ssí e

4 commo [E 9v]. $-5 T$ con consintimiento / sentimiento. $-6 T$ planetas. - 8 anima de n. materia que sentimiento / $T$ ssintiniento nin. 9-I $1 T$ minerales en ssiete man. - I $3 T$ pone por error ssuso ... derredor en páfy. 29. lín. 25/ $T$ de coraçón, de cuento, de medida, de acordança, de vista, de prueua, de cotendimiento. - 14-15 sobiendo t. via que va acriba a lo mas a. y. abajandose (va añadido sobre la línea, otra mano). - 17 tirando. - 18 en largueza / $T$ aderçador. - $22 T$ pone por error ninnez ... fallesçimiento en pág. 30, lin. $3 / T$ derecha, complida, verdadera, conueniente, preguntar, comeler, determinar. - 23 ninnes es la p. que dura. 
cómmo han nonbre. Et esto dura ya ffasta que es mançebo e entra en edal que podría casar e aner flijos; que dallí adelante cámiassele el nonbre e llámanle mançebo. Mauçebo es de que ua creçiendo en ssu vida flasta que llega a los quarenta annos e es omne conplido e a toda ssu ffuerça que deve aver. Omne con sseso es quando $j$ ua ssalicndo desta ssazón e llega a los ssesenta annos e comiença a entrar en fllaquedat. Fllacueza es quando viene a veiedat e le enfraqueçen los mienbros e va perdiendo la fiuerça que ssuele auer. Veiedat es quando ha visto e prouado todas las cosas e las connosçe çiertamiente, quáles sson e cómmo deue obrar dellas. ro Pero ua baxando en ssu vida e en ssu ffuerça, e ssegunt aquesto torna a auer en ssí assesegamiento e a sser sabio de guisa por que pueda mostrar a otro. Et tales vieios commo éstos deuen sser enuergonçados e onrrados. Thalleçimiento es otrosi desque va enfllaqueciendo la natura e pierde el ssentido e torna a sser commo i5 nimno en su manera, de guisa que non cobdicia ssinon comer e auer plazer. Onde todas estas siete cosas son de las ssiete naturas que sson dichas.

Ssabiduría, ssegunt dixieron los ssabios, ffaze venir a omne a acabamieato de todas las cosas que ha sabor de frazer e de acabar. 20 Et por ende ordenaron los ssabios los siete ssaberes, a que llaman artes, e éstas sson maestrías ssotiles e nobles que fiallaron por ssaber las cosas ciertamientre e obrar dellas ssegunt conuiniese, tan bien en las çelestiales commo en las terrenales.
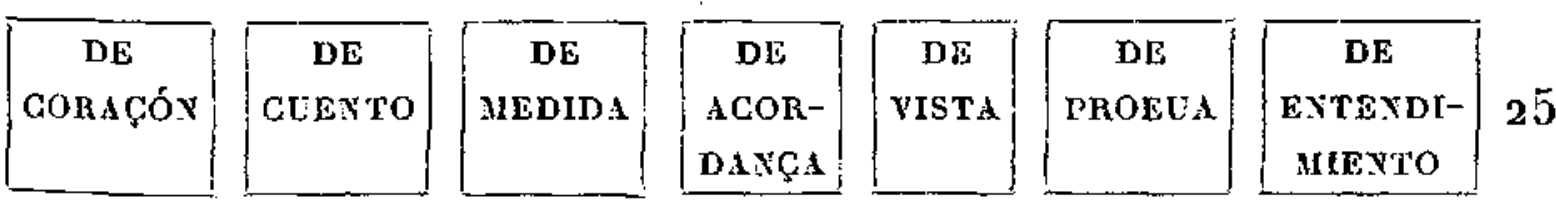

Et la primera, que es de fablar [9r] e mostrar todas las cosas, qué es en ssi e por qué ffué ffecha e qué obra flaz, partiéronla algunos de los ssabios en [tres] partidas. Llamaron a la vna gra-

I dura $f$. que es ya mans. -2 casar e de a. f. e de alli. -5 dene ome. -6 e que ll. a ses. -7 flaqueza. -8 enflaqueçen. -9 visto todas. - 10 $t$ ' deuen. - Ix abarando. - 12 sosegamiento. - Í desde quol va. - Iŏ-16 commo en [E 10r] m. de n. de g. que non codicia. - $1 ; T$ cosas de / naturales. 20 acabanientos / $T$ que ssaber de ffazer. -22 para. -23 conveniese. $-2 \overline{5} T$ pone por error de corapon ... entendimiento ch pág. 28 , lín. $13 \gamma$ en pág. 30, lin. 9/ $T$ ssuso, yuso, adclantc, atras, a diestro, a siviostro, en derredor; $E$ de cuento, de medida, de acordana, de vista, de coracon, de prena, de entendimiento. - 26 La p. que es $f$, e denostrar. - aS $T y E$ ssiele / E llamaron. 
mática, que quier dezir commo arte que muestra ffablar e escriuir derechamiente, e ffázesse con ssiete cosas :

\begin{tabular}{|c|c|c|c|c|c|c|}
\hline $\begin{array}{l}\text { GoN vo- } \\
\text { LUNTAD }\end{array}$ & $\begin{array}{l}\text { CON } \\
\text { BOZ }\end{array}$ & $\begin{array}{c}\text { GON } \\
\text { LETRA }\end{array}$ & $\begin{array}{c}\text { GON } \\
\text { SILIAUA }\end{array}$ & $\begin{array}{c}\text { CON } \\
\text { PARTE }\end{array}$ & $\begin{array}{c}\text { CON } \\
\text { DIGHO }\end{array}$ & $\begin{array}{c}\text { CON } \\
\text { RRAZÓN }\end{array}$ \\
\hline
\end{tabular}

Ca la noluntad enbía la boz; e la boz enbía la letra; la letra, 5 la ssillaba; et la ssíllaba, la parte; e la parte, el dicho; e el dicho, la rrazón. Ft assí ssalen vnas de otras e sse ayudan.

Lógica es otrossí aquella que muestra ffablar açierto e verdadero; esto en ssiete guisas, que sson diziendo la palabra :

\begin{tabular}{|c|c|c|c|c|c|c|}
\hline $\begin{array}{c}\text { DERE- } \\
\text { GH: }\end{array}$ & $\begin{array}{c}\text { CONPLI- } \\
\mathrm{DA}\end{array}$ & $\begin{array}{l}\text { VEHDA- } \\
\text { DERA }\end{array}$ & $\begin{array}{l}\text { CONUE- } \\
\text { NIENTE }\end{array}$ & $\begin{array}{c}\text { PREGUN- } \\
\text { TAR }\end{array}$ & $\begin{array}{c}\text { CONE- } \\
\operatorname{TEn}\end{array}$ & $\begin{array}{l}\text { DETER- } \\
\text { MINAR }\end{array}$ \\
\hline
\end{tabular}

10 Onde la primera, sse deue dezir derechamiente. E deue sser conplida, de guisa que non mingüe nada nin ssobre. Verdadera deue sser otrossí, de manera que non aya en ella mentira nin ffalssedat nin palabras engannosas. Conveniente, assí que sse diga cada palabra en ssu logar do conuiene. Pregunta deue sser otrossí ;

I5 ca ssi non lo ffuese, non podrían ssaber qué era la verdat nin Ja mentira, nin lo podrían escoger la vna de la otra. Cometersse deuen por rrazón vnos a otros aquellos que essa arte quieren ssaber; ca muchas rrazones sson ffalladas cometiendo e rrespondiendo, ca de otra guisa non sse podrían ffallar. Et a ésta llaman

20 argumentes, que quier dezir rrazones prouadas; porque proeuan por ellas Jo que quieren rrazonar. La sséptima es determinar, que muestra tanto commo ençerrar las rrazones que sson desputadas, quáles sson engannosas o ssin enganno.

Rrectórica llaman a la terçera partida destas tres, que sse entien25 de que enssenna a ffablar ffermoso e apuesto, e esto en siete rrazones :

\begin{tabular}{|c|c|c|c|c|c|c|}
\hline COLOR & $\begin{array}{l}\text { FERMO- } \\
\text { SURA }\end{array}$ & $\begin{array}{l}\text { APOS- } \\
\text { TURA }\end{array}$ & $\begin{array}{l}\text { CONCE- } \\
\text { NIENTE }\end{array}$ & $\begin{array}{l}\text { AMO- } \\
\text { ROSA }\end{array}$ & $\begin{array}{c}\text { EN BUEN } \\
\text { SON }\end{array}$ & $\begin{array}{c}\text { EN BUEN } \\
\text { CONTENENTE }\end{array}$ \\
\hline
\end{tabular}

$3 T$ ninnez, moşedat, mançebia, onne con sseso, fllaqueza, veiedat, ffallesçimiento. - 4-5 e la boz la l. e la l. la sylaba e la sill. $-7^{-8}$ muestra a $f$. çierto e $v$. e esto. -8 las palabras. $-9 T$ pone por error derecha ... delerminar en pág. 28, lin. $22 / T$ de coraçon, de cuento, de medida, de acordança, de vista, de proeua, de entendimiento / conviniente. - 10 primera que se. - 11 mengue. - $13 T$ engannosas assi. - $13-14$ diga la pal. - 14 o. - 5 lo fazie. -16 la podr. - 17 quisieren. - 19 E $[E$ 10v] a esto. - 20 argumentos / proeua. -21 quiere. -22 disputadas. -25 apuesto en. -27 conuiniente, amorosa, en buen ser, con buen cont. 
Ca esto conuyene mucho al que desta arte husare, que cate que la rrazón que ouyere a dezir, que la colore en manera que paresca bien en las uoluntades de los que la oyeren. Et la tenga otrosí por ffermosa, para cobdiçiarla aprender e saberla rrazonar. Et que sse diga apuestamiente, non mucho apriessa nin mucho de uagar. 5 Et que ponga cada rrazón allí do conuiene ssegunt aquello que quisiere ffablar. E que lo diga amorosamiente, non muy rrezio nin muy brauo nin otrosí muy fflaco; mas en buen sson mesurado, non altas bozes nin muy baxas. Et ha de catar que el contenente que touyere, que sse acuerde con la rrazón que dixiere. so Et desta guisa sse mostrará por bien rrazonado aquel que rrazonare, e moverá los coraçones de aquellos que lo oyeren para adozirlos más ayna a lo que quisiere.

Onde, por estos tres ssaberes que sse tornan en vna rrazón, touyeron por bien los ssabios que sse deuían contar por vna arte, is e pusiéronla por entrada a las otras; ca la rrazón ffazía entender todas las otras çiertamiente, cada vna quál era. Et en estas maneras [9v] de rrazones sse muestra que Dios es Trinidat conplida. Et la gramática, que es de palabra, sse entiende por el Padre; porque por el poder del su vierbo tan solamiente ffueron ffechas todas 20 las cosas. La lógica departe la mentira de la uerdat, et entiéndesse por el Ffijo; que ćl nos mostró el Padre nerdaderamiente e por él lo connosçiemos, e sacónos de yerro e de mentira, mostrándonos çiertamiente en quál manera nos ssaluásemos, e ganando ssu amor. La rrectórica, que es rrazón ffermosa e apuesta, se 25 entiende por el Spíritu Ssanto ; ca él alunbra e da color e ffermosura a todas las cosas que sson oscuras de entendimiento.

A la ssegunda arte llamaron arismética, e ésta es de cuenta; ca en ella sson todos los cuentos conplidamiente. Et esto en ssiete maneras :

\begin{tabular}{|c|c|c|c|c|c|c|}
\hline $\begin{array}{l}\text { GON- } \\
\text { TANDO }\end{array}$ & $\begin{array}{c}\text { DOBLAN- } \\
\text { DO }\end{array}$ & $\begin{array}{l}\text { MUCHI- } \\
\text { GUAXDO }\end{array}$ & $\begin{array}{c}\text { PAR- } \\
\text { TIEADO }\end{array}$ & $\begin{array}{l}\text { ORDE- } \\
\text { NAYNOO }\end{array}$ & $\begin{array}{c}\text { SACANDO } \\
\text { LA RAÍS } \\
\text { DEL CUENTO }\end{array}$ & $\begin{array}{l}\text { ASSU- } \\
\text { MANDO }\end{array}$ \\
\hline
\end{tabular}

Ca el cuento sse comiença en vno solo e llega a lo más que puede sser contado, vno e después otro; et doblando e ffaziendo

3 tengan. - 5 nin muy. -8 mas con buen ser mes. - $9 T$ bozes et. I 2 quel oy. $-14+15$ en r. t. $\operatorname{los},-17$ cs. -20 de su berbo. -21 logica que dep. $-21-22$ verdat se entiende. -22 ca. -23 le conosçimos. -24 que. -27 son vadas de ent. [E $11 r]$. $-3 r T$ omile muchiguando/T ssosacando lo mas de cuento. -32 el contar com. - 33 doblando faz. 
por de pocos o de muchos; et amuchiguando e ffaziendo muchos pares e non pares en vno, creçiendo toda vía el cuento; partiendo otrosí los cuentos por pares o por non pares, ffaziendo del que es par non par, e del non par que ssea par; ordenando las cabeças

5 de los cuentos por dezenas ffasta ciento, e de çiento por centenarios frasta mill; ca desta guisa saca la rrayz del cuento, ssabiendo ssi naçe de par o de non par, o de ssenziello o de doblado ; et sabiendo aquello, llegará a dar çima a la cuenta del asumamiento.

Et desta arte otrossí ssalen muchos artes e saberes marauillosos ro e de grant uertud, e ssennaladamiente del cuento de siete entre todos los otros; ca por éste ffallamos el nonbre de Dios e la Trinidat conplida, porque el comienço deste cuento es vno. E este senziello non ha par; ca él es por ssi mismo. Después ayuntan a él otro tal et flaze par. Después, ayuntado y otro, ffazen tres. E

15 desta guisa se torna a sser vno nonbrado ssin par. Et la trinidat en cuento es vnidat en nonbre; que maguer sson tres en vn cuento, en que comiença e sse acaba, desi allegue y otro, fláxensse dos paries a que llaman quatro; porque ssegunt el arte de geometría vienen en ffigura quadrada, egual cle cada parte. Onde cada quadra

20 ha vn rrencón en que se ençierran las linnas derechas, e poniendo en cada vno dellos vna letra, que sse la primera 0 , la ssegunda $\mathbf{r}$, la otra $o$, la quarta la $s$, dizen dros. Después viene otra lima que muestra tres letras, la primera $v$, la otra $v$, la terçera $o$, que quiere dezir voo. Et otrossí dirá vís, que sse entiende por carrera, 25 poniendo la $\mathrm{v}$, desí la $\mathrm{x}$, e después la $\mathrm{A}$. Et assí muestran estas letras que Dios es vno e carrera derecha para yr las cosas, e que es comienço e acabamiento de todo; ca por él se comiençan e sse acaban, ssegunt es mostrado en e] $[10 r]$ comienço deste libro por las ssiete letras que dizen Alpha [et $\mathrm{O}$.

3o Geometría quiere dezir arte de medir e de conpassar. E ésta sse parie en ssiete partes que sse muestran todas por ffiguras, assí commo :

1 amuchiguando faz. -3 o non. -5 dozenas. -6 guisa la. -7 non par e de s. o de doble. -8 llega / cuenta que llaman asum. -9 arles. o. m. sabores. - I2 es verdadero. - 12-13 $T$ vno scnz. - I4 fazen par e d. ayuntando y 0 . fazease tres. - 15 noubrandose non par. - $16-17$ nonbre por que m. sou tres c. encomiença. - ig $T$ venien. - 20 se ģierrar. - 21 que sea. - 22 quarta s $T$ 's despues. - 23 la vna. - 26 vno $[E / V]$. 26-27 yr a todas las c. e es. - 3i figura. 


\begin{tabular}{|c|c|c|c|c|c|}
$\begin{array}{c}\text { LINNA } \\
\text { DEREGHA }\end{array}$ & CORUA & $\bar{c} \begin{array}{c}\text { GSORRE- } \\
\text { FFAZ }\end{array}$ & $\begin{array}{c}\text { LON- } \\
\text { GUEZA }\end{array}$ & $\begin{array}{c}\text { AN- } \\
\text { GHEZA }\end{array}$ & $\begin{array}{c}\text { GUERPO } \\
\text { CONPLIDO }\end{array}$ \\
\hline
\end{tabular}

Linna, que es la primera, sse entiende por toda medida derecha en que non ha ninguna tortura. Et corua, por la que es yaquanto tornada, mas non es cerco conplido. Et çerco, por la que es toda çerrada e tornada en rredondeza a egual conpaso que non ba más 5 a vna parte que a otra, ssaliendo linnas derechas e eguales a todas partes del çerco rredondo. Ssobreffaz es medida llana que ygua todas las cosas, tornándolas a eguallat derecha, tan bien en lado commo en luengo. Longueza es otrosí medida muy grande e muy pequenna porque en ella sse ençierra mucho e poco, estendiéndose ro e encogiéndose. Ancheza es otrosí medida que conuyene que ssea en todos los cuerpos que entran en ella, mostrando la delgadez o la gordura que ha en ssí. Cuerpo conplido es todas las cosas que sse mudan por qualquier destas cosas ssobredichas.

Onde por todas estas ffiguras de medida sson ffiguradas e medi- $\mathbf{I 5}$ das todas las otras, non tan ssolamiente las que ueen por oio, mas aun las otras que sse entienden por entendimiento. Et por éstas sse muestran ssiete cosas que ha en Dios:

\begin{tabular}{|c|c|c|c|c|c|c|}
\hline $\begin{array}{c}\text { DERE- } \\
\text { CHURERO }\end{array}$ & GORUO & $\begin{array}{c}\text { CERCO } \\
\text { RREDONDO }\end{array}$ & $\begin{array}{c}\text { SSOBRE- } \\
\text { FFAZ. }\end{array}$ & $\begin{array}{l}\text { LON- } \\
\text { GUEZA }\end{array}$ & LADEZA & GUERPO \\
\hline
\end{tabular}

Derechurero es, commo linna derecha que non tuerçe a ninguna 20 parte, e por essol llaman justo juez. Coruo es ; ca esta ffigura muestra que sse abaxó con humillat, ffaziendo al omne de la tierra, commo lo ffizo, e desçendió del çielo a rredemir e darle ssaluamiento por de la carne e de la ssangre del ssu ffijo Ihesu Cristo. Gerco rredondo e egual es otrossi; ca él tiene ençerradas 25 en ssí todas las cosas e ninguna non puede ende ssalir. Sobreffaz es; que cubre e mantiene todas las cosas que él ffizo llanamiente con piadat e con merçet. Longueza e ladeza ha muy grande; ca todas las partes sson en ssu poder, tan bien en luengo cornmo en

I luna der. - 2 Ca luna. - 5 çercada / rredondez / conpas. - 5-6 mas la vna. - 7 es la med. / yguala, $-8 T$-la / egualdat. - 9 Largueza es 0. m. mucho grande. - I 1 encogendose a. es med. - 12 delgadeza. - 14 maneras. - 15-16 $T$ sson ffiguras e m. a todas. - 21 eso le. $-22 T$ abaxa, $E$ abaio. $-23 \mathrm{le} /$ redemir [E 12r]. -24 por la c. e la sangre. $-25-26$ tiene en sy e. todas. - 28 Longueza e largueza. 
ancho. Cuerpo es otrossí spiritual, de que sson ffechos e fformados todos los otros.

La quarta arte, que es de acordança, llaman música en griego. Et ésta, commo quier que los omnes vsen della en ssones e en 5 cantares e en estrumentos, tal es en ssí que en todas las cosas cae e ssin ellu non sse podrian ffazer; porque conpone e acuerda todo. Et ésta es partida en ssiete partes, que son éstas :

\begin{tabular}{|c|c|c|c|c|c|c|}
\hline $\cos$ & $\cos$ & $\cos$ & $\operatorname{cov}$ & CONGOR - & ESTRUMEYTO & GONTE- \\
\hline voz & SSON & PUNTO & TUENO & DANGA & & NENTE \\
\hline
\end{tabular}

Boz es cosa que ssal por aspiraçión que enbía el spíritu de la ro vida, que es dentro en el cuerpo del omne. E enbiándol, ffaz sson alto o baxo ssegunt la boz es ffuerte o fllaca. Punto es llamado allí do queda aquella boz de todo [10v] o sse camia. Tueno es quando la boz es fformada e asentada en el logar o conuiene. Concordança es otrosí lo que flaze las uozes que sson de muchas

Io maneras concordar en vno e ffazer vn canto. Estrumento es logar en que sse conpone la uoz naturalmiente, así commo en los pechos o en la garganta o en la boca del omne, o en otras cosas artiffiçialmiente en que rremedan a los omnes, contraffaziendo aquel sson que ellos ffazen. Et esto es contenente que conuyene mucho que 20 sse ffaga en la música para acordarsse la manera del omne con el sson.

Onde en estas ssiete maneras desta arte sse muestra otrossi Dios. Ca él es uoz de alegría, con que sse alegran todas las cosas. E sson ssabroso; que alegra los tristes e esffuerça los desmayados e 25 espierta los durmientes que yazen durmiendo en peccado, e adurmeçe por ssuenno sabroso los que uelan mucho en vanidades. Punto es llamado con grant derecho; ca en él quedan todas las cosas de guisa que non han después mouimiento ssinon quando él quiere que sse mueuan. Tueno es otrosí ; ca el ssu spíritu fformó 30 las uozes de todos los ssaberes. Concordança conplida es; ca él acuerda todas las cosas desacordadas. Estrumento es otrosí ; ca assí commo el estrumento es cosa que sse connosçe por vista, assí ffué Ihesu Gristo ssu ffijo connosçido por la nuestra ffigura. Ca fué

1 spiritual que. - 5 estormentes / cate. -7 pardida. -8 con tiene. 9 salle con espiraçion. - 13 sentada. - $14 T$ y $E$ ffazen. - I5 Estrumente. $-24 T$ y $E$ ssabrosas / alegran. - 25 dormientes / dormiendo. - $25-26$ adormeçe. - 27 derecho $[E 12 v]$ / puedan. - 29 quisiere / forma. - 3o-3 I ca es ac. - 3r-3a $E$ omite es... estrumento. - 33 Que commo sobrc que fie. 
oyda la boz del Padre, que aquél era ssu fijo mucho amado, en qui rreçibía mucho plazer. Desta guisa flué connosçido el Padre por el Ffijo et el Ffijo por el Padre, assí commo el estrumento es connosçido por el sson que dél sale. Desto que sse entiende por contenente deue sser llamado con derecho; ca así commo el gesto 5 muestra lo que omne tiene. en la uoluntad ssegunt la obra que quiere ffazer, así Ihesu Cristo mostró por ssus obras quál era Dios ssu padre, donde él ouo la uertud con que él obraua.

Astrología, que quier dezir saber que sse alcança por catamiento e por vista, el es la quinta arte destas ssiete e ffabla de los çielos, Io porque [sson llamados] en latín astra. E ésta es partida en ssiete maneras :

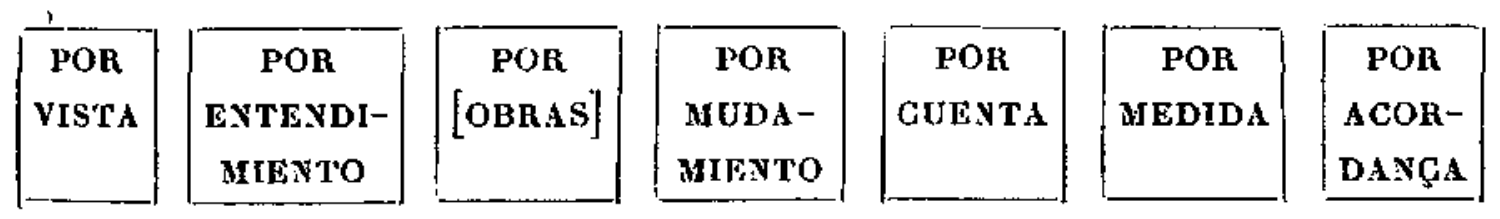

Onde la primera, que es por vista, ffaze connosçer las siete estre-llas a que llaman planetas, cada vna en quál çielo está e cómmo is sse mueue en dos guisas: la vna, en ssu çielo; la otra, en ssu çerco apartado. Et la ssegunda, de entendimiento, ffaze que entiendan los omnes de qué natura sson los çielos e quántos sson e cómmo sse mueven e por qué rrazón. La tercera es que, veyendo esto, an los omnes a connosçer a cada vna dellas, quál es e qué nonbre ha 20 ssegunt ssus obras. La quarta es cómmo se mudan de vn lugar a otro e por qué rrazón ffazen este mudamiento. La quinta es que pueden avn ssaber por cuenta de puntos, e de grados, e de oras, e de días, e de ssemanas, e de meses, e de annos, quándo sse ha esto de ffazer. La ssesena es de ssaber por cuenta [11\%] e por me- 25 dida e por entendimiento e por rrazón quánto ha en cada vna destas ssobredichas e de la vna a la otra. Et la ssetena es cómmo sse acuerdan los çielos en tenersse los vnos con los otros, otrossí en ssus mouimientos.

I era el su. - - rresçcbic grant p. e desta. -7 ouiere fazer. 8 onde el auie la $v$. con que obr. -9 Astrologia quiere / $T$ dezir que / $T$ catatamiento, $E$ acatamiento. - I I $T$ es llamada; $E$ han nonbre. 13 por vsar / T' ffabla, $E$ visto. - 14 primera es por vsar (con la letra $\mathrm{i}$ escrita y tachada despues de $\mathrm{v}^{-}$) fazer. - 16-17 çielo e la o, en çerco. - 20 conosçer cada. - 31-22 T omite La ... otro. $-23 T$ puede auer ssaber. -25 saber $\left[\begin{array}{ll}E & 13 r\end{array}\right]$. -27 La set. -28 tenerse $r$ con o. c otrosy. 
Et por ende estas ssiele maneras desta arte muestran cómmo Dios es connosçido ssegunt estas ssiele rrazones. Ca por él sson todas las cosas connosçidas, las vaas por vista, las otras por rrazón, ssegunt Nuestro Ssennor Ihesu Cristo dixo, quien veye a él, veye 5 a ssu padre. Et esto sse entiende porque las obras que él ffazíe, non las podría ffazer otre ssinon Dios. Et por ende, connosçiendo a él por vista, connosçen a Dios ssu padre, que non puede sser connosçido ssinon por entendimiento e por obras. Por mudamientos pueden otrossí connosçer quién es; ca él ffaze todas las

10 cosas mouer e mudar, e él está ssienpre quedo, que non sse mueue nin sse camia. Por cuenta es otrossí connoscido; ca él es comienço e acabamiento de todos los cuentos e en él sse ençierran, ssegunt dixo el rrey Dauid prophetando, que Dios ssabe el cuento de las. estrellas e cada vna llama por ssu nonbre. Et esso mismo la medida;

I5 ca por él sson todas las cosas medidas, e él non es medido nin lo puede sser. Otrossí es con derecho llamado concordança; ca él ffaze acordar todas las cosas, cada vna en ssu natura, tan bien las spirituales commo las tenporales, e da paz conplida, la que otro non puede dar.

20 Ffísica es llamada la ssesena destas ssiete artes, que quier dezir tanto commo natural ssaber de melezina, que viene por natura ssinple e conpuesta de vnas cosas con otras que fallaron los ssabios por ssu sabiduría para acreçentar la vida e toller las enfermedades e los dannos que rreçiben los omnes en ssus cuerpos naturalmiente 250 por ffuerça. Et ésta sse parte en siete partes:

\begin{tabular}{|c|c|c|c|c|c|c|}
\hline POA GON- & $\begin{array}{c}\text { POA } \\
\text { RRAzón }\end{array}$ & $\begin{array}{l}\text { POA ENTENDI- } \\
\text { MIENTO }\end{array}$ & $\begin{array}{c}\text { POR } \\
\text { SABER }\end{array}$ & $\begin{array}{c}\text { POK } \\
\text { GOARDA }\end{array}$ & $\begin{array}{l}\text { POR SE- } \\
\text { NNALES }\end{array}$ & $\begin{array}{l}\text { POR } \\
\text { OBRA }\end{array}$ \\
\hline
\end{tabular}

Onde la primera ffabia de connosçer la enfermedat. Et es vna de las grandes bondades que pueda auer en ffísica; ca sy el físico la bien connosçe, non puede seer que non conosca con qué la ha 3o de toller. La ssegunda es que connosçer non la puede conplida-

I-2 muestra c. que Dios. - 5 obras el. -6 podrie o. f. sinon. $-8-g$ mudamiento. - Io non mueve. - 13 profetizando, -14 e a cada. -16 acordança. 17-18 bien spir. - 18 lo que otre. - 20-2 1 quiere $t$. d. commo. - 21 mediçina. - 22 $T$ ssinple ca conp. / $T$ llamaron. $-23-24 T$ enffermedades que. 25 esto. -26 por conoscençia, por rrazon, por conosçer, por saber / por senales. -28 puede. $-28-30 T$ omite ca sy ... toller. -29 ha $\left[\begin{array}{ll}E & 13 v\end{array}\right]$. 3o pueden. 
miente ssi non connosçiere ante la rrazón por que auino, ssi por culpa del enffermo, que la buscó ffaziendo él mismo cosas por que ouo a enfermar, o ffaziéndogelas otre. La terçera es otrosí que deue conosçer el mienbro en que está la enffermedat, ssi es dentro en el cuerpo o ffuera, o ssi es de los más nobles o de los medianos o 5 de los más viles. Et la quarta es que ssin esto deue ssaber por los acaesçimientos que acaesçen al enffermo ssi es la enffermedat periglosa o non, o a quál parte tira más, o del bien o del mal. La quinta es otrosí en connosçer las mediçinas a muy grant ssabiduría ; ca ellas sson de muchas naturas e an a sser tales que con- 10 uengan para la obra ssegunt las enffermedades e las conplesiones de los omnes. Ca enffermedades y a que por guarda de dieta pueden guaresçer, dexando la sobejanía de aquellas cosas que les [11v] ffazian enffermar. Et otras y a que guaresçen tan ssolamiente por comer cosas ssanas e guardarsse de las contrallas. La ssesta es i5 que por sennales sse puede connosçer la enfermedat, ssi es de vida o ssi es mortal, o ssi guaresçrá ayna o tarde, o ssi ffincará bien sano o non ; ca todo esto deue ssaber el ffísico por cosas que sse muestran en las enfermedades, tan bien en las de dentro en el cuerpo commo en las de ffuera. Ca por las que veyen pueden connosçer 20 las que non sson vistas. La ssetena es que es obra que sse ffaze con mediçinas ssinples tan ssolamiente. Et las que sson más grieues, por conposiçión de yerbas o de espeçias o de otras cosas que mezclan en vno. Et guardan otrossí de muchas maneras los enffermos por que rreçiban ssalut. Onde qui esto ssabe non tan solamiente 25 dene sser llamado ffísico, mas philósoffo, connosçiendo las naturas conplidamiente e ssabiendo obrar las vnas con las otras.

Et en todas estas ssiete cosas sse muestra el nonbre de Dios, que es natura que ordena todas las otras naturas. Ca él connosçe todas las enffermedades commo aquel que las da por los mereçimientos $3 o$ de Jos omnes, tan bien en las almas commo en los cuerpos. Et

I conosçieren. -2 lo. -3 ovo de enf. / es que d. otr. -5 nobles o sy es de los med. - 6 La quarta. - 7-8 peligrosa. $-8 \mathrm{~T}$ yra mas / de bien o de mal. - 9 es c. o. las med. - 11 conplisiones. - $3 T$ la ssabiduria / le. - I4 fazen. - 15 contrarias. - 17 sy es de muerte o sy guaresçera. - 20 veen. ar $T$ las de ffuera que non (de añadido sobre la linea, otra mano). - sI-22 La s. que es o. que se f. de medizinas. - $22 T$ ssinple / graues. $-{ }_{2} 3$ por conpuestas de $y$. e de esp. e de otras. -25 quien. -37 vnas cosas con. $-28 T$ Et todas. - 29 hordena las. - 31 bien de las a. c. de los cuerpos. 
ssabe por qué rrazón es o deue sser. Et non tan ssolamiente las conplesiones e los mienbros de los omnes quáles sson, mas aun lo que tienen en las uoluntades para ffazer bien o mal. Et otrossí los acaesçimientos quáles sson e por qué han âcaesçer e de qué manera

5 e en quáles tienpos e por dó sse pueden desuyar que non acaescan. Et ssobre todas las melezinas spirituales e tenporales, tan bien las que pertenescen a las almas commo a los cuerpos. Por ssennales las connosçe otrossí, veyendo las buenas obras e malas que los omnes ffazen, tan bien a pro o a danno de las almas commo de los

ro cuerpos. Et obra en cada vna dellas ssegunt conuyene, en las de las almas spiritualmiente e en las de los cuerpos tenporal. Et por ende él es ffísico conplido que ssana tan bien los peccados commo ... Ias enffermedades, lo que otro ffísico non puede ffazer.

Metaffisica es la ssetena destas ssiete artes, e más noble e más I5 ssotil que todas ellas porque por ésta se conosçen todas las cosas ssegunt ssu natura, $\tan$ bien spirituales commo tenporales. E este conosçimiento es en ssiete maneras :

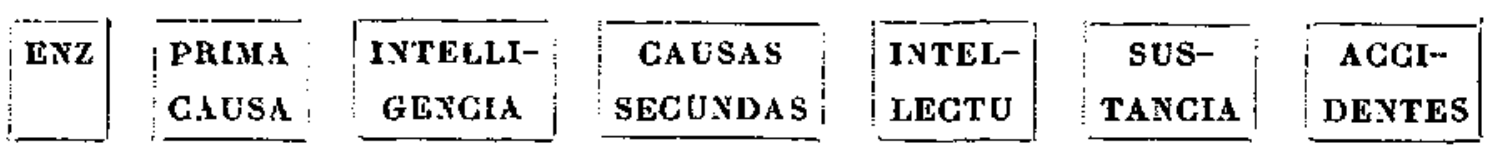

Onde la primera destas ssiete, que es dicha enz, quiere tanto 20 dezir commo sser la cosa en manera que puedan della e en ella e con ella ffazer lo que quisieren. Et esto non cae en todas cosas, ssinon en Dios ssolo; que él las ffizo todas e él nou ffué ffecho, e las otras sse pueden caboprender e él non. La ssegunda, que dizen en latín prima causa, demuestra la natura de Dios en ssí ; ca él es la 25 cosa primera e comienço e rrayz de todas las otras. Et él las conpuso e él las ordenó e las tornará a aquel estado que quisiere. [12r] La terçera, de intelligençia, quiere dezir tanto commo que Dios es entendimiento conplido e dél lo rreçiben todas las otras cosas spirituales e tenporales. La quarta es que llaman en latín causas

I-2 solamente sabe las conplisiones. - - avn [ $\left.\begin{array}{lll}E & 14 \mathrm{r}\end{array}\right]$. -3 bien e mal otr. -4 han de ac. -5 e por quales. -6 mediçinas. -7 las animas. $-8 \mathrm{co-}$ nosçen. -9 dano dellas commo. -14 desta s. arte. - i5 $T$ omite ellas ... todas / las otras. - i $8 T$ escribe enz sin encuadramiento / causas segundas, intellectus/açidentes. - I9-20 quiere d. $t$. commo. - 20-2 I della e can ella f. lo que quisiere e esto cahe. -22 porque. -26 e las hord. e las $t$. aquel e. quando quis. -27 inteligencia que q. t. d. commo. $-28-29$ e della r. t. las o, spir. 
secundas, que sse entiende por la natura de los ángeles, que sson spirituales ssegunt Dios e sson monederos e obradores ssegunt el poder que han dél. La quinta llaman intellectus, que quiere tanto dezir commo entendimiento obrador que obra ssobre todas las cosas, en cada una ssegunt ssu natura, e es assí commo el spíritu 5 en el cuerpo del omne quel ffaze beuir e mouer e obrar. Et por esso lo llamaron los philósophos alma del mundo. La ssesta, la ssustançia que ssale de la materia, que quiere dezir que es la cosa en ssí ante que ssea fformada nin obra flecha. La ssetena, que sson los acçidentes, que quiere dezir que sson acaesçimientos de auen - io tura que acaesçen después que la cosa es ffecha, por que la ffaze creçer e yr a bien o menguar e yr a mal.

Onde estas ssiete cosas sson en Dios conplidamiente. Ca es e ffué e sserá por ssienpre. Otrossí es la primera cosa ; ca todas las cosas ouyeron comienço dél, e él fué el primero de todas ellas e I $_{5}$ sserá el postremero. Entendimiento es otrossí conplido; ca por el ssu entendimiento es él connosçido e todas las cosas que él ffizo ssegunt pueden sser entendidas por sseso de omne. Causa ssecunda es él; ca la natura de los ángeles, dél la han quanto en sser spíritus entendidos e non cuerpos. Entendimiento obrador es e mara- 20 uilloso otrosí ; ca él ffaze las cosas de vida, lo que otro non podría ffazer, e él las desffará quando él touyere por bien. Ssustançia es llamado con grant derecho; ca dél la rreçibieron e la han todas las olras cosas, e por la ssu uertud sson aduchas a manera e a fforma. Acaesçimiento es otrosí; ca él ffaze acaesçer las cosas 25 commo entiende que conuyene segunt mereçimiento de aquellos ssobre qui quiere que acaescan.

Onde por estos ssiete ssaberes a que llaman artes ssopieron los omnes connosçer a Dios e a todas las cosas que él ffizo, quáles sson en ssí e cómmo obran. Et aun por ellas ssopieron los ssiete 30 çielos en que están las siete estrellas a que llaman planelas, e los nonbres de cada vna dellas. Et déstos ssacaron los cuentos de

I segundas. - a mouedores. - 3 La q. que ll. intelectus quiere. - 5 cosas e en. - 5-6 spiritu del cherpo [E 14v]. - $6 \mathrm{~T}$ cuerpo e del. $-6-7$ eso se llam. - 7 de mundo la s, es la. $-8 T$ de la manera. -9 nin f. o. la s. es que. -- 10 las açidentes que q. d. los acaesç. - 14-15 ca de t. las otras c. o. com. e el fue. - I6 postrimero. - I6-18 Entendimiento suyo es connosçido e t. las otras c. que el f. que pucden. -18 segunda. - rg es ca. -20 non auer cuerpos. - 20-2 I obrador e m. es otr. - 22 e las. - 23-24 han las o. c. por. - 26 meresçimientos. - 27 quien. - 3o ellos. 
los días de la ssemana e nonbraron a cada vno ssegunt el nonbre de ssu planeta. Et partièron el día e la noche por oras e por grados e por puntos e por otros cuentos tan menudos que sse entienden más por entendimientos de omne que por vista. Et ssopieron

5 otrossí partir las ssemanas por meses, e los meses por annos, e los annos por tienpos, e los tienpos por edades. Et ssegunt aquello partieron la rredondez del çielo en ssiete partidas. Et fezieron otrosí ssiete de la tierra que está en ssu derecho, tan bien yermo commo poblado, a que llaman en lenguaie griego as climas, que quiere ro tanto dezir commo logares ssennalados en que ha cada vna de las planetas ssu ssennorio e muestran y ssu uertud.

Et esto mismo ffizieron a los ssiete $[12 v]$ metales, que sson éstos:

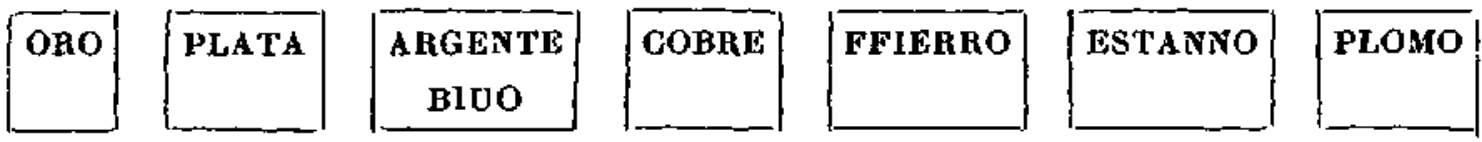

I5 Que a cada vno pusieron nonbre ssegunt la planeta que auya poder ssobrél, assí commo oro, el ssol, porque es linpio e ffermoso e noble más que los otros metales. Et la plata, a la luna, porque es comunal a los omnes e más noble que otro metal, assí commo la luna es más aprouechosa que otra planeta del sol en 20 ayuso. Et argente biuo pusieron a Mercurio, porque ha aparçeria con cada vno de los otros metales; que con los vnos sse ffaze bueno e con los otros sse danna, ssegunt ffaze Mercurio con las otras planetas. Ca ffaz bien con las buenas e ffaz mal con las malas. Et demás, ha en él spíritu demás que en los otros metales; ca ffuey 25 de ffuego, con que lo prenden, e alinpia a ellos. Et otrosí que sse torna del spíritu cuerpo, e del cuerpo spíritu. Cobre pusieron a Uenus, porque es metal dulçe de labrar e rreçibe más ayna tintura que otro. Et la meior color que cae en él es color de oro; ca ésta es más ffermosa e rreçíbela más de grado, assí commo Venus

4 entendimiento. - 5-6 annos por tienpos e. $-6 \mathrm{E}$ avn segunt. - 7 partes / $T$ ffueron. -8 en [E $15 r]$. - 8-ro yerma c. poblada a que llamaron en l. g. climas que q. d. t. commo. - i planetas su poderio e muestra mas su v. que en otro. - $13 E$ omile estos. - 14 argen biuo. - i5 $T$ Que c. vna / vno dellos pos. - I5-16 auie mayor p. sobre el asy c. el oro. - I7 a luna. - 8 metal e en sol en fuera asy. - Ig luna le es. - 20 porque aparçea. 22 otros d. s. f. M. contandose con. -23 e mal. $-24-25$ ca el fuy del fuego. -25 alinpian. -28 la que m. cae. -29 grado e asy. 


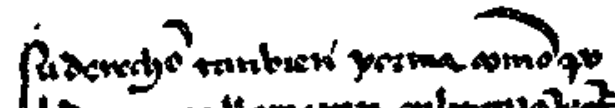

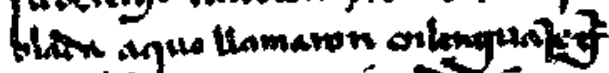

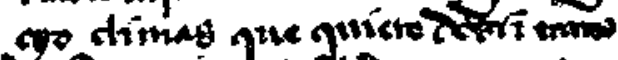

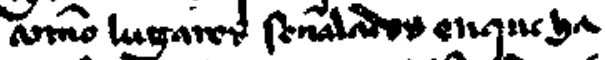

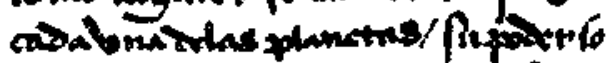

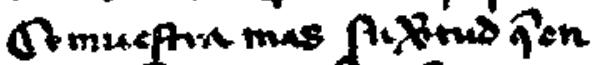

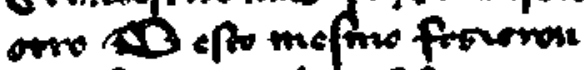
alos freer morsales ô 3 in- $/ 1:$ : (ivo) (10taris (fic) cpario) bins<smiles>[C]1CC[C]2CC[C]12</smiles>

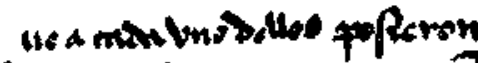
nonbre Bontriastanomo

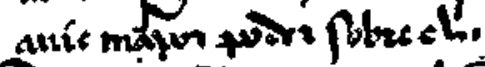

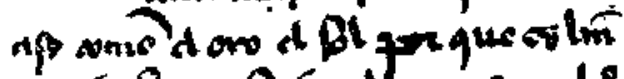
to is fermop li notle masi quats owos metales Otla platmalum 7 que co cumunal des omiss $\theta$ mas noble que otro motal perpt

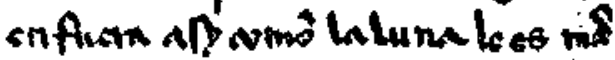
apromerfiofa quecorra plametriyl

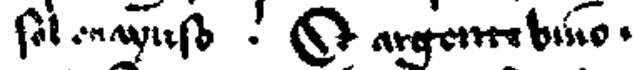

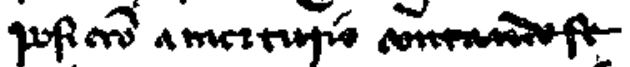

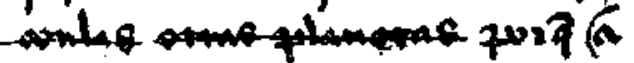

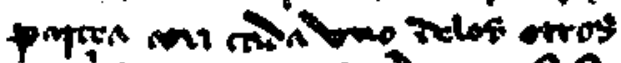
motale gic conlos brop PfA

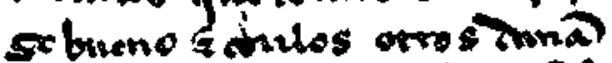
peris fase meztupo wontis E conlas orrad polanctas onfor bien contus busenas i mal cunts

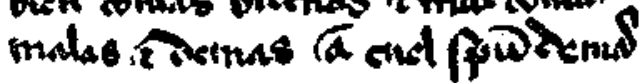

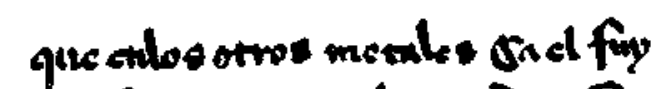
tot figy ongucloperition?

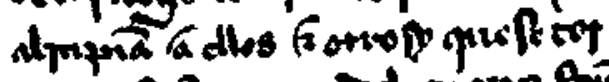

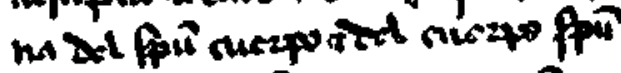

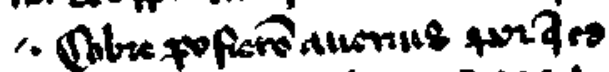
mind sudre telatiraz Ofinde mas coma fimem pue of ellot jue meín ace end ss slorivop

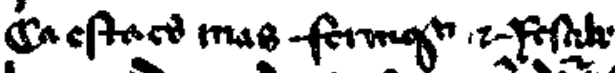
La mas ix yous is afy somis ling

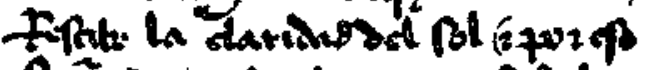
fisentel dez laten ropriadel en dordx oro ques la mas fimet

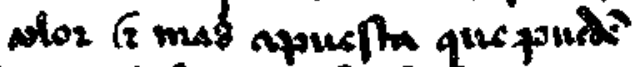

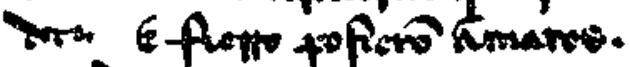

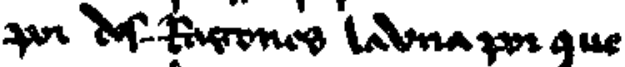

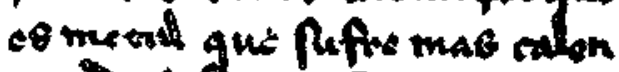
tuntor fusto gotro bu an.

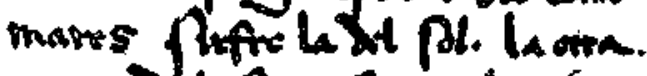
tor quent for fugen ho/so

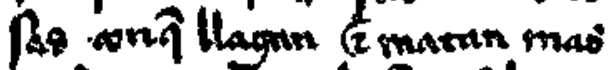
pux otw motnl Bgytlana twix to mures gue es mas ff

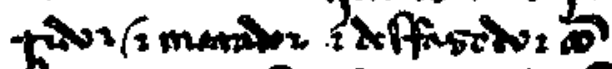

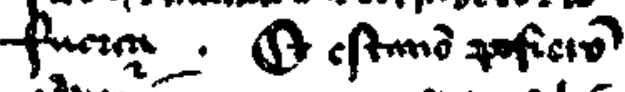
Alupvere por gut so mas lin

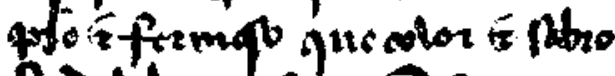
Priabras an amo jupinz manpo za bueno en conalonte

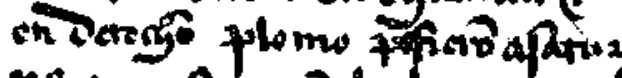
no que ap ame d promosesmy

MS. DEL ESCORIAL, FOL. $15 r$. 
rreçibe la claridat del ssol. Et por esso ffazen del cobre latón, tornándol en color de oro, que más ffermosa color es e más apuesta que pueden dar. Ffierro pusieron a Mars por dos rrazones: Ja vna, porque es metal que ssuffre más calentura del fuego que otro,

5 bien assí commo Mars ssuffre la del ssol; la otra, porque del ffierro frazen las cosas con que llagan e matan más que de otro metal, ssegunt la natura de Mars, que es más fferidor e matador e desffazedor con ffuerça. Et el cstanno pusieron a Jupiter, porque es más linpio e ffermoso de color e sabroso de labrar, assi commo

1o Jupiter lo es en bondat e amar uerdat e justiçia. Et déxase otrossí labrar sabrosamiente, ssegunt es Jupiter manso e bueno en eguallat e en derecho. Plomo pusieron a Ssaturno; que assí commo el plomo es más pesado que otro metal por rrazón de la tierra que ha más en él, e es frío e seco ssegunt la natura della, assí Ssa-

I 5 turno es más pesado que otra planeta en ssu andar e en ssu mouimieuto. Ca él anda más tarde que las otras planetas e demás es ffrio e sseco, ssegunt sse muestra en ssus obras que flaze. El otrossí es assí commo negro, ssegunt lo muestra Ssaturno en ssí más que otra planeta.

20 Onde, mostrando el ssaber de qué natura es e connosçiendo la ffuerça que ha en él, éste es Dios nonbrado e connoscido por el bien, assí commo por la moneda es connosçido el que la manda ffazer e la tierra en que la ffazen, nonbrando el nonbre della generalmiente en cada parte que es el dinero, en que ha el nonbre e la 25 ssennal por que es connosçido el que la manda fazer, e la tierra en que la ffazen por el logar en que la labran. Et por todas estas rrazones es manilfiesto e connosçido que los ssaberes sson de Dios e non dotre, e por él sson connosçidos e él por ellos. Et las partes desta moneda sson las artes e maestrías que los omnes buscan 30 para entender qué es ssabiduría e apronecharsse della. Et por esa rrazón llamaron los antigos a los ssaberes moneda de Dios; ca bien así commo la moneda non se puede ffazer conplidamiente nin derecha a menos de ssiete cosas -

5 color laton. -- 2 que es la mas $f$. c. e mas ap. $-3 \mathrm{E}$ fierro. -5 bien commo. - 8 E est. - 9 fermoso que color. - 10-r I $E$ omile lo es ... Jupiter. - 11-r 2 egualdat. - 13 mas $[E 15 v] .-18$ es c. n. asy commo lo muestra. - 30 Onde desta guisa nonbrando el saber. - 21 que en el ha es Dios. - a commo la m. es c. por el que. - 23 fazer la tierra. - $23-24$ generalmente o cada. - 25 senal. - 26-27 estas cosas es. 


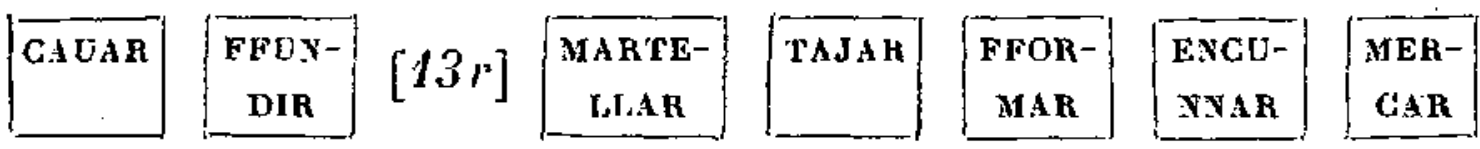

- otrosí, a semejança desto, ba mester en el ssaber olras ssiete para ssaberla çiertamiente.

La primera, que asi commo el metal cauan sso tierra bien ffondo e lo sacan e lo alinpian, otrosí los saberes deuen sser cauados 5 e escodrinnados muy porffundadamiente, alinpiándolos e tolliendo la ssuziedat de las dubdas e las escuridades dellos, e ffaziéndolos entender a los omnes que los non entienden. La ssegunda es que así commo el ffundir ffaze alinpiar el metal e esclaresçer, et quantas más uezes lo ffunden, tanto más es linpio e más ffermoso io e pueden los omnes meior obrar dél e ffazer lo que quieren, otrosí el ssaber quanto más es catado e sazonado, tanto más es apuesto e ssabroso para ayudarsse dél. La terçera es que bien commo el metal deue sser martellado e batido de guisa que non ffinque brisna ninguna nin quebrantadura, mas que ssea ssano en í mancra quel puedan estender e ffazer dél 'obras sotiles e buenas, otrosí el ssaber deue sser batido e rrazonado mucho, e estremado la uerdat de la mentira, de guisa que, auyendo los omnes sabor dél, se estiendan por el mundo et puedan otrosí con él ffazer obras nueuas e nobles en bondat e en ffermosura e ssotiles en maestría. 20 La quarta es que assí commo el metal taian por pieças ssegunt la quantidat de quanto quiere que ssea el dinero, e toma cada vno de los obreros quanto entiende que podrá labrar, otrosí del saber deue tomar cada vno de aquellos que lo aprisieren tanto quanto pudiere entender e rretener en memoria; ca palabra es de los 25 sabios, el que aprende los saberes e non los entiende nin los sabe rretener, que les menospreçia. La quinta es que así commo el metal es bien batido e taiado por pieças e ffecho de fforma rredonda o quadrada porque abiene meior que otra en moneda, otrosi

I fondir (fundir añadido en el margen, otra mano), martillar / encarnar. 6 profundadamente a. toll. -7 oscuridades $/ T$ dellas e faziendolas. $-8 T$ que las. -9 fondir / $T$ ffazen. - I2-13 quanto es mas cat. e s. t. es mas ap. - 13 para $\left[\begin{array}{ll}E & 16\end{array}\right]$. - I 4 martillado, - 15 brezna. - 16 que le. - if e sazonado m. e estremada. - $19-20$ puedan $f$. con el obras nobles en b. e.sotilesa (-a añadida sobre la línea, otra mano). - 22 quieren que sea en din. - 23-33 $T$ cada vna dellas obras $q$. e. que podran. - 24 aprisieron. - 25 podierén / $T$ aprender e. -26 sabios que el que. -27 los. 
el ssaber deue sser enfformado, onrrándol e preçiándol mucho, por que sse muestre la florma de Dios; ca bien así commo la rredondez non ha comienço nin ffin ssegunt su ffigura, así ffué Dios. Ca nunca ouo comienço nin puede auer acabamiento. Et de 5 aquella manera es el ssaber, ssegunt dixo el rrey Ssalamón, que tanto sse podría contar el ssaber de Dios commo los granos de la arena del mar nin las gotas de la lluuia. Et la otra fforma del dinero e es quadrada a linnas derechas a cada quadra. Et en esto sse entiende la bondat de Dios, que es derechera e ygual a todas Io partes. Et assi el ssaber que ha él en ssí mismo, derecho es e egual a todas partes para los que ssaben entender e obrar bien dél. La ssesena cosa es que pues la moneda ha rreçebido fforma, hanla de meter en el cunno, en que aya letras que demuestran cúya es aquella moneda. Et otrosí el ssaber ha en ssí escripto que de Dios I5 es el ssaber e non de otre, ssegunt dixo el rrey Ssalamón, que todo el ssaber era de Dios e con él ffuera ssienpre en todo tienpo e delante $\{13 v\}$ él estaua. La ssetena es que assí commo de la moneda sse aprouechan los omnes en conprar e uender, e ssaben quánto uale o por quánto la han a dar o tomar, otrossí sse deue 20 aprouechar del ssaber, ganando por él lo que non han por su entendimiento. Et nol deuen dar por más nin por menos de lo que ual. Que ssi por más fuesse dado, rrecibrie enganno el que lo aprisiere, assí commo el que conpra del que uende. Et ssi por. menos, el que lo enssennase, assí commo el vendedor del que 25 conpra.

Onde çiertamiente los ssaberes sson de Dios. Et qui a ellos despreçia, a él torna en despreçiamiento. Et este despreçiamiento, ssegunt dixieron los ssabios, es en ssiete maneras :

\begin{tabular}{|c|c|c|c|c|c|c|}
\hline $\begin{array}{c}\text { MOS- } \\
\text { TRANDO }\end{array}$ & $\begin{array}{l}\text { ENGU- } \\
\text { BRIENDO }\end{array}$ & $\begin{array}{l}\text { DESPRE- } \\
\text { GIANDO }\end{array}$ & $\begin{array}{c}\text { OBRAN- } \\
\text { DO }\end{array}$ & $\begin{array}{c}\text { NON } \\
\text { ORRAN- } \\
\text { DO }\end{array}$ & $\begin{array}{c}\text { NON } \\
\text { GUAR- } \\
\text { DANDO }\end{array}$ & $\begin{array}{l}\text { NOL ON- } \\
\text { RRANDO }\end{array}$ \\
\hline
\end{tabular}

I -lo / -lo. - 2 muestra en el la forma. - 3 rredondesa (-a añadida sobre la línea, otra mano). - 6-7 granos del a. de la mar nin las $\mathrm{g}$. de pluuia la o. f. que fazen del. $-8 \mathrm{En}$ este. - 9-ro derechero e egual a $t$. las partes. Ir egual de todas. - 13 demuestren. - $14 \mathrm{sy}$ spiritu que. - 15 saber que non / Salamon $\left[\begin{array}{l}E \\ 16 v\end{array}\right]$. -18 e en vender. - 19 vale e por $q$. lo han a dar o a tomar. - 21-22 $T$ lo ual. - 22 vale / rresçebirie. - 23 aprisiese. 26 quien. - 27 este despreçiar. - 29 obrando, nonlırando, non guardando, non honrrando. 
Et la primera, que es de mostrarse, entiéndese quando lo ensenna a omne menguado de entendimiento e de rrazón; que quien esto ffaze, ssegunt dixieron los ssabios, tanto es commo quien mete las piedras preçiosas entre los puercos. La ssegunda es de aquellos que han entendimiento para entender e sseso para guar- 5 darlo ssegunt conuyene. Et esto dixieron los ssabios, que quien esto ffaze mengua e encubre el ssaber de Dios. La terçera es de Ios que despreçian el ssaber, desdennándolo, non lo teniendo en nada. El ssobresta rrazón dixieron los ssabios que los que esto ffazen eran tales commo aquellos que despreçiauan el bien, non io lo queriendo aprender nin entender et ffazerlo. La quarta es de aquellos que los ssaberes uerdaderos e derecheros tornan en mentira e a enganno, obrando dellos commo non deuen, ffaziendo creer vna cosa por otra. Et atales commo éstos llamaron los ssabios ffalsarios de Dios e del mundo. La quinta rrazón es non obrando i 5 dellos ssegunt conuyene. Et esto ffazen los que non catan los tienpos que sse deue fazer; de que vienen dos dannos: lo vno, que non acaba la obra que comiença por el tienpo que los destorua; et lo al, ffazen tener el ssaber uerdadero por mintroso, e de lo que sse cuydan aprouechar ffazen ssu danno, entendiéndolo ellos 20 mal. Et déstos dixieron los ssabios que eran tales commo el ninno que veye la brasa del ffuego ffermosa e, queriéndola tomar, tómala e quémase en ella. La ssesta manera es non lo queriendo guardar pues que lo ssaben, e esto auyene en dos guisas : lo vno, podiéndolo acreçentar e non queriendo sseguir aquellas cosas por que ${ }_{2} 5$ sse acreçientan ; lo al, non mostrando a aquellos que lo muestran en manera que aprouechen dello nin ge lo gradescan. Et déstos dixieron los sabios que eran tales commo los que ayuntan tesoro e non lo quieren dar nin ffazer bien dello. Et vienen otros e ffúrtangelo o ge lo rroban, e non les ha ende grado. La ssetena ma 3o nera es en que ge lo ffalsan; es assí commo encaresçer mucho al vil e despreçiar al noble. Et déstos dixieron los sabios que sson atales commo quien toma por la mayor medida e da por la menor,

I mostrar se entiende / $T$ la. -3 qui. $-6-7 T$ quien f. rn. enc. -10 despreçian. - 12 saberes derechureros e v. tornan. - i5 manera. - 17 tienpos en que se. - 18-19 destorua lo al. - Ig mentiroso. - 22 queriendola $[E 17$,$] t. e tomala. - 23$ con ella. - 23-34 guardar por que. - 24 la vna. -25 non lo quer. $/ T$ aquellas por, -26 non lo m. aq. -27 que se apr. / T desto. -28 atales $c$. quien ayunta. -29 quiere. $-3 o$ han. -31 que lo / enacresçer. 
poniendo arreffezamiento en las [14r] cosas buenas e nobles e ençerramiento en las viles e malas, metiendo a ssí por falssos e ffaziendo danno a los otros.

Rrazón es la quarta manera de las ssiete deste ssetenario mayor 5 e de que ha nonbre el libro. Et ésta es atal commo la lunbre entre las tiniebras; ca ella alunbra el entendimiento e ffaz connosçer la natura e ssabe ciertamiente las cosas e demuéstralas, rrazonando e departiendo lo que sse muestra por ssignifficança, e ordena los ffechos, cada vno o deue, e dales acabamiento commo

ro conuyene, E por ende es puesta en el quarto ssetenario para sser endereçados todos los ssetenarios por él, assí commo el ssol es puesto en el quarto çielo; que alunbra a las tres planetas que sson ssobrél e las otras tres más baxas. E otrossí por rrazón sse muestran ssiete naturas que ha en ella por rrazón que es más no-

i5 ble que las otras. Et en estas ssiete sse ençierra toda la ffuerça que ha en ella.

Ca ssin ffalla ésta alunbra todas las cosas que sson oscuras de entender e de ssaber en todos los tienpos que los omnes han, tan bien en lo pasado commo en lo de luego commo en lo otro 20 que ha de venir. La ssegunda es que abiua las uoluntades de los omnes, aguzándoles el entendimiento por que entienden e aprenden meior, mostrando qué cosa es ssaber e en quál guisa deue sser entendido. La terçera, muestra los ssaberes de las sçiençias, cada vno quál es en ssí e qué obra deue ffazer con ellos. La quarta, 25 ayuntando las vnas cosas con las otras, ffaziendo entender cómmo obran todas en vno e cada vna por ssí. La quinta, que conpone e ordena lo que es desordenado e muestra cómmo ninguna cosa non deue dexar ssu logar nin pasar ssu ordenamiento. La ssesena, departe otrossí la deseguallat de las cosas eguales, e el bien del 30 mal, e el tuerto del derecho, e la mentira de la verdat, demostrando en quáles logares yazen acada vaa dellas. La ssetena, assesiega e ençierra todas las cosas, dándoles acabamiento. Et algunos de los ssabios ffueron que dixieron que la rrazón era spíritu de Dios en que $[14 v]$ ordena todas las cosas por estos siete nonbres ssobre-

I arrehezamiento. - 2 encateresciendo las viles. - 3 danno asy a. - 6 teniebras. - 7 sabclas çiert. e dem. - 8 departir. -9 dales el acatamiento comroo. - 10 apuesta. - 12 apuesto. - 13 bajas. - 44 por que. I5-16 fuerça que en ella ha. $-17 \mathrm{E}$ syn. $-17^{-18} T$ de enderredor e. $-31-27$ entiendan e puedan mejor. - 24 quarta $\left[\begin{array}{ll}E & 170\end{array}\right]$. -29 desegualdat. $-3 \mathrm{r}$ yaze. -32 acabamiento qual conviene e alg. -34 con que hordenaua. 
dichos. E diéronle tal ssemeiança que assí commo el Spiritu Ssanto non cae ssinon en cuerpo linpio, otrossí la rrazón non rrecibe ssinon cuerpo entendido.

Onde con ésta mostraron e ssopieron e obraron los omnes ssabios e entendidos todas las cosas que quisieron ssaber. Et aun 5 Dios mismo seguió carrera de rrazón, ssegunt dixo el propheta Dauid allí do muestra el ssu poder rrazonando : Ca dixo que ffuese e ffué ffecho, e mandó e ffué criado. Et dixo otrosí que por el vierbo de Dios ffueran los çielos criados, e por el ssu spíritu de la ssu boca, que sse entiende por rrazón, rreçibieron todos uertud.... Io

[Lex XII], — Qué quier dezir ssecta.

Secta tanto quiere dezir commo cosa departida de otra. Et por ende aquellos que creen las cosas luengas e enoiáuansse de la longura dellas, et apartauan vna partida quanto entendían que podría abondar a su poco entendimiento. E atal crençia commo ésta 15 llaman ssecta.

$$
\text { [LEY XIII]. - Qué cosa es opinión. }
$$

Opinión era ya más fflaca que esa otra; que bien commo la ssecta era vna partida de la crençia, assí la opinión era vna partida de la ssecta. Ca opinión non quiere dezir al ssinon poner omne 20 contra la ssecta apartada que cree rrazones con quél da muchos entendimientos, de guisa que non la dexa assesegar.

$$
\text { [LEY XIV]. - Qué cosa es antoiança. }
$$

Antoiança es manera otra más apartada de crençia que estas otras; ca antoiança el nonbre muestra que non es ssinon commo 25 cosa que sse parase ante los oios e sse tolliese luego, ssegunt lo que vee o lo que oye arrebatadamiente, e por ende non es firmeza ninguna.

[I_EY XV]. - Qué quier dezir ffantasía.

Fantasía es crençia más ssin rrecabdo que ésta porque viene 30

$6 T$ mismo ffiguro. - 9 beruo / el spir. - I I ssetas. - I3 creyen las creencias l. enoi. - 16 llamauan. -18 era mas $\mathrm{f}$. que esta otra. - 20 quiere al d, synon. $-22 T$ deua. -24 es o. m. mas. $-25-26$ synon cosa. $-27 T$ ffuerça. - 3o viene $[E 18 r]$. 
assí commo enffermedat; ca bien assí commo el enffermo que ha la ffiebre, e mayormiente en la cabesça, sse le antoian muchas cosas que non sson assí, otrossí la ffantasía ffaz entender muchas maneras de opiniones desaguisadas al omne e que [ $15 \mathrm{r}]$ non sson

5 de la guisa que él cuyda. Et por esto ha este nonbre, commo cosa que sse ffaze e sse desffaze ayna en manera de antoiança. Et en ésta veen ssienpre las cosas temerosas porque nasçe de rramo de malenconía.

[LEY XVI]. - Qué cosa es ssuenno.

10 Suenno commo quier que ssea natural que ordenó Dios en la natura del omne en quel dió tienpo en que ffolgase en dormiendo por los trabaios que lieua velando - et en aquel dormir, ssegunt dixieron los que ffablaron de naturas e es uerdaderamiente, los mienbros ffuelgan e están quedos - el spíritu de la vida mueue

r 5 los sentidos e quiere obrar con ellos bien commo ssi estudiesen despiertos. Et porque esta obra non es tan ffirme commo de la que husa el cuerpo quando non duerme, et por esso ssuennan muchas cosas, dellas naturalmiente e con rrazón e dellas de otra guisa, ssegunt lo que comen o beuen o lo al que ffazen en que 20 andan o cuydan mientra están despiertos, o ssegunt creçen o menguan los quatro humores de que es ffecho el cuerpo; que han de creçer en él los cuydados e las antoianças de manera que lo que ffalla tiene que es çierto en quanto está en ssuennos, e quando despierta non tiene nada. Et por ende los que ssobre tan fflaco 25 çimiento commo éste arman ssu crençia, bien se daua a entender que su creençia non era cosa ffirme nin ssana, nin podría durar luengamientre.

[Lex XVII]. - Ọué cosa es visión.

Visión quiere dezir otrosí cosa que non veen commo çierta3o mientre. Et porque esto non puede omne uer ssinon en dos ssazones - la vna, quando está el omne entre dos sentidos, de guisa

6 e desf. - 7 esta biuen sienpre / naçen. - I I durmiendo. - I 2 lieuan en $v$, en / $T$ et aquel. -15 estouiesen. - 17 duerme por. - 20 e cuydan. $-20-21$ o segunt c. o m. los q. elementos de que es (Lodo escrito sobre raspado). 2 I cuerpo por que. - 22 en ellos los. - 22-23 lo que $t$. que $f$. es asy çierto. -23 suennos quando. - 25 çemiento. $-25-26 T$ crençia non es cosa. -29 -3o vee omne c. e por esto non p. seer synon. $-30-31$ rrazones, -31 esta omne. 
que non es omne bien salido del vno nin entrado en el otro, assí commo entre velar e dormir; o entre cuydar omne tan ffirmemientre, estando despierto, que sse le oluide la çertedunbre de la obra en que ssee por la voluntad de la antoiança en que non es caydo aun del todo - et por ende los que asacauan creençias 5 $[15 v]$ e ssectas e opiniones de tales visiones commo ésta, bien se puede entender que non era rraygado el ssuenno donde tal creençia sse mouye nin podrie sser ffirme ninguna cosa que ssobre tal rrazón ffuesse.

Onde, por todas estas rrazones ssobredichas, todos los que en ro ellas creyen non auyan flirmes crençias nin ley uerdadera. Et por ende queremos mostrar todas estas crençias, cada vna cómmo era ssegunt aquellas gentes las creyen, por que connoscan los que las oyeren dónde sse mouyen todos estos yerros que ffazían a las gentes errar ssin rrazón.

\section{[LEX XVIII]. - De cómmo non deue omne aorar sinon a Dios solo.}

Orar es cosa que non deve omne ffazer a otro ssinon a Dios solo, e esto sse entiende por el nonbre de las siete letras de que ffablamos al comienço deste libro, que sson Alpha et $O$, que quier 20 dezir que Dios non ffué començado nin ffecho nin aurá acabamiento nin flin. Et aquél ssolo deue sser orado, e non otra cosa. Et por ende los que las otras cosas aorauan, que eran començadas e sse auyan âcabar, yuan contra la crençia uerdadera de Dios e contra la ley çierta, assí commo vnos que ouo y primeramientre 25 que començaron âorar los helementos, assí commo la tierra e el agrna e el ffuego, de que queremos dezir de cada vno cómmo lo ffazíen e por qué rrazones e cómmo sse camiauan vno en al. Pero mostraremos qué cosa es cada vno destos quatro elementos e por qué ha asi nonbre.

I del nin. - 2 cuydar commo tan. - 3 oluida. $-4 T$ sseen/del ant. - 5 es ava c. del / cnde avn los. - 6 vi[E $18 v]$ sioncs c. estas. - 7 pueden. - 9 fuese fecho. - 1 I crecn por abien firme creençia. - i a eran. I5 errar tan syn. - I6 aorar a otra cosa sinon. -- is otre. - 30 quieren. - 2 r $T$ añale que sobre la línea, olra mamo; $E$ lo anite. $-23 T$ y $E$ començados. - 2f auien a ac. -27 dezir cada. -28 lazie / camiauan on vno e en al. - 3o han. 
[LeY XIX]. - De los que adoranan la tierra.

Tierra es el primer helemento, que quier dezir tierra dura e sseca ssobre que andan todas las animalias. Et a ésta aorauan primero algunas gentes por ssu entendimiento, que era tal que pues 5 de la tierra nasçien todas las cosas de que los omnes biuíen e todas las otras animalias, e a la tierra tornauan e ella las desffazie después que murien e en natura della sse conuertien, que les era assí commo madre e por nascençia e por criança e por ssepultura, e por ende que a ella deuyan aorar e non al. Et por esso labrauan Io la tierra para auer los fructos en que sse mantouyesen; ca de aquello biuyen. Et quanto más esto ffazien, tanto más tenien que les $[16 r]$ daua la tierra más abondo de las cosas que auyan mester en que visquiessen. Et otrossí que los tornaua más ayna a ssu natura en desatándolos, e esto teníen por paraíso.

i5 El por ende labrauan la tierra en ssiete maneras, que sson éstas. Connosçiéndola, qué era buena e mala, para ffazer en ella lo que auyan mester. Sabíanla appareiar e endereçar por que les viniese meior lo que y labrassen. Et esto, ssenbrando en ella aquellas cosas que conuinie a ssemeiança. Et aun ssaber plantar e trasponer 20 e enxerir en ella los árboles e las otras cosas que conviníen que ffiziessen en ella ssegunt natura. Et otrossí rregarla a las ssazones que auye mester. Et aun ssaber ssacar de ella aquellas cosas que ffazían mal a las ssimienças e a las plantas. Et la setena dellas es ssaber coger los frructos della en ssus ssazones.

25 Et todas estas cosas ffazien, creyendo que la tierra era Dios e non parando mientes cómmo era la más baxa cosa e la más vil que él ffiziera. Et non les abondaua esta locura, e ffazíen ymágines de tierra a que ffazien oraçión. Et atal era ssu crençia, commo en manera de rreligión, que ssi alguno querie dexar este mundo, teníe 3 o que yua a Dios e él mismo se mandaua meter biuo sso la tierra. Et otrossí el ninno quando nasçíe, echáuanle tierra de ssuso e

I De las que a. a la tierra. -2 primero / cosa dura. - 5-6 beuien e $t$. o. cosas a a. -6 ella la. -8 madre por n. e por sep. -9 e ende a ella. - I I tanto ten. - I3-14 natura $[E 19 r]$. - i5 ende rresçebie la. - i6 qual era b. o m. para f. con ella meior lo. -17 Sabiendola end. o a. por. - I8 E otrosy senbr. - 19-20 $E$ omile que conuinie ... cosas. -22 auien. - 23 semejanças (symientes añadido en el margen, otra mano)/deslas. - 26 commo la mas baxa. - 27 feziera es esta e non / ymagenes. - ${ }_{2} 8$ Era atal su creençia. - 29 mundo e tenic. - 3 o Dios el / biuo en la. 
cubríenle todo della. Et esto ffazien commo en manera de baptismo. Demás, pagáuansse de matar las bestias e esparzían la ssangre e arrastráuanlas ssobre la tierra e comíen las carnes dellas commo en manera de comulgar. Et quemauan lo al por rrazón de ssacriffçio. Et a estas gentes llamauan los ffijos de la tierra. Et esta ssecta 5 duró muy grandes tienpos, ffasta que touieron que non tenían en ello rrecabdo.

[Ley XX]. - De los que aoranan el elemento del agua.

Agua es cosa húmida e ha en ssí dos cosas que ssemeian contrarias. La vna es de pesadunbre, et la otra es de liuiandat. Ca pesada ro es mucho, porque ssienpre desçende quando ffalla logar por do. Et liuiana es, porque sse mueue e corre, e demás los pescados andan $[16 v]$ ssobre la fiaz della e dentro rreçiben ayre por que biuan e non se affoguen. Et por ende ouo y algunas gentes que aorauan este elemento. Lt la opinión por que esto flazían era tal i5 que el agua era más noble que otra cosa; ca maguer que de la tierra nasçían todas las cosas, que tan grant era la ssequedat de la tierra que ssi por ella non ffuese que la tenpraua, non nasçería ninguna cosa. Et por ende la sequedat que dauan a la tierra, tolíela ella, esffriándola. Et aun alinpiaua los cuerpos ssuzios e era 20 ligera para mover de vn logar a otro, lo que non flaze la tierra. Et ssin esto que era en ssí clara e muy ffermosa de veer; ca non era buelta nin turbia commo la tierra.

Et por ende ssabiansse ayudar della en ssiete maneras : la primera, connosçiéndola; la ssegunda, gouernándosse della, be- 25 uyéndola e adobando con ella ssus comeres; la terçera, que la ssabian leuar de vn logar a otro allí do la auyan más mester; la quarta, que lauauan con ella e alinpiauan las cosas que non sson linpias; la quinta, que esffriaua lo que era mucho escalentado; la sesta, para tenprar la tierra para ffazer las cosas e las obras en que 30 contuyene que ssea metida el agua ; la setena, ssabiéndola endere-

I cubrielo. - 2 esparçien. - 7 ella. - 9 ha dos. - 10 oṭa liuiendad. I desçiende. - 13 dentro e rresç. - I6 maguer de. -17 grande. - is por el agua non fuese. - Ig daua la. - 20 cuerpos [E 19v]. -21 fazie. -2 2-33 non buelı. - 25 conosçiendola sy era sana la seg. (sy era sana añadido en el margen, otra mano). - 27 otro e alli. - 28 alinpiauan con ella las c. que non cran. - 3o cosas e las otras cosas en. - 3 I metido / $T$-lo. 
çar, quando sse dannaua, en manera que non rreçibiessen danno della, e guardarla que sse non dannase.

Et desto assacaron muchas ssotilezas estrannas en que trayen las aguas de vnos logares a otros por cannos encubiertamiente. Assí

5 que en vn logar ffizieron vna ymagen de estanno e hueca, e fforadáronla tan menuda que quando el agua entraua en ella, eran tan menudos los fforados que ssemeiaua que toda ssalía de vn cuerpo. Et a ésta llamauan dios del agua. Et a ellos otrossí llamauan los otros los fifijos del agua. Et quando los ninnos nasçien, metíenlos ro todos sso el agua e lauáuanlos, e teníen que era commo manera de baptismo. Et quando viníe aguaducho e leuaua algunos e muríen, dizíen que yuan a paraíso. Et el que querie dexar este mundo commo en manera de rreligión me[1 $\left.1 \gamma_{r}\right]$ tiósse sso el agua biuo e affogáuasse. Et otrosí matauan los pescados, e los que auyan ssan-

15 gre, derramáuanla ssobre el agua, e comíen los cuerpos dellos commo en manera de comulgar, e lo al quemauan por rrazón de ssacriffiçio.

[Ley XXI]. - De los que aorauan el elemento del ayre.

Ayre es el terçero elemento, que quier dezir ssotil alunbrador; 20 porque alunbra todas las cosas e amuestra las colores dellas. Et demás, que por él buelan las aues e andan altas contra el çielo. $\mathrm{E}$ a éste aorauan otra manera de gentes. Et ssu crençia era tal que maguer naçíen las cosas de la tierra e las ayudaua a creçer el agua, ssi el tenplamiento del ayre non ffuese, todo sseríe perdido; que 25 más podríen las animalias e las otras cosas biuas escusar la tierra e el agua que el ayre. Et por essol aorauan.

Et éstos ssabíensse ayudar dél en ssiete maneras. La primera, connosçiéndol, qué era bueno o malo. La ssegunda, ssabían catar los logares do lo auyan más claro e más linpio e más puro. La 30 terçera, desuyándolo, que non viniese por malos logares por que sse ouyesse a dannar. Et quando veyen que esto non podíen escusar, ffazíen ffumos de árbores e de yeruas e de otras cosas con que

I rresçebiese. -3 traen. $-4 \mathrm{E}$ asy. -5 destanno hueca. - 7-9) cuerpo e llamauanlos otrosy los fiios. - 9 tenienlos. - 10 eran. - I3 metiese. 14 Otrosy / $T$ auya. - 20 los col. - 24 tenpramiento / fuese [E 20r] / perdido e que. -25 cosas esc. -26 eso lo. - 28 conossiendolo qual ега. 29 avrien. - 32 arboles. 
adereçauan el ayre, tolliendo la mallat que rreçibie de aquellos logares corronpidos por do pasaua. La quarta, quando aduzíe viento caliente e lo flazíe passar por cuerpos muertos que eran ya corronpidos e olyan mal, e desuiáuanlos, tolliéndolos ende, e poníen otras cosas que olien bien. La quinta es que ssabían ffazer casas e moranças por do rreçibiessen el buen ayre e esquiuar el malo ssegunt los tienpos eran. La ssesta, quando enffermauan Ios omnes, catauan la parte donde vinía el ayre bueno e poníenlos y et guardáuanlos de poner con el malo. Et esso mismo ffazíen a los ninnos que criauan e a las otras cosas que querien que ffuessen 10 ssanas e durassen. La ssetena es que sse guardauan de comer cosas que non olyessen $[1 \%$ ] bien por que, ffablando vnos con otros, non sse onyessen a dannar nin a corronper el ayre nin ouyessen a tomar estrannedat en ssi, e punnauan de traer conssigo las cosas que olyan bien.

Et esto ffazian a onrra del ayre. Et en logar de baptismo, quando el ninno naçía, teníanlo descubierto all ayre. Et ssi algunos querían dexar este mundo commo en manera de rreligión, ffazíansse leuar a las ssierras altas e colgánansse de los árboles que les diesse el ayre de la vna parte e de la otra, non comiendo nin beuyendo 20 flasta que muríen. Et ffazíen ydolos de madera e cauáuanlos de dentro por que ffuessen huecos, e eran commo fliguras de omnes con quatro caras e que touyessen las bocas abiertas de guisa que entrase el ayre por la vna boca e ssaliese por la otra. Et a éstos Ilamauan dios del ayre. Et éstos se pagauan de matar las aues que 25 bolauan por el ayre e comíenlas e ffazían ssacriffiçio dellas. Et esto les era commo en manera de comulgación.

[LEY XXII]. - De los que aoraluan el ffuego.

Fuego es el quarto elemento, que quier tanto dezir commo cosa de ffortaleza e de ssotileza, todo buelto en vno; ca él es fuerte en 30

1 rreşebien. - 2 por pas. / aduze. -3 e el color faze. -3.5 eran y c. ol. mal e desuianlo t. ende e p. $y$ otras. - $5 T$ otros que ol. / quinta que. 6 morandas (relocado sobre morança, olra mano). - 1o e las / feziesen. - 13 ayre que ou, - $\mathrm{I}_{4}^{4}$ pugnauan. - ${ }_{7} 7$ los ninmos naçien tenienlos descubiertos al ayre. - 26 sacrifiçios. - 37 les $[E 20 v]$ / comunion (comulgaçión escrito y tachado, y comunion añadido sobre la linea, otra mano). -28 el elemento del fuego. - 29 quiere d. t. commo. - 30 toda buelta. 
dos maneras : en partir, destruyendo las cosas que sson vnas; e en ayuntar las departidas. Et por ende el ssu nonbre derecho en griego llámanle piro, que quier dezir quemador; porque la ssu calentura es más ffuerte que las otras en manera que destrúe quemando. Et

5 las gentes que aorauan esle elemento, era tal ssu antoiança que era más noble que estos tres elementos porque era más alto contra los çielos e era muy claro e rresplandiente a marauilloso rresplandor. Et la ssu lunbre alunbraua las cosas oscuras que estauan ascondiv das en tiniebras. Et demás, que era tan clara que ffazía ver al ayre, Io quándo está claro o toruado.

Et éstos sse ayudauan del fluego en ssiete maneras: la primera, calentándose a él quando omue a ffrío; [18r] la ssegunda, coziendo o assando a él lo que queríen comer; la terçera, destruyendo con él lo que querian destruyr ; la quarta, ayuntando con él las cosas 15 que non sse podían ayuntar por otra manera; la quinta, apurando e alinpiando con el las cosas que rreçibian alinpiamiento por ffuego; la ssesta, rreçibiendo dél lunbre en candelas e en otras cosas en el tienpo que conuyene; la ssetena, ssabiendo en quáles cosas yaze por nalura et sabiendo maestrias flazer e engannos para 20 ssacarlo ende quando mester lo auían.

Et por ende aquellos que auyan esta antoiança, quando los ninnos nasçían, pasáuanlos en cruz por las llamas biuas. Et esto era commo en manera de baptismo. Et los que querian que ffuessen a paraíso ante de ssu tienpo, ffazían ffuego de lenna seca e quemáuan25 los en él. Et los ydolos que ffazían eran de tierra cocha commo tinaias a ffigura de omnes que tenían las bocas e los oios abiertos et dentro huecos, e ençendíen ffuego de dentro de cosa que ffazía la llama muy clara e poníenlo de noche en algún logar mucho oscuro, e alli lo viníen onrrar todos. Et a éste llamauan el dios 3o del ffuego, e ellos sse llamauan otrossí ssus ffijos.

Onde este orar de los quatro elementos duró muchos tienpos, fasta que ssopieron los omnes que estas cosas sse corronpien e que

I partir e destr. (-r de partir añadida sobre la línca, otra mano, y la -r original dejada para servir de signo lironiano). - 2 Pero el su. -3 quere. - ¿́ destruye. $-7 T$ rresplandiente mar. - 9 claro que faze veer el ayre. ro e. - 12 quando auien frio. - 13 e/destruyen. -14 querien la. $-15 T$ apartando. - 17 rresçebiendo 1 . del en cand. - 19 yaze ençcrrado por $n$. e s. fazer $m$. e eng. / $T$ et ffaziendo $m$. ffazer. - 22 llamas claras del fuego 0 esto. $-23 \mathrm{E}$ a los. $-24 T$ seco. $-25 T$ era. -26 tinajas o fig. $/$ tienen. 28 lugar muy. -29 aorar. 
otras y auya que sse non podían corronper e que eran más nobles, assí commo el çielo e las estrellas. Et por ende dexaron éstas e tornáronsse âorar a aquéllas.

[Ley XXIII]. - De los que sse aorauan vnos a otros.

Omnes ouo y algunios que vinieron después destos que aoraron 5 los helementos, que cogieron ffantasía en ssí e sse començaron âorar vnos a otros. Et era ssu creençia atal que más valía aorar la cosa biua que ueyen que la otra que non podían uer. Et esto mostrauan ellos por ssiete rrazones. La primera, porque la cosa [18v] biua que auya cuerpo podían veer. La ssegunda, porque la podrían Io tanner con las manos e sentir quál era. La terçera, porque podrían ffablar con ella e oyr lo que les dizía en ffecho de ssus ffaziendas. La quarta, porque rrazonando con ella podrían tomar consseio a las cosas que auyan mester. La quinta, que podrían yr con ella o venir, mouyéndosse de vna parte a otra por do quisiessen. Et 15 todo esto auyan los omnes, e non los elementos. La ssesta, porque sse ssemeiauan vnos a otros en natura e en fforma. La ssetena, porque tenían que más valía onrrar a ssí mismos que non a otra cosa estranna.

Et por esso començaron âorarse vnos a otros, e desto cuydauan 20 sacar ssiete pros: que sseríen por ende más onrrados, más temidos, más orados, más loados, más poderosos ssobre las gentes; que rresçibiríen conorte por ende en todas cosas que auyan rreçebido pesar, ffincándoles rremenbrança de lo que auyan perdido que non podían cobrar; et otrossí, después que muriesen, que ffincaria 25 memoria de los ssus ffechos a los que después viniessen.

Et por esto sse aorauan vnos a otros en tal manera que ssi algún enperador o rrey era bicnjustiçiero en ssu vida, llamáuanle dios de justiçia. Et ssi era otrossí buen cauallero de armas, llamáuanle dios el de las batallas. Et assí commo ssabidor o letrado llamauan 3o dios del ssaber. Et ssi era bucn ffísico, dios de las mediçinas. Et esso mismo ffazien de las mugieres, que ssi alguna era buena e

\footnotetext{
I corronper $\left[\begin{array}{ll}E & 2 / r\end{array}\right] .-2$ estos. -3 aquellos. -5 aorauan. - 7 Era su. 8 podrien. - io podrien veer. - I5 e venir. - I6 elementos porque. 17 vmos con otros. - 21 proes. - 22 mas amados mas loados/gentes e que. -23 Trreçiben / conorte e por ende t. las c. en que. -25 podrien. -27 otras. - 28 buenjustiçiero. - $29-3 \mathrm{r}$ armas dezienle el dios de las b. e sy era omne s. o l. llamauanle el dios del saber.
} 
casta de ssu cuerpo, llamáuanla la deessa de voluntad. Et ssi alegre e de buen talante, dizíenle deessa de amor. Et más, yuan ya desmenuzando ssus creençias que ssi alguno era buen benedor, auya nonbre dios del vino. El ssi algún omne ffallauan [19r] muy

5 luxurioso además, llamáuanle el dios de la cubdiçia. Et ssegunt esto les ffazían ffiestas e comíen e beuyen con ellos e después aoráuanlos. Et esto duró grant tienpo, ffasta que vieron que sse camiauan los coraçones de aquellos dioses. Et aquel que era bueno en vna ssazón tornaua después a sser malo, de guisa que vsaua más Io de ssoberuia e de cobdiçia que de derecho e de franqueza.

Et por ende dexaron de aorar los biuos e aorauan los muertos que murieron sseyendo buenos. Et por rremenbrança dellos frazían ymágines ssegunt ssu ffigura, que aorauan. Et acatáuanlos mucho, assi que ningún omne que matase o ffiziese algút mal e sse acoI5 giesse allí do la ymagen estaua, non le osarían ffazer pesar. Et esto duró muy grant tienpo, ffasta que vieron que non tenía pro, pues que vieron que todo sse auya a destroyr; ca los biuos muríen e los muertos sse desffazíen. $\mathrm{E}$ por ende partiéronsse desta ffantasía.

[LEY XXIY]. - De cómmo el ssonnar ffazia a los omnes caer en grandes yerros.

Sonnar ffazía a los omnes muchas vezes caer en grandes yerros porque tan affincadamiente ssuennan que aquello que veen en ssuennos, tienen que es uerdat. E yendo en pos ellos, han a errar, por lo que veen en dubda, quieren meter por 25 çierto. Et ouo y algunos omnes antigos que ssonnauan que ssubían a los çielos e que veyen los ángeles e que ffablauan con ellos, e que les mostrauan creençias por que podrían connosçer a Dios. Por esso sse tornaron a creer que los cielos eran Dios por la grandeza e por la claridat e por la ffermosura que en ellos 3o veyen. E creyendo en ellos, adoráuanlos e ffazíenles ssacriffiçios de

I Llamauanla d. voluntad (castidat añadido en el margen, otra mano). - 2 talente. - 3-3 yuan avn desm. -4 llamauanle dios. $-4-5 \mathrm{E}[E 21 \%]$ si a. omne f. I. ademas ll. dios de la cobdiçia (luxuria añadido en el margen, otra mano). $\rightarrow 6$ le. -7 este. $-7-8$ camiaron. - 10 derecho que de. - It dexaronlos de. - I 3 ymagenes. - I 4 feziese mal alguno e. $-19-20$ De c. cl suenno f. caer a los o. en grant yerro. -23 veen por suennos / ello. -26 çielos $\theta$ que fabl. -27 podiesen. - 29 e la clar. -30 E creyen en ellos a ad. 
cosas que quemauan e olyen bien, creyendo que aquel ffumo que ssubya allá e que lo rrecibían aquellos spíritus [19v] que estauan en los çielos. Et parando mientes a esto, ffallaron por cuenta, ssegunt les ssemeió, que eran ssiete çielos, e pusieron a cada vno ssu nonbre. Et nonbraion otrossí los ángeles que los guardauan, 5 et dixieron que eran ssiete. Et estudieron muy grant tienpo, ffasta que catando en ellos, vieron que en cada vno de aquellos çielos auya vna estrella. Et cada vna dellas auya ssu mouymiento apartadamiente ssegunt el ssu cielo. Et vieron que aquellas estrellas auyan cuerpos más nobles que los çielos, e por esso tornaron a io creer en ellas.

\section{[Ley XXV]. - De las planetas.}

Planetas pusieron nonbre los ssabios antigos a éstas ssiete estrellas que pussiemos en la ley ante désta. Et teniendo que eran más nobles que los çielos en que andauan, diéronles ssiete noble- i 5 zas por onrra: la primera, nonbres que ffuessen connosçidas e onrradas e nonbradas; la ssegunda, dignidades de ssemnoríos; la terçera, ángeles que las mouyessen e las guardassen; la quarta, çielos apartados por do cada vna andudiesse; la va ${ }^{\mathrm{a}}$, cuento de ssu andamiento, en que ha ssiete términos assí commo anno, mes, 20 ssedmana, día, hora, grado, e punto; la ssesta, que les dieron vertud que dizín que rreçibien de los ángeles de Dios, con que obrassen ssobre las cosas del mundo; la ssetena, apartamiento de obrar ssobre las cosas que estauan apareiadas para rreçebirlo.

Et por esta nobleza e vertud que auyan en ssí, dixieron que $2 \tilde{5}$ auyan poder ssobre ssiete cosas, assí commo ssobre los elementos, - et ssobre las animalias, e ssobre las plantas, e ssobre las mineras, e ssobre los tienpos, e ssobre las edades, e ssobre las vidas. Et ssegunt las obras que ffazíen en cada vna destas cosas, pusiéronles assí nonbre.

I e que olien. -3 en aquellos c. e pararon $m$. a esto e fall. -7 ello / $T$ vno dollos çielos. - 9 veyeron. - I2 $T$ De commo a la luna llamauan los antigos mugier del ssol e por que rrazon la llamauan asi. - 3 nonbres. - 14 posimos $[E 22 r]$ - $-15-16$ dieronles por honrras s. n. la prim. - $16-17$, conoscidas e nonbr. - 17 sennores. - 31 semana. - 2 I-22 sesta cosa que les d. fue virtud. -23 aparejamientos. $-25 T$ nobleza de vertud. $-26 T$ los ssiete el. $-27 T$ planetas. $-27^{-28}$ plantas s. las m. s. los t. s. las he. s. las vidas. -29 las vidas que. 
LEY XXVI]. - De cómmo a la luna llamanan los antigos mugier del ssol, e por qué razón es asi llamada.

Luna, ssegunt de ssuso es dicho, es la primera planeta que está en el primero [20r] çielo más çerca de nos que las otras planetas, 5 que quier tanto dezir commo lunbre maca; porque la lunbre que ha es toda del ssol, e non de ssí, e creçe e mingua ssegunt él enbía los rrayos de la luz ssobrella. Et por ende algunos de los gentiles llamauan a la luna mugier del ssol. Et quando era llena, dizían que era prennada. Et otros llamáuanla ssu ffija. E ffiziéIo ronle anno de ccc e le quatro días e nueve horas menos quinta parte de hora. Et el ssu mes, el vno de treynta días e el otro de veynte e nueue. Et ssu día ssennalado en lunes, e ssus horas la primera e la ochaua deste día. E la ffuerça que auye, dizien que era de rreçebir vertud de las otras planetas e conpartirla ssobre

15 las cosas que sson de ssu cielo ayuso. Et diéronle poder ssobre las aguas, diziendo que las ffazía creçer e menguar, cotrossí ssobre los meollos de todas cosas biuas, e generalmiente ssobre aquellos en que ha vmidat. Et de las mineras diéronle la plata. Et ffazianle ymagen de fforma de duenna assentada en ssu cáthedra con corona 20 en la cabeça commo rreyna, vestida de pannos blancos. Et oráuanla contra parte de ocçidente. Et fiazíanle ssacriffiçios de aues que andan en agua e ssuffumáuanla. Et dáuanle otrossí parte con las otras planetas en aquellas ssiete cosas que de ssuso son dichas en la ley ante désta.

[LEx XXVII]. - De la propriedat que danan a Mercurio.

Mercurio llamauan a la ssegunda planeta, e quier tanto dezir commo cosa conuenible. Et por esto dixisron los antigos que quando sse $[20 \mathrm{v}]$ cataua de buen catamiento con las buenas planetas, era bueno, o quando con las otras, era malo. Et fliziéronle

6 es de la del sol. - 6-7 mengua s. le enbian. - 8 llamauan la. - 9 era priuada del sol o otrosy llam. - II mes es cl nno de t. c. - 12 sennalado es lunes. - $13 T$ y $E$ auyen. - $13-14$ dezien que auie vertud dia en que era de $r$. virtud. - I4 $T$-las. - 15 del su. - 16 o menguar. - 18 dieronle planeta. - 2 I oçidente / sacrifiçios [ $E 22 v]$. - 22 safumauanla / $T$ parte en las. 22-23 las plan. - 26 llamaron / quiere d. tanto. - 27 $\mathrm{T}$ esto d. por el los sabios ant. - $29 T$ buena / $\mathrm{E}$ dieronle. 
anno de trezientos e ssesenta días e quarta. Et ssu propriedat dizían que era de ffazer aprender los ssaberes e las cosas ssotiles e toda cosa que ffuesse ffecha por maestría e por engenio. Et diéronle poder ssobre el ayre, que buelue ayna e ffázel turbiar e esclaresçer, e ssobre la ffabla de los omnes e ssobre las escripturas. Et de las 5 mineras ha el argent biuo e de las piedras. Et ffiziéronle ymagen de forma de omne asentado, e era de plata e de cobre buelto en manera de omne que escriue, et vestido de pannos de muchos colores. Et aoráuanle entre la trasmiontana e poniente, e ffazianle ssacriffiçios de aues que frablan, assí commo gayos e tordos e 10 picaças e otras ssemeiantes déstas. Et dizían otrossí que auya parte con las otras planetas en aquellas ssiete cosas que de ssuso sson dichas en la ssegunda ley ante désta.

\section{[LEY XXVIII]. - Qué quier dezir Venus, e qué propriedades le dauan.}

Venus pusieron nonbre a la otra planeta que está en el terçero çielo, e esto tanto quiere dezir commo amor cobdiçioso. E esta rrazón mostrauan porque dizían que la natura que él auya era mouer los cobdiçiosos amores e de aduzirlos a conplido acabamiento de ssabor. Et ffiziéronle anno de trezientos e ssessenta días e quarla. 20 Et por ende auya parte en los elementos del agua e del ajre. Et la propriedat de toda ssu natura dizían que era ffrida e húmida. $\mathrm{E}$ de las mineras, que auye [21r] el latón amariello e el açil, e de las piedras auye el alióffar. Et la ymagen quel ffazíen era de aquel mismo metal et assí commo donzella que estaua en pie eque teníe 25 en la mano espeio e en la otra peyne, e teníe en la cabeça corona de violetas e vistía pannos dessa misma color. Et oráuanla contra mediodia, e ffazíanle ssacriffiçio de palomas e de tórtolas e de otras aues que cantan bien. Et dáuanle parte otrossí en las ssiete cosas que de ssuso sson dichas en la terçera ley ante désta.

a-3 sotiles e cada c. fuese. - 3 enganno. - 4 que lo b. ayra c lo fazc. - 4-5 $T$ turbiar e escalentar s. la ffabla. - 6 argente / fexieron la ym. $-7 T$ omite forma ... era de. $-9 T$ en la t. pon. - Io fablauan. - 15 dauan los antiguos. - 18 era de comer. - 19 adozirlos $/ T$ entendímiento. - 20 saber / sesenta e çinco dias. - 22 dizen / fria. - 23 amarillo e azul. -25 metal $e$ cra asy / e tenie / $T$ tiene. - 26 espeio e en la magno espeio $e$ en la otra. - 27 vestie. $-27-28$ contra $[E 23 r]$ el med. $-28-29$ palomas e de las $t$. e de las otras. 
[LEY XXIX]. - De las virtutes que dauan al sol.

Sol es la quarta planeta que está en el quarto çielo, que quier tanto dezir commo luz conplida ; ca la ssu natura es de alunbrar todas las cosas e ffazer paresçer la color e la ffaçión dellas. Et a 5 éste llamauan los gentiles padre porque cria todas las cosas. Et aun dizian más, que los omnes non podrian frazer ffijos en ssus mugieres ssinon por la ayuda del ssol. Et esso mismo de las animalias e de las plantas e de todas las otras cosas que nasçen de la tierra. Et dáuanle anno del ssu andamiento de doze meses, e el

Io mes de treynta días, e la ssemana de ssiete, e el ssol día conplido con la noche de veynte e quatro horas, et ssus horas e ssus grados e ssus puntos ssegunt aquesto. Et dáuanle parte con los helẹmentos el ayre e el ffuego mezclado. De las mineras le dauan el oro. De las piedras preçiosas, $[21 v]$ el rrubí e toda piedra buena e clara. E I5 ffazíen la ymagen de oro en ffigura de rrey coronado de piedras preçiosas et estando ssobre vn carro, vestido de pannos de oro. Et oráuanlo contra oriente. Et ffazíanle ssacriffiçio de grandes aues e de bestias assí commo de cauallos e de yeguas. Et dáuanle otrossí parte más flirmemientre que a las otras planetas en las ssiete 20 cosas que sson dichas en la ley quarta ante désta.

[LEY XXX]. - De la planeta Mars e de las propriedades quel danan.

Mars dizen a la otra planeta que está en el quinto çielo, e esto quiere tanto dezir commo amargo ; porque todas las cosas que ffaz sson amaryor de entendimiento amargoso e de ssanna e de ffuerça.

25 Et pusiéronle anno de ochenta e ssiete días. Et ssu propriedat era de destroyr e de esparzer ssangre e de quemar, e por essol dauan el elemento del ffuego. Et de los metales le dauan el ffierro porque ssuffre mucho el ffuego, e de las piedras, las bermeias espessas que non trasluzen. Et ffazíanle ymagen de fferro e teniendo en la mano 30 diestra vua espada e en la otra cabeça de omne colgada por los

2-3 quiere d. t. commo. - 4-5 fayçion d. e este llaman. - 5 porque el criaua. -6 podien. -7 sinon con la. $-8 T$ planetas / narien. - I I su ora. - I3 mesclado e de las $m$. le d. el oro o de. - 14 toda b. p. e clara. - 15 fezieronle ym. / coronado con corona de. - 17 aorauanle / façienle sacrifiçios. I 8 commo c. e yeguas. - ig que las atras. - $23-24$ fas coll amargor. - 36 de desparzir / eso le. -27 de fuego. -28 piedras berm. 


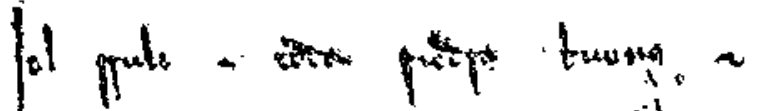

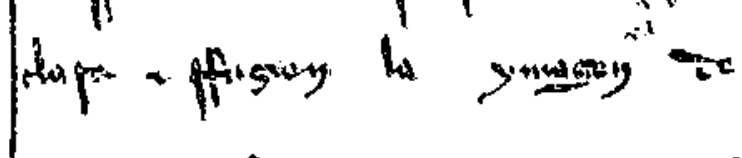

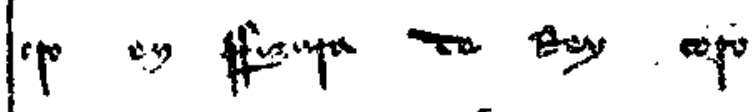

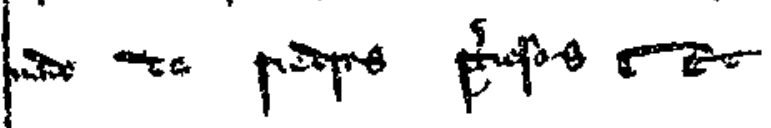

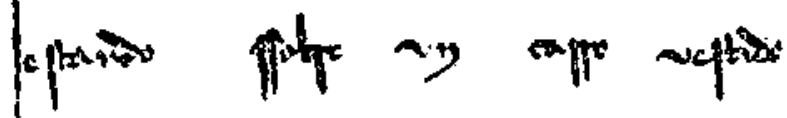
To prot $T$ op

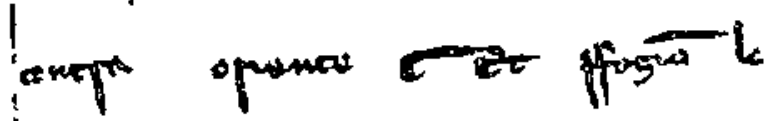

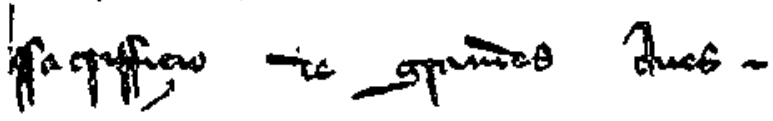

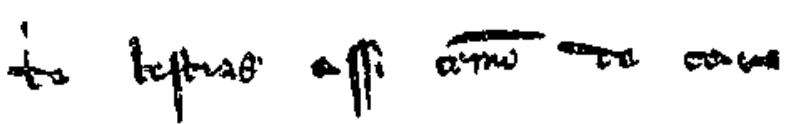

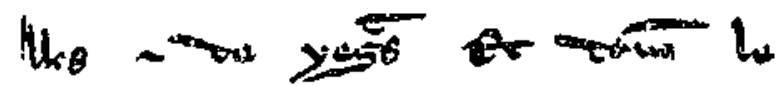

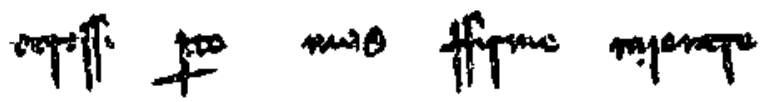

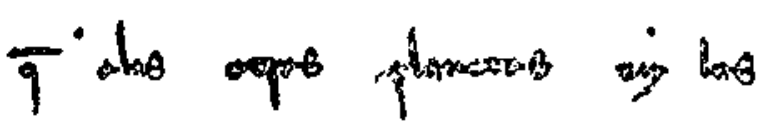

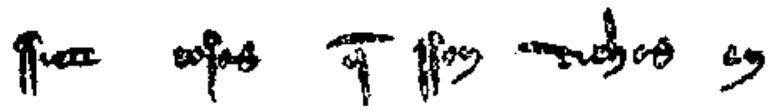

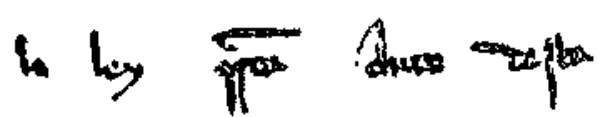

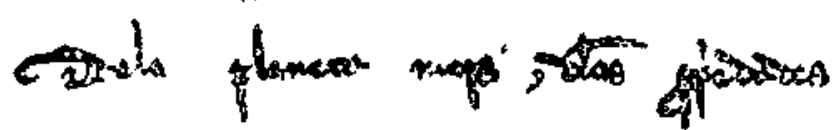
कt tom

app angay de apo po - Tato od dicos

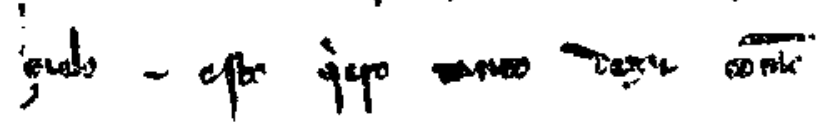

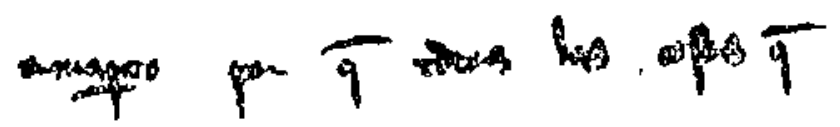

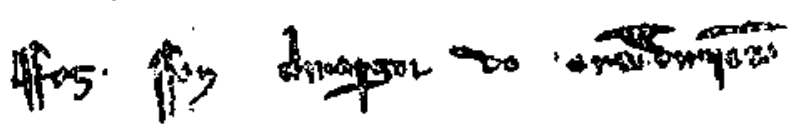

Dinate

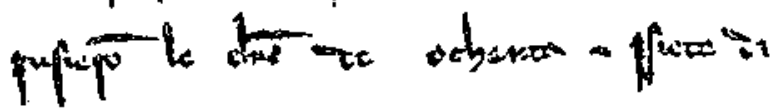

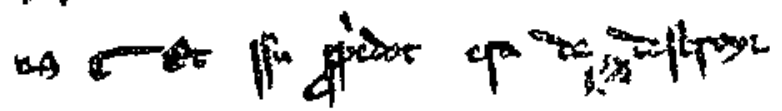

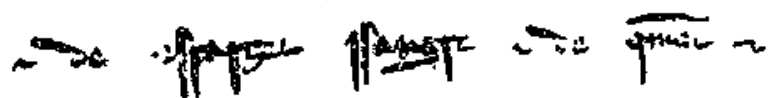

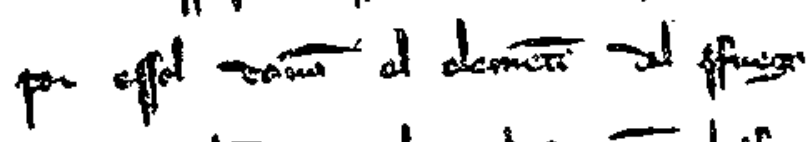

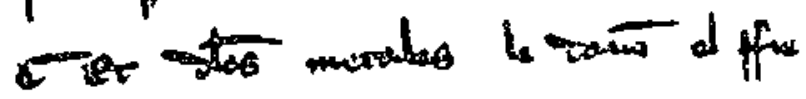

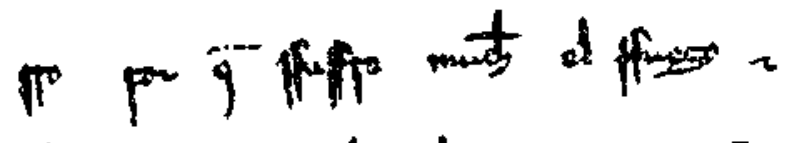

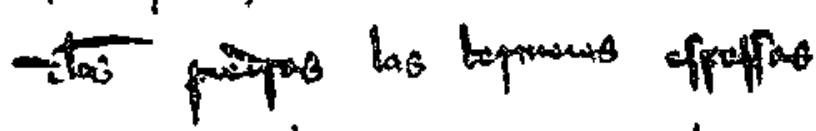

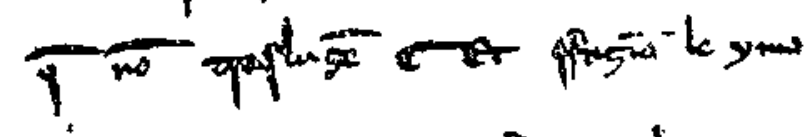

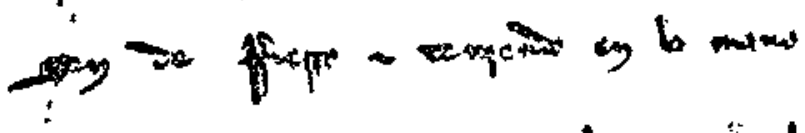

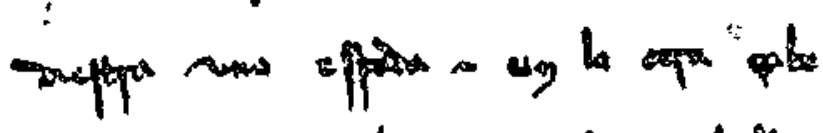

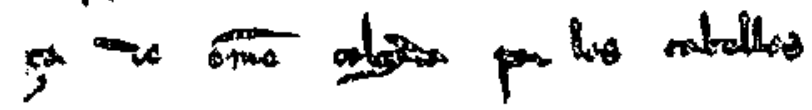

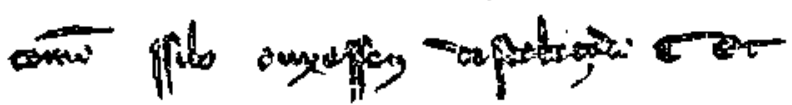

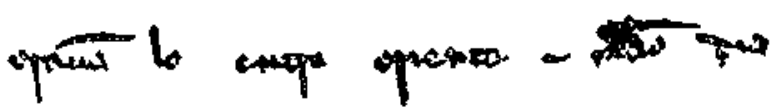

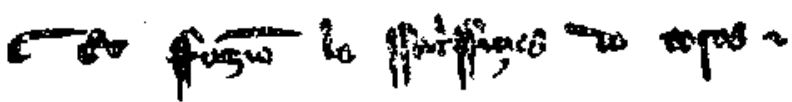

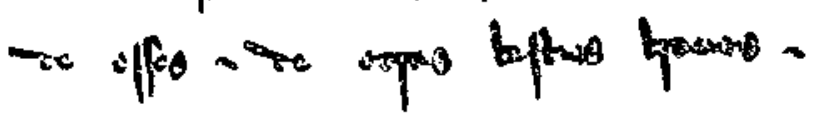

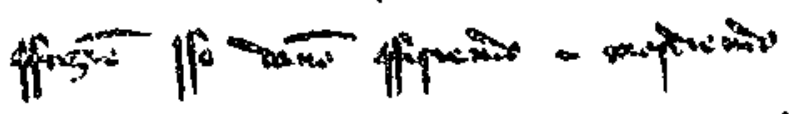

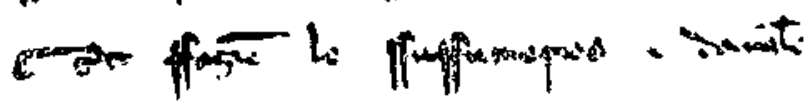

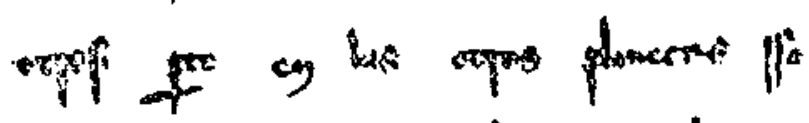

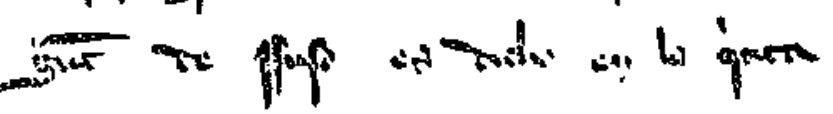
by ding opto

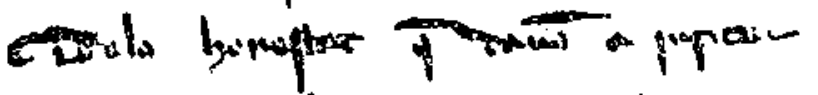

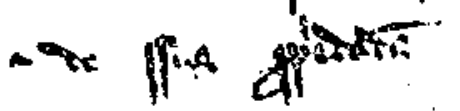

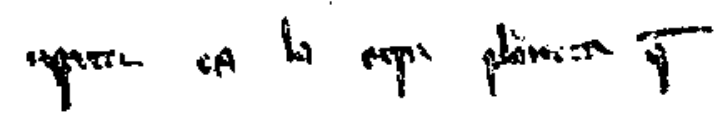


cabellos commo ssi lo ouyesse descabeçado. Et oráuanlo entre oriente e mediodía. Et ffazíanle ssacriffiçios de toros e de ossos e de otras bestias brauas que ffazíensse danno ffiriendo e mordiendo. Et ffazienle ssuffumerios, e dáuanle otrosí parte con las otras pla5 netas ssegunt de ssuso es dicho en la quinta ley ante désta.

\section{[LEY XXXl]. - De la honestat que dauan a Jupiter e de ssus propriedades.}

Jupiter es la otra planela que $[22 r]$ está en el ssesto çielo. Et quier dezir tanto commo honestat; porque todas las cosas que io ffaze sson buenas e honestas e derechas. Et ffazienle anno de honze annos de los del ssol [e] diez meses e quatorze días e medio demás. Et ssu propriedat era de amar paz e justiçia e nobleza e toda bondat, e connosçer e tenerle. Et por essol dauan el elemento del ayre linpio e claro. Et de las mineras le dauan el estanno porque la obra que 15 dél ffazíen era ssin rroydo. Et de las piedras le dauan las çaffires que sson de color cárdeno, assí commo el çielo quando está claro, e otras ssemeianças déstas. Et la ymagen quel ffazien era de aquel metal mismo en ffigura de omne aperssonado, vestido de pannos cárdenos e cauallero ssobre vn eleffante. Et aoráuanle entre oriente 20 e la trasmontana. Et ffazíanle sacriffiçio de bestias blancas e de color rruçio, tan bien de las que sse ssiruyen commo de las brauas, e ffazíenle ssuffumerios. E dáuanle otrossí parte en las ssiete cosas que sson dichas en la ley ssesta ante désta.

\section{[Ley XXXII]. - De la ffortaleza que dauan a Ssaturno.}

25 Saturno es la otra planeta que está en el más alto cielo sseteno, e quier dezir tanto commo tardioso; e porque ssu cursso dél e ssu çielo es muy grande e el ssu andamiento tardinero. Et pusiéronle ssu anno de veynte e nueve annos de los del ssol e [çinco] meses e seys días. Et la ssu propriedat quel danan era pereza e 3o tristeza e duelos. Et dáuanle de los elementos la friura del agua

I la / $T$ ouyessen / - le - $3 \mathrm{~T}$ brauas e $\mathrm{ffaz}_{+} /$feziesen danno [E 23v] feriendo, -4 safumerios $/ T$ parto en las. -9 - 10 cosas son. - Io fezieronle / $T$ mueuc. - J I $T$ ssol a diez; $E$ sol ha dies / catorze / $T$ medio de mes. ... I 2 era amar. - $13 T$ temer / eso le / ayre quando era linpio. - I 7 semejantes / la su y. f. de. -20 sacrifiçios / blancas e rruzias e de. - 2 I rruzio / seruien. - $22 T$-les i safumerios. - 26 tardioso porque. $-28 T$ treynta annos $/ T$ y $E$ quinze. - 3o tristezas. 
e de la tierra. Et de los metales le dauan el plomo porque es negro e huele mal e non ffazen dél color que paresca ffermoso. Et de las piedras, toda piedra dura e negra que non pasa el viso. Et la ssu ymagen era de plomo a fligura de omne vieio seyendo ssobre cátedra, todo desnuyo e enbuelto en manto. Et aoráuanle derecha- 5 miente $[22 v]$ contra la trasmontana, donde viene el frío. Et ffazienle ssacriffiçio de cabrones e de cabras que han cuernos e hunnas ffendidas, e otras bestias ssemeiantes que andan por las pennas e por logares altos. Et ffazienle ssuffumerios, e dáuanle parte con las otras planetas e en las ssiete cosas que sson dichas io en la ssetena ley ante désta.

\section{[LEY XXXIII]. - Por qué rrazón aorauan los antigos al octauo çielo.}

Octano çielo ffallaron por cuenta los ssabios antigos que auya ssobre estos ssiete que auemos dicho, en que están las estrellas i5 menudas que parescen, e a que llamaron çielo ffigurado; porque en él sson, ssegunt ellos dixieron, todas las ffiguras que sson en cl asmadas nin ffechas, en que dizian que auya grant virtud. Et porque este çielo es más alto que los otros, teníen que éra más çerca de Dios. Et por esso començaron âorar aquellas ffiguras de 20 estrellas que en él estauan. Et partieron el çielo en doze partes por allí en derecho do pasaua el ssol. Et en cada vno pusieron esta ffigura a que llamauan ssigno. Et al primero dixieron que era fligura de Aries; et el $\mathrm{ii}^{\circ}$, de Tauro; et al $\mathrm{ii}^{\circ}$, de Gémini ; et al iiii ${ }^{\circ}$, de Cangreio ; et al $\mathrm{v}^{\circ}$, de León; et al vi ${ }^{\circ}$, Virgo; et al vii ${ }^{\circ}, 25$ Libra; et al viii ${ }^{\circ}$, Scorpio; et al $\mathrm{ix}^{\circ}$, Ssagitario; et al $\mathrm{x}^{\circ}$, Capricornio; et al $\mathrm{xi}^{\circ}$, Aquario; et al $\mathrm{xii}^{\circ}$, Pisçis. Et por más ayna llegar a ssaber la virtud que auyen, partieron estos xii ssignos a los quatro elementos. Et dieron a cada vn elemento tres.

3 todas piedras duras e negras / pesa. - 5 manta. -7 cabras e han. -8 fendidas $\left[\begin{array}{ll}E & 24 r\end{array}\right]$ / semcjautes destas que. -9 por los lug. / afumerios. - I la ley. - I3 $T$ ssigno. - 15 estauan. - 16 menudas en que paresçien e aquel 11. f. afigurado, - 18 dezia. - I9 por ende este c. que es. - 22 posieron vna. -33 el prim. - $\$\{-27$ Tauro e el terçero de Gimini el quarto de Carnero el quinto de L. el sesto V. el setirno L. el otauo Escorpion el noueno S. el dezimo Capiconio el onzeno Acario el dozeno Dicis. - 27-28 E por Il. uas ayna a saber. -29 vno. 
[LeY XXXIV]. - Del departimiento de los ssignos.

Et aun ffizieron más, que los ssignos mismos partieron en tres partes para saber, quando el ssol passase por ellos, qué obras ffazíen acá al mundo. Et otras fliguras de estrellas que auje, vnas de

5 parte de mediodía e otras, que çierto nonbraron a cada vna ssegunt que eran affiguradas. $\mathbf{E}$ syn estas que eran afiguradas, aùy y otras que non auyan ffiguras de commo tomauan entendimiento cómmo sse podrían ffigurar, assi commo las que han nonbre Cabesça de Dragón e Cola. Mas a estos ssignos non les dauan annos assenna-

o lados, nin mes, nin ssemana, nin día, nin hora, nin puntos, nin grados, así commo las olras han. Ante partíen estos ssignos por ellas, dando a cada vna planeta dos, ffueras que dieron a la luna e al ssol ssennos. Et el ssigno que [23r] dieron a la luna por ssu casa es [Cangreio]. Et los dos ssignos que dieron al Mercurio sson

15 Gémeni e Virgo. Et los que dieron a Venus, Tauro e Libra. Et el que dieron al ssol es Leo. Et los que dieron a Mars, Aries e Escorpio. Et los que dieron a Jupiter, Ssagitario e Pisçis. Los que dieron a Ssaturno, Capricornio e Aquario.

Pero a los xii ssignos frazían ssacrifflçios ssegunt la natura;

20 que oraua cada vno a ssu ssigno. Los que aorauan a Aries flazían ssacriffiçios de carneros e de oueias. Et los que orauan a Tauro f́lazían ssacriffiçios de toros e de vacas. Los que orauan a Gémeni fazían ssacriffiçios de ximios e de maymones e de las animalias que nasçen clos en vno, quier ffuessen omnes, quier otra cosa. Los 25 que orauan a Cancro ffazían ssacriffiçios de cangrejos e de todas las conchas que sson en la mar. Et los que orauan a León ffazían ssacrifficios del mismo ssi lo pudiesen auer; ssi non, de las bestias branas que muerden e rrascan. Et los que orauan al ssigno de Virgo ffazien ssacrifficio de aue ffenbra e las primeras ffijas que

3-4 fazic aca en el mundo. - $4-5$ auie y mas de partes. -5 nonbraron scgunt. - $6 \mathrm{~T}$ omite $\mathrm{E} \ldots$ afiguradas. -8 los que. - 9-1o sennalados. - to $T$ hora nin cuentos. - I commo a las o. planetas ante. - i2 $T$ ellos. - I2-r3 dieron al sol e a la l. semnos. - 3 T ssennas. - 14 T y $E$ Carnoro / dos $[E$ $240]$ / a Marc. - 15 Gemini / Los que. - 16 sol Leo. - 16-17 Escorpion. I8 Saturnio/Acario. - ig fezieron. - 20 aoranan cada vno a su s. los que aorauan (todo menos la primera palabra escrito sobre raspado). - 2 I Los que.-22 Gemiui. - 23 gimios (ximios añadido en el margen, olra mano). $-24 \mathrm{dos}$ juntas en. - 36 Los que. $-27 \mathrm{syl}$ pod. - $28 T$ muerde / Los que aorauan cl signo. - 29 femina e los primeros fijos. 
nasçian. Los que orauan a Libra ffazían ssacrifficios de perdizes e de las aues que buelan derecho e ffazen muchos ffijos. Los que orauan a Escorpio ffazían ssacriffiçios del mismo ssi le podían auer; ssi non, de otras bestias venenosas. Los que orauan a Ssagitario ffazían ssacrifficios de potros pequennos e de yegüezuelas 5 quando nasçíen. Los que orauan a Capricornio ffazien ssacrifficio de cabritos e de enodios. Los que orauan a Aquario ffazien correr la ssangre de lo que degollauan ssobre las aguas. Los que orauan a Pisçis ffazíen ssacrifiçio de los pescados que matauan. Los que orauan a Cabesça de Dragón ffazian ssacriffiçio de aquellas cosas ro mismas que a Jupiter porque dezíen que essa misma propriedat auya que él. Los que orauan la Cola ffazían ssacriffiçio de aquellas cosas mismas que a Mars porque dizían que era daquella [23v] conplessión misma que él.

Onde en todas estas maneras que auemos dichas andauan los 15 omnes errados, buscando a Dios e queriéndol connoscer. Et commo quier que él es en todo, porque non auyan entendimiento derecho de connosçerle verdaderamientre, llegando por connosçençia verdadera al lugar o él era, por esso cayen todos en estos yerros. Mas Dios, que ffizo el mundo de nimigaia, non porque él lo 20 ouyese mester, mas por mostrar a ssus crialuras quamanno era el ssu poder e el su saber e la ssu buena voluntad, quísosse descobrir al mundo e alunbrar los coraçones que eran ciegos en tiniebras de entendimiento e de sseso. Et quiso otrossí que entendiesen e connosçiessen quién era él en ssí e qué obras ffazía e podía frazer, 25 et a qué tenía pro lo que él auya obrado e que obraua e que quería obrar adelante, ssegunt mostraremos agora. Et non tan ssola. mientre por la ley vieia nin por los dichos de los ssabios e de las prophetas, mas aun ssegunt natura de los ciclos e de las otras cosas spirituales, queremos prouar que la nuestra ssanta Ffe es ley dere- 30 cha e crençia verdadera, e non otra ninguna gue fluesse desde el comienco del mundo nin sserá ffecha flasta la flin.

I perdiçcs. - 3 Escorpion / $\mathrm{syl}$ pod, - 5 yeguas. - $6 \mathrm{~T}$ oraua / sacrifiçios. -7 aorauan Acario. - 9 sacrifiçios. $-11 T$ dizen. -14 conplision. - 16 Dios quer. - i 8 conosçer verd. - ig $T$ a llegar o/do/.cayen en t. estos. - 20 mundo [E 25r] de ninguna cosa non que. - 21 quantmanno. - $22 T$ poder e la ssu buena. - 26 obrado e obr. e queric. - 3o nuestra Fee. - 3a sera fasta, Después de ffin comiensa la primera laguna en $T$, saplida por $E$. 
[Lex XXXV]. - De eómmo Nuestro Sennor Dios non puede ser conoş̧ido por estas setas que son dichas, mas por la ley biaa e verdadera de Ihesa Cristo.

Todas estas antojanças e setas e opiniones que auemos dicho en 5 la ley ante désta, e otras maneras que non podríen ser contadas, fazíen a los omnes errar, e non sabíen connosçer a Dios nin creyen en él commo deuíen. E por eso yuan trabajando en las cosas e mudándose de vno en otro asy commo los ciegos que non veen por dó pongan los pies firmemente e van catando dó los pornán.

io E fazíen otrosy commo los otros que se van mudando de vnas cosas en otras, e non fallando firmeza ninguna con mengua de seso. Ca tanto era grande el su desentendimiento, e veyendo los çielos e las otras cosas tan marauillosas e estrannas que rion podíe otro fazer synon Dios, que dexaron de creer en el fazedor e creyen en

15 las fechuras. E yuan aorar las cosas que se mudauan e se desfazien e dexauan de orar a aquel que non se muda nin puede ser desfecho. E desta guisa se arredrauan de la verdad e allegáuanse a la mentira, [non] parando mientes de cómmo él non era cosa que se podiese connosçer nin por creencia vana, nin por antojança, 20 nin por seta, nin por opinión, nin por fantasya, nin por suenno, nin por bisión; mas por ley biua e verdadera, fecha e hordenada de Dios Padre por el su querer e por el su poder e por su sabe:.

E ésta es creençia e la fee e la ley derecha de [ $E 25 v]$ Nuestro Sennor Thesu Gristo, que non fué tomada de los elementos, que 25 se dannan, mezclándose vnos con otros, nin los siete çielos, do estauan las planetas que han sus mouimienlos a vezes delante, a vezes atrús, nin del otauo çielo, que es figurado de estrellas menudas, segunt auemos dicho; mas fué tomada del nono, que es sobre todos los otros, segunt dixeron los filósofos e los sabios anti3o guos. E mostraron por su saber que aquél era lugar e morança de Dios; porque aquel çielo non se mouíe e fazíe mover todos los otros, as y commo Dios non se mueue e fas mouer todas las cosas de nada. E él non fué fecho e mantiénelas e non puede ser mantenido de otri, e guárdalas cada vna en su estado e él non ha menes35 ter guarda de ninguno. E éste ha en sy siete cosas : la primera es seer, ca él fué sienpre e es e será; que es todo spiritu noble e conplido, donde nacen todos los otros; que es tan claro que ninguna 
cosa non le puede veer; que es linpiedunbre conplida, en que ninguna cosa non puede prender nin allegarse a él que sea suzia; que es todo bueno en sy e fas sienpre bien; que es en todo e non ha lugar sennalado; que non puede ser medido nin cabopreso por fecho nin por forma. E esto es la virtud del nońo çielo, que está 5 quedo e non se mueue, e que non podíen entender los locos nin los desentendidos, a que llamamos el poder del Padre.

[Ley XXXVI]. - De cómmo Dios Padre fizo por amor de Ihesu Cristo su fijo los çielos e la tierra.

Saber de Dios se entiende por Jhesu Cristo su fiio ; ca por amor ro dél sopo fazer çielos e tierra e fizo los omnes por quel conosçiesen por las sus obras quél auie fechas. E en bos de Jhesu Cristo su fijo, commo que fablase con él quando fizo Adam, dixo : Fagamos omne a nuestra ymagen e a nuestra semejança. E la ymajen puso por el Fiio e la semejança por sy mesmo, que quiere dezir tanto : 15 Aya el omne nuestro entendimiento para entender todas las cosas. E por ende Ihesu Cristo fué la virtud que se mouíe del Padre, que está quedo. Mas el Fiio convino que se mouiese por [ $E$ 26r] conplir voluntad del Padre en siete maneras : fincando la deydad dél conplida en el çielo, e desçendió la vertud della en tierra; tomando 20 carne en Santa María, en qui fué Dios e omne; sabiendo fazer vida de omne naturalmente syn miedo e sin pecado, andando entre los omnes naturalmente, faziendo miraglos de Dios sobre natura; fué otrosy grant mouimiento cómmo llegar la deydad de Dios en auer miedo commo omne segunt la carne; o morir naturalmente 25 commo omne e rresuçitar spiritualmente commo Dios ; e desçender a los infiernos commo omne e quebrantar el poder dellos commo Dios; sobir a los çielos donde descendiera a seer con el Padre vna cosa commo de primero. E por ende este mouimiento del Fiio salió de la virtud del Padre, que non se moúe.

\section{[Lex XXXVII]. - Qué cosa es Spiritu Santo.}

Spíritu Santo es llamada la obra que salie del Padre, que se non mouíe, e del Fijo, que se ono de mouer. E esto quiere tanto dezir commo amor que ha entrellos, que sale de amos a dos. $\mathbf{E}$ maguer que se ayan a nonbrar tres segunt cuento natural, non es 35 
más de vno segunt ayuntamiento spiritual. E a este Spíritu Santo dieron siete propiedades. Amor; que él lo mete entre Dios e los omnes. Ca segunt canta Santa Iglesia rrogando, que venga el Santi Spíritus e ayunte los coraçones de los sus fieles e enciéndalos del

5 su amor. E entendimiento; que él faze entender a los desentendidos que aprendan las lenguas que non aprisieron nin entendieron, segunt dixo Dauid el profecta: El spíritu de Dios finchó el mundo de todos los saberes e de todos los lenguajes. Sotileza; ca él va a todos los Iugares, segunt dixo Nuestro Sennor Jhesu Cristo, que ro el Spíritu Santo doquiere espiraua, e la bos dél oyen nin sabíen dónde venie nin dónde yua. Acordança es ; que él acuerda a los desacordados, segunt dixeron los sabios, que el spíritu del amor de Dios acordaua sienpre en lo mejor todos los sentidos que se mueuen por el spiritu de Dios. Sabidoría; que él sabe todas las

15 cosas en todos los tienpos e hordena sienpre lo meior, galardonando los bienes e escarmentando $[E 26 v]$ los males, segunt dixeron los prefetas, que el spíritu bueno de Dios galardonaua los bienes e abondaua todas las cosas de bien, e con el spíritu fuertê justiçiero de su boca mataua los males. E conorte da otrosy muy 20 grande; que faze a los omnes ser conortados quando grant mal o grandes tribulaçiones les vienen, segunt dixo el rrey Dauid quando erraua en alguna cosa contra Dios, que el spíritu aduríe ele meteríe en carrera derecha para que saliese de yerro. Fortaleza es muy grande cosa; ca segunt dixo Ysayas el profecta, el Spíritu

25 Santo [da] fortaleza que esfuerça los coraçones flacos e los fuertes tiénelos en su estado que non enflaquezcan.

Onde, porque los antiguos que cuydauan ser sabidores de los cuentos de los çielos e de los mouimientos dellos non pararon mientes al noueno çielo, que es el Padre, nin el mouimiento dél, 3o que es el Fijo, nin la obra que sale de amos, que es el Spívitu Santo, erraron en non conosçer a Dios nin creer en él commo deuíen. Mas la venida de lhesu Cristo, fiio de Dios, nos fizo entender todas estas poridades e nos dió dello ley çierta e verdadera en que crehemos e nos saluásemos, non tan solamente nos

35 que la creemos, mas todos aquellos que la quisieren creer.

E nos rrey don Alfonso, que este libro fezimos conponer porque entendimos que la voluntad de nuestro padre era en esta creencia que en otra cosa, e entendiendo otrosy que es esto verdad e

25 Santo de f. que es fuerça de los cor. 
derecho, que otra ley non ha nin puede ser verdad synon esto, rrogamos e conseiamos e mandamos, non tan solamente a los de nuestro sennorío, mas a todos los otros que nos quisieren creer, que esta ley tengan e obedescan, e non otra. E eso mesmo dezimos a los otros que las otras creençias creen ; ca entendemos que por $\overline{5}$ aquí serán quitos de pecảdo e ganarán amor de Dios. Ca sé çiertamente que sy bien se arrepentieren, serán perdonados del yerro quel fezieron.

\section{[Lex XXXVIII]. - Qué cosa es Santa Eglesia e por qué} la llaman asy.

Santa Iglesia es llamada el ayuntamiento de los fieles [E 27r] de Dios que creen la fee de lhesu Cristo su fiio, e en esta Iglesia ha dos poderes : vno, spiritual ; e otro, tenporal. El spiritual llaman en latín Trihunphant, que quiere dezir en nuestro lenguaje tanto commo vençedor, e éste es parayso del otro mundo en que los $x 5$ buenos verán a Dios e connosçerán asy derechamente cómmo es. E verán otrosy la corte çelestial de los sus sanlos, que meresçieron auer aquel bien por siete bondades que ouo en ellos: que fueron de buen entendimiento; que creyeron la bondad; que ouieron esperança que avríen por el amor de Dios por que lo ellos fazíen; 20 que esperando aquello que cobdiçiauan ber, sufrieron todo el mal que les podieron fazer el mundo e el diablo; que acabaron su vida en sufrençia e en esperança; que después de su muerte, por el trabaio que sufrieron los cuerpos, ganaron las almas folgança; onde que vençiendo las voluntades, vencieron al diablo e al mundo, 25 por que los llaman Iglesia Vençedor.

\section{[Ley XXXIX]. - De la segunda manera a que llaman Eglesia.}

Segunda manera de la Iglesia es la deste mundo, donde se ayuntan los fieles de Dios e lidian por la Fee con siete maneras de henemigos : contra sus voluntades; contra sus malas obras; con- 30 tra los henemigos del diablo; contra conseios de omnes malos; contra los sabores del mundo; contra las aduersidades de los tienpos; contra temor de la muerte. $\mathbf{E}$ porque sienpre está en guerra, llámanla Iglesia Militant, que quiere dezir lidiador ; por- 
que sienpre está guerreando contra aquellas cosas e hordenando cómmo guerree. Onde los santos omnes que fueron esta Iglesia, veyendo que el cliablo e el mundo non se podíen vençer por otra cosa tan ayna commo por la fee de Nuestro Sennor Ihesu Cristo,

5 seyendo mostrada e entendida e guardada commo deue, armáronse de siete maneras de armas: de creençia en las voluntades; de rrazón en sus palabras; de buen hordenamiento en sus posturas; de buenas obras en sus fechos; de buena esperança para acabar lo que quieren ; de granl sufrencia para vençer ; sabiendo las mane-

ro ras de vençer. Ga éstos vençen cada día los siete henemigos que dixiemos, de que solían ser vençidos ante que la nuestra ley $\left[\begin{array}{lll}E & 27 v\end{array}\right]$ fuese.

Onde esta Iglesia Vencedor, por mostrar meior las armas con que queríen vençer, hordenó e establesçió la creençia de Dios segunt 15 se deuíe entender en catorze artículos. $\mathrm{E}$ los siete dellos fablan sobre la diuinidad de Dios Padre. E los siete sobre la humanidad se mostrará adelante.

\section{[Ley XL]. - De los articolos de la Fe.}

Articulos quiere dexir tanto commo artejos, e palabra es en latín so e quiere dezir cosa que se tiene en vno, pero que se manda e se mueue en dos maneras: la vna, cada artejo por sy; la otra, todos en vno. E esto se muestra en la mano e en el braço, en que ha siete partes que se mueuen. Los çinco son los dedos por la mano. La sesta es la mano fasta el codo. E la setena es del cobdo 25 fasta el onbro. Ca por la mano se muestra el poder de Dios, asy [commo] dixeron los encantadores al rrey Pharaón quando Moysén mostraua por el poder de Dios los miraglos que mostró en Egipto. E ellos quisieron fazer otro tal e non podieron. E preguntóles Pharaón que por qué non lo fazíen, e ellos rrespondieron que la mano 3o de Dios feziera aquello. E por ende muestran los artejos con la mano por la virtud de Dios; e el braço por la fuerça del poder, que es tan grande que ninguno non podríe saberlo, segunt dixo Ysayas profecta : Senor, ¿quién podrá creer lo que nos oymos, e el braço del tu poder a quién será mostrado? Demás, quien bien

35 [parare] mientes fallará en la mano catorze aricjos que cada vno es más luengo que ella, pero cada vna mano e el braço e ellos fazen vna fuerça. E por ende la virtud del poder de los sacramentos,

ro esto. - $34-35$ Demas a quien bien fallare mientes. - 36 braco e ella. 
commo quier que sean departidos, vn poder e vna virtud han.

E segunt hordenamiento de Santa Iglesia que fezieron los apóstolos, son siete artículos que muestran que Ihesu Cristo, segunt la deydad del Padre, es Dios en sy mesmo; e los otros syete, segunt la humanidad de la carne, que es omne verdadero. Los de Ja dey- 5 dad son éstos: que es vn solo Dios e non más; que es Padre poderoso ; que crió los cielos e la tierra e todas las cosas que en ella son; que Ihesu Cristo es su fijo; cómmo el Spíritu Santo sale de amos a dos; cómmo [ $E$ 28r] fizo e bordenó la Santa Iglesia católica, en que se ayuntan los omnes con los santos por rremisión ro que ganan de sus pecados; cómmo rresucitarán todos en cuerpos e en almas, e avrán los buenos bien por sienpre e los malos mal, cada vno segunt su meresçimiento.

Los otros siete artículos que pertenesçen a la humanidad de la carne de Nuestro Sennor Ihesu Gristo : cómmo fué conçebido de i5 Spíritu Santo en el cuerpo de Santa María ; que rresçebió pasión e fué muerto; e soterrado e rresuçitado; que desçendió a los infiernos; que rresucitó dende a terçero día de muerte a vida; que subió a los çielos e está a la diestra parte de Dios Padre; que verná en fin del mundo a judgar biuos e muertos.

Onde conviene que todo cristiano pugne en saber bien estos catorze artículos; que sy bien los sopiere, fallará la creencia verdadera derechamente la fee católica de Nuestro Sennor Ihesu Gristo.

[LEY XLI]. - Quáles son llamados apóstoles.

Apóstolos son llamados aquellos que andudieron con Nuestro Sennor Thesu Gristo e vieron los sus fechos e los fezieron saber por todo el mundo. E este nonbre ganaron ellos por siete rrazones. Por rrazón de la mandadería a que yuan, de que ganaron el nonbre; ca tanto quiere dezir apóstolos commo mandaderos. E 30 porque fueron enbiados con verdat; ca los enbió Nuestro Sennor Ihesu Gristo, que lo era en sy conplidamente, con palabras çiertas e verdaderas, segunt él mesmo dixo: Yo so carrera de verdad e de vida. Ca la enbiada fué sobre mandadería de cosa cierta que convenie en todas guisas que se feziese; que asy commo Ihesu 35 Cristo veniera a saluar el mundo el tolliera el poder del diablo, que era muy poderoso entonçe por maldad de desconosçençia de los omnes, dándoles ley nueva e verdadera, asy que conosçiesen e 
sopiesen esto mostrar e feziesen entender a todas las gentes de la tierra cómmo biniera. Porque fué mandaderia conplida en todas las cosas, segunt buena mandadería deua ser; tal les dió poder que quanto ligasen en tierra fuese ligado en los çielos,

5 e quanto asoluiesen que fuese asuelto. $[E 28 v] \mathrm{E}$ demás, dióles Spíritu Santo por abogado que los lenguajes que non entendiesen nin sabien fablar, que ge los feziese entender e saber. Que fué la mandadería leal ; que aquellas cosas a que los enbiaua eran derechas e leales para toller los males e adozir el bien segunt Dios e

ro segunt bondad. E demás, mostró lealmente que se fiaua en ellos quando les dixo que non les querie dezir sieruos, ca el sieruo non sabíe qué fazíe el sennor; mas que los llamaríe amigos, ca todas las cosas que oyera a su padre mostraua a ellos. E avn dixo en otro lugar que aquéllos eran fieles sieruos e cuerdos que puso el

r5 Sennor sobre su conpanna. Onde la mandadería era leal e viene de lealtad, e liéuanla ellos que eran conplidos de bondad. E que yuan con mucha honrra de la mandadería, commo para destroyr el diablo e ganar el mundo, segunt las profetas dixeron: Mucho son honrrados los tus amigos, Dios, e mucho es confirma20 do el sennorio dellos. Que fuera la mandadería mucho prouechosa ; ca mayor prouecho en el mundo non podíe ser que ganar omne amor de Dios e beuir omne en este mundo bien e honrradamente para ser tenido por bueno, e parayso en el otro, que es folgança conplida. E esto ganaron los apóstoles, sabiendo ser buenos man25 daderos e rrecabdar bien la mandadería con que los enbiaron vnos en pos otros hordenadamente.

E porque dixo cada vno dellos pocas palabras e çiertas en cómmo creen, posiéronle nonbre sínbolo, que quiere dezir tanto commo bocado. E en estos dichos caboposieron toda la Fee, $3 o$ mostrando [el] fecho de Dios [en] siete maneras: las tres, en cómmo es Padre e Fiio e Spíritu Santo; la quarta, de sus obras que fizo marauillosas; de las quatro, desçendiendo del çielo a la tierra, seyendo Dios, e fazerse omne; beuiendo en la tierra commo omne e commo Dins; muriendo commo omne e rresucitando

35 commo Dios, desçendiendo a los infiernos, que es la más baja cosa que puede ser, e subiendo a los çielos, que es lo más alto. Onde estas siete maneras de que fablaron los apóstoles se encierran

7 fezicsen. - 30 mostrando en f. de Dios es sicte. -34 Dios o mur. - 37 En encierran termina la primera lagana en $T$. 
[24i] en el Credo in Denm, que deue todo cristiano ssaber. Et de cómmo los apóstolos lo dixieron ordenadamiente es assi.

[LEY XLII]. - De las palabras que dixieron los apóstolos en cómmo creyen.

Sant Pedro dixo: Creo en Dios Padre poderoso, criador del 5 çielo e de la tierra; Ssant Iohán dixo: En Ihesu Cristo, ssu ffijo vno, que es Nuestro Ssennor; Ssant Yago, ffijo del Zebedeo, dixo: Que es concebido de Spíritu Ssanto e naçió de Santa María virgen; Ssant Andrés dixo: Que rreçibió passión en poder de Ponçio Pilato e ffué crucifficado e muerto e ssoterrado; Ssant Ffelipe ro dixo: E descendió a los inffiernos; Ssant Thomás dixo: Al terçer día rresuçitó de entre los muertos; Ssant Bartolomé dixo: E ssubió a los cielos e ssee a la diestra parte de Dios Padre e poderoso ssobre todas las cosas; Ssant Matheos dixo: Verná dende judgar los biuos e los muertos; Ssant Yago Alpheo dixo: Creo en 15 el Spíritu Ssanto; Ssant Ssimón dixo: En la Ssanta Eglesia cathólica e ayuntamiento de los ssantos; et Judas Jacobi dixo: E rremissión de los peccados; et Ssant Mathías dixo : Rresuçitamiento de la carne e vida perdurable por ssienpre.

Onde estas palabras conprehenden dos cosas que conuyene que 20 ssepa todo aquel que quiere sser cristiano conplido: la vna, cómmo ha de crescer en cristiandat e de creer; la otra, cómmo ha de obrar. Ca por la crençia llega a connosçer a Dios, et por la buena obra a ganar su amor.

[LEY XLHI]. - De cómmo los que aorauan la tierra, a Santa 25 Maria querian aorar ssi bien lo entendiesen.

Doze ffueron los apóstolos, segunt que de ssuso oyestes, de qui rrecibiestes la mandadería de Thesu Cristo en cómmo autemos a creer e a obrar. El por esta mandadería entendemos que las cren-

2 le / asy [ $\left[\begin{array}{ll}E & 29 r\end{array}\right]$. -5 Dios todo pod. $-6 \mathrm{E}$ en. $-7-8$ Santiago $f$. del Z. que es. - I I Santo T. d. en el terçero. - I3 Dios su Padre. - I4 Matheo. - I $4-15$ dende a judgar. - I5 Santiago el Alfeo. - 16 Ximon d. e en. - I7-1 8 santos Judas $J$. d. c rredenpcion de los pecadores Sant $M$. d. e rres. - 31 quisiere ser conpl. c. la. - 22 T commo deue creer / creer e la. - 23 E por. - 27-28 segunt de s. oystes de que rresçcbistes. - 29 e obrar. 
çias que los otros creyen, de que ffablamos en las leyes ante désta, non eran çiertas porque las non entendíen los omnes así commo deuyen. Mas eran a ssemeiança desta ssanta ley que Dios auye a dar en el mundo. Ca los que aorauan a la tierra queríen tanto 5 mostrar commo que orassen a Ssanta María; ca ella ouo en si siete cosas a ssemeiança de la tierra.

Que fué más baxa en sser homillosa que otra mugier, assí commo sse muestra por las palabras que dixo al Ángel; que allí ol dixo que ssería bienauenturada entre todas las mugieres porque

Io ssería madre del rrey del çielo e de la tierra, alli rrespondió ella que era ssu ssierua e que ffiziese della lo que quisiese ssegunt ssu uoluntad. Et ffué sseca e enxuta de todo peccado, ssegunt dixo Ssalamón, que ffué rrey e propheta, por Spíritu Ssanto en boz de Dios: Toda eres fermosa, la mi amiga, e ninguna manziella non . 15 ha en ti. Que obró en [24v] ella el Spíritu Ssanto e la labró por que diesse buen ffructo, ssegunt dixo el Ángel mismo: El Spíritu Ssanto verná en ti e la uertud de Dios te cobrirá. Et esto sse entiende por tres rrazones que ffazían en la tierra leuar buen fructo: la vna, labrarla; la otra, estercolarla; la terçera, rregarla.

20 Labrarla ffué apartamiento que flizo el Spíritu Santo en el cuerpo della en que descendiese Ihesu Gristo para sser omne e Dios. Et el estercolamiento ffué la vida lazrada que ffizo en este mundo e la crúa muerte que ssuffrió por nos, en que ffué despreçiado e desechado, bien assí commo el estiércol que desecha omne de ssu 25 casa, ssegunt dixo el prophela Dauid : Yo so gusano e non omne, denuesto de los omnes e desechamiento de las gentes. Ca bien commo el estiércol ffaze podreçer el grano de trigo, que ssi non podreciesse non leuaria ffructo, bien assi Nuestro Ssennor Ihesu Gristo non pudiera llegar âquella onrra que deuye ssi ante non

30 passasse por aquel pudrimiento de todos los males e de las penas quel ffizieron, ssegunt él mismo dixo, que quanto el grano de trigo ssouyese en tierra e non sse dannasse, que non leuaría ffructo;

I $T$ creyen que / $T$ la ley, $E$ las leys. - 2 porque non las ent. -3 que auie Dios a. -7 baja. $-8-9$ el Angel que alli donde le dio que. - io alli le rresp. - 12 Que fue $[E 29 v]$. -15 ay / $T$ Ssanto arbol por, $-19 T$ labrala / labrarla est. / $T$ estercolala. - 20 Labrar fue aparejaniento. - 21-22 para o. e Dios el est. - 22 que lleuo. -23 cruel. - 24 estercol. - 25 so el gus. - 27 del trigo. -28 lleuaric. - 29 lleuar. - 30 e bas. - 3 1-32 quando el g. del t. se somiese en lierra. 
mas a la ora que ffuese muerto, que sse entendíe por dannado, que leuarie mucho ffructo. La terçera, rregar, que non se podia ffazer ssin agua, muestra la virginidat de Ssanta María, que ouo ante que ffuese prennada e en sseyéndolo; e después que parió, ffincó más clara e más linpia que agua. Et con esta agua ffué 5 rregada la lauor que flizo el Spíritu Ssanto en ella, por que esta tierra leuó buen ffructo en el tienpo que conuyníe. La quarta, que dió buen ffructo en el tienpo que deuye. Et esto ffué quando nasçió Ihesu Gristo; que era perdido el mundo por desconnosçençia. Et esto sse proeua por dos rrazones: la vna, por los malos ffechos 10 que y ffazíen; la otra, que los prophetas e otros santos omnes le pidíen a Dios que abaxase los çielos e les enbiase su ffijo, que les auya a ssaluar. Et otros dizíen que por la ssu uoluntad rronpería los çielos e uemíe. La quinta, que nos dió ffructo ffermoso ; que ouo en ssí todas las ffermosuras que sser podíen : la primera, i5 de Dios, que ssobra todas las cosas; la ssegunda, ffermosura de omne lo más que puede sser, ssegunt el propheta Dauid dixo: Ffermoso de fforma ssobre todos los ffijos de los omnes. La sesta, que nos dió ffructo ssabroso; ca assí commo el ffructo sabroso e bueno ssabe bien a los que an gusto conplido e çierto, assí lo que 20 Nuestro Ssennor Ihesu Cristo ffizo e dixo ssopo bien a todos los omnes buenos e entendidos. Et este ssabor ffué en dos maneras : la vna, en obra ; la otra, en palabra. En obra ffué quando ssanó los enffermos e los peccadores, ssegunt dizen los Euangelios, que la uertud ssalie dél para ssanar los enffermos. Et Dauid el propheta otrosí 25 dixo que ssana los quebrantados de coraçón, que sse entiende por los peccadores. E ata los ssus quebrantamientos, tolliéndoles los peccados, ssegunt él mismo dixo quandol preguntaron los judíos, que ninguno non podíe perdonar los pecados [25r] ssinon Dios solo. Et díxoles él que quál era mayor cosa, de perdonar los $3 o$ peccados o dezir al contrecho: Leuántate e anda. Et en esto les dió a entender que lo podría ffazer todo; que tan ligero le era lo

I fue. - I-2 entiende por d. leu. - 2 rregar lo que / puede. -4 aunque/seyendolo despues. - $6 \mathrm{~T}$ rregada et la / ella e por. - io esto proeua. - I 1 fazien e la / las prof. / lo. - I2 pedicron a Dios deziendo que abajase. - 12-ז3 que les (rotura en $T$, lección de $E$ ). - 13-14 rronpien. 14 dio [E 30r]. - 15 podrien. - r6 sobre. - if la mas que pueda. - $18 T$ tercera. - 19-20 dio $\mathbf{f}$. fermoso ca asy c. el $\mathbf{f}$. sabe a los que han gosto. 2 I $T$ Thesu ffizo / Cristo d. e f. sopo. $-23 \mathrm{E}$ en. $-25 \mathrm{E} \mathrm{D.} \mathrm{prof.}-26$ Jos pecadores quebr. $-27 T$ Atar los -28 quando $/ T$ judio. -30 el qual. -33 que el lo podia / $T$ ligera. 
vno commo lo al. Et Jas palabras otrossí ffueron muy ffermosas e muy ssabrosas; que lo que él dixo non ffué al ssinon mostrarnos cómmo ganásemos el rregno de los çielos e nos guardássemos de ffazer cosas por que ou yésemos de yr a las penas del inffierno. Et 5 más, que nunca ffablaua ssinon dando buen conseio e buen castigo e buen ensienplo por que deuan los omnes dexar el mal e ffazer el bien. Et esto sse proeua por lo que dixo Dauid el propheta por Ihesu Cristo: Es esparzida la graçia de bien ffablar en los tus labios, e por esso te bendixo Dios para ssienpre. La vii", que nos Io dió grant pro; ca el pan ssanto que nos rreçebimos que es el ssu cuerpo, comiendo cadal día por ssacriffiçio, et el vino que beuemos es la ssu ssangre, que nos aprouecha de guisa que nos abonda en este mundo por que podamos bien beuir e ganar el otro que dura ssienpre, ssegunt dixo el propheta Dauid: Ssaque pan de la

I 5 tierra - que sse entiende por el cuerpo de Nuestro Ssennor Ihesu Cristo, que ssacó de Ssanta María - et el vino alegra el coraçón de los omnes - que sse entiende por la ssangre de Ihesu Cristo, que nos dará alegría por ssienpre en parayso.

[Ley XLIV]. - De cómmo los que aoraulan el helemento del agua, erâ ssemeiança del baptismo.

El elemento del agua orauan otrossí los omnes por las rrazones que dixiemos de ssuso en las otras leyes. Et esto era a ssemeiante del baptismo que auye de sser, en que ay ssiete naturas ssegunt agua : de lauar; e de esffriar; de ffazer enterneçer las cosas duras; $2 \overline{5}$ e de gouernar; de esclareçer el viso; de alçar las cosas liuianas arriba; de desçender a lo más baxo.

Et todas estas ssiete ha en el baptismo muy conplidamiente. Ga non tuelle las manziellas de los peccados nueuos, mas los vieios en que nos auemos culpa, assí commo el que ffizo Adam por con-

I-2 lo otro e las p. fueron o. muy sabr. ca lo. -4 ouiesemos a yr. -5 fabla. -6 deuien. - 7-8 Dauid por I. C. esp. es la graçia. - 9 labrios. I0-I I santo su cuerpo es que nos r. com. por s. de cada dia e el vino. - 12 la sangre. - 13 otro rreyno que. - 14 diso D. p. que saque. - 16 Cristo e de / $T$ allegra (retocado sobre allega). - 18 parayso $[E 30 v]$. - $\mathbf{1 9 - 2 0}$ De los que a. el elimento del agua era a s. del agua del baut. - 22 leys e esto a sem. - 23 en que ha. $-23-24$ segunt el a. de 1 . de esfr. $-24-35$ duras de gou, -26 arriba e desc. / baio. -27 ha el. -28 non lauando las. 
seio del diablo e de Eua su mugier. Et esto sse proeua por los prophetas que dixieron: Lauatuos e sset linpios, e tollet toda ssuziedat del mal penssamiento de uuestros coraçones. La ssegunda natura, que es de esffriar, a el baptismo; ca él tuelle la sset e esffría los peccados de la uoluntad de la carne, que fazen al omne 5 peccar en muchas maneras, ssegunt dixieron los prophetas: Los que anedes sset, wenit a las aguas. La terçera, el baptismo que ffaz enterneçer las cosas duras; ca él amolleçe los peccados que tienen los omnes endureçidos en los coraçones e ffaz que ssean tiernos, rrepintiéndose e ffaziendo dellos penitençias, ssegunt dixo. La ro quarta, gouyerna mucho el baptismo; que el que bien cree en Dios, él le rresçibe e le ffaze [25v] auer abondo de todas las cosas que sson en la creençia, segunt dixo. La quinta, da claridat a los oios del coraçón del peccador; ca le ffaze uer claramiente, connosçiendo a Dios e amándol e temiéndol, ssegunt Nuestro Ssennor i 5 dixo al que naçiera ciego quando lo sanó : Vé, láuate en la nadadera de Siloé. La ssesta, que alça las cosas liuianas arriba, esto muestra por los peccadores, que sson liuianos de voluntad e para peccar ayna enbueltos en mallat. Et yazen assí commo las paias que están enbueltas en el poluo de la tierra, mas la fiuerça del 20 baptismo ffazles alçar los coraçones a Dios e partir del poluo de los peccados que ffizieron, ssegunt dixo. La vii ${ }^{a}$, assí commo el agua descende a lo más baxo et lieua allá toda la ffuerça, assí el baptismo, quien bien le guarda, decende a los inffiernos con grant ffuerça de la vertud de Dios; que los çierra que ninguno non 25 puede y entrar, ssegunt dixieron los philósophos, que el agua non pasa adelante fasta que ssean enchidos todos los forados que ffalla, menudos e granados. Et assí el baptismo çierra e tuelle los peccados granados e pequennos.

Onde este baptismo del agua rrecibió Ihesu Cristo en el ssu 3o cuerpo, et mandó que quantos creyessen en él que lo rreçibiessen. Et commo quier que él non lo onyese mester, non auyendo ssuziedat ningeuna en ssí, rrecibiólo; ca él era agua biua, ssegunt

I e de la su. - 1-2 E omite Et ... dixieron. - 3 de mal. - 3-4 segunda de. -5 faze. -7 bautismo faze. -8 amolesçe. - ro arrepentiendose. $/$ penitençia. - I I ca. - I2 $T$ Dios el le fraze / las otras cosas. - $13 T$ creençia la. -14 pecado. - $15 T$ Dio/ Dios am. - 16-17 $T$ omite al que ... Siloe. - I 8 voluntad para. - 2 I partirse. -23 desçiende / lieua [E31 r] ella. 24 bien lo g. desçiende (lo añadido sobre la línea). -27 fenchidos. -28 tuelle todos los. - 29 grandes. - 3o-3 I d cuerpo. - 33 -la. 
dixo a la ssamaritana, que si ssopiesse quién exa aquel con quien ffablaua, que ella le pidríe merçet e le daríe agua biua.

[Le X XV]. - De los que aorauan el elemento del ayre, ssinifficaua a la linpia vida que ffizo Nuestro Ssennor Ihesa Cristo en este mundo.

Ya oystes de ssuso cómmo algunos y ouo que aoraron el elemento del ayre. Et esto ffué a ssignifficança de la linpia vida e ssanta que ffizo Nuestro Ssennor Ihesu Cristo en este mundo, en que auya ssemeiança. E non auyendo entendimiento, oraron ellos Io aquello; ca assí commo el ayre bueno fazíe ssiete obras buenas que daua vida; que esclareçe las cosas ; que ffaz que paresca cada vna de ssu color; que les da ssalut a los que sson enflermos; que guarda en ella los que la an; que non dexa ningún logar uazío; que tuelle los malos baffos que sse leuantan de la tierra -, assí

I5 la vida de Thesu Cristo nos ffizo bien en ssiete maneras semeiantes déstas.

La primera, que es el ayre que da la vida e mantiene el spiritu de la natura natural, otrossi Nuestro Ssennor Ihesu Cristo fraze beuir los buenos por ssantidat; los que estauan en peccado, que 20 rrecibiesen penitençia, partiéndosse dello. Et mostró carrera por do ffuésemos a la vida que non ha ffin. La ii ${ }^{a}$, así commo el ayre linpio esclareçe las cosas, assí Nuestro Ssennor Thesu Gristo esclareçe los coraçones de los omnes por las buenas palabras e por buenas obras. La terçera, assí commo el ayre claro ffaz paresçer 25 las cosas cada vna de quál color es, assí la claridat de la nobleza de lhesu Cristo. La quarta, que assí commo el ayre linpio [26r] ffaze ssanar los cuerpos enffermos, assí la uertud de Nuestro Ssennor Ihesu Cristo sana los que enferman naturalmiente en los cuerpos, otrosí spiritualmiente en las almas. La quinta, que assí 30 commo el ayre tiene e guarda las cosas ssanas en ssu ssaluo e non las dexa enffermar, assí Nuestro Sennor Ihesu Cristo guardaua los

I $T$ que ssop. / supiese. - 2 pedirie m. e el lo. -3 senifica. $-4-5$ fizo Hhesu. - 6 aorauan. - 8-9 Cristo en que auia s. non lo entendiendo. - I I $T$ dauan / esclarescie. - I I-I $2 T$ paresca toda via de. - I/4 bahos. - I 7 que el es el ayre. - 19 beuir los muertos por s. e los. - 3 a ver la vida. - 22-23 esclaresçio. - 25 de su color. -26 quarta [E 31v]. 26-27 $T$ lin faze. -28 cnferma. -30 en salud c. -31 asy el N. S. J. C. g. a los. 
que ssanaua, tan bien de cuerpos commo de almas, que non fiziessen yerros por que cayesen en otro mal. La ssesta, assí commo el ayre non dexa ningún logar uazío, assí la uoluntad de Nuestro Ssennor lhesu Cristo non quiso que ffuese ningún coraçón uazío del ssu amor, que todos non le ouiesen, pero los que 5 por bondat lo meresçiesen auer. La ssetena, así commo el ayre tuelle e desata los malos baffos que se leuantan de la tierra, et esto faze mayormiente quando sale el sol, así la nenida de Ihesu Cristo, que flué ayre linpio en todo e sol de justiçia, desató todas las crençias uanas que en el mundo auye ante que él viniese; ca ro las tollió del todo o la major parte, faziéndoles entender ante que non era nada.

\section{[LEY XLVI]. - De las conparaçiones que ha el ffuego al Spiritu Santo.}

Dicho auemos en las leyes ante désta de cómmo auja vnas gen- 15 tes que aorauan el elemento del ffuego. E esto era a semeiança del Spíritu Santo, que deuien aorar; que así commo el ffuego que ha siete cosas que son naturales - que alunbra ; que escalienta; que ayunta; que destruye; et que fraze ssemciança de ffigura; et que sse lieua de vn logar en otro; et que ssienpre se mueue mien- 20 tre arde - , así el Spírito Santo alunbra los coraçones de los omnes, ffaziéndoles conosçer Dios, e ueyéndol por crençia. Los coraçones que sson esffriados por peccado, escaliéntalos en amor de Dios. E ayunta las uoluntades departidas que ssean vnas en la ffe de Jhesu Gristo. Et destruye el poder del diablo e los malos pen- 25 samientos en las obras que vsan los omnes por conseio dél, así commo el ffuego destruye las cosas liuyanas e secas. Et así commo el ffuego ffaze ffiguras que mueren e que salen arriba, muestra en las llamas commo lenguas agudas ; así el alunbramiento del Spíritu Ssanto muestra en los coraçones de los que lo rreçiben todos 30 los saberes e las Ienguas que sopieron los apóstoles e los otros

3 otro tal. -3 suzio. -5 lo / $T$ oyesen. -7 baos. $-9 T$ todo sol. I0-II ca o las tollo de todo. - 13-14́ fuego commo son conparadas al Spir. I5̃ $T$ y $E$ la lcy. - 15-10 $T$ gentes el elem, - 17-18 fuego ha. - i9 ayunta e que destr. - 20 lugar a olro. - 20-2 I mientra. - 21 Espiritu. - 3 i-23 coraçones que faziendolos con. a Dios e veyendole por c. c los. -23 esfriados en pec. - $25 T$ las malas. $-25-26$ pensamientos e las. $-25-28 E$ omite déstruje ... ffuego. -28 mueren que. -29 llamas $[E 32 r] .-30$ le. 
ssantos. Et bien commo el ffuego lieuan de vn logar a otro para ayudarse dél, asi ua el Spíritu Ssanto a los logares que conuyene, ssegunt ffazíen los apóstolos; que non tan ssolamiente lo traen ellos e eran abondados dél, mas aun ffazíanlo venir e descender 5 ssobre los otros en qui ponían las manos. Et bien así commo el ffuego cada que sse ençiende e arde ssienpre es nueuo, otrosí la graçia del Spíritu Santo ssienpre rrenueua e rreffresca los coraçones de los omnes.

[Lex XLVII]. - De cómmo los que aorauan los vii çielos, flué a 1o ssemeiança de los vii monimientos que ffizo Nuestro Ssennor Ihesu Cristo e de los vii dones que dió Dios a ssus amigos.

Celestiales llamauan los otros omnes que orauan los vii çielos. E esto auyan porque todo su entendimiento era de sser ssaluos por esta crençia, e tiraua a [26v] ssemeiança de los vii dones que I5 da Dios a los ssus amigos : saber; entendimiento ; seso; ffortaleza ; conseio; piadat; et temor de Dios. Et éstos sson los que dize Ssant Iohán apóstol e euangelista con que obra Dios ssobre todo el mundo; ca bien así commo los vii çielos dizen los antigos, e dizíen, que eran spíritus que sse mouyen por la uertud del çielo 20 que está quedo e es mouedor, otrossí estos vii dones sse mueuen por la uertud de Dios Padre que puso en Ihesu Cristo ssu ffijo, que mueue todas las cosas a lo meior. Onde los que en estos çielos orauan, era a ssemeiança de la vertud de Dios Padre, que non sse muene, e de Jhesu Cristo ssu ffijo, que se mouyó por mandado 25 dél, e por el Spíritu Santo, que ssalíe de amos a dos. Et la muestra de los vii çielos mostraua los vii mouimientos que ffizo Nuestro Ssennor Ihesu Cristo, assí commo de ssuiso es dicho.

I lieuan los omnes de. -3 lo creyen. - 5 magnos. $-7.8 T$ ssienpre los r. e los rreffr, con amisión de los c. de los omnes. - 9 aorauan a los. - i I Dios Padre a. - I 2 llaman. - I3 porque su. - 15 - 6 saber de e. de $s$. de f. de c. de p. de temor. -16 dis. - i 8 - ig antiguos que eran. - 22 los que los cielos. - - 3 eran / la trinidat. - 2' que se movie. - 26 çielos era otrosy a semcjança de los siete mou. 
[LEY XLVIII]. - De cómmo los que aorallan a la luna, a Ssanta María querien aorar ssi lo entendiessen.

Estrelleros llamauan a aquellos que dizíen que conosçien las estrellas e las aorauan, et ssennaladamiente las vii planetas. Onde los aoradores de la luna frazíanla ymaien a figura de mugier ves- $\mathbf{5}$ tida de pannos blancos, que mostraua esto que auya a sser. Et esto era a ssignifficança de Ssanta María que nunca ffué corronpida, que es ssemejada a la luna en vii maneras.

La primera, por virginidat; que assí commo la luna es virgen e non sse danna nin sse corronpe, assí la virginidat de Santa María io nunca ffué corronpida de peccado. La segunda, assí commo la Luna rreçibe la lunbre del ssol e alunbra el mundo con ella, otrosí Ssanta María rreçibió e rreçibe cada día la vertud de Dios e alunbra con ella los coraçones de los peccadores que están en tiniebras; que flué virgen que aduxo lunbre de Dios, que era Ihesu Cristo, i5 en que alunbró todo el mundo. La terçera, que assí commo la luna es más çerca de nos que las otras estrellas, assỉ Ssanta María es más çerca de los peccadores e de los cuytados que los otros ssantos para oyrlos e para acorrerlos, seyendo anogada entre Dios e ellos. La iiii, que la luna tira la ffuerça de los çielos e de las 20 estrellas e la aduze a nos, así commo los sabios dizen ; assí Ssanta Maria ha en ssí todas las ffuerças e ssantidades que ouyeron todos los otros ssantos. Et demás, ouo la Trinidat encerrada en ella. Et con todo eso nos ayuda e nos enbía la ssu graçia. Et ésta sse puede llamar bien con derecho mugier del ssol ; ca con Dios ovo ayunta- 25 miento e ffué prenada de Spíritu Ssanto e parió a lhesu Cristo ssu ffijo, que es sol de justiçia que escalienta los buenos con galardón et ffaz arder los malos con pena, ssegunt dixo Dauid el propheta: En el ssol puso ssu tienda - que sse entiende por Ssanta María - e él ssalió della assí commo esposo que ssale de sso tála- 30 mo. La quinta en que ssemeia a la luna, que es assí commo la lunbre de la luna apareçe vna uegada más e otra menos, ssegunt

2 entendieran. - 3 llaman aq. que dizen. - 4 aorauan senaladamente e las / Onde [E 32v]. - $6 T$ pennas blancas/anie de ser. $-7-8$ corronpida de pecado que es a semejança de la luna. - 14 tiniebra. - i6 con que alunbra a todo (a añadido en el margen, otra mano). - 16-I $T$ commo es. - 20 La quarta que asy commo los sabios dizen que la 1 . t. fuerça. - 2 I nos asy Santa. $-22-23$ onieron los. -23 demas de aquello ono. $-24-25 \mathrm{E}$ este se p, bien 11. con der. - 28-29 Dauid prof. - 33 luna que paresce. 
la lunbre del ssol que enbia Dios en ella, $[2 \%$ otrossí Ssanta María muestra en ssus miraglos e ssus merçedes de la uertud que rreçibe dél, ssegunt él entiende que lo nos mereçemos. La viّa, que assí commo a la luna dauan vertud en las onbras que los om-

5 nes frazian en la tierra para coger frulos della con que sse mantonyesen, otrossí Ssanta María ayuda a los que bien obran de manera que en este mundo ayan abondo de las cosas tenporales e en el otro que coian el ffructo de las spirituales, que es auer paraíso. La viï es que assí commo dauan poder a la luna en las ro aguas e en los omnes que andan ssobrellas, assi Ssanta María ha poder de acorrer a las tribulaçiones que sson en este mundo, que sson commo las aguas que sse bueluen e creçen e ffazen danno; et otrossí aquellos que andan en tormenta ssobrellas e en peligro de peccados de muerte.

I5 Onde el poder que dauan a la luna con las otras planetas ssobre los elementos e ssobre las animalias e sobre las plantas e ssobre las mineras e sobre los tienpos e ssobre las edades e ssobre las vidas, por derecho e por razón lo ha Santa María; que el día que ella ffué madre de Dios, ouo poder sobre todas las cosas que él flizo, 20 tan bien en el çielo commo en la tierra.

\section{[Ler XLIX]. - De cómmo sse muestra que los que aoranan a Mercurio, que a Thesu Cristo lo deuyeran ffazer.}

Escriuano affigurauan a Mercurio los antigos quel aorauan, E ffazíanle ymagren uestido de muchas colores, commo qui tenie 25 pargamino e tinta e escriuye. Et lo que ffazían vestidura a la ssu ymagen de muchas colores sse entiende por la grant justiçia de Ihesu Cristo, que muestra a cada vno lo que ha de auer ssegunt la color que pareçe en sus obras e en ssus fechos. Onde el poder que dauan a Mercurio con las otras planetas, a Jhesu Cristo lo douye30 ran dar; ca él las ffizo e por onrra dél flueron ffechas. Et a sse-

$3 \mathrm{~T}$ el entendimiento que. $-4 \mathrm{~T}$ commo la l. daua / obras que los [ $E 33 r$ ]. - $5 T$ ffazian della. $-5-6 T$ mantonyese. -8 los frutos $/ T$ los spir. 9 La selima que. - 12 fazen e dannan. - $15 \mathrm{E}$ el / $T$ daua. - $16-x_{7} T$ animalias e s. las min. - 18 rrazon. - 19 poder (rotura en $T$, lección de $E$ ). 22 Mercurio a. - 33 figurauan. - 24 vestida de muchos. -25 paregamino. - 39-3o devieran dar que. - 3 o $T$ ffizo por o. e del. 
meiança de Ihesu Cristo, que ffué escriuano uerdadero ; ca el su ssaber escriue todas las cosas.

Et por ende ouo en ssí ssabiduría en vii maneras. La primera, del tienpo que era pasado. La ir $^{a}$, en el que estaua. La terçera, del que auya de uenir. La quarta, que es libro de la vida en que 5 son escriptos los que biuen con Dios en cuerpos e en almas, ssegunt Ssant Iohán apóstol e euangelista dixo en el Apocalipsi, que el cordero de Dios que tenía en ssu mano vn libro sellado de dentro e de ffuera con ssiete sseellos que ninguno de quantos estauan en el çielo nin en tierra non lo osauan abrir ssinon el cordero to ssolo que era muerto, que sse entendíe por lhesu Cristo, que murió por nos. La $v^{a}$, que por el Spíritu Santo que él ssopo e enbió en el mundo, que les flizo ssaber e entender todos los saberes e los lenguaies. La ssesta es que el sso ssaber es tan grande [27v] que cunple e sse estiende por todo e da a cada cosa entendimiento e 15 sabiduría de lo que deue entender e ssaber. La viï, que lo que él flaze que sepan, que es ssin grant lazeria en que non ha mester de estudiar nin trabaiar por ello. Onde esto que dixieron los antigos por Mercurio, por Nuestro Ssennor lo quisieran dezir ssi sopiessen.

[Ler L]. - De cómmo se mnestra que las uertudes e las amiztades que dalan a la planela Venus ssus aoradores, a la piadal de Dios la deuyeran dar.

Amorosa dizíen los gentiles que era la terçera planeta, a que llaman Venus. E porque ha nonbre fleminino, por esso le ffazían 25 ffigura de duenna ffermosa. Et esto sse entiende por grant piadat de Dios que ouo contra nos en ssiete maneras: que nos ffizo de ninguna cosa ; que nos dió fforma ssegunt ssu ssemeiança; que él tomó la nuestra carne e ffué omne; e murió por nos; que nos

a escrivie. -5 es el libro. $-8 \mathrm{f}$ ssennalado. $-y^{-10}$ ninguno non cra en c., nin en $t$. nin lo osana a. synon $[E 33 v]$. - I i entiende. - r 20 cl enbio. - 13 los fizo. - $1 \frac{1}{4}$ sesta que el su. - 15 se entiende. - 6 e fazer. - $17 E$ lazeria (afan añadido en el margen, otra mano). -18 nin de trab. - 20 supiesen. - $21 T$ muestra las uert. / amistades. - $24 T$ eran. 25 femenino. - 29 touo (tomo añalido en el margen, otra mano) / nuestra e fue o. que murio. 
ssacó de poder del diablo; que nos dará ffolgança e plazer para ssienpre; que morará connusco e sseremos herederos en el ssu rregno o sson los ssus ssantos.

La ffigura quel dauan de donzella que teníe en la cabeça corona 5 de violetas e tenía en la vna mano vn espeio e en la otra peynde, ésta es la piadat de Dios; que veyendo los que la han mester, acórrelos con ella e láualos e péynalos commo el peynde ffaze los cabellos, poniendo entre nos paz e amor. Et los pannos de color de violete que ssemeian ssanguino, que sse entiende por el ssu ro cuerpo, que flué todo cubierto de ssangre por el martirio quel dieron ante quel pusiessen en la cruz e estando en ella después que ffué cruçifficado, et la corona quel pusieron en la cabeça de espinas, con que ge la ssangrentaron toda. Et por ende todas las vertudes e las amiztades que dieron a Uenus, a la piadat de Dios I5 las deuyeran dar: ca en él yazen más que omne non puede asmar.

[LEx LI]. - De cómmo errauan los que orauan el ssol, cuydando que la nobleza que él anye en ssí era de ssuyo, e non entendien cómmo lo auya de Dios.

Nobleza grande tenían los antigos que auya el ssol más que 20 en las olras planetas. Et por essol aorauan e le ffazían mayor onrra : ca dizían que toda la lunbre del mundo dél viníe. E quanto en esto dizían verdat, mas en lo al neciedat los fazía errar ; ca non connosçíen que la lunbre que el sol auye le viníe de Dios. Ca él es luz conplida que alunbra a todos, et esto en siete maneras: que 25 es luz clara; e rresplandeçiente; que es ssotil; ayuntada; fermosa; temerosa ; ssabrosa.

La claridat es tan grande de Dios que pasa todas las claridades,

I del poder / por. - 2 conusco. -3 do. -5 violetas e on la vna m. esp. 5-6 pende (peyne añadido en el margen, otra mano) e esta. $-7 T$ acorrerlos / $T$ peynaualos / el peyne f. a los. -8 metiendo. -9 violetas (-s añadida sobre la línea, otra mano) que es sang. se ent. - I I-1 a ella cruç. - $12 T$ et en la cor. - I2-13 corona de esp. qucl p. en la c. con que. - 13-14 todas virt. $14 E$ amiztades (-miztades subrayado y -mores añadido en el margen, otra mano) / dalian. - 5 T yaze; $E$ yazen (con la letra i escrita $\gamma$ tachada después de z) / onne podie. - 16 al sol. - 17 suyo $\left[\begin{array}{ll}E^{*} & 34 \mathrm{r}\end{array}\right]$. -18 commo era de. $-20 T$ por el ssol; $E$ por eso la / $T$ añade le sabre la línea; $E$ lo omite. -22 neçedad les. $-{ }_{2} 3$ conosçie. -25 es c. lux e r. solil. $-{ }_{27}$ La c. de Dios es tan g. que. 
sseguat dixieron Ssant Pedro e Ssant Yago e Sant Iohán de cómmol vieran trasfligurar e que rresplandeçíe su cara commo el ssol. Ga los ssus rrayos echa ssobre el ssol e ssobre las otras estrellas e las ffaze rre[28r]lozir; ca ellas non han lunbre ssinon la que él les enbía, que rreçiben de Dios. Sotil es su claridat; ca por todo 5 pasa por los çielos e por las estrellas e por todos los elementos, e llega fasta en la tierra et alunbra los oios de los omnes por uer las cosas tenporales e las uoluntades dellas. Ayuntada es la claridat de Dios en ssí ; ca maguer esclareçe en muchos de logares, pero ella vna es en ssí. Ca bien así commo Dios non sse podíe partir, yo assí ella non puede sser partida. Ffermosa es más que cosa que pueda sser ; ca ésta esclareçe e da color e ffermosura a todas las otras cosas. Temerosa es mucho; ca pues los omnes han uergüença de catar la claridat del ssol, quanto más la de Dios, onde la ha el ssol. Et por ende los oios mortales non la pueden uer en este r 5 mundo, ssinon en el otro, ssegunt él mismo dixo: Non me uerá omne que bitua. Sabrosa es la claridat de Dios mucho; ca aquellos que la rreçiben en este mundo por entendimiento et an aun grant ssabor della que flarán los otros que la rreçiben veyéndola por los oios en el otro ssieglo, ssegunl dixo Ssant Paulo apóstol, que 20 aquel ssabor que tenía Dios apareiado para los que él ama, que oios non lo uerán nin oreias non lo oyrán nin coraçón de omne non lo podríe caber.

Et por ende lo que ffazían al ssol ffigura de rrey coronado vestido de pannos de oro muy rricos, a Dios Padre lo deuyeran 25 ffazer, cuyo él es, ssegunt Ihesu Cristo ssu ffijo dixo: Aquél es Dios Padre que ffaze el ssol nasçer ssobre los buenos e ssobre los malos. E las uestiduras preciadas eran que él es uestido de onrra e de nobleza que non ha ffin. Et el poder que dauan al ssol ssobre las vii cosas que sson dichas, a Dios lo deuyeran ffazer, 3o que non a el que era ssu ffechura.

I Santiago e sennor Sant / commo le (le añadido en el margen, otra mano). - 4 que ellas / lo. - 8-9 dellas obran para las spirituales ayuntada es la c. toda en sy, - $9 T$ esclareçen. - 10 puede. - Ir-12 $T$ cosa pueda. - I 2 ca ella. - 13 Ternorosa. - I 4 de la clar. / mas a la / donde. - I 7 Saborosa es m. la c. de Dios ca. - 18 entendimien to han grand. - 20-21 otro segunt Sant P. a. d. que aquel sabe que. - 21 los que cl alma (el tachado y le aman añadido en el margen, ambos de otra mano). - 22 oios non v. nin.o. non los oyran. - 25 pannos dorados muy. -27 sol salir e $n$. sobre [E 34v]. -28 era que. -29 honrra de. 
[LEY LII]. - De cómmo sse muestra que el poder que auya Mars para destruyr ssu ffechura e en ffazer mal, ouo Ihesu Cristo en ffazer bien.

Fortaleza dauan los antigos a la planeta Mars e poder de des5 truyr los enemigos. Et esto era a semeiança de Ihesu Cristo por ssiete rrazones. En el nonbre, que es dicho Mars, quiere dezir commo amargo más que otro omne e la muerte que rreçibió él más crúa e más penada. Ffortaleza; ca él fué fuerte en ssoffrir todas las cosas que contra él mostraron en palabra e en obra. Que

ro ffué uençedor de los más poderosos enernigos que auye, asi commo el mundo e el diablo. Que es destroidor más que Mars; que él destruyó el inffierno et destruye cadal día los malos. Et destroyrlos ha más del día del juyzio adelante; ca les dará pena por ssienpre. Et a nos dará esfuerço con que ssepamos ssoffrir las

I5 cuytas deste mundo e las tentaçiones del diablo. Commo a Mars danan ssabiduría en ffecho de armas, assí Ihesu Cristo ffué ssabidor de armarsse de la cruz e de la passión, en que uençió ssus enemigos. Et esto sse acuerda con lo que dixo Ssant [28v] Iohán apóstol e entangelista, que viera a Nuestro Ssennor en los ciellos e 20 quel ssalie de la boca vna espada que taiaua de amas partes. Que assí commo a Mars danan ssabiduría e acuçia para vençer, assí Ihesu Cristo ffué tan acuçioso que en xxxiii annos uençió ssus enemigos quantos le contrallauan, tan bien en el çielo commo en la tierra. Et mostrónos ssabiduría de uençer con aquellas armas 25 que él vençiera.

Et por ende Ihesu Cristo ffué Mars tan bien en el nonbre commo en la obra de uençer. Et la color que dauan a Mars de fazión e de armaduras era toda bermeia. Et era a ssemeiante de la ssangre de Ihesu Cristo que fué todo cubierto por nos. Et la espada que 3o ponían en la mano que taiaua de amas partes, eran los poderes de

I-2 Mares en destroyr e fazer. - 4-5 poder destr. -- 6-7 nonbre que q. dezir am. -8 es. - I 2 destroye cada dia. - 3 el dia/para. - I4 Que nos da. -17 vencio todos sus. $-18 \mathrm{E}$ en esto. -19 vio / gielos. -21 acuzia p. saber vençer. -22 acuzioso. $-22-33$ vençio todos los hen. $-23-2 i$ en c. commo en tierra, -26 fuc el mayor (Mares añadilo en el margen, otra mano). - 27-28 T Et la cosa qued. a Mars de color e de arm. / fazion (facion añadido en el margen, olra mano) de arm. $-28 \mathrm{E} \mathrm{sem.}-29$ Cristo de quc. $-29-30$ espada que le pon. 
la justiçia que taiauan los yerros spirituales e tenporales. Et la cabeça del omne muy ffeo que teníe en la mano siniestra erâ ssemeiança de cómmo Thesu Cristo auye de descabeçar el diablo, tolliéndol el poder que teníe el dia que murió por nos. Onde esta ffigura a Ihesu Gristo la deuían ffazer ; ca Mars quando uençie, 5 mataua, e Jhesu Cristo uenciendo nos libró de muerte.

\section{[LFY LIII]. - De cómmo la onestad que dauan los antigos a Jupiter,} a Ihesu Cristo la denyeran dar ssi bien lo entendiesen.

Honestat e derecho e uerdat dauan los antigos a Jupiter, que auye por ssu natura en ssiete maneras. Et esto ffué a ssemeiança 10 de Nuestro Ssennor Ihesu Cristo; ca él ouo en ssí todas estas bondades más conplidamiente que otro omne. Que assí commo dauan a Jupiter linpiedunbre, assi Ihesu Crisito la ouo más que otro; ca él ffué en uoluntad e en obra. Que non cubdiçió ninguna cosa que ffuesse ssobeiana, por que él oujese a ffazer peccado. i5 Que frué honesto; que assí commo los gentiles ffazien a la ymajen de Jupiter uestiduras cárdenas de color de çielo, assí lhesu Cristo ffué viestido de dos maneras de uestiduras muy nobles : la vna, de color cárdeno e claco e çelestial, que ono de parte del Padre; la otra, conplida de honestat e muy bien ffecha, que ouo de la ssanta 20 bondad de ssu madre. De cómmo dauan a Jupiter las buenas palabras e rrazones bien dichas, esto ffué a ssemeiança de Ihesu Gristo, que ffué más conplido de rrazón que otro omne, diziendo ssienpre buenas palabras e uerdaderas e conplidas e prouechosas. Que dixieron a Jupiter que era mesurado en todos ssus ffechos, et 25 esto ssemeia que por Ihesu Cristo lo dixieron; ca él ffué tan mesurado en todo lo que ffizo e dixo que ninguna ssobeianía non y ouo nin cosa en quel pudiesen trauar con derecho. Ca él cunplió la palabra que dixieron los ssabios, que los que touyesen la carrera de medio scrían bienauenturados. Que assí commo los gentiles 30

2 fea / diestra. - 3 auie a desc -4 -le / nos $[E 35 r]$ - 5-6 rencic o m. J. C. veniendo (e añadido en el margen, otra mano). - i 3 lo. - I4 el lo fue en bondad $e$ / cobdiçio. - 15 sobejania por que la o. a f. pensando. - is fue cubierto. - I8- 19 $T$ nobles la color. - 20 conplida e honesta muj. - 20-2 I $T$ ssanta trinidat e de ssu. - $25 \mathrm{E}$ lo que fezieron a Jup. (E lo añadido sobre la línea, otra mana). $-25-26$ lechos esto. -27 que d. of. que. - 3o eran. 
dizien que Jupiter que aborreçie todos los peccados e las cosas desaguisadas que los [29r] omnes ffazíen, esto llanamiente a ssemeiança de lhesu Cristo ffué ffecho; ca él aborreçe tanto los peccados e las cosas desaguisadas que ffazen los omnes que por 5 ssacarlos dellos priso desonrra e muerte. La honestat que dauan a Jupiter en ssus mouimientos e en ssus cosas, esto ouo en ssí lhesu Cristo conplidamiente; que nunca se mouyó de vn logar a otro nin ffizo yda nin uenida ssinon cuerdamiente e ssin huffana e ssin uanagloria. Que dauan los gentiles a Jupiter que era alcalle Io derechurero que enderaçaua las uoluntades de los omnes que conosçiesen derccho e non ffiziessen tuerto, et esto otrosí por Ihesu Gristo sse entiende; que ouo dos alcallías nobles por linage para judgar derecho: la una, celestial de parte del Padre, que es juez conplido e acabado, aquel que ha a judgar los biuos e los I5 muertos; la otra, que es juez tenporal que viene de linage de rreyes e de prophetas que ssienpre judgaron uerdat e lo mostraron al mundo.

Por que Jupiter es verdadero Ihesu Cristo; que ouo en ssí estas ssiete cosas conplidamiente que auemos dichas. Et las otras 20 cosas que dizien, que era poderoso e ouo el poder de la uertud de Dios, Ihesu Cristo lo ouo de ssí mismo; que él era Dios e omne conplidamiente. Et por ende los que ffazían a Jupiter ffigura de omne cuerdo e apersonado en ssu cáthedra commo juez, a Ihesu Gristo deuyera ser ffecho; ca él ouo en el cuerpo persona de 25 omne e alma de Dios. Et lo que dizían que sseye en siella grande e alta, Ihesu Cristo es aquel que sseye en los altos çielos a la diestra parte de Dios ssu padre, ante cuyo juyzio nernán todos el día del juyzio en la ffin del mundo, e dará a cada vno ssu derecho conplidamiente.

I Jupiter aborresce. - $2 T$ llanamiente es a. -3 dicho. -4 cosas que f. los malos omnes (malos añadido en el margen, otra mano). - 8 vfania. 9 Lo que d. los g. que J. era alcalde (Lo añadido sobre la línea, olra mano). Io enderesçaua. - I i tuerto esto. - Ia entendie / alcaldes muy nobles. 13 parte $[E 35 v]$ de Padre. - I4 acabado commo a, que ha de judgar. - 15 tenporal que es de lin. - I8-19 Porque J. el v. I. C. fue que ouo en sy conpl. estas s. c. que a. dicho. - 20 que Jupiter dizen. - 22 fazien f. a J. de. 23 apresonado. $-\mathbf{2 5}$ e el alma (el añadido sobre la línea, olra mano). $-27-28$ todos en. 
[Ler LIV]. - De cómmo la antigüedat que dauan a Ssaturno e el mouimiento tardinero, a Dios Padre lo denyeran dar,

que nunca sse mueue.

Antigüedat dauan muy' grande los gentiles a Ssaturno. Por esso le ffazían en ffigura de omne muy vieio e cansado e que sse mouye 5 tarde e andaua muy a paso. Et las obras que ffazíe eran muy tardineras. E todo esto ffué a ssemeiança de Dios Padre, que está quedo e non sse mueue nunca nin sse camia de ssu uestido nin de ssu estado. E esto en vii maneras e sson éstas : que sse non mueue en ssí; que el mouymiento que ffazíe que era tardinero; 10 que en él eran ençerrados todos los saberes ascondidos; que él ffazíe las grandes lauores que durauan mucho; que él era guardador de todas las poridades; que el alegría que daua que auya ante de sser con lloro e con tristeza; que él era más çerca del cielo noueno del spíritu de Dios e más arredrado de las tierras i 5 que las otras planetas.

Onde todas estas vii cosas que dauan a Saturno deuyeran dar a Dios Padre; ca él las ouo más conplidamientre que otra cosa. Ca ssi Ssaturno sse mueue tarde, pero ffazíe muestra de mouimiento, mas éste nunqua la ouo nin podríe auer; ca ssi Dios sse 20 mouyese, por [29v] ffuerça conuinge que el mouedor quel fiziese moner o estidiese quedo. Et assí yrían contando de vno en otro ssin ffin. Que el ssu mouymiento ffué tardinero, esto se entiende por la enbiada que enbió Ihesu Cristo ssu ffijo, que ffué tan tarde que los omnes del mundo con mingua de entendimiento sse tornaron 25 a creer ante en las criaturas que non en aquel que las criara. Que en él eran todos los saberes ascondidos, esto se entiende Ilanamiente por Dioś; ca él es el saber e en él sson encerrados todos los ssaberes et dél ssalen. Que assí commo dizían que Ssaturno ffazíe las grandes lauores que durauan mucho, esto era a ssemeian- $3 o$

$2 T$ mudamiento / la. $-4 \mathrm{E}$ por. -5 lo. $-8-9$ camia de su estado. -9 maneras que son. - xo faze. - I $T$ en eran. - 12 fazie todas las / $T$ grande. 13-14 auie a ser ante con lloro. - I4 $T$ çerca de. - i5 noueno do es Dios. 19-30 E añade de mouimiento sobre la linea, otra mano; $T$ lo omite. -20 este Dios nunca la ouo nin la puede (Dios añadido en el margen, otra mano). - 22 estouiese / asy serie contado. - 24 enbio a Ihesu. - 25 mundo [E 36r] con mengua, $-26 T$ las que non / criaturas que en. -28 es saber. -29 dize. - 3o los g. sabores que d. m. e esto. 
ça de Dios que ffizo el mundo, que ffué marauillosa lauor e mucho estranna que non podría sser ffecha por otre ssinon por él, en que mantouyesse todas las cosas que él cuiara. Et ffizo el paraíso para los buenos e inffierno para los malos. Et así commo dizen que 5 era Ssaturno guardador de todas las poridades, assí el Nuestro Ssennor guarda los ssesos que los non ssepan los que él non ama, et descábrelos a los ssus amigos. Que el alegría que dana Ssaturno primero auya de sser con lloro e con tristeza, esto sse entiende que todos aquellos que Dios ama enssaya, castigándolos en este Io mundo los bienes que les él da con trabaio e con cuyta e con lazeria, por que entiendan que non ha otro bien ssinon el ssuyo e quel cubdiçien auer e ffagan por qué lo ayan. Que assí commo Ssaturno era más çerca del çielo noneno, o es Dios, e más arredrado de la tierra que las otras planetas, esto llana cosa es que por

15 Dios sse deue entender; que es más çerca del çielo noueno, commo aquel que está en el mismo, e el más luene de la tierra que es sseca, que sse entiende por los peccadores que están ssecos e endureçidos en mallat que non sse quieren rrepentir, que sson luenne de ssu amor.

20 La ffigura quel dauan de omne vieio sse entiende porque Dios Padre ouo fformado ssu ffijo Ihesu Cristo en la uoluntad. Et por ende sse puede contar por omne vieio antigo, ssegunt dize el Propheta: Vi el antigo de los días sser en ssu ssiella; que sse entiende por el Padre, en cuya uoluntad era ymaginado el Ffijo. Et

25 estas uestiduras negras quel dauan, esto es assí commo el color negro es oscuro que çierra el viso, assí a Dios ninguno non puede uer en este mundo en la deidat ssinon por Ihesu Cristo ssu ffijo.

Et pues que anemos dicho de los que creen en las siete planetas, queremos dezir de los que adorauan a los signos.

I marauillosa saber e. - a podie. - 4 e el inf. / Que asy. - 5 todas puridades asy Nuestro. - 8-9 entiende por todos. - 9 ensenna. - io que los. I 2 cobdicien / E asy. - I 3 do. $-\mathbf{x} 6$ e es mas luenne. - I 8 que se non quieren. - 19 del su. - $20 \mathrm{E}$ añade -1 de quel de otra mano; T' la omite / omne muy viejo. - 2 i formado a I. C. su f. en. - 23 en la su. - 24 emaginado. -25 que le. -26 asy Dios / $T$ non se puede. -27 mundo segunt la. 28 creyen. - $29 T$ adorama/aoran los doze signos. 
[Lex LV]. - De cómmo la ffigura de carnero que dauan al ssigno de Aries, a thesu Cristo la deuyeran dar, que es cordero uerdadero de Dios.

Aries llamauan al primero ssigno, e este nonbre quier dezir tanto commo fligura de carnero; ca las estrellas dizien que auyan 5 ffiguras en aquel çielo que eran desta manera. El esto ffué a ssemeiança de Nuestro Ssennor Ihesu Cristo, que ffué cordero de Dios Padre $[30 \mathrm{r}]$ que enbió en el mundo por toller los pecados dél. Et esto por vii rrazones : la primera, mandó que fuesse fijo maslo; la $\mathrm{ii}^{\mathrm{a}}$, que fluese todo blanco e ssin manziella; la ii $^{\mathrm{a}}$, 10 porque el cordero anda ssienpre en pos la madre; la iiiia, por quando comiença a pasçer, pasçe sienpre las yeruas menudas; la $v^{a}$, porque non faz mal a ninguno; la vi ${ }^{a}$, quando le tresquilan el manto, non se quexa tanto commo otra animalia ninguna; la vii", porque la carne dél sabe bien e non faze enbargo al í cuepro ninguno.

Et todo ouo en ssí muy cunplidamiente Nuestro Sennor Ihesu Gristo, que ffué cordero de Dios Padre. La primera, touo Dios por derecho que fluese maslo para andar entre los omnes e beuir commo ellos e mostrarlos cómmo auyan de ffazer, e rrecibiese 20 muerte por ellos, lo que non abiniera ssi ffuese mugier nin nos judyara el día del juyzio commo nos ha de judgar. La $\mathrm{ii}^{a}$, que ffué blanco e ssin manziella, esto ouo en ssí Nuestro Sennor lhesu Gristo muy conplidamiente, ssegunt que dixo el Propheta por él, que nunca ffiziera peccado nin ffuera ffallado en la su boca enganno. 25 La iii", que así commo el cordero anda ssienpre en pos la madre, otrosí Nuestro Sennor Thesu Cristo andudo ssienpre en pos la madre, ssiguiéndola en la virginidat e en la humillat, segunt él dixo. La iiií, que assí commo el cordero comiença ssienpre a paçer las yeruas más menudiellas, assí Nuestro Ssennor Ihesu 3o Cristo desque començó a predicar, ssienpre predicó a los pueblos

3 Dios [E 36v]. - 4 llaman el prim. - to blanco syn. - i 2 por que quando / menudillas. - $13-14$ trasquilan. -16 cuerpo / $E$ omile ninguno. I7 todo esto muy conplidamente lo ouo Nuestro. - 20 con ellos / $T$ mostrolos, $E$ mostrarles. - 22 commo nos judgara. - 24 segunt dixo. - 25 que non $f$. p. non. - 36 La tercera asy. - 26-27 anda en pos la m. s. otr. -27 andando. -28 seguicndola. $-28-29$ e h. segunt diro. -29 -3o comiença a p. e paçe s. las yeruas (e añadido sobre la línea, otra mano). - 3o $T$ assi commo Nuestro. 
e a las gentes menudas porque conosçió que eran más ssin entendimiento e ssin saber. E éstos conuertió e sacó de mala carrera porque entendiú que quando éstos ouyese convertidos, que los sabios e los grandes sennores ellos sse conuertiríen por sí desque

5 entendiesen la uerdat. La $\mathrm{r}^{\mathrm{a}}$, que así commo el cordero non ffaz mal a ninguno, así Nuestro Ssennor Ihesu Cristo en quanto andudo por el mundo ssienpre fizo bien a todos por palabra e en obra, consseiándolos que fliziesen sienpre buena vida en este mundo por que ffuesen tenidos por buenos e ganasen el amor de Dios por Io que, después que muriesen, fuesen con él al ssu rregno. Otrosí por obra rresuçitaua los muertos e sanaua los enfermos e partíe con ellos quanto teníe. La via ${ }^{a}$, que assí commo quando tresquilan el cordero, e nunca sse quexa tanto commo otra animalia, otrosí ffizo Nuestro Ssennor Thesu Cristo ; que por mal nin por tormenta I5 quel ffiziessen, nunca se quexó commo otro omne nin dió boz ssinon quando estaua en la cruz, que acomendó el alma al Padre e en las sus manos. Et esto se proeua por lo que dixo el Propheta: Así commo la oueia que traen a matar o el cordero que trahen ante el tresquilador e cierra la boca e enmudeçe que non da boz; 20 así ffizo Ihesu Cristo en la pasión ên la muerte que rreçibió por nos. La vii ${ }^{a}$, que assí commo la carne del cordero ssabe bien e abonda a los que la comen e non ffaze enbaroro, otrosí el ssacrifficio del cordero de Dios, que es el ssu cuerpo, e ssabe tan bien spiritualmiente que tuelle todos $[30 \mathrm{v}]$ los malos sabores tenpora${ }_{2} 5$ les. E demás, affuerça mucho, que es comer que abonda el cuerpo e la alma, ssegunt dixo el Propheta : Coman los pobres e ffártensse, e loarán a Dios que andan buscando. E ssin todo esto non enbarga en los cuerpos que sson linpios de peccado, ante les faze muy grant pro. Mas a los otros fraze muy grant enbargo, segunt dixo 3o Sant Paulo, que el que come el cuerpo de Ihesu Cristo, que es eI cordero de Dios, non sseyendo él linpio en ssí mismo, él se judga,

1 conosçie. - a convirtio. - 3 ouiesen convertido. - 4 converterian. 5 verdad commo despues lo fezieron Ia quinta. -7 todos en pal. -8 feziesen buena / este $[E 37 r]$. - Io a su. - 12-13 commo t. al c. el manto non se quexa. -14 fizo este N. S. I. C. ca nin por tormento. -15 quexo asy commo. $-16 T$ esta. - $16-17$ alma en $m$. de su P. e esto. $-17 T$ por que lo dixo. -1 7-18 dixo asy. - I8-19 $T$ cordero ante. - I 9 trasquilador e cierranle la boca. - 20 pasion e en. - 23 cuerpo sabe. $-25 \mathrm{E}$ afuerça (esfuerça añadido debajo de la linea, otra mano) / $T$ es commo que. $-25-36$ al c. e al alma. $-27 T$ andan e / $T$ enbargan. - 3o el que tiene el c. de Nuestro Sennor Ihesu. - $3 r$ siendo l. el m. se judga. 
que ffaze mal. Onde los que oraron el ssigno de Aries, a éste querían aorar ssinon que el sseso non les cunplió a ello.

[Lex LVI]. - De cómmo erranan los que orauan el ssigno de Tauro, queriendo aorar a Ihesu Gristo, por non lo entender.

Tauro llamaron en latín al ssegundo ssigno, que quiere tanto 5 dezir en el nuestro lenguaie commo toro. Et esto ssigniffica a Nuestro Ssennor Ihesu Cristo por vii rrazones: que el toro es bestia ffermosa; e que es ffuerte; e ardido; que ssabe bien acabdellar ssus uacas e los otros ganados de ssu natura que con él andan; que escoge las aguas claras e buenas; que quando ffalla 10 buen pasto, adelántase a paçer ssienpre; et quando truena, cata ssienpre al çielo.

Et estas cosas ouo en ssí ssienpre lhesu Cristo conplidamiente. Que assí commo el toro es bestia ffermosa, assí el Nuestro Ssennor Ihesu Cristo ffué el más ffermoso omne que en el mundo naçiesse i 5 entre los omnes, ssegunt dixo el Propheta; et esto non tan solamiente en color e ell ffaçión e en conponimiento de mienbros, mas aun en ffablar e en contenente e en todas las otras obras que auya de ffazer, de guisa que quantos le ueyen eran dél pagados, e aun aquellos quel buscauan mal e muerte por enbidia quel 20 auyen, ca non por cosas que él mereçiese. Que assí commo el toro que es muy ffuerte, et esto sse entiende por la ffortaleza de Ihesu Gristo, que quebrantó el mundo e el diablo e los inffiernos, ssegunt dixo Dauid, que quando mandó abrir las puertas del inffierno que preguntaron que quién era, dixo que él era Ssennor ffuerte e pode- 25 roso. Que así commo el toro es mucho ardido entre todas las animalias, assí el ardimiento de Ihesu Cristo ffué escogido entre todos los omnes del mundo; ca ssentiendo que él auya de morir, non rreçeló la muerte, ssegunt él mismo dixo, que era triste la

2 conplio. - 4 por lo non ent. - 5 llamauan / el seg. / $T$ que quien tanto. -6 en nuestro. -8 fermosa que es. $-8-9$ sabe a. bien sus. -Io $T$ andan que quando. - i I adelantase s. a p. que quaudo. - I 2 çielo $[E: 37 v]$. - 13 sy lhesu. - 14 fermosa asy Nuestro. - is que nunca nac. -17 fazion. - 18 las obras. - I9 del muy pag. - 20 aquellos mismos quel/ inbidia, - 2 I meresçie. - 2 I-22 toro es f. esto. - 24 de los infiernos quel. -26 ardid. -27 ardimento. -28 mundo e s. que avie a morir. $-29 T$ rreçelando / rreçelo muerte. 
ssu alma ffasta en la muerte. E ssabiendo que crúa muerte auya de sser e tan penada que con cuyta della ssudó el ssu cuerpo sangre, e con todo esto non la dubdó que la non ffuese a tomar por nos. Que assí commo el toro sabe bien acabdellar sus uacas e 5 los otros ganados de ssu natura que con él andan, assí ha esto Ihesu Cristo en ssí ; que de vna parle acabdiella los ssus ssantos en el çielo, et de la otra parte ssabe acabdellar sus amigos en tierra que ffagan buena vida e non yerren. Et deffiéndelos de los que los quieren ffazer mal, así commo de las tentaçiones del diablo e de

ro los periglos del mundo. Que assí commo el toro escoie las aguas claras e buenas, assí lhesu Cristo escoie para ssí aquellos que entiende que sson claros e linpios e buenos en uoluntad e en obra. Que assí commo el toro quando ffalla buen pasto, adelántase ssienprê lo ua paçer, otrosí Ihesu Cristo a esto sennaladamiente; que I5 quando ffalla los coraçones de los omnes apareiados para ssu seruiçio, pásçelos e mételos en el ssu cuerpo, que sse [31r] entiende por la ssu Ffe, que es toda liena de graçia que los engruesa fasta que los mate e los abonda del pasto del paraíso. Que assí commo el toro cata al çielo quando truena, así Nuestro Sennor Ihesu

20 Cristo en todas las cosas que ffazie ssienpre catana al cielo a ssu padre. Et este catamiento era en dos maneras : el vno, de uoluntad; e el otro, de vista. Que por la uoluntad daua a entender que todo lo que dallá quisiese que lo acabaría, commo sse lo ffazía luego. Et por la vista mostraua que veye la deidat del Padre, lo ${ }_{25} 5$ que non podríe uer otro omne. Et por ende los que orauan el ssigno del Toro, a Ihesu Cristo quisieran aorar ssi ssopieran.

[Lex LVII]. - Del ssigno de Gémini e de lo que ssignifficaua la ssu ffigura, que es dos caerpos ayantados en vno, que a thesu Cristo le deuieran dar.

3o Gémini era el tercero ssigno, que quier dezir commo dos cuerpos ayundados en vno que nunca sse parten. Et esto a ssigniff-

t-2 crua auie a ser. $-3 T$ e que. -3 fuese tomar. -4 las vacas. $-5-6$ esto en sy I. C. que. -6 acabdilla. -7 otra sabe. -8 e que non $/$ que les. - 10 peligros. - Io- I aguas mas claras. - i 2 que son c. e l. en vol. (todo eserito sabre raspado). - 13 toro $f$. buen $p$. e ad. / $T$ adelante. $-13-14$ sienpre e lo. - 17-1 $8 T$ graçia que los mate. - I8 e les de abondo. -20 las obras. - 21 maneras $[E$ 38r] -23 se fazie. $-25-26$ al s. de Toro. -37 Gimini / significa. - 28 es de dos. - $29 T$ omile que... dar. - 30 era terc. / quiere tanto dezir. - 3 I ayuntados. 
cança de Ihesu Cristo, que era ayuntado con el Padre en vno en ssiete maneras: que sson tres perssonas en nonbre; que es todo vna cosa en poder e en obra; que non sse pueden partir; que la ssu obra es doblada; que han dos flazes que calan a lo que es pasado e a lo que ha de venir ; que han dos ffuerças e vna uertud; 5 que ssienpre obran a todas partes.

Et todo esto ouo en ssí Thesu Gristo conplidamientre. Que él rreçibió fforma de Dios en ssí, fformándosse en el cuerpo de Ssanta María. Et esto se proeua por la vieia ley allí o dize que quando fizo Dios a Adam, dixo: Flagamos omne a ymagen e a sseme- Io jança nuestra; que sse entiende que ya Dios teníe la ffigura ymaginada en que la auya de fligurar. Et de parte de la madre rresçibió en ssi natura de omne ssin peccado e ssin corronpimiento dél. Que assí commo Gémini es todo vna cosa en poder e en obra, assí el Padre cel Ffijo han poder de vna guisa. Que assi commo estas i5 dos personas están ssienpre en vno e non se pueden partir, assí Dios Padre e Ihesu Cristo sson vna cosa, maguer sson dos nonbres, de vna guisa ayuntados en vno que non pueden ffazer ninguna partiçión. Que assí commo la obra es doblada, e non puede el omne rrecebir bien nin galardón que lo non rreçiba del otro, 20 otrossí nin pena nin escarmiento que de amos a dos non uenga. Et assi commo Gémini a dos fazes que catana lo que es pasado e lo que ha de venir, assí Ihesu Gristo ha estos dos catamientos: el vno, spiritualmientre del Padre; e el otro, tenporal. Desí torman amos a dos en vno. Con esto vee todo lo que sse ffizo en el tienpo 25 pasado e lo que sse ffaze luego e lo que sse ba de ffazer adelante; que, ninguna cosa non puede asconderse. Et por ende dixo Ezechiel el propheta, e sse acordó con él Ssant Iohán apóstol e euangelista, que los que traen la ssu ssiella de Dios, que sse entiende por el ssu poder, eran llenos de oios delante e detrás. Onde el poder de 30 Dios es en el ssu ffijo. Et commo quier que Dios es rrayz de todo,

$x$ de Nuestro Sennor I. G. que era a. en el Padre. - $3 T$ e en nonbra/ puede. - 4-5 lo pas. - 5 T la / fuerças la vna. $-7 \mathrm{E}$ esto t. ouo. 8 Dios form. - 9 do. - io Dios Adam / $T$ Adam ffag. -1 - 2 a tiene y. en sy la $f$. en que. -13 omne syn c. de p. que. - 14 toda / $T$ obrar. $1 \overline{5}$ han rn poder. -18 guisa que ayunt. $-19-30$ doblada asi non p. el vno rresçebir. - 20 el otro. - 22 Gimini / cata / $T$ los que. -23 acatamientos. - 23-24 $T$ el ouo spir. - 24-25 Desy que $t$. amos en vno e con. $-27-28$ Ezechiel prof. - $\mathbf{9 8}$ con el [E 38v]. -- â $T$ poder llenos / oios de del. $3 \mathrm{I}$ en el e en el fiio. 
dió poder de judgar a Ihesu Cristo su fiio porque era omne. E rrazón que ponen en Gémini que auíe dos fuerças e vna virtud, éstas ponen a Jhesu Cristo llanamientre; que ha la ffuerça del Padre ssegunt Dios e de la carne segunt omne. Pero la uertud 5 toda es de parte del Padre; que ninguna cosa non la ha ssinon él ssolo. Que assí commo los dos cuerpos de Gémini obrauan a todas partes, assí la vertud del Padre e del Ffijo obrauan en el çielo e en la tierra. Et por ende los que orauan a Géminy, a éste deuyeran aorar si bien lo entendiessen. [31v]

Io [Ley LVIII]. - De cómmo los que aorauan al Cangreio, a Ihesu Cristo denyeran aorar si bien lo entendiesen.

Cancro es llamado el quarto ssigno, que quier tanto dezir en nuestro lenguaie commo cangreio. Ésta es vna animalia que sse. cría en la mar e ha muchos pies, commo langosta, e es todo

I 5 cubierta de casco e ha la boca ascondida en los pechos e los oiọ puestos en los onbros, que anda quando quiere a todas partes, tan bien atrás commo adelante commo atrau yeso. E es animal que mora pegándose en las pennas de la mar e ffaziendo fforados en el lodo a la oriella, bien commo el coneio. Otrossí es ssabidor e artero, 20 bien commo oyredes adelante. Este ssigno dauan los gentiles por cosa alabada e teníen que auya grant uertud e oráuanlo mucho en ssiete maneras: que ffué animal bito; et cubierto de casco ; con muchos pies; que anda a todas partes; que vee todo en derredor; que sse asconde en los fforados en tierra commo coneio; que es 25 artero e ssabidor.

Eł todo esto cra a ssemeiança de Nuestro Ssennor Ihesu Gristo. Que assí commo el cangreio es animal biuo, assí Ihesu Cristo, auyendo la deidat del Padre, es animal que biue e biurá sienpre en çielo e en tierra. Que assí commo el cangreio es cubierto de 30 casco e anda él biuo dentro, assí Nuestro Ssennor Ihesu Cristo, tomando la carne de Santa María ssu madre, ençerró la deydat en

I-3 T omile su fiio ... Cristo. - a pone / vaa de virtud. - 5 toda de p. del P. es que. - - la voluntad. $-7-8$ en c. e en tierra. - 10 orauan el signo de Cancro. - Ir si lo bien ent. - i a Cancro era ll. el quinto s. que quicre d. t. en. -15 cubierto. -16 onbros $e$ anda. -18 pegandose a las $p$. del mar faz. - I9-30 artero scgunt o. delante e este. - 2 r -le. - 22 es. 34 esconde. -26 sjgnificança / Senor. $-27 T$ cangreio el an. -38 biuira. 29 Que bien commo. 
ssí, con que enartó al diablo de guisa que quandol vino a tentar, ffalló que la deydat de Dios era ajuntada con la humanidat e ffué uençido; que allí do él vino a çeuarsse en carne tenporal, ffué preso e perdido todo ssu poder por el alma de Dios Padre, que era en él spiritual. Que así commo el cangreio ha muchos pies 5 con que anda a todas partes, assí lhesu Cristo ouo ffuerça en muchas maneras del Padre, con que ffué o quiso yr: primeramiente, quando descendió del cielo a la tierra; et después, quando murió, en que ffué quebrantar los inffiernos; et la otra, mientre estudo en este mundo después que rresucitó de muerte a vida e fué el ssu ro cuerpo glorifficado, ca entonçe tan bien los omnes commo el diablo connosçieron que era Dios e omne todo ayuntado en vno. Que assí commo el cangreio anda a todas partes, tan bien ssobre las pennas de la mar commo ssobre las ondas del agua, assí Nuestro Ssennor Ihesu Cristo anda ssobre las pennas, que sse entiende i5 por los coraçones de los omnes que están endureçidos de peccado, e apégasse a ellos ffasta que los amollienta e los aduze a rrepentimiento e a emienda. Otrossí anda ssobre las ondas de la mar, que sse entiende por los tormentos que ffaze el diablo en el mundo; que los desata él, poniendo la uertud ssobre todo. Et aun commo 20 el cangreio punna en esclareçer las aguas turbiadas e las claras ffaze que lo ssean más, bien assí Nuestro Ssenuor Ihesu Cristo esclareçe los coraçones de los omnes que sson turbiados en peccado e los claros enclarésçelos más. Que así commo el cangreio vee en derredor, assí Nuestro Ssennor Ihesu Gristo vee los pensamientos e las 25 uoluntades de dentro del omne e las obras de ffuera, to que otro non podría ueer; ssegunt uee que cada vno meresçe, assí le da el galardón. Que assí commo el cangreio sse asconde en las cueuas e en los fforados que [32r] ffaze cabo del agua e mora allí ençerrado, así Nuestro Sennor lhesu Cristo a grant ssabor de morar en 3o los fforados de las uoluntades de aquellos que ffalla ssus amigos. Et bien commo el cangreio caua los prados e ffaze fforados en que sse meta, assí Nuestro Ssennor lhesu Cristo caua los peccados que tienen en los coraçones e ssaca la tierra de la dureza que ffalla

I sy por que en[ $E 39 r] a r t o /$ quando lo. -4 perdido su / $T$ del Dios Padre (Dios añadido sobre la línea). - $5 T$ en spir. -9 el infierno / mientra. ro $T$ e el. - Io-1 1 fue $g$ el su c. ca. - is conosçieran. - I 7 amolenta. 18 del mar. - 30 que d. el ponimiento la. - 21 puna / lurbias. -24 esclaresçelos. $-27_{-2} 8$ da gal. $-3 i$ falla por sus. -34 dureza que $y$ falla. 
e flaze casa en que more. Que assí commo el cangreio es artero e ssabidor e quando quiere comer la ostria, que está ençerrada entre dos cascos, e assecha quándo sse abre al ssol e mete y vna piedra por que quando sse quiere çerrar, non pueda, por que coma lo 5 que ffalare dentro; assí Nuestro Ssennor Ihesu Cristo quando vee que alguna alma que está ençerrada entre los cascos duros de las conchas e de las obras malas que ffaz por conseio del diablo, assecha quándo el alma sse abre quel dé el ssol, que es Dios, por cobdiçia de la rreçebir en ssu graçia, e métel en Ja uoluntad piedra

so de penitençia dura que sse non puede encerrar, comiéndola, que sse entiende por auer ssabor della e ssaluarla. Onde los que aoraron el Cangreio, a Thesu Cristo ffazíen aquel aoramiento ssi lo ssopiesen ffazer; ca él ha esta propriedat conplidamientre en ssí.

[LEY LIX]. - Del ssigno del León e de cómmo los quel aorauan 15 quisieran aorar a Ihesu Cristo si lo entendieran.

León ha [nonbre] el $v^{0}$ ssigno de los que dixiemos, e es animal muy marauilloso. Et esto ffué a ssemeiança de Nuestro Ssennor Ihesu Cristo en vii maneras : en el nonbre; en la nobleza; en sser ffuerte; et sser espantoso; ligero; en la propriedat; en cómmo 20 come.

En el nonbre ssemeia mucho, ssegunt dixieron los prophetas e los ssantos, que él es llamado león ffuerte del tribu de Judá para uençer. Ca él ffizo tres uençimientos que otro omne non podríe ffazer. El primero, que vençió a Luciffer en el çielo quando quiso 25 sser ssu ygual, e de ángel que era tornólo diablo en ffondón de la tierra. Et el ssegundo, que vençió la desconnosçençia del omne quandol ffué desobediente et ffizo lo que él uedó. Et diól por pena desto que assí commo auya toda vía a beuir en gozo e en alegría, que assí ssuffriese en este mundo mucho mal e mucha 30 cuyta él e todo ssu linage, e en cabo que muriese. Otrossí uençió

2 quier c. la hostia [E 39v]. - 3 cascos as. - 4 quisiere / pueda e que. - 5 fallare. -6 algunt a. esta. -8 abre al sol (qual escrito $y$ tachado, $r$ al añadido sobre la línea, otra mana). $\rightarrow 9$ cobdiçia de $r$. la su g. e metele (de añadido sobre la línea, otra mano). - Ia çerrar. - 12 al Cangr. / oramiento. - I3 estas propiedades conplidas. - I4 de Leon. - $15 \mathrm{~T}$ omite si lo ent. i6 Leon llamauan al quinto / deximos. - I6-17 animal mar. - ig fuerte ser / la piedad. - at semejo. -23 de tribu. -23 podiera. -25 -le. -28 auie a b. toda via en gozo. - 3o muriesen. 
el diablo en el inffierno, que auya muchos ayudadores para dar mal conseio a los omnes e ffazerles que fliziesen malas obras en este mundo. Onde Ihesu Cristo, connosçiendo las ssus ffalssedades, tolliól el poder que auye en este mundo, con que los enartaua. Et demás, ffuél quebrantar al inffierno, allí do él tenía ssu 5 ffortaleza e era más poderoso. Et tolliól los presos que teníe, e puso ley e mandamiento que dallí adelante non ffuesen presos daquella guisa. Et por ende fué la palabra uerdadera que dixieron los prophetas e los santos, que viníe el león ffuerte de linage de Judá; que daquél vino Ihesu Cristo de parte de Santa María ssu 10 madre. Que assí commo el león es más noble en linage e en grandeza de coraçón más que las otras a[32v]nimalias, assí Nuestro Ssennor lhesu Cristo es de más noble linage que nunca ffué otro omne nin será; ca de parte del padre viene de Dios, e de parte de la madre de los más nobles rreyes que nunca ouo en Jherusa- i5 lem, que ffué tierra que ssienpre amó Dios apartadamientre más que otra que ffuesse. Que assí commo el león es más ffuerte que las otras animalias, assí el poder de Ihesu Cristo pasa todas las ffortalezas; ca él ha poder en çielo e en tierra e en el inffierno, e ffaze lo que quiere e puédelo ffazer, segunt dixo el propheta Dauid en 20 el Ssalterio : ¿Quién es este rrey de gloria, el que es Sennor fuerte e poderoso de vençer? Que bien assí commo ante el león sse espantan todas las animalias quel veen e an miedo dél, assí de la uertud de Ihesu Cristo sse deuen espantar todos los omnes, mayormiente cuydando en el día del juyzio, que sserá tan espantoso que 25 çielo e tierra todo tremerá quando Thesu Gristo aparesçrá para judgar el mundo. Que assí commo el león es más ligero que otra bestia en saltar e correr ayna, assí la ligereza de Nuestro Ssennor Thesu Gristo non ha par; ca él es en todo logar e ua e viene quando quiere del çielo a la tierra, et obra en todo ssegunt ssu 30 uoluntad. Que la propriedat que ha el león, que es el ssu vnto ssabroso, e tuelle los grandes dolores, assí la graçia de Nuestro Ssennor Ihesu Gristo es tan ssabrosa en ssí que aquel que con ella

I al diablo. - 2 malos consejos / -los. -5 fuele q. el i. do. $-8 \mathrm{~T}$ ende la. 9 santos [E 40r] / T el ssanto fuerte. - ro ca. - I es el mas. - I4 venie. 16 tierra que Dios amo s. ap. - 21-23 $T$ omile Quien ... vençer. -24 omnes e may. - 25-36 $T$ espantoso que todo el mundo tremera. - 26 tremira / aparesçiere. -28 e en correr / ligereza de la virtud de. - 29 todo e va. 3i-32 leon es que el su v, es sabr. $-33-33$ asy N. S. I. C. e la su g. es tan s, en sy que al que vitan con ella. 
es vntado, tuéllel los dolores, tan bien el del cuerpo commo el del alma. Que assí commo el león come cada día de lo que caça, assí Nuestro Sennor lhesu Cristo sse gouyerna en los justos e buenos en uoluntad e en obra que ha ya caçados e tollidos al diablo. Et 5 por ende los que aorauan al León, a Ihesu Gristo douyeran aorar ssi bien lo entendiesen.

\section{[Ley LX]. - De las ssemeianças que ouo Santa María con [el ssigno de] Virgo.}

Virgo llamauan los antigos al sesto signo. E dáuanle ssemeiança Io de mugier; ffermosa ; virgen ; cinta por los pechos ; con alas ; que tiene los braços tendidos; e las palmas abiertas.

Et estas vii cosas ffueron a ssemeiança de los ffechos de Santa María. Que ella ffué mugier benedicta êscogida entre todas las otras en ffortaleza ; ca vençió la fflaqueza de las mugieres e las ten-

I5 taçiones del mundo e del diablo. Que flué ffermosa ssobre todas las que nasçieron e nasçerán ; ca ella ffué ffermosa en el cuerpo e en el alma, segunt dixo el ángel Ssant Gabriel, que ella era benedita entre todas las mugieres. Virgen ffué enteramiente, non tanto por nonbre nin por ssemeiança commo lo era este ssigno de Virgo,

20 mas por uoluntad e por obra uerdadera. Ca bien así commo dauan a la ffigura de Virgo çintura por los pechos, esto muestra cómmo Santa María ffué prenada ssin uoluntad e ssin ajuntamiento de mul uarón. Et asi commo a la ffigura de Virgo dauan alas, assí las ouo Santa María ; ca tanto sopo alçar ssu uoluntad que Dios quiso 25 della fazer ssu madre maguer ella era donzella pobre, commo quier que ffuese de tan gran linage. Et porque ffué ssu madre, ssubióla [33\%] a los çielos e coronóla por rreyna dellos, en quel dió alas con que boló tan alto que cubrió todo el mundo. Que assi commo la ffigura de Virgo dizíen que teníe los braços tendi3o dos, bien assí Ssanta María tiene tendidos los ssus braços para

1 vntado e tuelle / bien del c. commo del. - 2 come toda via. - 4 ya çerrados. - 5 aoran al signo de Leo / deuieran. -6 si lo bien ent. -8 T y $E$ la planeta Virgo. - 9 al signo s. e. - ro pechos [E $40 v$ ]. - Ir tenie / arbiertas. - I3 muger e virgen b. e esc. (e virgen añadido en el margen, otra mano). - 14 otras e en. - 16 cuerpo mas que otra e. - 17 angel Grauiel/blanca (bendita añadido en el margen, olra mano). - 18 non solo quanto por (solo añadido sobre la línea, olra mano). - 2 I $T$ esto commo. - 22 prennada. - 22-23 de $v$. ninguno e. -26 grant. -29 dezie. 
rreçebir e perdonar los peccadores e auerles merçet, rrogando a Dios por ellos. Que assi commo la ffigura de Virgo teníe las palmas abiertas, esto sse entiende por los miraglos que ffaz Ssanta María cada día por la uertud del poder de Dios. Onde estas ssignifficaçiones que pusieron al ssigno de Virgo, Ssanta María las deue 5 auer por derecho et porque los que orauan al ssigno, a ella aorauan ssi de tan buena uentura ffuesen que la connosçiesen.

[Lex LXI]. - De cómmo los que orauan a Libra, a Ihesa Cristo querían aorar ssi lo entendieran.

Libra llamauan al sseteno ssigno, que quier tanto dezir commo io peso o balanças que estudiesen derechas; que atal era el ssu ssigno que paresçje en ssu çielo. Onde los que a éste aorauan, a Dios Padre deuíen aorar con mayor derecho por vii propriedades que ha en él, ssegunt muestra el ssigno de Libra : que es peso ; derecho; que ha dos balanças; medida que ponen en cada vna dellas 15 por uer quál pesa más o menos; que ay vn logar en que tiene la mano el pesador, que llaman lengua, por que conoscan a quál parte tira más el peso; que por uer a quál parte tira más el peso, que lo camian de la vna balança a la otra; que ssegunt la quantía de lo que pesan, ponen medida a todos cuentos.

Que es peso, esto sse proeua por las Santas Escripturas, de cómmo quando Dios ffizo el mundo, pesó cada cosa por ssí. Et los çielos, que eran más liuyanos, puso de ssuso. Et los elementos que non eran tan ligeros puso sso ellos. Et después el agua e la tierra, que eran más pesados, puso más en ffondón, assí que a cada vno dió 25 su logar ssegunt pesaua. Et esto sse proeua por el Propheta, que dixo que midió la medida de las aguas pequenna a mano, et el cielo a grandes palmas. Que estaua el peso derecho, que non abaxa por ssí más a vna parte que a otra ssi nol pusiessen y cosa por

2 Dios sienpre por. - 2-3 tiene las manos ab. - 4 del padre de. 4-5 significanças. -5 deuie. -7 si tan de buena (otro de escrito $y$ tackado delante de $\tan ) / T$ lo. -8 aoran. -9 quirien. -11 ca tal. -13 deuieran. - 14 muestra [ $E 41 r$ ]. - I5 $T$ alabanças / $T$ ponien. - I6 meros lo que ay en que t. en la (ay en subrayado, $y$ lo $y$ el segundo en añadidos sobre la linea, todo de otra mano). - I 7 connosçen. - $18 E$ omite que ... peso. - 20 todos los cuentos. - al Despues del agua. - $27 \mathrm{~T}$ metio; $E$ midio (retocado sobre metio, otra mano) / medida peq. - 28 palmos. 
que lo aya de ffazer, esto sse entiende que la justiçia de Dios es ygual a cada vno en ffazer bien e merçet a todos, ssi non ffaze tamannos yerros por que aya de abaxar el peso de aquella parte. Que ha dos balanças con que se pesa la justiçia conplidamientre:

5 la vna es que alça arriba contra el çielo a los buenos e a los que sson aliuyados de peccados e de males; la otra, que abaxa ffasta los inffiernos a los que sson peccadores a gruesos e pesados en mallat. Et las balanças que sson en medio, que nin sse alçan ffasta lo más alto nin sse abaxan ffasta el ffondón, éstos sson los que ro uan a purgatorio, que están esperando la merçet de Dios ffasta el día del juyzio. Et cada vna de estas penas han ssennas naturas: la vna, en purgarsse por tormentos de los males que ffizo; et el otra, en ueer la ffaz de Dios, estando çerca della. Medida que ponen en cada vna dellas por uer quál pesa más o menos, e esto es

I5 para los pecados que son puestos en cada nno por ver quál pesa más o menos; ca el [33v] mayor es pesado e el menor es más liuiano. Onde el que biue en el mundo e está en la balança dél, esperando quándol dexará morir, bien deue catar que non ponga tanto en la balança por que ssea pesado e desçenda yuso. Qué así

20 commo buena balança ha logar en que tenga la mano el que pesa por que las balanças sse paren yguales, assí Nuestro Ssennor Ihesu Cristo tiene la ssu mano firme e queda ssobre los derecheros; que los non dexa abaxar nin torçer a otra parte. Et cosa que ffazen los omnes, que maguer el peso ssea derecho, por uer ssi

25 pesará assí toda vía, mudan las balanças, camiando lo que está a vna parte a la otra, et asy ffallan ssienpre ssi ay alguna cosa de endereçar que non uenga tan derecha commo deuye. Et desta guisa Nuestro Sennor Ihesu Cristo, mudando los ffechos deste mundo e las cosas de muchas maneras, connosçe luego los muda30 mientos de los coraçones de los omnes quántos sson, e ssegunt aquello pone en las balanças galardón o pena, más o menos assí commo entiende que conuiene. Que ssegunt que pesa la balança, ponen nonbre e medida a todos los cuentos, otrosí ffaze esto Nues-

1-a esto es la j. de Dios que a c. vno es egual en fazer. -3 tanmannos. 5 buenos e justos que. - Io pulgatorio, - ix sendas. - 12 el vno por purg. - 13 otro. - 14-16 T omile e esto ... menos. - 6 menor mas. - I9 balençia / desçienda ayuso. - 30 commo $\left[\begin{array}{lll}E & 41 v\end{array}\right]$ / tiene. $-23-23$ derechureros. 33 abajar / Es cosa. - 25 camiando las que estan. - $26 T$ et ssi ffallan. -27 $T$ que uenga / derecho $c$. venie. -- 28 mandando. - $29-30 T$ mudamientos de los omnes. - 3o quales. - $3 \mathrm{I}$ ponen / pena o. - 32 segunt lo que. 
tro Ssennor Ihesu Cristo muy conplidamientre; que él quiso que ouyesen nonbre los peccados pesados mortales, e los liuyanos veniales. Et por ende él es libra e balanças derechas, que non las estrellas que paresçen en los çielos, a las que orauan los çiegos sin entendimiento.

[LEX LXII]. - De laśs ssiete propriedades que dauan al Escurpión, a Nuestro Ssennor Ihesu Cristo las deuyeran dar, ssegunt sse aqui muestra.

Escurpión pusieron nonbre los antigos al octauo ssigno, al que dezimos en esta tierra alacrán. E es de dos colores: el vno, de io color de tierra; e el otro, negro. Mas el de color de tierra es más natural que otro. Et a éste dauan vii propriedades que ha Nuestro Sennor Ihesu Gristo : que nasçe de la tierra; que non ffaz mal a ninguna cosa ssinon deffendiéndosse que non ge lo ffagan; que ha dos manos con que toma; que ha muchos pies; que ha ssiete 15 nudos en la cola; que ha en ssomo de la cola aguiión frecho commo vnna de aue; que aquel a quien ffiere con aquella vnna ssuffre grant dolor.

Estas ssiete cosas ouo en ssí conplidamientre Nuestro Ssennor Ihesu Cristo. Ca nasçió de Santa María, que es dicha tierra por 20 las rrazones que de ssuso oyestes. Que assí commo el alacrán non ffaze mal a ninguna cosa ssinon deffendiéndosse que non ge lo ffagan, assí Nuestro Ssennor Ihesu Cristo non ffaze mal a ninguno, ante ffaze bien a todos. Et ssi en alguna cosa los castiga o les da pena, non es ssinon en deffendiéndosse contra aquellos que passa- ${ }_{2} 5$ ron e passan, non temiendo nin obedesçiendo los ssus mandamientos. Que bien assí commo el alacrán ha dos manos con que toma, assí Nuestro Ssennor Ihesu Cristo ha dos poderes : el vno, en ffazer miraglo e vertud en las cosas maniffiestas; lo al, de perdonar e de toller los peccados que sse ffazen en las uoluntades encubier- 30

I ca. - 3 Por ende / ca. - 4 aoran. - 6 Escorpion. - 7 Sennor las. $9 T$ las ant. - 10 aquesta. - I 1 tierra el otro. - i 2 que el otro / esta. 12-13 que a N. S. I. C. deuieran dar que nasçe. - I 5 manos en que toma. - I7 que al que fiere (el escrito $y$ tachado, $y$ al que añadido en el margen, otra mano). - 21 rrazones $[E 42 r] /$ oystes. -23 ansy / fizo / $T$ ninguna. -24 antes fazie / les castigo o les dio. -35 non fue $s$. def. / $T$ aquellos passaron. -- 26 obedesçiendo sus. - 29 manifiestas e lo. - 30 e toller. 
tas de dentro e en las obras paladinas. Que bien assí commo el alacrán ha muchos pies, assí Nuestro [34r] Ssennor Ihesu Gristo ouo las prophetas e los apóstolos e los otros santos, con que andudo la uerdat de la su ffe e de la su crençia e ffué toda vía adelante,

5 mostrando quál era. Et así commo el alacrán ha ssiete nudos en la cola, que cada vno ha ssu uertud, otrosí Nuestro Ssennor Ihesu Cristo ouo ssiete nudos, que sse entiende por los sacramentos que estableçió Ssanta Eglesia en cabo de la ssu vida, del que cada vno ha ssu uertud, ssegunt que adelante sserá mostrado. Que bien assí to commo el alacrán ha en ssomo de la cola aguiión ffecho ssegunt vnna de aue, assí Nuestro Ssennor Ihesu Cristo punne con la ssu yra, que muestra la ssu ssanna, los que non quieren obedeçer los vii ssacramentos de Santa Eglesia. Que al que ffiere el alacrán con aquella vnna ssuffre muy grant dolor, assí el dolor que ffaze Nues-

15 tro Ssennor con la su ssanna es el mayor que podría sser ; ca los otros dolores passan a tienpo, mas éste dura en esta vida e en la otra, ssegunt dixo Sant Iohán apóstol e euangelista en el Apocalipssi, que viera cauallos en visión, e desque contó todas ffaçiones que auyen, dixo que allí do las colas tenien vnnas así commo ala20 cranes, e a los que ffirían con aquellas vnnas que auyan pena e dolor de mill annos, que quier dezir tanto commo por toda vía. Onde todo aquel que en los vii ssacramentos non crouyere, conuyene que ssea fferido en este mundo e en el otro del aguiión de la yra de Dios que pene en los inffiernos por ssienpre. Onde Nues25 tro Ssennor Ihesu Cristo ouo en ssí derechamientre las propriedades del ssigno, por que a él deuyeran aorar, que non a las estrellas que dauan ffigura de Escurpión.

[Lex LXIII]. - Qué quier dezir Ssagilario e de la semeiança que dieron a Nuestro Sennor Ihesu Cristo dél.

3o Sagitario llamauan a aquel ssigno que dizíen que pareçíe en el çielo. Et ffiguráuanle de la meatad del cuerpo arriba ffigura de

I Ca. - 3 ouo en las p. e los a. e en los otros. - 5 Que asy. - 9 segunt ad. -10 fecho commo. - I $T$ lhesu a quien ffuere con. - I 2 que es $m$. de la. - I3 de la Santa. - i5 su vnna es. - 17 segunt lo dixo. - I 8 todas las faziones (las añadido sobre la línea, otra mano). - I9 commo de al. - 20 fieren. - 31 anos. - 21-92 por pena e dolor onde. - 23 creyere. - 23 aguijon de la vnna de. - 24 pone / sienpre [E 42v]. - 27 Escorpion. - 39 Sennor del. - 3o llaman / dizen que paresçe. - 3i Afigurauanle de la meytad. 
omne e lo al todo de cauallo. E dizíenle Ssagitario, que quier dezir tanto commo tirador de ssaeta. Et esto exa porque affigurauan en la mano ssiniestra vn arco con ssu cuerda encordada e en la ssaeta, commo quien quiere tirar. Onde la ssignifficança deste ssigno Ihesu Cristo la ouo en ssí conplidamientre por vii rrazones: la 5 primera, por la ffaçión que ha en ssí de omne; la ii*, de cauallo; la terçera, que tiene arco con cuerda ; la quarta, porque tira saetas; la quinta es porque el su tirar es sienpre adelante, e non atrás; la ssesta es porque tiene toca en la cabeça, puesta sobre los oios; la vii ${ }^{a}$, porque es tan grande que tiene el pie delantero 10 metido entre él e la cuerda.

La primera, commo este animal es estranna cosa de creer por oydos e más de ver por vista, assí fué el auinimiento de Nuestro Ssennor Ihesu Cristo al mundo, cómmo ffué conçebido de Spíritu Santo e nasçió de Ssanta Maria, ella sseyendo virgen, e murió e i5 rresuçitó después al terçer dia. La $\mathrm{ii}^{a}$, ffué muy ffuerte de ascuchar e de oyr e más graue de uer por vista, en dezir que Dios e omne es vna cosa. Et esto non podríe caber en natura de entendimiento fflaco que es vsado al mundo; mas cabe en entendimiento bueno e ffuerte de la natura de Dios, de ssaber connosçer con qué 20 ffizo e puede ffazer quanto [34v] quisiere ssin enbargo ninguno. La terçera, que así commo el Ssagitario tiene arco con cuerda, et éste es Nuestro Ssennor Ihesu Cristo, que tiene con su poder todo el mundo çercado, assí commo el arco con la cuerda ffaze çerco conplido quando es bien tirado. La quarla, que tira ssaetas, esto es a 25 ssemeiança de Nuestro Ssennor Ihesu Giristo. Que assí commo el que tira, la vna vegada espanta e non ffiere. [Et la otra, ffiere] e non llaga. Et la otra, ffaze llaga pequenna. Et la otra, llagando, mata. Et assí las ssaetas de Nuestro Ssennor Ihesu Cristo sson castigos e escarmientos en quatro maneras. La primera, que sse 30 deue temer e espantar, veyendo el su poder, segunt las obras que él fifizo. La ssegunda, déuensse castigar por los conseios de los omnes que sse guarden de mal. Et ésta es la segunda manera

I al de. -2 porquel. -3 encordado e en el saeta. $-6 \mathrm{~T}$ ssi omne. -8 quinta porque / adelante que non. - 9 sesta porque. - I $T$ assi el / abenimiento. - 15 Maria s. e. virgen. - I6 a $t$. dia otrosy fue / $T$ eseribe La iia sobre raspado, otra mano. - $16-17$ escuchar. - 19 cabe ent. -21 quisiere fazer syn. - $22 T$ escribe y tacha ssesta delante de terçera; $E$ quarta / cuerda esto. $23 T$ tiene en poder. - $25 T$ quando le es bien. -27 vegada $[E$ 43r] $T$ T escribe $y$ tacha ffiere la llaga delante del primer ffiere. - 29 Otrosy las. 
de ssaetas, que maguera fiere, non llaga. La terçera ssaeta, que ffiere e non llaga mucho, esto es, quando el culpado conosçe el yerro en que yaze e sse rrepiente dello e lo meten en uergüença del mal que ffizo e dan penitençia por escarmiento. La quarta es

5 fferida mortal, quando non sse quiere conuertir nin connosçer nin rrepentir nin tomar penitençia, porque caye en desperaçión mala e en descomulgamiento, por quel aya a uenir la yra de Dios por que non pueda ssanar. La $v^{\mathrm{a}}$, commo el tirar del Ssagitario es ssienpre adelante e non atrás, assí las ssaetas de Nuestro Ssennor

Io Ihesu Cristo ffueron tiradas adelante e non atrás, yendo contra ssus enemigos, ssegunt dixo Dauid quando llannía a Jonatás, que la ssu ssaeta nunqua tir a çaga. La vi ${ }^{\star}$, que el Ssagitario tiene toca en la cabesça, puesta sobre los oios, esto muestra vna de las penas que ffizieron a Nuestro Ssennor Ihesu Cristo quandol marti-

15 riaron, e quandol ffirieron, cubríenle la cabeça e los oios, diziendo que adeuinasse quién lo ffiriera. La vii ${ }^{a}$, que assí commo el arco del Ssagitario es tan grande que tiene el pie delantero entre él e la cuerda, esto sse entiende por los pies e por la ligereza de Nuestro Ssennor Ihesu Cristo, que anda en vno con el Padre e ffaze lo que 20 quiere. Et por ende las propriedades deste ssigno a Ihesu Gristo deuyeran sser dadas, que non a las estrellas que estauan en el çielo.

[LEY IXXIV]. - De cómmo las propriedades que dauan a la ffigura del Capricornio, a Jhesu Cristo las douyeran dar..

Capricornio es el dezeno ssigno de los doze que paresçen en las 25 estrellas fixas que paresçen en el octano çielo. Fste nonbre quiere tanto dezir commo cabrón con cuernos; porque el medio cuerpo de aquel animal contra delante, assí commo los cuernos e la cabesça e las baruas e el pescueço e los braços e las espallas, era todo

$2 T$ llaga esto / quando con. el c. al. -3 yazie. -4 danle. - 4-5 quarta for. -5 quiere connosçer. $-5-6 T$ connosçer nin tomar. -7 descomulgaçion. -8 puede. - 8-9 Sagitario s. es ad. - 9 del Nuestro. Io Cristo sienpre fueron / $T$ tirados delante yendo. - Io-1 I contra los sus. I $T$ llannian, $E$ llanie / Joanatas. - I 2 nunca tornaua. - 14-15 quando lo m. que q. firien. -16 le feriera. - I7 delantero metido entrel. - 19 el poder e. - $2 \mathrm{t}$ los çielos. - $22 T$ daua. -23 de Gap. / $T$ Capriconrnio a J. ląs / deuieran, $-25 T$ estrellas que. $-25-26$ quiere d. t. commo. -26 me-

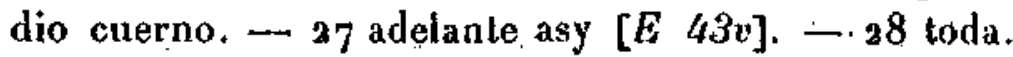


ffigura de cabrón. Et la otra meatad, vnos le ffazien en ffigura de cola de pescada, e los otros en figura de cola de culuebra. Mas las propriedades que dauan a esta ffigura, Nuestro Ssennor Ihesu Cristo las ouo en ssí todas conplidamientre, e esto en ssiete maneras : la primera, en ffazión de los cuernos; la ii ${ }^{a}$, en la ffaçión del rrostro; 5 la iii $^{2}$, en la de la barua; la iiii $^{a}$, en los braços e en los pies delanteros; la $\mathrm{v}^{\mathrm{a}}$, en las vnnas que ha fendidas; la $\mathrm{vi}^{\mathrm{a}}$, en la tortura del otro medio cuerpo; la vii ${ }^{*}$, en el otro cabo de la cola, que es fforadado commo pez, e luenga e aguda commo la de la culuebra.

Onde Thesu Cristo ssemeió mucho en ssus obras a este animal. La primera, que assí commo los cuernos sse muestrán por alteza [35r] e por poder, assí Ihesu Cristo ffué poderoso en dos maneras: la vna, de parte del Padre en el çielo; la otra, de parte de la madre en el mundo. Et ouo dos onrras que otro non ouo nin auerá : 15 de parte del Padre ffué Dios ; de parte de la madre, rrey marauilloso de grant uertud, cuy rregno non ha ffin.... La terçera, de la barua ; que commo los que la traen sse muestran por vieios assesegados, assí de parte del Padre ouo en ssí vertud e assesegamiento, ssegunt dixo el Propheta : Vi sser ssobre ssu cadera el antigo de los 20 días, a qui adorauan muchos ángeles. Et Ssant Iohán, en el Apocalipssi, dixo otrossí que viera desta guisa que auya los cabellos e la barua blanca commo la nieue. La quarta, que los braços delanteros de la ffigura de Capricornio que tiene ssienpre derechos quando sse quiere mouer, esto muestra la lealtad de Ihesu Cristo, que ffué 25 derecho en amar todas las cosas que veyen conplidamientre; ca él amó a Dios ssu padre de guisa quel ffué obediente ffasta en la muerte. Et ssu madre, por el trabaio que con él leuara, leuóla al çielo, lo que non ffizo a olro ssanto. Et a los omnes que ffueron ssu ffechura e ssus ssieruos mostró tamanno amor que tomó carne 3o de ssieruo por nos e murió otrossí por ssacarnos de sseruidunbre. E demás, dió la ssu vida por la nuestra, muriendo en tal que nos

I lo. - I-2 $T$ ffaze f. de c. de culuebra. -2 colebra. - 4 sy mas conpl. - 5 en la façion de los cuerpos / fazion. - 6 e los. - ro culebra. 14 çielo e la otra. - 15 avra. - 16 Dios e de p. de la m. fue rrey, - I7 cuyo. - I 8 que asy commo. - 20 sobre cathedra. - 2 I a que a. muchedunbre de los coros de los ang. - 23 braços tendidos. - $34 T$ tenien. ${ }_{27} T$ ama / Dios padre. - $28 \mathrm{E}$ a su / que en el. - 29 $\mathrm{E}$ los o. que somos. - 3I por que morio. 
visquiéssemos. Onde los braços delanteros e los con quél vsó estos pasos son derechos e leales, segunt dixo Ezechiel de las animalias que trahen la silla de Dios, que se entiende por el su poder, que auíen los braços derechos. La quinta, que auye las vnnas ffendidas,

5 muestra la ley vieia e la nueua, que sse ajuntaron por Ihesu Cristo. La vieia, que Dios mostró por ella el ffecho de Ihesu Cristo ssu ffijo quál auya a sser, ssegunt dixieron los prophetas. Et después quando él vino, conffirmó en la ley nueua, que estableçió por el ssu cuerpo, lo que ante auya ordenado en la ley vieia. La vi ${ }^{2}$, a Io ssemeiante de la tortura que ponen en el medio cuerpo de Capricornio, que es commo atamiento, et es que Ihesu Cristo en este mundo tuerçe los malos e dales penas por el mal que ffizieron e átalos que dallí adelante non pueden ffazer mal. La vii ${ }^{\mathrm{a}}$, que es commo manera de sserpiente de que sse espantan e han miedo los

I5 que la veen, esto muestra el día del juizio; que uerná Ihesu Cristo tan temeroso que çielo e tierra e todos los ssantos tremerán antél. Et aun sserá mayor, que aquellos que flueren ssantos e buenos ternán que auerán errado, por que merescan alguna pena. Et los que erraron uerdaderamientre ssabrán que auerán pena ssin ffin.

2o Onde por todas estas rrazones Ihesu Gristo ffué el Gapricornio derecho e él deue sser aorado, que non la ymagen de las estrellas.

[Ley LXV]. - De cómmo las propriedades que dauan a Aguario, a Thesu Cristo las douyeran dar, que las ouo en ssi conplidamientre.

25 Aquario es el onzeno ssigno. Et éste ba vna ffigura que dizen que ha en el octauo cielo, de estrellas menudas ffiguradas commo omne que vierte agua con vna cosa que es flecha de cuero, a que llaman en aráuigo lalaul. Et las propriedades que dieron a éste, Thesu Gristo las ouo. Ca él vierte las aguas uerdaderas en ssiete 30 maneras : la primera, de las ffuentes; la $\mathrm{ii}^{\mathrm{a}}$, de los arroyos que salen dellas; la terçera, de los rríos que sse fazen [35v] de los arroyos que entran en ellos; la iiii ${ }^{a}$, de las lagunas e de los estanques

I braços [ $\left[\begin{array}{ll}E & 4 \\ 4\end{array}\right]$ ]. - I-4 $T$ omile Onde ... derechos. -5 ayuntaron en Ihesu. - 6 Dios padre mostro. $-6-7$ de su f. I. C. qual. - I3 puedan. - 16 temeran. - 17 fueron. - 18 avran. - 19 avran. - 23 Cristo fuera a dar. - 25 Aquirio/ signo que esta en vna. - 27 es estrecha de. $-31 \Upsilon T$ los que. 
que sse ajuntan de la lluuia; la $v^{a}$, de los arroyos e de los rríos que corren de nueuo quando ffaze los grandes aguaduchos; la vi ${ }^{a}$, de las aguas que ffazen los omnes yr por ffuerça de vn logar a otro; la vii ${ }^{a}$, de la mar.

La primera, que vierte las aguas de las ffuentes, ésta ha Ihesu 5 Cristo enteramiente; que él es ffuente viua e uerdadera e nasçe ssienpre contra el ssol, que es ssu padre e Dios viuo e uerdadero onde a el poder de dar vida en dos maneras: la vna, a los que biuieron naturalmiente; la otra, a los que yazen muertos en peccado. La ssegunda, assí commo los arroyos ssalen de las ffuentes, io assí de Nuestro Ssennor Ihesu Cristo ssalen muchas graçias con que ffaz merçet a los que él ama, ssegunt dixo Ssant Paulo, que por el Spíritu Ssanto que él enbió ssobre los apóstoles les ffizo entender muchas cosas e muchas maneras de los lenguaies que las otras gentes ffablauan, ssegunt es ya dicho en otro logar, et así i 5 commo entender los ssaberes e ffazer entender las palabras dellos ssegunt eran e otras cosas muchas ssemejantes dellas; que eran commo arroyos que ssalieron del ssaber de Ihesu Cristo, bien assí commo los que ssalíen de las ffuentes. La terçera, bien assí commo los arroyos sse ayuntan muchos en vno e sse ffazen grant rrío, assí 20 las graçias de Ihesu Cristo Nuestro Ssennor, quando sson ayuntadas en vno, ffazen rrío ffazer conplido en que se pueden bannar los peccadores e alinpiarsse de ssus peccados e ffazer perder sset de la calentura del diablo, que los ffaze peccar. La quarta, que assí commo de las lagunas e de los estanques que sse ajuntan de la 25 lluuya, en que beuen los omnes e las animalias e las otras cosas, esto es la graçia de Nuestro Ssennor lhesu Ciristo, que viene del çielo assí commo lluuya; e sse ayuntan en vno e beuen della los justos e los amigos de Dios et los peccadores, que otrossí lo han mester commo las animalias. La $v^{\mathrm{a}}$, los rríos e los arroyos que 30 corren de nueuo quando ffaz los grandes aguaduchos, esto es la graçia del Spiritu Santo, que viene del çielo, que enbía Dios Padre

I-2 luuia la quinta de los r. e de los a. que. -2 faze $[E 440] / T$ las g. aguaduchs ; $E$ las g. aguas duchas. $-\mathbf{a}-3$ la sesta que. -5 vierten. -7 padre Dios. - 8-9 $T$ los biu. - 13 que enbio el s. los a. los fizo. -14 e de muchas. - i $j$ segunt ya es dicho. - $r_{7} T$ era en otras / semejantes destas que fueron. - Ig salen. - I9-2o bien c. quando los. - a de N. S. I. C. q. son ayuntados. - 22 lazen $t$. rrio conpl. -23 pecadores e fazer. - 34 del entendimiento del $\mathrm{d}$. que nos faze. -26 luuia. - 28 luuia / ayunta. -29 pecadores otr. - 3 I las g. aguas duchas. 
por ssu fijo Ihesu Cristo ssobre ssus amigos e ssobre los que él ama e ssobre los que an mester; e rreçibe cada vno della, quien arroyo, quien rrío, ssegunt su mereçimiento. $\mathrm{La} \mathrm{vi}^{\mathrm{a}}$, de las aguas que uan por maestría de vn logar a otro, esto ono lhesu Cristo;

5 que él ffizo por ssu ssaber que ffuessen las aguas de su piedat a los coraçones de los omnes e los amollentase que estauan ssecos e duros en peccado. La vii ${ }^{\alpha}$, assi commo el agua de la mar ha en ssí quatro cosas estrannas - la vna, que es muy clara ; la otra, que es amarga; la otra, ligera para andar en ella; la quarta, enbargosa Io para andar por ella por rrazón de las ondas que en ella sse mueuen, pero el ssaber del omne da rrecabdo e vençe todo esto - , assí Nuestro Ssennor Ihesu Cristo, con la bondat que ha en ssí de la carne e con la vertud spiritual del Padre, ssopo andar muy ligeramiente ssobre los tormentos del mundo, que es la mar, e del I5 diablo, que es el viento que mueue las ondas. Et lo que es agua clara e amarga, eslo sse entiende por los sabores del mundo, que parescen bien $[36 r]$ a los que los aman, et después amargan; que los ffaze perder el amor de Dios e yr a ynffierno. Esso mismo se entiende por la ligereza del agua de la mar; que entran los omnes a 20 nadar en ella de ligero, e después sson enbargados de ssalir della - por las ondas que los enbargan. Assí los omnes sson ligeros de entrar en peccado e enbargo de salir dellos por las ondas del peccado e del enlazamiento del diablo, que los cubre e non los dexa ssalir. Onde Nuestro Sennor Ihesu Cristo ssopo andar ligeramiente sobre 25 estas aguas, en que todos los otros sse ssumurgujauan, ssegunt dixo Dauid: El que anda ssobre las aguas de la mar e ssobre las pénnolas de los vientos; que sse muestra por la grant ligereza dellas. Et por ende los que aorauan al ssigno del Aquario, a Nuestro Ssennor Thesu Cristo lo douyeran ffazer ssi de buen entendi30 miento ffuesen.

a $T$ ama ssobre / quel. - 2-3 della que rrio que a. segunt. -4 otro $[E 45 \mathrm{r}] .-$ 7 duros e en pec. (e añadido sobre la línea, otra mano). - 8 la primera. -8-9 otra amarga. - 10 mueue. - 11 omne darrando e. - ${ }_{7} T$ paresce. 18 perder amor / al inf. - 19-20 omnes e entran en. $\rightarrow$ 2o enbargo / $T$ dellas. - $2 \mathrm{I}$ les enbarga. - 22 peeados e. - 22-33 hondas del enlaz. - 24-25 ligeramente en estas. - ${ }_{2} 5$ somurgauan. $-{ }_{2} 6-37$ e sobre ellas ponen las de los vientos. - 28 dellos / aoran el s. de Aquirio. - 29 deuieran. 
[LEY LXVI]. - De cómmo se muestra que los que aoraluan el ssigno de Pisçis, a lhesu Cristo lo douyeran ffazer.

Pisçis es llamado el dozeno ssigno. Assí auye nonbre porque dizien que auya vna ffigura en el çielo de dos pesçes que estaua en la cabeça del vno con la cola del otro. Et las propriedades que 5 dauan a este ssigno auya en ssí muy conplidamientre el Nuestro Ssennor Ihesu Cristo en ssiete maneras: en cómmo ffué ffecho; que ffué ffecho en agua clara e linpia; de cómmo sse fforma; la quarta manera, de cómmo biue el pez; cómmo pone ssus hueuos; de cómmo quiere ssus ffijos; [de cómmo está ascondido sso el 10 . agua].

Que bien así commo el pez sse fiaze de vn grano ssolo de aquellos de los hueuos, assí Nuestro Sennor Ihesu Cristo ffué ffecho de vn padre solo spiritual, que es Dios. Que assí commo el pez se ffaz en el agua clara e linpia, assí Nuestro Ssennor Ihesu Cristo 15 se ffizo en Santa Maria, que flué linpia e clara en cuerpo e en alma. Que bien así commo el pez se forma de aquel grano mismo onde es, así sse fformó Ihesu Gristo della ; ca la carne de Santa Maria ffué materia en que él fformó èl Spíritu Santo ffué fforma que ssopo fformar e ayuntar en vn cuerpo Dios e omne. La vida que 20 el pes ffaze después que es fformado, ffaz que come de aquellas cosas menudas que ffalla en el agua a que se él treue de que non rreçiba enbargo ; et desí, quando es mayor, come de las mayores segunt ua creçiendo. Et así es Nuestro Sennor Ihesu Cristo ; pu-. diendo fazer miraglos tan bien quando era ninno commo después, 25 non los quiso ffazer estonçe ssinon ssu edat ssemejante. Otrosí Nuestro Ssennor Ihesu Cristo ssemeió al pez en auer criança; que assí commo crían ellos cabo la tierra, poniendo ssienpre ssus hueuos, otrossí Nuestro Ssennor Ihesu Cristo ffizo peçes a los ssus ssieruos que crouyeron en él e púsolos cabo la tierra, que sse 30

I $T$ muestra los. - 2 deviera. - $3 T$ auyen. - 4-5 estauan la cab. (en escrito y tachado delante de la). - 7 maneras e commo. $-8 \mathrm{~T}$ ffecho agua. - 9 el $[E$ 450 $]$ pes e commo. - ro quier. - I 13 a aquellos hueuos. - 16 fue c. e l. en cuerpo. - 17 donde. $-17-18 T$ onde asi. -18 dellas. - I9 formo e el. - so cuerpo de Dios. - 23 a que el se t. por que. $-{ }_{2} 3$ rresçiba danno e enb. - 24-25 podiendo. $-26 \mathrm{~T}$ quisi. $-26-27$ hedad semeio o. semejo N. S. I. C. a los peçes. -28 comiendo. - 3o creyeron. 
entiende por el mundo, en logar do los ffiriese toda via el agua biua, que se entiende por la su criança. Amuchiguaron de guisa que doze apóstoles que ffueron llegaron de más en la cuenta a ssetenta e dos disçiplos, e desí a la mayor partida del mundo que

5 sse conuertieron a la predicaçión. Et por esto dixo él a Sant Pedro e a Sant Yague e a Ssant Ioán e a Sant Andrés, que eran apóstolos en qui él más ffiaua, quando los vió andar $[36 v]$ pescando, que sse viniesen para él e que los ffaría pescadores de los omnes, commo los ffizo después; que ellos ssopieron pescar de guisa que todo lo 10 más e lo meior del mundo conuertieron. Que así commo los peçes, quando sson fformados ssus fijos, los muestran a nadar, yendo toda vía adelante ellos e ffaziéndolos mouer poco a poco e tornándose a ellos; assi Nuestro Sennor Ihesu Cristo, adelantándose entre los suyos, e ssubió a los çielos e desí tornóse a ellos, enbiándolos I5 la su graçia del Spíritu Santo, por que los mostró la carrera por que ssubiesen o él subiera nadando, que se entiende pasar sobre los tormentos de las ondas del mundo. Los tienpos que el pez está so el agua es quando pone sus hueuos e quando ffaze grant frio, e después sale quando los ha puestô quando ffaze buen tienpo e ca-

20 liente. Otrosí Nuestro Sennor lhesu Cristo primero estaua ascondido; que la su ffe con pocos la començó, que era commo cosa encubierta e ascondida. Mas después que la ouo ordenada e enderesçada, salió con ssus ffijos e ffízola entender al mundo. Et otrosí estido ascondido mientre duró la pasión, ordenando con el Padre 25 en quál guisa auya a pasar por ella e morir e rresuçitar. Et después que la ouo ordenada, salió a padesçer por su cuerpo. Onde los que orauan al ssigno de Pisçis, a Ihesu Cristo quisieran aorar ssi sopiesen cómmo él era pez uerdadero, ssegunt estas rrazones que de suso sson dichas; et segunt cuenta de Tobías, que el ángel 3o Rraphael tomó la fiel del pez, con que segudó los diablos.

Estos doze ssignos que auemos dicho, segunt el entendimiento spiritual, son estas propriedades que ha en el Padre e en el Ffijo

1 o los feriese. - 2 E estos amuch. -4 sesenta. - 6 Yago / $T$ Ioan (con la letra $\mathrm{h}$ escrita y tachada después de $\mathrm{I}$ ). -7 en qui mas el se fiaua. $-9 T$ todo Ja. - ro de todo el mundo / el pes. - i i muestra / $T$ muestran andar. - 12 delante dellos. - 13 adelantase. - I4 al çiẹlo desy / enbiando[ $E$ 46r]les. - 15-16 graçia e del Spir. S. con que les muestra la c. por do s. a el sub.17 $\mathrm{E}$ los. - I9 $T$ sale a los paslos q. ffaze -23 Otrosy. -24 estudo a. mientra / hordenando en el. -27 Cristo auyan aorar. -28 supiesen. - 29 cuenta en T. de commo el. $-3 o$ T omite tomo ... diablos. - 3r $T$ Commo doze / dichos . 
e en el Spiritu Santo, que son tres personas e vn Dios. E segunt el tenporal, son los doze apóstoles, así commo dixo Sant Johán enangelista; que assí commo estos doze signos muestran la uerdat de las vii planetas, assí los xii apóstoles muestran la uertud de los vii sacramentos de Ihesu Cristo, que flueron puestos e orde- 5 nados en Santa Eglesia contra los vii peccados que los omnes fazen en connosçer las estrellas e aorarlas, que eran ffechuras, e non querien connosçer nin aorar Dios, que las ffiziera. Et los nonbres de los peccados diremos primeramiente, e desí quáles rremedios tomaron los santos para tollerlos.

[LEy LXVII]. - Commo Tolomeo fabla altamiente en ffecho de astrología, asíffizo Sant Iohán en las propriedades de Dios.

Tolomeo ffué vno de los grandes philosofos que nunca ouo en la arte de astrología; ca éste ffabló más al to en fecho de los çielos et de las estrellas que otro que ffué. Et departió más de cosas en I 5 ffecho de las planetas e de los ssignos que otro; ca ffué omne que entendió e punnó en saber más las poridades de los çielos.

Et aquella carrera misma touo Sant Iohán enangelista entre los apóstolos e los otros ssantos; ca así commo Tolomeo ssiguió la manera de las crençias antiguas que creyen las gentes, assí Sant 20 Iohán ssiguió otrosí las maneras de las crençias nueuas de Ihesu Cristo. Et sopo tanto de las poridades que ouo de ffazer libro, que llaman A pocalipsi, que quier dezir en griego visiones marauillosas de los secretos de Dios. E este libro es partido por cuento de siete e de doze, en que mostró el cuento derecho de las siete pla- 25 netas uerdaderas e de los doze signos. [37r] Et dixo que en vna de aquellas visiones que viera en el çielo ssennal grandề marauillosa de vna mugier que está vestida del ssol e que tiene la luna sso ssus pies, que sse entiende por el mundo, que non está en vn estado, que ssienpre creçe e descreçe; e la corona que teníe en la cabeça $3 o$ de las doze estrellas da a entender por los doze apóstoles, que esta-

I-2 segunt tenp. - 3 asy es commo. - 4 la verdad. - 7 fechura. - 8 aorar a Dios. - i De commo. - Í el arte / mas en. - i5 $T$ et lo destas estr. / fuese / mas cosas. - $16 T$ planetas de. -17 pugno / çjelos [E 46v]. - I9 que/ seguio. - 2 I seguio o. la manera de la creençia nueva. 22 fazer el libro (el añadido sobre la línea, otra mano). - 27-28 marauillosa vna muger (duenna escrito $y$ tachado, $y$ vna añadido en el margen, otra mano). -28 estaua / tenie / so los. - 29-3o estado mas sienpre. - 3o decresce / tiene. 
bleçieron e ordenaron la ley de lhesu Gristo, del qual ella ffué coronada.

Onde las siete planetas, de las quales ffué primeramiente ante Salurno, sse entiende por Dios Padre, que está en el más alto çielo. 5 Et aquél es llamado con derecho vieio porque nunca ouo comienço, ssegunt dixo Ezechiel propheta, que viera el antigo de días, cuyos annos non podrian sser contados. Et Ssant Iohán dixo otrossí en el Apocalipsi que viera en el çielo Dios sseyendo en ssu ssiella, e auye la cabeça más blauca que la nieue. La ssegunda planeta, a Io que llaman Jupiter, ssigniffica a Nuestro Ssennor Ihesu Gristo, que ffué derechero e justiçiero e leal dador de paz et uerdadero en todos ssus ffechos et amador de todo bien. La terçera planeta, que Ilaman Mars, ésta sse entiende por el Spíritu Ssanto; que es todo bueno a ssemeiante del ffuego que ssale del Padre e del Ffijo e ençiende las

15 uoluntades de los omnes en amor de Dios e de las cosas que sson derechas de amar. Et éste uençe ssienpre los enemigos assí commo los diablos e el mundo, e amolleçe los coraçones de los omnes ffuertes e duros, ssacándolos de la mala crençia e partiéndolos de las malas obras. La quarta planeta, que es el ssol, que es noble 20 así commo el poder de Dios; que alunbra e esclareçe las cosas, queriendo que ssea cada vna segunt deue, bien commo el sol ha poder de ordenar ssegunt ssu natura las cosas que nasçen de la tierra. La $v^{a}$ planeta es Venus; que así commo ésta da uoluntades de sabiduria de amor, assí el saber de Ihesu Cristo mostró 25 muchas carreras por do ssopiesen a Dios connosçer e amar e temer, por que amándol uerdaderamiente, él los ouyese a amar. La ssesta. planeta, a que llaman Mercurio, sse entiende por el querer de la buena uoluntad de Dios en tornar a auer merçet a aquellos que mereçen pena. E ffaz otrosí que las cosas ascondidas que non sabe 3o ninguno ssean maniffiestas e rreçiban por ellas escarmiento los que las ffazen. La vii ${ }^{a}$ planeta es la luna, que sse entiende por las obras de Dios que nasçen del ssu poder e ssabcr e querer; ca bien

I Cristo de que ella. - 3-4 primeramente Sat. que se (ante escrito y tachado. delante de Sat.). - 4-5 çielo sobre todos e aquel. -6 de dios. -7 podien. - II fue en todo e es derechurero e just. - I $2 T$ terçera que. - 13-14 todo bermejo a semejança. -17 el diablo e el $\mathrm{m}$. amoleş̧e. $-17^{-1} 8$ omnes duros e f. s. de mala. -20 cosas $[E 47 r]$. $-23 \mathrm{ca},-23-24$ voluntad (con -es escrito $y$ tachado). $-24 T$ el poder. -25 supiesen. $-25-26$ temer e por. -26 verdaderamente los o. el do amar. - 28 merçet aq. - 29 pena en fazer otr. 3 i es luna. 
así commo la luna es más çerca de nos que Jas otras planetas, assí las obras de Dios andan cada día entre nos. Et ssegunt la luna obra en las aguas e en las tierras e en las otras cosas que sson de ssu natura e ssobre que ha uertud, ssegunt las ffalla apareiadas, et otrossí obra en los omnes ssegunt ffalla endereçamiento o mengua 5 en las uoluntades dellos. Onde éstas sson las vii planetas uerdaderas, que muestran vii uertudes por que es flecho el mundo e mantenido.

[Ley LXVIII]. - De cómmo los xii ssignos son ffechos e conparados a los doze apóstoles.

Signos llamaron los antigos a doze ffiguras de estrellas que estauan en el octauo çielo, que es más alto que los otros ssiete, do estauan las otras planetas; ca dize la Bibria: Ffizo Dios las estrellas e púsolas en el ffirmamento del çielo, que las viessen ssobre la tierra e departiesen el día de la noche [37v] et la luz de I5 las tiniebras, e ffuesen ssennales e mostrasen los tienpos e los días e los annos. Onde el entendimiento desto es assí. Ca las estrellas sse entienden por los ángeles, que de Dios e de Santa María en ffuera sson la mayor lunbre que han en el çielo. Pero las mayores estrellas sson aquellas a que llaman ssignos, que quiere dezir cosas 20 ssennaladas, que sse entiende en dos maneras: Ja vna, que sson ffiguras; la otra, que ffazen ssennales. Et esto sse entiende por los doze apóstoles; ca los puso Dios por connosçer la Trinidat e, connosçiéndola, sser ffirmes en la ley, que es el ffirmar del çielo. Et lo que dizen que puso las estrellas por que luziessen ssobre la 25 tierra e departiessen la luz de las tiniebras e el dia de la noche, sse entiende otrosí que los doze apóstoles que alunbraron el mundo, ffaziendo a los omnes connosçer a Dios verdadero por ley e dexar las erranças en que andauan de las otras ssectas. Et por esso les dixo Nuestro Ssennor Ihesu Cristo que eran luz del mundo, Et $3 o$

$3 T$ otras obras. - 4-5 aparejadas o. obra el en, - 5 cresçimiento (enderesçamiento escrito y tachado, $y$ cresçimiento añadido debajo de la línea,

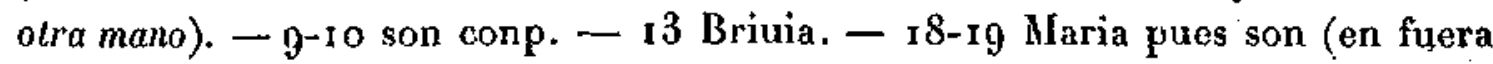
escrito $y$ tachado, $y$ pues añadido en al margen, otra mano). - ig ha. 22 figuras e las otras / sc $\left[\begin{array}{ll}E & 470\end{array}\right]$. 23 ca ellos puso. -24 firmar en el çielo. -25 dize. -37 apostolos al. / $T$ alunbran. -28 faziendo c. a los o. a Dios. - $29 T$ erranças que / andauan las. $-3 o$ era. 
dióles enxienplo de Ia candela que quando estudiese baxa, non daua tamanna lunbre commo ssi estudiese alta. Et en esto les mostró que ellos eran puestos tan altamientre en el çielo que la ssu Junbre paresçrie a todos, por que catarien a Dios su padre en

5 el çielo. Et esto ffué quando desçendió el Spíritu Ssanto sobre ellos e los alunbró los coraçones e la palabra, por que todo el mundo conuertieron a su predicaçión. Et otrosí o diz que departiesen la luz de las tiniebras sse entiende que departieron e flizieron entender a los omnes quál era la vida tenporal e quál la spiritual; ro et quál galardón auyan del bien que ffazien los buenos en parayso, que se entiende por el día, et qué pena los malos por el mal que ffazian en inffierno, que sse entiende por noche. Et lo que dixo que ffuesen por ssennales e por tienpos e por días e por annos, esto se entiende por los apóstoles, que ffueron ssennalados en dos 15 maneras: la vna, que los escogió lhesu Cristo por ssus amigos entre todos los otros omnes quando les dixo que él les podríe bien llamar con derecho amigos porque todo lo que oyera a ssu padre les mostrara; et aun los ssennaló de otra manera, que les dió el ssennal de las ssus armas. Que assí commo él tomó muerte e 20 passión por ellos, que lo rrecibiesen ellos por él. Et otrossí commo él ssanó los demoniados e los enffermos, que assí lo pudiesen ellos ffazer. Et desto dize la Escriptura que por mano de los apóstoles sse ffazían las grandes ssennales e marauillas entre los omnes. Et otrossí los apóstoles mostraron los tienpos e los días e 25 los annos, ffaziendo saber a las gentes en cada vno dellos cómmo auían de obrar en ffazer buena vida en este mundo et yr a parayso después que muriesen. Onde aquellos doze apóstoles ffueron los doze ssignos uerdaderos que parescen en el çielo e alunbran la tierra e departen la luz de las tiniebras e el día de la noche.

I candela quando estouiesen b. e non. - 2 fuese. - 4 paresçerie / acatarien. - 5 Esto fue q. el Spir. S. d. sobre. - 5-6 $T$ Ssanto por ellos. -7 a la su. -8 de la tiniebra. - Io e que g. a. los b. del bien que f. en par. -.. I I $T$ omite que ... dia / pena han los. - I feziesen. - I3 sennales por t. e por d. por annos. - 1/4 por que los/ sennales. - 16-17 el los p. llamar (bien eserilo y tachado después de llamar). - $\mathrm{I}_{7}$ oyeran. - I8 avn las sennales de. - ig la sennal. - ao que asy la rresç. - 2 I sana. - 2 I-22 pueden. - $22 \mathrm{diz} / \mathrm{T}$ Escriptura por. - 23 apostolos faz. - 24-25 apostolos a nos f. saber. -25 vna dellas. -26 obrar para fazer. -27 aquellos [ $E 48 r$ ]. 
[LEX LXIX]. - De cómmo los prophetas mostraron que quatro euangelistas deuen sser e non más.

Euangelistas sson dichas aquellos amigos de Ihesu Cristo que escriuieron la ssu vida e los ssus ffechos que él ffizo mientra andido en este mundo, a que llaman Euangelios, e éstos ffueron quatro: 5 los dos apóstoles, assí commo Ssant Iohán e Ssant Matheo ; e los otros non lo ffueron, assí commo Ssant Marcos e Sant Lucas. Et porque éstos ouyeron en ssí grant entendimiento en connosçer a Ihesu Cristo, que era Dios e omne, et escriuir los ssus fechos, [38r] queriendo que lo ssopiesen por todo el mundo. Et porque ro Ihesu Cristo es Trinidat ; ca Dios ffué en él e él en Dios, ssegunt él mismo dixo: Yo sso en mi padre e mi padre es en mí. Et por ende así commo los prophetas ffablaron en Dios, e queriendo en él mostrar manera de fifigura por que los omnes ouyessen mayor ssabor de connosçerlo e de creer en él e dexar las otras cren- i5 çias uanas, por ende mostraron quel vieron en el çielo commo rey muy noble sseyendo sobre cáthedra de luz, vestido de pannos rresplandientes commo el ssol et teniendo en la cabeça corona de essa misma guisa. Et dixieron que el rrostro dél era commo de llama de ffuego muy clara e los sus cabellos más [blancos] que nieue. 20 Et mostraron otrossí que guardauan aquella ssiella quatro cosas biuas que auyan alma : et la vna ssemeiaua omne; et la otra, león; et la otra, águila; et la otra, toro.

Et estas ffiguras muestran vii cosas en que está ençerrado todo el fecho de la Trinidat. La primera, el Padre, que sse entiende 25 por la cáthedra ; que así commo ella es logar para estar ssienpre queda, assí el Padre es luz, aquel que non sse mueve. Et por ende la ffigura del omne de la perssona que sseye ssobrella sse entiende el Ffijo. Et por la color de la cara bermeia e de las uestiduras de la claridat sse entiende el Spíritu Ssanto. Et las quatro animalias 3o que guardauan la ssiella sse entiende las quatro partes del mundo,

3 dichos. - 4-5 andudo. - 5 llamauan / $T$ euangelistas. -7 non $\mathrm{f}$. apostolos asy. - 8 ovieron grant. - to sopiesen todo. - I2 so en el mi. 13 las prof. -15 -le. -17 sobre la cath. $-{ }^{7} 7^{-} 8$ rresplandesçientes. - I9 commo llama. - 22 alma el vna. - $24 T$ mostrando. - 28 figura de la $p$. del o. que. - 29 bermeja e por las. 
que sson todas ençerradas en él, ssegunt Aristótiles mismo muestra en un ssu libro que llaman De las poridades, en que dixo que los spíritus mayores, que sse entienden por Dios, uuíen en ssí ssiete partes spirituales : la primera, adelante; la $\mathrm{ii}^{\mathrm{a}}$, detrás; la terçera, a diestro; la iiii $^{a}$, a ssiniestro; la $v^{a}$, arriba; la vi ${ }^{a}$, a ffondón; la vii ${ }^{\alpha}$, en medio. Et esto da a entender la Trinidat e la cátedra, e por esso pusieron âquellos que la guardan que auien oios delante e atrás, que sse entiende por Dios, que uee a todas partes que ninguna cosa non sse le puede asconder. Et en medio ro es el alma biua que da vida onde biuen todas las cosas. Et por ende estas quatro animalias dieron ssemeiança a cada vna dellas ssegunt las obras que él ffaze. Ca la vna dixieron que anya fación de omne, e la otra de águila, e la otra de león, et la otra de thoro, ssegunt algunos de los judíos mostracon en vn libro que dizen en 15 ebraico Martala, que ffabla desta rrazón misma. Et muestra la corte del çielo cómmo está e que paresce y Dios en ssí, et ffabla destas quatro animalias que están con él et lieuan la ssu cátedra. Pero algunos y ha que dizen que ffizo aquel libro el rrey Ssalomón por entendimiento de Spíritu Ssanto. Otrossí sse proeua en la ley 20 nueua de Ihesu Cristo, en vn libro que fizo Sant Iohán a que llaman Apocalipssi, en que ffabla desta rrazón misma, pero muéstralo más conplidamientre que los otros. Et proéuasse otrossí por Mahómat, que dizen los moros que ffué propheta de Dios; que él ffizo vn libro a que llaman en aráuigo $A$ mo $\overline{c h} r \overline{c h}$, que quier 25 dezir del ssubimiento. Et esto es porque quiso ffazer [38v] creyente por aquel libro que él ssubiera al çielo e que él viera a Dios e que ssopiera mucho de las ssus poridades. Et dixo cómmo viera estas quatro animalias e ffigurólas así commo auedes oydo. $\mathbf{E}$ puso en ssu rrazón que aquella que auya faz de omne rrogaría 30 a Dios en el día del juyzio por los omnes; et la que ssemeiaua águila, por las aues; et la del león, por las bestias ffieras.... Onde

I-9 mostro [E $48 v$. $-2-3 T$ dixo que de las poridad.es may. -3 entionde / auie. -4 atras. $-5 T$ de diestro, $E$ a distro / a sinistro. -6 Esto da el contender. -8 por que Dios vee. - to las otras cosas. - I $T$ dieron a ssem. - $12 \mathrm{E}$ a la vna/fazion (façion añadido en el margen, otra mano). - 13 e a la otra de ag. e a la otra de l. c a la otra de buey. 14 segunt despues alg. / dizien. - I $7 T$ estauan. - I8 Salamon. - 1 I-22 muestrala. - á Amacherth. - $25 T$ por quiso. $-26-27$ e que $r$ a Dios e supiera. - 27 las por. / dixo que c. que viera (el segundo que lachado, $y$ quier añadido en el margen $y$ luego tachado, todo de olra mano). $\mathbf{- 2 8}$ auedos ya oydo. 
la ley de los judíos e la nuestra e la de los moros e aun la de los gentiles sse acuerdan en estas quatro animalias.

Et por ende los quatro euangelistas ffueron a ssemeiança dellas. Et porque Ssant Matheo ffabló de cómmo Nuestro Ssennor Ihesu Gristo nasçiera e fuera omne, figuráuanle de aquella animalia que 5 auya ssemeiança de omne. Et Ssant Iohán, que ssopo las poridades de Dios e ffabló en ellas, e mostrando la Trinidat e diziendo que Dios era palabra, eque sse entiende por el Ffijo. Et dixo otra uegada que la palabra era Dios, que sse entiende por el Spíritu Ssauto. Et desta guisa mostró que eran tres perssonas e vn Dios. ro Porque él ffabló más altamientre que todos los otros ssantos et el águila bsela más altamiente que todas las otras aues, pusiéronle ssemeiança della. Et aun por otra rrazón que es más çerca désta, que assí commo el águila cata los rrayos del ssol derechamiente que non pestannea nin a uergüença, assí Ssant Iohán cató de- ${ }_{1} 5$ rechamiente a Ihesu Cristo, entendiendo que era Dios uerdadero e omne conplido, e mostrólo más conplidamientre que los otros. Cầ Ssant Marchos pintan en ffigura de león porque él ffabló en la predicaçión de Ssant Iohán Baptista, que andaua en los desiertos predicando que ffiziesen penitençia e sserian ssaluos. Et esto ffazía 20 por toller la presión de los omnes, que tenía el diablo en ssu poder por el peccado que ffiziera Adam. Et por ende Ssant Iohán Babtista andaua dando bozes por los desiertos para caçar los peccados, assí commo el león anda buscando la presa que caçe. Et aun ay otra rrazón semejante désta, que el león quando se 25 leuanta de dormir la primera cosa que ffaze, estiéndese e da vna grant boz et estonçe leuántase con grant ffuerça. Assí Nuestro Ssennor Ihesu Cristo quando se leuantó del ssuenno de la muerte, ffué la boz tamanna desta marauilla que fiziera que todo el mundo lo oyó e lo sopo ; que él sse leuantó con tan grant ffuerça que que- 30 brantó los inffiernos e ssubió a los çielos. Et porque Ssant Marchos ffabló más en 'esta rrazón que los otros, pusiéronle fforma de león. Sant Lucas pusiéronle ffigura de thoro porque ffabló del

9 gentiles $[E$ 49r] - 4 Mateos. - 5 naçio/ $T$ nasçiera de aq. - $6 \mathrm{E}$ a Sant / sopo altas por. - 8 palabra que. - Is E porque ( $\mathrm{E}$ añadido sobre la linea, otra mano). - Ia alto. - 13 es çerca. - 14 ca asy c. al ag. - $15 E$ pestannea (dos palabras, al parecer se tituba, añadidas en el margen, olra mano). - 17 altamente. - 18 A Sant. - I9 Bautista el. - 21 toller de la prision (de añadido en el margen, otra mano). -- 22-23 Sant Juan and. - 24-25 E omite anda... leon. -27 boz e. 1. con la grant. -32 mas desta. -33 posieron. 
ffecho de Nuestro Sennor Thesu Gristo, començando en Zacarías, padre de Sant Iohán, que era obispo de la ley vieia e ffazie ssacriffiçio. E vna de las cosas que vsauan entonçe más de ffazerlo eran toros e vacas, pero que más onrrado teníen el del toro que de

5 otro animal. Et aun ay otra rrazón ssemeiante de ésta, que Nuestro Ssennor Ihesu Cristo ffué rreçebir la muerte de su grrado e ssuffrió que ffiziesen ssacriffiçio de ssu cuerpo mismo, assí commo ffazian de Ios toros en la antigua ley, ssegunt lo dixo el Euangelista, que sse offreçiera quel matasen e ffiziesen sacriffiçio dél por yo saluar el mundo. [39r] E proéuase otrosí quando ffablaua con su padre Dios; que dixo que la su carne auye miedo de la muerte, mas el alma apareiada estaua. Onde por estas rrazones pusieron a Ssant Lucas euangelista en ffigura de toro, e rresponde a la ssemeiança del toro que es en los ssignos del çielo.

[Ley LXX]. - Quánlos sson los ssacramentos e en quántas maneras son guardados e sagrados e qué pro viene dellos a los que los rreçiben.

Sacramentos, ssegunt ordenamiento de Ssanta Eglesia, sson ssiete. Et este nonbre han porque ellos sson sagrados en dos mane20 ras : la vna, por la uertud que rreçiben del ssacramento spiritual de Dios; la otra, por las palabras que dizen ssobrellos aquellos que los sagran. Et la uertud que han çelestial obra en siete cosas nobles e buenas sin las quales el omne non puede sser amigo de Dios, e sson éstas: que lauan; que conffirman lo que an lauado; que 25 castigan los yerros; que conffirman los fflacos de uoluntad; que dan segurança a los buenos; que muestran por ó vaya omne derechamiente a Dios; que ffazen ganar al omne bien en este mundo e en el otro. Et esto ffazen todos los sacramentos ayuntados en vno, mas lo que ffaze cada vno por ssí es que tuelle el peccado 3o daquello contra que ffué puesto.

I de I. G. N. S. c. de Zac. -2 obispo en la, $-3 \mathrm{~T}$ Aun de las / cosas de que (de añadido en el margen, otra mano). - 5 otra animalia / ay [E 49v]. 6 Cristo el fue. - io $T$ prouasen. - I I Dios que la su. - I $3 T$ toro rresp. r6 son sagr. - 17 al que los rresçibe. - 23 syn que omne / amigos. - 34 estos. - $26 \mathrm{~T}$ muestra / muestran carrera por do. $-27 \mathrm{~T}$ ffaze/faze al o. g. bien. - 28 Esto. 
[Ley LXXI]. - Por qué rrazón sson los sacramentos ssiete $e$ non pueden sser más nin menos.

Guento çierto pusieron los ssantos padres en los ssacramentos que non pueden sser nin más nin menos de ssiete. E las rrazones por que lo ffizieron sson éstas. Porque del peccado de Adam nasçie- 5 ron dos males de que rreçibió danno non tan ssolamiente el que erró, mas todos Ios que desçendieron del ssu linage, maguer que non ouyessen errado; que tan grande ffué el ssu yerro que Dios echó ssobre él la ssu maldiçión et ssobre todos los otros del ssu linaje. Et esto es porque el peccado ffué traiçión contra ssennorío, por que 10 han de auer pena non tan ssolamiente los que lo ffazen o lo consseian o ayudan a ello, mas los otros que desçenden de ssu linaje, e nunca pueden sser perdonados de aquella culpa nin sser heredados nin sser par de otros ffasta que los perdone aquel contra quien ffizieron el yerro. Et este juyzio dió Nuestro Ssennor Dios 15 en el comienço del mundo quando ouo ffechos los ángeles. E porque el vno dellos sse touo por más onrrado que los otros e dixo que quería sser ygual de Dios, et ssobre esso, de ángel que era ffízol diablo e echól en el inffierno e deseredól del çielo por ssienpre jamás et diól por enemigo de los ángeles e de los omnes e de 20 las otras animalias que él ffiziera. Et otrossí el omne, que él ffiziera de tierra e metiera en parayso de viçio o nunca muriesse nin enffermase nin ouyesse pesar, desconnosçiendo esto con cubdiçia, queriendo ssaber tanlo commo él, comió del ffructo que él le uedara. E commo lo feziera por que visquiese sienpre, tornól 25 mortal. Et a lo que él non auya de auer enffermedat nin muerte nin pesar, ffizo que lo ouyese en ssí todo e lo ssintiese más que otra criatura.

3 Cuenta çierta (-mente escrito y tachado despacis de çierta). - 4 ser mas. - 6-7 solamente ol mas t. los que de su l. d, maguer (cl añadido sobre ta línea, otra mano). $-8 \mathrm{ca}$. - 8-9 yerro que la $m$. de Dios echo s. cl e s. t. los o. de su lin. - ro porque $[E 50 r$ ], - 10-I I trayzion c. el s. por que avn dan pena. - I 1-1 3 fazen e los que lo s. e le ayudan. - I 2 desçienden. 13-14 herederos. - 14 perdonen aquellos. -- 15 fezieron yerro. - 15-16 Nuestro S. Ihesu Cristo mismo en. - 16-i 7 angeles porque. -- I9 -10 / - 10 / - - 30 -lo. - 23 tierra e lo $\mathrm{m}$. en p. de deleyte do. -23 pesar e desconossiendol esto todo con. $-{ }_{35-26} T$ amite $\mathrm{E}$ commo ... mortal. $-25 E$ añade por, o quiza para, sobre la línea, olra mano. -26 que non. -27 fizole que lo o. t. e que lo sentiese. 
Et aun ay otra rrazón por que sson ssiete ssacramenlos, porcque en cada vno dellos gana [39v] omne vna vertud de las ssiete que de ssuso son dichas : por el baptismo, la ffe ; por la conffirmaçión, la esperança; por la penitençia, karidat, que es amor de Dios; por 5 la comunión, flortaleza, que es creer ffirmemiente; por la estrema vnçión, seso ; por la orden, mesura ; por el matrimonio, justiçia, que sse entiende auer cada vno lo que mereçe.

\section{Ex LXXII]. - Quántas maneras de clérigos pueden dar los ssacramentos conplidamente.}

Io Dos maneras ay en que se pueden dar estos sacramentos por ssiete maneras de omnes. Et la vna déstas es [los] sagrados e ordenados para ffazer los ssacramentos. Et esto sse entiende por los prelados clérigos o rreligiosos. La otra es de aquellos que non han orden ninguna para poder ssagrar, porque sson legos. Et las ma-

15 yores perssonas que esto pueden ffazer sson ssiete: primeramiente, el papa ; patriarcas ; primados ; arçobispos ; obispos ; cardenales ; prestes.

Ca éstos pueden dar todos los ssiete ssacramentos o algunos dellos. El papa los puede dar conplidamiente por rrazón de Ssant

20 Pedro, cuyas vezes tiene, a qui Dios dió las llaues del çielo para ssoluer e ligar. Et por ende ha poder de dar los ssacramentos ssobre todas las cosas que sse pueden ssagrar. Patriarcas pueden dar estos ssacramentos por las uezes que tienen de Abraam e de Ysaac e de Iacob, que ffueron padres de aquellos que mantouyeron la $\mathrm{Ffe}$ 25 uerdadera, mostrando a los otros carrera de ssaluaçión, e ffueron arcas de las poridades del ssaber de Dios ; ca ellos ffizieron entender a los del mundo cómmo deuen creer e connosçer a Dios e aorar a él, e non a los çielos nin a las estrellas nin a las otras cosas que aorauan. Ca Dios era ffazedor e lo al todo su ffechura.

4 que nos es. -5 fortaleza en la fee e on creer. -7 entiende para aner. 9-ro $T$ omile conplidamente ... sacramentos. - I $T$ maneras dos omnes / $T y$ $E$ es dos sagr. - 13 clerigos rrel. - 15 que [E 50v]. - 16-17 patrjarchas arç. o. c. prim. prestes. - $18 \mathrm{E}$ estos / alguno. - so a quien / de los rregnos de los çielos. - 23 Ysac. - 24 Jacob e Josep que f. padre (e Josep añadido en el margen, otra mano). $-26 \mathrm{~T}$ arcas del s. las p. de Dios. - 27 deuien. $28 T$ sielos nin a las otras. - ag todo era fech. I $T$ añade su sobre la línea. 
Primados tanto quiere dezir commo adelantamientos que han omnes en algunas tierras ssennaladas por poder de Dios o por ssennor tenporal, o porque ssepan sser tales que los de la tierra misma los tomen por primados. Onde éstos ffueron los santos padres que ayuntaron todas las prouinçias del mundo a Dios e 5 ffueron adelantados dellas, mostrando la $F$ fe e ffaziéndola tener. Et esto se proeua por Ssant Yago, que touo primaçía entre todos los apóstoles en el çielo porque rreçibió primero martirio por Ihesu Cristo. Arçobispo quier dezir cabdiello de los obispos; ca ssi los obispos erraren en alguna cosa, él lo deue ffazer entender, ssegunt 10 sse muestra adelante, e éste ha poder otrosi de dar los ssacramentos. Obispos tienen logar de los apóstoles; ca éstos an poder de ssoluer e de ligar, bien commo ellos auyan, e dar los ssacramentos. Cardenales otrossí sson commo disçiplos que andauan con lhesu Cristo e aprendien dél ; assí los cardenales andan con el papa, sseruiendo I5 la ssu corte, que es logar ssennalado de Ssanta Eglesia do sse muestra la $\mathrm{Ffe}$ más conplidamiente que en otro logar. Et por ende, assí commo los disçiplos eran seruidores de Nuestro Ssennor Ihesu Cristo, aprendiendo la Ffe e demostrándola, assí los cardenales tienen logar de estar ssienpre sseruiendo la Eglesia e guardar la 20 Ffe. Et assí an ellos poder de dar estos ssacramentos por rrazón de cardenaría saluo ssi non ouyere orden de preste. La ssetena manera de los omnes que pueden dar los sacramentos sson los prestes, que quiere dezir missacantanos, que ffazen cutianamiente quando dizen la misa el ssacriffiçio de Nuestro Ssennor Ihesu 25 Cristo ; ca ellos pueden dar de los ssiete ssacramentos los çinco que sson baptismo e penitençia e comunión e estrema vnçión e [40r] matrimonio.

I Primado, - I-3 adelantamiento que ha el omne en vna lierra sennalada por p. de Dios o de s. tenp. e porque sepa ser tal. - 4 misma le tenien (tengan añadido en el margen, otra mano) por primado. -6 dellas en ellas mostr. - 7 Esto / tiene. - 8 los otros ap. / muerte. - $9 \mathrm{E}$ arç. - io fazer emendar. - 12 tienen el lugar. - I3 auien e de dar. - 15 e la apr. - $16 T$ ssennalada. - I 7 por $[E 5 / r]$ - - $18 T$ sseruidumbres / de Ihesu. I 9 amostrandola. - 22 cardenalia / ouiese. - $33-24$ son prestes. $-24 T$ quieren. -27 bautisroo p. com. 
[LEx LXXIII]. - Quántas maneras de prelados rreligiosos pueden dar los ssacramentos.

Prelados ay otros de ssiete maneras que sson rreligiosos que pueden dar algunos de los ssacramentos. El éstos sson assí commo 5 abbades, priores, sopriores, guardianos, ministres, maestros, comendadores. Et las maneras por que los deuen dar sson ssiete, pero déuesse entender desta guisa. La primera, que los abbades pueden dar orden de rreligión a ssus menores. Et así cada vno de los otros prelados rreligiosos en ssu rreligión. La ssegunda, Io otrossí pueden dar los ssacramentos en toda iglesia, rrogándogelo el mayoral della e non de otra guisa. La terçera, baptismo pueden dar otrosí quando mester fuere, non auyendo y otro que lo ffaga, mas non han de yr a buscar a otro logar a quien lo den. Et ssi ge lo non rrogaren, non han de tener pila connosçida en su I5 monesterio para baptizar. La iiii" ${ }^{\circledR}$, esso mismo de las penitençias; que puede penitençiar a todo omne que lo ouyere mester, non auyendo y otro que la dé, o con liçençia de aquel ssu conffesor que era tenido de dar la penitençia. La quinta, esso mismo puede ffazer ssi ouyese sseydo ante ssu maestro de aquel que sse qui20 siesse conffesar, e el otro le enbiase rrogar que ffuese a él o lo veniese a buscar. La ssesta, otrosí tal sseríe en poder de dar la estrema vnçión. La vii ${ }^{\circledR}$, e avn del matrimonio, puede sser ffecho desta guisa ; ca pasando el rreligioso por aquel logar o sse ouyese a ffazer el matrimonio, e non auyendo y clérigo o otro que lo die25 sse e rrogándogelo aquellos que lo ouyessen a rreçebir, puédegelo dar. Mas non ge lo puede ffazer, yendo a buscar los lugares do se han a fazer los casamientos, auyendo y clérigo que lo fliziesse o otro alguno en qui sse acordasen los desposados o los nouyos que los desposassen o que los diessen bendiçiones. Onde en estas 3o maneras que sson dichas pueden los rreligiosos dar los sacramentos, e non de otras.

2 deuen. -5 guardianes ministro maestres. -6 maneras que. -7 deue. - 9 en cada una su. - io $T$ en otra manera rrog. - 11 mayor / $T$ mayoral e. - I1-12 puede. - I $T$ mester non. - I3 yr a otro l. b. a quien. - I6 ca. - 17 otry. -- I9 seydo su $\mathrm{m}$. de ante de aquel. - $20 \mathrm{~T}$ o el otro. - a $\mathrm{T}$ enbiase el buscar / $T$ poder dar. - $22 T$ La vii ${ }^{a}$ del / matrymonio [E $\left.5 / v\right]$. $24 T$ o non / auiendo c. otro. - $25 T$ o rrog. / los que lo o. de rresç. $-26 T$ non que lo / pueda. - 26-27 $T$ omite yendo ... fazer. -- 29 oles. - 30 pueden dar los r. los sacr. 
[LeY LXXIV]. - Por quáles rrazones pueden dar los legos los tres sacramentos que son baptismo e penitençia e casamiento.

Legos han poder de dar algunos destos ssiete ssacramentos, ssegunt aquí sserá contado. Et esto por ssiete rrazones que sse dirán en esta ley. Pero esto non puede sser ffecho ssinon en tres 5 sacramentos, assí commo en baptismo e en penitençia e en desposorio. Ca baptizar puede, sseyendo la criatura pequenna en peligro de muerte e non auyendo preste nin otro rreligioso que lo ffaga; otrossí ssi ffuese otro omne grande de otra ley que sse quisiese baptizar luego e demandase baptismo affincadamiente e non ouyese ro y quien ge lo dar ssinon el lego, o ssi ffuesse ya baptizado otra uez quando ninno aquel que lo demandase e non lo sopiesse él nin el que lo ouyese a baptizar. Penitençia puede dar otrosí el lego a otro que ge la demandase, estando en perigro de muerte por alguna manera e non ouyesse y clérigo que ge la diese. Otrossí en el desposo- i5 rio o en el casamiento, ca los desposados o otros quieren ffazer jura en poridat, ssi clérigo y non ouyese, valdrian las palabras e las posturas que entre los legos pusiessen por ssienpre.

Ca las ssiete rrazones que dize de ssuso en esta ley que sse mostrará adelante por que los legos pueden esto ffazer sson éstas : 20 porque la ffe rreçibieron de cristiandat; porque la frazen en [40v] ffiuza çierta que ualdrá; porque la ffazen âquellos que la demandan; porque es ffecha por cosa que non puede sser escusada; porque sse ayunta la uertud del que la demanda e del otro que ge la da en vna crençia; que allí do es ayuntada la uoluntad de estos 25 dos, luego es alli ayuntada la de Dios, ssegunt él mismo dixo: Do ffueren dos o tres ayuntados en el mi nonbre, yo sso en medio dellos; porque estos ffechos todos sson ssacramentos ssantos, ca sse comiençan en Dios e sse acaban en él. Et por esso quienquier que los ffaga, clérigo o lego destos que dixiemos, ha uertud con- 30 plida.

I pueden los 1. dar los tres. - 2 bautismo pen. - 3 destos sacr. 4 contenido. -7 pueden en s. Ja creatura. -8 otro de rreligion que. 9 fuese ompe. -14 peligro. -16 e en. $-I_{7}$ y ouiere valdran $/ T$ valdria. I $7-18$ e la postura que ante los 1 . posiere. - ig dizen. - 20 delante por los 1 . podrien. - 2 I $T$ ffazen e en. - 22 faze a aq. -23 porque [E 52r]. - 23-ah escusado e porque. $-24 T$ o. -26 es y ta virtud de. -28 fechos son $t$. sacr. $e$ santos. - 29 comiença / acaba / quiquier. - 3o faga quier c. o l. que destos. 
[Ley LXXV]. - Por qué rrazón es llamada la Eglesia cathólica.

Católica es llamada la Eglesia, que quier dezir tanto en griego commo cosa ssagrada lo más que puede sser por rrazón de ssantidat, porque en ella se ayuntan los ffieles de Dios por ssiete j rrazones : quel connoscan por Dios; quel deuen aorar et loar el ssu noubre omillosamiente; quel connoscan ssennorio ssobre los cuerpos e ssobre las almas; et porque la eglesia es logar do sse mienbran los omnes de los yerros que han ffecho más que en otro logar; et connosçiendo a Dios los yerros que han flecho, allíl Io piden merçet que los perdone, entendiendo que tan grande es el yerro que el omne ffizo contra él que emienda non ha ssi la ssu merçet nol acorre; et después que los ouyere perdonados, que les ffaga bien en este mundo, dándoles buena vida e abondo de las cosas que ouyeren menester; et que los guarde de enffermedat e

I5 de mal e de coytas e de pesares e que les dé parayso a las almas quando flinaren. Onde por todas eslas rrazones deuen sser dados los ssacramentos en la eglesia más que en otro logar, saluo ssi acaesçiesse alguna de las cosas que sse han a ffazer en hora de priesa que sson dichas en la ley ante désta, por que sse ouyesen a 20 flazer en otro logar.

\section{[LEy LXXVI]. - Quáles ssazones deuen sser catadas para dar los sacramentos.}

Sazones deuen sser catadas para dar los ssacramentos, e esto por ssiete rrazones, que sson éstas; porque el tienpo muestra quál 25 es la obra en ssí ; e el logar o deue sser ffecho; et el ffazedor que la flaze o manda a otro que la ffaga ; et la manera ssi es ffecha en la ssazón que deue; [que creçe ssu uertud quando es ffecho en la ssazón que deue]; que tuelle e arriedra el danno quando es ffecho commo deue; et de la pro quel aduze quando es ffecho en buena 3̋o ssazón.

I es la E. Il. cak. $-4 T$ porque se. -5 que lo c. por Dios e quel. $-7-8$ lugar en que se remienbran. -8 fechos. $-8-9 E$ omite mas...

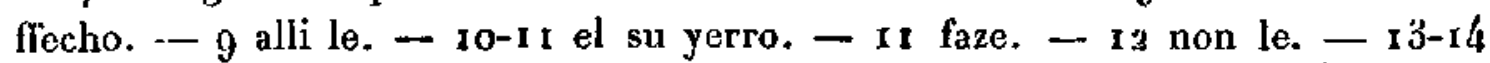
de lo que on. - I 4 enfermar. - 19 oujese. -20 en este lugar. -23 dar estos sacr. - 34 el $[E 52 v]$. - 25 sy el l. onde d. ser fecha e el fazer que. 26 manda otri. - 29 deue la pro que ad. 
La primera, porque el tienpo muestra quál es la obra en ssí, esto es cosa que paresce ssienpre. Assí commo el tienpo de la ssementera es meior para ssenbrar que otro e el tienpo que es maduro el fruto es meior para coier, assí a ssemeiança del tienpo dan los ssacramentos quando los demandan, los vnos apressurada- 5 miente et los otros más de uagar. La ssegunda, que el logar muestra el tienpo, que es porque todos los sacramentos más conuyene que sse fragan en la eglesia que en otro logar, ssegunt de ssuso dixiemos. Et esto que ssea en el tienpo que están los omnes ayunos e non en otro, nin después de comer ssi non acaesçiesse en alguna 10 priesa por que non pudiessen al ffazer; ca derecho es e rrazón que en logar tan noble commo éste, en que sse ffaze el cuerpo de Nuestro Ssennor Ihesu Cristo, que entren y los omnes a rreçebir los sacramentos en ssazón que non ayan comido nin beuido. Et por ende el logar muestra la ssazón. Et [41/] el ffazedor que fliziere 15 los ssacramentos o diere a otro ssus uezes que los flaga deue sser ssabidor de los ffazer en tres manelas: la vna, crençia; la otra, con deuoçión; la otra, linpiamiente. Et quien assí non lo ffaze yerra contra Dios e contra ssí mismo. Pero toda vía ualen los ssacramentos. Dados deuen sser otrossí en todo tienpo los çinco 20 sacramentos que todo omne deue rreçebir por ffuerça de ley, mas los dos de voluntad, assí commo orden e casamiento, sse deuen dar quando sse acordaren e lo demandaren aquellos que lo quisieren rreçebir. Et aun sseyendo el ssacramento ffecho en la ssazón que deue, creçe ssu uertud al quel da e esffuerça al quel rreçibe. 25 . Otrossí tuelle e arriedra el danno e la uergüença quando es ffecho commo deue; que podríe rreçebir tan bien danno el ffazedor commo el rreçebidor ssi assí non sse ffiziese. Et aduze pro, ca plaze a Dios, quando sse ffaze en el tienpo que ordenó Ssanta Eglesia por él. Et non tiene pro tan ssolamiente a los quel ffazen 3o. o lo rreçiben, mas aun a los otros que lo ueen ffazer; que les

I $T$ es en. -- 2 paresçe asy. - 3 simiença / $T$ ssementera quando es meior. - 5-6 presuradamente. -6 a vagar. -7 tienpo e es. -8 que fagan. - io e non despues de c. sy non si acaesçiere. - IO-I I $T$ alguna guisa por. - I I ca de der. - 12-13 cornmo este deuen ser fechos e por que se faze en la iglesia el sacramento del c. e de la sangre de N. S. I. G. non conviene que entren. I4 que ayan c. e beu. - I5 que quiere. $-17 T$ las flazer. - 18 la tercera. - $20 T$ ssiele. $-22 T$ dever, -25 cresçe la $v$. al que lo de e esf. al que lo rresc. $-27 T$ bien el. -39 Dios $[E 53 r]$. - 3o $\mathbf{E}$ non tan s. 1. pro a los que lo fazen. - 3 I fazer que los. 
aduze Jos coraçones a deuoçión, que es cosa que plaze mucho a Dios.

Onde por estas ssiete cosas deuen sser catadas las ssazones en que deuen sser ffechos los ssacramentos. Mas porque todo lo al 5 que de ssuso es dicho es general ssobre todos los ssacramentos, por esso conuiene que ffablemos aquí cada vno por ssí, e primeramiente del baptismo porque es el primero de todos, et mostrar siete cosas que conprehenden todo el ffecho dél, et sson éstas : la primera, quál es en ssí ; la ssegunda, cómmo ffué estableçido e ro quándo; la terçera, quántas maneras sson dél ; la quarta, a quántas cosas tiene pro; la quinta, quién le puede ffazer; la ssesta, cómmo deue sser ffecho; la sséptima, cómmo deue sser onrrado e guardado. e qué sacramento es.

Baptismo es cosa que laua el cuerpo del omne de ffuera con agua e el alma de dentro con çierta fforma de palabras santas e linpias. Et éstas sson a dezir las vnas ante del baptismo e las otras en baptizando e las otras después del baptismo. Et esto ffazen por 20 ssiete rrazones: por alinpiamiento de agua; por ssantidat de las palabras; por la buena crençia del que lo da ; por el ordenamiento de las oraçiones que sse dizen vnas en pos otras e cada vna en ssu logar; por la ffuerça que ha en el agua e en las palabras quando sson ayuntadas en vno; por la obra que deue sser ffecha con agua 25 e con palabras; por la buena ffe que ha en él el quel rreçibe.

Onde por la linpiedunbre que es en el agua sse deue ffazer con ella e non con otra cosa ; que es el elemento en que ha ssiete uertudes naturales, ssegunt de ssuso es dicho. Por las palabras sse deue ffazer otrossí ; ca ellas son ffuerça del nonbre santo e uerda3o dero, que es Dios Padre e Ffijo e Spíritu Ssanto, que da comienço e acabamiento a todas las cosas de bien. Et por ende el baptismo

4-5 lo que. - 5-6 sacramentos e por. -6 aqui a cada. -7 muestra. 9 sy e la. - i I-1 $2 T$ y $E$ invierten el orden de quien le $(E: l o)$ puede fiazer $y$ commo deue sser ffecho. - Í́-15 Que c. es en sy el s. del baut. - I7 dentro e con. - $21-25 T$ y $E$ invierten el orden de por la buena ... da $y$ por la obra ... palabras. -- 21 da e por. - 24 con el agua. - 25 palabras e por la fe que ha el que lo rresç. - 26 por linp. - $28 \mathrm{E}$ por. -29 ellas han fuerça / $T$ del spiritu santo / santo verd. 
es el primero de todos los otros [41v] ssacramentos e puerta e entrada para ellos. Et aun sse ayunta otra uertud al baptismo quando el dador ha en ssí buena crençia quandol da que sse cunplirá aquello que quiera que sse cunpla en el alma e en el cuerpo de aquel a qui lo da.... Et de cómmo sse dobla la uertud quando 5 sse ayuntan las palabras e el agua en vno, es que el agua la rreçibe de las palabras quando las dizen ssobrella, et las palabras della, acordándose en vno las vertıdes spirituales e naturales. Et la uertud marauillosa que en el agua ha e en las palabras quando son ayuntadas en vno es que pinta e sseella de ssennal de Thesu Gristo ro el cuerpo de ffuera e el alma de dentro. Et otrosí deue creer el que lo da que çiertamiente sserá ssaluo el que lo rresçibe por el sacramento del bautismo. E el que lo rreçibe, si es de edat; ssi non, ssus padrinos por él deuen creer esto mismo que el que lo diere, ssegunt dicho es de ssuso. Onde, por todas estas uertudes 15 del agua e del baptismo e de las palabras e del dador e del rrecebidor que se ayuntan en vno, es tan noble cosa en ssi e tan grande que ffaze al omne partir del diablo e sser amigo de Dios.

[LEY LXXVIII]. — Quién estableçió el baptismo e quándo, e cómmo Sant Iohán ouo nonbre Bablista por rrazón del baptismo.

Baptista ouo nonbre Sant Iohán, ffijo de Zacarías e de Helisabet, porque ouo en ssí dos ssantidades grandes: la vna, que flué pariente de Ihesu Cristo, porque ssu madre Helisabet ffuć cormana de Santa María ; la otra, que en cabo priso muerte por él. El éste estableçió el baptismo, en que mostró por él Dios ssiete ${ }_{2} 5$ cosas sennaladas e grandes e marauillosas. La primera, que él connosçió a Dios quandol mostró con el dedo, que dixo: the el cordero de Dios, que tuelle los peccados del mundo. La ssegunda, que él mostró primeramiente la manera del baptismo, cómmo auyen los omnes a sser baptizados por agua. La tercera, porque $3 o$

I de los / puerta [E 53v]. - 3 sy vna c. quando lo. - 3-4 cunpla. - 4 quicren. - 5 aquel que lo. $-6-7 T$ reçibe quando. -7 quando la dizcn. -9 que ha el agua o en. $-19-13 T$ omile el que ... bautismo. - $13 T$ rreçibe que es / hedad osy. - I j- 16 segunt de s. es d. onde por t. e. siele $r$ del b. del agua e de las pal. - r7 ayunta/noble en. - 88 faze p. al o. del d, a ser. - 21-22 Helisabet que ono. - 25 mostro Dios por el sjete. -26 sernaladas grandes. - 27 quando lo / Hac. - äo auien a ser los o. baut. 
él por sus manos baptizó a Nuestro Sennor Jhesu Cristo en el rrío que llaman Iordán. La quarta, quel connosçió ssennorjo, que era Ssennor del çielo e de la tierra, quandol dixo: Yo deuo de ti sser baptizado, pues ¿ cómmo vienes a mí que te baptize? La quinta,

5 porque en baptizándol vió los çielos abiertos, por quel mostró Dios muy marauilloso amor, queriendo que connosçiesse la Santa Trinidat uerdaderamiente cómmo es. La ssesta, que vió desçender el Spíritu Sanio en forma de paloma e posar ssobre Ihesu Cristo, segunt ante le ffiziera saber que aquel ssobre qui viese desçender

Io el Spíritu Santo commo ffigura de paloma e ffincaua sobrél, que aquél era el que baptizaua en Spíritu Santo e en spíritu de verdat. La ssetena era la boz de Dios Padre que oyó, que dizíe por Ihesu Cristo: Éste es el mío ffijo mucho amado, en qui he muy grant. plazer. Onde," por estos ssiete entendimientos de graçias que Dios.

I5 mostró a Sant Iohán, por qui ffué ordenado el baplismo, ouo nonbre Baptista.

\section{[LFX IXXIX]. - De las palabras çiertas por que sse ffaze el baptismo.}

Palabras çiertas son por que se ffaze el baptismo; que ffueron 20 ordenadas por el uerdadero baptismo que es Ihesu Cristo, que baptizó en Spíritu Santo [e en spíritu] de verdat, [ssegunt] él mismo dixo a los apóstoles e a los disçiplos quando los enbió a pedricar por el mundo. Que los ensennó la manera del bautismo. cómmo se auie a fazer, deziéndoles: Yd e ensennad las gentes,

25 bautizándolos en el nonbre del Padre e del Fijo e del Spíritu Santo. Estas tres palabras semejan la Trinidad porque ha tres. fuerças e tórnala todo en vno: la primera, rrazón del que pide e otrosy lo que rresponde el que ge lo da; la segunda, quántas. cosas yazen en el dador e en el rresçebidor ; la terçera, la pro que $3 \circ$ yaze en aquello quel da.

E estas palabras han siete rrazones que conprehenden todo el fe-

i $T$ por ssi mismo bapt. -3 quando le. - 4 baptizado [E $54 \mathrm{r}$ ]. 4-5 La $q$. que en bautizandolo vio arbierlos los $\varsigma$. por. -6 Dios mar. -8 pasar. - 9 segunt ge lo ante feriera saber que aquel que viese que desçendie. - Io commo paloma. - I I bautizaua en s. de. - I2 $T$ dizie a Ihesu. $13 \mathrm{mi}$ - - I4 por todos estos / graçias de Dios. - ID́ por que / bautismo o ovo. - 17 çiertas que. - I 9 por las que se. - 2 I $T$ baptizo el Spir. - 22 Después de quando los comienza la segunda laguna en $T$, suplida por $E$. 
cho del bautismo. La primera, que dize el que da el bautismo âquel que lo ouiere de rresçebir qué es aquello que pide por saber su voluntad; ca ninguna cosa non puede omne dar nin prometer sy non sabe omne qué. $E$ por ende ésta es la primera palabra que deue ser dicha de parte del dador, demandar lo quél pide. La 5 segunda, que viene de parte del rresçebidor, [es] así nonbrada aquella palabra que $[E 54 v]$ pide, deziendo que pide bautismo. La terçera palabra, que viene de parte del dador, ha de dezir cómmo ge lo da lo quél pide en el nonbre del padre, que se entiende por el poder de Dios. La quarta, en el nonbre de Thesu Cristo, que se ro entiende por el [saber] de Dios. La quinta, en el nonbre del Spíritu Santo, que se entiende por el amor verdadero e leal que es conplidamente de Dios. La sesta, que ge lo da por que gane amor de Dios, faziendo buena vida en este mundo. La sétima, por que después que moriere, vaya derechamente a parayso e avá í vida perdurable syn fin. Onde éstas son las palabras çiertas con que ha de ser fecho el bautismo, e menos déstas non se puede fazer.

[LEy LXXX]. - Quaintas e quáles son las maneras en que se non puede fazer el baulismo.

Maneras y ha en que non deue ser fecho el bautismo, êstas son siete : la primera, que non puede ninguno bautizar a sy mesmo; la segunda, que non deue bautizar a otro sy non ouiere poder de lo fazer, segunt de suso es ya dicho : la terçera, que maguer puede, non deue ser fecho synon con agua con aquellas palabras que de 25 suso son dichas; la quarta, que non deue bautizar a otro que sepa que es bautizado; la quinta, que si él mesmo non oviere rresçebido bautismo, fasta que lo rresçiba, non lo deue dar [a] otro seyendo cristiano; la sesta, que se guarde de non dar el bautismo por palabras que sean dichas commo en manera de juego o de escar- 30 nio; la sétima, que non se atreua a dárgelo al que non ge lo demandare.

La primera, que non deue bautizar ninguno a sí mesmo, desto nos dió enxenplo Nuestro Sennor Thesu Cristo ; ca maguer todo el bautismo es en él conplidamente, non se quiso bautizar, mas 35 que [dixo] a Sant Juan que lo bautizase. La segunda, que non deue 
bautizar a otro sy non ouiere poder de lo fazer, es que el [que] toma poder ageno syn rrazón deue perder aquel que tiene e lo al que ante auíe. E desto nos dió él mesmo enxenplo quando $[E 55 r]$ el diablo lo tentó tres vezes; que commo quier que cada vna dellas

5 le rrespondió con rrazón, a la terçera díxol que fuese atrás, que era cliablo, que non tentase su Sennor, mas a él solo adorase e sertiese. Ca asy era escripto que lo deuíe fazer por derecho. La terçera, que el bautismo non puede ser fecho sinon con agua e con las palabras sobredichas, esto se prueua por Ihesu Cristo, que non

ro fué bautizado synon con agua e las palabras que sobrél fueron dichas; díxolas la bos del Padre, en que fizo entender cómmo era su fijo e el grant amor quel auíe, que se muestra por el Spíritu Santo. La quarta, que non deue bautizar a otro que fuese bautizado, esto es muy grant rrazón; ca lo establesçieron los santos

I5 padres en la iglesia de Dios por dos rrazones muy derechas, la vna spiritual, la olra tenporal: Ca bien así commo el omne segunt natura tenporal non puede nasçer del cuerpo de su madre más de vna vez, otrosy el que nasçe por bautisnı spiritualmente non puede ser baptizado demás de vna vegada; ca pues que la cosa es con-

20 plida commo deue ser, non conviene que se faga otra vegada. Ca se daríe a entender que non fuera fecho commo deuíe, o por mengua del que diera el sacramento o del que lo rresçebiera. La quinta, que sy él mismo non oviere rrescebido bautismo, fasta que Jo rresçiba non lo deue dar a otre, esto se muestra por rrazón natu25 ral; que non puede dar omne lo que non ha. E desto nos dió enxenplo la cauallería tenporal; ca asy commo ninguno non la puede dar sy ante non la rresçebiere, quanto más la spiritual del sacramento del bautismo, que son las armas de los caualleros de Ihesu Cristo. Ca esto non puede ser dado nin rresçebido más de

30 vna vez. E quien de otra guisa lo da pierde el poder que auía de lo dar e non lo gana el otro que lo rresçibe. La sesta es que non se deue dar por palabras de juego nin de escarnio nin escatimosas; ca esto manifiesta cosa es e rrazón derecha, que la fechura non puede escatimar al fazedor nin la buena obra $[E 550]$ a su maestro.

35 E más, en la cosa que es conplida de todo bien, non cahe en ella escatima nin puede ser fecha en ella escarnio. La sétima, es muy conveniente cosa de non atreuerse ninguno a dar el sacramento del bautismo syn demandárgelo el que lo quiere muy afincada- 
mente, e esto por muy natural rrazón; ca sy la cosa que ome ha en su poder naturalmente non quiere dar al menos del afincar mucho por ella, quanto más [non] deue dar el sacramento de Dios, que es spiritual, syn pedírgelo afincadamente aquel que lo ha menester.

Onde por todas estas rrazones ninguno non deue bautizar a sy mismo nin a otro sy fuer bautizado, sabiendo que lo es. Otrosy non deue baulizàr a ninguno sy él mesmo non lo pediere a otre por él. Eso mesmo dezimos que aquel que es fuera de seso, que non ha entendimiento de conoscer lo que él mesmo faze nin lo so que los otros le fazen. Pero sy aquellos que lo ouiesen a bautizar dubdasen si era bautizado aquel que se quisiere bautizar o non, la santidat del bautismo non deue dexar de ser dada por eso ; ca más rrazón es de auenturar a la dubda que non dexar omne perder el cuerpo e el alma. Mas tanto deuen fer los bautizadores por ser i 5 quitos deste bautismo que non bautizan esta vez synon temiendo que non es bautizado, e con tanto son quitos.

\section{[LEY LXXXI]. - Cómmo son tres maneras del bautismo, pero la virtul toda es vna.}

Tres son las maneras del bautismo, commo quier que la vertud 20 sea rna, e esto a la semejança de la Trinidad: la primera es linpiedunbre de agua, [que se muestra por el Padre]; ]a segunda, el martirio de la sangre que omne rrescibe por Dios, que se muestra por el Fijo; la terçera, llama de fuego, que se muestra por el entendimiento del amor del Spíritu Santo. E esto se prueua 25 por siete rrazones : la primera, porque Dios es vno; la segunda, porque la voluntad es toda vna; la tercera, porque la su obra es toda vna; la quarta, porque el su poder es todo vno; la quinta, $[E 56 r]$ porque el su saber es todo vno; la sesta, porque la su honrra es toda vna; la sétima, porque el su loor es todo vno. 30 Onde por todas estas siete rrazones es [cada] vna apartada por sy, pero todas se ençierran en vna, que es la conplida Trinidad, Padre e Fijo e Spíritu Santo. E asy commo estas tres cosas se encierran en vna, asy en la Trinidad se ençierran todas estas siete que non se pueden partir vna de otra.

E por ende el bautismo del agua laua las suziedades que ha

31 es toda rna apar toda. 
omne fechas, segunt ya dixiemos. E esto se prueua por la Biblya allí o dize que quando fizo el çielo e la tierra, que el spíritu andaua sobre las aguas. E Dauid profecta dixo en otro lugar que la bos de Dios, del Sennor de la magestad, fué oyda sobre las

5 aguas. $E$ avn el mesmo Ihesu Cristo dixo que el que otra vegada que [non] nasçiese de agua de Spíritu Santo, que non entraríe en el rregno de los çielos. Onde por estas rrazones que tiene el bautismo del agua se entiende por el Padre, que ba poder sobre todos los pecados por el baptismo. La segunda manera de bautiIo zar, que es la sangre, esto se entiende por aquellos que matan, creyendo en la lee de la Trinidad, ante que sean bautizados. $\mathrm{E}$ tal semejança commo ésta tanne a la persona de Ihesu Cristo, que es fijo de Dios; que maguer era bautizado de agua, non dexó por eso de rresçebir el otro bautismo de la sangre quando priso

15 pasión e muerte en la crux por nos. Ca allí en lo que sallió dél se mostró la Trinidad conplidamente, porque tres cosas salieron del su cuerpo: agua, que se entiende por la deydad; sangre, por la humanidat; e el alma natural segunt la vida, por el Spíritu Santo. E el terçero bautismo es el que ha el omne por voluntad, que20 riendo ser bautizado e non fallando quien ge lo dé; porque si en esto muriese, $\tan$ bien es saluo commo si lo ouiese rresçebido. E aquí se muestra la terçera persona de Dios, que es el Spíritu Santo ; ca asy commo [d]el alma del omne, que es spiritual, e de la carne, que es tenporal, sale vna voluntad $[E 56 v]$ para cobdi25 çiar el bautismo, otrosy de Dios Padre e de Ihesu Gristo su fijo salo el Spíritu Santo, que es voluntad conplida do nasçe todo el bien, porque nos da a entepder de creençia por que nos saluemos.

[Lex LXXXII]. - A qué cosas tiene pro el bautismo quando es fecho commo deue.

Pro muy grande tiene el bautismo a muchas cosas quando es fecho commo deue, e sennaladamente en siete [maneras]. La primera, que faze que perdone Dios al omne los pecados que ha por linage, asy commo el que fizo Adam, por que cayeron todos

35 en pena por culpa dél. La segunda, que oluide Nuestro Sennor e le oluida todo - el mal quel queríe por aquel pecado que auíe fecho, segunt él mesmo dixo: En qualquier ora quel pecador gemiere, nunca me rrecordaré después de sus maldades; porque es 
mayor cosa de oluidar la culpa que perdonar el yerro. La terçera es que pues el pecador es perdonado, esfuérçase en la vircud e la graçia de Dios e faz enflaquezer la del diablo, que da voluntad de pecar. La quarta, que es perdonado de los pecados que auíe fecho fasta aquel tienpo que se rrepintió. La quinta, 5 que de allí adelante es fecho conviniente para rresçebir los otros sacramentos. La sesta, que el menospreciamiento que gana omne podiéndose bautizar e non queriendo, piérdelo quando por el bautismo es perdonado de sus pecados. La sétima, que aquel que ante era tan solamente por juyzio de Dios dentro en la iglesia, io eslo después por juyzio de la misa ; ca en ella ha poder de judgarle en cómmo puede ser suelto o librado.

Onde quien parare mientes en estas proes puede entender que tan grande es el bien que dellos viene e cómmo fas ayuntar omne con Dios por amor verdadero corporal e espiritualmente. Pero 15 esto tiene pro a los que lo rresçiben el bautismo commo deuen, segunt de suso es dicho, mas non tiene pro a ningunos que son de otra ley que dizen que quieren ser cristianos e non han ende sabor. Onde atales commo éstos, maguer que rresçiben el bautismo, non les tiene pro pues con enganno lo rresçiben, cuydando 20 fazer escarnio de la ley. Otrosí el que lo diese, enten- $[E 57 r]$ diendo este enganno por alguna manera, avríe pena commo adelante se muestra do fabla de las penas que se dan por esta rrazón. Mas si lo [non] entendiesen, non caerien en culpa pues lo non entendieran, maguer que después sopiesen que aquel que lo auie 25 rresçebido lo feziera por infynta engannosamente. Onde los que en algunas maneras déstas errasen, non les terníe pro el bautismo.

\section{[LEY LXXXIII]. - Qué quiere dezir saçerdote.}

Saçerdote quiere dezir tanto commo cabdillo sagrado, e este nonbre han en latín los clérigos que dizen la misa, a qui llama- 30 mos misacantanos. E hanlo con muy grant rrazón porque ellos son cabdillos de aquellas cosas que son sagradas e con que fazen sacrifiçio del cuerpo de Nuestro Sennor Ihesu Cristo, e éstas son siete : la primera es vestimentas; la segunda, el altar; la terçera, el ara ; la quarta, el calis ; la quinta, la patena ; la sesta, los 35

32 son cabdillas de (son añadido sabre la linea, y lo mismo -s en la línea y de en el margen, lodo de otra mano) / sagrados. 
corporales; la sétima, la hostia. Demás, el que es sagrado de la mano de los perlados, que lo son e las palabras que dizen otrosy son sagradas.

E por ende éstos pueden dar estos sacramentos más que otros. 5 Pero sy alguno déstos non podiesen aver en ora de coyta, puede bautizar el euangelistero o epistolero o lego o judío o moro o gentil o erege e avn muger; ca segunt dixieron los santos padres, non obran los meresçimientos de los seruidores, a que llaman ministro, en el bautismo, mas la virtud de Ihesu Cristo. Ca tal es

ro el bautismo qual es en sy en cuyo poder es dado, non qual es aquel en cuyo ministro es fecho; ca non enpeesçe sy el ministerio es malo, porque Nuestro Sennor Ihesu Cristo, en cuyo nonbre es fecho, es bueno. Nin otrosy non enbarga la maliçia del malo do el juez es piadoso; nin el que planta non es alguna

I5 cosa nin el que rriega, mas sólo Dios, que da acresçentamento a todas las cosas. Pues el bautismo asy es dado por el buen ministro commo $[E 5 \% v]$ por el malo. E esto es por la bondad que ha en sy; que maldat non le puede enbargar. Mas de los misterios el vno es mejor que el otro, pero el bautismo egualmente es 20 dado asy por el vno commo por el otro; ca él en sy non ha ninguna manera mala. E magner que los misterios sean deseguales, el dono de Dios egual es e non es de ninguno dellos, synon de Dios. E segunt aquesto el padre puede bautizar su fijo, veyéndolo en ora de muerte e non podiese aver otro que lo leziese.

$25 \mathrm{E}$ por esto non nasçe enbargo entre él e su muger que dexen de ser en vno por rrazón del conpadrasgo.

[Lex LXXXIV]. - De cómmo se muestra la Trenidat conplidamente en las cosas que se fazen ante del bautismo e en las cosas que son fechas después del bautismo.

3o Trenidat conplida se muestra que ha en todas las cosas que se fazen en el bautismo. E esto es por rrazón que vnas deuen ser fechas ante que lo den, e otras después que es dado. Mas porque las rrazones son muchas e muy luengas para ponerlas en vna ley, partímoslas en tres partes. Esto fezimos porque cada vna 35 déstas fabla de la Trinidad. E primeramente fablaremos del cathe-

I 1-1 2 ministerio (ministro añadido en el margen, olva mano). -21 misterios (ministros añadido en el margen, otra mano). 


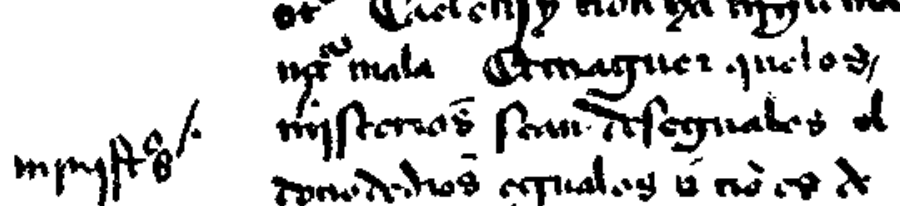

fordmalo (Otepaco for hemin

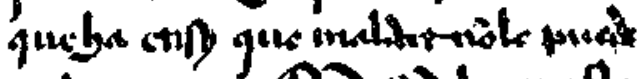
cringrer : QDisidelos mift. noy d bus émoloo qued orro to cllawer fro whal imato st

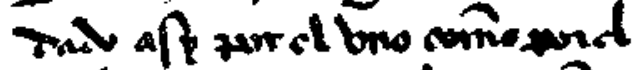

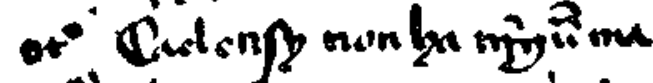

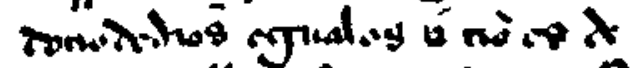
mingsillos Pnoxisos $\rho^{2}$ Neguphinto divare pured vingar pifo boynto lo meora To nutures fo non quindedxs oreg qudu frougk . 47 wurc? tinon nafe mhing cmped

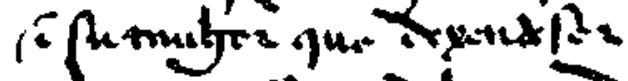

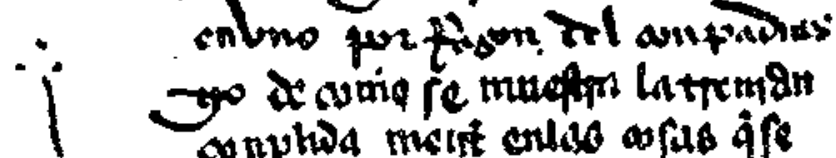

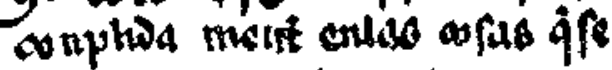
farin ature Sil batutino 2 ch. las was a con ferting aspuce Q1 balturnto $\therefore$ - $-:-:$

$\boldsymbol{T}$

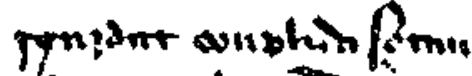
An que lanctiolics las allatiofiffores

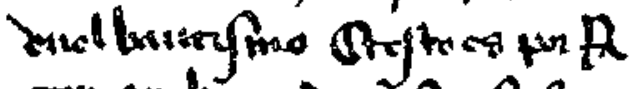

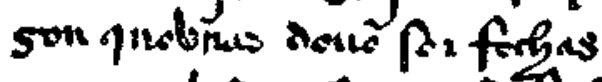
ake quads ail of on sifpus

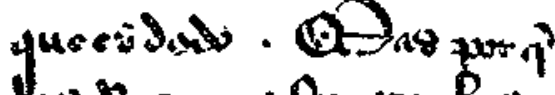

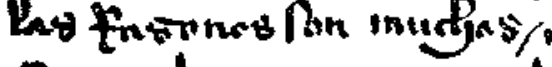

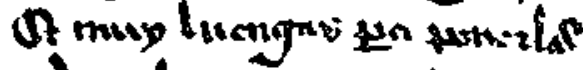

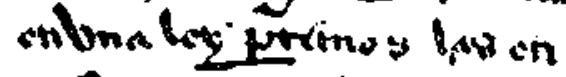
refpes: Ofte Aarmos porftem dunkinfes fith

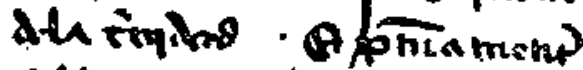
fillanemos $\mathrm{H}$ mith. orpmo:

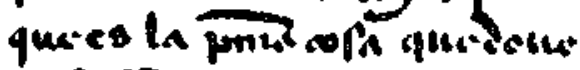

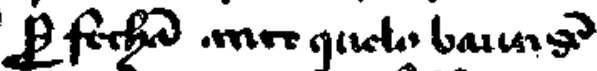
O. ofo tots R. Arto por powpo pur porgita

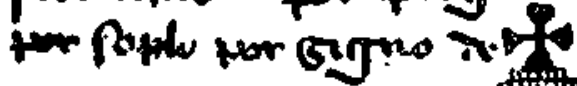

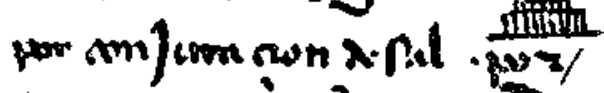

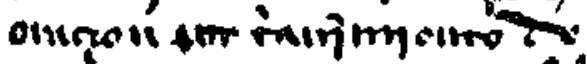

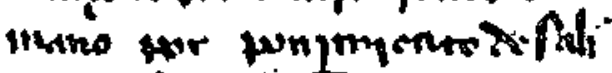

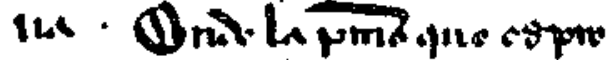

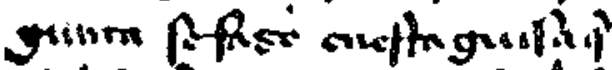

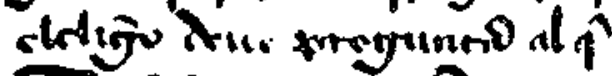

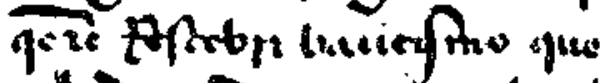

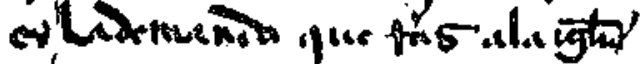

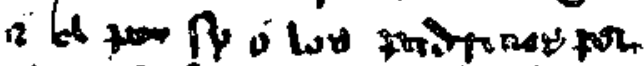

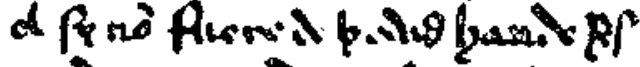
Hinir que priten fie a drtig

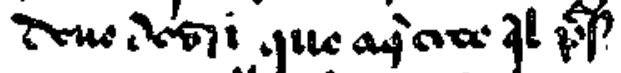

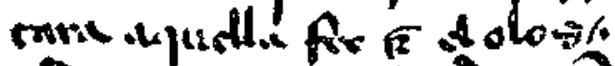

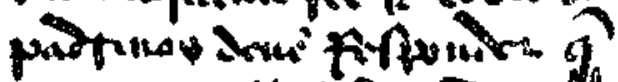
dalus far clla bate 50 izalle

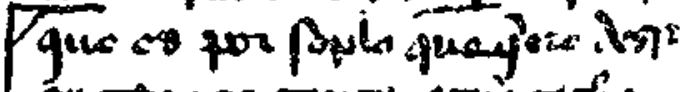

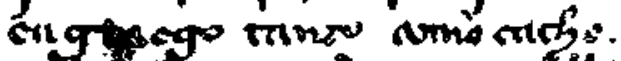

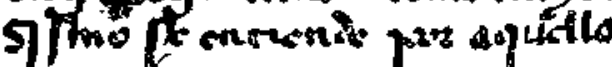

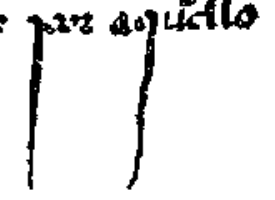


zismo, que es la primera cosa que deue ser fecha ante que lo bautizen. $E$ esto deue ser fecho por siete cosas : por pregunta ; por soplo ; por signo de t; por conjuraçión de sal ; por oraçión; por tannimiento de mano; por ponimiento de saliua.

$5 \quad$ Onde la primera, que es pregunta, se faze en esta guisa : que el clérigo deue preguntar al que quiere rrescebir baulismo qué es la demanda que faz a la Iglesia ; e él por syo los padrinos por él, sy non fuere de hedad, han de rresponder que piden fee; e el clérigo deue dezir que a qué cree quel prestará aquella fee; e él o los to padrinos deuen rresponder que a auer por ella vida perdurable.

[La segunda], que es por soplo, que quiere dezir en griego tanto commo cathezismo, se entiende por aquello $[E 58 r]$ que deue ser fecho a los que quieren rresçebir el bautismo ante que ge lo den nin que entre en la iglesia. E este soplo muestra grant signi-

5 ficança de virtud que ha el que es cristiano, porque el Spíritu Santo de Dios que aya rresçebido faze foyr el spíritu malo que es en el otro que non ha la fee, segunt él mesmo dixo en el Euangelio quando sanó el omne que era mudo e demoniado. E dixeron los judíos que lo fazíe con poder de Bersebú e él rrespondióles 20 que non era synon por poder de Dios; que cosa manifiesta es que el que es omne poderoso bien guarda lo suyo, mas sy otro venie más fuerte, que él [le] echarie ende, tolliendo las armas e quanto teníe. E en esto les dió a entender que el poder que él auie era de Dios para echar los diablos e fazerlos foyr. E

25 en este cathexismo non se deue fazer synon a puerta de la iglesia ante que en ella entre; ca de derecho es que quien va a demandar amor de Dios por creençia lo demande con miedo e con humildad grande, rrepentiéndose mucho del mal que fizo porque lo non rresçebió ante, e que non meta consigo el spíritu malo que es 3o henemigo de Dios. E por ende non deue entrar en la iglesia, que es su casa do loan el su santo nonbre e fazen el sacrificio del cuerpo de Ihesu Cristo, fasta que aya la su graçia, partiéndose del diablo e tornándose a él. E por ende deue prometer a la puerta de la iglesia por sy o por otre que de allí adelante sigua las

35 obras de Ihesu Cristo e se parta dellas del diablo e que rresçibe a semejança del Spiritu Santo aquel rresoplo quel faze el preste tres vezes en signo de crux, mandando firmemente al diablo que se parta de aquel omne que non es suyo de derecho. 
La [terçera], que es por signo de crux, se entiende que el clérigo deue fazer signo de crux en el pecho e en las espaldas, deziéndol que por la virtud della sea de allí adelante guardado en todas las cosas del poder del diablo e que pierda aquella dureza en que estaua enduresçido por pecado, que se torne blanco commo ninno $\overline{5}$ quando $[E 58 v]$ ua rresçebir la virtud de Dios, que sepa guardar los sus mandamientos por que con pura voluntad entre en la iglesia.

La quarta, por conjuraçión de sal, es que la deuen adozir al clérigo en algunt vaso linpio. E él deue poner la mano sobre ella, Io deziendo aquella conjuraçión por el nonbre de Dios Padre poderoso e por Ihesu Cristo su fijo e por la virtud del Spíritu Santo, e por Dios verdadero e por Dios santo, e por aquel Dios que la crió por guarda de los omnes e mandó que fuese consagrada para los pueblos que veniesen a su creençia. E que en nonbre de la Santa i 5 Trinidad fuese fecho este sacramento de salud para desfazer al diablo. E por ende que rruega a Dios Nuestro Sennor que aquella criatura de sal, santiguando, la santigüe e, bendeziendo, la vendiga, asy que sea a todos los que la rrescebieran conplida melizina. E después que esto oviere fecho, deue tomar un poquillo della e 20 metérgela tres vezes en la boca de aquel que quiere bautizar, deziendo: Toma esta sal, que es para conosçer a Dios e carrera prouechosa para yr a la vida perdorable. $E$ esto es fecho por grant sacrificança; ca asy commo la sal desata todas las humidades que son sobejanas en las cosas, otrosy el saber desfaze todas las dure- $2 \tilde{\mathbf{j}}$ zas e las nesçiedades que los omnes han en sus coraçones por non creer en la fe de Dios commo deuen.

La quinta, por oraçiones, es que deue dezir [esta oraçión] tan bien sobre las fenbras commo sobre los másculos, en que rruega [42r] a Dios de nuestros padres, que es en todas las cosas conpli- $3 o$ dor de uerdat, que él por ssu merçet quiera parar mientes ssobre aquellos ssus sieruos e por la su piadat los quiera rreçebir e por el gostamiento de aquella ssal non les dexe luengamiente auer ffanbre, que sse entiende por la ssu graçia; mas que ssean ssienpre abondados della e sseruyentes en el su spíritu, auyendo gozo en la 35 ssu ssanta esperança, et por ende ssirua ssienpre al ssu santo nonbre

I quarta, - 6 desfazer (la letra s añadida de otra mano). - 29 En rruega termina la segunda laguna en $T$. - 3 $\mathrm{I}$ virtud / deuē. - 32 sieruos que la. 34 la graçia. - 35 abondados e s. el. -36 su grant esp. / su nonbre. 
por quel aduga a lauamiento de aquella nueua naçençia e alcançe con los ssus ffieles los mereçimientos perdurables. Et después que ouyere esta oraçión ffecha, ha de dezir esta otra ssobre los maslos, en que rruega a Dios que non es mortal, mas ayuda-

5 dor de todos aquellos que demandan e libramiento de todos aquellos quel piden merçet e paz de aquellos quel rruegan e vida de los quel creen e rresuçitamiento de los muertos, e que a él llama aquel ssu ssieruo quel pide el baptismo por dono e que desea por aquel spiritual connosçimiento ganar la graçia perdurable, quel. rreçiba Io así commo por la ssu palabra dennó dezir: Pedit e rreçibredes, demandat e ffallaredes, enpuxat e abriruos han. Et auyéndolo rrogado, que ayan los bienes de paraíso entrada en él. Et en pos esta oraçión ha de dezir otra ssobre los maslos contra el diablo, diziéndol que el maldicho que es Ssatanás, quel conjura por el nonbre I5 de aquel que dura por ssienpre e de su ffijo Nuestro Ssaluador que uaya uençido con su enbidia tremiendo e gemiendo se parta de aquel sieruo de Dios, non auiendo comunaleza ninguna con él, por que aquel que demanda la ffe, teniendo mientes a las cosas celestiales, lo rreniegue por sienpre e aya la bienauenturada vida 20 ssin muerte; e que dé onrra al Spíritu Santo que viene demandar aquel que quiere sser baptizado, descendiendo de los más altos çielos para desatar todos los ssus engannos de guisa que ssea purgado el ssu coraçon por sacramento de aquella ffuente de Dios por que sse flaga casa santa para él, así que ssea librado de los 25 enpecamientos de los peccados que pasaron e dallí adelante ssea ssieruo de Dios, dándol graçias por ende e bendiziéndol el su nonbre. Et deue dezir comunalmiente por los maslos e por las ffenbras contra el diablo la ssentençia que es dada ssobrél, e que se parta dellos e dé logar a Dios biuo e uerdadero e dé onrra a Ihesu Cristo 3o su ffijo e al Spíritu Santo, partiéndose de aquel ssu ssieruo, al

3 que esta o. ouicre $\left[\begin{array}{ll}E & 59 r\end{array}\right]$ dicha. - 4 masculos! es natural. - 5 quel demanda / $T$ demandan libr. -6 que piden / vida de aquellos. 9 la gloria p. que rresc. - io de nô. - Io-I I rresçibiredes e dem. - i $T$ demandat ffall. / $T$ auyendo. - I2 ayan por ello los / entrada del. - 13 masculos. - I4 Setanas que conj. - 15 e por el su. - 16 inbidia teniendo e. 17 contra el. - 19 la anenturada. - 20-3 I Santo que biue aquel. - a descendiendo de somo de (de somo añadido sobre la línea, otra mano). -23 coraçon de santiguamiento de aq. -24 que f. cosa ; que el libr. -25 enprestimientos / pasaron de alli. - 26 bendeciendol. - 27 masculos / feminas. 28 diablo que conosca la. 
qual Nuestro Ssennor e Ihesu Cristo ssu ffijo quissieron llamar a la ssu ssanta graçia e a la bendiçión de la ffuente del baptismo. Et entonçe déuel ffazer vna cruz con el polgar en la fruente, diziendo que por aquella ssennal de la cruz que él le ffaze el maldicho diablo nunca ose passar nin quebrantar aquello de quel conjuran. 5 Et otrosí por los maslos lo conjura por el Padre e por el Fijo e por el Spíritu Ssanto que ssalga e sse parta daquel ssieruo de Dios, e que ge lo manda por aquel que andido en ssus [42v] pies ssobre la mar et ssacó en ssu mano diestra a Ssant Pedro que sse non ssomorgujó en ella. Et deue rrogar otrossí a Dios que es Ssennor io de los ssantos patriarchas Abraam e Ysaac e Iacob, que él que apareçió en el monte de Ssinay a Moyssén ssu ssieruo e ssacó los ffjos de Isrrael de Egipto e los dió al ángel de ssu piadat que los guardase e guiase de dia e de noche, quel rruega quel quiera enbiar el su santo ángel quel guarde aquel ssu ssieruo que quiere sser bap- 15 tizado e quel aduga a la graçia del ssu baptismo. El después desto deue dezir otra oraçión ssobre las ffenbras, en que rruega a Dios, que es Ssennor del çielo e de la tierra e de los ángeles e de los arcángeles e de prophetas e de apóstolos e de los mártires e de los conffesores e de las vírgines e de todos aquellos que bien biuen, et a 20 qui toda lengua otorga e ante quien todos ffincan los ynoios, tan bien en los çielos commo en la tierra commo en los inffiernos, e a qui todos llaman Ssennor, que enbíe ssobre aquella ssu ssierua la graçia del ssu ssanto baptismo. Et aun le deuen frażer conjurar al diablo por el Padre e por el Ffijo e por el Spíritu Santo que sse 25 parta daquella ssu ssierua de Dios, e quel amenaza, diziendo que aquel Ssennor ge lo manda que abriera los oios al que nasçiera çiego e rresuçito a Lázaro, que anya quatro días que yazía en el monimento. Et ssobre esto ha de dezir el Euangelio de Sant Matheos euangelista, en que cuenta cómmo Nuestro Ssennor Ihesu 30 Cristo dixo, commo en manera que sse conffiessa a Dios ssu padre e Ssennor del çielo e de la tierra, que ascondiera las poridades de

I Sennor Dios e / depnaron. - 3 pulgar. - 4 sennal $[E 590] /$ el faze. 5 de aquel conjura. -6 le. -7 e que se. -8 andudo sobre. -9 saco con su. - I 1 las santas p. A. Ysac e J. el. - I 2 monte Synay. -13 e les dio angel / les. - I 4 noche que le $r$. que le deue. - ró que guarde. 17 feminas. - I 8 Senor. - 21 quien $t$. l. se confiesa e ante quien todas. 22-24 infiernos que a ol S. Il. sobre aq. su s. que la deue adozir a la g. del b. suyo e arn le $d$. conj. - 27 Senor ge la / $T$ mando / abrio. -28 e que rres. - 3o euangelista que. - 3 I dixo en m. c. se confesaua. - 3i-3a padre Sennor. -32 escondiera las sus por. 
los ffechos a los ssabios e entendidos de los ssaberes tenporales e los descubrió a los pequennos, que sse entendíe a los que an entendimiento de entender e creen ffirmemiente con uerdadera uoluntat. Et este Euangelio mostró la Trinidat maniffiestamiente o

5 dixo: Padre, a ti do graçias porque te plogo de mostrar esto en mi, que sso tu ffijo. Et aun dixo más, commo ssi dixiese al mundo: Todas estas cosas sson a mí dadas por conseio e por mandado de mi padre; ca ninguno non connosçió el Ffijo ssinon el Padre nin al Padre ssinon el Ffijo, ssaluo aquellos a quien lo él quiere mosIo trar. Et en esto sse ençierra toda la Trinidat e por esto dixo adelante en este Euangelio : Venit a mí todos los que trabaiastes, ssuffriendo muchas coytas en este mundo, e sodes encargados de peccados, ca yo uos pecharé; commo quien dize: Daré a cada vno lo que ouyere mester, a los que trabaiaron ffolgança e a los pecca-

15 dores perdón. Et dixo más: Tomat el mi yugo ssobre uos que quier dezir: Atatuos comigo damor - e aprendredes de mí cómmo sso mansso e homilloso de coraçón; et desta guisa ffallarán ffolgura uuestras almas, ca el mi yugo - que sse entiende por atamiento ssabroso - es blando e la mi carga liuiana. Onde este

20 Eaangelio, en que sse muestra la Trinidat, ordenó Santa Eglesia que sse dixiesse ssobre aquellos que quieren rreçebir virtud della por crençia e por baptismo.

La ssesta, que es por tannimiento de mano, muestra de cómmo el ssaçerdote deue poner la mano ssobre [43r] la cabeça de aquel 25 que sse quiere baptizar e, teniéndola y, ha de dezir el Credo in Deum, en que sse muestran conplidamiente todas las maneras en commo deue omne creer en Dios. Et después que esto ouyere acabado, deue dezir esta oraçión, en que rruega a la piadat de Dios que dura por ssienpre et es derechurera, assí commo a Santo Padre 30 poderoso que es lunbre uerdadera, que quiera alunbrar aquel ssu ssieruo de ssantidat e de ssabiduría uerdadera por que digno pueda

1 los sus f. a los s, ent. los sab. -2 entiende. -3 creer $f_{\text {, e con. }-4}$ manifiestamente e. - 5 Padre asy g. e porque p. mostrar [ $E$ 60r] aquesto. 6 soy fijo. - 7-9 cosas que son a mi d. por mi padre ca $n$. non conseio el $F$. saluo aq. a quien el lo quiere. - i $T$ desencargados (des- añadido sobre la línea). - 13 vos rrefare. - 14 trabajan f. a. - I6 aprenderedes. - I 7 manso hom. / fallacon. - 18 folgança. - I 9 acatamiento sobre eso es muelle / T blanda. 2 $T$ rreçebir della. $-23 T$ ssesta por que es tann.; $E$ sesta es que por tann. - 26-27 maneras c. denen crecr. -27 onieren. -30 dene. 
allegar a la graçia del ssı ssanto baptismo que rreçibe con ssu ffe e con ssu santa sperança e derecho consejo e ssanto ensennamiento, por que ssea atal que conuenga para rreçebir la graçia del baptismo. Et aun teniendo la mano ssobrél, ha de dezir e amenazar al diablo commo en manera de sanna e de despreçiamiento, diziéndol 5 menazas muy ffuertes de las penas e de los tormentos del día del juyzio quando de Dios aurá miedo e pidirá merçet a Ihesu Cristo, vejéndol uenir claro e temeroso commo llamas de fluego que arden, porque él sserá apareiado e todos ssus ángeles para él, quebrantándolo por ssieopre. Et por ende, amenazándol, dize que por io. la ssu mallat es por derecho juyzio condenpnado e sserá aquel día, et que connosca e dé onrra a Dios uerdadero e a thesu Cristo ssu ffijo e al Spíritu Santo, por cuyo nonbre e uertud manda que to ffaga, e de qual natura quier que ssea, que sse parta e sse arriedre de aquel ssieruo de Dios, a qui él por la ssu graçia denne llamar is para ssí. Et por aquel agua del baptismo ssea ffecho commo casa de ssu morada. Et esto es en ssignifficança de la Trinidal, que sse entiende por el Padre; ca assí commo Ihesu Cristo fiziese la ssu ssanta ley, commo quier que los omnes entendidos e flieles connosçiesen que vn. Dios era padre e criador e gouernador de todo, 20 pero porque non auyan entendimiento conplido para connosçer la Trinidat del Ffijo e del Spíritu Ssanto, por ende estauan commo ffuera de la Eglesia. Onde a ssemeiança desto están ffuera de la Eglesia aquellos que demandan la crençia de Ihesu Cristo, que es la Trinidat, e non la han entendida aún por crençia conplida- 25 mientre commo conuyene nin rreçebida por baptismo.

La ssetena, que ffabla por ponimiento de la ssaliua, esto es que el clérigo deue escopir en la ssu mano ssiniestra e tomar con el polgar de la mano diestra e con el otro dedo que está cabo dél de aquella escopedina e poner della en las narizes e en las oreias de 30. aquel que quiere baptizar, diziendo estas palabras que dixo Nues-

I llegar a la tierra del su s. b. e que rresçiba / $T$ añade a la graŗia sobre la linea y retoca del sobre al. - 1-2 fee firme esperança. - $2 T$ derecho e / ensemejamicnlo. -3 tal. -4 de am. $-6 \mathrm{~T}$ penas de. -7 avran / pidiran/ Thesu [E 60v]. - 9-10 aparcjado a el e t. sus a. quebrantandol. - Ir-I 2 condenprado s. a. dia que. - 12 Dios biuo e verd. - 15 deue. - 16 t que por i cosa. - 17 la Santa Trin. - 25 la Santa Triu. / $T$ añade e sobre la línea; E lo omite / ha arn e. por. - $\mathbf{2} 7$ de sal. -28 su palma. - 29 pulgar de la otra diestra. - 3o escopetina e ponerla en las nar. / Tañade della sobre lar. linea, olra mano. 
tro Ssennor Ihesu Cristo, que sse muestra en el Euangelio que ffizo Ssant Matheos, en que cuenta que aduxieran vn omne que ffuera çiego de ssu naçençia e él escupiera en tierra e ffizo lodo con la escupedina e púsogelo ssobre los oios e mandól que sse

5 ffuese lauar en vna laguna en que sse mostrauan los moços [43v] a nadar e que ueríe, e ffué luego assí ffecho. Et esto mostró él porque los judíos non querían creer que él era ffijo de Dios porquel veyen omne, que lo creyesen por las obras que ffazíe, ssegunt él mismo les dixo: Si non queredes creer que yo sso enbiado de

10 Dios Padre por las palabras que yo digo, creetlo por las obras que me veedes ffazer. Et en esto dió a entender la Santa Trinidat, mostrando el poder que él auye de Dios Padre, ssegunt dixo en otro logar : Yo e el mi padre vno ssomos; commo quien dize : Yo non lo podría ffazer ssegunt natura de omne, mas ffágolo por la

55 de Dios, cuyo ffijo yo so. Et otrosi muestra la humanidat quando non quiso ffazer ssinon escupedina ssolamiente que escupió en tierra, que es cosa ssobeiana que echa el omne de sí, en que dió a entender que asi commo él era conplido santo, que todas las cosas que dél ssalían eran ssantas e linpias e auyan uertud para ffazer

20 por ellas ligeramiente e ssin ffin lo que el diablo nin todos los del mundo non podrían ffazer con quanto ssaber e poder ouyessen. Et lo que boluió aquella escopedina con la tierra dió a entender el Spíritu Santo, que ssalió del Padre e del Ffijo, boluyéndose con ellos amos en manera que es todo vna cosa ssin departimiento.

25 Et por ende el clérigo, quando pone en las narizes e en las oreias del que baptiza, ha de dezir effetá tres uezes, que quier dezir en ebraico commo abre en nuestro lenguaie. Et cada vegada que lo dixiere conuyene que diga que ssea esto ffecho con olor manso, que sse muestra por la piadat de Dios; ca así commo las cosas que

30 bien huelen dan conorte e esffuerço a los que las rreçiben, otrosí la merçel e la piadat de Dios guaresçe e conorta a los que la han mester e esffuerça a los fflacos de coraçon, que por ssu flaqueza caen en peccado, non se treuyendo esfforçarsse en el poder nin en

2 dixo Sant $M$. en que c, quel aduxeron y omne. -3 nasçençia el entonçe escopio en la tierra. - 4 el escopetina. - 5-6 mostrauan a $n$. los m. e que. 6 fue asy. -7 que era. -9 so $[E 6 / r]$ - I I $T$ la ssu Trin. - 12 mostrando que el poder. - I 3 mio / $T$ vnos. $-14 T$ ssegunt $o$. de 1 . rnas $f$. por lo. -15 fijo so. - I6 escopetina. - I 7 omne naturalmente de. - i 9 quel del salicran. -21 podien con. -22 escopetina. -26 dezir tres $v$. efecta que. $-3 o$ bien vicnen dan / a las que las (el segundo las añadido sobre la línea). - 33 atreuicndo a esf. 
la uertud de Dios. En lo que diz que [á]brasse, sse entiende que el baptizado desque ouyer la uoluntad abierta para rreçebir a Dios en ella e echar al diablo ende, ffaziéndol ffoyr, diziénclol que sse llegará el juyzio de Dios por que non aya poder sobre las cosas quel non conuyene de auer, et ssennaladamiente ssobre el omne, 5 que es ffecho a ssu ymagen e a ssu ffigura de Dios. Et depués que todo esto ouyere ffecho el ssaçerdote, ha de dezir ssobrél [el] Credo in Deum et el Pater noster, que sson dos oraçiones muy conplidas: la vna, que sse muestra la ife muy conplidamiente; la otra, que nos enssenna en quáles cosas deuemos rrogar a Dios e en qué ro manera. Et esto dicho, al de ffazer la ssennal de la cruz en la cara, diziéndol quel ssennala en el nonbre del Padre, del Ffijo, e del Spiritu Ssanto. Estonçe hanlo de leuar a la pila do ha de sser baptizado. Onde a estas cosas Ilaman catezismo, e denen sser ffechas al que quieren [44r] baptizar ante quel baptizen.

[LEY LXXXY]. - Quántas e quáles sson aquellas cosas que ffazen en vno con el baplismo.

Babtizar es la ssegunda cosa de las tres que sse frazen ante del baptismo, en que sse muestra la Trinidad conplida, ssegunt de ssuso dicho es. Mas porque ffasta aquí dixiemos del catezismo en 20 qué manera deue sser ffecho, agora queremos mostrar aquellas cosas que sse ffazen en vno con el baptismo, que sson ssiete: la primera, por pregunta; la ssegunda, por partir el agua en ssigno de cruz; la tercera, por tanimiento e por esparzimiento de agua ; la quarta, por aspiramiento; la quinta. por çirio; la ssesta, por 25 crux, que deue ffazer; la ssetena, por rrenegamientos.

Onde la primera, que es por pregunta, que sse entiende por rrogar a Dios, quier dezir tanto commo ledania, que es oraçión en que rruegan a todos los ssantos que rrueguen a Dios que bendiga

I dize / T y $E$ obrasse. - I-2 entiende que d. el b. aya. - 3 echar ende al d. e fazerle. - $f$ allcgara / que el non. - 6 ymagen $[E 61 v]$ / despues. - 7 ouiese. - 9 vna en que. - I h hale / senal. - I 2 deziendo / Padre del Fijo. - I $3 \mathrm{E}$ entonçe halo. - 14 Onde estas. - 8 Bautizar la / que fazen. - $19 T$ la uertut / conplidamente. - 20 suso es d, mas. - 20-2 I en commo dene. -94 tannimiento e esp. -25 quarta espiramiento. -26 rrennegamiento. -28 quiere t. d. c. l. es. - 29 rruega / $T$ rruegen. 
aquel agua con que ha de rrecebir el ssu ssacramento santo del baptismo, que es frecho por creer en la $\mathrm{Ffe}$ los que nueuamiente la vienen rreçebir, e que enbíe al Espiritu Ssanto muy deseado, assí que [lo que] por el nuestro offiçio de ssinple uoluntad non podría

5 sser conplido, que él por la ssu graçia lo cunpla e lo acabe. Et esto dicho, ha de dezir ssobre el agua este preffaçio, que muestra tanto commo oraçión que conuyene que sse diga ante que ffaga aquella cosa que quiere ffazer, en que rruega a Dios que es dador de ssalut. e cuyos ffechos sson todos derecheros e eguales e que es digno de 10 auer piedat e ffazer merçet a los que la han mester et ge la demandan, porque es Dios ssanto e Padre poderoso ssobre todas las cosas e dura ssin ffin, al que deuen sser dadas graçias por ssienpre en todo logar porque por el ssu marauilloso poder nos mostró e nos muestra por obra los ssus ssacramentos. E commo quier que nos 15 non seamos dignos de ffablar en manera que podamos consseguir nin alcançar los ssus ffechos, que él por esso non dexe de abaxar las ssus piadosas oreias para oyr las nuestras pregarias, assí commo non mengüe el don de la ssu graçia en acquel ssacramento del baptismo; ca él es aquel Ssennor cuyo spíritu andaua ssobre las aguas 20 al comienço del mundo, por la qual natura dellas rreçibió en ssí entonçe uertud para poder sagrar. Et él que es Dios quiso lauar los peccados deste mundo quando enbió el diluuyo sobre la tierra, por que por el olfiçio de aqueste helemento ffuesse ffecho ffin dellos. Por ende quel ruega que pare mientes ssobre la Eglesia et que 25 ffaga amuchiguar en ella los nuevos linages por que, enbiando y la su graçia abondadamiente, que sse pueble la ssu eglesia e sse allegue con los que nasçicren de la ffuente del ssu baptismo por poblar con ella la ssu çibdat, que es el ssu rregno santo de parayso.

La ssegunda, partir el agua en ssigno de cruz, sse muestra que 30 después que esto ouyere ffecho, deue tener la mano e ayuntar los dedos en vno e frazer vna cruz en el agua commo quien la parte por quatro partes, diziendo a Dios que el que estableçió aquella

I aquella. - 2 para/nucramente lo. $-3 T$ al Ssanto; $E$ al E. Santo. 5 Esto. - 6 profacio. - 7 oraçion $\left[\begin{array}{ll}E & 62 \mathrm{~N}\end{array}\right]$. $-8 T$ ffazer et que rruega / sallud. - 9 derechureros. - 10 c de fazer / menester e gloria den. - I $T$ es P. e santo e pod. -13 su nonbre e mar. $-13-14$ e muestra. $-1 \overline{0}-16$ fablar n. para c. c alc. - I6 abajar. - I7 plegarias asi que. - 18 su santa gracia. - 20 por que la nat. - a3 $T$ que el / oficio que aq. / fecho syn fin. 24 rrogaua que el pare. - 25 amortiguar. - 26 puebla. - $27 T$ lo que. - 3o dicho. - 3 I commo a quien. -32 en quatro. 
agua que estudiese sienpre [440] apareiada para dar a los omnes por crençia nueuo engendramiento, que ffaga aparesçer apuestas las ssus poridades, boluiendo con ellas la claridat de la ssu lunbre, que ssean alunbradas en tal manera, por el conçibimiento de Ja ssu ssantidat e el enprennamiento que es ffecho de la ffuente santa 5 del baptismo, que acquella criatura que es naçida de çelestial linage pueda en ella sser metido e lauado, e tornen commo ninnos ssin peccado e de vna uoluntad los que por natura de linage ffueron despartidos en el cuerpo [e] por natura de edat en el tienpo. Et por ende que mande Nuestro Ssennor Dios que es poderoso que todo ro el spíritu malo sse parta ende e ffuya muy lexos, assí que en ninguna manera non pueda enbargar la ssantidat de la vertud. Et quando estas palabras ouyere dichas, deue dezir otras contra el diablo, commo menazándol, que sse uaya e que non ande a derredor commo quien assecha para engannar o para ffazer algún i 5 danno.

La terçera, por tanimiento e por esparcimiento de agua en quatro partes, e es que el ssaçerdote deue tanner el agua con la mano, rrogando a Dios que aquella criatura ssin culpa ssea libre de todos aquellos que la acometieron para ffazer mal o destoruo e que ssea 20 ffuente ssanta para nasçer otra uez el cuerpo por crençia de aquel que sse quiere baptizar e para dar la vida a la alma para ssienpre. Et otrossí que ssea onrrado alinpiamiento por que todos aquellos que con ella sse lauaren rresçiban perdón de ssus peccados, obrando en ellos la graçia del Spiritu Ssanto. Et por ende que él la bendize 25 por Dios biuo, por Dios uerdadero, e por Dios santo, el qual departió la tierra por su palabra en el comienço del mundo e cuyo spíritu sse monyó ssobrella et después la flizo manar de paraíso e por quatro rrios rregar la tierra. Et quando esto dixiere, esparga la agua en quatro partes de la pila en manera de cruz, diziendo 30

I estodiese. - 2 creençia e nuevo / paresçer apostas. -4 alunbrados en tal $\left[\begin{array}{ll}E & 62 v\end{array}\right] \mathrm{m}$. que el por cl conçebimiento / $T$ por que el. - 5 fecha de la su fuente. - 6 criatura non es $n$. del çel. -- 7 puede / lauado e se tornen. -8 fueren. -9 departidos. - ro manda. - 14 menazando. - 14-16 ande en d. c. quien ha fecho para eng. nin $f$. ningunt danpno. - i 7 tannimiento / esparzimiento. - $18 T$ añade e sobre la linea; $E$ lo omite / $T$ tener. - Ig se libre. - 20-3 I cometieren para fazerle mal o d. que sea fuerte s. para n. el c. otra vez que creençia. - 32 darle v. al a. por. $-23-29 E$ pone por crror $\mathrm{E}$ otrosy ... rregar la ticrra después de tienpo, linea $9 .-23$ sera hourra de alinp. -25 bendiga. -26 biuo e verd. -37 por la su. -29 esparça. - 3o el agua. 
que la bendize por aquel que en el desierto la ffizo manar de piedra e la tornó dulçe, sseyendo amarga, para ffazer que perdiesen por ella la grant sset que ante era en el pueblo; otrossi que la bendize por Ihesu Gristo ssu ffijo, que en Caná Galilee por el ssu

5 marauilloso poder la tornó vino et andido ssobrella de pies, non se ffundiendo, et ffué baptizado en ella por mano de Ssant Johán Babtista en el rrío de Iordán e la ffizo que ssaliese por el ssu costado buelta con ssangre e mandó a los sus disçiplos que ffuesen por todo el mundo, ensennando a los omnes la crençia de Santa Tri-

to nidat el baptizando a los que la creyessen en el nonbre del Padre, del Ffijo, del Sspiritu Santo.

La quarta, que es por aspiramiento, muestra que el clérigo deue camiar en otro sson commo quien lee lección, rrogando a Dios que el que es Sennor spiritual aspire en aquellos que guardaren

a 5 ssus mandamientos. Et estonçe deue aspirar en aquella agua tres uezes en manera de cruz e rrogar a Dios que aquellas aguas quiera bendezir de ssu boca por que pueda lauar los cuerpos de los omnes de ffuera e las almas de dentro, ssin [45r] el natural aspiramiento que ellas han en ssí e por que sson de natura spiritual.

20 La quinta, que es por çirio, enssenna que el ssaçerdote deue tomar vn çirio e meterlo en el agua de la parte que non ardiere, rrogando a Dios que enbie en aquella ffuente la uertud del Spíritu Santo assí que toda la substançia que ha en aquella agua torne en ffazer engendramiento nueuo. Et estonçe ssaque el çirio del agua 25 ef rruegue a Dios que todas las manziellas de peccado della ssean estructas e la criatura que es ffecha a su ymagen e rrefformada al comienço de la ssu onrra ssea rresfriada de todos los escalentamientos non linpios de peccado, assí que todo omne que entrare en aquel ssacramento ssea tornado commo ninno chiquiello que 3 o nasçe otra uez.

La ssesta, de la cruz que deuen ffazer con olio e con crisma, es que el clérigo que deue ffazer cruz con olio bendito en el agua, diziendo assí que aquel ayuntamiento del olio santo e del agua

a perdiese. - 3 clla grant sed que auic en el P. e otr. -4 por su f. I. C. [E 6.3r] que en Cana Galilea por su: -5 andudo. -6 se somiendo. 7 del Jordan. - 9 de la Santa. - ro que lo. - xo-r I Padre e del F. e del Spir. - 13 leçion. - 14 aspire por la su bondad en. -16 deuc. -18 e a las / espiramiento. - 23 T la justiçia. - 24 fazer $n$. eng. e / de agua. $25 T$ rruege / pecados dellas. -26 la natura. $-37 T$ ssea linpia; $E$ se rresfr. - 28 pecados. - $39 T$ commo chiq. / chequillo. - 3o nasçiese. - 3I T ssesta que la: $-32-33$ clerigo d. f. cruz en el agua con o. b. dez. 
del baptismo sea fecho en el nonbre del Padre e del Ffijo e del Spíritu Santo. Et ha de ffazer luego otra cruz en ella con la crisma, diziendo que ssea ssantiguada e bienauenturada aquella agua por aquella crisma en el nonbre del Padre e del Ffijo e del Spíritu Santo.

La ssetena, de rrenegamientos, e en queriendo el preste baptizar aquel que quiere sser baptizado, ha de preguntar tres uezes a él o a los padrinos ssi rreniega o parte de ssí al diablo Ssatanás e a todas ssus obras e a todas ssus offanías. E él o ellos deuen rresponder que ssí. Et entonçe déuel el preste ffazer vna cruz con olio en los pechos e otra en las espallas, diziendo quel vnta con aquel olio de salut por Nuestro Ssennor Ihesu Ciristo por que aya la ssu vida perdurable. Et esto dicho, al de preguntar el clérigo algunas palabras ciertas que sson en el Credo in Deum, assí commo ssi cree en Dios Padre poderoso, criador del çielo e de la tierra. E el que quiere sser bap- í tizado o los padrinos deuen dezir ssí que cree. Et al de dezir la ssegunda uez que ssi cree en Nuestro Ssennor Ihesu Cristo, que rreçibió muerte por nos. E él a esto deue rresponder que ssí. Et aun al de preguntar la terçera uegada ssi cree en el ssu Spíritu Santo, que es ayuntamiento de las cosas e rremisión de los pecca- 20 dos, e en cómmo ha de rresuçitar la carne después de la muerte e auer vida con Dios por ssienpre. Et an de rresponder otrossí que lo creen. Et después desto al de preguntar el ssaçerdote tres uezes qué pide. Et él o los padrinos deuen rresponder que baptismo. Et él a de dezir otras tres uezes, preguntándol ssi quiere sser bapti- 25 zado. Et él o ellos rrespondan que ssí. Et estonçe el ssaçerdote déuel tomar por las espallas cabo los costados, ssi ffuere ninno, et meterlo sso el agua tres uezes - la primera, en derecho ffasta el ffondón; las otras dos, la cara contra el agua a diestro e a ssiniestro e en manera de cruz -, diziendo que lo baptiza en el non- 30 bre del Padre, del Ffijo, e del Spíritu Ssanto. Mas ssi ffuere omne grande, hal de ffazer que él mismo sse meta sso el agua; $[45 v]$ o

I Trañade sea fecho sobre la línea, otra mano; $E$ lo omile. -2 fazer otra crus 1 . [ $\left[\begin{array}{ll}6 & 63 v\end{array}\right]$ en, -3 aquel. $-6-7$ rrenegamien los que en q. el p. aquel. 8 rreniega e p. de sy el d. Setanas. - 9 vfanias. - to deue f. el p. vira $/$ $T$ cruz en. - I3 hale. - I6 dezir que sy cree / $T$ añade ssi sobre la línea, otra mano / E ha de. - 17 vez sy. - I 8 E a esto. - I 9 hale / el Spir. - 2I-22 muerte e ha de auer. - $22 \mathrm{E}$ ha. -23 cree. $-24-25$ bautismo e hale de. $-25 \mathrm{~T}$ preguntantandol. $-28-39$ fasta fondon. $-29-30$ agua e a d. e a $\sin$. en maul. - 3o quel baut. - 3r Padre e del Fujo. - 32 -le / meta [E 64r] / e. 
ssi non, echarle tanta della de ssuso quel cubra todo, diziéndol essas mismas palabras que al ninno. Onde todas estas cosas han de sser ffechas dándol el baptismo, et el que desta guisa lo rreçibiere es baptizado conplidamiente.

[LEY LXXXVI]. - De las cosas que denen ffazer después del baptismo, cómmo son ffechas en ssiele maneras.

Acabadas estas cosas ssobredichas que sse deuen ffazer ante'del baptismo e con él en vno, conuyene que sse digan las otras que sse han de ffazer después que ffuere ffecho. Et éstas sson [en] ssiete ro maneras : cómmo deuen ssacar de la ffuente el baptizado; cómmo deven ffazer la cruz en ssomo de la cabeça con la crisma; et cómmol deuen poner el capiello que llamamos alba; cómmol deuen poner la candela en la mano; cómmo sson los padrinos ffiadores del baptizado; cómmo en el baptismo rreçiben la graçia 15 de Dios; et cómmol deuen onrrar después que fuere baptizado.

Et al que ffuere baptizado dénenlo ssacar ffuera del baptismo. Et esto deue fazer ssennaladamiente aquel padrino quel tomó a la puerta de la eglesia, et déuel tener ffasta que ssea acabado este ssacramento. Que muestra cómmo le deue ffazer poner la crisma, 20 et esto es que el clérigo deue ffazer vua cruz con crisma al que ffuere baptizado en ssomo de la cabeça en ssignifficança que es parçioncro de Ihesu Gristo -- ca del ssu nonbre es llamado cristiano -, diziendo esta oraçión, en que rruega a Dios, padre de Nuestro Ssennor Ihesu Cristo, que flizo nasçer aquel que baptiza 25 por agua e por Spíritu Ssanto, dándol por baptismo rremisión de sus peccados, que él quiera vntarle de crisma de ssalut, que sse entiende por ssaltnamiento, por que gane por ende vida perdurable. Et que ffabla del alua muestra que el ssaçerdote deue poner vn panno de lino en la cabeça al que ffuere baptizado, diziéndol

I echarle d. t. de. - - 3-3 han a ser. - 5-6 A que cosas tiene pro el bautismo quando es fecho commo deue. - 8 digan estas otras. -9 han a fazer. - I 2 conmo le deuen. - 12-13 alua e commo le han a poner. - 13 mano e commo. - 1/4 del pateo e e. el bautizado rresgibe. - i 5 de Ihesu Cristo e commo le / $T$ dene. - 16 baleado denenle s. f. del bateo. - I7 Esto. - ${ }_{19} T$ añade le $y$ poner sobre la línea, otra mano; $E$ los omite. I9.30 crisma esto. $-2[-33$ es fecho parc. -23 ca el su. -23 oraçion que. - 24 nasçer a aquel. - 35 Espiritu d. por bateo. - 26 que quiera. - $28 T$ Et frabla; $E$ Que fabla / de alma. - 29 vn capillo de. 
que tome aquella uestidura que es blanca e ssin manziella e que la traya en ssu uoluntad, con que biua por ssienpre. Por candela es que el clérigo le deue poner vna candela en la mano diestra, diziendo que tome aquella candela linpia ardiente por que guarde ssin rreprehendimiento ssu baptismo de guisa que quando Nues- 5 tro Ssennor Thesu Cristo viniere a la ssu boda, que sse entiende por el día del juyzio, que pueda luego yr con él al ssu palaçio del çielo, que es vida ssin pesar e ssin flín. Et cómmo los padrinos sson ffiadores del baptizado, es esto que ellos deuen sser ffiadores de los ninnos que ssacan de la fruente ante Nuestro Ssennor Ihesu ro Cristo. Et ssegunt dixo Ssant Agostín, ellos le deuen mostrar otrosí guardar castidat e amar justiçia e caridat. Et ante de todas las otras cosas que les muestren el Credo in Deum e el Pater noster. Et de cómmo rreçibe la graçia de Ihesu Cristo por el baptismo, es por rrazón que le sson perdonados por él los peccados que auya 15 ffechos ante que ffuesse baptizado. Et ayúdal a mantener ffe en estado de buena vida por que non torne más en ellos. Et cómmo lo han a onrrar después que ffuere baptizado, es porque los padrinos e las madrinas lo deuen leuar a ssu casa muy onrradamiente por rrazón que lo traen de rreçebir onrrado ssacramento, 20 en que rreçibió lauamiento del cuerpo e del alma. Et [46r] por ende, así commo los padres tenporalmiente heredan los flijos en los bienes tenporales, assi los padrinos ffazen heredar por crençia del baptismo a los affijados los bieries del paraíso. Onde tanto quier dezir padrino spiritualmiente commo padre temporalmiente. 25 Ec otrossí ffazen de los ffijos e de los affijados; ca ffijo sse entiende por tenporal e affjado por spiritual. Onde estas cosas acabadas, la primera que sse ffaze ante del baptismo e en vno con él e las otras después dél, es baptismo acabada e conplidamiente en onrra de ssantidat al quel rreçibe de los otros que lo an rreçebido.

2 Por $\left[\begin{array}{ll}E & 64 v\end{array}\right]$. -3 clerigo deuele. $-6-7$ su boca por. -7 pueda yr 1. con. - 8 cielo do es $\mathrm{v}$. $\sin \mathrm{p}$. $\sin$ fio. -9 bautismo. - 10 fuente a Nuestro, - I1-12 deuen o. $m$, guardar. - I $2 T$ otrosi cast. / amor. - I5 quel son. - 16 ayudol. - $T_{i-1} 8$ commo han. $-18 T$ ha onrrar. - ig le/ $T$ deuen a. - 2o rrescebir muy honr. - 32-23 heredan los b. de los f. tenp. - ${ }_{3} 3$ por la creençia. - 29 -3o despues del b. acabado $c$. e es estremado e honrrado de s. al que lo rrescibe. $-30 T$ otros que non an; $E$ otros que lo non han. 
[LEY LXXXVII]. - De cómmo deue sser onrrado el baptismo por ssiete rrazones e guardado por otras tantas.

Onrrado deue sser el baptismo por siete rrazones e guardado por otras tantas: por la onrra del Ssennor cuyo sacramento es; 5 por las palabras ssantas e onrradas que en él sse dizen; por la onrra que ganan los que sse batizan entre los otros que non sson bateados; [por la uertud que rreçibe el agiua]; por el esffuerço que toma aquel quel rreçibe; porque sse rriedra del diablo que el poder que ante auya ssobrél, piérdelo e gánalo el baptizado;

Io porque ssabe que después que muriere en este mundo, sserá onrrado en el otro e biurá ssin ffin.

Onrrado deue sser por la onrra del Ssennor cuyo es; ca es de Nuestro Ssennor Ihesu Cristo. Et quísolo él onrrar ssobre todos los otros sacramentos spiritualmiente quando quiso que la ssu I 5 santa ca:ne, que era ssin peccado, ffuese baptizada por dar enxienplo a nos que ssomos carne mortal que, rreçibiendo el baptismo, esquiuaremos las penas del inffierno. Et deue sser onrrado por onrra de las ssantas palabras que en él dizen; ca las dixo aquel a qui aoran todos los ssantos por la ssu graçia ssanta e por la ssu 20 boca, quando dixo a ssus disçiplos: Yt e baptizat todas las gentes en el nonbre del Padre, del Ffijo, del Spíritu Santo. Et deue sser onrrado otrosí por la onrra que gana el que sse baptiza entre todos los otros que non sson baptizados; que de uasallo que era del diablo tornó a sser uassallo de Ihesu Cristo. Et por la uertud 25 deste sacramento es avuntado a él e es ssaluo e libre e rredemido e alunbrado de la ssu ssanta lunbre e conuenible para rreçebir todos los ssacramentos. Et onrrarle deuen otrossí por la onrra e uertud que rreçibe el agua ; ca ella por ssí non es ssinon elemento, mas por las palabras del ssu ssanto nonbre, que es Padre e Ffijo e 3o Spíritu Santo, que sse allegan al elemento, que es ffecho ssacra-

2 tantas [E $65 r]$. - 4 otras siete por. -6 bautizan. -7 bautizados / $T$ $y E$ por el logar onrrado de que el ( $E$ : honrrado que aquel que es) baptizado en la eglesia. - $\delta$ toma aquel que faze honrrar aquel que lo rresç. / sc parte. - 9 bateado. - I I otro con los santos que beuiran. - I 4 denō. - 15 bateada. - I $z^{-1} 8$ por la honrra. - 18 que se dizen. - I 9 a quien / su s. g. e. - zo bautizad a todas. - 2 i Padre e del F. e del Spir. S. deue. - 24 tornase vas. / Por la. -25 sacramento e es ay. -26 la santa. -2 7-28 Honrrarse deue o. por la ho. de la virtud / $T$ añade onrra sobre la línea. - 3o elemento es. 
mento. ¿Ca dónde le viene al agua tan grant vertud que tanxiese el cuerpo de fuera e lauase el alma de dentro ssinon por la obra de las santas palabras? Et non tan ssolamiente por las palabras, mas por la crençia. Otrosí lo deuen onrrar por el esffuerço que toma aquel quel rreçibe; ca bien commo por el ssacramento del baptis- 5 mo es quita el alma de las penas e de los tormentos del diablo, bien assí es guardado el cuerpo en este mundo de los peligros dél, que sson muchos e de muchas maneras. Onrrar deuen [46v] otrossí el babtismo; ca quando los ssaçerdotes por la graçia del exorżismo, que conjurio es, ponen la mano ssobre los creyentes e deffien- 10 den a los spíritus malignos que non ffagan moradas en ssus uoluntades, e échanlos ffuera dellas. Et por esta rrazón el poder que los diablos auyan antiguamiente ssobre los omnes han los omnes ssobrellos. Porque ssaben que después que mueren en este mundo, biurán con Dios en el otro, ssegunt dixo Nuestro Ssennor i5 Ihesu Cristo en el ssu Euangelio, que el que creyere e ffuere baptizado sserá ssaluo. Et dixo más, que qui otra uez non ffuese naçido del agua, que sse entiende por el baptismo, non puede entrar en el rregno de Dios. Otrossí deue sser guardado por ssiete rrazones; ca sseyendo el baptismo onrrado e guardado, sson por 20 él los que lo honrran e lo guardan tenidos por derechos cristianos e ganan conplidamiente por él amor de Dios.

\section{[LEy LXXXVIII]. - Qué cosa es en si la crisma e quién la puede ffazer.}

Fasta aquí auemos dichas todas las maneras del baptizar que 25 deuen sser flechas. Mas porque la crisma es vnto ssanto con que sse deue ffazer el baptismo, queremos dezir primeramiente qué cosa es en ssí la crisma e quién la puede ffazer ; et de qué cosas ha de sser ffecha; e en qué tienpo e en qué logar; e en qué manera deuen tener apareiadas las cosas para ffazer la crisma; et de $3 o$ cómmo la deuen adozir los clérigos al altar para ssagrarla ; [et de

I vernie el agua. - $2 T$ cuerpo de dentro / lauase $[E 65 v] .-4$ le. 5 que lo. -6 penas de. -9 -זo exerçismo. - to que es c. pone las manos / T pone. - io-1 I T y $E$ deffiende. - I 1 malinos. - i 3 dellos. - 14 morieren. - 15 biuiran en el o. con Dios segunt. - I6 creye. - I $7^{-1} 8$ que quien non $f$. o. ves nasc. - 20 baulismo g. e ho. son. - 20-2 I $T$ omile por... guardan. - $22 T$ guardan. - 25 bautismo. - 26 vagento. - $29 T$ ffecho. $-3 o$ apartadas. - 3r commo d. adozirla / $T$ clerigos para el altar. 
cómmo deuen boluer el olio de la crisma con del olio del bálssamo]; et en qué guisa deue sser benedito e sagrado el olio para los cathecúminos e neóffitos e aducho al ssagrario onrradamiente.

\section{[ LEY LXXXIX]. - De cómmo estableçieron}

los santos padres la crisma.

Crisma es vntura ssanta que estableçieron los ssantos padres en la eglesia de Dios por o ffué el baptismo ssagrado por ella, et esto por siete rrazones: por el nonbre que ganó de lhesu Cristo; porque él ffué vntado con ella spiritualmiente por ssaçerdote; porque Io tenporalmiente fué vntado por rrey; de los que la pueden ffazer; cómmo lo ssolían ffazer antiguamiente a los rreyes e a los ssaçerdotes; por rrazón que frué más noble la vnçión de Ihesu Cristo que la de los otros; de cómmo Thesu Cristo fué ssagrado tenporalmiente ssegunt rrey.

15 Por el nonbre que ganó de Nuestro Ssennor Ihesu Cristo, por ende es llamada crisma. Et esto sse muestra por dos rrazones, la vna spiritualmiente, la otra tenporal; ca él ouo en ssí dos vnçiones, la vna de rrey, la otra de ssaçerdote. Et porque cada vna dellas ha nonbre por ssipsse - la de los rreyes, rreal ; la de los 20 ssacerdotes, spiritual -, por esso ouo nonbre Nuestro Ssennor Ihesu Gristo conplidamiente estas dos, ês llamada vnçión. Onde, commo quier que el baptismo quanto en rrazón de la crençia es conplido, muy mayor conplimiento rrecibe el que es baptizado, sseyendo vntado con la crisma.

25 Ca ffué Ihesu Gristo vntado con ella spiritualmente por uerdadero ssaçerdote, et esto es porque él ffué vntado con ello muy lleneramiente de los donos del Spíritu Santo, ssegunt dixo Ssant Iohán en ssu testimonio, que quando le baptizaua, que oyó la boz del Padre que dixo que aquél era el ssu ffijo, el que él 3o mucho amaua. En aquesta misma ssiguifficança sson vntados los

a $T$ benedilo para. - $z$-3 cateaminos e $[E 66 r]$. - 7 por que fue. 8 gano Ihesu. - 8-9 $T$ Cristo por el que fue. $-9 T$ spiritualmiente. 1o $T$ tenporalmienle por. -12 vnzion. - 13 olros omnes de. -15 Por ende g. n. C. e por. - ig syse / rreys es r. e la. -20 saçerdotes es spir. / $T$ nonbre Ssennor, -21 dos e es / $T$ llamadas. -25 Que / crismado / $T$ ella por. -36 rntado muy. -27 dones de Spir. - 39 fijo muclo amado que. - 30 E en esta. 
ssacerdotes spiritualmiente [4\% $]$ et sson juezes en las cosas ascondidas, ssegunt dixo Dauid el propheta: Non tangades los mis vntados nin sseades maliçiosos contra ellos.

Que Ihesu Cristo ffué vntado por uerdadero rrey tenporal muestra el ssu nonbre; que Ihesu Cristo en griego tanto quiere 5 dezir commo vntado. Et antiguamiente todos aquellos que eran llamados para sser rreyes auyan a sser vntados. Et él ouo en ssí todo esto ; que ffué volado e dió enxienplo de ssí a los otros rreyes tenporales, que an poder de ffazer justiçia en las cosas maniffiestas que sson, por que por la ayuda de aquel uerdadero rrey cuyo logar ro ellos tienen en la tierra ssean enffortaleçidos para mantener los pueblos en justiçia e en derecho. Et que los rreyes deuen sser vntados, muéstralo Ysayas en nonbre de Ihesu Cristo o dixo: EI mío ssagrado Çirio, cuya diestra yo tomé.

- Poder de ffazer la crisma, esto non es dado a otre ssinon a los prelados mayores, assí commo apostóligos o patriarchas o primados o arçobispo o obispo, porque ellos tienen logar de los apóstoles, que ffueron conpaneros de Nuestro Ssennor Ihesu Gristo et vieron todo ssu ffecho et entendieron spiritualmiente las sus obras, a que ouyeron a rrecudir; et conosçieron por el ssu ssuor e ssu 20 trabaio e la ssangre que esparzió, ssuffriendo penas e en cabo muerte en la cruz por nos, que flué vngüento por que fuuésemos ssanos e rredemidos de nuestros peccados. Et que a ssemeiante de aquello que ffué estableçido ffiziessen este otro, que es llamado crisma, por que los cristianos sson ssagrados e an nonbre de 25 Cristo; ca crissma tanto quiere dezir en griego commo vngüento sagrado en ssí que sagra las otras cosas. Et por ende ordenó Santa Eglesia que otro non ouyese poder de ffazer crisma, que es el ssu vngüento, ssinon los prelados mayores, porque ellos tienen las ssus vezes en tierra a ssemeiante dél.

Que a los rreyes e a los ssaçerdotes ssolian vntar antiguamiente con olio e con otros vngüentos preçiados, et esto non tan ssola. miente ge lo ffazían en la ffruenle e en las espallas, commo vntan

I $T$ tenporalmiente. $-\mathrm{I}-\mathbf{3}$ asondidas. -2 tengades los mios, -3 nit querades ser. - $4 \mathrm{E}$ Ihesu / tenporal [E 66v]. - 5 muestralo el. - Io $T$ por que par / por quel ay. - 13 en boz de I. G. do d. al. - 15 E poder $T$ esto es d. ssinon. - 16-17 apostoligos e a patr. e a prim. o a arc. $-I_{7} T$ de ap. - 18 conpanneros. - 20 rrecodir e c. que el. - 21 la su 5 . que esparçio. - 22 fue vntado / $T$ ffuenos: - 24 establesçido este. - 25 que son c. sagr. - 27 sagran. - 28 que non o. p. otrie de. - 29 synon perl. - 3r Ca. 
los de agora, mas de ssomo de la cabeça ffasta ffondón de las piernas. Et Moysés mismo lo ^ffizo Aarón quando lo vngió por ssaçerdote en la eglesia de Dios que era entonçe por que ffiziese el ssu ssacriffiçio. Et Ssamuel el propheta vntó a Ssaúl, que ffué el

5 primero rrey de los judíos, por mandado de Dios, et otrossí lo ffizo al rrey Dauid. Eit Natán el propheta vntó a Ssalamón.

Que ffué más noble e más conplida la vnçión de Ihesu Cristo que todas las otras, et esto ffué porque todos los otros lo rreçibieron por mano de omnes, et él rreçibiólo por Dios ssu padre. Et

ro ssi ellos lo ouyeron rreçebido por ayuntamiento de conffecçiones, él rreçibiólo por ayuntamiento de la Ssanta Trinidat, que sse ayuntó en él. Et por ende a Sant Iohán Babtista, por quien dixo Nuestro Ssennor Ihesu Cristo que era propheta e más de profecta, vinieron preguntar los judíos a qui dizían phariseos ssi era él

I5 Cristo. Et él dixo non, mas después dél uer[47v]níe aquel que " ffuera ffecho ante que él, del qual él non era digno de descalçar la correa del ssu çapato. [Et en esto mostró la Trinidat, do dixo que después dél uerníe aquel que ffuera flecho ante que él, del qual non era digno tan ssolamiente de descalçar la correa del ssu

20 çapato.] Et otrossí dió este testimonio de la Trinidat, allí do mostró que ssopiera por Dios que ssobre aquel que viesse desçender el Spiritu Santo en ffigura de paloma, que aquél era el que baptizaua en Spíritu Santo.

Que tenporalmiente ffué ssagrado Nuestro Ssennor Ihesu Cristo 25 ssegunt rrey muestra que ffué rreçibiendo muerte e passión por nos ; ca allí do lo alçaron en la cruz e le pusieron corona de espinas por desonrra, [allí ffué él alçado de Dios ssu padre por onrra] quandol dió poder ssobre todas las cosas e le coronó en los çielos e le dió el rregno por ssienpre. Et la vntura sagrada desto ffué la 3o ssangre que ssalió del ssu cuerpo, de que ffué cubierto e vntado de ssomo de la cabeça fasta flondón de los pies. Onde por todas estas rrazones que anemos dicho ffué Nuestro Ssennor ssagrado

I-2 cabeça sta en f. de los pies. - 2 Moysen / fizo a A ron / $T$ quando sse vngio / vnguio. - 4 profecta $[E$ 6\% $]$. - 5 otrosy fizo. - j-6 T fizo Dauid al. 7 conplida fue la $v$. de Nuestro Sennor Ihesu. - 10 confaçiones. - 13-14 $T$ era propheta vin. - I 4 a que. -15 dixo que non mas que despues. I6 desatar. -2 I supiera. -25 rresçcbiendo p. e m. por. -26 e alli. -28 quando / e el cor. - ag para. - 3o quel salio. - 31 desde s. de la c. f. en fondon. - 32 Sennor Ihesu Gristo sagr. 
ssegunt obispo en ssantidat e en ssaber, ssegunt rrey en poder e en justiçia.

\section{[Ley $\mathrm{XC}]$. - De las maneras de los olios de que sse faz} la crisma.

Los olios de que sse ha de ffazer la crisma sson en dos maneras, el vno del bálssamo, el el otro de oliuas. El esto ifué estableçido en la eglesia de Dios a ssignifficança de Nuestro Ssennor Ihesu Cristo, onde la crisma rreçibió el nonbre, ssegunt de ssuso es dicho por el bautismo. Et el olio, [del bálssamo e el] de las oliuas sson ssemeiantes a Nuestro Ssennor Ihesu Gristo en ssiete cosas : 10 en buena ffama; cn bucna olor; en que el bálssamo es en vn logar ssolo; en que non sse puede dannar; en que ssana las llagas nueuas e tuelle las ssennales vieias; en que gouyerna e mantiene; et en que amansa e amolleçe las cosas duras.

Et en que el bálssamo es ssemeiante a Nuestro Sennor Ihesu i $\overline{5}$ Cristo en buena ffama, esto es porque ffué enffamado conplidamiente en todo bien, ssegunt dixo Sant Ioháu apóstol e euangelista en el Euangelio, que la ffama de la su buena predicaçión e de ssanar los enffermos ssonaua por toda la tierra. Et en buena olor muestra que Nuestro Ssennor Thesu Cristo ffué de buena uoluntad 20 en demostrar tamanno amor a los que demostraua e amaua commo querer prender muerte muy mansamientre e homilloso para ssaluarlos, ssegunt dixo Ysayas propheta, que assí commo oueia mansa quiso venir a la muerte e commo cordero que es aducho ante el tresquilador, que ssol non ssabe abrir la boca para dar 25 bozes nin sse quexa. Que assí commo el fiuste onde ssale el bálssamo non es ffallado en todo el mundo ssinon en vn logar ssolo, otrossi Nuestro Ssennor Thesu Gristo nasçió de Santa María, que ffué virgen anle que nasciese della e en nasçiendo e después, lo que nunca auino a otra mugier nin auerná. Et demás, que es ffijo 30

I $T$ rrey en ssaber e. -3 olios e de. -5 olios que. -6 la vna / la otra. -9 $T$ por el balssamo et. -9 -ro oliuas semejante es N. Senor. - ro cosas [E $67 v]$. - I r color / $T$ olor é el. - I3-r 4 mantiene en. - If́ molesçe. - 5 es a semejança de Nuestro. - I6 es en que fue. - i 8 en su Eu. / su p. b. de. Ig $T$ y $E$ en que buena. - 2 i que am. - 22-23 saluarnos. - 34 commo el cord. - 25 trasquilador que sol que sabe. - 26 quexar e asi. - 28-29 Maria ante que naçiese $d$, e en $n$. fue $r$, e despues. 
de Dios en tal manera que él e ssu padre sson en vno ssin ningún departimiento. Et que assí commo el bálssamo non sse puede dannar nin corronper, nin dexa esso ffazer a las cosas a que allega, otrossí Nuestro Ssennor Ihesu Cristo nunca ffué corronpido nin

5 dannado nin lo puede sser, et guarda que lo non puedan sser los que a él sson allegados por graçia del Spíritu Ssanto. La quinta es que el bálssamo ssana las llagas nueuas e tuelle las ssennales de las vieias; muestra que Nuestro Ssennor Ihesu Gristo ssana [48r] los coraçones que sson llagados por yerros que ffizieron los peccadores o e tuelle las ssennales de las tentaçiones que les metió el diablo en los uoluntades, perdonándolos e auyéndolos merçet quando sse rrepienten, et doliéndose non tán ssolamiente de los peccados que ellos mismos conffiesan que ffizieron, mas aun de los antigos que non ffueron en ffazer nin en consseiar que los fliziessen, assí ij commo el de Adam o los otros que llaman en latín originales, en que caen los que nasçen en pecado por culpa de los padres e de las madres. Que el olio de las oliuas gouyerna e mantiene, esto que es a semeiança de Nuestro Ssennor Ihesu Cristo; que bien así commo el olio gouyerna e mantiene mucho el cuerpo del omne 20 que lo come, otrossí Nuestro Ssennor Ihesu Crislo da conplidamiente buen gouyerno en este mundo e mantiénel en el otro al que el ssu cuerpo rreçibe, comiéndolo commo deue, ssegunt él mismo dixo, aquel que come la ssu carne e beue la ssu ssangre, sserien amos en vno. Et aun más, que assí commo el olio es más 25 blando e ssabroso de comer, assí Nuestro Ssennor Ihesu Cristo da ssabor a los peccadores quel tengan, rrogándol e pidiéndol merçet que los perdone. Que el olio amansa los dolores e ablandeçe las cosas duras muestra que Nuestro Ssennor Ihesu Cristo tuelle los dolores e las cuytas que el diablo mete por los malos pensamientos 30 en las uoluntades de los omnes e ffaze amolleçer los coraçones de aquellos que sse non quieren arrepentir nin doler de ssus peccados.

1 padre en. - 3-4 llega e olr. -5 non sean a los. $-6 \mathrm{E} \mathrm{la.}-7 \mathrm{~T}^{\mathrm{r}}$ nueuas e ssalna las ssenn. (ssalua relocado sobre ssana). - ro que los. - I I auiendoles. - 13 rrepienten en dol. $/ T$ ssolamiente de los peccadores e de los peccados. - I2-r 3 que $\left[\begin{array}{ll}E & 68\end{array}\right]$ c. que e. m. fez. - 14́ consejar que lo. - i5 $T$ commo es Adam / o a los. - 16 que ahen los que / $0 .-17 T$ gouyerna esto. - I $7_{-1} 8$ esto es. - I9-20 del que. - 30-2 I conplidamente gou. - $2 \mathrm{I}$ mantienc. - 22 tomandolo. - 23 dixo qui come. - 24 que bien asi, - 25 saboroso. - $26 T$ peccadores rrog. / pediendol. - 38 Cristo que tuelle. - 29 cueytas! por malos. - $30 \mathrm{~T}$ los e / amolesçer. - $3 \mathrm{r}$ que non se quieren. 
Et demás, assí commo el olio ffaze mayor ssabor sobre las cosas en que cae que otra cosa quando lo echan alto, otrosí la merçet de Ihesu Cristo, que es tan noble e tan alta, e es más ssabrosa que otra cosa que pueda sser al cuerpo e al alma de aquel ssobre qui quiere que caya. Et por ende dixo el rrey Ssalamón prophetando, que el 5 nonbre de Ihesu Cristo tal era commo el olio que naçía. Et ssin estas cosas ay aun otra cosa, que assí commo el olio ssale de la oliua, que es ssienpre uerde e con ffoias, assí Nuestro Ssennor Ihesu Cristo ssalió spiritualmiente de Dios Padre, que está ssienpre en ssu poder e en ssu uertud, e nasçió spiritualmiente de Santa to María, et estido ssienpre en virginidat. Onde, por todas estas ssemeianças que ha el olio del bálssamo e el de las oliuas a Nuestro Ssennor Ihesu Cristo, estableçieron los ssantos padres de los boluer en vno. Et a este boluimiento llamaron crisma por el nonbre de Cristus.

\section{[Lex XCI]. - Del tienpo que fué estableçido para ffazer la crisma.}

Estableçieron los santos padres en la eglesia de Dios tienpo ssennalado en que ffuese ffecha la crisma, et esto en ssiete maneras: en qué día; et en qué tienpo; et por qué rrazón ffué ffecho en 20 tienpo de la pasqua; que sse deue fazer en Jogar linpio; et en logar onrrado; ef que los obispos lo pueden ffazer en los arçobispados, non seyendo y ssus mayorales; et que la pueden ffazer por rruego de otros.

Et que en jueues de la çena estableçieron los santos padres en 25 Ssanta Eglesia que ffuese ffecha la crisma, et esto ffizieron porque en tal día commo aquél çenó Nuestro Sennor [48v] Ihesu Cristo con los ssus disçiplos e con los apóstoles e consagró el pan e el vino, diziendo que era la ssu carne e la ssu ssangre, et quien aquello comiese e beuyese biuríe por ssienpre. En qué tienpo. 3o [Tienpo] de ayuno escogieron a ssemeiança del Nuestro Ssennor

2-3 quandol e. a. o. que la m. de Nuestro Sennor Ihesu. - 3 alta de saber sabor mas que. -4 puede / sobre que el quiere. -5 profectizando. -6 que vazian. - 7-8 de oliua. -8 Senor. - i Maria que estudo. - i 2 semejanças $\left[\begin{array}{ll}E & 68 v\end{array}\right] /$ e de. - I $4 T$ Et deste. $-20 T$ et en que hora. $-{ }_{2} 3 T$ puedan. - $2 \tilde{0}$ En quel jueues. - 28 con sus d. c consagro. - 29 -3o qui aqcomiesen e beuiesen que biuirie. - 3 I estudieron. 
Ihesu Cristo; ca bien assí commo él ayunó quarenta días e quarenta noches ssin peccado que él ouyese ffecho por que él ouyese de ayunar, otrosí touyeron por bien e por derecho que nos que ssomos muy peccadores ayunásemos otros tantos cada anno. Et

5 esto porque de vna parte magreçiésemos los cuerpos ayunando, et de la otra las uoluntades, tolliendo los engrosamientos de los peccados. Et otrosí a ssemeiança desto, de cómmo Nuestro Ssennor Ihesu Gristo ffizo aquella çena con ssus amigos - en que dió ssignifficança de dos cosas: la vna, de tristeza ssegunt la carne 10 por la muerte que auya de rreçebir; la otra, de alegría por la pasqua que flazía ssegunt la ley en este mundo con los apóstoles et auye de yr a ffazerla en el otro con los ssus santos -, nos dió a entender el lienpo de la pasqua, on que nos deuemos arrepentir de nuestros peccados e ffazer emienda dellos e lauar oios e pies 15 vnos a otros, assí que cada vno ffága a ssu cristiano aquello que querría que ffiziessen a él, por que todos, sseyendo amigos e de vna uoluntad en la ssu $\mathrm{Ffe}$, podiésemos por nuestras obras tener la muy noble pasqua con él en el su rregno. Que flué ffecho en tienpo de la pasqua, esto es que assí commo ella es luenne del 20 tienpo destenporado del yuyerno e llégasse al verano, que es tienpo nueuo con grant tenplamiento porque non ha en él ffrío nin grant calentura e veen los omnes las cosas que les plaze e rreçiben grant plazer e grant ssabor dellas; otrossí qui bien sse arrepintiere de ssus peccados e sse aluenga dellos por penitençia e 25 sse allega al amor de Dios, que es ssienpre nueuo e lleno de plazer e de alegría e de que sse gouyernan bien e conplidamiente en este mundo los cuerpos e en el otro las almas, en que non ha nin puede auer sobeianía de ninguna cosa, aduze a los que esto ffazen a non auer miedo de la muerte quanto por rrazón del diablo que 3o los pueda destorbar en este mundo e en el otro. En logar linpio e linpiamiente estableçieron los santos padres que sse ffiziese la

I Ćrisio ayuno ca. - r-2 quareynta. - $3 T$ touyeron por der. -- 4 pecadores que a. otras. -5 emagreşiesemos. -6 de otra. -7 semejante. -8 $T$ amigos e que. -9 tristiça (con la letra i escrita y tachada después de c). Io que el auia. -- I2 yrla a fazer / con sus, - 13 nos auemos de rrepentir. - I 4 dellos [ [ $69 r]$ - I5-I6 faga aq. a su c. que querrien. - I 7 Ffe por. - 18-ı9 $T$ pasqua que ffue f. en la pasqua. - 19 commo es. - 20 destenprado del ynuierno / el ver. - 2 I ienpramiento / ay. $\rightarrow 22$ veyen / plazen. -23 rresçiben sabor / quien. -24 rrepiente. -30 puede estoruar en e. $m$. nin en. - 3o-3 I linpio linp. 
crisma. E por ende escogieron la eglesia en que sse ffiziese, que es más ssanto logar e más linpio que puede sser, commo aquel en que ssagran el cuerpo de Nuestro Ssennor Ihesu Cristo et en que sse dan todos los otros ssacramentos, ssegunt de suso es dicho. Et que sse ha de ffazer en logar onrrado, esto es por rrazón que 5 ella es vngüento más onrrado por ssantidat que todos los otros. Et por ende deue sser ffecha e conssagrada en la ssee, que es la más onrrada cosa en el obispado onde ffuere aquel obispo que la ffaze, e non en otra. Pero ssi acaesçiesse que aquella eglesia ffuesse entredicha o enbargada por alguna cosa, déuesse ffazer en ro otra eglesia la más onrrada que ouyese en aquel obispado mismo, e non en otro logar. Que los obispos lo pueden flazer en los arçobispados, non sseyendo y ssus $[49 r]$ mayorales, esto es, sseyendo los obispos ssufraganos de otros mayorales dellos, assí commo patriarcha o primado o arçobispo, que sson los prelados i 5 mayores del papa en affuera, et non seyendo estos prelados en la tierra e les dexassen ssus vezes, bien pueden aquellos que assí ffincan ssagrar la crisma en woz de los otros que los dexaron en aquel logar do ellos lo pudiessen ffazer ssagrar. Que la pueden ffazer por rruego de otros. Et quando acaesçe que algún prelado 20 ffuese enffermo o fflaco en manera que lo non pudiese ffazer la crisma e pasase por y otro a quien él rrogase que lo fliziese, bien lo podía él ffazer en el logar do el otro lo ffaría ssi pudiese. Et esso mismo ssería ssi en la eglesia mayor non onyese obispo et el cabillo della rrogasse a otro que por y pasasse que lo ffiziesse. 25 Onde en cada vno destos logares que sson dichos puede e deue sser ffecho.

[LEY XCII]. - De cómmo dellen tener apareiadas todas las cosas que sson mester para ffazer la crisma.

Miércoles ante de pasqua por noche estableçieron los santos 3o padres que touyessen en el ssagrario de aquella eglesia do quisiesen ffazer la crisma todas las cosas que ffuessen mester para ella,

I quo la feziesen. - 2 es el mas alto lugar $/ T$ sser aquel. -3 consagran / Cristo en. - 5 honrrado e esto. -7 ende ser / en ella que. -8 cosa del ob. o. fue. - to e. - 1 oniere. - 12 la. - $13-14$ soyondo [E 69p]. I'́ solraganos. - I5 primano / son perl. - 17 dexasen estos perlados sus. so $T$ otras / Es quando. - at en vida que la non. - 29 la. - 23 la puede fazer / la. -25 la. -27 fecha la crisma. 
por que otro día las ffallen apareiadas para conplir en ello ssu offiçio. Et esto por ssiete rrazones, que sson éslas : cómmo deuen apareiar los olios e las anpollas; cómmo deueu tanner el jueues a la misa; cómmo el obispo sse deue rreuestir para bendezir los

5 olios; cómmo los deuen conjurar; qué ffuerça ha para obrar aquel conjuro; qué es el exorzismo que ffaze ssobrellos; e a qué tiene pro aquel exorzismo.

Que deuen apareiar los olios e las anpollas sse entiende que el miércoles por noche, ssegunt de suso es dicho, deuen primeraIo miente apareiar los olios de bálssamo e de las olinas en buenas anpollas de cristal o de vidrio o de otra cosa la más noble e más linpia que pudieren auer. Et estas anpollas deuen sser quatro: la vna, para el bálssamo; la otra, para el olio de las oliuas que an a boluer con él, que llaman crismal ; la otra, apartadamienle para

$\$ 5$ los enffermos; la otra, para los catecúminos, que quier tanto dezir en griego commo los que sson cathezizados a la puerta de la eglesia, ssegunt de ssuso es dicho, o para neóffitos, que se entiende por los que sson de otra ley e sse tornan a la ffe de lhesu Cristo. E la anpolla en que está el bálssamo deue sser cubierta de panno 20 de ssirgo blanco el más fermoso que pudiere auer.

El deuen tanner el jueues las canpanas a misa. Esto es que otro día quando es hora de ssesta deuen taner todas las canpannas de la villa a la missa mayor, assí commo las tannen en las grandes ffiestas por que todos sse ayunten en la eglesia. Et después non 25 las han de tanner ffasta el ssábbado a la grant penitençia. Et esto que las tannen el jueues es por semeiança de la grant ffiesta que flizo Nuestro Ssennor Ihesu.Cristo quando çenó con los apóstoles e ssagró el ssu cuerpo. Et lo del ssábado otrossí es por el alleluya [49v] que cantan, que quier dezir tanto en ebrayco commo alegría, 3o por onrra de la ffiesta de pascua en que rresuçitó Nuestro Ssennor Ihesu Cristo.

Que el obispo sse deue rreuestir para bendezic los olios muestra que el jueues después que ffueren tannidas las canpanas e la gente

2 Esto. - 3-4 a misa. - 5 conjurar e que. - 6 conjuro e que es / fazen sobrellas e a quien. - 9-ro deven a. p. los o. del bals. - I1 vidro. - 11-12 $T$ la mas linpia. $-\mathrm{r} 2$ anpollas $[E 70 \mathrm{r}]$. -14 el a que. $-15-16$ quiere d. $t$. en. - 16 cateziezados. - 18 fee de Nuestro Sennor lhesu. - 20 signo / podicren. - 2 i Que d. el j. t. las. - 32 tanner / canpanas. -25 a la gloria pen. - 28 consagro / sabado es o. por. - 29 dezir en / $T$ tanto commo. - 3o-3r pascua que el rres.; con omisión de Nuestro S. I. Cristo. - 33 ouicren. 
ffuere entrada en la eglesia, déuesse el obispo rreuestir de todas sus vestimientas las meiores e más apuestas que él ouyere, et otrossí los que han a dezir el euangelio e la epistola; deue començar a dezir la missa. Et quando llegare al logar o quisiere entrar a dezir la ssagra, anle de offreçer los clérigos la anpolla do está el 5 olio con que deuen vntar los enffermos. Et al de conjurar e de bendezir desta manera, diziendo que conjura a Ssatanás e a todos los ssus malos spíritus e a toda manera de ffantasía en el nonbre del Padre e del Ffijo e del Spíritu Ssanto; que ssi ha poder en aquel olio, que lo pierda e que sse parta ende, por que ssea ffecho ro vnçión spiritual para dar ffortaleza a la Eglesia, que es cosa de aquel que dura por ssienpre, por que en el ssu nonbre pueda morar el Spíritu Santo en aquel olio que él ffizo ssalir de la oliua uerde, commo quier que es ffuste; e que lo denne bendezir por que ssea conplida melezina spiritual a los que ffueren vntados con él o lo 15 gostaren o lo tanieren para darles ssalut tan bien en las voluntades commo en los cuerpos, assí commo él quiso vntar los ssaçerdotes e los rreyes e los mártires. Et después desto a de dezir, bendiziéndol, que Dios, que por la ssu acuçia del entendimiento del linaie de los omnes dió graçias de bendiçión a las cosas que crió por pro- 20 uecho de las almas e de los cuerpos dellas e mandó que ffuessen ffechas e ordenadas en ssus tienpos por las nuestras obras, que él enbíe ssobre aquel olio la su ssantidat por que ssaque de los mienbros que con él ffueren vntados los poderes del diablo, que es nuestro aduerssario; et que la graçia del Spíritu Santo los esffuerçe, 25 tolliéndolos la flaqueza que el diablo metió en ellos por uençimiento de pecar, et los aduga a ssanidat e a ssaluaçión conplida. Et después que aquel olio ffuere bendicho, deue sser tornado de aquella manera quel aduxieron a aquel logar onde lo sacaron.

Cómmo lo deue conjurar. Conjurio es palabra que maguera lo 30 ssaben lodos comunalmiente, por esso pocos lo entienden; ca el conjurio sse leuantó de jura. Et la jura non puede sser ffecha ssi-

2 vestimentas. -3 la pistola. $-5 T$ an. - 5-6 anpolla del olio. 6 hale. $-7-8$ todos sus. - 10 e se p. dende. - i I casa. - r 2 sienpre que $/ T$ que el / pueda [E $70 v]$. -14 deue. - I5 çelestial / el olio o. $-16 T$ lo vnxieren / tanieren olio p. darlos. - I $7 T$ assi que commo / de nō. - I8-i 9 bendezicndol. - $19 T$ Dios por / que el alcuzia. - 20 dio grant bend. / por el prou. -- 21 dellos $/ T$ dellas mando. -26 -les / $T$ ffranqueza. $-26-27$ venziroiento. -27 saluamiento conplido. - 3o E commo/maguer la. - 3I encomunalmente : la. -3 a leuanta. 
non por Dios e por las palabras del ssu nonbre, en que ha toda uertud. Et por esso la jura, maguer la husen todos los omnes e los ssennores mayores o ellos otrossí vnos con otros, con todo esso non puede sser ffecho ssinon ementando y a Dios. Et porque en 5 el latín dizen jux por el derecho, esta palabra de jura ha de uenir ssobre las cosas uerdaderas e derechas que omne ffaga o quiera ffazer, otorgandô prometiendo por Dios que las terná o las conplirá uerdaderamiente; por esso es llamada jura. Et conjurio ssale desta palabra, que quiere dezir commo aquella cosa que sse deue 10 dar e conplir. Et por ende los conjurios non tannen ssinon ssobre cosa que aya entendimiento, quier ssea tenporal o non. Onde los que ffazen contra los spíritus malos, es amenazándolos con $\mid 50 \mathrm{r}]$ miedo que les meten que les darán pena ssi non ffizieren aquello que les mandan por la uertud de las palabras de Dios, assí commo

15 se muestra en vn salmo del Sallerio que es de loor de Dios, en que dize que todas las cosas lo deuen loar, diziendo que por la ssu palabra ffué ffecho todo e por el ssu mandamiento criado. Et otrossí en el Ssalterio, ssegunt dize el rrey. Dauid, que por el vierbo de Dios son los çielos ffirmados e por el ssu spíritu, que sse entiende 20 por la palabra, rreçibieron todos uertud. Et ssegunt lo muestra Ssant Iohán auangelista en el ssu Euangelio, quando dixo que Dios era palabra e la palabra era con Dios e Dios era palabra. Ca o dize que Dios cra palabra, tanne en el Padre; et o comiença que la palabra era con Dios, tanne en el Ffijo; et en lo que torna a dezir otra uez 25 que Dios era palabra, tanne en el Spíritu Ssanto, que ssale de amos a dos e tórnasse en ellos mismos. Et otrossí ssegunt Ysayas propheta dixo commo en uoz de Dios, que assí commo el rruçio e la nieue desçende del çielo e non sse torna al logar onde viene, mas enbéuesse en la tierra para dar ssimiente al que bien senbra e pan al que ha 30 uoluntad de comer, que assí es de la palabra que ssale de la ssu boca; que después que es enbiada, non sse torna vazía a él, mas aprouecha ssobre aquellas cosas que la enbió.

Que la ffuerça que ha para obrar el conjurio es ésta ; ca porque sse faze por palabra, que sse entiende por la humanidal del ffijo 35 de Dios, e ha poder de obrar e lener pro en aquellas cosas ssobre

2 vsan los. $-3 T$ otros todo. -4 deue. -5 dizen jura por el d. e esta. -7 e. -9 quiere tanto dezir. - I r aya [E $7 / \mathrm{r}]$ / corporal. - is que se fazen. - i 6 le. - 18 berbo. - 19 formados. - 31 euangelista. - 23 do. -24 torna 0 . vez a dezir. $-26-27$ segunt d. Y. p. c. en. -27 rroçio. -28 desçiende. -29 semiente / sienbra. - 29-3o ha grant vol. -32 enbja. -34 por la pal. -35 cobrar. 


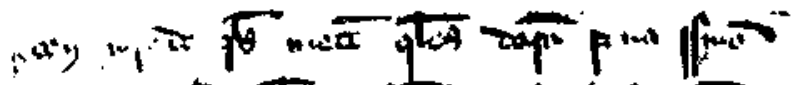

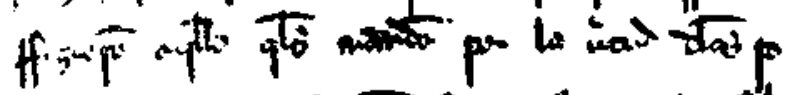

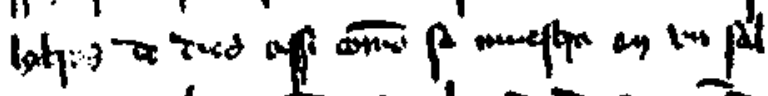

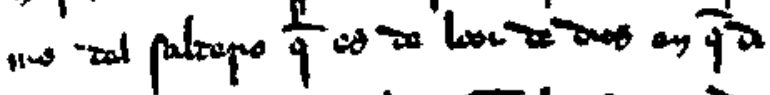

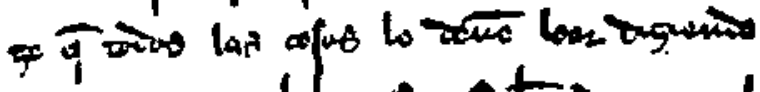

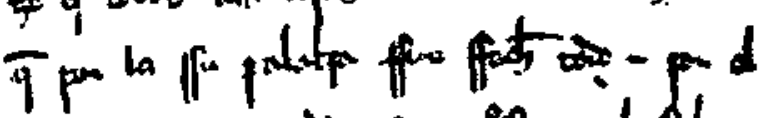

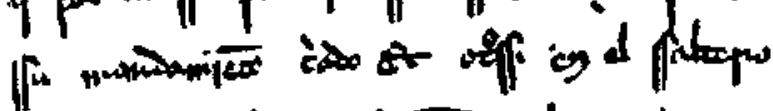

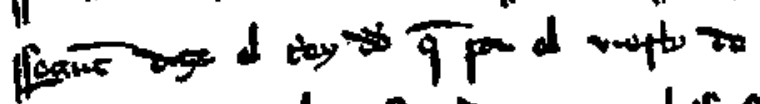

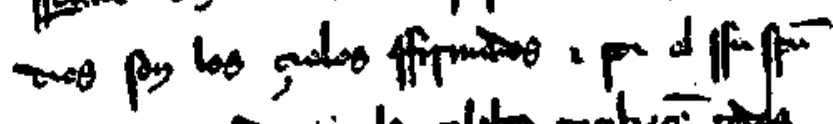

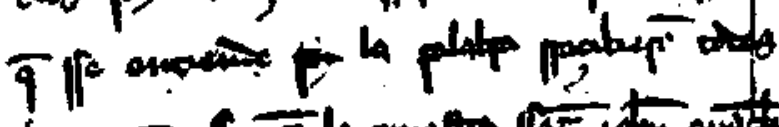

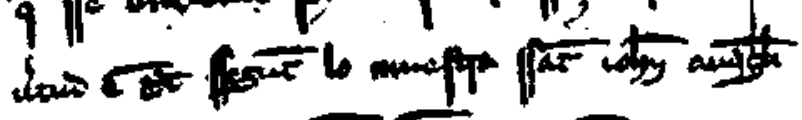

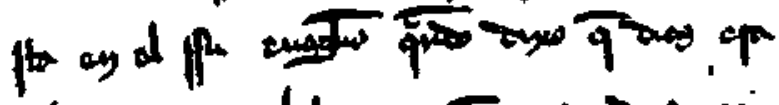

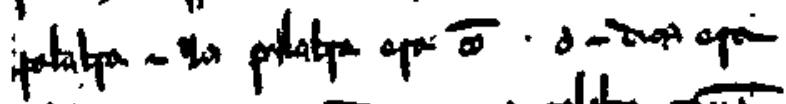

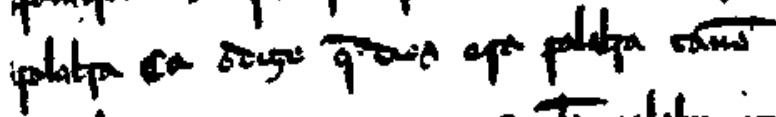

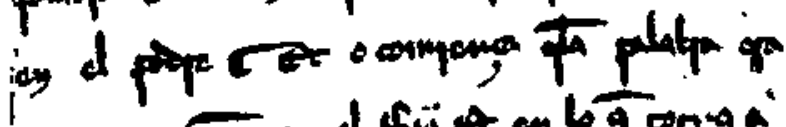

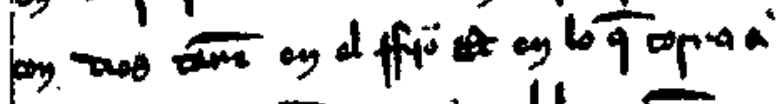

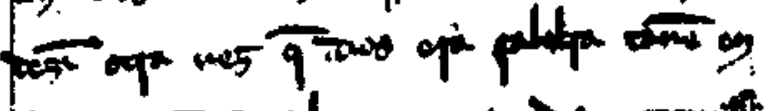

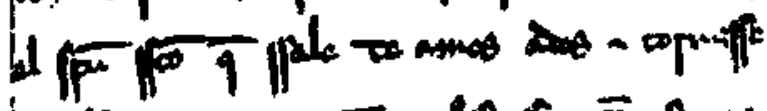

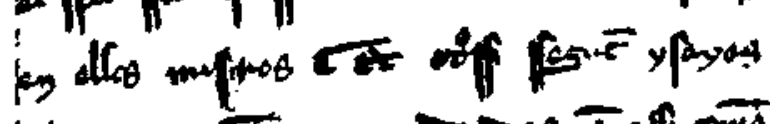

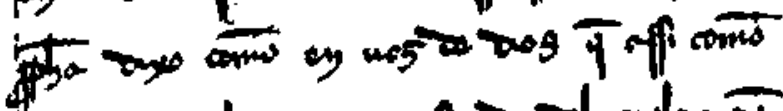

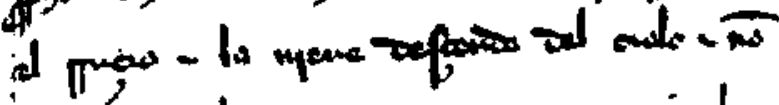

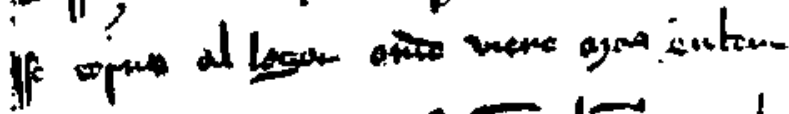

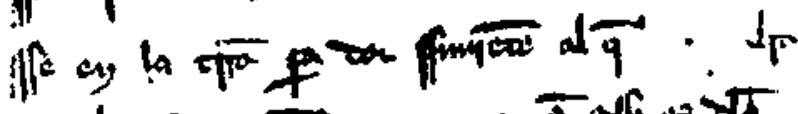
F

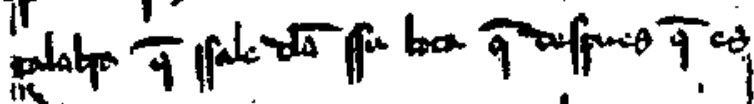

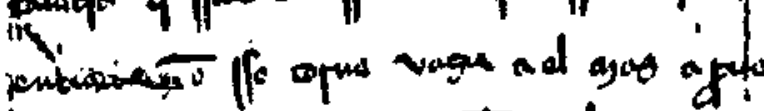

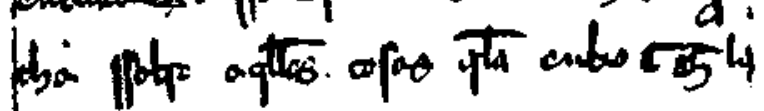

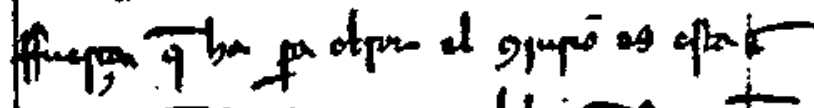

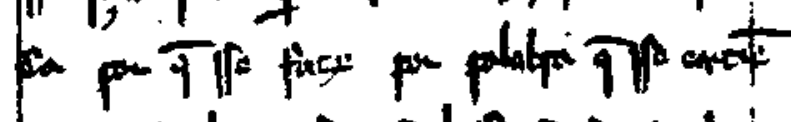

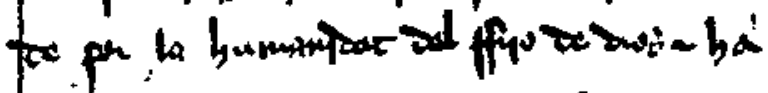

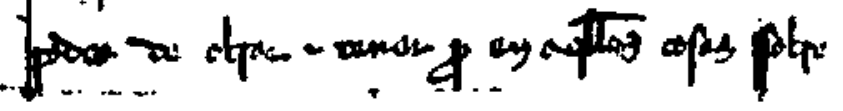

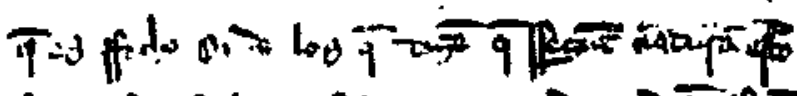

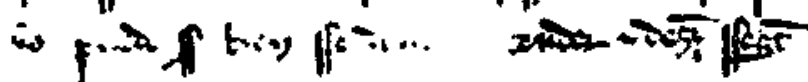

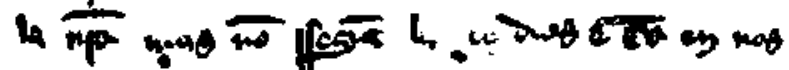

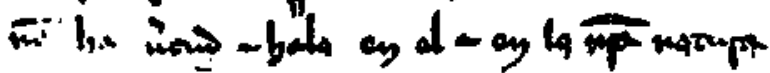

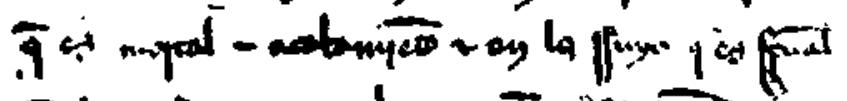

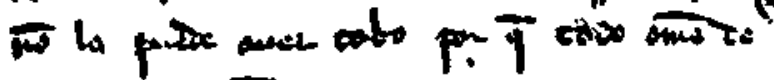

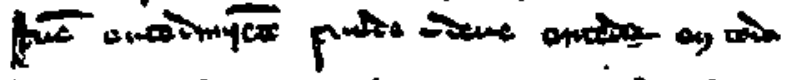

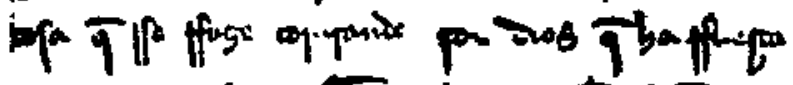

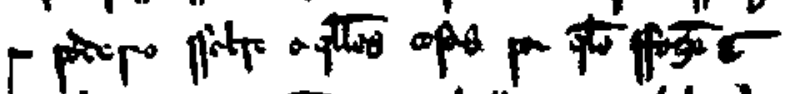

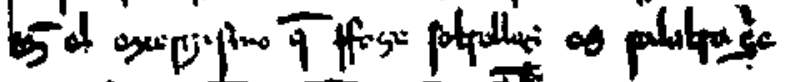

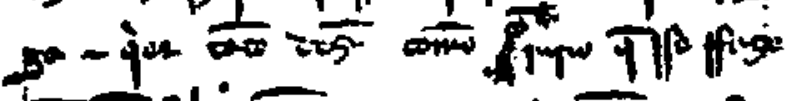

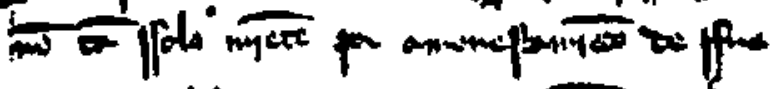

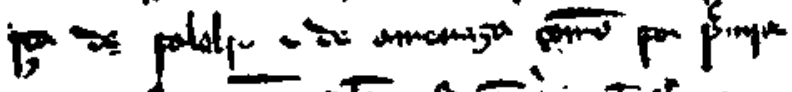

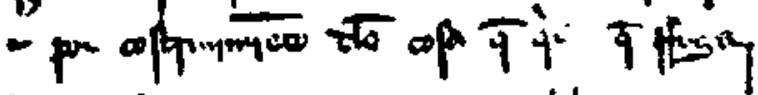

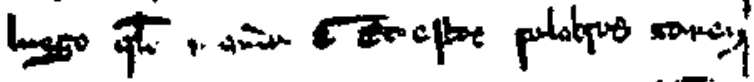

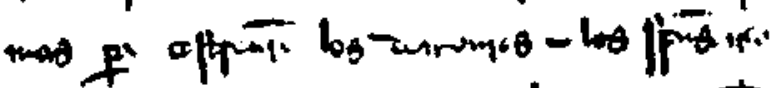

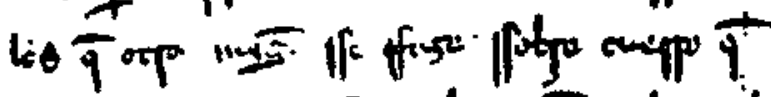

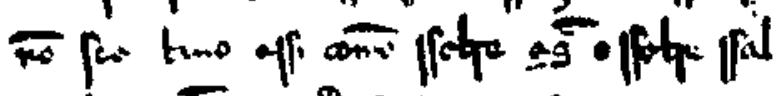

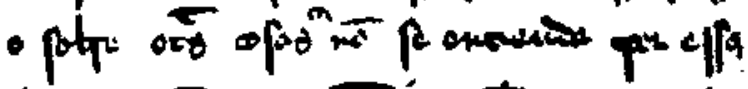

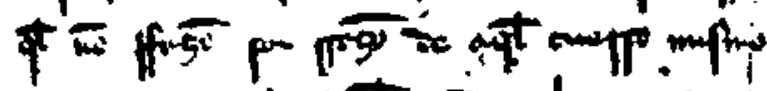

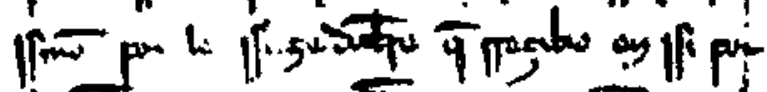

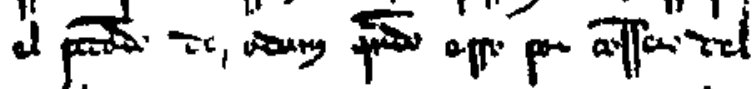

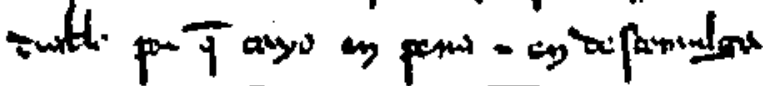
rictud

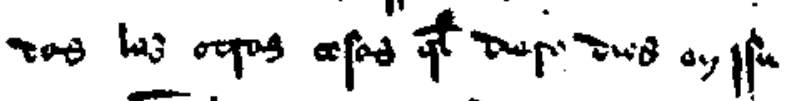

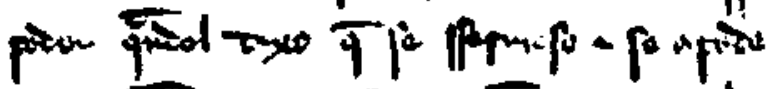

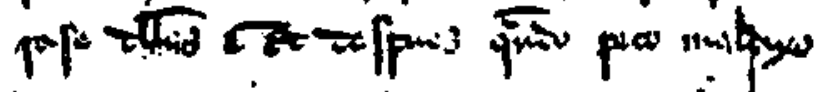

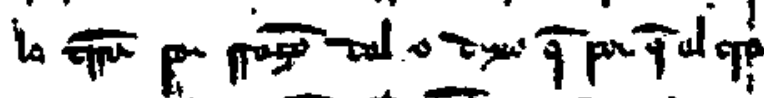

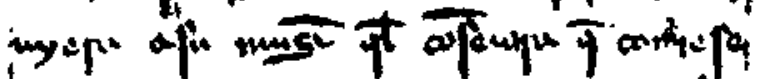

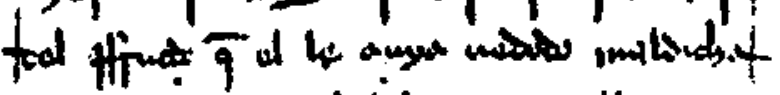

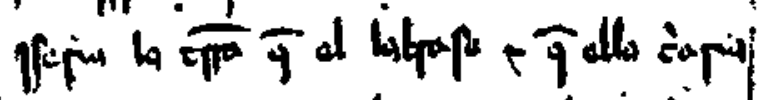

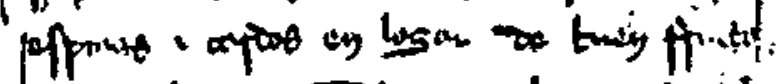

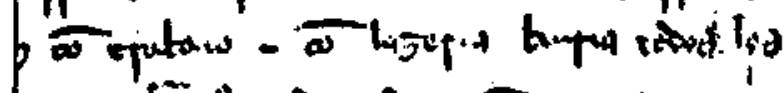

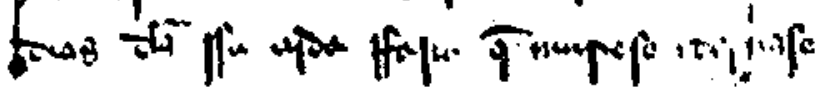


que es ffecho. Onde los que dizen que ssegunt natura esto non puede sser, bien sse dece entender e dezir: Ssegunt la nuestra, mas non ssegunt la de Dios. Ca en nos non ha uertud e hala en él, e en la nuestra natura, que es mortal, e âcabamiento e en la ssuya,

5 que es spiritual, non la puede auer cabo; por que todo omne de buen entendimiento puede e deue entender en toda cosa que sse ffaze, conjurando por Dios, que ha ffuerça e poderio ssobre aquellas cosas que lo ffazen.

Que el exorzismo que ffaze sobrellas es palabra griega e quier

Io tanto dezir commo conjurio que sse ffaze non tan ssolamiente por amonestamiento de ffuerça de palabra e de amenaza, commo por premia e por costrinimiento de la cosa que quier que ffaga luego que lo manda. Et estas palabras tanen más para costrennir los demonios e los spíritus malos que otra cosa; e maguer sse ffaze ssobre

15 cuerpo que non sea biuo, assí commo ssobre agua o ssobre ssal o sobre otras cosas, ca non se entiende por esso quel ffazen por rrazón de aquel cuerpo mismo, ssinon por la ssuzedunbre que rreçibió en ssí por el peccado de Adam quando erró por consseio del diablo, por que cayó en pena e en descomulgaçión de Dios non tan ssola20 miente él, mas todas las otras cosas quel diera Dios en ssu poder quandol dixo que se sseruiese e se apoderase dellas. Et después quando pecó, maldixo la tierra por rrazón dél e dixo que porque él crouyera a su mugier, quel conseiara que comiese del firucto que él le auya uedado, maldicha ssería la tierra que él labrase e 25 que ella criaría espinas e cardos en logar de buen fructo e con trabaio e con lazeria bitría todos los días de la ssu uida flasta que muriese e tornase [50v] a ella, onde ssaliera; ca poluo era e poluo auye a tornar. Et por esa ssentençia del juizio de Dios ffué descomulgada e maldicha la tierra tan bien commo Adam.

$3 o$ A qué apronecha el exorzismo. Es que aquella ora que el diablo sse apoderó en el omne en tal manera que quando muríe que le

5 aver porque. - 6 entender que toda. -7 faga / poderio de obrar sobre. $-8 T$ cosas por que. -9 exerzismo $[E 7 / v]$. - I I palabras / amenazar. - 13 o por costrennimiento (retocado sobre estrenimiento, otra mano)/ quicre. - 12-13 luego lo quel manda. - 13 tannen / $E$ costrennir (retocado sobre estrenir, atra mano). - $14 T$ otra maguer. - I6 $T$ añade ca sobre la linea, otra mano; $E$ lo omite / $T$ quel non frazen; $E$ que lo non fazen. - I7 suziedunbre. - I 8 crro por el cons. - 2 r quando le. -23 creyera. -24 maldita. - 25 del buen. - $25-26$ trabajos. -36 biuirie / de su. -28 esta. $2 \$-29 T$ descomulgado. -29 maldicta. -31 morie le. 
leuaua el alma al inffierno, et tomó otrosí poder para dannar e ensuziar todas las otras cosas que Dios diera al omne de que sse seruiese e ayudase, aquel poderío que el diablo entonçe ganó ssobre todas las cosas, tuéllegelas el exorzismo que sse ffaze por la palabra de Dios Padre e de Thesu Cristo ssu ffijo, que enbió por 5 heredar el paraíso e el mundo, de quien sse deseredara Adam por ssu mereçimi snto.

[LeY XCIII]. - En qué manera sse deue ffazer la crisma.

Conjurando el exorzismo e bendicho sseyendo el olio para vntar los enffermos, ssegunt de suso es dicho, deue el obispo, después so que esto ouyere dicho, tornarse al altar e dezir ssu misa ffasta que ssea acabada, et después començar el ordenamiento de la crisma, que sse ha de ffazer en esta guisa, en que ha ssiete cosas: ordenamiento ; testimonio ; rreçibimiento ; bendición ; enxanellar ; conjuraçión; oraçión.

Por ordenamiento es que, sseyendo el obispo assentado en ssu ssiella e con él el clérigo que dixo el euangelio, deuen uenir ordenadamiente dos acólitos con sennos çiriales en que trayan çirios ençendidos, e en pos ellos dos clérigos que trayan ssenas cruzes, e en medio aquel que traxiere el olio del bálssamo, e en pos éstos otros 20 dos acólitos que an a traer cada vno dellos ssennas anpollas con olio de oliuas, cubiertas de panno de ssirgo blanco de guisa que paresca descubierta la meatad contra ssuso. Et la vna déstas es para boluer con el bálsamo para ffazer la crisma, e la otra para los catecúminos e neóffitos. Et han de uenir dos clérigos ençen- 25 ssando estos olios.

Por testimonio, es esto que han de uenir en pos los dos clérigos que vinieren ençensando doze prestes rreuestidos así commo quando quieren dezir la misa, los sseys de la vna parte e los seys de la otra en manera de proçesión. Et éstos an âyudar a ffazer la 3o crisma e sser commo testimonios deste ffecho en ssignifficança de

3 e se ay. - 4-5 por pal. -6 de que (de añadido en el margen, otra mano). - 8 crisma $\left[\begin{array}{ll}E & 72 r\end{array}\right]$. - I 1-1 2 fasta que la ayan ac. $-13-14 T$ ordenamiento de test. - 14 rresçebimiento / exaneldad (ensaneldar añadido en el margen, otra mano). - i $E$ añade el segando el sobre la linea; $T$ lo omite. -18 sendos. - $18-19$ açendidos. - Ig $T$ en por / pos dellos / sendas cruçes. - 20 medio de aquellos el que / pos destos. - 2 I han de traber / sendas. - a3 moytad. 27 que deuen venir. - 39 e los otros seys. - 30 otra e en / han a ay. 
los apóstoles, ante quien Nuestro Ssennor Ihesu Gristo ffizo este día ssu testimonio quando çenó con ellos. Et por ende deuen yr todos derechamiente al obispo o aquel que está en ssu logar. Et antellos han de venir dos moços de choro, cantando estos viesos

5 en loor de áquel offiçio, en que rruegan a Dios que el que es rredemidor de los peccados e juez de los muertos e esperança de los que han de morir, que oya aquel cantar e que lo rreçiba por buen don en paz; ca a él traen homillosamiente para conssagrar el ffructo del árbol quél alunbró, por quel pidan merçet que él quiera

ro que ssea conssagrado por mano del obispo que está antel ssu ssanto altar, esperando para consagrarla. Et que el ssigno de la cruz que se ha de ffazer con él quebrante el poderío del diablo e rrenueue el linage del omne para la uoluntad de aquella crisma que ssea melezina ssanta en vertud e en onrra e en obra. [51r] Et con grant

I5 alegría ssea ssagrada la ffuente en que la han de echar para ffazer ffuyr al diablo e a todas ssus obras. Et que aquel que rreçibió carne de Santa María e nasçió della e nos rredimió, muriendo por nos, dé a los que ffueren vntados con la crisma carrera perdurable, assí que aquel día en que sse ffaze el ssu sacramento della le sea 20 ffiesta onrrada por ssienpre. Et a cada vn vieso déstos deuen rresponder los otros que uan en esta proçesión, ssegunt dixiemos en el comienço dellos.

Por el rreçibjmiento muestra que, estando antel altar ordenadamiente el ostiario e el leedor e el exorzista e el acólito, han de 25 rresçebir las anpollas de aquellos que las traen e darlas vno a otro ssegunt el ordenamiento del grado que an, començando primeramiente en el hostiario ffasta que llegue al obispo. Et él alas de tomar e ponerlas ssobrel altar. Et entonçe deuen ordenar en manera de proçessión a diestro e a ssiniestro del obispo los çiriales 3o con los çirios ençendidos e las cruzes e los ençensarios e los libros de los euangelios. Et otrossí deuen estar aquellos doze prestes que dixiemos en cabo de la proçesión çerca del obispo. Et todo esto así ordenado, deue el obispo por ssí, o otro por él ssi lo él non

2 testamento. -3 o al que esta en 1 . del e. -4 versos. -5 aqueste. -8 ca le trahen / consagrar [E 72v]. - 9 piden. - Io- I s su a. esperandolo p. consagrarlo. - I 2 fazer que con el que quebr. - I $4 T$ melezina e ssanta. - 16 foyr. - I 7 nos rresçebio. - I8 nos e a. - I8-19 con aquella abra la carrera p, e çierre la de la muerte asy (abra la añadido en el margen, otra mano). - 20 vierso deuen. - 23 rresçebimiento / $r$ muestran / delante el. $-24 T$ e leedor. - 26 que en com. - ${ }_{27} T$ llegue el ob. - 30 cruçes. -33 otre por el si el. 
pudiese, fiazer ssermón al pueblo qual conuenga âquella ffiesta. E acabado el ssermón, hasse el obispo a tornar al altar a bendezir el bálssamo ssi otra uez non ffuere bendicho.

Que es por bendiçión, esto es que el obispo deue bendezir el olio del bálsamo desta guisa : rrogando a Dios, que es obrador de 5 las cosas çelestiales e apareiador de todas las uertudes, que oya las ssus pregarias, assí que aquella ssudor que ssalió de la corteza de aquel arbol bienauenturado ssea rreçebido por muy buen vngüento para ffazer con él aquella obra que conuyene; et que él lo quiera bendizir e ssagrar por la ssu ssanta piadat.

Por conjuraçión es que el obispo deue enssanellar otras tres uezes ssobre el olio crismal, diziendo cómmo conjura aquella criatura del olio por Dios Padre poderoso, que ffizo el çielo e la tierra e la mar e todas las otras cosas que en él sson, por que todel poder del diablo Ssatanás e todas las ssus huestes de las ssus conpannas e toda tentaçión de ffantasma ssea derraygada e ffoyda antél, assí que todos los que con él ffueren vntados ssean bendichos ffijos de Dios, desçendiendo ssobrellos el Spíritu Santo; en el nonbre de Dios Padre poderoso, e en el amor de Nuestro Ssennor Ihesu Cristo ssu ffijo, que en vno con él biue e rregna por ssienpre jamás. 20

Que es por oraçión muestra que, desque estas cosas ssobredichas ffueren acabadas, deue el obispo dezir esta oraçión, en que rruega a Dios, que es muy alto Padre, que pare mientes al rruego que él le ffaze. Et commo quier que él ssea peccador e mesquino. que él le endereçe e enbíe ssobrél el ssu Santo Spíritu, con el 25 qual él vntó al ssu ffijo Ihesu Cristo ssobre todos aquellos que ffueron ssagrados. Et otrossí que ssantigüe e conffirme aquel olio ssanto, apareiado de aquella crisma, con graçia de los ssiete dones del Spíritu Ssanto, con que nos rredimió, lauándonos spiritualmiente. Et que assí nos quiera amolleçer, por que aquella $3 o$ vnçión nos ssea bendita e spiritual e comienço de cristiandat, por

2 obispo de tornar / $T$ tornar a bend. $-4 T$ esto por que. -6 çelestiales [E 73r]. - 7 plegarias / suor / de aquella cort. -8 rresçebida. - Io deuē bendezir. - I I exaneldar (enssaneldar añadido en el margen, otra mano). - I 2 conjura a aq. - 13 de olio. - 14 el mar / otras que / que el poder. - i5 Sa. tan e toda la hueste. - 16 fantasia sean derraygadas e fuydas. - I7 los que en el. - I9 poderoso en. - 2 I quando. $-25 \mathrm{~T}$ el end. -26 qual $v$. al su f. e sobre (e añadido sobre la línca, otra mano). - 27 que c. e s, a aquel / $T$ olor. - 29 rredemio. - 3o-3 I asy non deuē enmolesçer para que aq. b. nos sea v. celestial e com. 
que la ayamos por uestidura assí commo pannos onrrados para boda, et por allegamiento perdurable, que sse entiende por llegar nos $[5 i v]$ a Dios e por auer nos rremisión de nuestros peccados, de guisa que sseamos ssus ffijos escogidos çerca de la ssu merçet, 5 que es acabamiento conplido de graçia spiritual; et sseyendo ssennalados con aquel vngüento, podamos rreçebir en esle mundo el ssacramento del cuerpo de Nuestro Ssennor Ihesu Cristo ssu ffijo, que sseamos en ssu deffendimiento e en ssu guarda e ayamos con él vida ssin ffin. con del olio del bálsamo.

Boluer deuen del olio de la crisma con el del bálssamo, e este boluimiento da uertud por tres rrazones: la primera, por la uertud que ha en ellos e en cada vno por ssí ; la ssegunda, por el

I5 mezclamiento que les ffaze el obispo vno con otro; la terçera, por santas palabras de las oraçiones que dize sobrellos. Et por ende estableçieron los sartos padres que quando los boluyesen vno con otro, que lo ffiziesen en ssiete maneras : la primera, por oraçión; Ia segunda, por ayuntamiento; la terçera, por ssaludamiento; la 20 iiii $^{*}$, cómmo el obispo deue ssaludar la crisma; la $\mathrm{v}^{2}$, cómmo la deuen ssaludar las perssonas más onrradas con los saçerdotes; la $\mathrm{vi}^{\mathrm{a}}$, cómino la deuen poner ssobre el altar desque ffuere ssaludada; la ssetena, cómmo sse deuen homillar para ssaludarla.

La primera, por oraçión, esto es que el obispo deue rrogar 25 a Dios que aquel mezclamiento de aquellos olios ssean perdón de todos ios peccados a aquellos que con él ffueren vntados e guarda de ssalut para ssienpre. Et desí ha de rrogar a Dios Nuestro Ssennor que es poderoso ssobre todas las cosas; el qual, non podiendo en ssí sser cabopreso nin ençerrado por ninguna mane30 ra, quiso caboprender e ençerrar al ssu ffijo Thesu Ciristo, queriendo que rreçibiese nuestra carne, e que por marauillosa oraçión

2 allegar. -3 vuestros. -5 que $[E 73 v]$. -6 con este $v$. sagrado podemos. - 7 sacramento de Nuestro. -8 seamos so su def. (en escrito $y$ tachado, $y$ so añadido sobre la línea). - In-1 i crisma e del olio. - 12 el olio $f$ ca este. - 13 de. - If́ ellos cada. - is mesclamiento. - I9 saluamiento. - I I honrradas e los. - 22 de que. - 23 setima que se d. h. a la crisma quando la saludan. - 2\}-3j deue pedir merçet a. - 26-37 $T$ vntados de ssalut. 27-28 Dios que. -28 lodas cosas. -39 podiendo ser en su cabo preso. -30 el su. 
ffizo este ayuntamiento de guisa que non se pudiese partir; que, obrando la graçia del Spíritu Santo, vntó del olio de la grant alegría ssobre los que fueron vntados por que la heredat de los çielos que el omne perdió por conseio del diablo, la cobrase por el ssu Ifijo Ihesu Cristo ; por ende quél rruega que el que ffizo todas 5 estas cosas quiera que aquellos olios que sson criados de materia gruesa, que la ssu Santa Trinidat los bendiga e, bendiziendo, los santigüe.

La ssegunda, por ayuntamiento, esto es que el obispo deue ayuntar los olios, rrogando a Dios que aquel ayuntamiento dellos 10 ssea vno, assí que qualquier que ssea vntado con ellos de ffuera en la carne lo sea de dentro en la uoluntad, para toller de ssí toda ssuziedat de peccado por que pueda sser aparçero en el rregno de los çielos. El después que esta oraçión ouyere acabada, deue dezir esta otra, en que rruega a Dios que es perdurable, el qual en 15 el comienço del mundo por su bondat fízo que entre todas las cosas que la ticrra leuase árboles e ffructo escogido, de los quales árboles naçiese la grosura destos olios por que dellos ffuese ffecha la crisma santa del ssu olio, segunt Danid el propheta lo connosçió por la graçia del Spíritu Santo ante que ffuese esto ffecho, quando 20 dixo en el su Cantar que las nuestras hazes auyan a sser alegres con este olio. Otrossí después a muy grant tienpo que enbió Nuestro Ssennor Dios el diluuyo que destruyese el mundo por los peccados que en él eran ffechos, mostró en seme[52r]jança del galardón que auye a dar a los buenos la paloma que aduxo vn 25 rramo de olina, demostrando que assí commo el olio deste árbol era mansso, que assí era amansada la ssu ssanna e daua paz a la tierra. Et aun ffué amostrado ante grandes tienpos que por el baptismo del agua sserian destruydos los peccados. Et por ende rruega a Dios que el que esto ffizo ffaga con la vertud deste olio 30 los nuestros cuerpos apuestos e alegres, que sse entiende por

I puede. - 3 fueron $[E 74 r]$. - 5-6 $T$ todas las cosas. -7 bendeziendo. - $9 T$ estos. - Io santiguar. - 13 aparzero. - 14 acabado. - 16 las otras cosas. - $\mathrm{I} 7$ de quales. - 18 que meresçiesen quc fuese. - I9 su fruto s. el rrey D. prof. - $20 T$ Santo que. - 3 I $T$ hazes (h- añadida de otra mana); $E$ fazes / auian de ser. - $22 \mathrm{E}$ otr. ha / enbio el Nuestro. - $23 T$ Ssennor Ihesu Cristo el dil. / por que los. - 24 mostro ensenança. - 34-25 $T$ de g. que (que añadido sobre la línea, otra máno). -26 demostran. - 27 manso asy era la sanna am. e. - 38 mostrado g. t. a. que. - 29 destroydos todos Ios. - 3o rruegan. 
apostura de buena vida en este mundo e por auer alegría con él en el otro. Et ssin todo esto lo mostró Nuestro Ssennor Dios en otra cosa, quando mandó a Moysén que ffiziesse Âaron ssu hermano primeramente lauar con agua, et después que lo vntase con

5 este vngüento para ssaçerdote. Et queriendo que llegase este ffecho a mayor estado de onrra; ffizo a ssu ffijo Nuestro Ssennor. Ihesu Gristo que ffuese lauado en el agua de lordán por mano de Sant Iohán Babtista, por que viniese el Spíritu Ssanto ssobrél en ssemeiança de paloma. Et demás, por testimonio ffué oyda la su Io boz que dixo que aquél era el ssu ffijo que él mucho amaua, e esto ffué prouado maniffiestamiente ante muchos que estauan y. Et por ende que rruega a el que es Santo Padre ssobre todas cosas e Dios perdurable, e por el amor de ssu ffijo Ihesu Cristo, quiera ssantiguar e dar ssu bendiçión ssobre aquella criatura I5 de aquel olio grueso, assí que la uertud del ssu Spíritu Santo ssea mezclado con él, obrando por el poder de Ihesu Cristo, onde es llamada crisma; que él quiera que aquellos que ffueron nasçidos para baptismo de agua de Spíritu Santo rreçiban ssalut por esta vnçión, por que ssean aparçeros en la gloria del çielo e ayan 20 vida perdurable.

Et la terçera, por saludaçión, ésta es palabra natural que deue dezir vn omne a otro que ssea ssu amigo o lo deua sser, por que muestra grant ssignifficança de amiztat, diziendo que Dios le dé salut; ca el que la ha es omne conplido para beuir mucho 25 e ssin enbargo de ssu cuerpo. Onde desta palabra ssalut es dicha ssaludaçión. Et commo quier que en los omnes cae esto comunalmiente, tan bien a los mayores commo a los menores, pero quanto más onrrada es la perssona a quien es dicho, tanto mayor onrra rreçibe por ella. Et por ende por dos rrazones ffizieron esta $3 o$ ssaludaçión a la crisma más conplidamientre que a otra cosa que non aya alma: la primera, que ella es santa e onrrada en ssí, por

I $T$ aspostura. - 2 Avn todo (asin escrito y tachado, $y$ Avn añadido sobre la línea). - 3-4 feziese a su h. Aron prim. / $T$ hermano Iauar. $-4+5$ que le vntase por sac. [E 74v] con este $r$. e quer. - 6 mayor honrra. - $8 \mathrm{Bau}$ tista e que / $T$ añade por sobre la línea, olra mano. - Io aqual. - I 2 rrogaua. 1 3-1 3 es Dios P. s. t. las cosas. - 13-14 del su f. I. C. que deuen sant. - I4 bendezion. - 15 virtud del Spir. - 16 sea con el mezclada o. con el poder. r 7 crisma e que el q. de aq. - I 9 aparzeros. - 3 I La terç. - 23 amistad. 24 para poder beuir. - 29 honrra meresçe por ello. - 3r que es ella santa / $T$ añade por sobre la línea, otra mano; $E$ lo omile. 
que ffaze onrradas e santas todas las otras cosas ssobre que la ponen; la ssegunda, porque da ssalut a ornne conplidamiente en el cuerpo e fázel sser de buena vida, tolliendo los peccados della e ffaziéndol ganar amor de Dios.

La quarta es que el obispo deue ssaludar la crisma. Esto esta- 5 bleçió Ssanta Eglesia, que después que el obispo la ouyere bendicha, que la ssaludasse mucho omillosamiente, teniendo las manos ayuntadas contra ella, diziendo que ssalue Dios aquella vntura santa e grosura de salut; ca él la ssaluda por Ihesu Cristo, cuyo nonbre an los cristianos, otrossí porque es bendicha e sagrada [52v] 10 para dar lauamiento de guarda a los que nasçieron por baptismo, por que Nuestro Ssennor ssea aorado por todos los ssieglos, del qual rreçibieron todos los cristianos galdrdón de ssalut perdurable.

La quinta, que Ia deuen ssaludar las perssonas más onrradas e los ssaçerdotes, e es esto que después que el obispo la ouyere 15 ssaludada, hanla de ssahudar las perssonas más onrradas e los ssaçerdotes que y estudieren, omillándosse cada vno dellos, teniendo las manos ayuntadas, diziendo las primeras palabras de la ssaludaçión ssegunt el obispo mismo dixo.

La ssesta, que depués que la ouyeren ssaludada, la deuen poner 20 ssobre el altar, esto es que la deuen saludar tres vezes. Después que la ouieren saludada, hanla de poner sobre el altar o ssobre vna mesa que ssea cubierta de pannos de lino muy blancos.

La ssetena, la rrazón por que estableçió Ssanta Eglesia que sse homillasen a la crisma quando la ssaludassen ffué porque assí 25 commo los judíos ffincauan los ynoios ante Nuestro Ssennor Ihesu Cristo quando estaua en la cruz e le saludauan por desonrra, diziendo que era rrey de los judios, otrosi los cristianos deuen ffincar los inoios, homillándossele e onrrándola, diziendo que Dios la ssalue porque ha nonbre de Ihesu Cristo, que es rrey de $3 o$ los cristianos, e dende rreçibieron la saludaçión e cuyo rregno spiritual non ha ffin, et con ella sson vntados los ssus ssieruos.

1 faze s. e ho. todas. -3 faze. -6 el [E 75r]. -7 salude. $-8-9$ vntura de salud g. santa ca (de salud añadido en el margen). - to han c. e otr. Io- I $T$ e para. - 11 nascieren. -12 siglos. - 13 rresçebieron $\operatorname{los} / T$ cristinos ssalut. - 15 sacerdotes esto es que despues. - $20 \mathrm{E} \mathrm{la} \mathrm{s.} \mathrm{que} \mathrm{despues/}$ ouiere / dene. - 2 I-23 $T$ omite esto ... altar. - 23 e. - 2' setima rrazon. - 2 ; lo. -28 judios e otr. -3 c donde r. sal. - 3a spiritualmente. 
[Ley XCV]. - Por quáles cosas dene sser conssagrado el olio para los cathecúminos e neótfitos.

Sagrado e bendito deue sser, ssegunt estableçimiento de Ssanta Eglesia, el olio que es para los catbecúminos e neóffitos, que sson 5 aquellos que non han entendimientos e los quieren baptizar o están en prueua para rresçebir la Fle, assí commo es ya dicho de ssuso e se muestra adelante allí o conuyene. E esta sagraçión es ffecha por ssiete maneras : por conjurio; por oraçión; por preffaçio; por ponerlos en logar linpio; por la vertud que ha en ella; e Io cómmo deue sser onrrada; e cómmo deue sser guardada.

Por conjurio, esto es que pues que el obispo ouyere ssagrada la crisma, ssegunt de ssuso es dicho, que ha de tomar la anpolla deste olio, e conjurándolo, diziendo cómmo conjura aquella criatura de olio por Dios Padre poderoso e por Ihesu Cristo ssu ffijo I 5 e por aquel ayuntamiento de la Trinidat e de la vertud de Dios ; que todo el poder malo del diablo e todo peccado antigo e toda la ffuerça del ssu corrimiento, que es espantoso e dannadero e ciego, que sse entiende por los que non veen la uerdat para connosçer Dios, ssea derraigado e conjurado que sse parta de aquella criatura 2o de olio, que es puesta por prouecho de los omnes, de manera que ssea aquella vnçión apurada e ffecha de los ssacramentos de Dios por que sse muestren en los cuerpos e en las almas por ssus escogidos aquellos que ffueren autados con él, auyendo rremisión de ssus peccados por que puedan sser apareiados para rreçebir toda ${ }_{2} 5$ graçia spiritual.

Por oraçión es que rruega a Dios, que es conplimiento e acabamiento de todas las cosas, et más que es galardón de todos los bienes, por la uertud del Spíritu Santo tuélgal el esffuerço del diablo e conffirme las voluntades fflacas de neçessidat de aquellos

I quantas. - 1-2 sagrado el o. que es para. - 3 deue otrosy ser. $-\hat{\mathbf{b}}$ e los que q. baut. [E 75v]. -6 proeua. -8 prefaçion. -9 poner / $T$-las. I 2 el anp. - 13-14 creatura. - 14 e de Thesu. $-16 E$ añade que sobre la linea, otra mano; $T$ lo omite. - $17 T$ corrimiento e esp. $-18-19$ conosçer a Dios. - $19 T$ derraigada, $E$ desarraygado / creatura. -20 para. -2 I $T$ apartada. - 22 se demuestra. - 26 conplido ac. -27 galardonador. $-28 T$ Spiritu tuelgal / tuelga. - 28-29 $E$ añade del diablo en el margen, otra mano; T lo omile. 
que vinieren a nos otra uegada por el lauamiento ssanto del baptismo e ffueren untados con aquel olio, por que ssean por y alinpiados de lodo peccado, tan bien en las carnes commo en las uoluntades, de ma[53r]nera que ssi algunas rremasaias ffincaren de tenptaçión del diablo o de ssus obras, ssean todas tollidas por el 5 . tanimiento de aquel ssanto olio, de guisa que non flinque en aquel logar ninguna cosa de ssus maldades nin pueda y dexar ascondidamiente ninguna cosa de su poderío para fazer mal ; mas que les ssea esta vnçión aprouechamiento de ssalut para los cuerpos e para las almas.

La terçera, por preffaçio. Que es esto que, dicha la oraçión, deue dezir el obispo en alta boz este preffaçio, que quiere dezir tanto commo palabras de oraçión que deuen sser dichas ante que la ffuerça de la obra sse ffaga, en que dize asy, que rmega a Dios, que es durable por ssienpre, que denne bendezir aquella criatura i 5 del olio; e él le mostró a Noé quando ffizo ueer la paloma que él dió de mano e a qui tornó con el rramo de oliua en la boca, en que dió a entender a él e a los que estauan en la arca, que andauan ssobre las aguas, que era el ssu Spíritu Ssanto que les enbiaua en ssignifficança de paz. Entonçe el obispo e cada vno de los que 20. estudieren con él en ssu grado deuen ssaludar este olio por orden, assi commo el otro de la crisma que de ssuso es dicho. Et todas estas cosas acabadas, deuen leuar aquellos olios al ssagrario assí ordenadamiente commo los aduxieron.

La quarta es que, tornando los olios al ssagrario, ssegunt que de 25 ssuso es dicho, déuenlos poner en logar muy linpio; ca ssin la grant onrra que rreçiben después que sson ssagrados, gana por la onrri dellos e por las palabras ssantas que ssobre ellos sson dichas tan grant uertud que ffazen perder la ssanna que Dios ha contra el linage de los omnes por el peccado de Adam e por los otros 30 . peccados que ellos ffazen, ssiguiendo ante la uoluntad ssobeiana

I $T$ vinieron. -2 ffueron $/ T$ ssean y. -3 la carne. $-4 T$ ffincaron. -5 tentaçion. - 6 tannimiento. $-7 T$ ninguna de / cosa [E 76r]. - I I prefaçion es / $T$ la missa. - $12 T$ obispo este / esta prefaçion. - 14 de obra / $T$ dize que. - 15 perdurable $/ E$ denne (retocado sobre deuen, otra mano). - i5-16 creatura de aquel $o$. que el $\mathrm{m}$. a Noe $\mathrm{q}$. le fizo. -17 a quien. -18 en el arca. - $30 \mathrm{E}$ ent. - 20-2 I no dellos questodieren. - $23 T$ aquelos olios (retocado sobre aquel olio). - 24 aduxeron. - 25 tornados / segunt de. - 28 palabras que. - $28-29$ dichas que tan. -3 I seguiendo. -3 I $y$ sig. voluntad. de la c. s. por. 
de la carne por conseio del diablo que non en buen entendimiento del sseso.

La quinta, por la uertud que ha en ella muy grande. Ca la crisma ffaze muy grant pro; que arriedra el diablo del omne, 5 ssacándol de ssu uoluntad e ffaziéndol partir de ssus obras, quel era ya ffecha commo ssu morada antigua en que moraua ssin derecho, apoderándosse de lo que non era ssuyo, auyéndolo Dios conpuesto para logar en que morase, fformándol a ssu ymaien e a ssu ssemeiança. Et demás, da assegurança al omne para non caer

ro en la culpa primera, por que el diablo non aya después poder en él ssi por ssu grant mereçimiento non ffuere.

La ssesta, cómmo deue sser onrrado. Onrrada deue sser mucho la cosa por que los omnes sson onrrados. Onde, por la onrra que rreçebimos destos olios ssobredichos, touo por bien Santa Eglesia

15 que ffuessen onrrados desta guisa: que los tengan en logar muy linpio e mucho apuestamiente en el ssagrario, ssegunt de ssuso es dicho, e deuen sser puestos en mesa o en arca o en armario e cubiertos de pannos linpios e ffermosos; et quando quisieren ssagrar algunas cosas de aquellas que deuen sser ssagradas con 20 ellos, non los deue otro tomar ssinon clérigo preste e mucho omillosamiente; e quando los leuare para vntar con ellos al que quiere sser baptizado e vngido, déuenlos leuar lo más onrradamiente que pudieren, e el preste que los leuare deue yr rreuestido de sobrepelliça e la meior e la más linpia que pudiere auer.

25 La ssetena, cómmo deuen sser guardados, esto es que deuen parar mientes [530] cómmo guarden mucho los olios de la crisma aquellos a quien es acomendado e de mandar que los non dexen tomar a omne del mundo a qui non conuenga, e mayormiente a aquellos e aquellas que sse trauaian en ffazer ffechizos o encanta30 mientos o otras melezinas que non sson conuenientes para tan santa cosa e onrrada commo ésta. Et onrrando e guardando estos olios desta manera e de todas las otras que lo más pudieren ffazer,

3-4 han en e. virtud muy $g$. ha en la c. ca faze. -4 arriedra al o. del diablo. -5 que le. -7 auiendo. -8 para su lugar. $-8-9$ formando la su $y$. e la su sem. [E 76v]. - $10 T$ diablo aya. - 10-I I despues en el p. si por grant. - I2-13 E' la s. c. d. ser honrrada ho. d. ser la cosa m. por que. I 7 arco. - $20 T$ las / otrie t. syn cler. - 2 I $T$ las. - 2 I-2 2 leuare a v. con e. quien quiera. - 24 sobrepelizia la mejor. - 20े deue ser guardado. 27 aquello que es ac. de manera que. -28 quien. - $28-29$ mayormente aquellos o a. $\mathrm{I}$. 3 o convinientes. 
commo quier que ayan en ssí estas uertudes que de ssuso sson dichas, muy mayormientre lo aurán quando desta guisa ffueren onrrados e guardados; ca naturalmiente quanta propiedat de la uertud que ha la cosa en ssí, [ssi] llega a logar linpio e onrrado quel convenga, esffuerça e creçe en ella más que ante era.

[Ley XCVI.] - Del ssegundo ssacramento, que es la conffirmación, e de las cosas que sse deucn ffazer en él.

Conffirmaçión es el ssegundo ssacramento, que viene en pos el baptismo, de los ssiete que de suso sson dichos que ffazen en Ssanta Eglesia. Onde, pues que es ya mostrado en lo que sse dixo ro flasta aqui de todas las maneras del baptismo e de la crisma con que sse ffaze, conuyene de aqui adelante que sse muestre el ssacramento de la conffirmaçión, êsto por ssiete rrazones: la primera, por qué ha assí nonbre; la ssegunda, por qué rrazón flué estableçida; lá terçera, a quién deue sser dado; la quarta, qué 15 deuen ffazer los que la quisieren rreçebir ante que la rreçiban; la quinta, en qué manera deue sser fecha; la ssesta, las cosas que han de ffazer los que la rreçiben después que es rreçebida; la ssetena, cómmo ninguno non deue conffirmar a ssí mismo.

La primera, por qué ha assí nonbre. Nonbre ha la conffirma- 20 çión porque es conffirmamiento, e es palabra que cae ssobre toda cosa que omne quiera ffazer, $\tan$ bien en dicho commo en ffecho. Et conffirmar es quando sse dobla aquello que ffué ffirmado, diziendo o fraziendo por que sse conffirme. Onde el ffirmamiento que es dicho en la Ffe por el baptismo, conffírmase por este 25 ssegundo ssacramento.

La ssegunda, por qué rrazón ffué estableçida. Estableçida e ordenada flué la conffirmaçión a ssemeiança de la ssanta ley de Nuestro Ssennor Thesu Cristo; ca todas las cosas que en ella ffueron estableçidas e ordenadas ffueron a semeiança uerdadera. Et por 30

9 la. $-3 T$ quando. -5 cresçe con ella. -7 fazer con el $[E \pi 7 r]$. -- 9-1o dichos que se f. en la Igl. - to $T$ Pues que es. - I I-I a crisma en que se f. e conv. - 14 que asy ha nonbre. - 15 dada. -17 deuen. - 18 deuen fazer $/$ despues que la han rrese. - I9 non puede nin dene. - zo que asy ha nonbre. - $2 \mathrm{I}$ porque conf. / $T$ añade e sobre la linea, otra mano ; $E$ lo omite. -- $\mathbf{3}$ confirmamiento. -27 fue est. e. -29 Gristo e todas. - 3o fueron todas a. 
ende la conffirmaçión, que viene ssobrel baptismo cn que puede y auer dubdas ssi es baptizado o non aquel que sse quiere conffirmar o ssil baptizó quien deuye o en aquella manera quel deue baplizar, tuelle todas estas dubdas a ssemeiança de quando Dios

5 fformó el mundo; que eran todas las cosas toruadas e el ssu spiritu andaua ssobre las aguas. Ca en aquella manera el spíritu de Dios que es enbiado sobre los omnes por este ssacramento, ssegunt andaua ssobre las aguas del baptismo, que es el primero. Et aun ssin esto ay otra ssemeiança, que es, assí commo los apóstoles to poníen las manos ssobre los omnes que creyen en la fle de Ihesu Cristo e que rreçibian luego el Spiritu Santo, assí los obispos quando ffazen este ssacramento e ponen las manos ssobre aquellos que conffirman, luego es conflirmado por Spíritu Santo el baptismo. que rreçibieron.

i5 La terçera, a quién deue sser dada la conffirmaçión. Dado deue sser este ssacramento a todo omne que ffuere baptizarlo e non fluere conffirmado; ca ssi dotra guisa lo ffiziese el prelado, erraría en ello e darsse ya por omne non entendido e que non [54r] ssabia ffazer ssi olliçio, nin ualería nada ssu ffecho. Et ssin todo esto 20 non ternía pro al que lo rreçibiese, porque rreçibe cosa que non deue rreçebir de mano de aquel que ge lo non puede dar.

La quarta, qué deuen fazer aquellos que la quisieren rreçebir ante que la rreçiban. Ffazer deuen algunas cosas ssennaladas los. que la quisieren rreçebir ante que la rreçiban, por que el Spíritu 25 Ssanto los ffalle apareiados e linpios para desçender en ellos e alunbrarlos de la ssu ssanta graçia. Et esto es que sse conffiesen de ssus peccados bien e conplidamiente. Et esta conffessión que la ffaga ante que coma nin beua; e después que la ouyere ffecha, que busque cada vno ssu padrino quel ate el panno en la cabeça 30 quando el obispo le ouyere conffirmado, ssegunt adelante sse dirá. El déuenlo todos rreçebir sseyendo ayunos; ca ssi poco o más comieren, non touo por bien Ssanla Eglesia que lo rreçiban. Que non es guisado que el Spíritu Santo, que es cosa çelestial, falle el

I confirmaçion viene. - $\mathbf{3}-\mathfrak{l}$ sy lo $b$, quicn d. e en la $\mathrm{m}$. que convinie baulizarlo. -4 semejante. -8 el $[E j 7 v]$. - I I e r. l. al Spir. - i2 $T$ estos ssacramentos. - $13 T$ son conffirmados. - I6 lodo aquel que. -18 por desentendido e por omne que non sabie. - 19 valdrie / sin e. todo. - 21 rrescebir nin de $\mathrm{m}$. de a. que non ge lo podrie dar. -32 los que. -23 rresçiba / deue. - 24 que quis. -26 esto que. -28 nin que beua / $T$ ouyeren. -- 29 que le. - 30 lo. $-33 T$ los/Por que. $-33 T$ que es commo çel. 
cuerpo del que sse quiere conflirmar enbargado de comeres tenporales, mas muy limpio de dentro en la uoluntad de peccado e de fluera en el cuerpo de ssuziedat. Nin olrosí non deve rresçebir este sacramento omne que ssea doliente o ferido, ssaluo ssi por aquella enffermedat o flerida sse temiere de muerte.

La quinta, en qué manera deue sser fecha. Ffecha deue sser la conffirmaçión desła guisa. Que el obispo deue uestir vna ssobrepelliça blanca e apuesta e vna estola ssobrel pescueço, atrauesada en los pechos en manera de cruz. E déuese assentar en ssu cáthedra, et estando assentado, han de uenir aquellos que sse quieren to conffirmar mucho omillosamiente, abaxando las cabeças, e ffincar los ynoios antél. Et entonçe los clérigos que y estudieren con él han de dezir dos ssalmos de los del Ssalterio ssobrellos, en que rruegan a Dios en el primero que conffirme lo que obró en nos, êsto se entiende por el baptismo; et en el ssegundo que rruegan i5 otrosí que se leuante con su poder, por que los ssus enemigos, que sse entiende por los diablos, ssean destruydos e derraygados ante la su ffaz. Et después que estos ssalmos ouyeren acabados, a de dezir ssobrellos el obispo esta oraçión e bendiçión, que el Spíritu Ssanto uenga sobre aquellos que se quieren conflirmar, et la 20 uertud del muy alto Dios los guarde ssin peccado. Et quando esto ouyere dicho, dize esta oraçión, en que rruega a Dios, que es Padre poderoso que quiso flazer que naçiesen otra uez aquellos ssus ssieruos por agua e por Spíritu Santo e les dió rremisión de ssus peccados, que él enbíe sobrellos de los ssus çielos los ssiete ${ }_{25} 5$ dones del Spíritu Santo, que sson éstos: consseio; frortaleza; ssaber ; piedat; seso ; entendimiento; et ssobre todo que los abonde del spíritu del su [temor] et los sennale de la ssennal de Ihesu Cristo su flijo, por que ganen la vida perdurable. Et esta oraçión acabada, deue él llamar a cada nno por ssu nonbre de aquellos a 3o quien quiere conffirmar e ffazer vna cruz con la crisma en la ffruente, diziendo quel ssennala de la ssennal de la cruz e quel

a $T$ dentro e en. $-4 T$ doliente ssaluo. -5 de morir. -6 quinta es en $/ T$ sser f. deue. -7 con[E $78 r]$ firmaçion. $-7-8$ vestir sobrepeliz. $8 \mathrm{~T}$ puesta vna. - 9 sobre los. - Io e a. est. han. - I I abaxadas. - I eslouieren. - 14-15 nos e esto. - 15 baulismo en el s. el quel rruegan, - i6 letianten. - I 7 destroydos. - I8- 19 acaluados de d. el ob. s. esta bend. / $T$ an de. - a I $T$ la. -22 dicho deue dezir esta o. que rruega. -23 denne (deuen escrito $y$ tachado, $y$ denne añadido sobre la linea; olra mano). - 34 Santo e por los de rrem. -25 los çielos. -26 son cons. -28 el spir. / Ty $E$ amor. 
conffirma con la crisma de ssalut; en el nonbre del Padre e del Ffijo e del Spíritu Santo. Et esto dicho, al de dezir quel dé Dios paz, e déuel dar estonçe vna palmada en la tienlla, por quel uenga emiente cómmo rreçibió aquel ssacramento e que $[54 \mathrm{v}]$ sse guarde

5 de lo rreçebir otra uez por oluidança. Et entonçe aquel conffirmado a qui rrogó que ffuese su padrino déuel atar en derredor de la cabeça vn panno de lino blanco sobre aquella cruz quel ffizo el obispo con la crisma. Eit después que los ouyere el prelado así conffirmados, deue dezir sobrellos esta bendiçión que ffué tomada

ro de vn vieso del Salterio que ffizo el rrey Dauid, en que dize así, deue sser bendicho el omne que teme a Dios. Et después deue dezir este otro vieso, que los bendiga de Ssión, que se entiende por los çielos, e que uean los bienes de Jherusalem en todos días de ssu vida, et esto sse da a entender por el paraiso, e que los

15 guarde Dios en el ssu santo temor; que viue e rregna por todos los sieglos. E entonçe déueles dezir que paz sea en ellos, e aquí han de rresponder Amén. Et después que esto acabare, deue dezir esta oraçión ssobrellos, que Dios, que enbió a aquellos sus disçiplos el Spíritu Santo e que por ellos lo dió a los otros ssus ffieles que 20 vinieron después, que quiera parar mientes a la humillat del que es ssu sseruidor; e que quiera que las oraçiones de aquellos que vntó las ffruentes de la crisma ssagrada e [ssennaló]los de la ssennal de la cruz, enbiando el su Spíritu Santo ssobrellos, ssean ffechos tenplo en amor de lhesu Gristo ssu ffijo; que viue e rregna 25 en vno con él por todos los sieglos.

La ssesta, de las cosas que deuen ffazer los que rreçiben la conffirmaçión, sson éstas. Que los que ffueren conffirmados, ssegunt que de suso es dicho, deuen traer los pannos que diximos ffasta tercer día, que sse enxugue la crisma de la frruente e de los $3 o$ pannos. Et después hángelos de toller en la eglesia ssobre la pila del baptizar et lauarles las ffruentes con agua linpia. Et estos que ge los desatan sson commo manera de padrinos. El entonçe

x confirma de la. - 2 hale / que le. - 3 -le / tiella. - 4 miente / e se. 5 aquel [E 78v]. - 6 a quien / atar a derr. - $13 \operatorname{los}$ altos çielos / $T$ y $E$ uea $f$ el bien $;$ todos los dias. - 14 parayso que. - I6 siglos. - I6-I $7 T$ omile E... Amen. - I 7 que esta a. deue desta. - 18 Dios que aq. sus d. enbio / $T$ añade a sobre la línca. - I9 le dio otrosy a. - 20 venieren / deuê. - 2 I e quiera. - 2 a las fuerças / $T$ ssennales los de; $E$ sennales de. -23 senal. -24 de Nuestro Sennor Ihesu. - 25 siglos. -27 estos los. $-27-28$ segunt de. $-28-29 T$ pannos ffasta. -29 fruente de. $-30-g$ gelo. 
deuen leuar aquellos pannos al obispo, e él o qui él mandare hanlos a quemar o echar en algún rrío por que después non ffagan con ellos alguna cosa que sse tanne en vso tenporal.

La setena, cómmo ninguno non deue nin puede conffirmar a sí mismo, es que confirmar ninguno non puede, segunt ordenamiento 5 de Santa Eglesia, a sí mismo. Et esto es que así commo todo prelado de aquellos a qui es dado de fazer la conffirmaçión non deue dezir nin alabarse que ha el Spíritu Santo, maguer lo aya de Dios, otrosí non puede él mismo conffirmarse, mas déuelo rreçebir de otro que ge lo pueda dar, segunt es ya dicho. Et esto ordenó ro Santa Eglesia por guardar todos los yerros que y podrían uenir, assí commo podría acaesçer que algún obispo por cubdiçia de non perder su obispado, non auyendo rreçebido este sacramento, que sse conffirmase por sí mesmo ante algunos de su conpanna o de otros para veerlo o algunos que lo ffiziesen commo tesligos r 5 dende. Onde tal conffirmaçión commo ésta non ualdría nada. Ante deuya perder la onrra e la dignidat que ouyese en Santa Eglesia, et non tan solamiente por ffazerlo, mas avn por ordenarlo cómmo ffuese ffecho. Otrosi non puede a ninguno conffirmar que ouyese ya rreçebido este sacramento otra uez, sabiendo en uerdat 20 que lo rreçibiera. Et eso mismo ordenaron, que lo non demandase el que lo ouyese ya rreçebido. Et por ende ordenó Santa Eglesia que los que ha çiente errasen en este ffecho, que ouyesen tal pena commo de suso es dicho de los que a ssabiendas sse ffiziesen baptizar dos [55r] vezes o más de los que los baptizasen.

[LEÝ XCVII]. - Del terçero ssacramento, que es la penitençia, e dónde tomó este nonbre.

Penitençia es el tercero ssacramento de los ssiete e vno de los más nobles que y ffueren; ca él aduze al que lo rreçibe commo deue ha poder de rreçebir todos los otros más conplidamiente 30 e con mayor ssantidat. Onde, pues mostrado es ffasta aquí del

I quien. - a fagan [E 79r]. - 3 corporal. -4 non p. vin d. conf. -5 confirmar non p. n. segunt. - 6 Esto. - 7 a quien / fazer conf. - Io otri. - Io-I I Esto cataron en Santa. - $14 T$ conffirmase ante / e. - 15 ver. - 15-16 commo es ende onde. - 17 deue. - $18 T$ mas por. -19 fue / puede c. a $n$. que. 23 los que asy err. - 24 dicha. - 29 fueron. - 3 I pues que m. avemos fasta. 
baptismo e de la conffirmaçión, queremos agora flablar e mostrar en ssiete maneras el bien que en ella ha: la primera, que assí ha nonbre; la $\mathrm{ii}^{\mu}$, qué cosa es ; la iiiª a qué tiene pro; la iiii", quál deue sser ; la va , cómmo deue sser ffecha; la ssesta, cómmo sse

5 taian los peccados por ella; la ssetena, cómmo deuen ffazer la emienda.

La primera, que assí ha nonbre. Esto toma ella destas dos palabras de pena e de tener; ca entiéndese que la pena que dan al peccador por el mal que ffaze deue sser tenida, doliéndose conplito damiente de los peccados que ffizo, por ganar el amor de Dios que auya perdido. La ssegunda, qué cosa es penitençia. Penitencia es, segunt dixieron los ssantos padres, rrepentirse e dolerse omne de los peccados que ha ffechos en manera que non aya uoluntad de tornar más a ellos. La terçera, a qué tiene pro.

I5 Tiene muy grant pro el ssacramento de la penitençia a los que la rreçiben corumo deuen; ca le alinpia de toda ssuziedat de peccados a los que los ffazen, que es la cosa de que más manziella ssea contra Dios e contra el mundo. Et ffázelos beuir buena vida. Demás, dales esffuerço para non caer dallí adelante en peccado e 20 ffaze ayuntar al omne con Dios, cobrando el ssu amor que auya perdido. La quarta, quál dene sser la penitençia. Verdadera e conplida deue sser la penitençia porque cunplimiento bueno del ffecho ffaz por ffuerça que aya buena cima. Et por ende el que sse conffiessa deue auer en ssí estas tres cosas : primeramiente, que sse rrepienta ${ }_{2} 5$ con grant dolor, assí commo de ssuso es dicho; et otrossí que descubra los peccados él por ssí mismo, non de otra manera; et aun que ffaga abondamiento de emienda por obra, ssegunt le mandare aquel a qui sse confliesa. La quinta, cómmo sse deue ffazer. Ffazer deuen la penitençia con grant dolor que dene auer en ssí el 3o peccador por los yerros que flizo o dixo, poniendo en ssu uoluntad de conffesarlos e de ffazer emienda dellos, tomando quebranto en la uoluntad e pena en el cuerpo. La ssesta, cómmo sse taian los peccados por conffessión. Conffessión es palabra griega que

I agora [E $79 v$ ]. - 2 maneras en bien. - 3-4 $T$ y E invierlen el orden de qual d. sser $y$ commo d. sser ffecha. - 5 tiran. - 7 tomo. -8 e temer. - 9 temido. -13 ayan. - $\mathbf{s}$ Pro t. muy grande el sacr. / que lo. - 16-17 deuen e el alinpia de p. toda s. a los que. - 22 por conplimiento b. del f. e faz. -25 commo es ya d. otr. -36 mesmo e non. $-27-28$ le el $m$. aquel a que. -29 deue la. -3 r tomado quebrando, -32 cuerpo $[E$ $80 r$ ] / tiran (trabajan escrilo y tachado, y tiran añadido sobre la línea, olra mano). 
quiere tanto dezir commo taiar el peccador los peccados que tiene ayuntados e enduresçidos en ssí. Et este taiamiento es en tres maneras: la vna, llorando con grant amargura del coraçón; la otra, rrepintiéndose dellos e despreçiándolos; la terçera, descubriéndolos todos conplidamiente ante aquel a quien sse conffiesa. $j$ La ssetena, cómmo deue ffazer emienda. Emienda buena e conplida deue el omne ffazer a aquellos a qui erró en este mundo porque, ssegunt dize la Ssanla Escriptura, ningún peccado non es perdonado al peccador a menos de ffazer emienda de los yerros que ha ffechos. Et ssi emienda deue sser ffecha a los omnes, quanto más Io a Dios, que nos ffizo, a cuyo juizio auemos a yr. Onde el que sse conffessase de ssus peccados, la emienda quel mandaren que ffaga puede sser ffecha en estas maneras: $[55 v]$ assí commo en oraçiones; et en ayunos; e en alimosnas; et en auer buena esperança; et en ffortaleza; en justiçia; en rromerías; et en ençerra- I 5 mientos ; en tenplança de orden ; en tomar disçiplinas; en comer pan con çeniza; et otras cosas muchas que sson quebrantamiento de la carne, que non se pueden contar por escripto.

[Le Y XCVIII]. - De los peccados que ffazen los omnes de que han mester de tomar penitençia, e quántas maneras sson dellos.

Pues ffasta aquí auemos mostrado en la ley ante désta de la penitençia, por qué assí ha nonbre e qué cosa es en ssí, queremos mostrar los yerros por que los omnes caen en peccado, et dezir primeramiente quántos sson e las emiendas que han a flazer por ellos. Et esto en ssiete maneras : quántas naturas son de peccar ; 25 quántas naturas sson de peccados; quáles sson ueniales e por qué han assí nonbre; quáles sson los peccados criminales e por qué los llaman assi ; por qué sson dichos mortales e quántas mañeras sson dellos; et en qué manera sse tornan los veniales mortales e los peccados mortales criminales; por quáles emiendas que 30

[-2 liene fechos e end. - 3 rna con / de cor. - 4 repentiendose. - 6 fazer la om. - 7 deue o.f. aq. que erraren. -9 pecarlor $m$. de emendar los. - io sy esta deue. - I f fizo e cryo. - 13 confiesa. - 15 e f. e en j. e en rroin. I5- 16 enterramientos. - 16 horden e en $t$. d. e en. $-1 / 5 T$ ha. - 20 dellas, 21 contado. -23 yerros en que / pecado dezir. -26 quales pecados son. 26-27 que asy han nonbre. -29 dellos en. - 29-3o los pecados $r$. en m.o los c, on m. e por. - 3o $T$ peccados c. m. por / que $[E 80 v]$. 
ffagan les sserán perdonados los peccados veniales e criminales e mortales.

Et quántas maneras sson de peccar. Las naturas de peccar sson en ssiete maneras : la primera, en cuydar cómmo ffará aquel mal 5 omne que quiere ffazer por ssí o por otre; en acordándolo; en dezirlo él mismo o dar a otro que lo diga; en obrarlo o dar [a] otro que lo obre; en conseiar a otro que lo ffaga; et en consentirlo, pudiéndolo vedar; en auyendo enbidia de aquel que lo ffaze. Onde estas ssiete maneras de pecar sson assí commo rrayzes de que naçen

Io todos los pecados que sse pueden ffazer, ssegunt sse contará adelante do ffabla de los ssiete peccados que sse pueden ffazer segunt natura.

Quántas maneras sson de pecados. Peccados ffazen los omnes de muchas naturas, segunt la uoluntad les da e los ffechos sse los 15 guisan, pero todos tornan en tres maneras : la vna, venial; la otra, criminal; la otra, mortal. Et de cada vna diremos en ssu logar ordenadamiente por qué assí ha nonbre e en quántas maneras se pueden ffazer e por quáles emiendas que los omnes ffagan sserán perdonados. Mas porque los primeros sson menores que los otros 20 et pueden más ligeramiente los que los ffizieren auer perdón, conuyene que sse diga primeramiente de los veniales, e desí los criminales, et después de los mortales.

Et quáles sson peccados veniales. Veniales peccados sson aquellos que omne ffaze en comer e en beuer más que non deue; o ffa25 blar o callar más que non conuyene; o rresponder brauamiente al pobre o al cuytado quando pide almosna o demanda ssu derecho; o non quiere ayunar en el tienpo que los otros, pudiéndolo ffazer; o venir tarde a la eglesia a oyr las horas por ssabor de dormir o de otro viçio de la carne, non auyendo enbargo ninguno por que 3o lo deuyese dexar; o yazer con ssu mugier ssinon con entendimiento de ffazer ffijos o conplir el debdo que ha en ssí natural-

I le. - 4-5 fara o. a. mal que. - 5-6 acordandolo e d. el m. a otre (o dar escrito y lachado, $y$ a añadido sobre la línea, otra mano). - 6 obrar o dar otre. -7 otre. -8 podiendolo v. e au. / $T$ auyendo vida de. - I fabla los. $-13 T$ de peccar. - 14 maneras / se les. $-17 T$ e quantas. 18 e quales / fagan les seran. - 20 e los pueden. - a veniales d. de los. 34-25 deue e f. e callar. - 25-26 $T$ al padre o a la madre o al cuyt. $-36 E$ pobre (retocado sobre padre, otra mano) / quando le p. alimosna e dem. $9_{7}$ e / en tienpo / podiendolo. -28 e venir. - 3o podiese. - 31 han. 31 y sig. naturalmente [ $E 81 \mathrm{r}]$. 
miente, cobdiçiándolo mucho. Essa misma rrazón ssería ssi ella lo demandase e él ge lo pudiesse dar e non ge lo diesse. Otrossí es peccado uenial non yr visitar los enffermos o aquellos que yazen en la cárçel, o non los ayudar de palabra o de ffecho en lo que pudiese; o sabiendo que están [56r] algunos en desacuerdo e en 5 malquerençia, e podiendo meter abenençia o paz entre ellos e non lo ffazer. Ca todas estas cosas plaze mucho a Dios porque sson obras de misericordia. Otrosí es peccado uenial sser rreçeloso o brauo de palabra o de mala conpanna a ssu mugier o a sus ffijos e a los otros que con él biuieren, non mereçiendo por qué; leson- ıo jando a alguno más que non deue, mayormiente a omne quẻ es poderoso, por sabor de leuar algo dól et por ffazerle plazer, loándol más que non deue et diziéndol por el mal que ffaz bien ; maguer non uenga mal y a ninguno, pero por todo esto pecca venialmiente. Et aun peccado venial es dar comeres muy adobados a los 15 pobres, et por dos rrazones: la vna, porque así commo a los que los han vsados los buenos comeres non terníen pro las viandas gruessas e mal adobadas, assí a éstos non ternían pro las buenas e las ssotiles; la otra rrazón es que les ssería asy commo carrera de cobdiçiar lo que non podían auer. Otrossí es peccado uenial en 20 dezir palabras de escarnio en algún logar de que non puede nasçer danno, et mayormiente ssi es en la eglesia, que es casa de oraçión en que deuen a Dios rrogar que los perdone los peccados, que non en ffazerlos en ella; o jurar liuiana jura por manera de escarnio o de juego, en guisa que non torne en danno a él nin a 25 otre; o dezir palabras de maldezir liuianas e ssin rrecabdo contra alguno más en manera de rriso que por maldiçión. Et todas estas maneras de peccar e otras ssemejantes dellas llaman veniales. Et este nonbre es tomado de vna palabra de latín que es dicha veni, que quier tanto dezir commo venir pedir perdón homillosamiente. $3 o$

3 yr a vis. -4 en carzel e non los ayudase. $\rightarrow 5-6 T$ algunos e en malq. -6 meter paz o a. entrellos. -7 faze, -8 venial rrenzilloso. -9 muger e. - Io-I I por que o lisonjando, - I I T deuen / deue e may. - $12 T$ por saber leuar. - 13 deue nin conbiene o d. por el mal (todo menos la primera palabra escrilo sobre raspado). $-14 \mathrm{~T}$ mal a / pero con t. eso. $-\mathrm{r} 5 \mathrm{~T}$ abondados. - 16 e esto por / $T$ porque a. - 17 vsado non ternie. - I8-ig ternie pro b. e sot. - I 9 es por que le farie asy / $T$ sscria rrazon commo: 20 puede. -22 en igl. -23 deue $r$. a Dios que. $-23-24$ pecarlos e non faz. - 24 $T$-las. - 2\{-35 linianamente en esc. o en juego. - 26 e deziendo pal. - 26-27 liuianas alg. - $27 \mathrm{Ca}$ estas. - 28 semejantes llaman. 29 deste. - 3o quicre d. c. venir $[E 81 v] / \xi$ omile homillosamiente. 
Et quáles sson peccados criminales e por qué los llaman assi. Comienço e medio e acabamiento an todas las cosas naturalmiente. Et los dos cabos, el primero e el postremero, sson los más fllacos que el de medio, porque el que comiença ua ssubiendo, e el que 5 acaba es ya en la fín et non puede yr más adelante. Mas el que es en medio ya a ssobido quanto pudo ssobir, et está la ssu ffortaleza alrenyéndosse commo [començó] osadamiente e leuó ssu ffecho más adelante que pudo. Et por ende a ssemeiante desto sson las tres maneras de peccados. La primera es de los veniales, que dixie-

ro mos que sson comienço para poder ssobir a los otros. La ssegunda es de los̀ criminales, et éstos sson commo en medio. Et sson peccados muy ssin guisa, por que aquellos que los ffazen mereçen auer pena tan bien en el cuerpo commo en el alma. La terçera es de los mortales, e esto es ya ffin de todo el mal porque el alma ba I 5 mortal pena, commo quier que ella en ssí non puede morir. Onde, pues que dicho auemos de los veniales, conuyene que se diga de los criminales, que sson muy ffuertes e sse ffazen mucho atreuidamiente e con grant osadía ; ca tanto quier dezir crimen commo peccado mucho atreuido, por que el que lo ffaze vale mucho me20 nos que ante que lo ouyese ffecho en ssu onrra e en ssu ffama. Et esto sse departe en [dos] maneras: la vna, que tanne en los frechos spirituales que pertenesçen a Santa Eglesia ; la otra, en los sseglares que pertenesçen al mundo. [56v]

Que los eclesiásticos departieron otrosí en quatro maneras. A la 25 primera pusieron nonbre ssimonía, que es vn peccado de grant cubdiçia e en que caen los omnes por atreuerse a conprar o a uender las cosas spirituales. E ouo este nonbre de Ssimón Mago, vn encantador, que quiso conprar el poder de Dios por el Spíritu Santo que desçendió en los omnes quando ponien las manos los 30 apóstoles ssobrellos. La ssegunda manera es eregía, et ésta sse de-

1 veniales. $-3-4$ postrimero son que el de. -4 començaua sub. -6 puede. $-7 T$ comienço, $E$ comiençe / $T$ llega. -8 Por ende. -9 primera de. - I I criminales que son en. - 13 por que quien los faze meresçe (que añadido en el margen, otra mano). - Í́ e es / todo mal. - i 5 ella non. - 16 pues dicho/ veniales diremos de. - 17-18 fazen nuy a. ca. - ig muy atr. que el. - 20 lo faga en su ho. e su. - 2 se parte / $T$ y $E$ ssicte. $\rightarrow 32$ la segunda. $-23 T$ pertenesçc. $-24 \mathrm{E} \operatorname{los}$ e. $\mathrm{d}$. en $\mathrm{q} . \mathrm{m}$. la. $-25 T$ pusieron ssim. / simonia e es pec. -26 cobdiçia en / omnes en c. o vender. $-27-28$ ovo $\mathrm{n}$. de $\mathrm{S}$. M. enc. -28 la virtud. - 29 -30 manos sobre ellos. $-30 \mathrm{~T}$ ssobrellas / segunda es / $T$ es et. - 3o y sig. esto se parte on. 
parte otrossí en tres maneras. La primera es quando alguno yerra en la Ffe, creyendo primeramiente en ella et después tomando en ssí algún pensamiento por menguar en la crençia, mostrando a otros por carrera o por obra para ffazer esso mismo. La ssegunda es corronpiendo las Isscripturas, dándoles mal entendimiento. La j terçera es de los que están descomulgados e rrebelles, porffiando en ello, non queriendo ffazer emienda, ssegunt mauda el derecho de Ssanta Erlesia. Et el terçero peccado es apostaçía, e éste sse parte en tres maneras, e quier dezir tanlo en griego commo rrenegamiento en lenguaie de Espanna. Et la primera déstas es de ro aquellos que sse parten de la $\mathrm{Ffe}$, porffiando en aquellas 'cosas que sson contra ella, ayudándola a destroyr. La ssegunda manera es de aquellos que de ssu uoluntad e ssin premia ninguna traspassan los mandamientos de Dios, despreçiándolos. Et eso mismo es de los que non quieren obedesçer los estableçimientos de Ssanta Egle- 15 sia. La terçera es de los que dexan ssu orden después que ffizieron promisión de las tener, ssegunt mandamiento de ssu rreligión. Ei quarto peccado es de los que sse atreuen a quebrantar las eglesias e ffazer otras ffuerças o males en cosas ecclesiásticas, atreuyéndosse a ellas assí commo ssi ffuessen sseglares, ssinon por aquellas 20 cosas ssennaladas que conuyene que les ffagan, ssegunt sse muestra adelante en ssu logar. Et a este peccado llaman ssacrilegio, que quier tanto dezir commo atreuersse omne a demandar las cosas ssagradas. Et este demandamiento es en tres maneras. La primera es en las cosas ecclesiásticas, assí commo clérigos o rreligiosos, ffiriéndolos 25 o matándolos. La ssegrunda, quebrantando el logar mismo de la eglesia o de ssu çiminterio, o ssus priuilegios o ssus ffranquezas que les ffueron dadas derechamiente. La terçera es las cosas ssagradas de Santa Eglesia. Esto es en [dos] maneras : la primera es rrobando o ffurtando o tomando por ffuerça las cosas ssagradas del logar 30 ssagrado; la ssegunda, ssi las tomaren del logar non ssagrado.

La [ssegunda] manera de peccar criminalmiente, que tanne a

a creyendo en. - 2-3 tomando algunt. $-3-4$ creençia $c \mathrm{~m}$. o. por c. e por. - 4-5 esto lá s. corr. -6 descomulgados porf. -7 non $[E 82 r]$. - 7-8 manda Sauta. $-8 \mathrm{El}$ terç. / apostasya. -9 maneras que quicre d. en. 9-10 rrennegamiento. - I cuydandola destr. - 19-13 mancra de aq. - 14 mesmo de. - 17 la. - 18 es que. - 19 en las cosas. - $\mathbf{2}$ conviene que se $f$. s. que se. -- 23 sacrilejo. - 25 feriendolos. -27 cimenterio o de sus preuillejos. $-28 T$ terçera cosas es. $-29 \mathrm{E}$ esto $/ T \gamma E$ tres. -3 I iomar de lugar. - 3a $T$ y $E$ terçera / $T$ animalmiente / tanne en. 
los ffechos sseglares, es toda manera de traiçión. Et ésta sse parte en tres maneras. La primera es a que llaman traiçión mayor, porque cae en los ffechos mayores, a que dizen en latin crimen lese maiestalis, que quiere tanto dezir commo peccado más atreuido 5 que otro para dannar la perssona o la onrra del ssennor mayor. La sscgunda, aleue, que cae en los medianos. La terçera, ffalssedat, porque cae en los menores, ssegunt sse muestra adelante de cada vna dellas en ssu logar do ffabla destas rrazones. Otrossí es peccado criminal adulterio que ffaze omne casado con mugier que Io ha ssu marido, o el ssoltero con la casada; et auer por ffuerça qualquier mugier virgen o casada o por casar ; o de matar omne a sabiendas o de grado, non meresçiendo por qué ; o peccado contra natura, assí commo el que ffaze [57r] peccado ssolo antigo o con alguna otra animalia; o ffurtar o rrobar; o ffazer otros peccados

I5 ssemejantes déstos, por que meresca auer pena en el cuerpo, sseyendo prouado.

La quinta, por qué sson dichos peccados mortales. Mortales llaman a los peccados que matan el alma. Et este nonbre han porque assí commo la muerte es acabamiento de la vida tenporal, 20 assí es el peccado mortal en la muerte del alma por ssienpre, commo quier que ella en ssí non puede morir; et ha de ssoffrir grandes penas, que querría ante la muerte tenporal que ssoffrirlas. Et los peccados que han este nonbre sson éstos : adulterio de omne casado con mugier ssoltera; corronpiniento de mugier virgen 25 con quien non ssea desposado; jazer omne con ssu parienta, o con ssu cunnada, o con mugier de orden; et toda otra manera de fforniçio que aya omne ssoltero con mugier ssoltera, que sse entiende que non ssean desposados nin casados; otrossí jurar ffalsso testimonio, o quebrantar jura ; o ffurtar; o ffazer ssoberuia, 30 o sseer auariento o cobdiçioso, o tener ssanna luenga, o ser de grant cubdiçia; o enbeudarsse a menudo, o comer tanto que aya de enffermar o de morir ; et dormir ssin rrazón, por que mengüe de ffazer bien; o tornarsse de uanagloria, o aucr grant tristeza, o

2 primera que. - 3-4 crime 1. magrestats. - j sennor $[E 82 v],-6$ segunda es a. por que / terçera es fals. - Io casada o. -- I virgo ' casar o matar. - I3-14 con otra. - I5-16 cuerpo de muerte syendol prou. - ib $T$ prouada. - I7 quinta es por. - 20 asy el p. m. es la. - 23 ante sofrir la muerte. $23 T$ estos nonbres. -24 de virgen. - 25 yazer con su. -27 forniçio con. - 38 son / $T$ desposados otr. -29 -3o jura o ser au. - 3o $T$ luenga o de. - 33 o trabajar de. 
mentir ; o blasmar a Dios, que quiere tanto dezir commo denostar el ssu nonbre o dezil a ssu cristiano denuestos por que uala menos; - lesonjar a ssennor en manera que por aquella lesonja venga mal a él ssi lo crouyere; et otrossí engannar en dichoo en fecho, de guisa que por aquel enganno nasca algún mal. Onde todos estos 5 peccados e cada vno dellos sson mortales.

La ssesta, por qué se tornan los pecçados veniales mortales, et los mortales en criminales. Et assí los peccados sse mudan vnos en otros, ssegunt muestran los santos padres, en la manera que aquí diremos. Et ésta es que los veniales sse tornan en mortales, io assí commo quando alguno come o beue más de lo que conuyene, de guisa que el danno que dende viene sse torna en él mismo e non en otro, non lo faziendo a sabiendas por que aya de enffermar o de morir ; ca atal peccado commo éste, segunt es ya dicho, es contado por uenial. Mas ssi lo ffaze adedre, de guisa que uenga 15 danno a él o a otro, luego es mudado en mortal. Eso mismo es del que, sseyendo sano, non quiere ayunar en los tienpos que sson estableçidos por Santa Eglesia ; ca ssi lo fliziesse, non podiendo mas, sseria peccado venial. Mas ffaziéndolo en despreçiamiento de la $\mathrm{Ffe}$, mudarse ya en mortal. Otrossí ssería de aquel que oujese 20 uoluntad de auer algún gasaiado con ssu mugier e ella lo esquiuase en manera que él oujese de yr a otra ; ca quanto en el esquiuamiento della, ssería peccado venial. Mas luego que él errasse con otra, tornarsse ya mortal. Et esso mismo dezimos ssi ella lo demandase e él non quisiesse, podiéndolo ffazer. Et aun ay otra 25 rrazón por que el peccado venial sse torna en mortal. Esto ssería quando alguno pudiese poner paz o abenençia entre los que sse quisiessen mal e non lo fiziesse; que ssería peccado [mortal] ssi lo non ffiziese e entrellos entrase bolliçio e desacuerdo, por que 'sse quisiessen peor que sse ante querien o sse ouyesen a ffazer mal 3o

I T Dios commo. - 3 o alisonjar a senor/lisonja. - 4 creyere o otro eng. -5 que [E 83r]. -6 o qualesquier dellos. $\rightarrow 7$ sesta es por / veniales en mort. -8 criminales lo pec. - 9 mostraron. - I commo alg. / quel. - 12 cnde veniere. - 13 otre non lo f. tan sobejanamente a s: que. - 14 morir en tal pec. - 150 sy lo $\mathrm{f}$. adrede. - I5-16 venga ende danno. - 16 otre / E eso. - I8-I $9 T$ podiendo sseria. -3 I-2 $2 T$ escusasse. -21 ya en m. eso. $-26 \mathrm{E}$ esto. -27 meter paz e. -28 quieren $/ E$ añade e non lo fiziesse en el margen, otra mano ; $T$ lo omite / fiziesse es pec. / $T$ y $E$ reniạl. -29 non quisiese fazer e meter entrellos bollizio. -- 30 que de ante non q. $e$. 
vnos a otros, o de desonrras o de fferidas o de muertes. Esso mismo sserie quando alguno $[\tilde{5} \tau v]$ lesonjasse al ssennor en manera que non viniese mal a ninguno; ca non veniendo ende danno, sserie peccado venial. A la hora que nasçiese ende algún danno,

5 sseria peccado mortal. Onde, por todas estas ssemejanças o por otras desta guisa, tórnanse de los peccados veniales en mortales.

Et los [mortales] tórnansse de otra guisa, assí commo quando alguno ffiriere a otro a sabiendas con palo o con piedra o con cuchiello o con arma qualquier por algún despecho o sanna quel Io ouyese mereçido, mas non con entençión de matarle; tan ssolamienle porque ffiriera con cosa por que podría morir, cae en peccado mortal quanto al alma. Mas ssi a çiente lo ouyese fferido para matarle, es peccado criminal, por que deue morir por ello. Et eso mismo sserie del que conseiase a alguno en manera de I5 enganno tal cosa por que ouyese a prender muerte; que quanto el conseio ante que llegase el ffecho a acabamiento, ssería peccado mortal. Mas después que sse acabase, tornarsse ye en criminal. Otrosí lal sseríe del que ffuese dezir mentira ssobre que ffuese después alguna desonrra o fferida o muerte; ca en quanto la men20 tira ffuesse por ssí, ssería peccado mortal. Mas después que en obra entrase, tornarse ya en criminal. Et esto se entiende en todos los otros flechos que ffuessen desta natura.

La ssetena, por quáles emiendas que los omnes ffagan les sserán perdonados los peccados veniales e mortales e criminales. Emen25 dándose los males que sson dichos e ffechos en estos peccados sobredichos, tan bien en los veniales commo en los mortales, la piadat de Dios es tan grande que quiere rreçebir estas emiendas e dar por ellas perdón. Et por ende es estableçido en Santa Eğlesia que todo aquel que ffaze peccado venial, que lo emiende desta 30 guisa: primeramiente, doliéndose dél ; desí, conffesándose e connosçiéndose a Dios que erró ; feriendo en ssus pechos con ssu mano por ssennal de arrepintimiento; echando ssobre si agua

I vnos con o. de des. / $T$ otros o des. / E eso. -2 lisonjase. -3 veniese ende mal ning. - 4 Mas a la. - 4-5 ende d. alguno tornarse ye en mortal. 5 e. -6 tornanse los. -7 En criminales fazese de / $T$ criminales. -- 8 alguno feriere algmno a sab. / piedra o con [E 83v]. - 9 con otra arma / $T$ despecho a sannas. - Io- I m matarle que s. p. feriera. - I 3 sy açidente. - I 5 ouiese de prender. - ז5-16 quanto en el cons. - I6 fecho o ac. - Ig despues des. $23 T$ sserian. - 24 los v. e los c. e los m. e emend. - $250 .-29$ feziere.

- 3r feriendose a sus. - 32 arrepentiniento. 
bendita; rrogando a Dios, que es agua biua e linpia e tuelle los peccados deste mundo, quel quiera lauar daquellos peccados veniales que sson ffechos; et otrosí rreçibiendo la bendiçión del obispo quando la da, abaxando la cabeça muy homillosamiente. Desffázegrelos ssin otra penitençia e ssin quebrantamiento de la carne. 5

Mas la emienda que deuen ffazer por los peccados criminales es de otra guisa. Qne aquellos que los ffizieron, quando sse connosçieren que erraron e quisieren auer perdón dellos, deuen primeramiente rrepentirsse con grant quebranto del coraçón de lo que ffizieron con muy homillosa noluntad para quererlo emendar e 10 conplir lo que les mandaren, estrannando mucho lo que ffizieron ; e auyendo duelo dessí que por ssu maldat ffizieron cosa por que mereçieron auer doble pena - la vna tenporal, la otra spiritual - en el alma et en el cuerpo, ssin las otras penas que deuen auer por las penitençias que les dieren. Et la emienda desto es que is cunplan lo que les mandaren, poniendo en ssu coraçón que nunca más tornarán en ello; ca ssi tornasen en ello, non ssería la emienda conplida nin ternían pro las conffessiones que ouyessen ffechas. Mas cunpliéndolo, sy morieren, yrán derechamiente a parayso. Et ssi la mucrte les acaesçiese, estando en penitençia, ante que la 20 conpliesen, lo que aquí non ouyesen conplido auerlo yan de conplir en purgatorio, que es logar do se purgan las almas, ante [58r] que entren en parayso, de lo que non emendaron por penitençia en este mundo. Mas la pena tenporal que deueu auer en los cuerpos por tales peccados commo éstos, sseyendo acusados dellos e 25 prouándogelos, esto sse muestra adelante conplidamiente en este libro do ffabla de las penas tenporales.

Et esta misma emienda deuen ffazer los que caen en peccados mortales quanto por rrazón de las almas. Mas de los cuerpos non les tanne nada, porque esto non cae ssinon en juyzio de los sse- 3o glares.

1 agua l. a b. e tuelle. - a que denne lauarle (denne retocado sobre deuen $y$-Le añadido en el margen, ambos de otra mano). -3 lechos otr. $-3-4 T$ obispo ab. -4 cabeça hom. -5 syn rresçibimiento de otra pena e. -6 deuen por. $-6-7 T$ los olros p. es otra. $-7^{-8}$ conosçieren [ $E$ \&4r]. 9 de cor. - 10 fezieron e con hum. - I T T mandare / mandaren e estr. r maldad supieron(fazer. - 13 meresçiesen dello pena. - $\mathrm{r} / 4$ las penas. 15 las otras pen. - 17 tornaran a ello ca sy t. a ello / $T$ tornase. - 18 ternie pro la confesion / fecho. - r9 $T$ cunpliendolo jran. -20 en la pen. -2 I $T$ conpliese. -26 muestra c. a. en. -27 libro alli do / corporates. $-3 o T$ porque non / en el juyzio. 


\section{[LEY XCIX]. - Qué quier dezir çitar e dónde fué tomada esta palabra.}

En qué manera rresuçita Niuestro Ssennor Thesu Cristo los peccadores de los peccados que ffazen por conffessión o por penitençia.

5 Citar es palabra en latín que quier tanto dezir en lenguaie de Espanna commo llamar, et daquí flué tomada rresuçitar, [que sse entiende] por sser llamado qui nou es a que ssea. Et esto cae en los muertos más que en al, quando por la uertud de Dios tórnan de muerte a vida, porque han mester de sser rresuçitados spiriro tualmiente ssegunt las almas. Esta misma ssemeiança es de las almas de los peccadores; que por los males que los cuerpos ffazen, que ellas conssienten, caen en pena de yr a inffierno, que es [muerte] ssin ffin. Et por ende queremos aquí mostrar ssiete maneras de llamamientos por que los omnes sse pueden guardar 15 de caer en peccado: la primera dellas es por conffessión; la ssegunda, por uergüença que rreçibe el que sse conffiessa; la terçera, non tardar la conffessión; la quarta, por rressuçitamiento; la quinta, cómmo deuen ffazer las emiendas; la ssesta, non deuen sser melezinados los cuerpos de ssus enffermedades ffasta que lo 20 ssean las almas de ssus peccados; la ssetena, que ninguno non se puede conffesar por mandadero nin por carta.

Onde la primera, por conffessión. Conffesarsse deuen los omnes de cada vno de los peccados que de ssuso sson dichos. Et esto dene sser ffecho en tres maneras, ssegunt los ssantos padres mues-

25 tran : la primera, auyendo muy grant uergüença del mal que ffizieron los que sse conffiessan; la ssegunda, diziendo uerdat de lo que ssopieren o les preguntaren que por ninguna cosa non mengüen nin ascondan ; la terçera, que șe arrepientan mucho de; los males que ouyeren ffechos, poniendo en ssus coraçones que nunca torna3 o rán más a ellos. Et por que sse fraga commo conuyene, ordenaron que el que viniese a conffesarse, que lo ffiziesse con grant humillat, ffincando los ynoios ante el penitençiador e assentándose a

I $T$ o. -4 confision. -5 palabra de latin. -6 tomado / $T$ çitar. $-7 E$ omile por ... cae. $-8 T$ quando la. $-9 T$ ha $/ T$ rresuçitadas. - Io $\mathrm{E}$ esa. - 11 almas [ $E$ 84v]. - 12 fazen e ellas / al inf. - I3 $T$ y $E$ mortal. - 14 lauamientos. -18 quinta $d$. $f$. en. -20 de los pec. $-24-25$ los p. s. m. la vna a. grant. -26 de todo lo. $-27 T$ y $E$ mengue. $-{ }_{28} T$ asconda / $T$ arrepienta, E rrepientan. 
ssus pies e tendiéndose antél en tierra, diziendo ssus peccados muy llorosamiente, ssospirando e rrepintiéndosse mucho dellos; et en todo esto teniendo la cabeça cubierta e abaxada, catando con los oios contra la tierra, o ffizo el peccado, e con la uoluntad contra el çielo, onde cuyda auer perdón de Dios. Et ffaziendo la conffe- 5 ssión desta guisa, non puede sser que non aya perdón de Dios e que non llegue a auer la vida perdurable, et guardándosse después quanto más pudiere de non caer en peccado.

La ssegunda, por uergüença que rreçibe el que sse conffiesa. Vergüença es vna de las más ffermosas cosas e más nobles que 10 omne a en ssí naturalmiente [58v] para guardarsse de errar, partiéndosse de mal e ffaziendo bien. Onde los que la entienden auyessas, auyendo uergüença de ffazer bien e non mal, an el entendimiento dannado. Et commo quier que esto sse da a entender por muchas cosas, ssennaladamiente sse entiende en este logar en r 5 el ffecho de la penitençia. Porque algunos y a que toman vergüença de maniffestar los peccados que ffizieron, queriendo sser más uasallos del diablo que de Dios, et temiendo más los dichos de los omnes nesçios que non la ssanna de aquel que puede ffazer en ellos lo que quisiere, $\tan$ bien en los cuerpos commo en las almas, ssegunt 20 Nuestro Ssennor Ihesu Cristo dixo en el ssu Euangelio, que non temiesen a aquellos que podían matar el cuerpo, mas a aquel que ha poder, después que ffuere muerto el cuerpo, de matar el alma en el ffuego del inffierno por ssienpre. Et por ende el peccador ba de auer uergüença en ffazer los peccados, mas non la ha de auer 25 en sse maniffestar dellos por palabras quel digan nin por escarnio que dél ffagan los omnes que sson nesçios o locos; ca nol podrian tanto escarnir que más escarnido él non ffincase sseyendo en poder del diablo, perdiendo el amor de Dios que puede ganar en dezirlos. Demás, déuel uenir emiente de quántas uergüenças Nuestro Sse- 3o nnor Ihesu Cristo rreçibió en ssu cuerpo por rredemir el omne de

1 tendiendose en. - 2 rrepentiendose. -3 cubierta con alguna cosa e. 4 do. -5 faziendose. -7 llegue auer la v. p. guard. [E $85 \mathrm{r}]$. -8 podiese. - Io vna cosa de las mas nobles (cosas escrito y tachado despues de nobles). - I-I 2 errar e partirse del mal faz. - i2 $T$ que lo, - I $3 T$ auyessas es au. i $T$ e ffazer mal, - I $5 T$ en otro logar. - I 7 de venir a man. (a añadido sobre la línea, olra mano). - 1 $^{-1} 8$ vasallo, - 20 quisieren. - 21 en su. - 22 pueden / mas aquel. -23 que el c. f. m. de. $-24-2 j$ pecador de f. los p. ha de auer $v$. mas non la deve auer. -27 non le. -28 escarnido non $f$. el siendo. $-29 T$ pueden. -30 emienle quantas. 
los peccados que auya ffechos e darles carrera de ssaluaçión ssi por ellos non ffincasse. Et que otra uergüença él non rreçibiese ssinon estando en la cruz desnudo, commo él estudo por nos, es grant cosa ssólo en pensar en ello. Mas non lo ffizo ssinon por dar

5 a nos a entender que ssi nos quisiéssemos ssaluar, que rreçibiésemos martirio por los peccados que ffiziéremos, assí commo lo él ssuffrió por nos, estando en la cruz. Et que nos deuemos otrossí desnudar ssin uergüença, partiéndonos de los peccados, commo él estido todo desnudo en la cruz, veyéndol la gente, e non dando Io nada por el escarnio quel ffazíen nin temiendo las palabras malas quel dizían aquellos quel tormentauan. Et por ende aquel que era ssin peccado e ssin manziella e Ssennor del çielo e de la tierra quiso ssoffrir tantas uergüenças por saluar a nos, quanto más lo deuemos ssoffrir nos por él, que ssomos todos encargados de mal-

15 dades e de yerros, e catando carrera por que perdamos uergüença, guisando cómmo ayamos ssu amor.

La terçera, por qué non deuen tardar los omnes de ffazer la conffessión. Vagar es vna cosa que tiene pro a los omnes en algunos ffechos e dannos en otros. Essto es assí commo quando alguno 20 asma de ffazer alguna cosa en que aya mal, que lo dene tardar, porque en tardándolo puede sser que sse le ssalirá de la uoluntad por que sse partirá della, o le acaesçrá enbargo por que non lo podrá ffazer. Mas ssi ffuere el ffecho por bien, non lo deue enbargar nin alongar, podiéndolo ffazer, porque el alongamiento aduze 25 muchas uezes a non sser ffecha la cosa commo la ffiziera ssi sse non alongase. Et ssi esto deue sser catado en las cosas que pertenesçen al cuerpo, quanto más las spirituales, que pertenesçen a la alma. Onde los que sse dan uagar de ffazer confessión [59r] e penitençia, sseyendo sanos, viéneles ende tan grant danno que sse

1 fecho. - 2 por el non finc. -4 fizo el synon. - 5-6 quisieremos s. que deuiemos sofrir mart. -6 commo el. $-7-8 T$ otrossi $\operatorname{ssin},-8$ dellos commo [E 85v]. - 9 estudo d. t. en la cruz veyendo toda la g. non. - I I aquellos que lo. - I3 tan grandes verg. / $T$ uerguenças quanto, - $-13-14$ mas nos que lo $\mathrm{d}$. sofrir por (a eserito $y$ tachado delamte de nos, y lo mismo otro nos delante de sofrir, ambas tachaduras de otra mano). - 14 cargados (con en- escrito, $y$ tachado de otra mano). - 15 catar. - 17 terçera que non d. los o. aver vagar en fazer (aver vagar en añadido en el margen, olra mano). - 18 Que vagar es c. que t. a omne pro en. - ig danno / E esto. - 2 I tardarlo / saldra. - 22-^3 acaesçera tal e. por que la non podra. - $33-24$ deue alongar. $-36 T$ assi. $-27-28$ al alma. -28 confision. 
les aluenga e por ende que non han la merçet de Dios ffasta que sse conffiessen. Et por esso sse deuen conffesar a menudo e non ssobreponer los peccados nin dexarlos enuejeçer; ca pues toda cosa por que omne gana amor de ssu ssennor non la deue tardar, quanto más lo de Dios, quel ffaze auer buena vida en este mundo 5 e ssaluar el alma en el otro. Et tan grande es la ssu merçet e la ssu piedat, segunt ya dixiemos, que nunca despreçia la penitençia de los peccadores, maguera ayan ffecho muchos peccados e grandes, ssolamiente que la ffagan uerdadera e ssin enganno. Et por ende todo cristiano la deue ffazer a menudo quando es ssano e en io ssu memoria ; ca atal penitençia commo aquésta más plaze a Dios e la gradeçe que la otra que es ffecha commo amidos, pasando tienpo e llegando a estado que non puede más. Et aun ssin todo esto viene muy grant danno en tardar la penitençia, porque a las vezes tanto quexan a omne Jas enffermedades quel ffazen perder la i 5 ffabla e el sseso, de guisa que non ha poder de conffesarsse commo deue. Et los ssabios antigos dixieron ssobresto palabra uerdadera, que quien tienpo ha e puede obrar en él e atiende, quel pierde después por tardança, e non lo auyendo quando lo quiere auer.

La quarta, por rresuçitamiento. Santa Eglesia nos da enxienplo 20 de cómmo rressuçita Nuestro Ssennor Ihesu Cristo las almas de las tres maneras de peccados que de ssuso sson dichos, a ssemeiante de los tres muertos que rressuçitó quando andaua por la tierra. El primero dellos ffué la ffija del mayor ssaçerdote de la ssinagoga, que yazía muerta en ssu casa. Ante que la rresuçitase, mandó que 25 callasen e non ffiziesen duelo por ella. Otrossí a ssemeiança desto rresuçita largamiente, perdonando por penitençia, el peccado venial. Et esto nos dió a entender que los omnes non sse deuen meter a rroído para ffazer mal, nin otrosí ffaziendo duelo, cayendo en peccado mortal, que ssería de mayor dolor que muerte. El sse- 3o gundo muerto que rresuçitó que ffué ffijo de vna biuda que ffalló

I aluenga por aquella tardança que non. - 2 confiesan / confesar e non. 4 que gane o. amor / deue de tardar. -5 auer v. b. en. - 8.9 pecados sol. - io sano en. - I 1 me[E 86r]moria / tal / esta. - i2 $T$ e lo. 13 allegando / pueda. - 14 esto ay otro muy (ay añadido en el margen, otra mano) / $T$ viene aun muy. -15 al omnè. - 16 han. -17 deuen / palabras verdaderas. - I 9 tardança non / querie. - 21 rresucito. - 24 sacerdote que auie en la signagoga. - $25 \mathrm{E}$ ante. -26 semejante. -27 T rresuçito. - 27-29 pecado $v$. que los $o$. fazen metiendose a carreras de fazer mal. 
que leuauan a ssoterrar fluera de la çiudat. E encontróse con él e ouo duelo de ssu madre e de las que la aconpannauan e que llorauan con ella, e rressuçitólo y luego ante que lo ssoterrasen. Et a ssemeiante desto rresuçita Nuestro Ssennor Ihesu Cristo el peccado

5 que ssale por el penssamiento del omne, que sse entiende por la cubdiçia, e liéual a ffazer peccado mortal, que es assí commo ssoterramiento. Et encontrándosse con la penitençia, que es obra de Ihesu Cristo, torna assí commo de muerte a uida. El terçero muerto que rresuçitó Nuestro Ssennor Ihesu Cristo ffué Lázaro,

Io hermano de Santa María Magdalena e de Ssanta Marta, que auya quatro días que era muerto e ssoterrado e olíe mal. Et estas dos hermanas ffueron luenne de aquel logar dol ssoterraron e rrogáronle por él, diziendo que ssi él y ffuera, non muriera ssu hermano. Et a ssemeiante desto Nuestro Ssennor Ihesu Cristo, dolién-

I5 dosse ssegunt omnê auiendo piedat segunt [59v] Dios, rressuçita por penitençia a los que caen en peccados mortales e huelen mal las almas dellos, seyendo corron pidas por los yerros que fizieron, assí commo el cuerpo de Sant Lázaro era corronpido por los humores que sse desataran en él. Para mouer a Dios que aya uoluntad 20 para perdonarlos, a ssemeiança de Santa María Magdalena lloró spiritualmiente por oraçiones por aquellos que, desffaziéndose e podreçiendo, [yazían] en peccados mortales. Esso mismo ffaze la Eglesia corporalmiente en ssemeiança de Ssanta María, echándosse a prezes, pidiendo merçet, e ffaziendo bienes e dando limos-

25 nas por que ssalgan de peccado mortal aquellos que yazen en él assí commo ssoterrados. Onde, mouidas estas dos hermanas que auemos dichas e rrogando por los que yazen en peccado, mouyéndose la piadat de Dios, que sse entiende por ssu ffijo lhesu Cristo, a âuerles merçet e perdonarlos por la penitençia que ffazen, rrepin30 tiéndose e doliéndosse mucho de aquellos yerros en que cayeron.

La quinta, a quién deuen ffazer las emiendas. Ffazanna muy derecha ffalló Ssanta Eglesia por que todo peccador deue ffazer

I que lo leu. / la villa. - 2-3 los que le a. que il. por el e rres. -4 deste rresucitarniento Nuestro / $T$ rresuçito. -6 -lo. -7 encontrandose en la. 12 de su l. do le sot. $[E \delta 6 v]$. - I4-15 deziendose. - i5 onbre e au. (onbre añadido en el margen, olra mano). - I9 E para. - 20 Madalena. -23 en asemejança. - 24 preçes. - 34-25 merçet $f$. b. por que salga. - 25-26 mortal el que yaze en el c. soterrado. - 26 mouiendose. -27 yazien. $-29-30$ rrepentiendose. - 32 fablo S. Maria (Iglesia añadido en el margen, otra mano). -32 y sig. deue p. f. e. aquel / $T$ ffazer prim. 
emienda primeramiente a aquel que ffizo el tuerto que a Dios; ca primeramiente deuen ffazer emienda al omne, e después a Dios. Ga maguer él es poderoso ssobre todas las cosas e los pesares quel ffazen los omnes sson de tan grant assannamiento e tan ssin rrazón que non ge los puede omne emendar por emienda quel ffaga, con $\overline{5}$ todo esso mayor es la ssu ssufrençia e la ssu piadosa uoluntad para auer piadat e dar pasada a las cosas e perdonar con grant merçet que non es la liuiandat de los omnes nin el poco sseso que han para errar nin el atreuimiento que han para lo osar frazer, ssegunt Ysayas propheta lo dixo por él mismo: Assí commo los 10 çielos sson más altos que la tierra, assí las ssus carreras e los ssus cuydados sson más altos que los de los omnes. Et por ende Nuestro Ssennor Ihesu Giristo ssu fijo mandó que ffiziessen ante emienda a los omnes que a Dios ssu padre, quando dixo que ssi alguno estidiese ante el altar e tonyesse ssu offrenda apareiada e le men- 15 brase del tuerto que él ffiziera al otro, que dexase el offrenda ante el altar e gre lo fluese primero emendar, e después tornase a ffazer ssu oblaçión con linpia uoluntad. Onde por esta mazón deve el peccador emendar primeramiente los tuertos que ffizo a los omnes, desí los que fliziere a Dios.

La ssesta, que los ffísicos non deuen melezinar los enffermos ffasta que ssean conffesados. Conffesarsse deue todo cristiano para sser sseguro de ssu alma; ca Dios conpuso el omne, quandol ffizo, de dos cosas contrarias: la vna, tenporal, assí commo el cuerpo, que es ffecho de los helementos, en que ha materia e 25 fforma que sse danna e sse corronpe; la otra, çelestial, assí commo el alma, que es conpuesta spiritualmiente de entendimiento e de rrazón, e que non puede morir nin rresçebir en ssí danno ssinon quando pecca, acordándosse con el cuerpo en ffazer mal, quel da entendimiento $[60 \mathrm{r}]$ por que pierda el amor de Dios. Et por ende 30 puso Dios melezina a cada vna destas cosas quando mal rreçi-

1-2 Dios e por ende d. f. e. p. al omne. $-2 T$ emienda e. -3 es muy pod. -4 atrouimiento i $T$ e de tan. -5 puede emendar / T fagan. $-9 T$ ha p. errar / $T$ lo ffazer. - to profecta dixo. - 12 mas $[E 87 \mathrm{r}]$, -15 estudiese / la ofr. - 16 tuerto fecho al (fecho añadido en el margen, otra mano) $/$ su ofr. - 17 primero a cm. - 18 su ofrenda / Onde con pura voluntad por. - 19-20 omnes e desy. $-23 T$ quando el. $-24 T$ commo es el. - 28 rrazon que. - $30 E$ entendimiento (atreui- añadido en el margen, otra manoj/ el ama de. - 31 Dios la mel. / destas dos cosas. - 3r y sig. rresçiben. 
biessen, assí commo el cuerpo que guardasse por ffísica êl alma por penitençia. Et commo quier que el cuerpo paresçe que es ffecho de cosas conpuestas, e non el alma, que es spiritual en todo, mayor nobleza es la de la alma, que non puede morir, que la del 5 cuerpo, que muere. Onde, quando alguno ha enffermedat en el cuerpo por que el ffísigo aya de penssar dél, ante deue acorrer a la enffermedat de la alma que a la del cuerpo. Et por ende ffué estableçido en Ssanta Eglesia que ningún ffísigo non metiesse mano en el enffermo ffasta quel conseiase que penssase de ssu alma. Et

ro después que esto ouyere ffecho el enffermo, deue el ffíssico melezinarle, e non ante; ca muchas uezes acaesçe que agrauian las enffermedades a los omnes más affincadamiente por los peccados en que están. Et que esto assí lo deuan ffazer, auemos por enssienplo de vn enffermo que non quiso Nuestro Ssennor Ihesu Cristo

15 ssanar ffasta que primeramiente non le perdonó los peccados que auya ffechos. Et después quel ouo ssano, díxol: Daquí adelante non quieras peccar, por que esto te aya de acaesçer otra uez. Onde el ffísico que contra esto ffiziere deue sser echado de Santa Eglesia e non entrar en ella, porque ua contra el deffendimiento 20 de la ley. Otrossí es deffendido, non tan ssolamiente por castigo de palabras, mas so pena de descomunión, que ningún ffísico por enffermedat que el enffermo aya, aunque lo entienda aguaresçer della, nol conseie por que caya en peccado mortal. Et esto es porque las almas sson más nobles e más linpias que los cuerpos, 25 ssegunt ssobredicho es.

La ssetena, que ninguno non se deue conffesar por mandadero nin por carta. Mandadero nin carta non deue ninguno enbiar por sse conffesar por ellos, mas el peccador mismo lo deue ffazer por ssu boca a aquel que da la penilençia. Et otro medianero non 30 deue y sser ssinon Dios, que es Ssennor e lo ssabe todo, ffueras

I fisica e el. - 2 Commo / peresçe. - 3-4 spiritual con t. eso mayor. $-4 T$ es de / del alma. -6 fisico. -7 del alma. -8 fisico non ponga. $-g$ en enf. f. que primero lo confiesen que. - to que el enf. esto o. f. deue. - I $T$ ante el muchas / vegadas. - I 2 omnes $[E 87 v]$. I5 sanarle f. que prim. confeso los. $\rightarrow 16$ que lo. $-17-18$ que peor desto non te aya de conleçer onde. - 19-20 contra d. de la iglesia. - 2 I palabra / excomunion. - 22 aya nin por esperança del guaresçer (por esperança añadido che el margen, olra mano). -23 non c. que faga cosa por. $-26 \mathrm{E}$ la set. - 27-28 enbiar por conf. - 29 quel da / Otrosy med. - 3o Sennor lo, 
ende ssi non sopiese el lenguaie de aquel a quien sse quiere conffessar o ouyesse en ssí enffermedat o otro enbargo alguno por que non lo pudiese dezir por la boca e lo ouyese de escriuir por ssu mano; ca estonçe bien pude maniffestar ssus peccados por medianero, estando delante aquel a quien sse quiere conffesar, e nol 5 enbiando de otra guisa carta nin mandadero, ssegunt de ssuso es dicho. Esso mismo ha de ffazer el que dize ssu conffessión por escriptura ; ca antel conffessador la deue escriuir, e non en otro logar. Esto sse entiende de aquellos que an tal enffermedat o enbargo por que non lo pudiessen mostrar de otra guisa o non 10 ssopiessen rresponder o entender al lenguaie del penitençiador, ssegunt ya de ssuso dixiemos. Et que esto deua sser assí fecho e dicho, Nuestro Ssennor lhesu Cristo nos dió ende enxienplo quando ssanó los gaffos dos e les dixo: Yt e mostratuos a los ssaçerdotes. Et en esto sse entiende que touo por bien que cada 15 vno ffuesse por ssí a mostrar ssus peccados, e non vno por otro. Et otrossi sse muestra por $[60 v]$ lo que dixo el apóstol Ssantiago, que sse conffesassen los omnes los vnos a los otros por que ffuesen ssaluos. Onde qui ffaze la conffessión desta manera, vale, e non de otra guisa.

[LEY G]. -- Quién puede dar la penitençia e de las preguntas que deuen ffazer.

Mostrado auemos en la ley ante désta de cómmo los peccadores rresuçitan de los peccados que ffazen por conffesión e por penitençia. Et agora conuyene que sse diga de aquellos que la 25 pueden dar e de las preguntas que deuen ffazer, et esto en ssiete maneras : la primera, que a los clérigos missacantanos es dado de dar las penitençias; la ssegunda, por quáles rrazones la pueden dar otros que non ssean missacantanos ; la terçera, cómmo deuen sser entendidos los que la dieren; la quarta, quáles preguntas 30 deuen ffazer a los que sse quieren conffessar; la quinta, en qué

a e ov. - 2-3 enbargo por que lo non pod. -3 escrivir con su. -4 puede. -5 non le. -6 mandado. $-7 \mathrm{E}$ eso. -8 confesor. $-9 \mathrm{E}$ esto. -9 -1o enfermedad en el cuerpo que lo non $p$. de. - Io $T$ pudiesse. - 10-1 t o non podiesen ent. o r. al. - I3-13 $T$ assi dicho. - I4 los dos g. e les. - 55 saçerdotes $[E 88 r]$. - I9 quien. - 21 las penitençias. -23 deue. -23 las leys. - 98 quales Ia. 
manera les deuen preguntar ssi ssaben el Pater noster e el Aue Maria e el Credo in Deum ; la ssesta, cómmo el conffesador deue preguntar honestamiente al que sse quiere conffessar por que la penitençia ssea tal qual conuyene ; la ssetena, en qué manera deue 5 demandar consseio el que oyere las conffessiones quando dubdare.

Onde la primera, que a los clérigos misacantanos es dado de dar las penitençias. Penitençiar non deue ninguno a otro ssinon los clérigos de misa, porque tienen logar de los apóstoles en tierra para predicar la ffe de Nuestro Ssennor Ihesu Cristo, sse-

Io gunt en otro logar es ya dicho. Et esto sse entiende cada vno de ssu ffilegresía, a ssemeiança de la" tierra en que enbió Nuestro Ssennor Ihesu Cristo a los apóstoles, cada vno qual conuertiese. Et por ende ninguno non sse deue conffessar ssinon al clérigo que ffuere ssu parrochiano, porque con derecho non lo puede ffazer

15 ssin otorgamiento dél o del prelado mayor de aquel parrochiano, que ha poder de ge lo mandar. Et esto es porque ellos han poder de abssoluer de ssus peccados a aquellos que sse les conffiessan, assí commo el prelado mayor a los que sson tenidos de obedeçerle e el parrochiano de ssu ffeligresía. Pero los prelados

20 mayores, assí commo los obispos de qual manera que ssean, $o$, olros omnes onrrados que non ssean de orden, assí commo los enperadores o rreyes e aun otros poderosos ssennores de grandes tierras, éstos sse pueden conffessar a qual clérigo quisieren ssin demandar liçençia, ssolamiente que aquel a qui sse conffesaren 25 ssea ordenado de misa. Pero los de rreligión, commo quier que puedan penitençiar a todo tienpo, non pueden abssoluer ssi non les ffuere otorgado por priuilegio del papa ssinon de vna manera, assí commo quando el prelado mayor de aquel logar pusiesse alguno dellos para sseruir alguna rreligión parrochial que ffuese 3o de aquella ssu rreligión. Et esto se entiende por ssu conssintimiento del major de la orden de aquel rreligioso.

1-2 saben el A. M. e el P. n. e Credo. - 3 quiere (borrón en $T$, lección de $E)$. -4 deuen. $-6 T$ los m. c. es. -7 non puede nin d. o. n. synon. - 8 tienen el lugar. - i su fe la iglesia a. - i2 Cristo los/ vno el qual. - 16-17 Esto es porque e. pueden [E 88v] a. de sus p. aq. que ge los. 19 perrochano a sus feligreses. -20 los apostoles de qual $m$. quier que. - 2I-22 commo enp. - $22 T$ poderosos e ssenn. / senores. - 23 tierras e estos. -24 a que / $T$ conffesare. -26 pueden $p$. en todo / $T$ non puede. -27 preuillejo. - $29 T$ sseruir aquella rrel. $-30-31$ a omile Et ... rreligioso. 
La ssegunda, por quáles rrazones la pueden dar otros que non ssean misacantanos, sseyendo en cuyta el que la demandare. Cuytado sseyendo alguno de tal enffermedat o sse viese en tal periglo por que quisiese tomar penitençia e que él que tenía en uoluntad de la ffazer, et ssi non le puede auer, bien sse puede 5 conftesar a otro $[61 r]$ clérigo, aunque non ssea de missa, ssin demandar liçençia. Pero ssi aun aquél non pudiesse aner, tan ssanta cosa es la penitençia e tan grant uertud ha que con lego la puede ffazer. Et commo quier que éste non aya poder de abssoluer de los peceados, con todo esso gana amor de Dios por el arrepen- io timiento bueno que ha e por la uoluntad que tiene que sse conffessaria al clérigo ssi le pudiesse auer. Mas ssi después estorçiesse de aquel perigto o de aquella muerte, déuesse maniffestar de cabo al clérigo que sse quiere maniffestar o a otro que aya poder de abssoluer; ca atal conffessión commo la que auya ffecho non uale i5 ssinon a hora de cuyta, non podiendo al ffazer.

La terçera, cómmo deuen sser entendidos los que la dieren. Entendidos e ssabidores deuen sser los que dan las penitençias; ca mucho conuyene al que quiere ssaber la uoluntad del otro que ssea entendido, et esto en dos maneras : la primera, en preguntar; 20 e la otra, en aluedriar. Ca por las preguntas llegará a lo que quierc ssaber, e por aluedrío ssabrá lo que y deue mandar. Et por ende deue y parar mientes el penitençiador qué perssona es aquel que sse le conffiessa ; primeramiente en ssu hedat, ssi es moço o mançebo o vieio ; el desí en estado de ssu cuerpo, ssi es ssano o enffer- 25 mo, o rrezio o flaco, o gruesso o magro, o layrado o viçioso ; otrossí ẹn estado de ssu ffazienda, ssi es clérigo o lego o ssin letradura, o casado o por casar, o rrico o pobre, o libre o ssieruo. Et ssin todo esto dénel preguntar la vida que ffaze o ha vsada de ffazer e punnar en ssaber qué costunbres ha en él, ssi es omne que 30 cubdiçie mucho conplir la uoluntad de la carne, assí commo en

I $T$ qual rrazon / puedan. - 2 demandase. -3 de enf. -4 peligro / $T$ añade e sobre la línea; $E$ lo omite. -5 nol podiere aver. -7 Pero avn sy aquel. -8 cosa commo la $p$. que tan $/ T$ e de tan. -9 asoluerle. - ro-r $\mathbf{r}$ gana el a. de Dios por aquel rrepentimiento b. el por la buena vol. - i a sy lo p. auerle. - I3 peligro. - 14 clerigo a quien se suele confesar. - 15 asoluerle ca tal. - 8 E ent. e sabios / dieren. - 20-2 1 preguntar la $\mathrm{ii}^{\mathrm{a}}[\mathrm{E} 89 \mathrm{~F}]$. - 21 quisiere. -22 por el alu. - $25-26$ sano of. o enf. o rreçio o grueso. -26 lazdrado. - 27-38 letradura o por. - $28 T$ casar o libre. - 30 punar de saber. - 3 r cobdicie. 
comer o en beuer e en Juxuria e en otras cosas ssemeiantes déstas; o ssi tiene la uoluntad ssana o enfferma, o vsada de penssar malos pensamientos o a dezir malas palabras, o ssi es estable en la cosa que ha de ffazer o camiadizo, o ssoberuioso o humilloso, o cubdi-

5 çioso o ssin cubdiçia, o escaso o granado, o mansso o brauo, o grande de coraçón en dicho o en ffecho o vil o rreffez. Et deue otrossí ssaber el logar que tiene, ssi es omne onrrado, así commo papa o patriarcha o primado o arçobispo o obispo o otra perssona qualquier que ssea de orden o de rreligión ; o ssi es omne que ha Io poder de ffazer justiçia, assí commo enperador o rrey o otro que tenga logar para ello. Et ssin todo esto déuel preguntar qué mester ha o qué offiçio, ssi es cauallero que aya de beuir por armas, o labrador por ssu lauor, o menestral por ssu maestría, o mercadero por ssus mercaderías. Et catando el penitençiador todas estas cosas,

I5 luego entendrá e ssabrá quál penitençia conuyene quel dé por los peccados que ffizo o dixo, o la que podría ssoffrir e adozir a contenplamiento, catando que ssi andido con ssus pies en ffazer malas obras, que ande otrosí carreras en que lazre bien. Pero ssi ffuesse commo vieio o fflaco de cuerpo o enffermo de cuerpo, déuesse

20 mouer contra él piadosamiente, non le dando tantas carreras nin tales que non pudiesse conplir, por que ouyese omne a menguar la penitençia quel diesse o por quel creçiese más la enffermedat o que muriese por ello. Esso mismo dezimos del que peccasse comiendo mucho o beuiendo mucho, por quel penitençiasse con 25 ayuno e con astinencia; que tal ge la deue dar que non enffermase por ello de guisa que ouyesse [61v] a morir. Otrossí ssería de aquellos que ouyessen peccado en dezir malas palabras, por que lo ouyessen a encargar con oraçiones; ca atales sserían éstas que non las entendería maguer las dixiese, o tan muchas que non sse

I comer e en b. e en l. o en / $T$ otras ssem, - 2 enferma o ha vsado. - 3 o dezir m. p. e (aduzir escrito y tachado, y dezir añadido sobre la línea, otra mano). - 4-5 cobdiçioso. $-5 T$ cubdiçioso, $E$ cobdiçia. -6 grant c. en fechos e vil o rrafez. $-7-8$ commo el papa. - 8-9 arçobispo ob. o otra p. de q. manera que sea. - io $T$ commo es enp. - I I-I 3 preguntar a o que of. o si. - 13 mercador. - 14 mercadurias. - 15 qual es la p. que el convien. - i6-I que el d. o f. o lo que podra s. o dezir a conplimiento c. que and. - 18 anden / lasdren. - ig enfermo deue. - so mouer [E 89v]/ non dando. - 21 ouiese omen amengoa (omen tachado con un rasgo oblicuo y un tilde añadido sobre -oa, ambos de otra mano). - 22 que diesen o por que el c. mas la dolençia. - 23-24 comiendo m. por quel penitençiasen. - 250 con abstinençia. $-27-28$ por quel ouiese. -28 tales. -29 entendrie. 
atreueria a dezirlas. E tal ssería de aquellos que por ssu auer peccassen, ffaziendo ssoberuias; ca maguer les mandassen que de aquel ssu algo diessen a pobres o en hospitales o en algunos logares de limosnas, non les deuen mandar que den tanto por esso que anden a mendigar. Et por ende conuyene que aquellos que han a 5 dar las penitençias ssobre tales cosas commo éstas o otras ssemeiantes dellas, que las den en manera que los omnes las puedan tener e conplir. Et ssobre tal rrazón conmo ésta dixo Nuestro Ssennor Ihesu Cristo, rreprehendiendo los phariseos, diziendo que encargauan los omnes de muy grandes cargas que ellos tan ssolamiente 10 non queríen mouer con ello. Et esto sse entiende en este logar por aquellos que dan grandes penitençias a aquellos que la non pueden conplir. Et a ssí mismos non querrían que las diessen, maguer ellos mismos cayessen en aquel peccado. Et por ende el que da la penitençia deue sser ssabio que de manera la pueda dar que ssea con 15 justiçia e con piadat.

La quarta, quáles preguntas deuen ffazer a los que sse quieren conffessar. Preguntando el omne las cosas, viene por ellas a ssaber más çiertamiente lo que non ssabría dotra guisa ssi las non preguntase. Onde al que quiere preguntar, deue tomar la manera de la pre- 20 gunta ssegunt la cosa que quiere ssaber. Et por ende estableçieron los ssantos padres que los que diessen ssus penitençias, quando preguntassen a los peccadores por ssaber dellos los peccados que ffiziessen, que los amonestassen primeramiente que los non negassen nin encubriessen ninguna cosa de lo que ssabian en que erra- 25 ran, ffaziéndolos entender que lo que a él dizian tanto era commo ssi lo dixiessen a Dios, a qui nada non sse puede encobrir; ca pues él ssabe todas las cosas ascondidas e es en él uerdat toda conplida, e non conuyene que antél diga mentira. Et ssi por estas palabras dixiere uerdat de guisa que aquel que la pregunta en- 30 tiende quél cunple, nol deue dallí adelante preguntar más. Pero

I atreuerie en d, otro tal / su grant aver. -3 obspitales. - $4 T$ mandar tanto. - 4-5 mandar por eso que den t. que tornen a mend. - 5-6 convien que aq. que dan las. -7 de las que les den de man. / $T$ de. - I0-i I cargos que e. s, non las quer. - II Esto. - is a los que las. - 13-14 maguer que e. cay. - 15 sabio do $m$. que la sepa dar con. - i7 deue. - 20 el que quisiere. - 22 padres $[E 9 O r]$ / las pen. $-25-26$ sabie en que erraron faziendoles. - -9 dixiese / quien. $-28-39$ en el t. v. c. non convien que d. a. ment. - 3o dixiese la verdad (la letra v eserita y tachada delante de la). - 3o-3 I entiende ende que cunple. 
ssi ge la non quisiere dezir o non ssopiere, hale de ffazer pregunta de aquellos peccados que sson más husados, assí commo enbidia, o ssoberuya, o auariçia, o fforniçio, o ffurto, o ffalsso testimonio, e los otros yerros en que los omnes caen a menudo. Et ssi viere

5 que sse rreçela en alguna cosa o ha uergüença de lo dezir, al de preguntar daquello que toma uergüença o rreçelamiento ffasta que ssepa ende la uerdat. Pero déuesse guardar que non le pregunte peccados estrannos e muy ssin rrazón que los omnes non han vsado de flazer, porque podría acaesçer que alguno de mal entenIo dimiento por tales demandas sse mouría a prouar e ffazer algunas cosas malas que ante non las ssabría penssar nin atreuersse a ffazerlas.

La quinta, en qué manera los deuen preguntar ssi ssaben el Aue Maria e el Pater noster e el Credo in Deum. Son tres oraçio-

ij nes que deue ssaber todo cristiano. Ca en la primera sson las ssaludes que el ángel Gabriel dixo a Santa María quando la ssaludaua, amostrándol çiertamiente cómmo Nuestro Ssennor Dios rreçibríe carne della e sserie omne, en que le contó buenos mandados a ssemeiança de las çinco letras [62r] que sson en el ssu nonbre: el

20 primero ffué diziendo que Dios la ssalue; el ssegundo, que era llena de graçia; el el terçero, que Dios Nuestro Ssennor era con ella; et el quarto, que era benedita entre todas las mugieres; el quinto, que ssería bendito el ffructo del ssu vientre. Et en la ssegunda oraçión del Pater noster sson ssiete petiçiones que Nuestro

25 Ssennor Ihesu Cristo nos amostró, con que ssopiéssemos pedir merçet a Dios ssu padre, ssegunt es dicho en el comienço deste libro, o ffabla del cuento del ssetenario. En la terçera oraçión, que es el Credo in Deum, sse muestra conplidamente la crençia de Nuestro Ssennor Ihesu Cristo en cómmo los omnes deuen creer, 3o ssegunt los apóstoles lo ordenaron e es dicho de ssuso de los artícu-

I ge lo / e / -1. - 3 aquellos que. $-40 .-6$ preguntar en aquello. 7 qual non preg. - 10 e a fazer. - 11 antes. - I3 les. - 14-15 Que son tres o. senaladas que (e escrito y tachado, y Que añadido en el margen, otra mano), - 15 - 16 las que. - 16 Grauiel. -17 amonestandol (mostrandole añadido en el margen, otra mano) / Sennor rresçebrie. - is quel c. comioo buenos. - 19 semejança del cuento de / $T$ la sinco. - 20 el dos. - 20-21 $T$ ssegundo que Hlena. - 21 graçia el iii que N. S. Dios era. - 22 ella el / entre las. -23 que fue $[E 90 v]$ / En la. -25 mostro. $-28 T$ muestra la. - 3o suso alli o se dizen los. 
los de la Ffe. Et por ende estas tres oraçiones deue el penitençiador preguntar al que sse conffiessa por tres rrazones: la primera, porque ssi las ssopiere, déuegelas loar, diziéndole cómmo le preçia más por ende e lo tiene por meior cristiano porque esto quiso ssaber ; la ssegunda, que ssi las non ssopiere, que ge las muestren; 5 la terçera, porque estas tres oraçiones dene dar por penitençia a los que sse conffessaren de ssus peccados porque sson meiores de dezir e más vsadas que las otras e ha en ellas uertud. Ca en la primera loan a Ssanta María, que han mester los peccadores mucho ssu ayuda. Et en la otra rruegan a Dios que les aya merçet ro en ssiete rrazones. En la terçera sse muestra cómmo cree en la Trinidat.

La ssesta, de cómmo el conffesador deue preguntar honestamiente al que sse conffesare por que la penitençia ssea tal qual conuyene. Con grande honestat deuen los conffesadores oyr los 15 peccados de aquellos que sse les conffiessan; ca maguer que el poder es en ellos de preguntar e de maltraer e de dar pena por la culpa, con todo esso con grant homillat lo deuen ffazer, catando primeramiente lo de Nuestro Ssennor Dios. Ca maguer él es poderoso ssobre todo que viene de ssuso de los altos çielos do él está, 20 deuen abaxar la ssu uoluntad para oyr los rruegos de los peccadores en que erraron e yazen en grant culpa, et esto a ssemeiante de Nuestro Ssennor Ihesu Cristo; que porque él en ssí en la deidat non ha cuerpo nin cosa en que rreçiba danno nin pesar de que los omnes sse ayan a doler, ffué tan graut la karidat de amor que nos 25 ouo que sse quiso ygualar connusco, rreçibiendo la nuestra carne por que sse ouyese en ssí cosa de que ouyésemos piadat e dolor, commo él de nos. Onde el conffesador que está en ssu logar deue sser piadoso e dolersse del peccador quandol oyesse dezir con grant uergüença los peccados que ffizo. Otrossi el escarmiento quel diere 30 por la penitençia, déuelo dar con piadat, catando dos cosas : la primera, quánto puede ssoffrir la fflaqueza del omne, maguer me-

1-2 oraçiones a de saber por tres (a de añadido sobre la línea y lo mismo -r de saber en el margen, ambos de otra mano). - 3-4 deziendol commol p. por ende mas el ticne. -5 segunda por que/sopiese. - 6 oraçiones les deuen / $T$ dar pen. - g-io han mucho m. los p.su. - Ir En las tres que

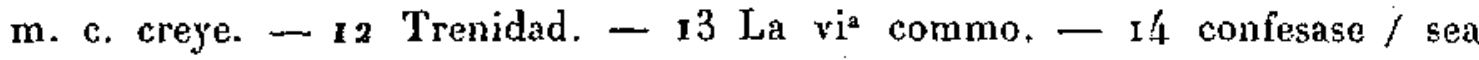
qual. - $15 \mathrm{E}$ con grant. - I0 se c. ca m. el. - $2 \mathrm{l}$ abajar. - 33 sy quanto en. -25 omes $\left[\begin{array}{lll}E & 9 & \mathrm{r}\end{array}\right]$. -26 egualar conusco. -27 que ouiese / ouiesemos aver piedad. -29 ouiose. -32 pueda. 
resca mucho; la ssegunda, quánto puede perdonar la piadat de Dios, maguera es justiçiero. Et por ende para ffazer meior el que sse conffiessa todas estas cosas, deue tener la cara abaxada e cubierta de guisa que ge la non uea aquel a qui sse conffiessa. Pero con todo

5 esso algunas uegadas le deue parar mientes el conffesador por ueerle ssi tiene triste contenente o alegre; ca ssi trisle lo touyere, entiéndesse que sse duele de ssus peccados; et ssi alegre, que lo ffaze por [62v] dar passada a ssu ffecho, ffaziendo creyente por ssemeiante que es buen cristiano, non lo sseyendo. Et ssi omne on-

ro rrado o rrico o poderoso, sse le maniffiesta que sson tres maneras en que los omnes toman orgullo quanto más ouyere de cada vna déstas o de todas en vno, mas lo deue mostrar que erró pecando con cada vna dellas. Et esto dene ffazer por quebrantarle el coraçón de la ssoberuia e del orgullo que auye e aduzirlo a homillat para I5 rrepentirsse de ssus peccados e flazer uerdadera penitençia dellos; et ssi otros omnes ffueren, castigarlos ssegunt el estado en que los ffallare toda vía homillosamiente, ssegunt de ssuso es dicho. Mas ssi ffuere mugier, déuela mandar assentar tan aluenne de ssí de guisa que pueda él oyr ssu conffessión, e non otro ninguno de 20 los que estudieren a derredor. Et que la non tanga con ssus uestiduras nin con otra cosa ninguna nin le deue mucho parar mientes a la cara nin a otro mienbro que tenga descubierto, porque dixieron los ssantos padres que atal es la cara de la mugier e los mienbros a los peccadores commo la rrede en que caen los pescados; ca 25 maguer la veen, nơn sse ssabiendo guardar, caen en ella. Nil deüe dar otrossí penitençia en logar apartado nin encubierto do non esté otro ninguno ssinon ellos amos, et esto porque naturalmiente la cosa que más ffaz a los omnes mouer las uoluntades para peccar, e ssennaladamiente con las mugieres, es quando ffablan en logar 3o conueniente para ello.. Et contra tales commo éstos dixo Ssant Paulo en castigo que non quisiessen en ssí mismos dar logar al

I la otra q. pueda (dos escrito y tachado, y otra añadido sobre la línea, otra mano). - a-3 mejor el confesador todas. -4 aquel que. -6 ver (seer escrilo y tachado, $y$ ver añadido sobre la línea, otra mano) / lo tiene. - I ghmanifestare. - I1 vno. - is le. - I2-13 pecando cada. - I4 -le. - $16 T$-las. -18 luenne. - 20 en derr. - 20-2 r vestidos. - 23-2h padres atal es la c. e los $\mathbf{m}$. de la muger a los p. commo [E $9 I \mathrm{v}]$ la rred. - 25 ven non sabiendose $\mathrm{g}$. van caer (van añadido sobre la línea y caer retocado sobre caen). -26 dar p. o. no en (no añadido sobre la línea, otra mano). - 27 amos esto nat. - 3o conviniente. - $3 \mathrm{t}$ en castigando. 
diablo. Onde los penitençiadores, faziendo esto en la penitençia, ffazerla han bien e conplidamiente commo deuen e ffarán mouer las uoluntades de los omnes a confesarsse de ssus peccados de grado e uerdaderamiente guardar meior la penitençia que les dieren.

La ssetena, en qué manera deue demandar consseio el que oyere 5 las conffessiones quando dubdare. Dubda es cosa que torua las uoluntades de los omnes, enbargándolos que non pueden llegar conplidamiente a lo que quieren ssaber o ffazer. Et por ende tal enbargo commo éste deuen toller de ssí en dos maneras, e ssennaladamiente los que dan las penitençias: la vna, preguntando los ro que non ssaben a los que ssaben; la otra, demandando conseio en lo que quieren ffazer a los que lo ssaben e han poder de ge lo dar. Et por ende estableçió Ssanta Eglesia que quando algún clérigo por mengua de entendimiento cayesse en alguna dubda de dar penitençia ssobre peccados que alguno ouyesse dicho en ssu con- i5 ffessión e, queriendo ssalir della, ffuesse preguntar a otro que ssopiesse más que él, que ge lo ffiziesse entender de guisa que aquel a qui lo preguntasse non pudiesse ssaber quién era aquel que sse le conffesara, ssobre cuyo ffecho dubdara; ca ssi por aquella demanda ffuesse connosçido, tanto era commo ssi él mismo lo descu- 20 briese.

[Ley CI]. - Quáles deuen sser llamados conffesadores e cómmo deuen guardar en poridat lo que les dixieren.

Conffesadores sson llamados los que oen las conffessiones e dan la penitençia. [63r] De cómmo la deuen guardar e las cosas que 25 deuen ffazer los que sse quieren conffesar, diremos en ssiete maneras: la primera, en cómmo la conffessión non deue sser descubierta; la ssegunda, qué pena deuen auer los que la descubren;

I $E$ añade faziendo esto en el margen, olra mano; $T$ lo omise. - $2 T$ ffazer bien / $T$ deuen ffaran. $-3 T$ consseiarsse. -5 La otra (dos escrito $y$ tachado, $y$ otra añadido en el margen, otra mano). - $6 \mathrm{E}$ dubdar. -8 conplidamente lo que quiere f. o s. e por. -9 deue. - io la penitençia preg. 11 los que s. e la. - I I-12 $T$ consejo en a lo que (en añadido en el margen, otra mano). - I2 quisiere a / e non poder. - I $4 T$ entendmiento. - 15 pe-

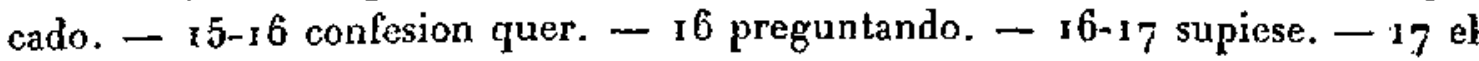
que lo sopiese de / $T$ añade entender sobre la línea, otra mano: - I 8 a quien el preg. / aquel quien se. - 20-21 conosçiese. -- 23 guardar to / dixieren [E 92r]. - 24 oyen. - 25 las penitencias e de. $-37-28 E$ omite la primera ... descubierta. - 28 penitençia / descubrieren. 
la terçera, para sser ssaluos los que sse conffiessan deuen auer en ella grant ffe ; la quarta, qué ffuerça han los ssacramentos quando con la ffe sson bueltos; la quinta, qué quiere dezir parrochia, et por qué rrazón puede demandar licençia el que sse quiere conffesar

5 a ssu conffesador para y rsse conffessar a otro; la ssesta, por quáles rrazones los parrochianos de vna eglesia sse pueden yr conffessar al clérigo de otra ssin liçençia; la ssetena, que todo cristiano sse deve conffessar cada anno.

La primera, de cómmo la conffessión non deue sser descubierta.

Io Descubierta non deue sser la conffessión en ninguna manera. Et en esto ay muchos males, ssennaladamiente dos entre todos los otros. Et el mayor es atreuersse omne a descubrir los peccados que dizen los omnes a Dios en poridat; et el otro, meterlos en uergüença de los omnes e ffazer que sse quieran mal. Et por ende

15 flué ordenado en Ssanta Eglesia que aquellos que las conffessiones oyeren, que las non descubran por ninguna manera; ca el que lo. ffiziere es traidor a Dios e desobediente a Ssanta Eglesia et aleuoso a ssu cristiano. E demás, es omizero; que mete malquerençia entre los omnes, onde nasçen muertes e otros grandes males, e dales 20 enxienplo de ffazer mal, metiéndolos en carrera por que rreçelen de conffesarsse, temiendo que mal les puede uenir por la conffessión más que bien, e ffázeles despreçiar la ley e encargarsse de peccados e ssobre todo perder el amor de Dios. Et por tal commo éste dixieron los santos padres que es tal commo ffalssario que 25 quebranta carta sseellada con sseello de Nuestro Ssennor o de amigo que ge la ouyesse dada, ffándosse en ssu ffiallat, o tomasse auer en guarda de algunos e que lo diesse a otros quel quissiesen mal, non lo ssabiendo aquel que ge lo diera; ca atal es la conffessión commo sseello de poridat que aguarda lo que es escripto en 3o la carta de dentro por que ninguno non lo pueda ssaber. Et aun más lo encaresçieron los ssantos padres, que dixieron que ssi mandasen a algún clérigo ssus mayorales en uertud de obedençia

I confesaren, - 4 quier. -5 al su. -7 otro. -9 de la c. commo omne desc. - ro E desc. ; Ca. - IO-I $\mathrm{T}$ Et ay. - I I sennaladamente entre. - $\mathrm{I}$ I $\mathrm{El}$ primero el $\mathrm{m}$. es averse o. descobrir. - 14 verguença e fazer. - I 7 faze. - I 8 omiziero ca. - 30 enxenplo para fazer. - 2 I teniendo que mas. - $22 \mathrm{mal} /$ fazerles. - 24 esto / es tanto. -26 fialdad. -27 guarda o que. $-27-28$ otro que el quisiese mal o non. -28 tal. -29 guarda / escripto [E 92v]. - 3o carta dentro / Avn. - 3 i le / $T$ ençerraron. - 32 mandasen aigunt. 
que dixiesse lo que ssopiesse de conffessión de alguno, que lo non descubriesse por premia quel ffriessen. Ante deue dezir toda vía que lo non ssabe e dirá uerdat; ca él non lo ssabe commo omne, mas commo Dios. Et ssi por auentura por tal rrazón le matassen, ssería mártir por ello et yria derechamiente a paraíso.

La ssegunda, qué pena deuen auer los que la descubren. Descubriendo algún conffesador algún peccado quel aya alguno dicho en conffessión, o por palabra o por sennal o por otra guisa, et esto es grant yerro en dos maneras: la vna, descobriendo lo que non deue descobrir ; la otra, metiendo en uergüença al que deue ro ssacar della, ssegunt dicho es en la ley ante de ésta. Et por ende estableçió Ssanta Eglesia que el que lo [63v] fliziese ffuese despuesto de la onrra e del offiçio que touyesse e quel ençerrassen en algún monesterio por toda ssu vida e que ffiziesse ffuerte penitençia, dándol mal a comer e mal a beuer e mal en que yoguiesse, r 5 de manera quel pesasse con la vida e que ouyesse plazer con la muerte. Et esta pena touyeron por bien de darle porque es piadosa e Ihesu Gristo, que es ffundamiento della, quiso morir auyendo piadat de nos. Mas ssegunt mereçimiento tenporal, pusieron los grandes ssennores que otra tal la rreçibiesse, ssegunt sse muestra 20 conplidamiente en el libro o ffabla de las penas tenporales, porque tanne en vna de las grandes ffalssedades que puedan sser; ca por descobrirle podria acaesçer al que ffuesse descubierto quel darían pena por ello en el cuerpo e en lo que ouyese.

La terçera, para sser ssaluos los que sse conffessaren deuen 25 auer en ella grant fre. Ffe es palabra que ssale de grant ffiança, et quiere tanto dezir commo ffiar omne en la cosa que tiene de todo en todo que es assí e que lo sserá. Et la ffe, quien bien la ha en ssí rraygada, ffázel beuir buena vida en este mundo e alegre, dándol çierta esperança que aurá después que muriere el bien del paraíso 30 que dura por ssienpre. Et demás, esffuérçalo para ssoffrir las ten-

2-3 descubriese deue d. que lo non s. toda via e dira v. que. - 4-5 Si por a. lo $m$. por ello por tal r. serie. -6 deue. -- 6-8 descubrieren e desc. el c: a. p. que aya d. alg. en su conf. - 8-9 guisa esto. - 9-1o que d. .encobrir. - I 3 feziese que fuese. - I4 para. - I4-15 que sufriese e feziese $f$. pena. - I 5 beuer e mala cama en que yuguiese (-a de mala añadida sobre la línea y lo mismo cama en el margen, ambos de otra mano). - 16 e ouicse. - 17 touo. - r 7-18 piadoso Ihesu. - I 8 fundamento. - a libro es fabla. - $22 T$ tannen / pueden. - 23 acacsçer que f. descobierto que el. $-37-38$ de que t. en t. es. -28 La fe. -- 29 este [E 93r]. - 3o de par. -3 I Demas esfuerçal. 
taçiones quel vienen por los ssabores deste mundo e por los penssamientos del diablo. Et ssin todo esto ffázele sser leal e de buen coraçón, que sson dos uertudes muy nobles e muy grandes a quien Dios las quiere dar, e es commo acabamiento de todo bien; ca lo 5 da buen conorte e buena esperança. Et la buena esperança ffaz bien. pasar el tienpo ssin rreçebir en ssu uoluntad grant cuyta e grant pesar. Et por ende dixo Nuestro Ssennor Ihesu Cristo a ssus disçiplos que ssi ouyessen en ssí ffirme ffe, ssiquier quanto vn grano. de xenabe, et mandassen a vn monte grande que sse mouyesse de ro vn logar a otro, que luego ssería ffecho. Et aun díxoles más, que ssi ellos bien abondados ffuessen de ffe, que toda cosa que demandasen a Dios ssu padre que ge lo daríe. Et por ende conuyene al que sse conffiesa que la aya en ssí muy ffirmemiente, creyendo. que por aquella cuyta que ha en ssu uoluntad del mal que ffizo e

15 por la uergüença que lieua en conffessando e rrepentirsse dello e por la emienda quel mandan ffazer, cunpliendo lo quel mandan, que de todo en todo sserá quito; ca el pesar e el rrepentimiento e la conffessión ssin la emienda non es nada, ssegunt Nuestro Ssennor Thesu Cristo dixo, que la ffe ssin obra muerta es. Esso mismo 20 dezimos del que oyesse la conffessión e del que da la penitençia; ca nol abonda en creer que sserá el otro ssaluo por conffessarsse ssi él non cree que por aquel ssu mandamiento lo sserá et que él ha poder de Nuestro Ssennor Ihesu Gristo para ffazerlo ssaluar. Et por ende quando desta guisa bien sse ayuntan las uoluntades. ${ }_{25} 5$ del que sse conffiessa e del otro que da la penitençia, luego es y la obra de la merçet de Dios, ssegunt él dixo: Doquier que dos o. tres ssean ayuntados en vno en mi nonbre, yo sso en medio dellos. Et [64r] esto nos mostró quando enbiaua ssus apóstoles a predigar, diziéndoles que en el ssu nonbre ssacarien los diablos, que sse 3o entiende en este logar de la conffessión por los peccados de la uoluntad; otrossí que ffablaríen lenguaies nueuos. Et bien es nueuo

I viene. - 3 a qui, $-4-5$ ca el da buen c. e da buena. -6 pensar / coyta nin grant. - 8 que asy lo ou. -9 genabe ( $\mathrm{x}$ - añadida sobre la línea, otra mano) / e si mand. a vn grant m. que. - i2 ge la. - 12-13 conviene que al que se le conf. - 15 confesandose. - i6 que faga conpliendo. - 17 pensar, - 18 nada (rolura en $T$, lección de $E$ ). - I8-I9 segunt dixo N. S. I. G. que. - ig $\mathrm{E}$ eso. - 20 que rresçibe la c. e de la pen. (las cuatro últimas palabras escritas sobre raspado). -23 -le -24 endo d. g. q. bien. -25 confiesa del o. quel da. - 26-27 Do que dos sean. - $27 T$ ayuntados en mi. - 30 entienden. - 3 r nuevos [E 93v] ca bien. 
- marauilloso lenguaie de auer vn onne a dezir a otro por ssu boca los peccados que fizo, creyendo que aquél que estaua en bes de Dios para dar la carrera de ganar perdón e de sser ssaluo. Et alli do les dixo que les daua poder de toller las sserpientes sse da a entender que, auyendo ffe en la conffessión, sse partirían los 5 peccados dellos que ellos ffiziessen, que sson commo sserpientes enpoçonadas. Et aun dixo que ssi algunos beuyessen poçonia, quél non enpeeçerie. Et el enlendimiento desto es que, auyendo omne crençia con ffe en estas cosas que sson dichas, ssi beuyesse tentaçión del mundo o del diablo, que es enpoçonnado, quel non ro terníe danno; ca sseyendo las uoluntades de aquel que sse conffiessa e la del otro quel da la penitençia ayuntadas en vna ffe, por ffuerça es y el perdón de Dios. Et commo quier que los omnes ffazen peccados e yerran de muchas maneras, mayor es la ssu merçet e la ssu piadat que quanto ellos pueden errar en penssa- $\mathbf{5}$ miento. Et por ende ningún peccador non deue desesperar de auer el ssu perdón e la ssu merçet; ca maguer el omne non aya poder de dezir ssus peccados por la boca nin los pueda mostrar en otra manera nin por escripto, doliéndosse en ssu uoluntad, connosçiéndose que erró e aujendo ffe e esperança en Dios quel aurá piadat 20 e merçet, ssi en aquella hora muriere, non puede sser perdido. Et por ende el que desespera cae en perdiçión por ssienpre. Et el que ha buena esperança ssáluasse. Onde tan bien el que da la penitençia commo el que la rreçibe deue creer que por el arrepentimiento e por la emienda quel mandan ffazer sserá ssaluo el que 25 sse conffiessa.

La quarta es qué ffuerça an los ssacramentos quando con la ffe sson bueltos. Bueltos sseyendo los ssacramentos con la ffe en vno, han muy grant ffuerça; ca pues cada vno la ha por ssí, quanto más la pueden auer quando sson ayuntados. Ca maguer los 30 ssacramentos sson muy ssanta cosa, ssi la ffe non han los que los rreçiben, non les tiene pro. Et por ende tan buena cosa es en ssí

I omne de dezir. -3 pecados fizo / $T$ que crey. / aquel est. / $T$ boz; $E$ bes (retocado sobre bos). - 3 carrera para ganar. - 4 alli o les d. adelante que daua / serpientas. -5 partiesen. -6 de los que los fez. -7 enponzonnadas / ponzonna. - 9 sy ouiese. - ro enponzonnado. - I I del que / $T$ aquel sse. -12 e del o. que da. -18 dezir los sus / $T$ nin pueda. -21 merçet e si en aquello mor. - 22 que se despera. -23 Ende. $-24-25$ rrepentimiento. -25 manda. -26 se le conf. $-28-29$ sejendo en vno los s. con la fee han. -- $29 T$ y $E$ lo. $-30-31$ maguer son $\operatorname{los}[E 94 r]$ s. muy. - 3 I que la. 
la ffe e tamanna ffuerça ha que, quando alguno acaesçe que viene a hora de muerte e non puede auer a quien sse conffiesse, auyendo dolor de ssus peccados e arrepintiéndosse en ssu uoluntad e affincándosse en la merçet de Dios, es ssaluo ssin dubda ningu5 na para non yr al inffierno. Otrossí quando alguno fluesse mudoe sse quissiesse maniffestar, o ouyese perdida la ffabla por enffermedat o por fferida, o que non ssopiesse el lenguaie o por otra manera qualquier, maguer que ouyesse clérigo o lego a quien sse conffessasse, pues que non lo puede confesar por ssí mismo, ssol Io que aya dolor en ssu coraçón porque [64v] peccó e muestra ssennales de arrepentimiento, assí commo alçando las manos a Dios e fferiéndosse en ssus pechos o emiendo o ssospirando - llorando o escriuiendo ssus peccados con ssu mano ante el conffessador, ssolamiente que aya ffe que sserá ssaluo por ella,

5 tiénel grant pro; que sse ssaluará, commo quier que aya alguna pena en el purgatorio por aquello que non pudo emendar. Por ende non deue perder ninguno de los ssacramentos nin de los otros bienes de Ssanta Eglesia que ge los non den tan bien commo ssi sse conffessase por palabra.

20 La quinta, qué quier dezir parrochia, e por qué rrazón puede demandar liçençia el que sse quiere conffessar a ssu conffessor para yrsse conffesar a otra parrochia. [Parrochia] tanto quiere dezir commo logar ssanto o mora el padre que ha de dar conseio spiritualmiente a las almas de los peccadores, así commo el ten25 poral lo ha naturalmiente para dar a ssus ffijos. Et por ende sson llamados parrochianos aquellos que moran cabe aquella eglesia en que oyen las horas e de que rreçiben los ssacramentos de la ley. Et algunos ha en Espanna que llaman a estos parrochianos ffiligreses. Et este nonbre es otrosí derecho; ca alanto quiere dezir 3o commo ffijos de la eglesia de que sson uezinos. Et por ellos la llaman ffilegresía, assí commo para los parrochianos es llamada parrochia. Onde estos que moran cabe estas eglesias non pueden yr

a qui. - 3 rrepentiendose. -4 fiandose. $-5-6 T$ mudo sse / e q. m. e que ov. $\rightarrow 7$ lenguaje e. $-8 T$ que non ou. $-9 T$ lo conffessasse o por. - I1 rrepentimiento. - I2 feriendo/gemiendo. - 14 confesor / ello. 16- 7 7 non vujo em. e por ende nol deuen ning. - r8 atan. - a $T$ sse conffessar / confesador. - 22 yr conf. - 23 santo en que mora. - 35 ha de dar n. a / Por ende. - 36 cabo la igl. -28 Espanna en que. - 28 -29 feligreses. - 29 Este / tanto. - 3o $T$ de egl. - 3r feligresia asy c. los / $T$ las parr. - 32 cabo destas. 
conffessarsse a clérigo de otra ssi non mostrassen rrazones derechas por que ge lo aya de otorgar, diziendo que ffallará meior conseio e mayor para ssu alma en el otro a quien sse quiere conffessar que en él, ssegunt los peccados que ffizo; ca ssi tal rrazón commo ésta o otra ssemeiante désta non mostrase, non es tenido 5 el clérigo de ge lo otorgar. Pero él mostrándogelo uerdaderamiente con humillat, ssi el clérigo dar non ge la quisiere la liçençia, puédesse querellar a ssu mayor, así commo al arçipreste o al arçidiano o en cabo al obispo de aquel obispado onde ffuese aquel clérigo. Mas ssi tanta ffuesse la maliçia de los mayorales que so auemos dicho que ge lo non quissiessen ffazer otorgar, e él entendiese uerdaderamiente que meior conseio ffallaríe en el otro clérigo a quien quiere yr conffessarsse, bien lo puede essa hora ffazer ssin otorgamiento de aquéllos; ca palabra es de Nuestro Ssennor Ihesu Cristo que los ffíssicos non conuyenen para melezi- 15 nar los ssanos, mas los enffermos. Et por ende el que es enffermo de peccado, quanto mejor ffíssico ouyere para darle conseio al alma, tanto más ayna puede guaresçer por ello. Onde non es bien que el omne dexe enuejeçer el peccado; ca bien assí commo la enffermedat pequenna podría ssanar ayna ssi tomasen a ella con- 20 seio, e ssi la alongasen, creçeríe el mal de guisa que uerníe el enffermo a muerte, otrossí el peccado que es pequenno, quando sse enduresçe que el peccador non sse conffiessa dél, creçe de guisa que de venial sse ffaze criminal o mortal. Assí cae por ende en muerte del alma por ssienpre. Pero ssi alguno demandasse licen- 25 çia maliçiosamiente o con enganno o auyendo uergüença $[65 r]$ de algún clérigo porque por auentura sse tornó en alguno de aquellos peccados de que auya ya tomado penitençia dél o por malquerençia que ouyesse contra él, non le auyendo mereçido el clérigo por qué, o despreçiándolo, teniendo que non auya poder de assol- $3 o$ uerle; por qualquier destas rrazones ssi demanda liçençia, maguer

I otro. - 2-3 deziendol que f. mayor a m. c. para. -3 quiere [E 94v] yr conf. -5 della. - 7-8 clerigo non ge lo quiere dar la l. p. del quer. $-8 T$ commo a arç. -9 arçediano e en c. al arçobispo o al obispo, -9 -10 fuese el cler. - Io $T$ tanto / de aquellos may. - I3 querie yr confesar. - I4 dellos. - 15 Cristo que dixo que / conviene. - 16 mas a los. - 17 mejor (rolura en $T$, lección de $E$ ). - 20 tomasen ayna cons. $-{ }_{2} 3$ non se manifiesta. - 25.26 demandase la $1 . \mathrm{m}$. e con eng. au. - a7 aquel cler. $-27_{-28}$ en algunt pecado de aq. de que a. tom. - 29-3o meresçido por, - 30 teniendol. - 3o-3 I asoluer. - 3r y sig. maguer ge. 
que ge la otorgue el clérigo, flaze enganno a ssí mismo e ua yrado de Dios de manera que al que da la liçençia non tiene dauno nin assí pro, e muéstrase por ffalsso e por atreuido en que por ffazer escarnio a Dios, en cuyo poder es e tiene el cuerpo e el alma e a

5 quien non puede mentir nin asconder ninguna cosa de ssu ffecho, e busca ssu danno en $\tan$ mala manera que por aquella carrera que deue ganar ssaluaçión gana ssu conffondimiento.

La ssesta, por quáles rrazones los parrochianos de vna eglesia sse podríen yr conffessar al clérigo de otra ssin licençia. Liçençia

Io tanto quiere dezir commo otorgamiento dado ordenadamiente ssobre cosas ssennaladas. Onde ordenó Ssanta Eglesia que ninguno non ffiziese ninguna cosa en ffecho de alma para dexar ssu parrochia e yrsse conffessar a otro a menos de dar liçençia el ssuyo. Pero cosas podrían acaesçer por que podría yr a otro ssin 15 mandárgelo. Et esto sseríe ssi aquellos que sse quieren conffessar ffuesse mugier con qui el penitençiador ouyesse ffecho peccado o touyesse uoluntad de lo ffazer; o ssi ffuesse uarón quel ouyesse acaesçido de peccar con la barragana daquel clérigo o con alguna ssu parienta o ouyese muerto o fferido o desonrrado o ffecho al20 guna desonrra a algún ssu pariente çercano, de quien entendiesse que el clérigo rreçibriesse grant desonrra o pesar ssi lo sopiesse; ca por qualquier de las rrazones ssobredichas bien puede yr conffessarsse a clérigo de otra eglesia. Et ssi alguno dexasse su parrochia e ffuese morar a otra ; ca estonçe bien podíe yr maniffestarsse 25 ssin otorgamiento de ninguno al clérigo de aquella a que ua. Otrossí quando alguno ua de vna tierra a otra, non sseyendo vezino de algún logar, puédesse conffessar a qualquier clérigo que aya poder de dar penitençia e de oyr conffessiones. Otrossí tal acaesçerie que quando andudiese por tierra o por mar, bus-

I $T$ otorge. - I-2 mesmo yerra de man. - Dios c. p. tiene. - 5 qui. - 6 buscase danno. -8 por que las r. los perr. [E 95r]. - 9 pueden. - I 2 feziese cosa / del alma. - 13 menos del dar 1. primeramente el. - 14 cosas acaesçerien que podrien yr. - 15 demandargela / quisiesen yr conf. - 16 con que. - 17 touiese en $\gamma$. de lo f. otrosy si / que el. - I8-i9 o con su. - r9-20 alguna grant des. - 20-3 I pariente al que tanxiese mucho çerca de que e. que rresçebie el c. grant. - a $T$ rreçibriesse pesar. -22 e por. $-23 \mathrm{~T}$ a otra / Si alg. -24 fue / puede. $-24-25 \mathrm{~T}$ maniffestarsse a otra ssin. $-25 T$ clerigo que. -26 alguno andase de. -27 qual c. quier. $-29 T$ acaesçie. 
cando a olro logar ado morasse, o ffuese en rromería o en mercadería o en otras rrazones ssemeiantes déstas ; ca esto bien lo puede ffazer con derecho, porque mientra andasse non auría otro parrochiano a qui sse conffesasse ssinon a aquel de aquella tierra o ffuesse omne que sse assessegasse de morada. Et esso mismo 5 sseríe de aquel que ffuesse parrochial de alguna eglesia e ffiziesse peccado en otra ; ca éste bien sse puede conffessar, ssi quișiere, al otro clérigo de la otra parrochia o peccara. Onde por todas estas rrazones non aurie por qué demandar liçençia a ssu parrochiano ssi non quissiesse.

La vii ${ }^{z}$, que todo cristiano se deue confesar cada anno. Cada anno sse deue conffessar todo cristiano de ssus peccados quando sse ssintiere culpado dellos, en manera que los non dexe rraigar en ssí, mas que los eche de la uoluntat e de la palabra e de la obra; ca non es derecho que el que es uassallo de Ihesu Cristo 15 traya a ssus cuestas la carga del diablo, que es [65v] ssu enemigo. Et por ende ffué estableçido en Ssanta Eglesia que sse conffiesse tres uezes en el anno por las tres pascuas; a lo menos vna uez, ssi más non pudiere, et esto por la quaresma, et ssennaladamiente ante de pasqua. $\mathbf{E}$ qualquier que essto non ffiziere, ssegunt ssobre- 20 dicho es, ordenó Ssanta Eglesia que lo echassen della assí que non oyese las horas con los otros ffieles; et ssi muriere, que nol entierren entre los otros cristianos. Et por que ninguno non se pueda escusar que non aya esta pena, diziendo que lo non ssopo, ffué estableçido que ge lo ffiziessen ssaber ssus parrochianos en las 25 quatro ténporas del anno e en los días del abiento e de la quaresma, que sson días ssennalados para esto ssegunt el tienpo más que otros. Pero el que bien ffiziere non deue tardar de sse conffessar, mas déuelo ffazer lo más ayna que pudiere, ssegunt Nuestro Ssennor Ihesu Cristo dixo, que ninguno non ssabia el día nin $3 o$

I-2 lugar o $m$. o $f$. en pegrinaje o en $r$. o en otras. $-2 T$ pueden. $3 T$ porque and. / andasen non avrien. - 4 a quien se c. s. aquel. - 5 o fuesen o en que sosegasen / Esto. - 6 perrochial de una igl. e feziesen. 7 podrie / quisiese. -8 al c. de otra / do (d- añadida sobre la línea, otra mano). - ro quisiesen. - I I T omite La ... anno. - I2 de [E 950]: - I3 sentiere. - $15 T$ derecho el que; $E$ derecho que el que (el que añadido en el margen, otra mano). - I6 trayga. - I7 $T$ conffiesson. - 18 pascuas o a (o añadido sobre la línea, otra mano). - 20 de la pascua / feziese, - 21 quel ech. - 22-23 moriese que non lo enterrasen. - 26-27 quaresma major por que. - 28 Para / tardarse de conf. - 3o $T$ non le ssabia / sabe. 
el hora que él le llamaría. Et aun él mismo dixo en otro logar que ssegunt el omne fallasse, que assi lo judgaría. Onde ha mester quel ffalle de guisa quel judgue con los que ffueren a la diestra parte, que non con los que ffueren a la ssiniestra.

5 [LEx GII]. - De cómmo sse muestra quál penitençia es ssolenpne e quál pública e quál priuada.

Porque el ssacramento de la penitençia es muy ssanto e muy prouechoso a aquellos quel rreçiben con uerdadera ffe, ssegunt ordenamiento de Ssanta Eglesia, conuyene dezir los departimienro tos e las maneras que ha en ella e las palabras que deuen dar los conffessadores a los que sse conffiessan. E esto por ssiete rrazones: la primera, quántas maneras sson de penitençia; la ssegunda, en qué manera sse deue dar la que llaman ssolenpne e por quáles peccados; la terçera, quál es la que llaman en latín I5 pública e en qué manera deue sser dada; la quarta, qué es a la que llaman en latín priuada e cómmo deue sser ffecha; la quinta, en qué manera deuen abssoluer los conffessadores a los que sse les conffiessan, sseyendo ssanos ; la ssesta, cómmo deuen sser abssueltos los que están enffermos o los que están en periglo de muerte; 2o la ssetena, de las ssolturas en quántas maneras las ffaze Ssanta Eglesia.

La primera, quántas maneras sson de penitençia. La penitençia es partida en tres maneras, ssegunt lo mostraron los ssantos padres que ordenaron ffecho de Santa Eglesia. Et la primera 25 llamaron ssolenpne, que quiere dezir tanto commo onrrada; et la ssegunda, pública, que sse entiende por pública; la terçera, priuada, que muestra tanto que deue sser ffecha secretamente. Et cada vna déstas ffué ordenada por grant ssemeiança. Ca la primera, de la ssolenpnidat, es para castigar a omne crúamiente en tres 3o guisas los muy ffeos peccados que ffizo: primeramiente, es quel

1 la ora que le llamara. - 2 le. - 3 menester que en tal mancra lo fable quel judgue. $-4 \mathrm{ca},-5-6 \mathrm{De}$ c. se m. la pen. qual es s. o qual es priuada o qual es publica. -7 sacramento penitençial (-1 añadida en el margen, olra mano). -8 que lo. - Io ella e en las. - I I Esto. - I3 deuen. - 15 qual es, - I6 ser [E 96r]. - I -18 se conf. - I9 los enf. / estan a peligro. - 93 la. $-24 \mathrm{E}$ a la. $-25-26$ honrrada a la seg. - $26 T$ ssegunda por p. que. $-27 T$ ffecha et. $-3 o$ que lo. 
rreprehendan e le maltrayan de palabra por el mal que ha ffecho; la ssegunda, quel metan en uergüença ante muchos por que ayan de ssaber en quáles yerros cayó ; la terçera, quel den pena tal que aquellos que la vieren o la oyeren escarmienten por ella. Et la otra, que llaman pública, dió otrossí la Eglesia por muy grant 5 escarmiento; ca maguera nol porffazen al que erró commo en la ssolenpne, por esso esle grant uergüença porque sse ffaze conçeieramientre ante todos, e demás quel dan pena por ello. El en la terçera, que sse ffaze conffessando vno a otro, e que non lo deue ssaber ssinon amos, pero non deue sser pública, ssegunt de ssuso ro es dicho. Onde estas tres maneras fallaron de la penitençia e non más.

La $i^{a}$, en qué manera se deue dar la que se llama solepne e por quáles pecados. Solepnidad tanto quiere dezir en latín commo ayuntamiento a que se llegan los omnes commo a fiesta o a otra $\mathbf{1 5}$ honrra que rresçibe el lugar en que se deue fazer o algunt omne sennalado que la faze a la cosa que conviene sobre que se faga. E porque estas tres acaesçen en la penitençia primeramente que de suso es dicho, llamanla solepne porque el perlado mayor la ha de fazer. Otrosy deue ser fecha a la puerta de la iglesia e ante todos, 20 sobre pecados grandes e malos. La manera en que deue fazer ésta. [E 96v] Que el primero miércoles de la quaresma mayor han de venir aquellos que se quieren confesar a la puerta de la iglesia, descalços e véstidos pannos de lana viles e rrefezes, e han de traher las caras abaxadas contra la tierra muy homilldosamente, demos- 25 trándose por culpados de los pecados que fezieron, auiendo vergüença dellos; otrosy mostrando que han grant voluntad de fazer todo lo que les mandaren por penitençia. $\mathrm{E}$ deuen y estar sus arçiprestes e sus clérigos onde son perrochianos, que oyeron sus confesiones. E después desto deue sallir el obispo a la puerta 3o de la iglesia con sus clérigos a rresçebirlos, rrezando los salmos penitençiales, e tomarlos por las manos e meterlos dentro en la iglesia. E deue el obispo echarse a preçes ante el altar, rrogando a Dios que los perdone. $\mathbf{E}$ en quanto él esto feziere, sienpre ellos

1 rreprehenden e lo maltraen/ quel. $-3 T$ y $E$ aya. -3 atal. -4 e $i$ ello. $-5 T$ priuada / publica e dio / $T$ Eglesia muy / por grant. - 6 non lo porfazian (profaçan añadido en el margen, otra mano). - 7 eso grant v. es porque. $-7-8$ consejeramente. $-8 \mathrm{den}$ - 9 confesandose. -9 -1o e que se non d. fazer sin escarmiento pero. - i I Despaés de tres comienza la lercera laguna en $T$, suplida por $E$. 
deuen yazer tendidos en tierra, llorando e rrogando a Dios que non cate a sus pecados, que son muchos e grandes, mas a la grant merçet que es en él para perdonar a los culpados e oyr a los que rruegan con homilldad. E desque los psalmos fueren rreçados,

5 déuese leuantar el obispo e poner la mano sobre las cabeças dellos. E después que ge las tirare, hales de poner en ellas çeniza e echar agua bendicta sobre ellos; e desy cobrirlos en su çeliçio, que es panno de estamenna, deziendo estas palabras, llorando con sospiros, que asy commo fué Adam echado de parayso, conviene

ro que ellos asy sean echados de la iglesia por los pecados que fexieron. E estonçe deue el obispo mandar a los ostiarios, que son porteros de la iglesia, que los echen della. $\mathbf{E}$ en echándolos, deuen yr los clérigos en pos ellos, cantando vn rresponso que dize ansy, que en suor de su cara e en lazerio de su cuerpo cobran

r 5 su pan. E éstos han de morar a la puerta de la iglesia en cauannuelas. E en el día santo jueues de la çena deuen venir de cabo los arciprestes e los clérigos que oyeron las confesiones dellos a presentarlos otra ves a la puerta de la iglesia e desy meterlos dentro. E han de estar en la iglesia a todas las [E 97\%] horas fasta el do20 mingo de las ochauas, mas non deuen comulgar nin tomar pas en aquellos dias con los otros nin de entrar en la iglesia después fasta la otra quaresma. E esto han a fazer cada anno fasta que ayan acabada su penitençia, segunt las quarentenas que les dieren. $\mathrm{E}$ quando onieren acabada su penitencia, déuelos el obispo rreconçi-

25 liar a la puerta de la iglesia, dándoles con vna correa, estando ellos desnudos, e rrezando los clérigos el salmo de Miserere mey, Deus sobre ellos. E desque lo ouieren acabado, déuelos el obispo asoluer e meter en la iglesia dentro e amonestarlos que fagan de allí adelante vida de buenos cristianos. E tal penitençia commo ésta non 3o la deuen dar más de vna ves, porque aquel que della non escarmienta, bien se da a entender que non ama a Dios nin prescia nada su alma para quererla saluar. E el que esto feziere, si fuere lego, deue el obispo e los clérigos que son dichos mostrarlo a las justiçias seglares de aquel lugar do acaesçiere, que ge lo deuen

35 escarmentar sin muerte e syn lisión del cuerpo. E el que tal penitençia commo ésta non quisiere fazer, sy fuere clérigo que aya hórdenes sacras, non ge la deuen dar por honrra del sacramento dellos, fueras sil desgradasen primeramente, tolliéndogelas, e de 
allí adelante non dene ser clérigo otra vez, mas con los malos legos. Sy fuere lego, non pueda rresçebir hórdenes nin ser cauallero nin deue casar nin vestir pannos de color. Pero si se casase o fuese casado, non se podríe por esto partir el casamiento; ca pues que Dios los ayuntó por sy mesmo, non puede otro desfazerle 5 sinon sobre aquellas cosas sennaladas que [sc] muestran adelante allí o fabla de los casamientos.

La iii^, quál es la que llaman pública en latín e en qué manera deue ser dada. Pública es dicha la penitençia que se deue fazer concejeramente, segunt dicho es en la ley ante désta. ıo E la manera en commo deue ser fecha es yendo en rromería luenne de su tierra; o andando desnuyos en pannos menores, e non trayendo sobre sy otra cosa vestida nin cubierta ; [o] que aduga palo codal, que se entiende por de codo en luengo, o açote con que se fiera con qualquiera destos que traxiere en cada iglesia que 15 [E 97v] entre, teniendo los ynoios fincados, deziendo el salmo de Miserere mey, Deus e otra oración qual les mandaren ; o trayendo fierro çinto al cuerpo o al derredor de la garganta o en los braços o en alguna vestidura áspera a carona de la carne; o faziéndolos estar encerrados en algunt monesterio o en otro lugar apartado, 20 dándoles mal a comer e a beuer por tienpo sennalado o en toda su vida, segunt los pecados que ouiere fechos. $E$ este ençerramiento déuengelo fazer concejeramente ante todos por que rresçiban grant vergüença de las gentes por aquellos yerros que fezieron. $\mathrm{E}$ ésta es la $\mathrm{ii}^{\mathrm{a}}$ manera que fezieron de las tres que de suso son di- 25 chas. E porque se faze conçejeramente [ante] el pueblo, llámanla pública.

La [iiii ${ }^{\Re}$ qué] es a la que llaman en latín priuada e cómmo deue ser fecha. Priuada llaman a la penitençia que se faze entre el que se confiesa sus pecados e el que asuelue dellos e ha el poder 30 para mandar quál penitençia faga, segunt los yerros que ha fechos. E ésta se deue fazer comunalmente, tan bien omnes commo mugeres, lo más ayna que podieren, segunt su estado o cl hordenamiento de su vida o las cosas que les acaesçiesen o demientre que les podríe acaescer; ca sy el que es enfermo naturalmente en 35 la carne non deue atender sazón para guaresçer de su enfermedad, mas tomar conseio lo más ayna que podiere por que pueda beuir

6 que le. - 13 cubierta a que. - I4 codal (cobdal añadido en el margen, otra mano) / codo (cobdo añadido en el margen, otra mano). $-28 \mathrm{La}^{\mathrm{iij}}{ }^{\mathrm{a}}$ es. 
en este mundo sano e alegre, quanto más esto el que es enfermo de pecados en el alma, para poder ayna sanar dellos e ser çierto que por la penitençia que fizo, sy la bien toviere, que averá la vida perdurable en que nunca ya más non podrá enfermar nin

5 morir. E por el apartamiento que ha de ser fecho en poridad del que se confiesa e del que da la [penitençial, en que non ha destar otro ninguno synon ellos amos a dos, llaman a esta penitençia priuada.

La quinta, en qué manera deuen asoluer los confesadores a Io los que [se] les confiesan, seyendo sanos. Absuelto non puede ser ninguno de sus pecados a menos de se confesar dellos, asy commo es ya de suso dicho. [ $E 98 \mathrm{r}$ ] E sy fuer sano, déuel asoluer aquel a qui se confiesa desta manera. Primeramente, mándel fazer la confesión, deziéndol cómmo se confiese a Dios e a Santa Maria

15 e a todos los santos. E a el su hermano manifiesta todos los sus pecados que él fizo por soberuia, pensando, fablando, obrando en todos los viçios malos de la carne, e deziendo a Dios su culpa; e por ende que rruega a la bienauenturada virgen Sanla María e a todos los santos, e aquel que es su hermano que rruegue a 20 Dios por el que es pecador, a Nuestro Sennor porque él es pecador quel perdone. $\mathrm{E}$ entonçe dénel asoluer de sus pecados, deziéndole que por el rruego de Santa María e de todos los santos quel aya merçet Dios, que es poderoso sobre todas las cosas, e que él siendo perdonado dellos, lo aduga con los sus santos a la vida 25 perdurable. $E$ entonçe déuel mandar el confesador que todo lo que touo de lo ageno commo non deuíe, que lo torne a sus duennos sy los podiere auer; e sy non, que lo dé en las cruzadas que fueren fechas contra los henemigos de la Fe o en otro lugar que paresca que entre pro de la Iglesia o en obspitales o en algunas otras cosas 30 que sean de caridad o de limosna.

$\mathrm{La}\left[\mathrm{vi}^{\mathrm{a}}\right]$, cómmo deuen ser asueltos los enfermos o los que están en peligro de muerte. Presurados seyendo algunos de enfermedad o de muerte o de otro peligro en que se viesen por que, auiendo miedo de sus almas, touiesen que se auien a penitençiar, conviene 35 que sean acorridos; ca asy commo los físicos son tenudos de acorrer con melezinas para saluar los cuerpos, así los que han de pensar del alma deuen ser apercebidos e venir a corrimiento a los

I esto lleva un ligero rasgo oblicuo de otra mana, quizá con intención de tacharlo. - 6 la confesion. -3 I vii ${ }^{\mathrm{a}}$. -32 muerte o pres. 
pecadores para saluarlos de pecados con misericordia de conortes e de perdones. E por ende establesçió Santa Iglesia que quando alguno fuese afincado de grant enfermedad que estudiese en peligro de muerte êl clérigo que veniese a él non fuese tan entendido para dar luego conplidamente conseio a su alma, sil viese estar en peli- 5 gro de muerte, dénel asoluer después quel ouiere confesado de sus pecados, deziéndol que por el lugar que tiene de Sant Pedro e de San Pablo, a quien diera Nuestro Sennor Ihesu Cristo poder de asoluer e ligar, que él le asuelue todos los pecados que fizo e dixo, de guisa que sy moriere $[E 98 v]$ de aquel peligro e de aque- ro lla enfermedad, que non valla por ellos al infierno; e quel otorga que las misas e las oraciones e las limosnas e los otros bienes quel mandasen fazer a otre, feziese por ellos que sean asoluimiento de su alma. Mas con todo eso déuel mandar que sy de aquel mal guaresçiere, que luego vaya tomar penitençia de sus pecados 15 del mismo quel ha confesado o de otro, para auer conseio conplidamente para su alma.

La vii ${ }^{2}$, de las solturas en quántas maneras las fazen en Santa Iglesia. Muchas vezes enbargan los pecados al omne mientra está en ellos de guisa que non puede fazer buena vida nin aver amor de 20 Dios. E por ende Santa Iglesia, que es llena de piedad, cató muchas carreras por que fuesen suel tos destos atamientos, e éstos son en dos maneras: la vna, por aquello que mandan fazer los que rresçiben las confesiones a los que se les confiesan; las [otras] son dadas por los perlados mayores syn confesar[se]le los omnes. E esto 25 quando dan sus cartas en que rruegan e consejan a los omnes que fagan ayudas para fazer cruzadas para los henemigos de la Fe para sacar captiuos, o para lauor de las iglesias o para consagrarlas, o para ospitales o para puentes o para otros bienes [que] sean para obra de piedad e de merçet. Ca las solturas que ellos fazen, per- 30 donando los pecados que los omnes han fecho de que tomaron penitençia, contándolos por dias o por annos, deziendo que Jos perdonan por aquellas ayudas que dicho auemos, sy les fezieren tal soltura commo ésta, faze pro para menguarlos aquellas penas que averíen eu purgatorio por aquel tienpo que non ouiesen en este $\mathbf{3 5}$ mundo conplido la penitençia que les mandaron. Pero estos perdones que diximos non valdríen sinon a los de su obispado; fueras ende sy algún obispo de olro lugar lo feziese por rruego del perla-

24 confiesan las quales son. - $\mathbf{2 5}$-lele. -29 bienes de sean. 
do de aquel obispado do aquellos bienes se oviesen a fazer, sobre que aquellos perdones se diesen. Mas los perlados mayores, así commo patriarchas o primados o arçobispos, bien las pueden dar sobre los otros obispados de sus prouinçias. Mas generalmente no

5 las [puede] fazer otrie $[E 99 r]$ synon el papa, nin perdón otrosy non puede dar otro perlado ninguno synon de quarenta días. Pero quando consagran alguna iglesia, puédenlo dar de anno, e esto es quando están muchos obispos en vno. Mas el papa ha poder de darlos quanto tienpo quisiere, por cuenta de días o de annos.

ro $\mathbf{E}$ estos perdones todos tal pro han en [sy] e [asy] valen commo los otorgan aquellos mesmos que los dan; ca en qualquier manera que ome faga emicnda de sus pecados, segunt le mandare Santa Iglesia, es quito e suelto dellos. Ca bien así commo Santa Iglesia liga por poder de Nuestro Sennor Ihesu Cristo a los que meresçen por 15 qué, otrosy les suelta por meresçimientos quando fazen emienda.

[Lex CIII]. - De cómmo se amortiguan los bienes que omne faz por el pecado mortal e cómmo se abiuan por la penitençia.

Perdonando los pecados a los que han fecho yerros por que deuen aver perdón, segun de suso es dicho, tiénelos muy grant pro.

20 E esto es en siete maneras : la $i^{\natural}$, qué pro [viene] a los omnes de los perdones que les dan los perlados; la ii ${ }^{a}$, a qué aprouechan los bienes que los omues fazen, estando en pecado mortal; la $\mathrm{iii}^{\mathrm{a}}$, cómmo los bienes se amortiguan por el pecado mortal e abíuanse después que fazen penitençia; la iiii $^{\mathrm{a}}$, en quántas maneras fazen.

25 bien los biuos que tenga pro a las almas de los muertos; la $\mathbf{v}^{\mathrm{a}}$, quáles cosas fazen los omnes que fazen danno a los muertos e non a ellos pro; la vi $i^{a}$, cómmo non deuen fazer las grandes sepulturas. çerca de los altares; la viï, qué prendas faze Santa Iglesia a los. que fazen duelos desaguisados por los muertos.

3o La $\mathrm{i}^{2}$, qué pro viene a los omnes de los perdones que les dan los. perlados. Primeramente, que les fazen de sus pecados arrepentir e manifestar pues que saben que serán perdonados. E desy, fảzelos. partir dellos e fazer emienda a Dios por el mal que fezieron, e adúzelos a auer su amor. E demás, fázelos auer buena vida en este. 35 mundo, non temiendo enfermedad nin peligro de muerte. E syn

$4 E$ añade no sobre la línea, otra mano. - $10 \mathrm{en}$ su c sy valen. - 20 licne. -21 apiouccha. -25 de los o muertos. 


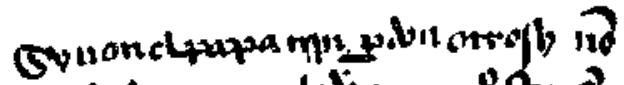

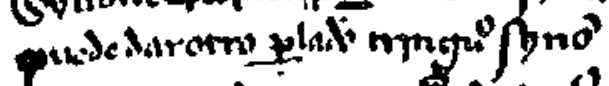

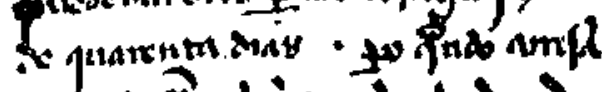

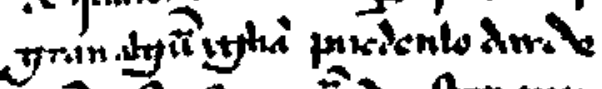
anc of foes ồn . fan min tos abos thune mas dip

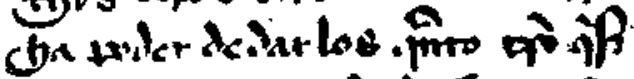

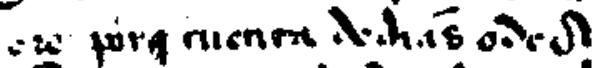
nos Nafhis plotie rotos anl

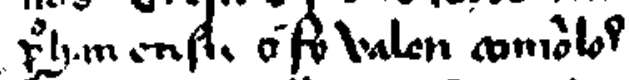
otongan aniudlos mop Phos ilos

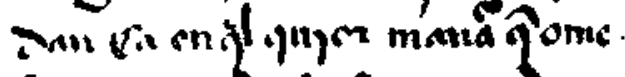

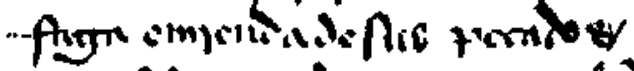

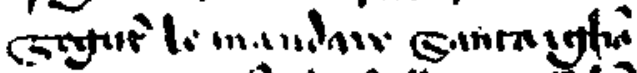

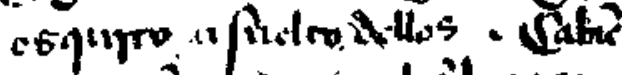
a

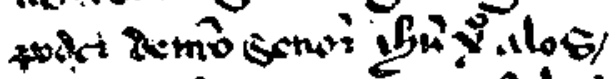

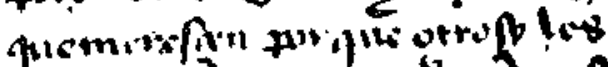

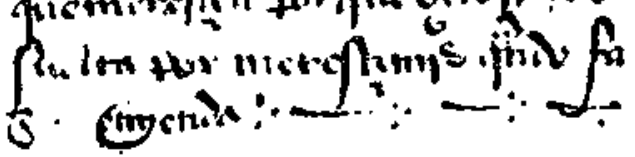
25 contro fe anotugnialos.

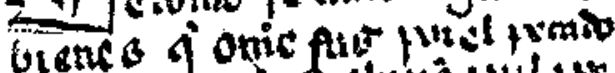

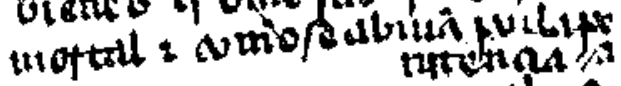
endnaniolos +'cribsd los qualun fage yayo forguctelis halier oygut.jugespug on

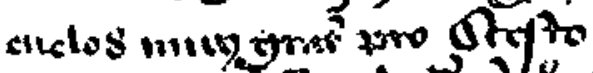

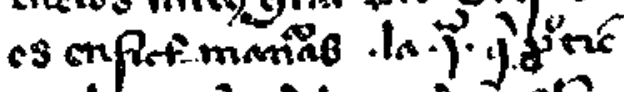

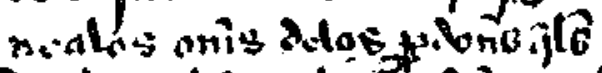

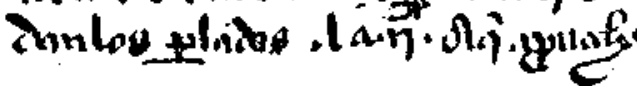

losbien's gitid.s onis fintu y mine anerwo matril lain

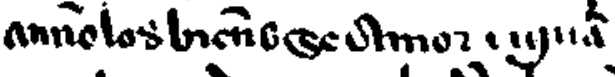

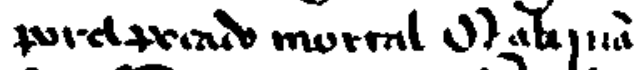

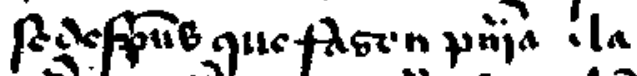

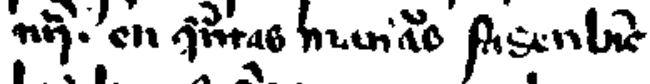
hus bues grongn wro slay/ almub ados amuntus .la. li.

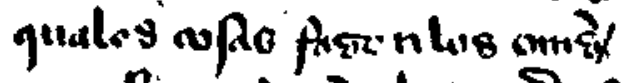
que fisendina ulos wientue otrour adlos ino clativo monondmic factirlagerrurge

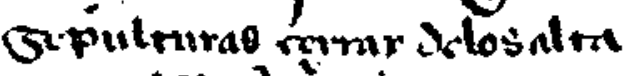
we laby. juc jomentho fis

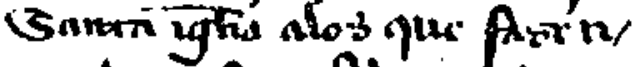

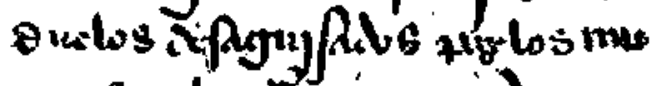
errob la íg que :"vobicte alos anz dostabris qudes Sanlos slabio - pmameto

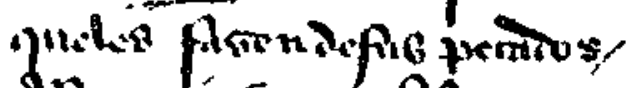
Sppontio e inanfeftar alies Awe palen que Aran polmons indep fistos zon-ictloy figer cmpinte asios quid ol

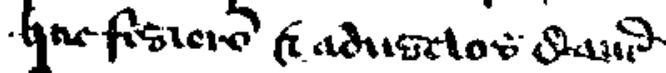

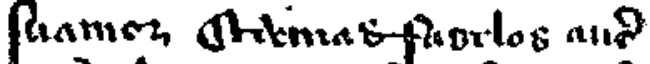

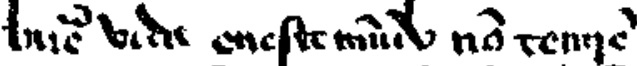

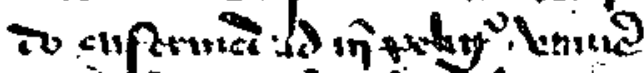

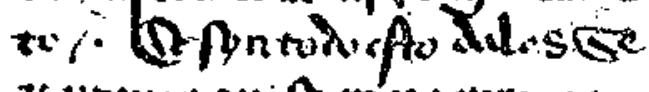

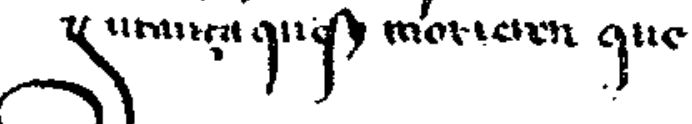




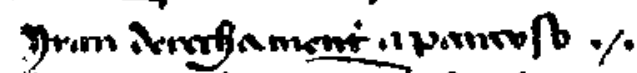

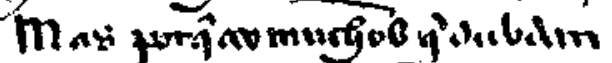

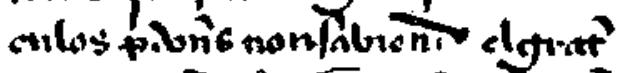

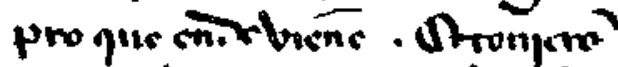

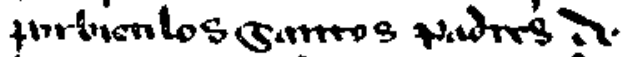
Lo moprar - Naluenen is ahe qutos janos nus wenffrm

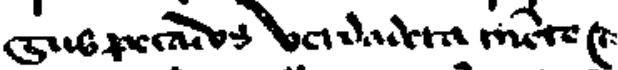

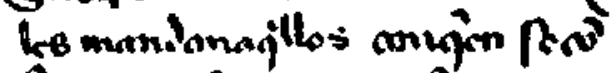
fer An enj mancru fignn cm

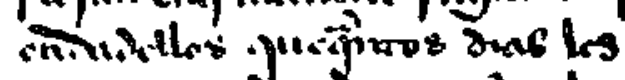

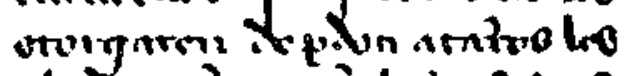

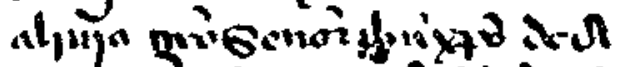

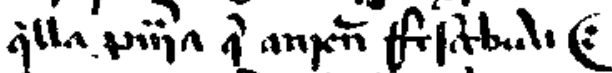

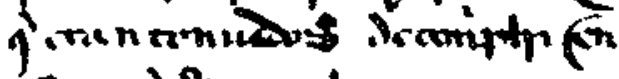
of mis oend mo enzer yotoric Nto fa smeendet

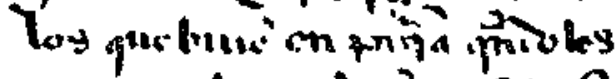
oryan las tulud Nuap

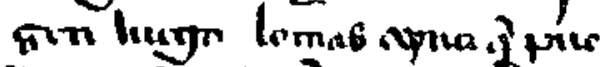
in - Natens quilos Gino corgent eque ran orami

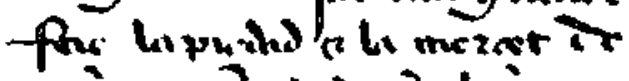

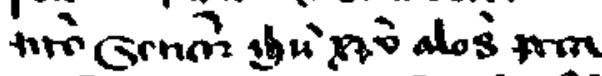

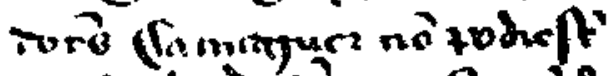
smiti havinga chefemis

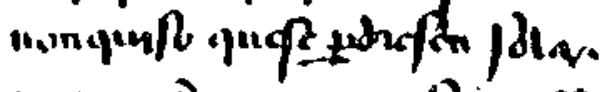
meres inom moreppientr. mino muzorl. Ofranmami falve oiro Nos pilurar.jplo

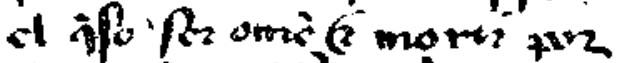

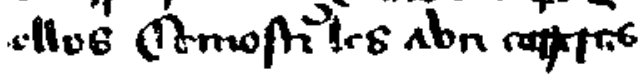

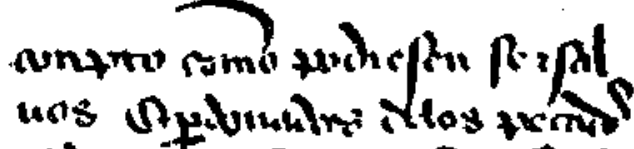

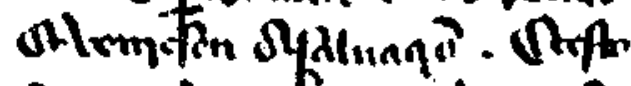
pacucsinure que dixys

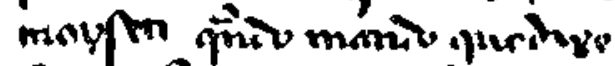
Rish frmon gu: $\beta$ tenk ol

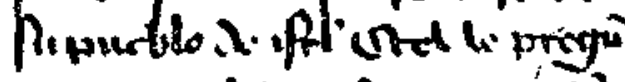
roqu qualdws 3 pro gity te

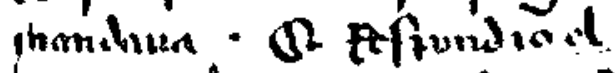

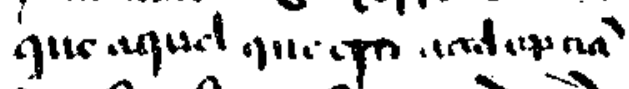

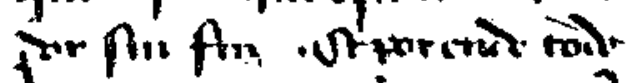
Amisule sitrondz que mo

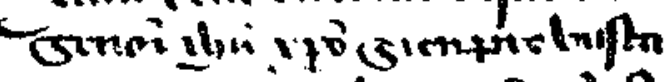
covemi piotot promond $\Omega$ Uiw sion fo pontlose no prea

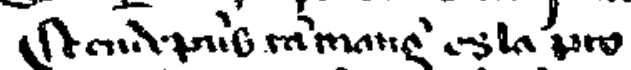
jurne infos pions a fectemé

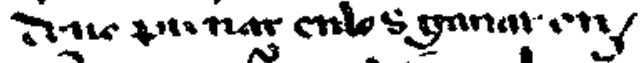

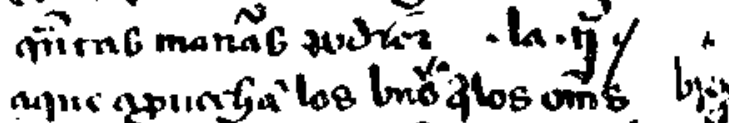

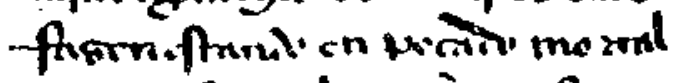

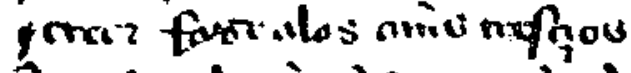

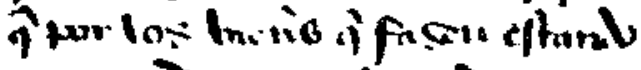

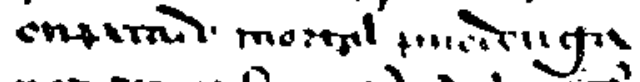

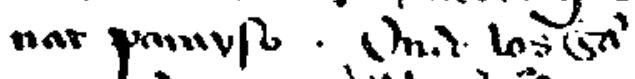

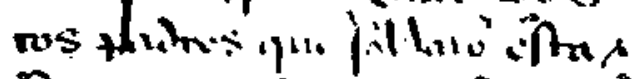
Finom mofnuvind iurfe"

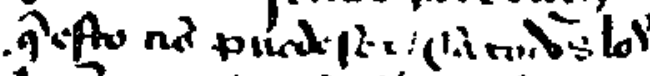
bicho yuid oin? fignj his wh

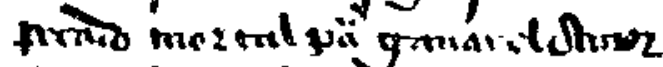

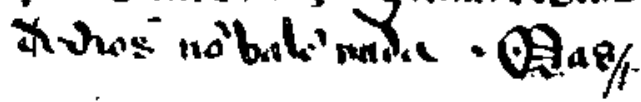


todo esto dales segurança que sy moriereu, que $[E 99 v]$ yrán derechamente a parayso. Mas porque ay muchos que dubdan en los perdones, non sabiendo el grant pro que ende viene, e touieron por bien los santos padres de lo mostrar. E dixeron que cada que los cristianos confesan sus pecados verdaderamente e les mandan $\mathbf{5}$ aquellos con quien se confiesan en qué manera fagan emienda dellos, que quantos días les otorgaren de perdón, atantos les aliuia Nuestro Sennor Ihesu Cristo de aquella penitençia que auíen rresçebida e que eran tenudos de conplir en este mundo o en el otro en purgatorio. Esto se entiende de los que biuen en penitençia ıo quando les otorgan los perdones, e la fazen luego lo más ayna que pueden, e después que los han otorgado; que tan grande fué la piedad e la merçet de Nuestro Sennor Ihesu Gristo a los pecadores. Ca maguer non podiesen conplir las penitençias en este mundo, non quiso que se perdiesen, solamente que non moriesen en pecado 15 mortal. E tanmanna sabor ouo de los saluar que súlo él quiso ser omne e morir por ellos e mostrarles avn carreras con pro commo podiesen ser saluos e perdonados de los pecados e veniesen a saluaçión. E esto se acuerda con lo que él dixo a Moysén quando mandó que dixesen a Faraón que soltase el su pueblo de Isrrael, e él le 20 preguntó que quál dios dirie que ge lo mandaua, e rrespondió él que aquel que era acalonpnador sin fin. E por ende todo cristiano deue entender que Nuestro Sennor Ihesu Ćristo sienpre busca carreras por o los pecadores ayan perdón sy por ellos non finca. $E$ [por:] ende, pues tanmanna es la pro que viene destos perdones, 25 que todo omne deue punar en los ganar en quantas maneras podier.

La $\mathrm{ii}^{\mathrm{a}}$, a qué aprouechan los bienes que los omnes fazen, estando en pecado morlal. Porque algunos fazen creer a los omnes nesçios que por los bienes que fazen, estando en pecado mortal, pueden ganar parayso, onde los santos padres que fablaron en esta rrazón mos- 30 traron por derecho que esto non puede ser; ca todos los bienes que el omne faga, estando en pecado mortal, para ganar el amor de Dios non valen nada, mas [E $100 r]$ han enteramente la su sanna. Pero commo quier que non tiene pro para auer la su graçia, váleles quanto les faze Dios merçet en darles más de los bienes del 35 mundo e menguarles otrosy de las penas tenporales e en ayudarlos para salir más ayna de los pecados en que están, por que mues-

$5 E$ escribe y tacha nos delante de confesan. - $28 E$ escribe y tacha laze dispaés de crecr, $y$ añade Porque algunos fazen en el margen, otra mano. 
tren que aquel bien que fazen es entrada para llegar âuer merçet a Dios, partiéndose del mal, e carrera para yr a saluaçión. E demás, faziendo bien, acostúnbranse en fazer buena vida. Mas en quanto para auer perdón de Dios e ganar su amor por que vaya a parayso,

5 non les vale ninguna cosa que faga de limosna nin de merçet, estando en pecado mortal.

La terçera, cómmo los bienes se amortiguan por el pecado mortal e abíuanse después que faze penitençia. E amortiguados son los bienes que los omnes fazen, estando en pecado mortal, segunt de Io suso es dicho en la ley ante désta. Pero sy algunos oviesen fechos alimosnas [o] otros bienes, non estando en este pecado sobredicho, e después cayesen [en] ellos, perderíen la fuerça de aquellos bienes que fezieron. E amortíguanse mientra en él estudieren, mas después que fezieren penitençia dél, así commo él rresucitaríe del pe-

I 5 cado que ouiese fecho, así abiuar[íe] en los bienes que feziera ante que pecase. E por ende se deuen esforçar todos los cristianos quanto más podieren de non estar en pecado mortal, pues que los bienes que entonçe fazen non les ayudan a ganar el amor de Dios por que entren en su rregno quando morieren. E olrosy deuen punar 20 quanto podieren para fazer quel bien que fezieren que les vala e vaya toda vía esforçándose e cresçiendo en ello para ganar conplidamente el amor de Dios.

La iiii ${ }^{a}$, en quántas maneras fazen bien los biuos que tenga pro a las almas de los muertos. E descreençia dizen muy grande los 25 que cuydán mostrar por rrazón que los bienes que fazen por las almas de los muertos, que les non tiene pro. Onde, por que non entiendan que es asy, muestra por vn enxenplo que dió Nuestro Sennor lhesu Gristo a sus dicípulos e a los judíos quando $[E 100 \mathrm{v}]$ les fizo departimiento entre vn muy rrico [e] otro muy pobre que

30 morieron amos en vno; el pobre fué a parayso porque feziera buena vida e el rrico al infierno porque la feziera mala. El rrico que estaua en aquellas penas viera al pobre estar en parayso con Abraham e rrogól mucho humilldosamente que mandase aquel pobre que metiese el su dedo pequenno en el agua e le echase vna

35 gota della en la boca por que non sufriese tamanno tormento commo sufríe. E dixo Abraham en boz de Dios que aquello non podrie ser; ca él avie auido mucho bien en este mundo e aquel

It alimosnas a otros. -18 ayuda, -23 tengan. -29 o. -37 avrie auido (auido añadido en el margen, otra mano). 
otro mucha lazeria, e agora que lazdrase él e el otro folgase. E rrogól otrosy después que rrogase a Dios por él que[1] dexase tornar otra vez al mundo por que dixese a sus hermanos e a sus amigos que non feziesen cosas por que veniesen a yr âquel tormento. E Abraham le rrespondió que non podría ser; ca por eso enbiara 5 Dios a Moysén e a los otros profectas a los pueblos, por que les mostrasen lo que auien de fazer, faziendo lo que les terníe pro. E otrosy Judas Machabeo, que era muy buen cauallero de armas, quando venció vna batalla, e de aquello que ganó tomó muy grant pieça de aver e mandólo ofresçer en Iherusalem por las almas de 10 los muertos que y morieran de su parte, mostrando que non podríe ser que los que bien fezieran en este mundo que non ouiesen por ello y buen galardón en el otro, o que los sacaríe de pena o les aliuiarie grant parte della. E que por otra cosa non lo feziesen, si lo deuíen fazer, porque creyen que rresuçitarien. E pues auien de 15 rresuçitar, que non les dene doler quequier que podiesen fazer de bien por ellos ; ca non podríe ser que grant bien non les touiese. E los bienes que a ellos pro tienen son en quatro maneras. La primera es en dezir misas, en que se faze el sacrificio de Nuestro Sennor thesu Cristo, que es la más noble cosa que puede ser fecha 20 nin que aya mayor virtud para saluamiento de los cuerpos e de las almas. La $\mathrm{ii}^{\mathrm{a}}$, las oraçiones que por ellos son fechas, en que rruegan a Dios que les aya merçet e a los santos que ge Jo rrueguen. La iiia es las limosnas que dan a los pobres o en otros lugares que conviene, segunt entienden que terná pro a las $[E 101 r]$ almas de 25 los finados. La quarta es los ayunos que ayunan por ellos sus parientes o sus amigos o otros qualesquier que los fagan. Ca por estas quatro cosas que los omnes fazen, por ellos les faze Dios quatro merçedes: la primera, que abaxa su sanna contra ellos; la iia, que aliuia a los que yazen en infierno de las penas que han; la iii $^{2}$, 30 que saca de purgatorio más ayna a los que y yazen porque non podieron conplir en su vida la penitençia que les dieron; la $\mathrm{iii}^{\mathrm{a}}$, que los mete en parayso, do son seguros de nunca aver pena nin coyta.

La quinta, quáles cosas fazen los omnes que tienen danno a los muertos e non a ellos pro. Danno tiene a las almas de los muertos 35 e non tiene pro a los biuos algunas cosas que fazen por ellos; que son sobejanas además, así commo faziendo grandes duelos syn rrazón, desfaziéndose o mesándose los cabellos o las baruas o rron-

29 abaxa (amansa añadido en el margen, otra mano). 
piéndose las caras, o feriéndose con alguna cosa, o dexándose caher en tierra muy de rreçio por que ouiesen de enfermar por ello o morir o fincar lisiados. E esto les faze dos dannos : el vno, sy lo fazen con verdad, pierden las almas en querer que la figura

5 que Dios fizo e a quien dió vida, desfigurarla ellos por sy e adozirla a muerte ; la otra, que sy lo fazen con mentira, tiene danno a los cuerpos. Ca se muestra que non es así commo lo ellos quieren fazer entender. E por ende non faze pro a los muertos e tiene danno a los biuos. E demás, es cosa que tomaron los gentiles que Io creyen que quando el omne moríe, que todo moríe, tan bien el cuerpo commo el alma. E por esta desesperança cayen en cuydado que ninguno non rresucitaríe nin se saluariê despreçiauan las almas. E non se querien rrepentir nin fazer penitençia de sus pecados, mas fazíen duelos desaguisados por los que moríen commo 5 omnes desperados dellos, $\tan$ bien de las almas commo de los cuerpos. Nuestro Sennor [Dios], queriendo sacar a los omnes destos pecados, defendió en la vieja ley que dió a Moysén, en que mostró que auie parayso para los que feziesen bien e infierno para dar pena a los malos, que rresuçitaríen todos en el día del juyzio.

20 E por esto vedó que estos $[E 101 v]$ duelos non los feziesen en manera que las otras gentes vsauan de lo fazer nin desfeziesen la figura del omne apuesta que él feziera. E después desto quando vino Nuestro Sennor Ihesu Gristo, que tolló del mundo los yerros e las çeguedades en que los omnes beuien, e defendió otrosy en la ley 25 nueva que non feziesen duelo por los muertos, e esto quando rresuçitó el fijo de la biuda; que dixo que non llorasen por él. $\mathbf{E}$ otrosy quando rresucitó la fija del prínçipe de la sinagoga ; que mandó que echasen de la casa do yazíe la muerta todos los que fazíen duelo por ella, e non la quiso ante rresucitar. E por esto $3 o$ nos dió a entender que nol plazíe los duelos; que non se aprouechauan dello las almas de los muertos. Mas los bienes que fazíen por ellos tienen pro a los biuos e a los otros eso mesmo. E [esto] establesçieron los santos padres, que hordenaron muchos bienes en Santa Iglesia ; ca vedaron mucho afirmadamente que non feziesen

35 dueio por ellos porque auíen ende muy grant danno syn pro. E por esto dixo el apóstol Sant Pablo que non se entristeçiesen por los muertos que finauan, commo fazíen las otras gentes que non auíen creencia nin esperança de rresuçitar; ca los que muríen

16 Sennor lhesu Gristo quex. 
non se perdíen, segunt la $\mathrm{Fe}$ católica, mas son atales commo los que pasan de vn lugar a otro, e los que fazen bien van a parayso e todos los otros van a pena de purgatorio o de infierno.

La vi ${ }^{\star}$, cómmo [non] deuen fazer las grandes sepulturas çerca de los altares. Sepulturas grandes nin pintadas non touieron por 5 derecho los santos padres que feziesen en las iglesias por rrazón que non tenien pro ninguna a las almas. $E$ demás, que algunas dellas alçan tanto que semejan altares más que monimentos. E otro tal de los que cubren las fuesas con manteles e porien y pan e vino e otras viandas para dar a los pobres; ca maguer lo fazen por rra- io zón de alimosnas, esto non tiene pro a las almas de los muertos porque non es fecho commo deve. Ca por derecho ante los pobres que han de comer deve ser puesto, que non sobre las fuesas. [E 102r] E por ende el rrey Dauid traxo mal a vnos que comieran de tal sacrifiçio commo éste, partiéndose de la ley de Dios e tomándose i5 a creer en el ydolo de Velfagor. E con todo lo que auien fecho, dixo que se fezieran enaziados, dexando a Dios, creyendo en el ydolo e comiendo el sacrificio de los muertos. Onde los que alimosna quieren fazer que tenga pro a las almas de Jos muertos, conviene que le fagan de guisa que plega a Dios e a ellos aproue- 20 che e paresca biell al mundo; ca la otra que asy non es fecha non tiene pro a los muertos nin a los biuos.

La vii ${ }^{a}$, qué prendas faze Santa Iglesia a los que fazen duelos desaguisados por los muertos. Prenda e pena, commo quier que sea vna cosa, dos entendimientos han; ca la prenda es para llegar 25 a omne auer conplimiento de derecho de la cosa que demanda, e la pena es para escarmentar el mal que otra ves non sea fecho. Onde Santa Iglesia non touo por bien de dar pena a los que feziesen duelos desaguisados por los muertos, mas commo en rrazón de prenda defendió que non los diesen los clérigos los sacramentos 30 de Santa Iglesia nin los rresçebiesen en ella quando dixiesen las oras fasta que fuesen sanos de las sennales que ouieseu fechas en sus caras e feziesen penitençia dello, fueras ende sy ge la ouiesen a dar en grant enfermedad o en otra coyta que estudiesen en ora de muerte; ca tal sazón non los deuen vedar a ningunt cristiano. 35 E otrosy mandaron que quando los clérigos aduxiesen la crux a la casa do estudiese el muerto e oyesen que fiziesen rruydo, dando bozes o endechando, que se tornasen de la casa. Otrosy esto esla-

t9 quiere. $-3 \overline{7}$ oyese que fiziese. 
blesçieron, que quando touiesen el muerto en la iglesia, que non diesen bozes nin feziesen rroydo por que dexasen de dezir la misa; ca todos deuen alli callar e rrogar a Dios e escuchar las oras e las oraciones que dizen. Esto es porque ninguno non deue enbargar

5 el ofiçio de Dios, e mayormente quando dizen la misa o consagran el cuerpo de Nuestro Sennor Ihesu [Gristo]; ca tan noble e tan honrrada cosa es ésta que todas las otras cosas deuen dexar por ella. E el que contra esto feziese, mandaron que le echasen de la iglesia sin calonna ninguna, quier fuese clérigo o lego. E sy leua-

ro sen el muerto a la fuesa, o lo feziesen, que los clérigos lo dexasen de soterrarle fasta que callasen. $E$ avn touieron por bien que qualquier que vesase el muerto o se echasen con [E 102v] él en el lecho, que ayunasen ocho días en pan e en agua e quel non rresçebiesen en la iglesia por vn mes. E defendieron otrosy que a los muertos i5 que los non touiesen en la iglesia las caras descubiertas. E esto por que los omnes, en catando, non se mouiesen âuer piedad de guisa por que ouiesen a fazer grant duelo por ellos. Ca todas estas cosas establesçieron los santos padres, catando y rrazón spiritual e natural, por que los omnes por cada vna dellas deuíen destas 20 sobejamías dexár. Pero el que quisiere fazer duelo fágalo en dos maneras: la vna, dentro en su coraçón, llorando naturalmente aquel que perdió de muerte, e mayormente si sabe quel alcançó en mal estado; e otra, llaniendo los pecados que él mesmo fizo, rrepentiéndose dellos, sabiendo que non puede foyr de la muerte. [LEY GIV]. - Del quarlo sacramento, que es la comunión.

Comunión es el quarto sacramento de los siete que son nonbrados que todo cristiano deue rresçebir por fuerça de ley, podiéndolo auer; ca maguer sea lauado por bautismo e confirmado por la confirmación e alinpiado en la voluntad por penitençia, sy el cuerpo

3o de Nuestro Sennor Ihesu Gristo non rresçibe, non deue ser llamado conplido cristiano. Ca este sacramento es sobre todos los otros porque por él les viene la consagraçión que han; por allegar a éste fueron los otros hordenados e establesçidos. Onde, pues que del bateo e de la confirmaçión es dicho, conviene por derecha rra35 zón que se diga deste que es más honrrado que todos; ca bien 
commo el sol es en medio de las otras siete planetas e alunbra tan bien las tres que están de suso commo las otras tres que están de yuso, asy este sacramento alunbra los tres que son ya dichos, asy commo el bautismo e la confirmaçión e la penitençia, e Jos otros, que son la estrema vnçión e la horden e el casamiento, de que se 5 dirá adelante de cada vno en su lugar. E por ende conviene agora que se diga de estas siete rrazones : la primera, qué cosa es comunión e por qué asy ha nonbre; la iiّa, quién la establesció ; la iii $^{a}$, de qué cosas se faze; la iiii ${ }^{\mathrm{a}}$, en qué manera deue ser fecha; la $\mathrm{v}^{\mathrm{a}}$, quién la $[E 103 r]$ puede fazer; la vi ${ }^{a}$, a qué tiene pro; [la víi $\left.{ }^{a}\right]$, 10 cómmo deue ser honrrado e guardado.

La primera, qué cosa es en sy [e] por qué ansy ha nonbre. Sacrifiçio es en sy, la más noble cosa que puede ser, que muestra tanto commo mostrar cosa sagrada a Dios, de que rresçiben sacramento todas las otras cosas. E esto se proeua por la vieja ley; que y 5 quanto más linpiamente faze sacrifiçio a Dios, tanto más le plaze con él e faze de mejor grado lo que rruega, tan bien en perdonarles los pecados commo fazerles otras merçedes muchas quel piden. Onde sy esto faze Dios Padre por los de las animalias biuas e por pan e vino e por los otros frutos de la tierra, con que entonçe sa- 20 crificaua, quanto más lo faze agora e es tenudo de lo fazer por el cuerpo de Nuestro Sennor Ihesu Cristo su fijo, en quél dennó por la su grant e marauillosa humildad e merçet que nos faze que fuese fecha por nos sacar de poder del diablo e adozirnos al su rregno. E por ende este sacramento es tan conplido en sy commo aquel 25 que ha tres noblezas, las mayores que ser pueden e que otro sacrificio non ay nin puede auer: la primera, porque es fecho el cuerpo de Nuestro Sennor Ihesu Cristo Dios verdadero; la ii ${ }^{\star}$, que mostró que los sacrifiçios eran fechos por toller cada vno su pecado, e éste para tollerlos todos; la iii ${ }^{\star}$, porque éste sacrifiçio es 30 que se da a entender que Nuestro Sennor Dios non nos oluida nin se parte de nos synon quando viene por nuestra grant culpa. Ga ante es comunal a todos los que los rresçiben, de manera que non los puede ninguno rresçebir más que otro nin menos por poder nin por rriqueza nin honrra que aya, nin por bien nin por mal 35 que faga. E por ende es dicho comunión, que quiere tanto dezir. commo cosa en que han muchos parte comunalmente. Ca quanto en el rresçebimiento, aquel que lo rresçibe non lo puede rresçebir 
synon todo enteramente, commo quier que algunos lo rresçiban non tan conplidamente commo deuíen; nin ha pro de sy, ante se les torna en grant danno, scgunt adelante será mostrado allí o conviene fablar desta rrazón.

5 [La] segunda, [quién la establesçió]. Que la establesçió Nuestro Sennor, verdadero Dios Padre e omne, quando quiso rresçebir muerte para saluar a nos. Establesçió este sacrifiçio por sy mesmo el $[E 103 v]$ jueues de la çena quando comie con sus dicípulos, e tomó el pan e el vino en las manos e díxoles: Éste es el mi cuerpo, ro que vos será traydo a la muerte; $[66 \mathrm{r}]$ et esto ffazet en mi rremenbrança. Et por ende lo ffaz Ssanta Eglesia e lo deue ffazer ssienpre commo aquella cosa que es estableçimiento de Dios. Et aun ssin estas palabras que dixo aquel dia, auyales ya dicho otras en esta rrazón: Yo sso el pan biuo que desçendí del çielo, e qui comiere I5 deste pan biurá por ssienpre; et el pan que yo daré es mi carne por vida del mundo; et non sserá esto commo uuestros padres, que comieron la magna en el desierto e murieron, mas este pan que uos yo do es cutiano por ssienpre iamás. Onde por esta rrazón ordenaron los ssantos padres que sse ffiziese cadal día el ssacriffiçio

20 de Nuestro Ssennor Ihesu Cristo en la eglesia e en horas ssennaladas del día, que sson éstas: la hora de prima; la hora de terçia; la hora de ssesta; la hora de nona. Et esto ffizieron por muy derechas rrazones, ssegunt sse dirá do ffabla de las horas del día.

La terçera, de qué cosas sse ffaze. Consagrar el cuerpo de Nuestro 25 Ssennor Thesu Cristo, ssegunt estableçimiento de Ssanta Eglesia, non deue sser ffecho a menos de auer y estas tres cosas : pan; e vino; e agua. Et cada vna déstas es y puesta por grandes ssignifficanças. Primeramiente, el pan por tres rrazones. La primera, por el nonbre dél ; ca ssegunt palabra griega, tanto quiere dezir en 30 nuestro lenguaie commo todo. Et por ende ffazen dello la hostia, que muestra que por ella rreçibimos cunplimiento de todo bien para ffazer buena vida en este mundo e ganar amor de Dios. La ssegunda rrazón es porque el ffructo que lieva la tierra e que más

10 En muerte termina la tercera laguna en $T$. - 11 e lo faze sienpre. - 13 que el d. en aquel / otra. - I4 quien, - 15 beuira. - 16 mundo non. 17-18 este que. - 18 cutidiano. - Ig cada. - 21-22 estas a la ora de $p$. $e$ de t. e de vin e de nona. - 24 cosa. - 26 y tres. - 27 Cada /. T conpuesta. - 3o fazen de la. - 3 I muestra por ella rresçebimos conplimiento. - 33 que la t. l. que mas / $T$ añade o que sabre la línea. 
abonda para la vida del omne es el pan. Et a ssemejança desto ffué Santa María, en qui llouieron las nuues, que sse entiende por Dios Padre e el ssu Ssanto Spíritu que rreçibió en ssí, onde sse engendró el ssu ffijo Nuestro Ssennor Ihesu Cristo, Nuestro Ssaluador. Et ssegunt dixo Ysayas propheta: Rroçíen los çielos de ssuso, e 5 las nuues Ilueuan justo; et ábrasse la tierra-que sse entiende por la voluntad de Ssanta María - e engendre el Ssaluador - que es Ihesu Cristo. La terçera, porque el pan, ante que uenga a sser ffecho conplidamiente, pasa por más trabaios que otro ffructo que ssea; ca el non puede nasçer nin ffrutiguar ssi ante non muere. 1o Et esto sse entiende por el grano del pan que es ya nasçido. A menos de morir otra vez sso tierra quando sse ssenbra, non puede nascer nin dar mucho ffructo, ssegunt dixo Nuestro Ssennor Ihesu Cristo, que ssi el grano del trigo, después que cae en tierra, non muriesse, ffincarsse ya ssolo; mas desque ffuere muerto, leuará 15 mucho ffructo. Et aun desque es naçido, ffuéllanlo los omnes e cómenlo Jas bestias e las aues cada que pueden. Et esto auyno en Nuestro Ssennor Ihesu Cristo; ca tres maneras de omnes sse ayuntaron a matarle. La vna, el pueblo, quel ffollaron entre los pies, pidiéndole a Pilato que ge le diesse para matar, el que non mere- 20 çíe nada por qué, e que ssoltasse a Barrabás, ladrón que por ssus malos ffechos que fliziera meresçie muerte. Et aun le ffollaron más, que dizien que la ssangre, que era la cosa más preçiada dél, tornauan ssobre ssí e ssobre ssus filjos en manera de despreçiamiento. La ssegunda manera de omnes, que ffueron de judíos, quel acusa- 25 uan que muriesse, non queriendo entender que lo ffazie por Dios, mas que lo ffazíe por encantamiento. Et [66v] este entendimiento ouyeron más de bestias que de omnes. La terçera manera de omnes ffueron los rromanos, que vinieron de luenne en manera de águilas que buelan e diéronle a los judios quel pidieron para matar. 30

$x$ abonda a vida. $-3 T$ en $\bar{q}$ la vieron; $E$ en quel llou. - 4-5 Cristo segunt. -6 lleuauan. -7 e entre el. $-8 T$ quarla (escrilo sobre raspado); $E$ iii $^{\mathrm{a}},-8-9$ vengan asy fecho. - 9-10 iruto que pueda ser ca. - Io muere [E.104r]. - I I por que el g. que es nasc. -- I a sienlbra. - 13-14 segunt 1. C. mesmo d. que sy, -14 de trigo. -15 moriere f. s. mas de que. -16 despues que. - 19 que. -20 -lo / ge lo. - so-2r al que non m. por. 2 I $T$ ssoltassen. $-2 t-23$ sus $f$. m. que. $-23-24 E$ tornanan (tornase añadido en el margen, olra mano). - 34 desmenospreçiamiento. - $25-26$ omne que $f$. los $j$. que lo acusaron por que mor. $-26-27$ lo que $f$. por Dios non lo f. synon por entend. $-28 \mathrm{iiii}^{\mathrm{a}},-30$ - lo / que lo pedieron. 
Onde destas tres guisas bien ouo Nuestro Ssennor Ihesu Cristo ssemeiança al pan. Et aun le ssemeió en al, que quando el pan es ya maduro, ssiéganlo. Et assí ffué flecho de lhesu Cristo; que quando él era en estado de omne cunplido, entonçe le aduxieron a

5 la muerte. Et ante quel matassen, lo trillaron e lo quebrantaron con desondras e con fferidas e de todas las maneras que ge las pudieron ffazer. Et el meior pan de todos es el trigo, e por esso ffazen la hostia dél. Et éste deue sser amasado tan ssolamiente con agua ssin leuadura e ssin otro mezclamiento ninguno, assí commo él

10 ffué ffecho linpiamiente en Ssanta María por Spíritu Ssantossin mezclamiento de omne carnal.

La otra manera con que sse ffaze el ssacrifficio es el vino, a ssemeiança de la ssangre de Nuestro Ssennor Ihesu Cristo; ca assí commo ha él en ssí propiedat de conortar la calentura natural e de

. 5 abiuar los spíritus, assí la ssangre de Nuestro Ssennor Ihesu Cristo abiua la calentura spiritual, que es el amor de Dios e del Spíritu Santo con los omnes et otrossí de los vnos con los otros, auyendo paz en este mundo e buena vida, et en el otro después de la muerte alegría en paraíso. Et por ende del pan e del vino ordenó Santa

20 Eglesia que sse ffiziesse el ssacriffçio, ssegund dixo Dauid el propheta en el Ssalterio: Por que adugas el pan de la tierra, e el vino alegra el coraçón del omne.

La terçera cosa con que deuen ssacrifficar es el agua ; ca ésta obra en el pan e en el vino, tolliendo al pan la ssequedat que ha,

25 ffaziendo que lo puedan comer e ssepa bien, et el vino, tolliéndol la ffortaleza que ha quel puedan beuer. Et esto es en ssemeiança del Spíritu Ssanto, que ha en ssí dos cosas, linpiedunbre e ffriura, con que alinpia los peccados de los omnes e los esffría las uoluntades que non los ffagan. Et amanssa la dureza de la ssanna de Dios

3o Padre que sse dexa rregar, que es assí commo la ssequedat de la ffarina quando non ay agua; et la ffortaleza del Ffijo de las de-

1 estas. - I-2 ouo sem. N. S. I, C. al pan. - a ca. -34 fecho Nuestro Sennor I. C. quando era. - 4-5 conplido e. lo aduxeron a muerte. 5 que lo. -6 deshonrras. -8 Este. - to fecho en S. M. 1. por el Spir. I $E$ omite carnal. - $12 T$ otra (escrito sobre raspado); $E \mathrm{ii}^{\star} / T$ es el vno a. - 14 commo el ha en sy naturalmente p. de notar. - 15 abiuar [E 104v]. 27-18 auiendo en este $m$. pas e b. v. con el, - 20 dixo el. - 22 alegre e el (e añadido sabre la línea). - $23 T$ terçera con. $-24 T$ tolliendoles la s. que han. - $25 T$ los / $T$ ssepan / bien el $v$. tolliendo. - $26 T$ ffortaleza quel / que lo. -27 forura. - 28 que el alinpie / e les enfrie. - 3o rrogar. - 3 t agua la. 
mandas que ha contra nos por los yerros que ffazemos, assí que el que nos ha de judgar e dar pena por ello nos dexasse por el amor que el Spíritu Ssanto mete entre nos e el comer la ssu carne e el beuer la ssu ssangre. Et aun ay otra ssignifficança por que meten el agua en el vino. Et esto es porque Nuestro Ssennor Ihesu Cristo 5 quando estaua en la cruz, apareçieron en él tres maneras de muy grant martirio: la primera, que la ssu [carne] ffué fferida e rronpida de muchas maneras; la ssegunda, que la ssu ssangre flué esparzida por muchas partes; la terçera, porque ssalió el agua con ella de conssoúuo mesturada que non ffincara en él humidat nin- 10 guna. Et por ende deuen boluer el agua con el vino, e non ffazer ssacriffiçio con el vno dellos ssin el otro. Et aun ssin todas éstas ay otra ssignifficança; ca el vino ssigniffica la ssangre de Nuestro Ssennor Ihesu Cristo, ssegunt de ssuso es dicho, et el agua el pueblo de los cristianos. E quando los ayuntan en vno, entiéndesse que i 5 sse ayunta el pueblo de los ffieles cristianos a Ihesu Cristo, cuyos sson.

La quarta, en $[67 \%]$ qué manera deue sser ffecho. Sagrar sson oraçiones que ordenaron los ssantos padres que dixiesse el preste cada que ouyesse de conssagrar el cuerpo de Nuestro Ssennor Ihesu 20 Cristo. Et ha en ella ssiete cosas. La primera, que luego en el comienço rruega el preste a Dios Padre quel plega aquel ssacriffiçio que él ha de ffazer e lo quiera rreçebir piadosamente, e rruega otrossi a Ssanta Eglesia e a todos los ssantos quel ayuden a esto, e comiença assí: Pues a ti, muy piadoso Padre, nos homillosos 25 rrogamos e pedimos que ayas plazenteros estos dones e estos sseruiçios e estos muy ssantos ssacriffiçios; primeramiente los quales offreçemos a ti por la tu ssanta eglesia cathólica; et que quieras apaziguar e guardar e ayuntar e gouernar en todo el çerco de las tierras, en vno con tu ssieruo nuestro papa $\mathrm{N}^{\circ}$, et nuestro obispo 30 $\mathrm{N}^{\circ}$, e nuestro rrey $\mathrm{N}^{\circ}$, e con todos los cristianos que guardan la Ffe catholical e apostoligal. Sennor, rremiénbrate de todos los tus ssieruos e de todas las tus ssieruas, e de todos los que están en de-

3 ello dexasemos. - 3-4 $T$ nos e le comen la ssu c. e le beuen. - 4 ain otra. - 5-6 porque q. N. Senor I. C. est. $-7 T$ y $E$ ssangre. -10 de so vno mostrando que non $f$. con el. - 11 aboluer. - 18 Sagrar. es. - 20 oviese [E 105́r] a cons. -23 e el deuē rresç. $-23-24 T$ rreçebir otr. $-35 T$ comienço / Pues han muy. - 28 ofrescimos / dennes (retocado sobre deues, otra mano). - 30 su. - 3o-3i obispo e n. rrey e con t. c. que guarden. 3. catolica e apostolical. 
rredor, de los que es la ffe connosçida a ti e maniffiesta la deuoçión; por los quales nos offreçemos, e offrecen a ti este ssacriffiçio de loor por ssí e por todos los ssuyos, e por rredençión de ssus almas, e por esperança de ssalut e de ssu ssanidat; . e ffazen ssus oraçiones 5 a ti, Dios viuo e uerdadero ssin ffin.

La segunda, cómmo se ffaze el pan carne: Sennor, nos ffaziendo comunión, e onrrada la rremenbrança, primeramiente de la gloriosa e ssienpre virgen Ssanta María, madre de Dios; et otrossí de los bienauenturados apóstoles e tus mártires, Ssant Pedro,

10 Ssant Paulo, Ssant Andrés, Ssant Yago, Sant Iohán, Sant Thomás, Sant Yago, Sant Philip, Sant Bartolomé, Sant Mathé, Sant Ssimón, Sant Thadeo, Sant Lino, Sant Cleto, Sant Clemente, Sant Ssisto, Sant Cornelo, e Sant Çibrián, Sant Llorente, e Sant Viçente, Sant Grisógono, Sant Iohán, et Sant Paulo, Sant Cosme,

I5 et Sant Damián, e todos los tus santos; por cuyos mereçimientos e rruegos te pedimos merçet que otorgues que sseamos guerreados del tu deffendimiento e de la tu ayuda. Por aquel mismo Nuestro Ssennor Ihesu Cristo. Amén. Sennor, pedímoste merçet que rreçibas con plazer esta offrenda de nuestro sseruiçio e de toda tu

20 conpanna; et que ordenes en la tu paz los nuestros días, e nos libres del dannamiento gue dura ssin ffin, et mandes que sseamos con todos los tus escogidos. Por Ihesu Cristo Nuestro Ssennor. La qual offrenda tú, Dios Padre poderoso en todas las cosas, te pedimos merçet que quieras ffazer bendita, ssennalada, firme, rrazo25 nable, e plazentera; que sea a nos ffecho cuerpo e ssangre de tu ffijo, Nuestro Ssennor Ihesu Cristo. (Et quando dixiere bendita e ssennalada, dene ffazer tres ssignos de $f$ ssobre la hostia. Et quando llegare o dize cuerpo e ssangre, ha de ffazer vn ssigno de $t$ ssobre la hostia et otro ssobrel cáliçe, et desí tomar Ja hostia con grant So rreuerençia, amas las manos ayuntadas, e dezir:) Que vn día ante que ssuffriesse la passión tomó el pan en las ssus santas e onrradas manos e alçó los oios al çielo a [ti], Dios, ssu padre poderoso en

I dellos que / conosçida cay e. - I-2 $T$ ti m. la donaçion. - a las quales. 3 rredenpcion. -- 4 de su salud. -5 syn comienço e syn fin. -8 Santa madre. - 9-1o Pedro e Sant Pablo. - ro Yague. - 10-12 Santo T. Santiago Sant Filipo Sant B. Sant Ximon. - 13-15 Cornelio Sant Cebrian Sant Lloreynte Sant G. Sant Juan Sant P. e todos, - 20 conpanna que. $-20-21$ dias c los tires del. -22 Cristo [ $E$ 105v]. $-34 T$ ssennalada rraz. -25 plazenteria / $T$ que sseamos ffecho. - 26 Quando. - 27 signos de la cruz. 28 signo de crus. -29 e sobre el. -3 I-3a santas manos e ho. e alço. 


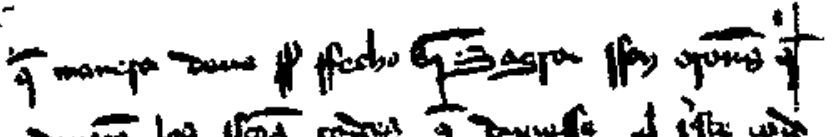

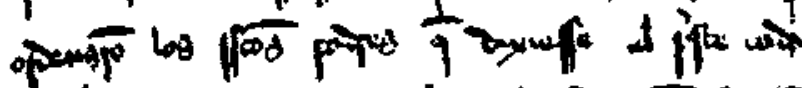

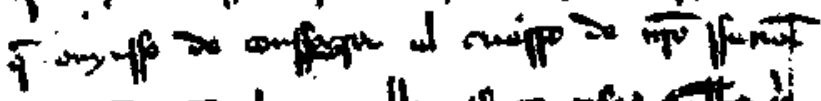

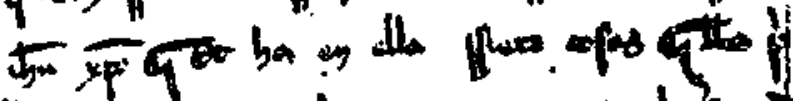

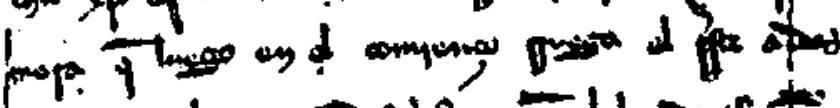

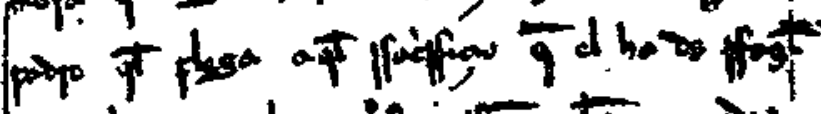

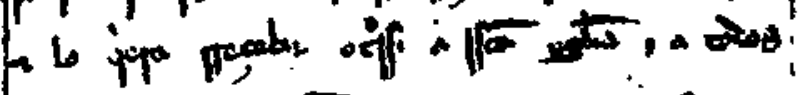

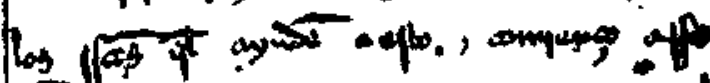

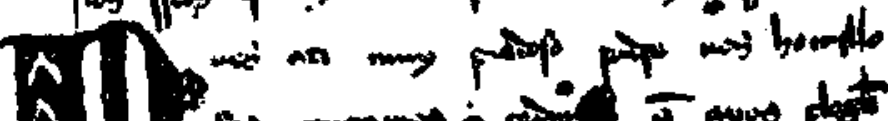

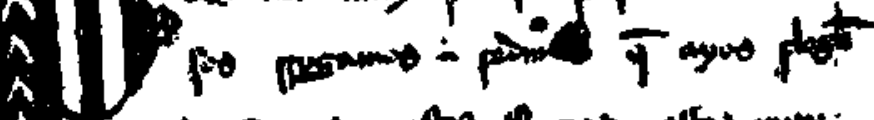

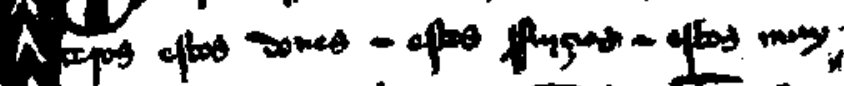

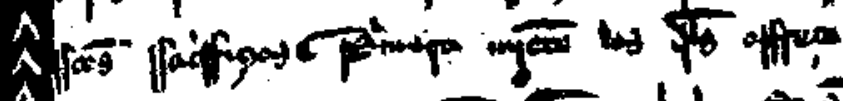

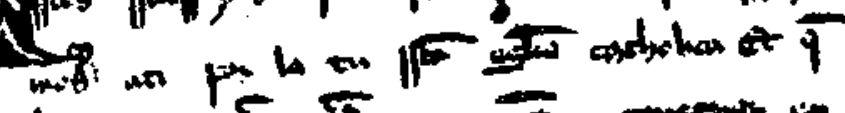

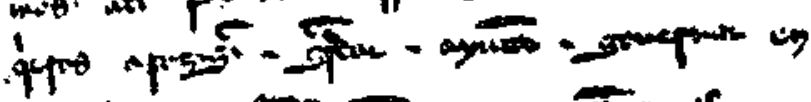

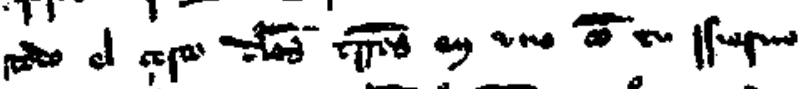
तर

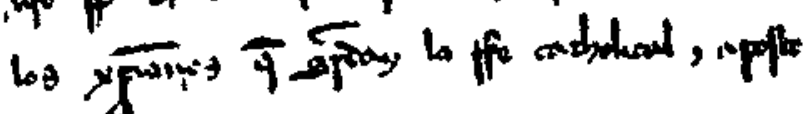
lonat

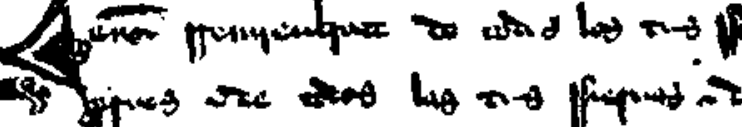

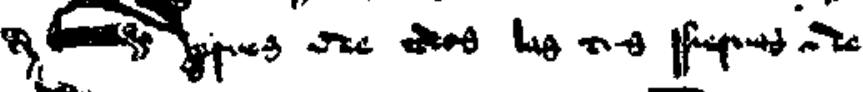

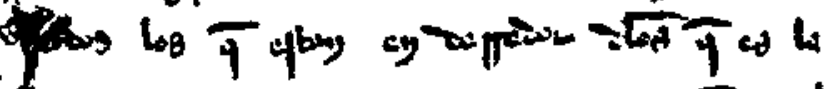

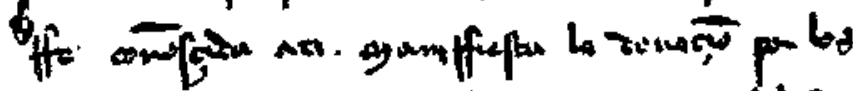
可方

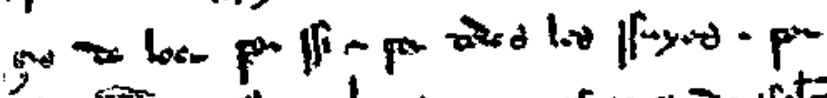

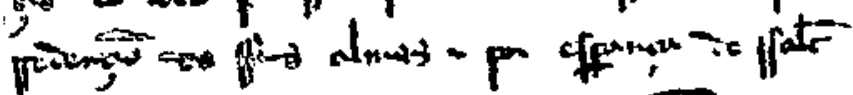

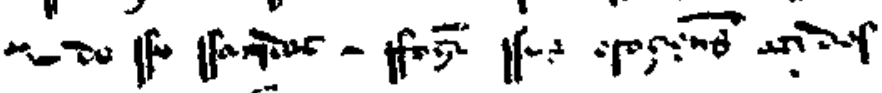

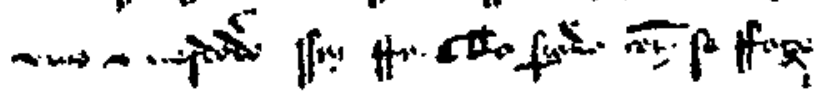

d pan sapes

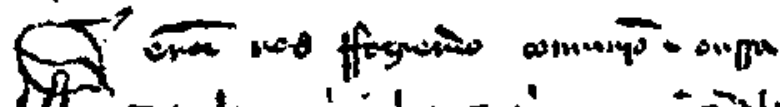

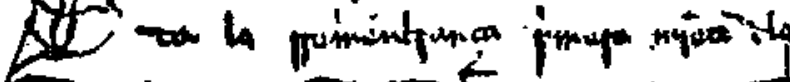

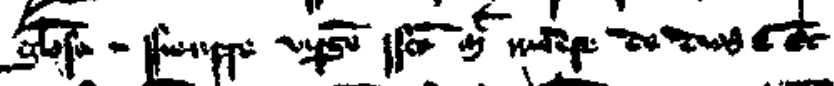

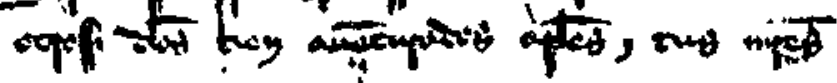
of

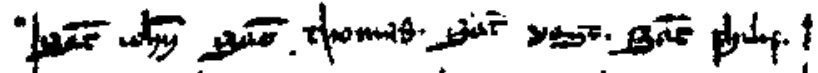

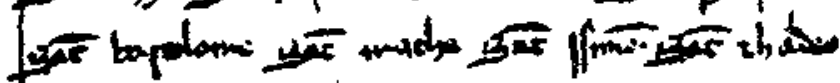

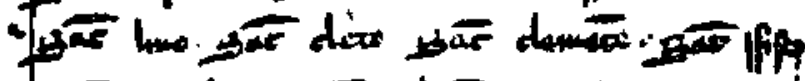

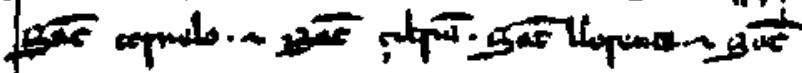

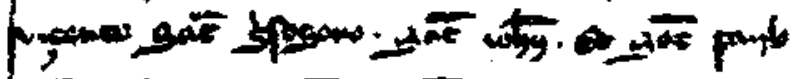

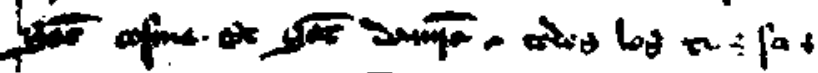

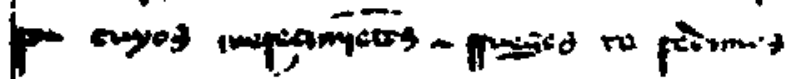

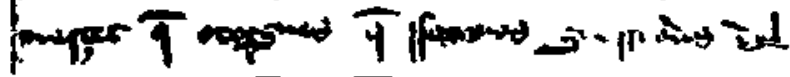

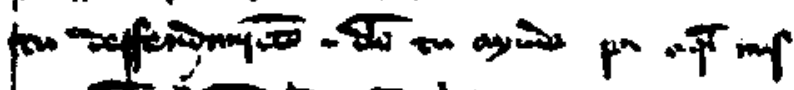

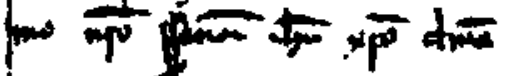

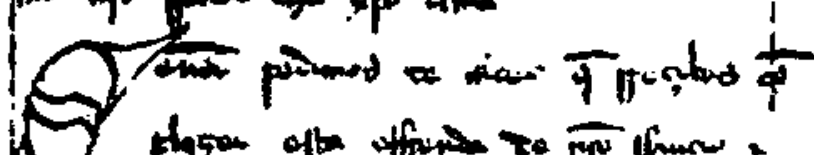

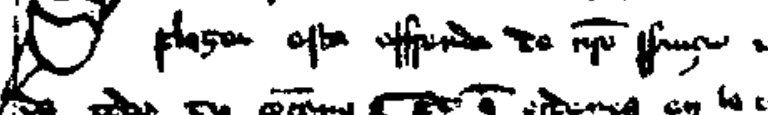

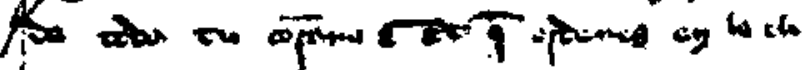

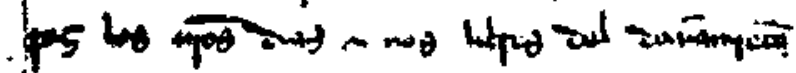

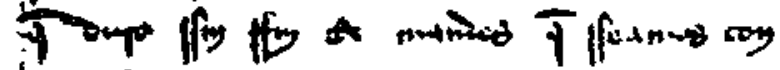

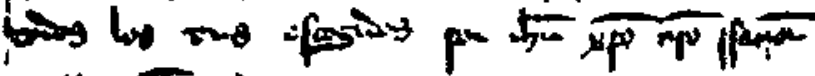

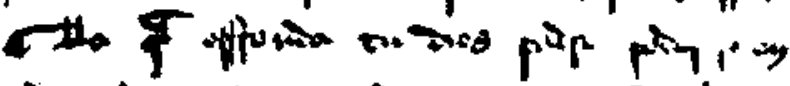

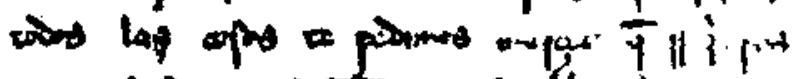

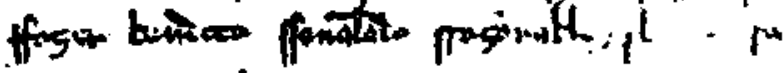

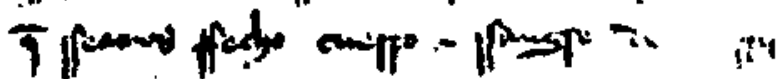

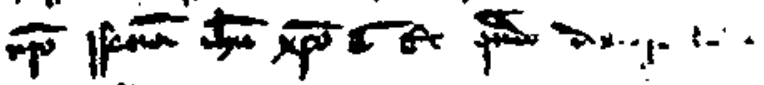

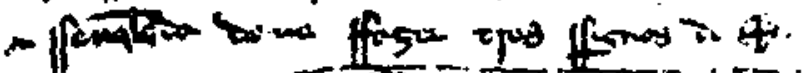

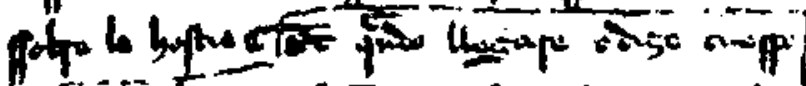

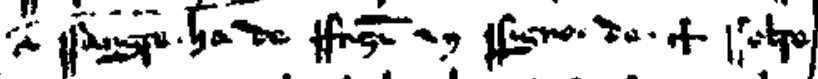

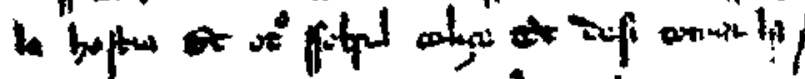

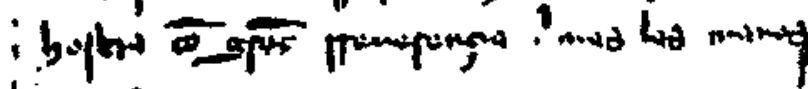

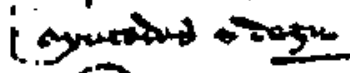

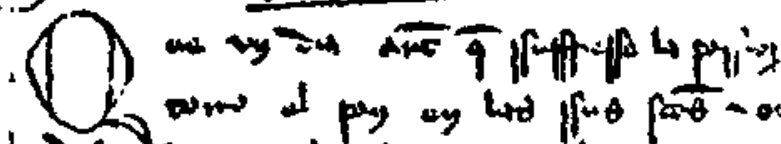

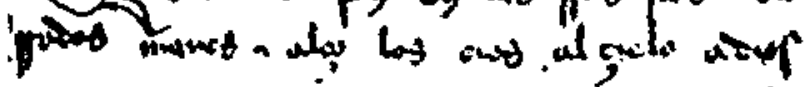

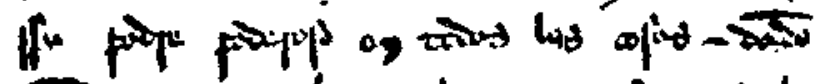

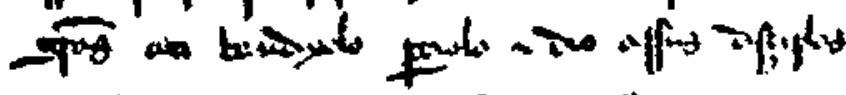

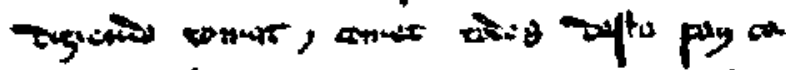

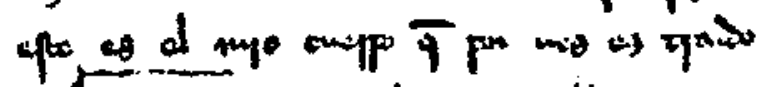

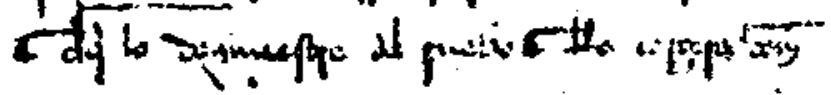




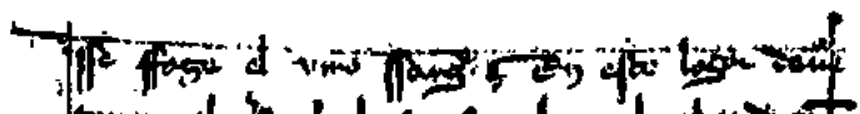

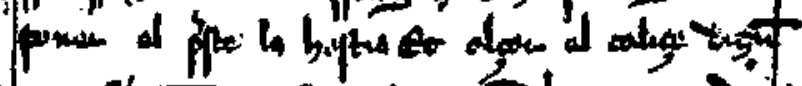

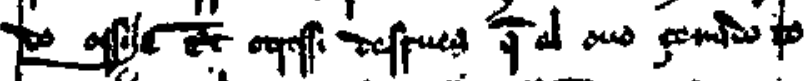

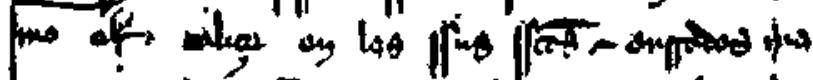

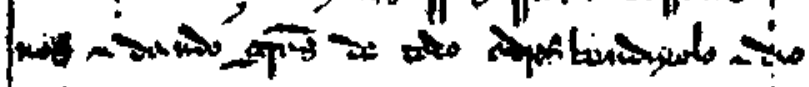

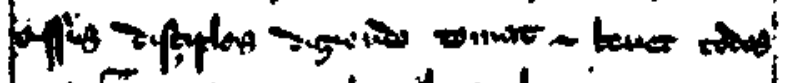

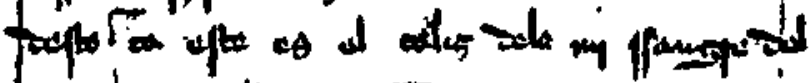

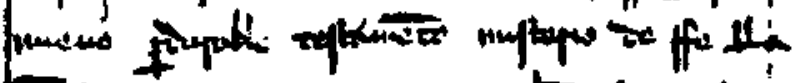

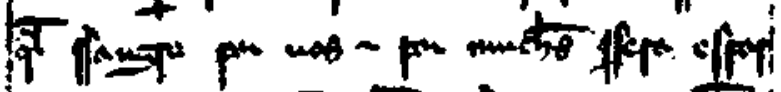

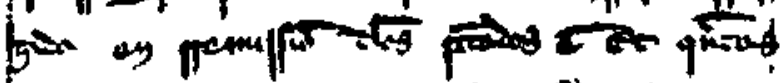

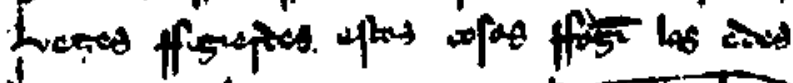

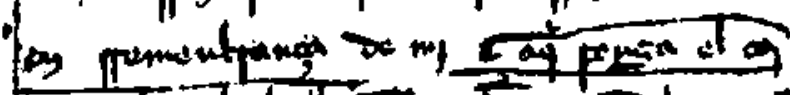

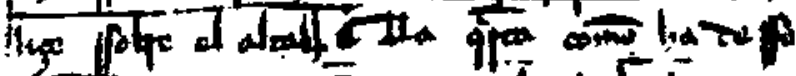

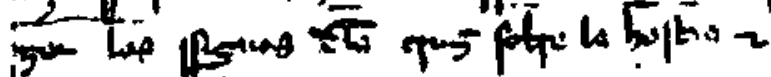
hrotpa d adroes

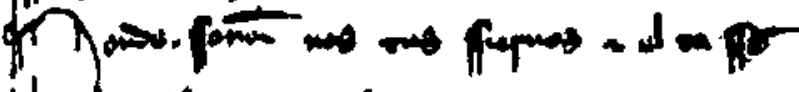

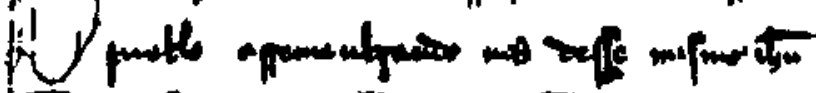
布 on fit

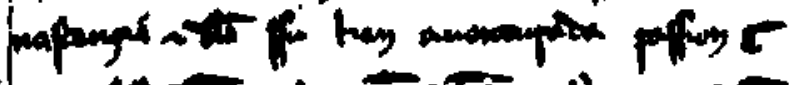

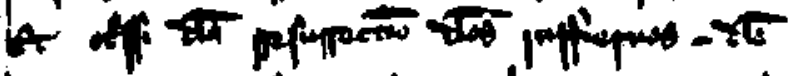

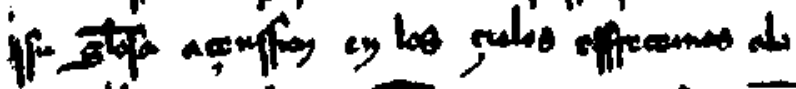

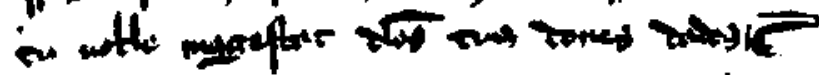

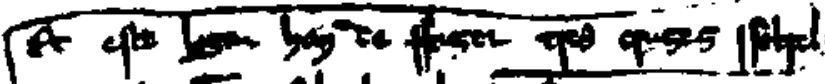

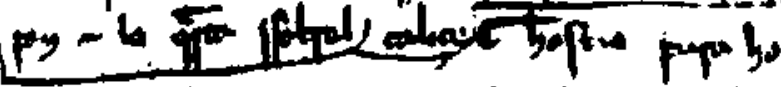

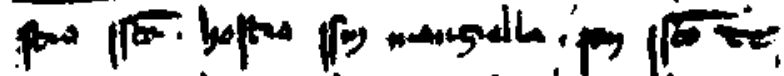

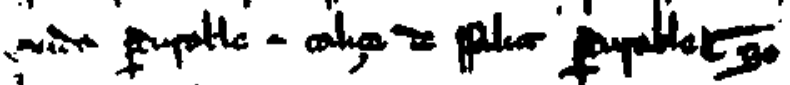

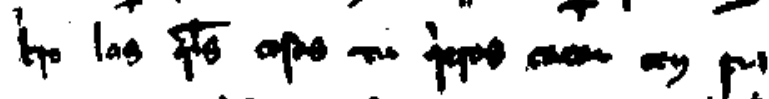

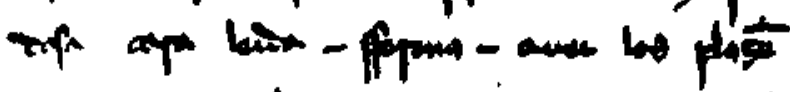

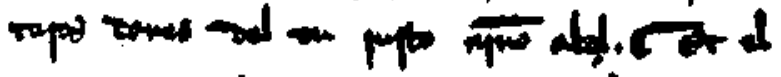

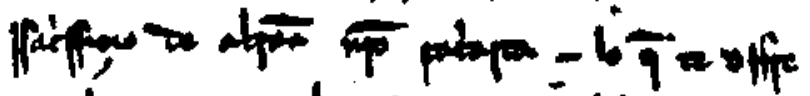

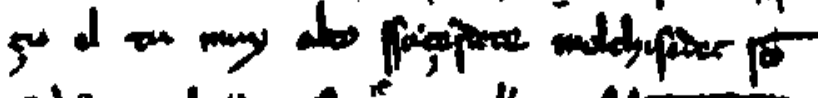

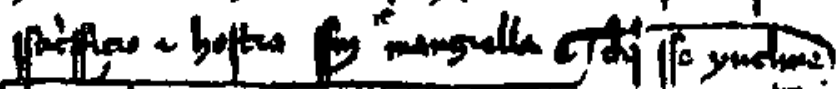

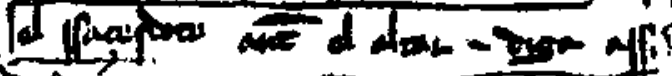

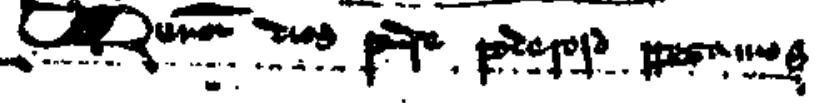

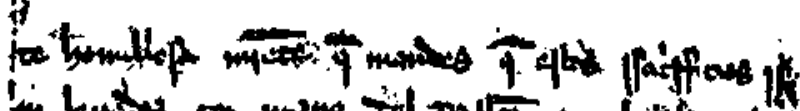

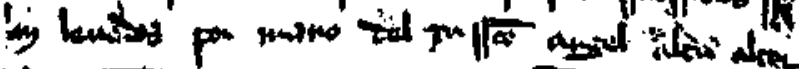

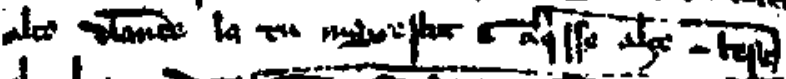

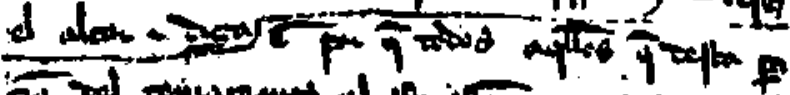

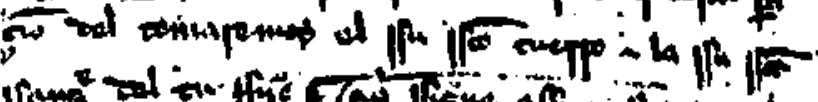
If

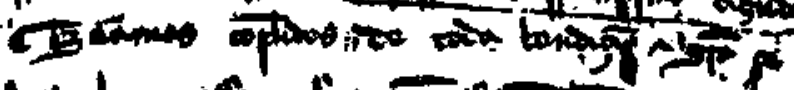

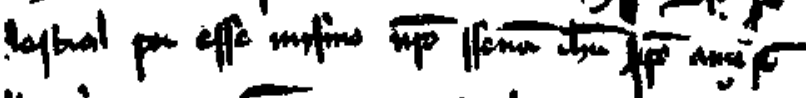

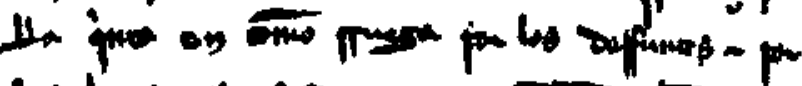

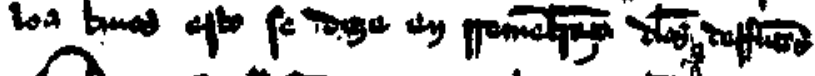

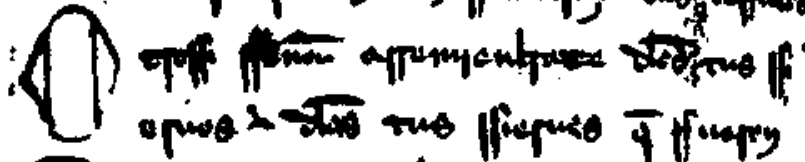

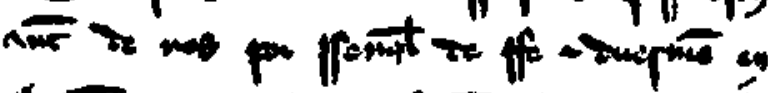

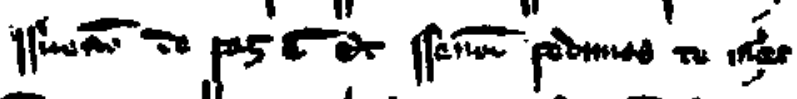

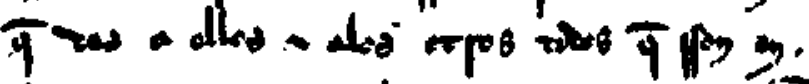

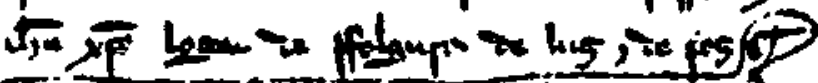

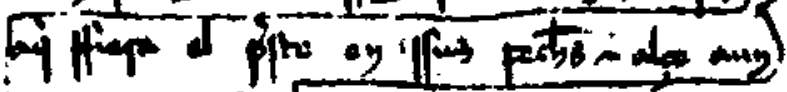
is by tostos

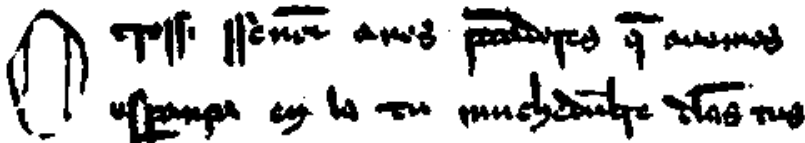

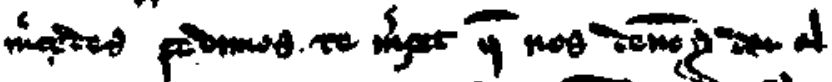

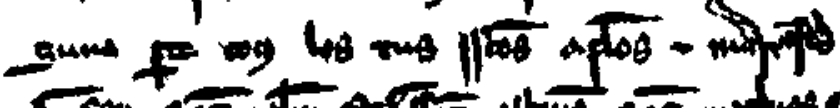

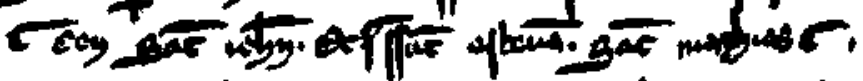

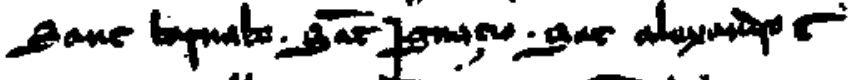

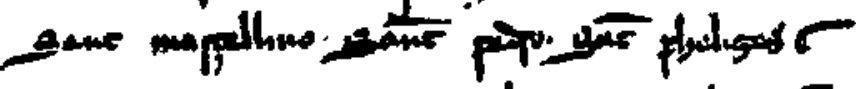

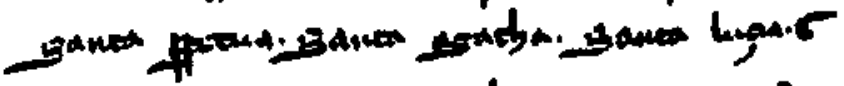

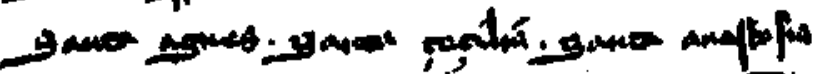

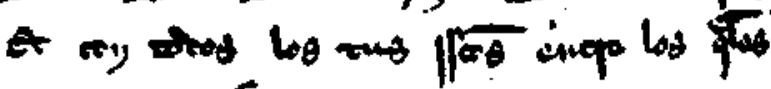

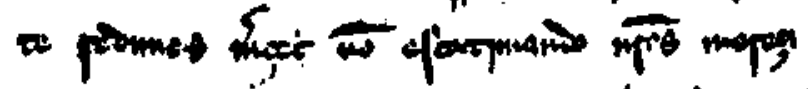

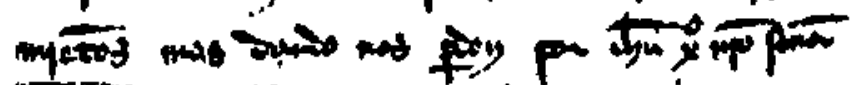

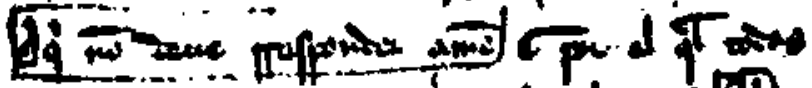

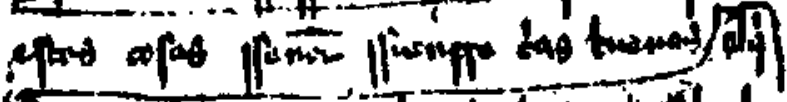

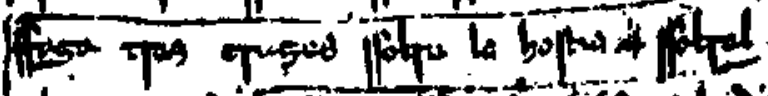

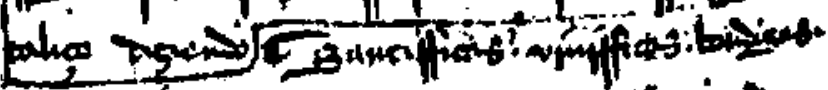

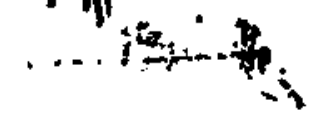


todas las cosas; e dando graçias a ti, bendíxolo, partiólo, e dió a ssus disçiplos, diziendo: Tomat e comet todos deste pan, ca éste es el mío cuerpo, que por uos es traído. (Aquí lo demuestre al pueblo.)

La terçera, cómmo [67v] sse ffaze el vino ssangre. (En este logar 5 deue poner el preste la hostia et alçar el cáliçe, diziendo assí :) Et otrossí después que él ouo çenado, tomó este noble cáliçe en las ssus ssantas e onrradas manos; e dando graçias de todo a Dios, bendíxolo e dió a ssus disçiplos, diziendo: Tomat e beuet todos desto, ca éste es el cáliz de la mi ssangre, del nueuo [e] perdurable ro testamento, misterio de ffe, la qual ssangre por uos e por muchos sserá esparzida en rremissión de los peccados; et quantas vezes ffizierdes estas cosas, ffazerlas edes en rremenbrança de mí. (Aquí ponga el cáliçe ssobre el altar.)

La quarta, cómmo ha de ffazer los ssignos de la cruz sobre la hos- 15 . tia e ssobre el cáliçe: Onde, Ssennor, nos tus ssieruos, e el tu ssanto pueblo, arremenbrándonos desse mismo Ihesu Cristo, tu ffijo, Nuestro Ssennor Dios, e de la ssu onrrada nascençia, e de la ssu bienauenturada passión, et otrossí de la rresurrecçión de los inffiernos, e de la ssu gloriosa açenssión en los çielos; offrecemos a 20 . la tu noble Magestat de los tus dones dados (et en este logar han de ffazer tres cruzes ssobre [la hostia], e la quarta ssobrel pan, e la quinta sobre el cáliçe), hostia pura, hostia ssanta, hostia ssin manziella, pan ssanto de vida perdurable, e cáliçe de ssalut perdurable. Sobre las quales cosas tú quieras catar con piadosa cara leida e 25 . sserena, e auerlos [commo quisiste auer los] plazenteros dones del tu justo ninno Abel, et el ssacrifficio de Abraam nuestro patriarca, e lo que te offreçió el tu muy alto ssaçerdote Melchisedec, santo ssacriffiçio e hostia ssin manziella. (Aquí sse yncline el ssaçerdote ante el altar e diga assí:) Sennor, Dios Padre poderoso, rrogá- 3o. moste homillosamiente que mandes que estos ssacrifficios ssean leuados por mano del tu ssanto ángel al tu altar alto, delante la tu

I bendixolo e p. e diolo. -3 cuerpo aqui lo demuestra. -6 deue el p.poner la o. e alçe. $-6-7$ asy otr. $-7 T$ tomo el cal. (el escrito sobre raspado). 8-9 santas $m$. e ho. e dando $g$. de cabo b. e diolo. - 12 de pecadores. - 13 fezieredes. - 15 signos de cruz. - $16 T$ Donde / seruos. - 18 Senor / honrra de la nasc. - ig pasion o. de la su rresurreçion e de (e añadido sobre la línea, otra mano). - 20 asçension de los. -21 dones $e / T$ et este. $-22 T$ cruzes ssobrel pan e la quarta; $E$ cruçes s, el caliz e la quarta. - 22-23 $T$ omite pan ... el. - 23-24 manzilla e pan santo [fin de $E]$. 
Magestat (aquí sse alçe e bese el altar e diga), por que todos aquellos que desta partiçión dél tomaremos, el ssu ssanto cuerpo e la ssu ssanta ssangre del tu ffijo (aquí ssigne a ssí mismo, diziendo), seamos conplidos de toda bendiçión e graçia çelestial. Por esse 5 mismo Nuestro Ssennor Ihesu Gristo. Amén.

La quinta, en cómmo rruega por los deffuntos e por los biuos. (Esto se dize en rremenbrança de los deffuntos:) Otrossí, Ssennor, arremiénbrate de los tus ssieruos e de las tus ssieruas, que ffueron ante de nos por ssennal de ffe e duermen en ssuenno de paz. Et,

co Ssennor, pedímoste merçet que des a ellos, e a los otros todos que sson en Ihesu Cristo, logar de ffolgura, de luz, e de paz. (Aquí ffiera el preste en ssus pechos e alçe aún la boz, diziendo:) Otrossí, Ssennor, a nos peccadores, que auemos esperança en la tu muchedunbre de las tus merçedes, pedímoste merçet que nos dennes dar a 5 alguna parte con los tus ssantos apóstolos e mártires; con Sant Iohán, et Ssant Esteuan, Sant Mathías, Sant Barnabé, Sant Ignaçio, Sant Alexandro, Sant Marçellino, Sant Pedro, Sant Phelizes, Santa Perpetua, Santa Ágatha, Santa Luçia, Santa Agnes, Santa Çeçilia, Santa Anastasia, et con todos los tus ssantos; entre los 20 quales te pedimos merçet, non escatimando nuestros mereçimientos, mas dándonos perdón. Por Ihesu Cristo Nuestro Sennor. (Aquí non deue rresponder Amén.) Por el qual todas estas cosas, Ssennor, ssienpre crias buenas (aqui ffaga tres cruzes ssobre la hostia e ssobrel cáliçe, diziendo), santifficas, viuifficas, bendizes. [68r] ( $\mathbf{E t}$

25 desaquí descubra el cáliçe et tome la hostia e ffaga tres cruzes con ella ssobre la ssangre, diziendo:) Por él, et con él, et en él (aquí ssigne el preste dos uezes con la hostia entre ssí e el cáliçe, diziendo), [es] a ti, Dios Padre poderoso [en] todas las cosas, toda gloria e onrra. (Aquí, teniendo la hostia con la mano diestra, alçe el cá-

$3 o$ liçe con amas las manos, diziendo:) Por todos los ssieglos de los ssieglos. Amén.

La ssesta es que pida a Dios que les libre de lodo mal e les dé paz. (Aquí ponga el cáliçe e cúbralo, diziendo :) Rroguemos. Nos, amonestados de los mandamientos de ssalut e enfformados por el

35 estableçimiento de Dios, osemos dezir Pater noster. (Después que ha dicho el Pater noster, dize esta oraçión:) Sennor, pedímoste merçet que nos libres de todos los males passados, presentes, e de los que han de venir; et por rruego de la bienauenturada Ssanta 
Maria ssienpre virgen, madre de Dios, e los bienauenturados Sant Pedro, Sant Paulo, Sant Andrés, e todos los otros tus ssantos (aquí deue tomar la patena e ssignarsse con ella ssimplemiente), da tu piadosa paz en los nuestros días, por que nos ayudes de la ayuda de la tu misericordia [e] sseamos ssienpre librados e ssegu- 5 ros de toda tribulaçión. (Aquí tome la patena e ssignesse con ella, e desí métala vn poco sso la hostia e ponga la hostia en la patena, e descubra el cáliçe e con rreuerençia quebrante la hostia ssobre el cálice por medio; e la media parte que tiene en la ssiniestra mano, ponga en la patena; e de aquella que tiene en la diestra io mano, tome vna parteziella; et la que está en la ssiniestra mano, ayúntela a la parte que está en la patena e diga:) Por aquel Nuestro Ssennor Jhesu Gristo, tu ffjo, que contigo vite e rregna en la vnidat del Spíritu Ssanto Dios (et aquella parte que es en la diestra mano, téngala ssobre la ssangre e el cáliçe vn poco alçado e $\mathbf{5}$ diga), por todos los ssieglos de los ssieglos. Amén. (Et con aquella parteziella ssigne tres vegadas tan ssolamiente ssobre la ssangre e diga :) Paz del Nuestro Ssennor ssea ssienpre conuusco; (rresponda el choro:) e con el tu spíritu. (Aquí meta la parteziella en la ssangre, diziendo:) Sea ffecho mezclamiento e conssagramiento del 20 cuerpo e de la ssangre de Nuestro Ssennor Ihesu Cristo a nos, rreçibiéndolo, en vida perdurable. Amén. (Aquí es dicho tres vezes el Agnus Dei. Ante de la paz, besando aquel altar e enclinándosse, dize :) Sennor Ihesu Cristo, que dixiste a los tus apóstoles : La mi paz do a uos, e paz dexo a uos; non pares mientes a los míos 25 peccados, mas a la ffe de la tu eglesia; que la dennes catar, ssegunt la tu uoluntad, paziguar, e ayuntar; que biues e rregnas en el çielo. (Aquí sse leuante e bese en el altar, dando paz al ministro, diziendo:) Paz contigo, e con el [tu] spiritu. (Después dize el ministro:) La paz de Ihesu Cristo e de la Eglesia abonde en unes- 30 tros coraçones; (et dize él mismo:) e con el tu spíritu. (Et enclinándose, diga esta oraçión ante que comulgue:) Sennor Ihesu Gristo, ffijo de Dios viuo, que por la voluntat del Padre, obrando el Spíritu Ssanto, por la tu muerte abiuaste el mundo, librame por aqueste tu ssanto cuerpo e tu ssangre de lodas mis [69v] mal- 35 dades; et ffazme ssienpre allegar a los tus mandamientos, e nunca me dexes sser partido de ti jamás; que con aquel Dios Padre Nuestro Ssennor biues e rregnas en los [ssieglos de los] ssieglos. Amén. (Otra oraçión:) El rreçibimiento del cuerpo de Nuestro Ssennor Ihesu Gristo, el qual yo non digno oso tomar, non uenga a mí en 40 
juizio nin en dannamiento; mas por la tu piadat aproueche en mí e ssea melezina rreçebidera a deffendimiento de mi alma e de mi cuerpo ; que biues e rregnas etçétera. (Aquí, tolliendo el corporal de ssobrel cáliçe, tome la patena e leuántela vn poco con la diestra

5 mano, e tome el cuerpo de Dios e téngalo ssobre la patena, diziendo con la vmillat e con rreuerençia:) El pan çelestial rreçibré, e llamaré el nonbre del Ssennor. Sennor, non sso digno que tú entres en mi techo; mas tan ssolamiente di la palabra, e ssanará la mi alma. (Esto diga tres uezes. Aquí sse ssigne con aquel misIo mo cuerpo e con grant rreuerençia ssúmalo. Et ssi alguna cosa ffincasse en la patena, con el dedo polgar póngalo en el cáliçe. Aquí tome el cuerpo de Dios e diga :) El cuerpo de Nuestro Ssennor Ihesu Cristo guarde la mi alma en la vida perdurable. Amén. (Aquí tome el cáliçe con grant rreuerençia e diga :) ¿ Qué daré al

15 Ssennor por todas las cosas que me dió? Cáliçe de ssaluamiento rreçibré, e llamaré al Ssennor; c sseré ssaluo de mis enemigos. (Aquí ssuma la ssangre de Ihesu Cristo e diga :) La ssangre del Nuestro Ssennor Ihesu Cristo guarde la mi alma en la vida perdurable. Amén.

20 La ssetena, el rreçibimiento del cuerpo de Nuestro Ssennor Ihesu Cristo rrenunçia el cuerpo del omıne. (Después que ouyere comulgado, diga esta oraçión :) Sennor, aquella cosa [que hemos tomada] con la boca [tomemos] con pura uoluntad, e de tenporal galardón ssea a nos ffecho rremedio perdurable. Por el Nuestro

${ }_{2} 5$ Ssennor. (Otra oraçión :) Sennor, el tu cuerpo que yo tomé, e la ssangre que beuy, alegre ssienpre las mis entrannas; que non ffinque en mí manziella de peccado, el qual los ssacramentos puros e ssantos rrenouaron; que vines e rrenas etçétera. (Ante que digá Dominus uobiscum, bese en el altar e de cabo diga, cantando,

3o Benedicamus Domino; o por el Ite, misa est. Et diga esta oraçión :) Santa Trinidat, plega a ti este galardón de mío sseruiçio; e otorga que este ssacriffiçio, que yo non digno offresçí a los oios de la tu Magestat, ssea a ti plazentero por mí e por todos los otros que le yo offreçí ; et tú, auyendo merçet, aproueches a nos con Jhesu 35 Cristo Nuestro Ssennor.

La quinta, quién lo puede ffazer. Estableçió Ssanta Eglesia que ningún clérigo non ssagrasse el cuerpo de Nuestro Ssennor Ihesu Cristo ssi non ffuesse ordenado de quatro grados : ... e epístola; 
e euangelio ; e después de missa. Ca por todas éstas ha de passar ante que allegue a ffazer el ssacriffiçio. Et por ende ninguno non lo deue prouar de ffazer ssinon estos ssobredichos; que ssi alguno lo enssayasse por menospreçiamiento o por escarnio o por otra manera qualquier, ordenó Ssanta Eglesia que non ouyesse orden 5 de missa e quel desgradassen por ello primeramiente de los grados que auya rreçebidos, e lo metiessen en logar quel diessen por pena mal a comer e mal a beuer e que yoguiesse en cárçel por todos ssus días, assí quel ploguiesse más con la muerte que con la vida. Et ssi ffuesse clérigo que non ouyesse órdenes, e que ffu[69r]esse io metido en presión commo el clérigo ssobredicho. Pero ssi cayese en mano de juez sseglar ante que de los clérigos, que aya tal pena commo muestra en la ssetena partida deste libro, o ffabla de los escarmientos.

La ssesta, a qué tiene pro quando es la comunión rreçebida lin- 15 piamientre e con grant deuoción. La hostia con que sse ffaze la comunión del cuerpo de Nuestro Ssennor Ihesu Cristo aduze muchos pros a quien Dios quiere dar uoluntad e entendimiento de rreçebirle commo deue: primeramiente, quel ffaze connosçer a Dios; e connosçiéndol, que ssepa amarlo e temerlo; e temiéndol 20 e amándol, que ffaga buena vida; e biuyendo bien, que ssalga del poder del diablo; et sseyendo ffuera del ssu poderío, sserá librado e sseguro de non auer qué temer en este mundo; et non aurá en esta vida qué tema e sserá çierto de auer la del otro mundo que es perdurable, sseyendo ssienpre en paraíso, veyendo a Dios.

La ssetena, cómmo deue sser onrrado e guardado. Santa Eglesia touo por bien de enssennar cómmo deuen onrrar e guardar el cuerpo de Nuestro Ssennor lhesu Cristo. Et mandó que quandol quissiessen condesar, quel tomasen muy homillosamiente e con muy grant onrra e lo pusiessen en logar linpio apartado que ffuesse 30 cerrado con llaue de guisa que non le pudiesse ninguno tomar para ffazer ninguna cosa con él. Otrossí deuen onrrar todos los cristianos, e aun los omnes de otra ley, ssegunt sse muestra en otras leyes que vienen adelante, o ffablan desta rrazón.

[Ler GV. - De las cosas que sson estableçidas en Ssanta Eglesia 35 para ffazer el cuerpo de Nuestro Ssennor Ihesu Cristo.]

Conuenientes cosas estableçieron en Ssanta Eglesia en que sse ffiziesse el cuerpo de Nuestro Ssennor Ihesu Gristo: la primera, 
altar ; la ssegunda, ara ; la terçera, los corporales ; la quarta, cáliçe; la quinta, patena ; la ssesta, hostia ; la ssetena, lauamiento de manos.

La primera, altar, es cosa estremada de otras para ffazer el 5 ssacriffiçio de Dios. Et el nonbre lieua destas dos altezas : la vna, del logar alto en que deue sser ffecho, e non mucho cabo tierra; la olra, porque en él ensalçan el cuerpo de Nuestro Ssennor Ihesu Cristo, que es alto ssobre todas las cosas. Et ssegunt cuenta la vieia ley, Abraam ffué el primero omne que ffizo altar, ssobre que

ro quiso degollar ssu ffijo Ysaac, vno que auya e non más, para ffazer ssacriffiçio dél a Nuestro Ssennor Dios, ssegunt le él mandara que lo ffiziesse. En ssignifficança de aquello es el altar de nuestra ley, en que quisso Dios que ffuesse ssacrifficado el cuerpo de Nuestro Ssennor Jhesu Cristo. Et el logar alto sse entiende por las

5 dos rrazones ssobredichas. Et demás, porque quando Nuestro Ssennor Ihesu Gristo lo pusieron en la cruz, alçáronlo mucho alto ssobre la tierra.

La ssegunda, el ara. La ara a de sser ffecha de piedra, a ssemeiança de quando vió Jacob a Nuestro Ssennor Dios en visión e 20 puso y vna piedra e ffizo della altar e echól olio de ssuso, e por esta rrazón ssagran el ara. Et aun ay otra ssignifficança, ssegunt la ley vieia, de la visión que vió Nabucodonosor, rrey de Babilonia, de vna piedra que sse arrancaua de vn grant monte ssin mano de ninguna cosa que la tanxiesse e ffiría en vna ssu ydola e que ge la 25 quebrantaua. Et [69v] esta piedra ffué Jhesu Ciristo, que nasçió de Santa María ssin tannimiento de uarón et ffirió en el poder del diablo, que sse da a entender por Nabucodonosor, e en la mallat del mundo, que sse entiende por Babilonia, e quebrantólo todo. Et otrossí ssigniffica de quando Moysén ffué en el desierto e los 3o ffijos de Isrrael pidiéronle agua, diziendo que rrogase a Dios que ge la diesse, que murían de sset; e eran en logar do non lo auya et el rrogólo, e mandól Nuestro Ssennor que ffiriesse en la piedra dura con la piértega e que ssaliría ende agua. Et fué assí que ssalió tanta della que beuyeron quanto quisieron ellos e ssus bes-

35 tias. Et Moysén quier tanto dezir commo qui ffué ffallado en agua, e sse entiende por los patriarcas e por los prophetas, que ffueron ffallados en este mundo por amigos de Dios e por omnes de buena vida entre todos los otros peccadores e malos. Et en lo que pidieron agua en tal que non muriessen de sset sse entiende que los 40 omnes buenos e derecheros pidieron merçet a Nuestro Ssennor 
Dios que les diesse el ssu ffijo Jhesu Cristo, que era agua biua que les auya prometido, para que les tirase los peccados en que estauan en este mundo e que yuan en cuerpos e en almas a inffierno, ssegunt dixo Ysayas el propheta: Todos los que auetes sset, venit a las aguas. Et Jhesu Cristo mismo lo dixo a la ssamaritana, 5 que ssi ssopiesse ella quién era él, quel pidiría agua biua, e él que ge la daría por que nunca ouyesse sset. Et Dauid el propheta lo mostró en otro logar quando dixo [por] Dios: Por la uoluntad abrió los çielos. Onde tantos ffueron estos que rrogaron a Dios que la ssu dureza del Padre, que auya antiguamiente contra el so mundo por los males que en él sse ffazían, óuose âmollentar por la buena vida e por las buenas oraçiones que los buenos vsauan a. ffazer, en manera que, fferiendo en él e rrogándol e pidiéndol merçet, a ssemeiança de la piértega de Moysén con que ffirió en la piedra dura, abrióse la ssu uoluntad, tornando la ssu ssanna en 15 perdón e la dureza en piadat. E enbiónos el ssu ffijo Jhesu Cristo, que es agua biua que nos alinpia e nos esffría de los peccados por que perdamos sset de la calentura de la ssequedat del inffierno, que sse entiende por el desierto, e merescan la gloria del paraíso, o non ha ffanbre nin sset nin ffrio nin calentura, ssegunt que dixo 20 Ssant Iohán apóstol en el Apocalipssi, que los que assí estauan, que non auyan sset nin ssintían calentura. Et [dixo] Nuestro Ssennor Ihesu Gristo por esta piedra ssobredicha en esta rrazón dél mismo, que la piedra que desdennaran los que labrauan, que era puesta en cabeça del rrencón. Ét esto sse entiende que los que 25 auyan poder en el mundo e eran entendidos non lo connosçieran, ssegunt dixo Ssant Iohán, que el mundo era ffecho por él e nol connosçieron, e que viniera a lo ssuyo mismo e los ssuyos nol rreçibieron. Et la piedra que fué puesta en el rrencón que ayuntaron amas las paredes, et esto sse entiende por la ssu venida, 3o que ffizo [70r] ayuntar la ley vieia con la nueua; ca por la vna sse proeua la otra, ssegunt él mismo dixo: Quien sse en ésta ffiriere sserá fferido todo maltrecho. Et otrossi dixo [a] Ssant Pedro, quandol connosçió que era Ifjo de Dios, porque ffuera ffirme commo piedra, que ssobre él mismo [que] ffuera piedra verdadera 35 labrarie la ssu eglesia, que sse conssagra ssobre la piedra del ara, que es ssobre el altar.

La terçera, corporales, que quier tanto dezir commo aquellos 
pannos en que enboluyeron el cuerpo de Nuestro Ssennor lhesu Gristo quandol desçendieron de la cruz e lo pusieron en el monimento. Et éstas ffueron en dos maneras: la vna, la mortaia que cubrió el cuerpo todo, que es uestidura de los muertos; el el otro,

5 quel cubrió la cabeça, que llaman en latín ssudario. Et a ssemeiança de aquel en que enboluyeron el cuerpo ponen la vna parte ssobre el ara, e la otra con que cubren el cáliçe es a ssemeiante del ssudario con que cubrieron la cabeça. Et estos corporales han de sser de lino, e non de otra cosa, et esto por tres rrazones Io que cada vna dellas ha ssu ssignifficança. La primera, que el lino nasçe bien e apuesto, assí commo Jhesu Cristo nasçió de Santa María. La ssegunda, porque quando es grande e está en fflor, parcsçe muy fermoso e ha color de çielo. Assí ffué Nuestro Ssennor Jhesu Cristo; que quando era de hedat, començó a predicar è

15 mostró las obras çelestiales a ssu padre en rressuçitar los muertos e ssanar los enffermos, la cosa que omne en carne non podría ffazer ssin ajudamiento de Dios. La terçera, que assí commo el lino es fferido e majado e rrastellado de muchas maneras ante que llegue a sser tela, assí el cuerpo de Nuestro Ssennor lhesu Cristo 20 ffué penado e tormentado de muchas guisas ante quel diessen la muerte. Et murió en la cruz e flizo de la ssu ssangre con que nos vistió, mostrándonos en este mundo ffazer buena vida por que ayamos la otra en el ssanto paraíso por ssienpre jamás. Et aun ay otra ssignifficança de los corporales ; ca la parte que está esten25 dida ssobre el ara, que es de piedra, muestra que la ffe que omne ha deue sser ffirme, assí commo es la piedra; et la que está doblada ssobrel cáliz ssigniffica entendimiento buẹo e ssano que deuemos auer para tener ssin dubda e ssin inffinta que es assí e non de olra [manera].

3o La quarta, el cáliz, aquel uaso en que conssagran el cuerpo e la ssangre de Nuestro Ssennor Jhesu Cristo. Et commo quier que ssea ffecho en manera de uaso con que beuen, en este logar uon ssigniffica ssinon amargura de tormento e de muerte, assí commo la él rreçibió en dos maneras: la vna, ffaziendo bien ; la otra; non

35 mereçiendo mal, lo que él non deuyera rreçebir, mas auer galardón del bien que ffiziera. Onde el cáliz es a ssignifficança del ssepulcro en quel metieron después que ffué muerto et lo touyeron mortaiado. Et por ende los ssantos padres cataron ffaçión conueniente en cómmo ffuese ffecho el cáliz e de qué cosas, et esto a sse40 meiança del ssacriffiçio que auya [70v] de sser ffecho en él. Et por 
ende toujeron por bien los santos padres que lo fiziessen ancho en ssomo de la boca e toda vía ssonducho de ffondo ffasta allí do sse ayunta la copa con el pie, por que el vino e el agua que y echassen sse ayuntase todo en vno e non se pudiesse estender por el cáliz, en guisa por que el clérigo, quando lo quisiesse ssomir, 5 que lo pudiese ffazer más ayna, ffallándolo todo más ayuntado assí que non sse ouyese a detener en ello; ca en la delenençia muchas vegadas acaesçe que caen y cabellos o otra cosa, que coia vsgo el que lo ssume por que lo aya de camiar, lo que non deue sser ffecho en ninguna manera ssinon non podiendo. Et por ende ordenó to Santa Eglesia que el que ha enffermedat de que camie, que non ge lo den mientra lo ouyere, nin ffaga otrossí ssacriffiçio en naue nin en otro logar fflaco que sse aya de mover. Et aun por esta rrazón misma estableçieron que non lo ffiziesen en cáliz de cobre, et esto es por el aborrençia que da al omne de camiar, nin aun en $\mathbf{} 5$ otro metal que ouyese esta natura; nin en el de piedra, por rrico que ffuese, ssi non ouyesse de dentro oro o plata o otro metal de aquellos que [non] ffazen aborrençia; nin lo ffazen otrossí de ffierro porque sse orinesçen ayna e non sse pueden lauar; nin de plomo porque tienen e han ssienpre en ssi naturalmiente ssuzedunbre; 20 nin de vidrio porque quiebra ayna; nin de madero, commo quier que algunos lo ffiziessen al comienço de la ley e lo ffazen agora, por ssignifficança que Nuestro Ssennor Ihesu Cristo ffué cruçiffcado en cruz. Et commo quier que ellos buena rrazón muestran, non touo por bien Ssanta Eglesia que lo fiziesen en cáliz de ma- 25 dero porque non puede sser que alguna cosa non rreçiba o non ffinque en él de aquello que y meten, lo que non conuyene al cuerpo de Nuestro Ssennor Jhesu Cristo; ca todo sse ha de conssumir quandol conssagran, e non deue ffincar dél nada. Ca assí commo en la Trinidat sson tres perssonas e vn Dios, assí de la 30 hostia ffazen tres partes e en vna ffinca la uertud della. Et otrossi es del vino e del agua que en ello meten; ca todo esto sse torna en vna hostia por rrazón del ssacriffiçio, e por esso todo sse deue conssumir en vno, [comiendo] lo que es de comer e beuiendo lo que es de beuer. Et por desuyar que en este consumimiento non 35 ouyese enbargo nin peligro, estableçieron que los cáliçes ffuessen de oro o de plata, o de estanno, que es el metal más çerca della.

La quinta, que ffabla de la patena, ésta muestra que este nonbre della nasçe de.padesçer. Et esto sse entiende que el que padeçe, non fferidas de otra manera, mas teniendo alguna cosa de ssuso 40 
tan ffuerte e tan pesada ssol que non pudiesse salir. Et porque a los muertos, desque los ssotierran, ponen ssobre las ssepulturas en que jazen grandes piedras, et por ende, a ssemeiança de aquella piedra que ffué puesta ssobrel ssepulcro de Nuestro Ssennor Ihesu 5 Gristo después quel metieron en él, ponen la patena ssobrel cáliz. Et quando ende la tuelle el ssaçerdote e la pone ssobre el altar, [71r] estonçe es a ssignifficança de quando el ángel desçendió del çielo e rreboluió aquella piedra $e$ sse assentó ssobrella.

La ssesta, la hostia, de que sse ffaze el cuerpo de Dios. Ca ésta ro sse conssagra e, después que es consagrada por las ssantas palabras que ssobrella dizen, luego sse torna en carne. Et commo quier que la non pueden uer oios mortales, déuenla uer los del coraçón en creer ffirmemiente que es assí, ssegunt Jhesu Cristo mismo dixo por el pan, que era la ssu carne, e el vino la ssu ssangre. Et

I5 aun les muestra en muchos logares en guisa que lo puedan uer, e ssennaladamiente a aquellos que en ello dubdan en cómmo el pan sse torna carne e el vino ssangre. Et por ende tan noble cosa commo ésta que es assí ssagrada, commo quier que el clérigo coma lo que pertenesçe della e beua otrossí la ssangre, toda la uertud maraui-

zo llosa de la deidat de Dios que dél desçendió en ffazer esta obra tórnasse a él onde vino. Et es enbiada por quatro rrazones: la primera, porque nos la enbiamos a Dios por las manos del clérigo que la conssagra, rrogándol que rruegue por nos; la ssegunda, que la enbía el clérigo ssobredicho por la mano de los ángeles que la 25 rreçiben; Ia terçera, [a] ssignifficança de Dios Padre, que enbió ssu ffijo Nuestro Ssennor Jhesu Cristo en este mundo que rreçibiese carne de Ssanta María e nos rredimiesse, ssacrifficando el ssu cuerpo en la cruz, enbiando la ssu alma al Padre, de que ffazen rremenbrança ssobrel altar; la quarta, porque Nuestro Ssennor

3o Ihesu Cristo, después quel enbió ssu padre en tierra por ssaluar a nos e ouo conplido en el mundo aquellas cosas que touo por bien que cunpliesse, quiso que sse tornase a él ondel enbiara. A ssemeiança desto ge lo enbían agora por offrenda de ssacriffiçio.

La ssetena, el lauamiento de las manos. Después que el ssaçer-

35 dote ha offreçido el cáliz e la hostia ssobrel altar, laua las manos, ssegunt la auctoridat del Ssalmista, que dize: Lauaré entre Ios non culpados mis manos e çercaré el tu altar, Ssennor, Ca la ssuziedat de las manos non enssuzia el ssacramento diuinal, mas ssi alguno lo come o lo beue non dignamiente, juyzio come o beue 40 para ssí mismo; ca non ensuzia a omne comer con las manos non 
lauadas, mas lo que ssale por la boca del coraçón, e aquello enssuzia a omne. Et las cosas que enssuzian a omne sson éstas : malos penssamientos ; omeziellos ; ffurtos ; ffalssos testimonios; denuestos. Onde con grant pensamiento nos deuemos esfforçar que non tan ssolamiente alinpiando las manos de fruera, mas los enssuziamien- 5 tos que sson en las uoluntades. Et en esto sse entiende dos cosas : la vna... [e la otra], que es lauado dentro en las uoluntades de los peccados que ffizo pues que ha rreçebido penitençia.

[Ler GVI. - De las vestiduras que sson estableçidas en Ssanta Eglesia para los prelados menores.]

Linpiedunbre muy grande deue auer en todas las cosas con que sse dize Ja missa o sse ssagra el cuerpo de Nuestro Ssennor Ihesu Cristo. Et por ende estableçió Ssanta Eglesia que las vestiduras con que sse dixiesse la missa ffuessen linpias e más rricas que pudiessen auer; ca muy grant derecho es que aquel que tan noble cosa 15 e tan grande commo el cuerpo de Nuestro Sennor [71v] Ihesu Gristo conssagra, que ssea vestido linpiamiente e apuesto. Onde en la vieia ley, quando Moysén ordenó a ssu hermano Aarón por mayor ssaçerdote, que era estonçe assí commo papa poderoso ssobre todos los otros que auyen a demostrar la ley e ffazerla tener, 20 estableçió que ouyesse uestimientas de muchas maneras, vnas para vestir al cuerpo e otras para poner ssobre la cabeça, et a todas puso ssus nonbres ssegunt la manera de las ssignifficanças que eran ffechas. Et aquéllas vsan agora los prelados mayores, que diremos en ssu logar. Los otros que dizen la missa, commo quier que los ${ }_{2} 5$ prelados ssean mudados, [vsan] dellas en otra manera. Et commo quier que ellas ssean muchas, conuyene que sse diga aquí de las ssiete que vsan los prelados menores que sson clérigos de misa, que sson comunales a todos e sson éstas: la primera, ssobrepelliça; la ssegunda, el amito ; la terçera, el alua; la quarta, Ia çinta; la 30 quinta, el maniplo ; la ssesta, la estola ; la ssetena, la casulla.

La primera, la ssobrepelliça, es vna manera de uestimienta que deuen traer los clérigos uestida primeramiente ssobre las otras uestiduras que viste. Et porque los clérigos ssolíen antiguamiente vestir pielles más que otra cosa e vistíenla de ssuso, por essol pu- 35 
sieron nonbre ssobrepelliça. E ésta deue sser de lino e muy blanca a ssignifficança de la primera cosa que el ssacerdote deue auer en ssí, que es linpiedunbre e caslidat. Et por estas dos cosas la deue toda vía traer uestida, et otrossí por que ssean por ellas connosçi-

5 dos entre todos los otros clérigos que sson ellos prestes. Et porque la han a usar a traer cutianamiente, non la bendizen los prelados commo las otras uestimientas. Et ssi por auentura alguna non la traxiere por neçessidat o por non vsarlo o por alguna otra manera, déuela vestir ante que otra vestimienta quando quisiere dezir misa.

Io La ssegunda, a mito, que quiere dezir commo cobertura. Et éste es vn panuo muy blanco de lino e quadrado que sse echa el preste ssobre la cabeça, e ha dos rramales luengos con que sse çinne por los pechos. Et esto es a ssigniflicança de amas las leyes, de la vieia e de la nueua. Et porque Aarón ordenó que la traxiesen los ssaçer-

I5 dotes quando entrassen a ffazer oraçión, e por ende cubrieron la cabeça e lo que ffincaua, echáuanlo ssobre las espallas, rreboluyéndolo en derredor del pescueço, a ssemeiante que la ley de Dios era blanca e linpia, e ellos metían la cabeça sso el jugo della porque deuyan rrogar por el pueblo homillosamiente, teniendo las 20 cabeças cubiertas e abaxadas; que ningún ssennor non deue ninguno rrogar ssinon con grant humillat, mayormiente a Dios, en cuyo poder sson todas las cosas. Onde a ssemejança de aquel panno fizieron el amito con que cubre el preste la cabeça e los onbros. Et ssegunt la nueua ley, es a ssignifficança de la ley de Dios,

25 commo cobertera de carne que ffué uestido con quel viésemos assi commo a nos mismos e que ssopiéssemos çiertamiente que Ihesu Cristo era Dios, ssegunt dixo Ysayas, que el ninno nos era [72r] nasçido e el ffijo nos era dado, que sse entiende todo por Jhesu Cristo, a qui pusieron ssu inperio ssobre los onbros, e ffiziéronle

3o leuar la cruz a cuestas en que ffué puesto e murió por nos, que vençió al mundo e al diablo. El qual rregno e inperio dura por ssienpre, et es llamado el ssu nonbre Ángel de Grant Conseio. Et otrossí Ssant Johán dixo en el A pocalipssi que el ángel de Dios desçendiera del çielo cubierto de nieue. Et esto sse entiende por

35 Ihesu Cristo, que sseyendo Dios, cubrió la ssu deidat con la vmanal carne, que engannó al diablo en guisa que nunca ssopo ssu ffecho ffasta que to ouo destruido e vençido. Et los rramales con que ata el clérigo el amito ante los pechos ssigniffica que el ssaçerdote 
deue auer en el coraçón que tiene en los pechos ffirme crençia con buenas obras.

La terçera es alua, vestimienla que el ssu nonbre ssale desta misma, et esto porque ha de sser muy blanca. Ssegunt la ley vieia, ssolíen[la] ffazer estrecha en ssignifficança que deue omue costrenir 5 e apretar el coraçón para sseruir a Dios e guardarsse de peccar, mas ssegunt el ordenamiento de Ssanta Eglesia ffázenla ancha. Et esto ssigniffica que por la blancura della, que sse entiende por el agua del baptismo, que nos laua los peccados; et por la longura [della], la muchedunbre de que nos ssomos quitos de la sseruidunbre del 10 diablo, en que ante yazíamos apretados, et por el priuilegio que Ihesu Gristo nos dió, en que nos ffizo libres, quando murió en la cruz por nos, ssegunt dixo Ssant Paulo en ssu epístola, que aquella libertad ouyéramos por Jhesu Cristo. Et aun hay otra ssigniffcança que ha en ssí el alua, et esto es por lo que passa el lino ante ${ }_{15}$ que ssea ffecha el alua, assí commo arrancándolo primeramiente, e después majándolo, e texiéndolo, e aun curándolo ffasta que sse ffaga blanco. Ft todo esto deue auer el clérigo que ha de uestir el alua : primeramiente, arrancar del coraçón los peccados que tiene; e después, majándosse él mismo, conffessando los peccados por la 20 boca e ssuffriendo las majaduras quel dieren por penitençia ; después, texiéndosse, ffaziendo buenas obras; e curándose otrossi, guardándosse de peccar dallí adelante e ffaziendo buena vida e linpia, por que las oraçiones que él dixiere ssean oydas con Dios e la ssu alma [uenga] blanca e linpiamiente antél quando deste 25 mundo ssaliere.

La quarta es cinta. Cinta es cosa con que omne aprieta las vestiduras e las llega a ssí. Et este nonbre ha de çindere, que quier tanto dezir commo taiar el cuerpo. Pero con todo esso ssemeiança ffaz e departimiento dél en dos partes: la vna dellas, lo de más $3 o$ arriba; e la otra, dende ajuso. Et por ende deue sser çennida e apretada por aquel logar. Et esto es a ssignifficança de la justiçia, que es dar a cada vno ssu derecho, en dos maneras : la vna, dando galardón a los buenos por el bien que ffazen; la otra, castigando a los malos por el mal que ouyeren ffecho. Et esto dixo Ysayas 35 el propheta por Ihesu Cristo: Sserá la justiçia çertera de ssos lomos, et la ffe cimiento de ssus rrenes; esto muestra de la cinta

9-10 $T$ longura de much. $-36 T$ por que Ihesu (que añadido sobre la linea). 
ayuso. Et otrossí dixo el rrey Dauid que Dios derechero es e amó justiçia e yguallat vió la ssu cara; et esto ssigniffica de la çinta arriba. Et esto sse entiende por ssu ffijo Ihesu Cristo, que quiso [72v] que sse ygualasse connusco en sser omne commo nos.

5 Et Ssant Johán lo amostró en el Apocalipsi, o dixo que viera a Nuestro Ssennor Ihesu Cristo en los çielos, vestido con muy nobles uestiduras e çinto con çinta de oro por los pechos, que sse muestra por justiçia de grant rrey, assí commo lo Dios ouo en ssí quando nos [enbió] al ssu ffijo Ihesu Cristo que nos jud-

10 gasse. Otrossí ssigniffica uertud de castidat, que deue auer en ssí todo omne que quier ffazer plazer a Dios e beuir en este mundo buena vida, e mayormiente aquel que es tenudo de conssagrar el ssu cuerpo, ssegunt él mismo dixo en el Eaangelio a ssus apóstoles: Ssean los uuestros lomos çenidos - que sse entiende por cas-

i5 tidat - e auet en vuestras manos candelas ardientes - que sse da a entender que ffagan buenas vidas e buenas obras en manera que todos las uean e den loor a Dios. Por los dos cabos que [cuelgan] egualmiente de la çinta sse muestran dos maneras de egualdat que ha en la justiçia que quiere bios que ayan todos los omnes 20 vnos con otros: la vna, que aquello mismo quieran para otre, lo que querrían para ssí quel ffiziessen....

La quinta, maniplo, es otra manera de ordenamiento de vestimientas que ordenó Ssanta Eglesia que ha de tener el clérigo en la mano ssiniestra quando dize la misa. Et quiere dezir commo 25 cosa que sse toma con quanto en ella cabe. Otrossí muestra doblamiento de que sse dobla de ssomo con la mano. Et estas dos rrazones conuyenen mucho al maniplo; ca él es ffecho en manera que non es más ancho de quanto pueda caber la mano por él. Et deue sser puesto en la munneca do sse ajunta la mano con el $3 o$ braço, o sse dobla quando es mester. Et esto es a ssignifficança de escudo, que deue ssienpre el que dize la misa poner ante ssí para sser por él guardado de tentaçión. Et la mano ssiniestra en quel ponen ssigniffica la vida deste mundo, que es cosa en que toman los omnes ssabores que non sson duraderos e por que pierden 35 el amor de Dios. Onde, maguer la mano ssyniestra non ha tan grant ffuerça commo la diestra, el maniplo quel ponen la ffaz ygual con ella. Et por ende dixo el rrey Ssalamón prophetando : La ssu ssiniestra sserá ssobre la mi cabeça e la ssu diestra me 
abraçará. Et por essol ffazen dos cabos yguales colgados por que la mano ssiniestra, que obra naturalmiente, sse eguale con la diestra por la vertud spiritual que gana por el maniplo quel ponen en ella, por que el ssaçerdote egualmiente pueda ffazer el ssacriffiçio con amas las manos, ssegunt conuyene.

La ssesta, el estola, que ha de sser de lino o de sseda. Et ésta es vna manera de panno luengo e estrecho tanto commo la mano del omne puede sser en ancho. Et ha de sser tamanna commo del pescueço, do sse ajunta la cabeça, ffasta $[73 r]$ los pies. Et ésta muestra homillat e obediençia e paçiençia e yugo de sseruidun- Io bre. Todo es esto a ssemejança de lo que ouo en ssí Ihesu Cristo. Ca él sse homilló tanto con obediençia a ssu padre ffasta en que murió desonrradamiente en la cruz. Paçiençia ouo en ssí más que otro omne; ca por ninguna cosa quel ffiziessen nunca sse quexó, ssegunt dixo Ysayas propheta, assí commo oueia ffué traído a la i5 muerte, et assí commo el cordero que, quando le tresquilan, non abre la boca nin da boz. Et él mismo lo dixo a los apóstoles : En uvestra paciençia passaredes uuestras almas; et esto sse da a entender que: Quando ssopiéredes ssoffrir en paz lo que uos abiniere, sseredes ssennores de uuestras uoluntades. Yugo de sserui- 20 dunbre ouo en ssí Ihesu Cristo; que por ssacar a nos della metió a ssí mismo, ssegunt dixo Ssant Paulo, que commo él era en fforma de Dios, e sseyendo derechero que ffuesse egual dél, abaxósse tanto commo en fforma de ssieruo. Onde a ssemeiança de estas cosas pone el ssaçerdote el estola ssobre el pescueço e trauyessa 25 en los pechos en manera de cruz, en ssignifficança quel venga emiente de la passión de Ihesu Cristo et punne de auer estas quatro cosas que él ouo; et que assí commo çinne la estola con los cabos de la çinta, ssea él çinto de vertudes por que el diablo ṇon lo pueda vençer de tentaçión.

La ssetena, casulla, es uestimienta ancha e grande et non ha otra abertura ssinon por do la visten et el cabeçón por do ssaca la cabeça. Et ssigniffica casa de oraçión en que deue estar metido aquel que ffaze el ssacriffiçio, e por [essol] dizen casulla. Et ésta commo quier que es toda vna, quando el clérigo la ha vestida, 35 alça los braços e ffaz en ella departimientos a ssignifficança de la antigua ley que ffué ante de la passión de Nuestro Ssennor Ihesu

${ }_{7} T$ boco. $-34 T$ por el ssol. $-36 T$ añade braços sobre la linea, otra mano. 
Cristo e de la nueua que ffué después. Et porque el amito, de que ffablamos de ssuso, torna ssobrel cabeçón de la cabeça en derredor rel pescueço, ssigniffica que el clérigo deue sser çercado de caridat; ca ssegunt es ya dicho, éste ffaz ayuntar a Dios con omne 5 por amor.

\section{[Lex CVII]. - De las vestimientas que sson establecidas} en Ssanta Eglesia para los mayores ssaçerdotes.

Apartadas vestimientas, ssin estas ssiete que sson dichas, estableçió Ssanta Eglesia que ouyessen los mayores ssaçerdotes, assí ro commo el papa e los otros prelados. Et ffizieron por onrra esto por los logares que teníen e de la mayoría ssobre los otros clérigos; ca ellos los ordenan e les dan beneffiçios en que biuen e les demuestran en quál guisa enssennen la $\mathrm{Ffe}$ e digan las horas et ffagan los otros offiçios que pertenescen a Ssanta Eglesia. Et por 15 esso ffué estableçido que traxiesen cosas ssennaladas que non deuen traer otros clérigos ssinon ellos, et esto por onrra de la [73v] missa quando la dixieren: la primera, calças de sseda; la ssegunda, ssandalias; la terçera, Iuuas; la quarta, aniello; la quinta, croça ; la ssesta, milra ; e la séptima, pallio.

20 La primera, que ffabla de las calças, esto es que el prelado que deue calçar calças de lino o de sseda ante que vista ninguna uestidura de las otras que sson dichas quando sse començare a rreuestir. Et esto es por ssignifficança que deue tener apareiado piernas e pies para andar, mostrando toda vía carrera de paz, que sse 25 enliende toda vía por el Euangelio en que sse muestran las obras que Ihesu Cristo ffizo, que sson todas de paz e de ssaluaçión, ssegunt dixo Ssant Paulo: Preparate pedes uuestros en euangelio paçis. Et éstas deuen llegar ffasta la rrodiella e atarsse allí en derredor della. Et este atamiento muestra esfforçar los ynoios ffla3o cos por que los pueda doblar mucho a las vezes, ffincándolos en tierra e ffaziendo prezes, quando rrogare a Dios por el pueblo. Et ha este nonbre de calçitrare, que es palabra de latin que quier tanto. dezir commo coçear. Et esto es porque la primera cosa que omme coçea, [ffablando] entre ssí de aquellas cosas que viste o cubre,

35 sson las calças. 
La ssegunda, ssandalias, sson otra manera que sson ffechas ssegunt çapatos anchos que quepan ssobre las calças e han de auer las ssuelas de ffuste, assí commo de çuecos. Et deuen sser abiertos de parte de delante do sse ayunta el pie con la pierna, e tener cuerda de dentro con que sse aprieten por que sse paren bien 5 quando fueren calçados. Et las ssuelas sson a ssignifficança que los prelados más sse deuen trabaiar en las carreras spirituales e de paz que en las tenporales, de que puede naçer scándalo que es rrayz de guerras, ssegunt dixo Ysayas propheta, que muy ffermosos sson los pies que predican paz e bien. Las rrazones por que las ro ssandalias sson cerradas contra la punta del pie e abiertas contra arriba es porque la predicaçión del euangelio non deue sser descubierta a todos, nin otrossí ascondida, ssegunt Nuestro Ssennor Ihesu Gristo dixo a los apóstoles : A uos es dado de connosçer las poridades del rregno de Dios uerdaderamiente, e a los otros por 15 palabras. Et esto les dizía porque los tenía por amigos e les descubría las poridades de ssu padre, ssegunt él mismo dixo, que ellos eran ssus amigos e por esso los llamaua assí, porque todas las cosas que oyera a su padre les ffazía connoscer. Onde non quiso que otre lo ssopiesse ssinon ellos por que los oydores non lo ssopiessen 20 nin los entendedores bien entender. Et despaladinóles aun esta rrazón más abierta, ffaziéndoles entender que non teníe por bien que otre ssopiese los ffechos de Dios ssinon ellos, quando les dixo: Non querades dar el ssanto a los canes nin ssenbrar las piedras preçiosas entre los puercos. Et por todas estas rrazones las palabras 25 [74 $\mathrm{r}$ ] déuensse ffazer entender a los omnes entendidos que han ssabor de las oyr, e non a los otros.

La terçera sson luuas, que es vestidura con que cubren las manos, e éstas ffazen de lino o de sseda de qual manera los omnes las quieran ffazer; ca assí commo las luuas cubren las manos, assí las $3 a$ alimosnas que ffizieren los prelados deuen sser encubiertas. Mas la ssignifficança por que las traen los prelados es por que las alimosnas que flizieren sse ffagan encobiertamiente, ssegunt el mismo Ihesu Cristo dixo, que quando ffiziessen la alimosna, ffuesse tan en poridat que non ssopiesse la ssiniestra mano lo que fliziese con 35 la diestra; que las ffaga más por ganar el amor de Dios que por. darsse a vanagloria del mundo por lo que ffazen, ssegunt Ihesu Cristo dixo a ssus diçiplos, que non ffiziessen commo los que 
ffazíen oraçiones por las plaças por que los viessen los omnes orar, nin diessen ssus limosnas descubiertamiente, mas tan en poridat que lo que ffiziesse la mano diestra non lo ssopiese la ssiniestra. Et aun les dixo ssobresta rrazón, que sse entiende en este logar 5 por buenas obras, non las quisiessen ffazer entre los omnes por que ouyessen ende vanagloria. El los çercos dorados que ponen a las luuas en derredor de la boca por do las meten en las manos demuestran que las buenas obras que los prelados ffizieren, que deuen sser çerrados de loor de Dios en manera quel plegan.

ro La quarta es aniello. Aniello es cosa muy vsada que assacaron los antigos para traer los omnes onrrados ssennaladamiente entre todos los otros. Et quier tanto dezir commo fforado rredondo, ffecho por manera por do quepa el dedo, e éste ha de sser de metal del meior que puedan auer, assí commo oro, e rredondo en derre-

15 dor. Et ssin todo esto ha de sser engastonada en él piedra preçiosa, et esto por tres ssignifficanças que deue auer en ssí todo omne bueno, e mayormiente los cabdiellos. La primera, sser de rrico coraçón e noble para querer los grandes ffechos e ffazerlos, e ssaber e esquiuar los viles e a los malos, a ssemeiança de commo el oro 20 es más rrico metal e más noble que todos los otros. La ssegunda, sser çerrado de buenas maneras e de buenas costunbres para ssaberlas ellos ffazer e mostrarlas a los otros cómmo las ffagan, que es commo el aniello en derredor; et muestra con él o con las manos las cosas que quiere que ssean ffechas. La tercera, sser muy 25 ffirme en bien; ca ésta es la preçiada vertud que omne puede auer, a ssemeiança de la ffirmedunbre de la piedra. Et por ende los prelados que sson cabdiellos de los otros clérigos la deuen traer. $\mathbf{E}$ trayéndola en el dedo, es ssemeiança, ssegunt la ley vieia, quando Moysén ffizo por mandado de Dios [diez] ssennales en Egipto para 3o ssacar los ffijos de Isrrael de catiuerio. Et los ssabios de Pharaón [74v] ffizieron otras tales commo las primeras tres, mas dalli adelante non pudieron ffazer ninguna. Et preguntóles Pharaón que por qué era aquello, et ellos rrespondieron que aquello que Moysén ffiziera que en el dedo de Dios era, que sse da a entender por la vertud.

35 Otrossí. Ihesu Cristo mismo lo dixo quando le dizían los judíos que ssanaua los demoniados en poder de los diablos, et él rrespondióles, mostrándoles que non era assí ; ca los que él ssanara, con el dedo de Dios lo ffazíe, que sse entiende por el ssu poder. Et ssin 
todo esto, en traer el prelado aniello es a ssignifficança de cómmo es desposado con la Eglesia, a ssemejante del aniello que da el esposo a la esposa quando sse desposan. Et por ende el prelado ha de ffazer dos cosas : la vna, sser de buena vida; la otra, mantener la Eglesia, assí commo el casado que ha de beuir bien con ssu 5 mugier, e manteniéndola e guardándola.

La quinta, blago. Blago es tomado de vna palabra de latín, bajulans, que quier dezir ssostenimiento. Et es porque ssienpre sse ssuffre e sse ssostiene ssobrél aquel quel tiene. Et désta es tomada vna palabra que dize vn omne por otro, mostrando quel ffizo pla- 10 zer quando lo auya mester, que sse entiende más en pobreza que en veiedat nin que en otra cosa, quando dize que : Esste ffué o es blago de mi fflaqueza o de mi veiedat. Et por ende el blago ha de sser tal que pueda el omne tener en la mano e, apretándol, ssoffrirsse ssobrél; e ha de sser todo derecho e contra ffondón agudo, e en 15 ssignificança que derechamiente ha de venir ffazer ssus obras aquel quel traxiere. E la agudeza dél, que sse ffinca en la tierra e prende en ella, es ssignifficança que el enssennarniento sse deue affinccar e prender en los coraçones que sson ssecos e duros, ffaziendo buenas obras e apretándoles, e que les ha a [despertar] e non les dexe 20 dormir en pecado. Lo al que viene de ssuso, ssobre que tiene las manos e sse ssuffre, ssigniffica que el prelado deue poner las manos ffirmemiente en las cosas que sson derechas de guisa que las manos de Dios, que sse entiende por el ssu poder, e las del prelado, que sse entiende por buenas obras, sse acuerdan en vno. Et este 25 blago es ssegunt la vieia ley. Mas ssegunt la nueua ffázesse más luengo en altura e ençima corbo, e a éste llaman croça, porque sse muestra por ella que el prelado deue sser mesurado e humilloso.

La ssesta, mitra, ssegunt ordenamiento de Ssanta Eglesia, deuen traer los prelados mayores. E ésta ponen a manera commo la tra- $3 o$ yen los obispos en la ley vieia, pero la ffaçión della es ssennas guisas. Ca antiguamiente era ffecha rredonda, en que entraua la cabeça ffasta las ssobreçeias, e dende arriba yuase ajuntando de guisa que todo sse çerraua ssuso en vn poquiello. Et esto ffazíen por ssignifficança que Dios era vno e la ley vna, e que todas 35 estas cosas sse comiençan en él e sse acaban. Et por ende la llaman en ebrayco thiara, e quiere tanto dezir commo corona. Et trayen en la ffruente delante vna tabla de oro en que era escripto el non-

so $T$ desapretar. -- $36 T$ lla llaman. 
bre de Dios e el nonbre de los cabdiellos e de los doze tribos de [75r] Ysrrael. Et aquestos nonbres eran escriptos en piedras preçiosas, cada vno en aquella piedra que entiende ssu natura e ssu uertud e para ffazer con ella su oraçión, rrogándol que les ffiziesse

5 merçet. Mas ésta traen agora los prelados mayores a que dizen mitra, e es ffecha de otra ffaçión ; ca pero que es redonda para caber la cabeça por ella, commo la otra, es cubierta de panno blanco de sseda o de lino a ssignifficança de buena vida o de castidat, e ffázenla baxa; e la otra sse alçaua más por mostrar que en la maIo yor alteza que omne rreçibiese en este mundo de onrra, que allí sse deue más homillar, et mayormiente en aquello que rreçibe por rrazón de Dios, ssegunt Nuestro Ssennor Ihesu Cristo dixo, aquel que sse homillasse sseria enssalçado. Et ffazen otrossí la mitra que la agudeza que la otra auya ssola ha ésta dos, vna delante ssobre

I5 la ffruente e otra detrás a las espallas, que muestran los dos testamentos, el vieio e el nueuo, que deue ssaber todo prelado para ffazer conplidamiente ssu offiçio. Et los dos rramales que desçenden de la mitra por las espallas ssigniffica dos cargas que tiene el. prelado ssobre ssí : la vna, spiritual, por ganar amor de Dios para 20 ssí e para los otros que ha en ssu guarda; et la otra, tenporal, para ffazer buena vida entrellos e darles enxienplo por que la ffagan. Et porque estos rramales que sson liuyanos, se entiende por la palabra que dixo Nuestro Ssennor Ihesu Cristo, que el ssu yugo ssabroso es e la ssu carga liuyana. Et desto ay proeua natural; ca las. 25 cosas liuyanas ssuben e las pesadas desçenden. Et por ende que los que sson buenos ssuben a paraíso, ffaziendo buena vida en estemundo, et los malos, que la ffazen mala, desçenden al inflierno. Onde los prelados han de encargar los omnes de tal manera que. puedan ganar amor de Dios et guardarsse de los que ponen tan

3o grandes cargas que non pueden ssoffrir e an a caer en grande desesperança e, cayendo en ella, uan a perdiçión.

La ssetena, pallio llaman a vn panno angosto, commo en manera de çinta que non es mucho ancha, que quier dezir tanto commonoble cobertura e rrica que deuen traer los prelados ssobre todas.

35 las vestiduras que touyeren quando dixieren la missa; pero non. todes, que non es dado a otre que lo traya ssinon al papa o al primado o -1 arçobispo. Et esto por onrra que han en ellos; ca han. los obispos sso ssí que los obedeçen. Et los obispos non los pueden auer ssin dispenssamiento del papa. Et este pallio ha de sser de 4o llana toda blanca que ssea de oueia o de cordero, en tal manera 
ffaçionado que entre por la cabeça e ssea tan ancho que uenga por los pechos e por las espallas en derredor, e ha de auer dos listas que cuelguen, va delante e otra detrás. Et deue sser doblada de la parte ssiniestra e ssenziella de la diestra. Et otrossí ha de auer quatro cruzes, vna en los pechos, e otra en las espallas, e otra sso- 5 brel onbro diestro, e otra ssobrel ssiniestro. Et éstas [75v] han de sser de color negro o bermeio, texidas en el pallio mismo o puestas de dentro de aquella color misma. Et este pallio ha de sser preso en la casulla con tres agujas de plata. E muestra disçiplina, que quier tanto dexir commo enssennamiento de que deue sser en- io ssennado el que lo traxiere cómmo biua bien e enssenne a los otros cómmo lo ffagan. Et las tres agujas que sson ffincadas en el pallio sson tres maneras de apuntamiento de dolor que el prelado deue auer en ssu uoluntad: la vna, por los peccados que sson ya ffechos; la otra, de los que sse ffazen; la otra, de los que sse podrían i5 ffazer. Ca de cada vna déstas sse deue doler mucho e dar consseio quanto pudiere, a lo que es ffecho cómmo sse emiende, et a lo que puede uenir que non sse ffaga. Et por esso lo flazen que trae en derredor por los pechos e por las espallas en ssignifficança de las ssartas que ponen a la nouya, e mayormiente quando está en 20 el thálamo. Et por ende el arçobispo, quando ha de entrar en Ia missa dezir, deue leuar este pallio en ssemeiança de la palabra que dixo Ssalamón prophetando, commo en manera que castiga a ssu ffijo, diziendo : [Oye], mio ffijo, la disçiplina del tu padre - que sse entiende por el mandamiento de Dios - et non dexes la ley de 25 tu [madre] - que es el ordenamiento de Ssanta Eglesia - por que la graçia del Spíritu Santo ssea ayuntada a la tu cabesça e ssarta de ffermosa vida al tu cuello. Et aun amuestra otra cosa, que en lo que cae el pallio ssobre los onbros ssigniffica que el prelado deue auer amor de Dios para non alçar las manos para non 3o ffazer ninguna cosa que desaguisada ssea. La rrazón por que el pallio es [doble] en la ssiniestra parte ssigniffica que doblada ffortaleza deue auer, que pone ante ssí assí commo escudo en la parte ssiniestra, que es más fflaca, para poder bien ssoffrir los pesares deste mundo e las tentaçiones del diablo, que meten en yerro, 35 e ffaze esfforçar a los fflacos con rrazón. Et porque el pallio es ssenziello en la diestra parte ssigniffica que aquello deue omne tener desenbargado para fferir, assí commo la ssiniestra para 
ssoffrir. Et porquel ffazíen de lana que es áspera demuestra el aspereza que deue auer Ssanta Egglesia contra los descreídos. Et por lo que es pallio plano es la piedat que ha después ssobre los que bien sse arrepienten e sse tornan a ella. Et porquel frazíen de lana

5 de oueia o de cordero, e non de otra animalia, ssigniffica la muerte que ssuffrió Nuestro Ssennor thesu Cristo por nos muy manssamiente, ssegunt es dicho ya en otro logar. Et las quatro cruzes quel ponen ssigniffican las quatro uertudes mayores por que sse mantiene el mundo, assí commo ssabiduria, ffortaleza, justiçia,

Io tenpramiento. Lo otro porque las cruzes sson bermejas demuestra que deue ssienpre el prelaro tener en ssu uoluntad en cómmo Nuestro Ssennor Thesu Cristo esparzió la ssu ssanta ssangre por nos e sser [ $76 r]$ triste por quanta pena e martirio ssuffrió por nos, et venirle ssienpre emiente la muerte muy graue que passó. Et 15 estas quatro cruzes deuen sser puestas cada vna en ssu logar por grant ssignifficança : la justiçia, en los pechos, porque sse ha de leuantar del coraçón en amarla mucho el que la ffiziere; la ssabiduría, en las espallas, para ssaberla mantener e desamar a los que la desamaren ; la ffortaleza, en la parte ssiniestra, por que las co20 sas contrarias non abaxassen al que la touyere; et el tenpramiento, en la parte diestra, por que ssepa ssoffrir la buena andança e non tome orgullo ninguno nin ffaga cosas por que la aya de perder. Onde todas estas uerludes deue auer en ssi el prelado para ganar amor de Dios e de los omnes. Los dos cabos que cuelgan, el vno

25 detrás ssigniffica la vida de los malos ssabores deste mundo que deue el prelado oluidar e dexar tras las espallas; et el otro que tiene ante ssi, las buenas obras quel deuen venir ssienpre emiente et ffazerlas para auer el amor de Dios e ganar paraíso.

[LEY CVIII]. - Que assí commo las armaduras tenporales ffueron 30 eslableçidas para deffendimiento de la carne, otrossi las spirituales para se deffender del diablo.

Armaduras tenporales ffueron ffalladas e estableçidas para acometer los omnes ssus enemigos a deffendersse dellos cada que mester ffuesse. Et a cuya ssignifficança estableçió Ssanta Eglesia 35 ssus uestimientas, con que sse guarnescan los ministros della assí

$9 T$ mantienen. 
commo armaduras contra las tentaçiones del diablo, que es enemigo del humanal linage: la primera, espalleras; la ssegunda, yelmo; la terçera, loriga ; la quarta, çinta; la quinta, escudo; la ssesta, coffia ; la ssetena, ssobressennales.

La primera, [a] ssignifficança de las espalleras, ssobre que vis- 5 . ten la loriga, ffué estableçida la ssobrepelliça, que viste el preste primeramiente quando quiere dezir la missa e es aquella ssobre que echa el alua, e ésta muestra linpiedunbre e castidat, ssegunt ya dixiemos. Porque ésta ya non paresçe porque todas las otras uestimientas están ssobrella, por esso non le dizen oraçión ssenna- to lada quando la visten; ca touyeron que asaz abondaua la ssignifficança que auya en ella por que la visten, que es linpiedunbre.

La ssegunda, a ssemeiança del yelmo pusieron el amito, con que cubre el clérigo la cabeça, que es el más alto e más noble mienbro de todo cl cuerpo. Et quandol pone, dize esta oraçión, en i 5 que rruega a Dios que ponga yelmo de ssalut en la ssu cabeça para lidiar e uençer todos los engannos del diablo.

La terçera, loriga es palabra griega que sse entiende por el arma que sse viste omne más çerca del cuerpo en logar de ssaya. Et a ssignifficança désta es el alua, que viste el clérigo después que ha 20 vestida la ssobrepelliça e cubierto el amito. Et dize assí, rrogando a Dios quel uista [76v] de uestimienta por quel ssea guardado el cuerpo de malas obras e quel çerque de justiçia por que ffaga bien e obre derecho en todo. Esto conuyene al que trae la loriga, que en esffuerço della comete meior ssus enemigos e es guardado de 25 prender muerte assohora nin de flazer cosa por que caya en uergüença.

La quarta es la çinta. Cennir el alua después que la ha uestida el clérigo, et esto es a ssignifficança de la loriga. Et ffázesse por dos rrazones: la vna es que ssuffre el que la viste meior la pesadura 3o della ; la otra, porque alça más ligeramiente los braços para fferir ssus enemigos. Onde el alua, quando el clérigo la ha çennida, ffaze dos cosas: la vna, que la longura della torna a estado derecho, que es ssalut del cuerpo e del alma, ffaziendo lo que deue; la otra, porque puede meior alçar ssus braços para ffazer el ssacriffiçio 35 con que uençe el diablo, quebrantándol la ssu ffuerça. Et por ende la oraçión que dize quando çinne la çinta es ésta, en que rruega a Dios quel çinga los lomos de ssu cuerpo de çinta de ffe, que sse 
entiende por ffortaleza de buena crençia, e que amate en él ardor de luxuria de guisa que ssea ffallada en él toda castidat; ca éstas sson cosas que uençen al diablo e dan ssalut al alma.

La quinta, escudo. Escudo es arma que para omne ante todas

5 las cosas, e tiénelo ssienpre en la mano ssiniestra porque es de parte del coraçón, et está ssienpre aperçebido de pararsse a los colpes dol quissieren dar. Et por ende el maniplo, que en essa mano ponen, es a ssemejança dél. Et por ende estableçieron que dixiese el clérigo esta oraçión quandol pusiessen, et rruega a Dios

Io que quiera que él meresca traer aquel maniplo con ffiel uoluntad assí que, en trayéndol, aya parte con los que auyan derecho e lidian por la $\mathrm{Ffe}$ contra el diablo e contra los peccados.

La ssesta, coffia, ssobre que ponen el almóffar de la loriga e el tiracol del escudo e la çinta del espada, todas éstas ssigniffican el $1 \check{5}$ estóla. Et porque la ponen primeramiente ssobre la cabeça es a ssemeiança de la coffia. Et a la que echan después ssobrel pescueço es a ssemeiança del tiracol. Et los cabos que cuelgan delante o la çinne, la çinta del espada. E por esso ha tres oraçiones. La primera, en que rruega el preste a Dios quel vista de estola de ale20 gría, que sse entiende para ssoffrir las tentaçiones del diablo de guisa que alegremiente entre en el paraíso, et quel ponga ssobre la cabeça corona de ffermosura, que sse da a entender por uençer el diablo e todas las ssus obras. La ssegunda, en que rruega a Dios que el que dixo que el ssu yugo era ssabroso e la ssu carga liuya$25 \bar{n}$ na, que él que quiera que pueda auer la ssu graçia e la pueda ssotener. La terçera es que rruega a Dios que él le cobre por la ssu merçet la uestidura non mortal que perdió por la culpa de Adam, el primer omne, assí que maguer él non es digno de la auer por ssí mismo, que la aya por ssu $[77 r]$ piedat por que pueda en3o trar con ella a la ssu Eglesia.

La ssetena, ssobressennales sson aquellas armaduras que visten los caualleros ssobre todas las otras quando han de lidiar. Et esto es por que ssea cada vno por y connosçido, quién es o quién ffaze de bien o de mal. Et a ssemeiança desto es la casulla, que viste el

35 clérigo que ha de ffazer el ssacriffiçio de la missa ssobre todas las vestimientas; ca ésta ffaze connosçer a todos que aquel que la viste es el que ha de conssagrar el cuerpo de Nuestro Ssentor Ihesu Cristo, por que ssi buena vida ffaze es más preçiado por él que 
otro; e ssi mala, menos, por que deue auer dos penas: la vna, de uergüenças; ]a otra, de penitençias. Et por ende la oraçión que dize el clérigo quando viste la casulla es ésta, que rruega a Dios, que es derechamiente justiçiero, quel enffortalezca, guameciéndol de vestiduras de justiçia e de ornamentos de homillat e de ssalut e 5 de castidat, por que pueda poderosamiente contrastar a los viçios deste mundo, que sse entiende por los peccados, e dignamiente sseruir a los ssacramentos de la misa. Et otrossí commo la casulla cubre la túnica e la dalmática, assí esta oraçión abonda e cunple. Et por ende ffué ordenado que otra ninguna apartada non aduxie- 10 sen ssobbrellas. 



\section{ÍNDICE DE LÁMINAS}

Página

I. Manuscrito de Toledo, fol. $5 r \ldots \ldots \ldots \ldots \ldots \ldots \ldots \ldots \ldots \ldots, 17$

11. Manuscrito de Toledo, fol. $5 v \ldots \ldots \ldots \ldots \ldots \ldots \ldots \ldots \ldots$, 8

III. Manuscrito del Escorial, fol. $15 r \ldots \ldots \ldots \ldots \ldots \ldots \ldots \ldots \ldots$ \& 4

IV. Mantuscrito de Toledo, fol. 2 $\mathrm{v} \ldots \ldots \ldots \ldots \ldots \ldots \ldots \ldots \ldots$ 6

V. Manuscrito del Escorial, fol. $57^{0} \ldots \ldots \ldots \ldots \ldots \ldots \ldots \ldots \ldots \times x_{7}$

VI. Manuscrito de Toledo, fol. $50 r \ldots \ldots \ldots \ldots \ldots \ldots \ldots \ldots \ldots \ldots . \ldots \ldots$

VII. Manuscrilo del Escorial, fol. $99 . \ldots \ldots \ldots \ldots \ldots \ldots \ldots \ldots \ldots{ }_{22} 3$

VIII. Manuscrito del Escorial, fol. $99^{0} \ldots \ldots \ldots \ldots \ldots \ldots \ldots \ldots \ldots \ldots 294$

IX. Manuscrito de Toledo, fol. $67 r \ldots \ldots \ldots \ldots \ldots \ldots \ldots \ldots \ldots$ s3

X. Manuscrito de Toledo, fol. 67 $v \ldots \ldots \ldots \ldots \ldots \ldots \ldots \ldots \ldots$ s38 



\section{ÍNDICE GENERAL}

Página

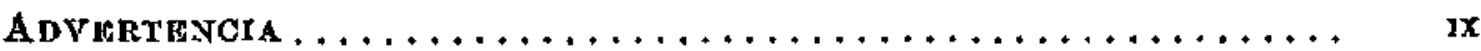

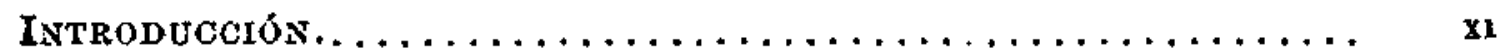

I. Antecedentes del Setenario ..................

II. Bibliografía del Setenario ................... xvm

III. El Setenario y las Siele partidas...............

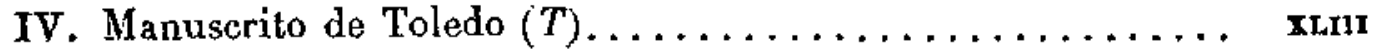

V. Manuscrito del Escorial $(E) \ldots \ldots \ldots \ldots \ldots \ldots \ldots \ldots \ldots \ldots \ldots$

VI. Manuscrito de Madrid $(\boldsymbol{M}) \ldots \ldots \ldots \ldots \ldots \ldots \ldots \ldots \ldots \ldots \ldots \ldots \ldots \ldots$

VIf. Parentesco de los manuscritos ................. L L

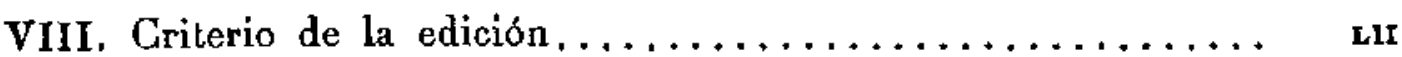

IX. Transcripción de $T \ldots \ldots \ldots \ldots \ldots \ldots \ldots \ldots \ldots \ldots \ldots \ldots$ Lri

X. Variantes de $T \ldots \ldots \ldots \ldots \ldots \ldots \ldots \ldots \ldots \ldots \ldots \ldots$ nxin

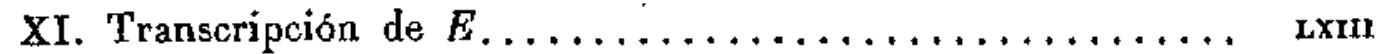

XII. Variantes de $E \ldots \ldots \ldots \ldots \ldots \ldots \ldots \ldots \ldots \ldots \ldots \ldots \ldots \ldots$

XIII. Particularidades del uso ortográfico de $T$ y $E \ldots \ldots \ldots \ldots \ldots \mathbf{L x \times 1}$

XIV. Nota sobre las láminas . . . . . . . . . . . . . Lxxvi

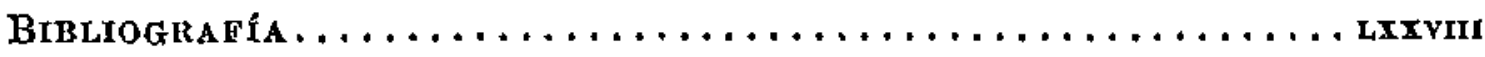

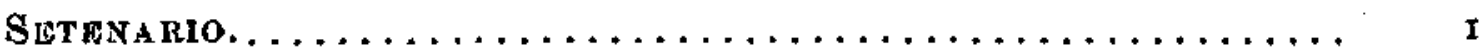

LFX I. - [De las ssiete letras de Alpha et $\mathrm{O}$ que muestran cada vna ssiete

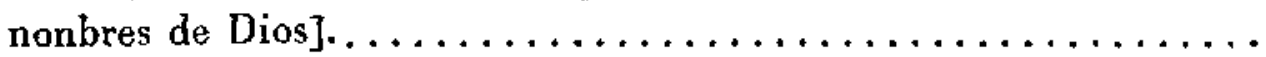

LEY IX. - De lo que muestran las ssiete letras del nonbre del rrey don Ffernando ..............................

Lwy III. - De los bienes que entendíe el rrey don Ffernando en esta

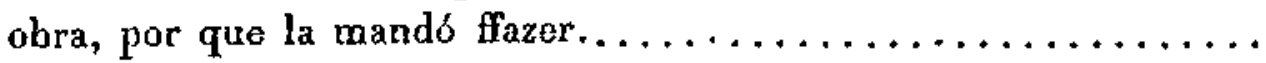

LEY IV. - De los bienes que ffzo el rrey don Fernando al rrey don Alffonso su ffijo .......................... to

Ley V. - De las vertudes ssiete que puso Dios en el rrey don Ffer-

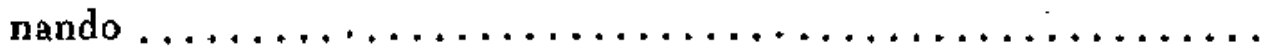

LEY VI: - De cómmo el rrey don Ferrnando era bien costunbrado en

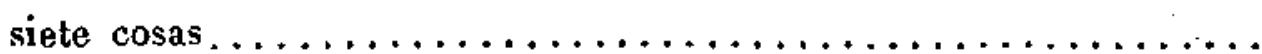

LeY VII. - De cómmo el rrey don Ffernando era bien acostunbrado

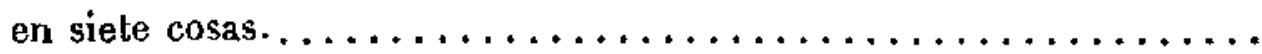

LIFY VIII. - En qué cosas se mostró el rrey don. Ffernando por ssier-

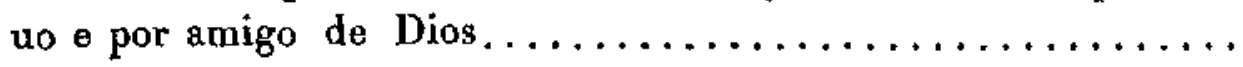


LwY IX. - De las merçedes que ffizo Dios al rrey don Ffernando en

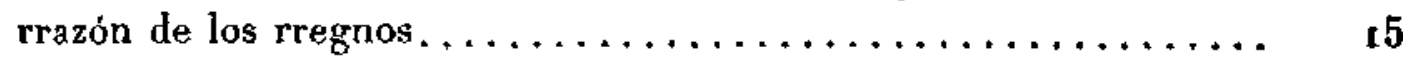

LEY X. - De las bondades del rregno de Seuilla ............. 19

LEX XI. - Por quáles rrazones pusiemos nonbre a este libro Sselenario. $\quad 25$

LWY XII. - Qué quier dezir ssecta................ 47

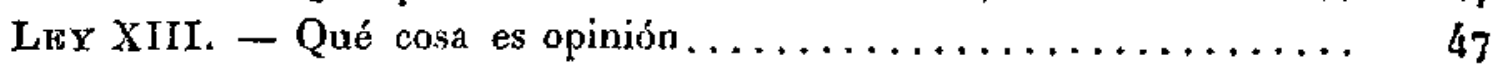

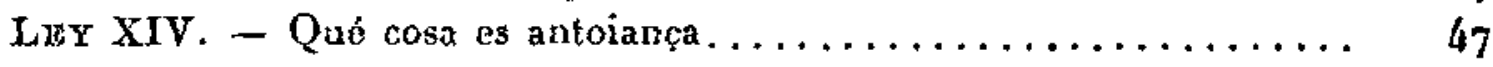

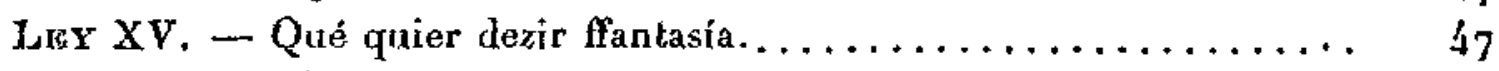

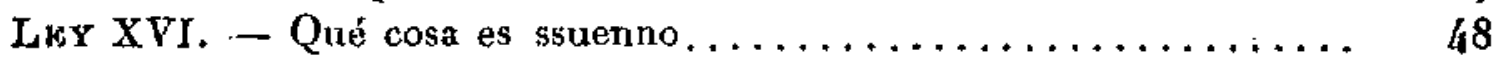

LEY XVII. - Qué cosa es visión .................... 48

LEY XVIII. - De cómmo non deue omne aorar sinon a Dios solo... 49

LaY XIX. - De los que adorauan la tierra.............. 5o

LwY XX. - De los que aorauan el elemento del agua .......... 5r

LEY XXI. - De los que aorauan el elemento del ayre.......... 53

LwY XXII. - De los que zorauan el ffuego................ 53

LkY XXIII. - De Ios que sse aorauan vnos a olros............ 55

LEX XXIV. - De cómmo el ssonnar ffazía a los omnes caer en gran-

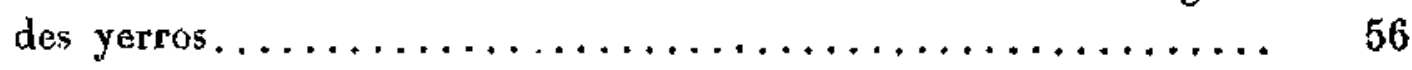

Lex XXV. - Do las planetas.................... 57

LEY XXVI. - De cómmo a la luna llamauan los antigos mugier del ssol, e por qué rrazón es así llamada .................. 58

Lex XXVII. - De la propriedat que dauan a Mercurio.......... 58

LeY XXVIII. - Qué quier dezir Venus, e qué propriedades le dauan. $\quad 59$

LeY XXIX. - De las virtudes que dauan al sol .............. 6o

LEY XXX. - De la planeta Mars e de las propriedades quel dauan... 60

LxY XXXI. - De la honestat que dauan a Jupiter e de ssus propriedades. $\quad 62$

LkY XXXII. - De la ffortaleza que dauan a Ssaturno........... 63

LeY XXXIIr, - Por qué rrazón aorauan los antigos al octauo çielo. . 63

LiY XXXIV. - Del departimiento de Ios ssignos.............. 64

LuY XXXV. - De cómmo Nuestro Sennor Dios non puede ser conosçido por estas setas que son dichas, mas por la ley biua c verdadera

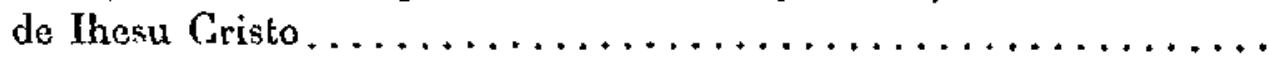

LaY XXXVI. - De cómmo Dios Padre fizo por amor de Jhesu Cristo su fijo los pielos e la tierra.................. $6_{7}$

LRY XXXVII. - Qué cosa es Spíritu Santo................ 67

Ley XXXVIII. - Qué cosa es Santa Eglesia e por qué la llaman asy. $\quad 69$

LEY XXXIX. - De la segunda manera a que llaman Eglesia...... 69

LwY XL. - De los artícolos de la Fe................ $7^{\circ}$

LEx XLI. - Quáles son Ilamados apóstoles.............. $7 \mathbf{I}$

LrY XLII. - De las palabras que dixieron los apóstolos en cómmo

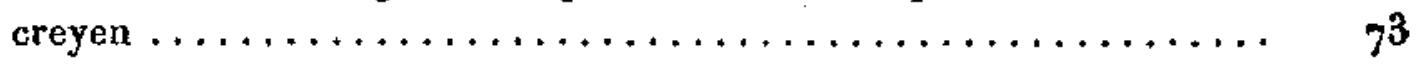

LeY XLIII. - De cómmo los que aorauan la tierra, a Santa María

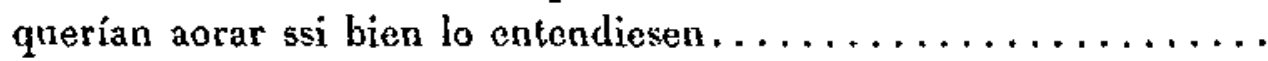

LEX XLIV. - De cómmo los que aorauan el helemento del agua, erâ

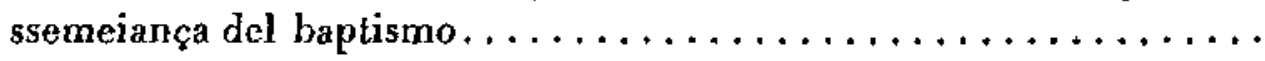

LnY XLV. - De los que aorauan el elemento del ayre, ssinifficaua a la linpia vida que fizo Nuestro Ssennor lhesu Gristo en este mundo. 
LeY XLVI. - De las conparaçiones que ha el ffuego al Spíritu Santo. LEY XLVIX. - De cómmo los que aorauan los vii çielos, fiué a ssemeiança de los vii mouimientos que fizo Nuestro Ssennor thesu Cristo e de los vii dones que dió Dios a ssus amigos............

LiY XLVIII, - De cómmo los que aorauan a la luna, a Ssanta María

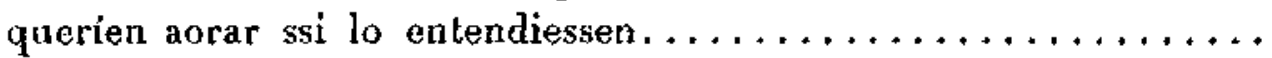

LeY XLIX. - De cómmo sse muestra que los que aorauan a Mercurio, que a Ihesu Cristo lo deuyeran ffazer..................

LaY L. - De cómmo se muestra que las uertudes e las amiztades que dauan a la planeta Venus ssus aoradores, a la piadat de Dios la

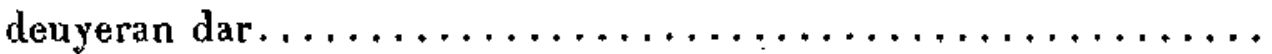

LwY LI. - De cómmo errauan los que orauan el ssol, cuydando que la nobleza que él auye en ssí era de ssuyo, e non entendíen cómmo

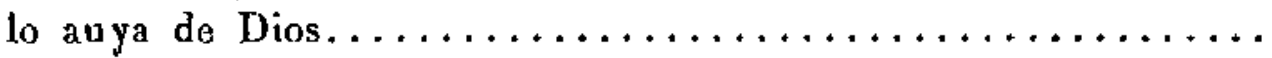

LeY LII. - De cómmo sse muestra que el poder que auya Mars para destruyr ssu ffechura e en ffazer mal, ouo Ihesu Cristo en ffazer

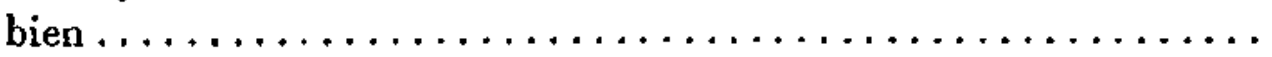

LkY LIII. - Do cómmo la onestad que dauan los antigos a Jupiter, a Ihesu Cristo la deuyeran dar ssi bien lo entendiesen...........

LEY LIV. - De cómmo la antigüedat que dauan a Ssaturno e el mouimiento tardinero, a Dios Padre lo deuyeran dar, que nunca sse

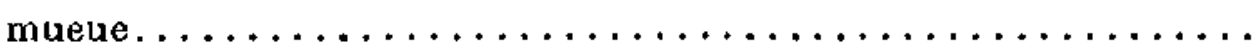

LEY LV. - De cómmo la ffigura de carnero que daun al ssigno de Aries, a Ihesu Gristo la deuyeran dar, que es cordero uerdadero de

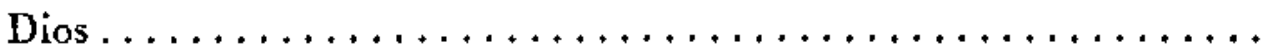

Lry LVI. - De cómmo errauan los que orauan el ssigno de Tauro, queriendo aorar a thesu Cristo, por non lo entender..........

Luy LVIT. - Del ssigno de Gémini e de lo que ssignifficaua la ssu ffigura, que es dos cuerpos ayuntados en vno, que a Ihesu Cristo le deuieran dar $\ldots \ldots \ldots \ldots \ldots \ldots \ldots \ldots \ldots \ldots \ldots \ldots \ldots$

Lry LVIII. - De cómmo los que aorauan al Cangreio, a Ihesu Cristo deuyeran aorar si bien lo entendiesen................

Lxy LIX. - Del ssigno del León e de cómmo los quel aorauan quisieran aorar a Ihesu Cristo si lo entendieran ..............

Lex LX. - De las ssemeianças que ouo Santa María con [el ssigno de]

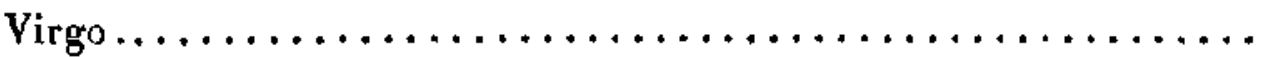

Lex LX: - De cómmo los que orauan a Libra, a Ihesu Cristo querían aorar ssi lo entendieran .....................

LEY LXII. - De las ssiete propriedades que dauan al Escurpión, a Nuestro Ssennor lhesu Cristo las deuyeran dar, ssegunt sse aquí

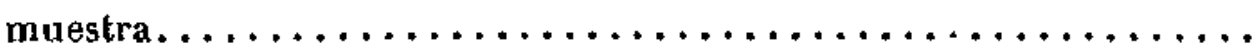

LEY LXIII. - Qué quier dezir Ssagitario e de la semeiança que dieron a Nuestro Senuor Ihesu Cristo dél.................

LEY LXIV. - De cómmo las propriedades que dauan a la ffigura del Capricornio, a Jhesu Cristo las douyeran dar.............

Lex LXV. - - De cómmo las propriedades que dauan a Aquario, a Ihesu Cristo las douyeran dar, que las ouo en ssí conplidamientre. 
LeY LXVI. - De çómmo se muestra que los que aorauan el ssigno de Pisçis, a Thesu Cristo lo douyeran ffazer.................

LEY LXVII. - Commo Tolomeo fabla altamiente en ffecho de astrología, así flizo Sant Iohán en las propriedades de Dios..........

LEX LXVIIr. - De cómmo los xii ssignos son ffechos e conparados a

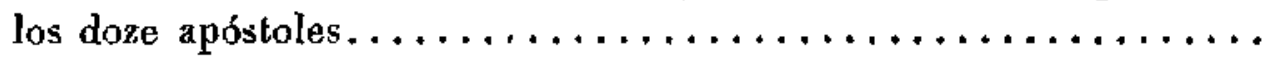

LwY LXIX. - De cómmo los prophetas mostraron que quatro euangelistas deuen sser e non más.......................

LEY LXX. - Quántos sson los ssacramentos e en quántas maneras son guardados e sagrados e qué pro viene dellos a los que los rreçiben.

Lxy luXX1. - Por qué rrazón sson los sacramentos ssiete e non pue-

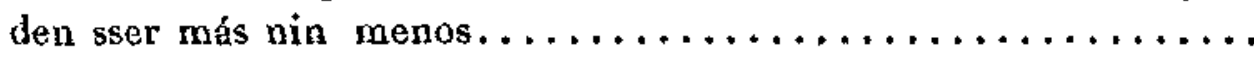

LIEY LXXII. - Quántas maneras de clérigos pueden dar los ssacramentos conplidamente.........................

LẹY LXXIII. - Quántas maneras de prelados rreligiosos pueden dar

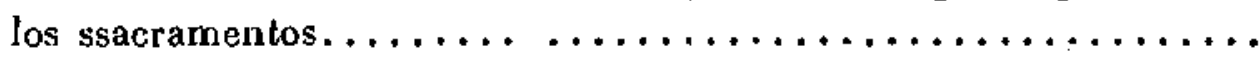

LEX LXXIV. - Por quáles rrazones pueden dar los legos los tres sacramentos que son baptismo e penitençia e casamiento.........

LEY LXXV. - Por qué rrazón es llamada la Eglesia cathólica......

Ley LXXVJ. - Quáles ssazones deuen sser catadas para dar los sacra-

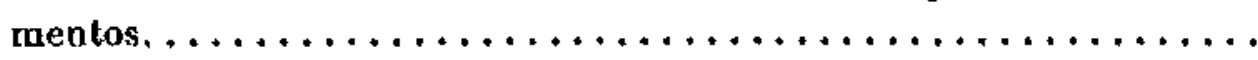

LEY LXXVII. - Qué cosa es en sí el baptisno e qué sacramento es.

LIt Y LXXVII, - Quién estableçió el baplismo e quándo, e cómmo Sant Iohán ouo nonbre Babtista por rrazón del baptismo........

LeY LXXIX. - De las palabras çiertas por que sse ffaze el baptismo. .

LEY LXXX. - Quántas e quáles son las maneras en que se non puede fazer el bautismo..........................

LEY LXXXI. - Cómmo son tres maneras del bautismo, pero la virtut toda es vna.............................

Lry LXXXII. - A qué cosas tiene pro el bautismo quando es fecho

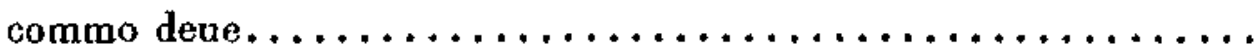

LeY LXXXIII. - Qué quiere dezir saçerdote.............

LwX LXXXIV. - De cómmo se muestrá la Trenidat conplidamente en las cosas que se fazen ante del bautismo e en las cosas que son fe-

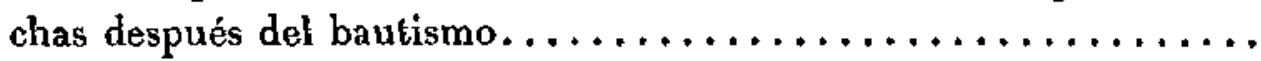

LEX LXXXV. - Quántas e quáles sson aquellas cosas que frazen en vno con el baptismo........................

LEY LXXXVI. - De las cosas que deuen ffazer después del baptisrao, cómmo son ffechas en ssiete maneras. .................

LEY LXXXVII. - De cómmo deue sser onrrado el baptismo por ssiete rrazones e guardado por otras tantas.................

LuY LXXXVIII. - Qué cosa es en sí la crisma e quién la puede ffazer

LwY LXXXIX. -- De cómmo estableçieron los santos padres la crisma.

LEY XC. - De las maneras de los olios de que sse faz la crisma....

LEY XCI. - Del tienpo' que fué estableçido para ffazer la crisma...

LWY XCII. - De cómmo deuen tener apareiadas todas las cosas que sson mester para ffazer la crisma.................. 
LRY XCIII. - En qué manera sse deue ffazer la crisma.......... 167

LEY XCIV. - De cómmo deuen boluer el olio de la crisma con del olio del bálsamo...........................

LEY XCV. - Por quáles cosas deue sser conssagrado el olio para los cathecúminos e neóffitos . ......................

LEX XCVI. - Del ssegundo ssacramento, que es la conffirmaçión, e de las cosas que sse deuen ffazer en él. ..................

LEX XCVII. - Del terçero ssacramento, que es la penitençia, e dónde

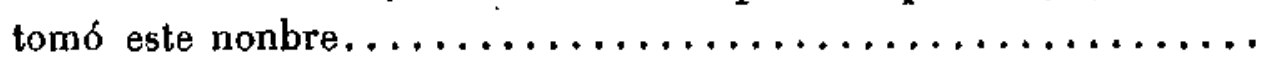

LEx XCVIII. - De los peccados que ffazen los omnes de que han mester de tomar penitençia, e quántas maneras sson dellos.......

LEY XCIX. - Qué quier dezir çitar e dónde fué tomada esta palabra

Lex C. - Quién puede dar la penitençia e de las preguntas que deuen

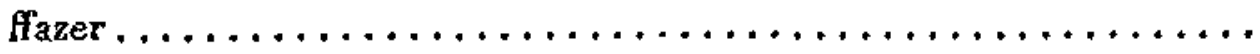

LkY CI. - Quáles deuen sser llamados conffesadores e cómmo deuen

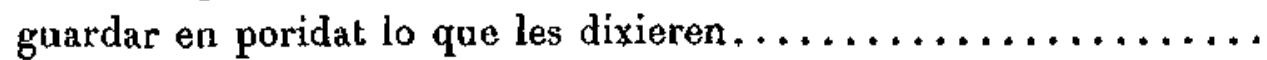

LEY CII. - De cómmo sse muestra quál penitençia es ssolenpne e

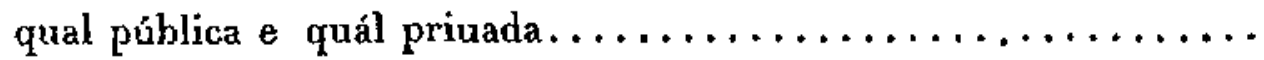

LWY CIII. - De cómmo se amortiguan los bienes que omne faz por el pecado mortal e cómmo se abiuan por la penitençia.........

LwX CIV. - Del quarto sacramento, que es la comunión.........

LIE Y CV. - [De las cosas que sson estableçidas en Ssanta Eglesia para frazer el cuerpo de Nuestro Ssennor Ihesu Cristo $]. . . \ldots \ldots \ldots$.

LFY CVI. - [De las vestiduras que sson estableçidas en Ssanta Egle sia para los prelados menores $]. \ldots \ldots \ldots \ldots \ldots \ldots \ldots \ldots \ldots$

LEY CVII. - De las vestimientas que sson establecidas en Ssanta

Eglesia para los mayores ssaçerdotes...................

Lxy CVIII. - Que assí commo las armaduras tenporales fiueron estableçidas para deffendimiento de la carne, otrossí las spirituales para se deffender del diablo..........................

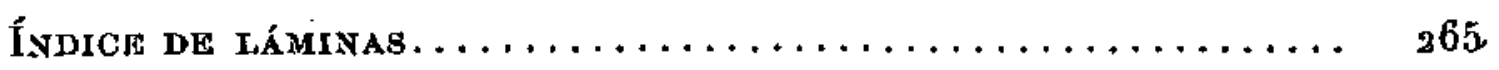



ESTA OBRA SE TERMLX́ DE IMPRIMIR EN LA IMPAENTA

y CASA EDITORa ( CONI ), CALle perú 684 BUENOS AIRES, REPÚBLICA ARGENTINA

EL 29 DE NOVJEMERE DE I $945^{\circ}$ 